\title{
GEOLOGIA DA REGIÃO DIAMANTÍFERA DE POXORÉU E ÁREAS ADJACENTES, MATO GROSSO
}

\author{
RICARDO KALIKOWSKI WESKA
}

Orientadora: Prof. Dr. Darcy Pedro Svisero

TESE DE DOUTORAMENTO

COMISSÃO JULGADORA

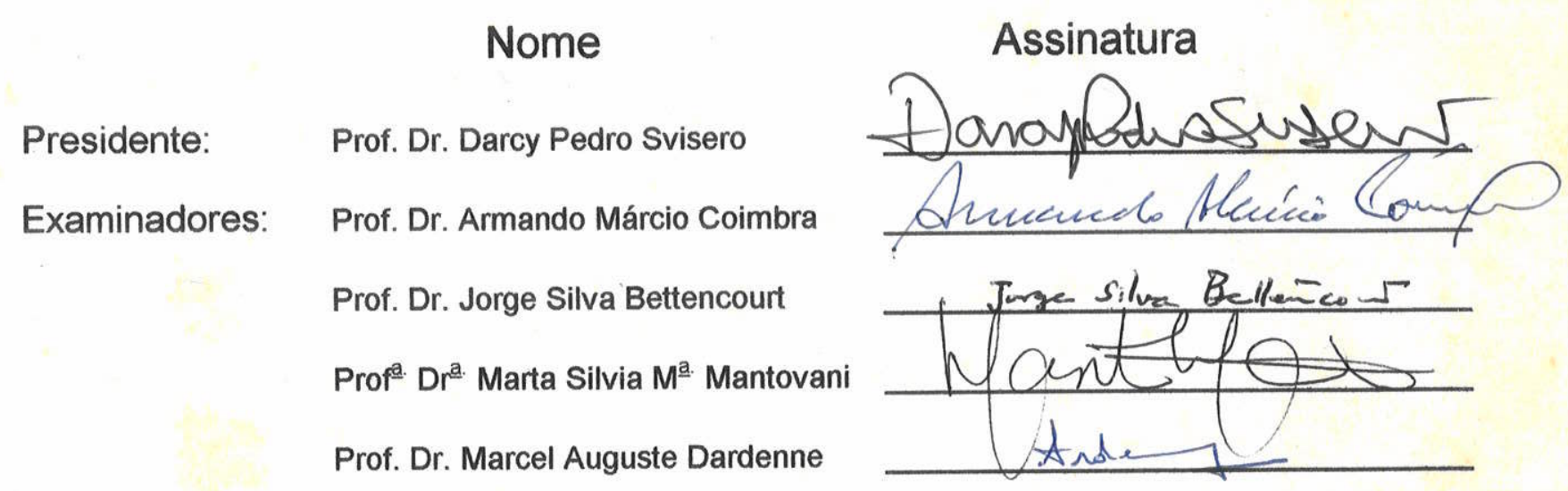

SÃO PAULO

1996 


\section{UNIVERSIDADE DE SĀO PAULO INSTITUTO DE GEOCIENCIAS}

\section{GEOLOGIA DA REGIĀO DIAMANTÍFERA DE POXORÉU E ÁREAS ADJACENTES, MATO GROSSO.}

Ricardo Kalikowski Weska

Orientador: Prof. Dr. Darcy Pedro Svisero

TESE DE DOUTORAMENTO

Programa de Pós-Graduação em Mineralogia e Petrologia
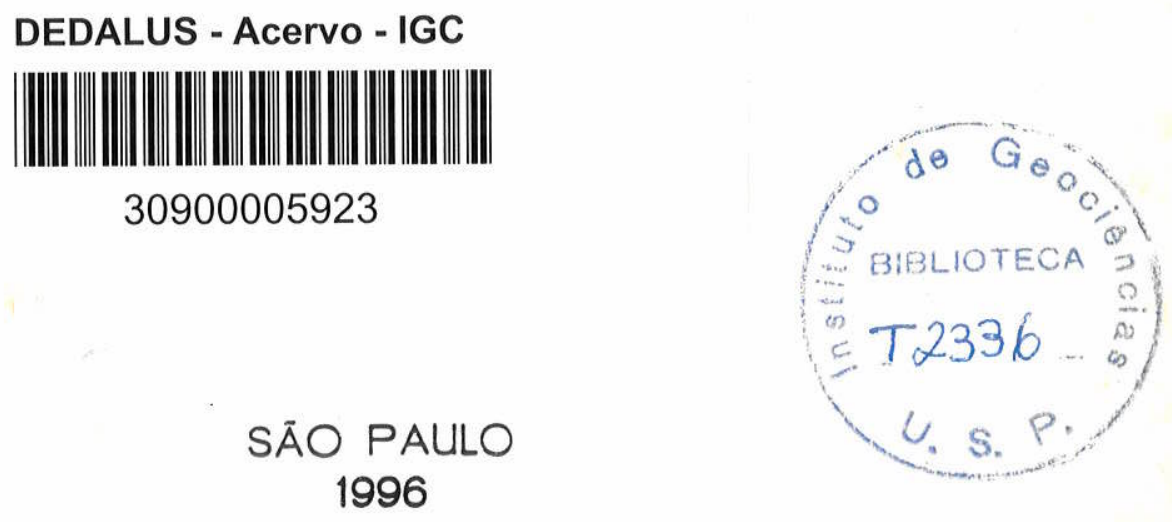
A

Adriana, Targus $e$

Bárbara. 


\section{Í N D I C E G ERA L}

\section{1 - INTRODUÇÃO}

1.1 - Localização e vias de acesso

1.2 - Histórico

1.3 - Objetivos desta Tese

1.4 - Plano de organização da Tese

\section{2 - MÉTODOS DE TRABALHO}

2.1 - Trabalhos de campo

2.1.1 - Mapeamento geológico

2.1.2 - Amostragem

2.2 - Trabalhos de laboratório

2.2.1 - Preparação de amostras

2.2.2 - Microscopia óptica

2.2.3 - Difração de raios X

2.2.4 - Fluorescência de raios $\mathrm{X}$

2.2.5 - Microssonda eletrônica

2.2.6 - Espectrometria de massa

2.2.7 - Digestão em ácido 
3- ASPECTOS FISIOGRÁFICOS 16

3.1 - Clima 16

3.2 - Vegetação e solos 17

3.3 - Relevo 19

3.4 - Hidrografia $\quad 22$

4 - GEOLOGIA REGIONAL 24

4.1 - Grupo Cuiabá 26

4.2 - Grupo Alto Paraguai 28

4.3 - Granito São Vicente 29

4.4 - Grupo Paraná, Formação Furnas 30

4.5 - Grupo Paraná, Formação Ponta Grossa 31

4.6 - Grupo Itararé, Formação Aquidauana 32

4.7 - Grupo Guatá, Formação Palermo 34

4.8 - Grupo São Bento, Formação Botucatu 35

4.9 - Grupo São Bento, Formação Serra Geral 36

4.10 - Grupo Iporá

4.11 - Grupo Bauru 39

4.12 - Formação Cachoeirinha 41

4.13 - Formação Pantanal 43

4.14 - Aluviões Atuais 44

5 - GEOLOGIA LOCAL 45

5.1 - A estratigrafia da região compreendida entre Dom Aquino e General Carneiro 
5.1.1 - Formação Aquidauana

5.1 .2 - Formação Palermo 56

5.1.3 - Formação Botucatu

5.1.4 - Antrusão Tamburi $\quad 59$

5.1.4.1 - Características geológicas $\quad 59$

- $\quad$ 5.1.5 - Formação Paredão Grande, Grupo Bauru 66

5.1.5.1 - Características macro e microscópicas dos Derrames da Raizinha

5.1.5.2 - Características macro e microscópicas das intrusões e extrusões de Paredão Grande e Meruri

5.1.5.3.- Características macro e microscópicas dos Derrames da Lajinha e do Córrego Preto

5.1.5.4 - Posicionamento estratigráfico, contatos e idades

5.1.5.5 - Características geoquímicas e isotópicas

- 5.1.6 - Formação Quilombinho, Grupo Bauru

- 5.1.7 - Formação Cachoeira do Bom Jardim, Grupo Bauru

3 5.1.8 - Formação Cambambe, Grupo Bauru

5.1.9 - Formação Cachoeirinha

5.1.10 - Unidade Terciário-Quaternário Indiviso

5.1.11 - Fácies Coité (Aluviões Atuais)

5.2. Ambientes deposicionais do Grupo Bauru e da Fácies Coité

6 - EVOLUÇÕES GEOMORFOLÓGICA $\quad$ E 134 GEOTECTÔNICA

6.1 - $\Theta$ condicionamento estrutural 
6.2 - Os elementos estruturais

6.3 - Evolução geomorfológica

6.4 - Evolução geotectônica

7 - TIPOS DE DEPÓSITOS E ARMADHLHAS DO

\section{DIAMANTE}

7.1 - Distribuição no espaço e no tempo

7.2 - Os tipos de depósitos

7.3 - As armadilhas (traps)

8 - ESTUDO DE MINERAIS PESADOS

8.1 - Amostragem

8.2 - Dados químicos

8.2.1 - Granadas

8.2.2 - Ilmenitas

8.2.3 - Espinélios

8.2.4 - Diamante

9 - CONCLUSÕES 


\section{ÍNDICE DE FIGURAS}

Figura 1 - Mapa de localização da região compreendida entre Dom Aquino a General Carneiro.

Figura 2 - Mapa geológico regional abrangendo a área estudada.

Figura 3 - Colunas estratigráficas comparativas entre trabalhos anteriores (a) e a proposta dessa Tese (b), Alvo PX.

Figura 4 - Colunas estratigráficas comparativas entre trabalhos anteriores (a) e a proposta dessa Tese (b), Alvo PG.

Figura 5 - Colunas estratigráficas comparativas entre trabalhos anteriores (a) e a proposta dessa Tese (b), Alvo DA.

Figura 6 - Mapa geológico de detalhe da região de Poxoréu, Alvo PX, escala 1:50.000.

Figura 7 - Mapa geológico de detalhe da Intrusão Tamburi, Alvo PG, escala 1:30.000.

Figura 8 - Mapa geológico de detalhe de Paredão Grande, Alvo PG, escala 1:15.000.

Figura 9 - Mapa geológico de detalhe da Colônia Indígena Meruri, Alvo PG, escala 1:30.000.

Figura 10 - Mapa geológico de detalhe da região de Dom Aquino, Alvo DA, escala $1: 50.000$.

Figura 11 - Coluna estratigráfica da região compreendida entre Dom Aquino a General Carneiro.

Figura 12 - Mapa geológico da Intrusão Tamburi e a posição dos poços de amostragens

$$
\left(\mathbf{P}_{1} \text { a } \mathbf{P}_{6}\right) \text {. }
$$

Figura 13 - Comparação entre a Intrusão Tamburi com as intrusões L1, L2 e L3; Indaiá I1

$$
\text { e I2. }
$$

Figura 14 - Coluna estratigráfica mostrando o contato entre as Formações Paredão Grande e Cachoeira do Bom Jardim (Alvo DA).

Figura 15 - Coluna estratigráfica da Formação Paredão Grande no Córrego Preto (Alvo 
DA) .

Figura 16 - A Província Ígnea de Poxoréu em relação as províncias de Iporá e Alto

Paranaiba.

Figura 17 - Diagrama álcalis versus sílica para rochas da Formação Paredão Grande.

Figura 18 - Tendência de contaminação crustal $\mathrm{Y} / \mathrm{Nb}$ versus $\mathrm{Zr} / \mathrm{Nb}$.

Figura 19 - Razões isotópicas $\mathrm{Nd}^{143} / \mathrm{Nd}^{144}$ versus $\mathrm{Sr}^{87} / \mathrm{Sr}^{86}$.

Figura 20 - Conglomerado basal da Formação Quilombinho, Grupo Bauru (Ponto MT-309).

Figura 21 - Coluna estratigráfica da Formação Quilombinho, Grupo Bauru, na

Fazenda Jataí.

Figura 22 - Coluna estratigráfica da Formação Cachoeira do Bom Jardim, Grupo Bauru na Caieira Rocha.

Figura 23 - Coluna estratigráfica da Formação Cachoeira do Bom Jardim. Grupo Bauru na Fazenda Santa Maria.

Figura 24 - Coluna estratigráfica da Formação Cachoeira do Bom Jardim, Grupo Bauru na Fazenda Primavera.

Figura 25 - Coluna estratigráfica da Formação Cambambe, Grupo Bauru no Morro do Quati.

Figura 26 - Coluna estratigráfica da Formação Cambambe, Grupo Bauru no Morro do Carvão.

Figura 27 - Coluna estratigráfica da Formação Cambambe, Grupo Bauru na Fazenda Chico Nunes.

Figura 28 - Coluna estratigráfica da Formação Cambambe, Grupo Bauru $3 \mathrm{~km}$ à SW da Fazenda Primavera.

Figura 29 - Coluna estratigráfica mostrando o contato basal entre as Formações Cachoeirinha e Cambambe. No topo, contato da Formação Cachoeirinha e 
a Unidade Terciário-Quaternário Indiviso.

Figura 30 - Coluna estratigráfica da Unidade Terciário-Quaternário Indiviso,

Fazenda Juracy Macedo.

Figura 31 - Coluna estratigráfica da Unidade Terciário-Quaternário Indiviso,

Alvo DA.

Figura 32 - Coluna estratigráfica da Fácies Coité, Alvo PX.

Figura 33 - Diagrama esquemático relativo à paleogeografia no Cretáceo Superior.

Figura 34 - Elementos estruturais da Bacia Bauru situada entre o sul do Cráton Amazonico e o noroeste da Bacia do Paraná.

Figura 35- Evolução geomorfológica regional envolvendo a área da Bacia Bauru entre o Cretáceo Superior e o Quartenário.

Figura 36 - Quadro tectônico da Bacia Bauru na regiâo de Poxoréu.

Figura 37 - Posições relativas da Província Ígnea Poxoréu e da Pluma de Trindade.

Figura 38 - Diagrama mostrando a atuação da Pluma de Trindade sobre os Estados de Mato Grosso, Goiás e Minas Gerais.

Figura 39 - Armadilhas do tipo travessão no Rio Coité, Alvo PX.

Figura 40 - Diagrama Ca-Mg-Fe de granadas da região de Poxoréu.

Figura 41 - Diagrama $\mathrm{CaO} \times \mathrm{Cr}_{2} \mathrm{O}_{3}$ das granadas estudadas.

Figura 42 - Diagrama MgO x FeO das ilmenitas estudadas.

Figura 43 - Diagrama ternário $\mathrm{FeTiO}_{3}, \mathrm{MgTiO}_{3}, \mathrm{Fe}_{2} \mathrm{O}_{3}$ das ilmenitas estudadas.

Figura 44 - Diagrama $\mathrm{Cr} / \mathrm{Cr}+\mathrm{Al}$ x $\mathrm{Fe} / \mathrm{Fe}+\mathrm{Mg}$ de espinélios.

Figura 45 - Diagrama $\mathrm{Fe}^{3+}+\mathrm{Ti} \times \mathrm{Fe} / \mathrm{Fe}+\mathrm{Mg}$ de espinélios.

Figura 46 - Diagrama de raios X do microdiamante na Intrusão Tamburi. 


\section{ÍNDICE DE FOTOGRAFIAS}

Fotografia 1 - Vegetação tipo cerrados e relevo plano (chapadões).

Fotografia 2 - Vegetação tipo matas ciliares e relevo de superfícies residuais.

Fotografia 3 - Forma de relevo tipo morros testemunhos e de blocos basculados.

Fotografia 4 - Relevo de forma convexa nos diques da Formação Paredão Grande.

Fotografia 5 - Em (a), estruturas "tepees" na Formação Palermo; e em (b), contato discordante erosivo entre as Formações Botucatu e Quilombinho.

Fotografia 6 - Vista geral da Intrusão Tamburi que se destaca na topografia em meio aos cerrados circundantes.

Fotografia 7 - Poço de amostragem de forma circular na Intrusão Tamburi. No fundo do poço destacam-se xenólitos sedimentares de tamanhos e natureza variada.

Fotografia 8 - Xenólitos na Intrusão Tamburi. Em (a), de rochas sedimentares das encaixantes; e em (b), de rochas ígneas máficas alteradas.

Fotografia 9 - Derrames da Raizinha como altos topográficos à Sul (a) e à Norte (b), Alvo PX.

Fotografia 10 - Outros diques e derrame da Formação Paredão Grande. Em (a), diques de Paredão Grande; em (b), dique Primavera; em (c), diques na Colônia Indígena Meruri; e em (d), derrame de topo da Lajinha.

Fotografia 11 - Aspectos macroscópicos das rochas da Formação Paredão Grande. Em (a), textura porfirítica e fragmentos de rocha; em (b), estrutura de fluxo; em (c), fraturamento; e em (d), esfoliação esferoidal.

Fotografia 12 - Detalhe dos conglomerados tipo basal da Formação Quilombinho, interdigitados por lente de argila conglomerática. $O$ conglomerado possue 
$>90 \%$ de clastos vulcânicos.

Fotografia 13 - Conglomerados intermediários da Formação Quilombinho com gradação inversa.

Fotografia 14 - Conglomerados intermediários da Formação Quilombinho interdigitados por lente de argila conglomerática.

Fotografia 15 - Matacão de basalto alterado com diâmetro $>50 \mathrm{~cm}$, segundo o eixo maior, em conglomerados intermediários da Formação Quilombinho.

Fotografia 16 - Lente de arenito argiloso com estratificação plana, interdigitada em conglomerados monomíticos da Formação Quilombinho.

Fotografia 17 - Lente de arenito argiloso com estratificação cruzada, interdigitada em conglomerados monomíticos da Formação Quilombinho.

Fotografia 18 - Conglomerados da Formação Cachoeira do Bom Jardim sobrepostos a arenitos argilosos conglomeráticos.

Fotografia 19 - Lentes de arenitos argilosos da Formação Cachoeira do Bom Jardim interdigitados por lentes de conglomerados.

Fotografia 20 - Arenito conglomerático da Formação Cachoeira do Bom Jardim, Alvo DA, com estratificação cruzada e Derrame da Lajinha no topo.

Fotografia 21 - Detalhe da estratificação plana e cruzada acanalada da Fotografia 20.

Fotografia 22 - Aspectos das calcretes da Formação Cachoeira do Bom Jardim. Em (a), frente de lavra na Caieira Rocha; em (b), calcrete nodular com recristalização de calcita em geôdos; em (c), calcrete laminar e favo de mel; e em (d) calcrete nodular com pelotas de argila.

Fotografia 23 - Arenito conglomerático da Formação Cambambe, Alvos DA e PX.

Fotografia 24 - Siltito argiloso silicificado interdigitado em conglomerados intermediários da Formação Cambambe, Morro do Quati.

Fotografia 25 - Tubos de sílica, característicos das silcretes da Formação Cambambe. 
Fotografia 26 - Formas bizarras de silcretes na Formação Cambambe.

Fotografia 27 - Contato entre as Formações Cambambe e Cachoeirinha.

Fotografia 28 - Crostas lateríticas (ferricretes).

Fotografia 29 - Cascalhos da Unidade Terciário-Quaternário Indiviso de arcabouço aberto, canal de corte e preenchimento no topo.

Fotografia 30 - Unidade Terciário-Quaternário Indiviso com cascalho de superfície 120 residual.

Fotografia 31 - Cascalhos de canal da Fácies Coité em discordância erosiva sobre rochas do Grupo Bauru.

Fotografia 32 - Cascalhos de canal da Fácies Coité recobertos por capeamento areno-argiloso.

Fotografia 33 - Cascalhos depositados sobre 'bedrock" irregular e recoberto por areias argilosas.

Fotografia 34 - Cascalhos coluviais da Fácies Coité em armadilha tipo bolsão.

Fotografia 35 - Elúvio sobre o capeamento da Unidade Terciário-Quaternário Indiviso (Alvo PX).

Fotografia 36 - Colúvio na Unidade Terciário-Quaternário Indiviso (Alvo PX).

Fotografia 37 - Depósitos aluviais situados nas cabeceiras do Rio Coité (Alvo PX).

Fotografia 38 - Depósitos aluviais na região da Raizinha (Alvo PX).

Fotografia 39 - Vista geral do Rio Coité nos depósitos formados à montante do travessão 1 (Figura 33).

Fotografia 40 - Armadilha tipo "veia" na Unidade Terciário-Quaternário Indiviso, Rio Coité, Alvo PX.

Fotografia 41 - Armadilha tipo "bolsão" na Unidade Terciário-Quaternário Indiviso, Raizinha, Alvo PX. 


\section{ÍNDICE DE FOTOMICROGRAFIAS}

Fotomicrografia 1 - Características microscópicas da Intrusão Tamburi. Em (a) macrocristal de granada com zoneamentos, nícois paralelos, aumento $25 \mathrm{x}$; em (b), macrocristal de flogopita circundada por carbonatos e na auréola um cristal de perovskita, nícois paralelos, aumento $12,5 \mathrm{x}$.

Fotomicrografia 2 - Características microscópicas da Formação Paredão Grande. Em (a), textura subofitica e traquítica, aumento $100 \mathrm{x}$; em (b), textura glomeroporfirítica, aumento $40 x$; em (c), bordas de reação no plagioclásio, aumento $40 \mathrm{x}$; e em (d), fragmento de rocha reagindo com a matriz, aumento $40 x$.

Fotomicrografia 3 - Características microscópicas dos diques da Formação Paredão Grande, de Paredão Grande e Colônia Indígena Meruri, aumento de 40x. Em (a), fenocristal de olivina; em (b), vidro vulcânico sob nícois paralelos; em (c), idem com nícois cruzados; e em (d), cristal de magnetita. 


\section{ÍNDICE DE TABELAS}

Tabela 1 - Localização e dimensões dos Derrames da Raizinha.

Tabela 2 - Quadro com a localização e dimensões das intrusões e extrusões na região de Paredão Grande.

Tabela 3 - Localização e dimensões dos diques da Colônia Indígena Meruri. $\quad 70$

Tabela 4 - Localização e dimensões dos Derrames da Lajinha e do Córrego Preto.

Tabela 5 - Diferenças petrográficas entre basaltos toleíticos e alcalinos (Hughes, 1982; In: Wilson, 1994).

Tabela 6 - Elementos maiores e traços das intrusões e extrusões da Formação Paredão Grande.

Tabela 7 - Em (a), cálculo de norma das rochas da Formação Paredão Grande; em (b) dados isotópicos $\mathrm{Nd}^{143} / \mathrm{Nd}^{144}$ e $\mathrm{Sr}^{87} / \mathrm{Sr}^{86}$ de algumas rochas dessa formação.

Tabela 8 - Amostragens de concentrados realizadas na Intrusão Tamburi e nas Formações Paredão Grande e Quilombinho.

Tabela 9 - Composição químicas de granadas da Intrusão Tamburi.

Tabela 10 - Composição química de granadas da Formação Paredão Grande.

Tabela 11 - Composição química de granadas da Formação Quilombinho.

Tabela 12 - Composição química de ilmenitas da Formação Quilombinho.

Tabela 13 - Composição química de ilmenitas da Intrusão Tamburi..

Tabela 14 - Composição química de espinélios da Intrusão Tamburi.

Tabela 15 - Composição química de espinélios da Formação Quilombinho. 


\section{RESUMO}

Nesta Tese foram desenvolvidos estudos geológicos gerais na região diamantífera situada entre os Municípios de Dom Aquino $\&_{a}^{\natural}$ General Carneiro, cobrindo uma área de aproximadamente $12.000 \mathrm{~km}^{2}$. O trabalho inclui também estudos químicos e isotópicos de rochas básicas de natureza basáltica, bem como estudos de química mineral de granadas, ilmenitas e espinélios presentes em algumas rochas básicas/ultrabásicas, conglomerados e sedimentos de corrente.

Durante o mapeamento regional foi elaborada uma nova coluna estratigráfica, cuja sequência da base para o topo, é constituída por um conjunto vulcânico-clasto-químico de idade cretácea, equivalente ao Grupo Bauru, englobando as Formações Paredão Grande, Quilombinho, Cachoeira do Bom Jardim e Cambambe. Seguem-se a Formação Cachoeirinha de idade terciáriaquaternária representando os eventos da Superficie Sul Americana na região, um pacote terciárioquaternário indiviso constituindo terrraços laterais de drenagens, e por fim a Fácies Coité no topo da coluna englobando as aluviões recentes. Essas duas últimas unidades encerram as mineralizações diamantíferas mais expressivas da região, concentradas em torno de Poxoréu.

A Formação Paredão Grande é constituída por rochas equivalentes a basaltos do tipo OIB, datados em 83,9 $\pm 0.4 \mathrm{Ma}$. pelo método $\mathrm{Ar}^{40} / \mathrm{Ar}^{39}$, englobados na Província Ígnea de Poxoréu e resultantes da atividade da Pluma de Trindade sob o Estado de Mato Grosso. As Formações Quilombinho, Cachoeira do Bom Jardim e Cambambe, de idade cretácea superior, são constituidas por sequências cíclicas de conglomerados, arenitos e argilitos conglomeráticos. A Formação Quilombinho é vulcano-derivada contendo mais de $90 \%$ de clastos da Formação Paredão Grande; a Cachoeira do Bom Jardim possui por volta de 50,0\% desse tipo de clastos, e destaca-se pela presença de calcretes. A Cambambe, quase desprovida de clastos vulcânicos, caracteriza-se pela presença de silcretes. Seguem-se a Formação Cachoeirinha com cascalhos, areias, argilas e ferricretes; um pacote terciário/quaternário indiviso, e a Fácies Coité com deposições de cascalhos, areias e argilas. 
Esse conjunto vulcano-clasto-químico, formado por leques aluviais, desenvolveu-se em uma bacia do tipo rifte denominado neste trabalho de Rifte Rio das Mortes. A evolução geomorfológica do Cretáceo Superior ao Quaternário, sugere que essa Bacia Bauru depositou-se sobre uma paleosuperficie de meio graben, cujo depocentro estaria localizado sob o vale atual do Rio das Mortes. Esta bacia está sendo capturada pelos eventos erosivos e deposicionais da Bacia Intracratônica do Pantanal.

Os depósitos diamantéros da área são representados por placeres localizados junto às drenagens, sobretudo em torno da cidade de Poxoréu. O diamante possui distribuição heterogênea e seus depósitos mais ricos estão condicionados por armadilhas de pequeno a grande porte. Esse mineral ocorre desde os conglomerados cretáceos (fonte intermediária) até cascalhos recentes. Suas fontes primárias ainda não foram localizadas na região. Contudo, no decorrer desse trabalho detectamos a presença de um microdiamante em uma intrusão básica/ultrabásica alterada denominada Intrusão Tamburi.

Os minerais pesados granadas, ilmenitas e espinélios amostrados na Intrusão Tamburi, em piroclásticas da Formação Paredão Grande e em conglomerados da Formação Quilombinho, são constituídos por duas populações distintas, com caracteristicas químicas diferentes de kimberlitos. As evidências de campo sugerem que a Intrusão Tamburi poderia ser a fonte alimentadora dos depósitos quaternários junto à drenagem adjacente do Rio Paraiso. Entretanto, ela não poderia ter contribuído para os ricos depósitos situados nas circunvizinhanças de Poxoréu. Dessa forma a origem primária desses diamantes continua sendo uma questão em aberto. 


\section{ABSTRACT}

During this thesis we carried out a large amount of geological surveys in an area of $12,000 \mathrm{~km}^{2}$ located between the Municipalities of Dom Aquino and General Carneiro, central east Mato Grosso State, Brazil.

Field work revealed a new stratigraphic column whose sequence from the bottom to the top is characterized by volcanic-clastic-chemical rocks of Late Cretaceous age equivalent to the Bauru Group, encompassing the Quilombinho, Cachoeira do Bom Jardim and Cambambe Formations. Next in the column lies the Tertiary-Quaternary Cachoeirinha Formation representing the the South American peneplanization in the area; an indivisible Tertiary-Quaternary sequence of terraces found along the fluvial system, and finally, the Coité Fácies representing recent placers. The latter two units contain the rich diamond-bearing deposits which have been mined around Poxoréu in the last decades.

The Paredão Grande Formation is made up of basic rocks equivalent to OIB basalts, dated at $83.9 \mathrm{Ma}$. by $\mathrm{Ar}^{40} / \mathrm{Ar}^{39}$ method. These rocks represent the magmatic events of the Poxoréu Igneous Province produced by the Trindade Plume under the State of Mato Grosso during the Late Cretaceous. The Late Cretaceous Quilombinho, Cachoeira do Bom Jardim and Cambambe Formations, are made up of cyclical sequences of conglomerates, arenites and conglomeratic clays. Furthermore, the Quilombinho Formation contains more than $90.0 \%$ volcanic clasts derived from the Paredão Grande Formation. As for the Cachoeira do Bom Jardim Formation, calcretes are conspicuous but volcanic clasts still amount to around $50.0 \%$. The Cambambe Formation is enriched in silcretes produced by evaporation under arid conditions and depleted in volcanic clasts. The Cachoeirinha Formation is made up of gravels, sands, clays and ferricretes; the indivisib Tertiary-Quaternary unit and the Coité Fácies are both composed of gravels, sands and clays.

This volcanic-clastic-chemical sequence developed as an isolated basin, herein named the Rio das Mortes Rift. Geomorphological evolution from the Late Cretaceous till the 
Quaternary suggests that this basin was developed upon a paleosurface of a half-graben. Its depocenter was located under the current Rio das Mortes Valley. Presently, the basin is being eroded by processes related to the Intracratonic Pantanal Basin.

Diamond-bearing deposits are widespread throughout the area, being particularly rich around the locality of Poxoréu. Diamond distribution is heterogeneous but the presence of traps accounts for the concentrations worked in some diggings. Chemical analyses of pyrope garnets, magnesium ilmenites and chromium spinels recovered from pyroclastic rocks of the Paredão Grande Formation, Tamburi Intrusion, Quilombinho Formation and stream sediments revealed the presence of two distinct populations unrelated to kimberlites. The presence of a microdiamond recovered in the Tamburi intrusion could represent the source of some deposits but not of the entire diggings around Poxoréu. Therefore, the origin of Poxoréu diamonds still remains unknown. 


\section{1 - INTRODUÇÃO}

O Estado de Mato Grosso tem sido um produtor importante de bens minerais desde os tempos coloniais. Nesse sentido, o ouro já era conbecido no final do século XVI, porém dados oficiais só são conhecidos a partir do século XVIII, entre 1721 a 1725 (Pinto, 1979 apud Amaral, no prelo), com uma produção total nesse período da ordem de $600 \mathrm{~kg}$. $\mathrm{O}$ diamante, por sua vez, foi descoberto primeiramente nas porções de cabeceiras do Rio Paraguai, tendo sido explorado à época do Império a partir do ano de 1746 (Baxter, 1988), pouco depois das descobertas iniciais da região de Diamantina, Minas Gerais, durante a terceira década do século XVIII (Abreu, 1973). A descoberta e a expansão da exploração do diamante na região de Poxoréu teve início a partir da segunda década do presente século, mais precisamente no ano de 1924 (Baxter, 1988), no Rio das Pombas, afluente do Rio São Lourenço. As descobertas ocorridas mais tarde nas cabeceiras do Rio Poxoréu deram origem a um povoado que evoluiu para a cidade homônima atual.

Modernamente, o Estado vem sendo o maior produtor nacional de diamantes nos últimos cinco anos, conforme dados do Departamento Nacional da Produção Mineral. Existem garimpos em praticamente todas as bacias hidrográficas, com ênfase para aquelas situadas na região noroeste (Juína-Aripuanã), e porções centrais como as cabeceiras dos Rios Paraguai (Arenápolis-Diamantino), Cuiabá (Chapada dos Guimarães), Vermelho (Poxoréu-Dom Aquino) e dos Rios Teles Pires e Xingu (Paranatinga). Garimpos situadas nas porções extremo sudeste (Itiquira) e extremo leste do Estado, região de cabeceiras do Alto Araguaia, são também regiões produtoras de diamante aluvionar, porém são mais antigas que as anteriores. Além disso, merece destaque a lavra mecanizada que opera na Fazenda Camargo, Município de Nortelândia. A região compreendida pelos Municípios de Poxoréu, Dom Aquino e General Carneiro, é um dos polos produtores importantes do Estado, destacando-se n̉ela os garimpos de Poxoréu. A exemplo do que se observa nas demais regiões diamantíferas do Brasil, o diamante de Poxoréu e áreas adjacentes é explorado a partir de jazidas aluvionares recentes, situadas junto aos canais atuais, em suas planícies de inundação e nos terraços laterais mais antigos. Em menor escala, é explorado também, em conglomerados das Formações Quilombinho e Cachoeira do Bom Jardim 
do Grupo Bauru (Fleischer, 1993), nos Garimpos da Raizinha, Jaraguá e Buritizal e nos Garimpos Balaio de Gato e da Raizinha (Weska et al., 1993). Além disso, existem explorações similares em aluviões recentes, como por exemplo na Formação Pantanal ao longo do Rio Cuiabá, bem como em leques aluviais do Terciário na Formação Cachoeirinha e Facies Estiva, na Chapada dos Guimarães (Weska, 1987 e Weska et al., 1991). Outros autores trabalhando na região, admitem também a possibilidade de que os pacotes cretáceos poderiam ser a fonte intermediária do diamante dos pacotes aluvionares quaternários, como por exemplo Schobbenhaus et al. (1984), Gonzaga \& Tompkins (1991) e Svisero (1994).

Com relação à fonte primária do diamante, também aqui são conhecidos corpos intrusivos mineralizados de natureza kimberlítica, nas regiões de Paranatinga e Juína. O problema é complexo, não havendo dados oficiais sobre essas rochas e nem informações sobre a presença ou não de minerais kimberlíticos associados ao diamante na área, com exceção de uma citação de Gonzaga \& Tompkins (1991) sobre a presença de um kimberlito no "graben" de Poxoréu.

A partir dos trabalhos realizados nesta Tese envolvendo mapeamento, amostragem, análises e interpretações dos tipos litológicos do Grupo Bauru e das intrusões e extrusões a eles associados ( Formação Paredão Grande ), bem como de uma intrusão alterada (Tamburi), associados a dados do autor a respeito das regiões de Chapada dos Guimarães e Paranatinga, pretende-se propor um modelo para a origem do diamante da região, diferenciado da proposta glaciogênica de Gonzaga \& Tompkins (1991) e Gonzaga (1993), respectivamente para os Estados de Minas Gerais e Piauí.

\section{1 - Localização e vias de acesso}

A região de estudo situa-se na porção centro leste do Estado de Mato Grosso, distando em linha reta aproximadamente 140 a $320 \mathrm{~km}$ de Cuiabá (Figura 1). A descrição dos acessos rodoviários serão subdivididos em alvos, como melhor forma de situar as áreas e adequar a sistemática de descrição dos estudos desenvolvidos. Tomando-se como ponto de partida a capital do Estado, percorre-se a BR 364/163, em direção a Rondonópolis, por estrada asfaltada até o entroncamento dessa rodovia com a BR-070, totalizando $87 \mathrm{~km}$. A partir daí, toma-se à esquerda, a BR-070, estrada asfaltada em direção a Primavera do Leste. Percorridos $46 \mathrm{~km}$, passa-se pela cidade de Campo Verde e a $95,2 \mathrm{~km}$ atinge-se o ponto extremo oeste da região estudada, no Município de Dom Aquino, denominada nesse trabalho alvo Dom Aquino 


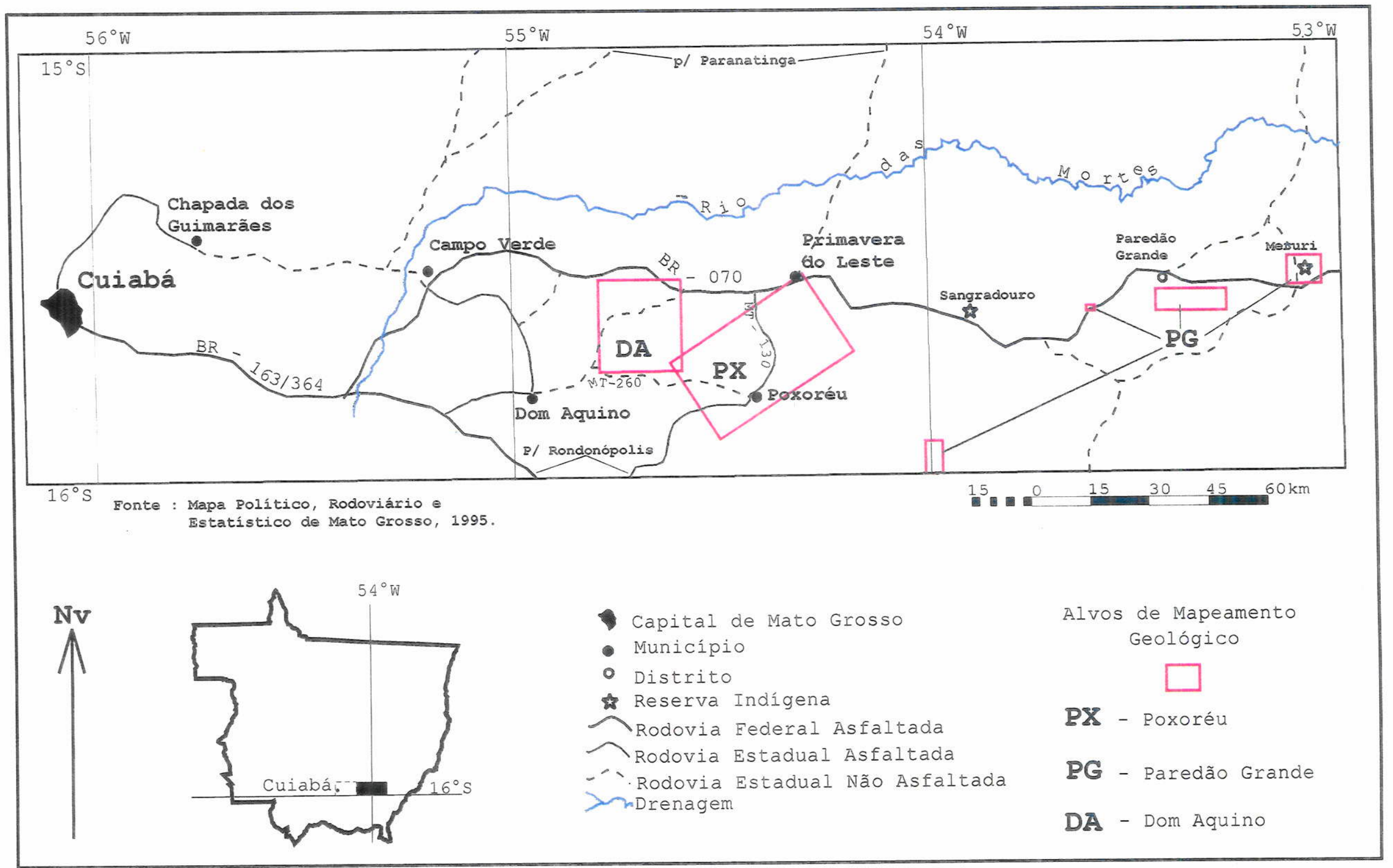

Figura 1 - Localização geográfica da área estudada e vias de acesso 
(DA) (Figura 1). A partir desse ponto e continuando-se pela mesma rodovia federal, em direção leste, após 47,5km atinge-se o entroncamento entre a BR-070 e a MT-130. Desse entroncamento chega-se à cidade de Poxoréu após $35 \mathrm{~km}$ de asfalto, a região intermediária da área de pesquisa, situada no Município de Poxoréu e aqui denominada alvo Poxoréu (PX) (Figura 1). Para chegar-se a porção extremo leste da área, toma-se a continuação da estrada federal, trecho compreendido entre Primavera do Leste e Barra do Garças. Os acessos para os alvos estudados, a partir da cidade de Primavera do Leste, possuem as seguintes distâncias: a) entrada para o corpo Tamburi a $50,25 \mathrm{~km}$ para a direita; b) o dique Primavera a $108,60 \mathrm{~km}$ aflorando no corte da estrada; c) os corpos intrusivos de Paredão Grande a $136 \mathrm{~km}$ aflorantes a direita da estrada; e d) entrada para os corpos situados na Colônia Meruri 172km de Primavera do Leste e à esquerda da rodovia. Todos esses pontos foram incluídos no alvo denominado de Paredão Grande (PG) (Figura 1) em referência a localidade de mesmo nome, Distrito do Município de General Carneiro.

Além dos acessos asfaltados, onde a BR-070 cruza toda a região de estudos, há uma malha de estradas estaduais não asfaltadas, como por exemplo a MT-260 ligando Poxoréu a Dom Aquino, as MT-434 e 455 de acesso a Dom Aquino, bem como a MT-373 de acesso a Poxoréu, que interligam-se a BR-070. Estradas vicinais ou trilhas unem-se às estaduais e federais, permitindo assim que os alvos como um todo fossem mapeados de forma adequada. As estradas ou trilhas possuem boas condições de trafegabilidade durante a estação seca do ano (abril a agosto). Durante a estação chuvosa (setembro a março) esses acessos nas regiões dos alvos DA e PG podem tornar-se inacessíves e de risco para trabalhos de campo; entretanto, é durante esse período que os afloramentos estão mais bem expostos, ao contrário do período da seca onde os mesmos são encobertos pela poeira.

\section{2 - Histórico}

No âmbito da área estudada, o Município de Poxoréu vem se destacando como o maior produtor de diamante; no restante da área a produção é esporádica e restrita a alguns poucos garimpos. A nível estadual, Poxoréu sempre ocupou posição de destaque no desenvolvimento de lavras diamantíferas (Garimpos da Maria Pina, Faz. São João, do Rio das Pombas, da Raizinha, do Balaio de Gato, entre outros), nas cabeceiras e afluentes dos Rios 
Poxoréu e São Lourenço, onde foram extraídas gemas de excelente qualidade, mas que por falta de fiscalização beneficiaram pouco o nível de vida da sociedade local.

A procura de ouro pelos Bandeirantes no decorrer do século dezoito impulsionou a colonização do centro-oeste mato-grossense e trouxe como resultado, a formação de inúmeros núcleos urbanos na região. Muitos evoluíram e transformaram-se em grandes cidades como a capital Cuiabá, enquanto outros continuam sendo núcleos de pequeno porte, como é o caso de Poconé, Livramento, Chapada dos Guimarães, Diamantino, entre outros. A história do diamante de Poxoréu foi tratada de forma brilhante e completa por Baxter (1988) sob o ponto de vista sócio-econômico e ambiental. Nesse trabalho o autor expõe as inúmeras questões que acompanham esses ciclos rápidos e curtos de geração de riquezas, associados a conflitos entre grupos, proprietários de terras e garimpeiros, conflitos entre garimpeiros e populações indígenas, flutuação da população dos núcleos garimpeiros, entre outros.

No final dos anos setenta, a empresa Mineração São José Ltda. do Grupo Saint Joe, após intensos trabalhos de pesquisa ao longo do Rio Coité, descobriu uma jazida de pequeno a médio porte rica em diamante. Esse fato tornou-se público e a empresa foi invadida por garimpeiros apoiados por lideranças políticas e compradores de diamante. A região de Coité presenciou então uma nova explosão da atividade garimpeira nas proximidades de Poxoréu no início dos anos 80. Não existem dados oficiais de produção e do contingente humano envolvido, mas sabe-se a partir de estimativas da Prefeitura Municipal de Poxoréu que 180 dragas de sucção e 5.000 garimpeiros (Baxter, 1988) extrairam, depredaram e exauriram a jazida descoberta pela empresa. Em função do sucesso alcançado pelos garimpeiros em Coité que obtiveram inclusive a demarcação de uma reserva garimpeira (Portaria Ministerial $\mathbf{n}^{\circ} 2.230$, de 08/11/1979 e publicada no Diário Oficial da União em 12/11/1979), tal procedimento tornou-se moda no início e meados dos anos 80 com a invasão de outros empreendimentos minerais em Nortelândia-Arenápolis (Mineração Santana Ltda., Grupo Brascan), Juína (Mineração Itapená Ltda., Grupo De Beers) e região de Alta Floresta (Mineração Jaruana Ltda.). O conflito entre garimpeiros e empresas, insuflados por interesses políticos em épocas eleitorais e a incompetência administrativa dos órgãos federais em aplicar a legislação mineral vigente, causaram prejuízos enormes às empresas de mineração, ao Estado de Mato Grosso, ao povo e à nação brasileira. Nos dias atuais, Poxoréu está passando por um período de profundo declínio, uma vez que após quase um século com vários ciclos de intensa atividade, as jazidas aluvionares 
mais fáceis foram praticamente exauridas ou depredadas por falta de controle e fiscalização por parte dos órgãos públicos.

\section{3 - Objetivos desta Tese}

A área em apreço possue grande importância econômica no desenvolvimento da atividade exploratória do diamante. Apesar disso, os conhecimentos geológicos disponíveis encontram-se ainda em fase pioneira, razão pela qual escolhemos como alvos desta Tese os itens listados a seguir.

a) Mapear a área em questão procurando elucidar as relações entre os diversos tipos litológicos existentes.

b) Discutir a evolução geomorfológica da área delineando as drenagens do Cretáceo ao Recente.

c) Delinear o arcabouço geotectônico da área, do Cretáceo ao Quaternário, com vistas a elucidar o comportamento da distribuição do diamante.

d) Caracterizar os tipos de depósitos de diamante na região.

e) Estudar os minerais pesados com o intuito de identificar fases de filiação kimberlítica, eventualmente presentes na área, a partir de amostras em conglomerados e rochas piroclásticas cretáceas.

f) Caracterizar a intrusão Tamburi uma das possíveis áreas fontes primárias do diamante.

g) Identificar as áreas fontes do diamante aluvionar.

h) Estabelecer um modelo para a origem do diamante na região.

\section{4 - Plano de organização da Tese}

No decorrer desta Tese procuramos reunir o maior número possível de informações no afã de tratar não somente as ocorrências diamantíferas da região de Poxoréu, mas também, na medida do possível as demais questões pertinentes ao diamante. Esta postura nos obrigou a incursionar por vários ramos do conhecimento geológico, e ao mesmo tempo, fazer uso de 
metodologia variada na tentativa de resolver os problemas levantados na área. Para facilitar a exposição bem como a compreensão dos tópicos abordados, julgamos ser conveniente a apresentação do plano de organização utilizado nesta Tese.

Após a introdução (Capítulo 1), segue-se um bloco relativo aos métodos de investigação usados onde são discutidos todos os procedimentos de campo e de laboratório. Trata-se de um capítulo importante onde apresentamos e justificamos a sistemática usada nos mapeamentos, bem como as diversas técnicas analíticas usadas, identificando os laboratórios e aparelhos usados (Capítulo 2). No Capítulo 3 relativo aos aspectos fisiográficos e no Capítulo 4 relativo à geologia regional, apresentamos o quadro regional no qual está inserida a área de estudo e os trabalhos já executados. O Capítulo 5 trata das questões geológicas das áreas mapeadas destacando-se a estratigrafia do Cretáceo ao Quaternário, incluindo a intrusão Tamburi, uma estrutura isolada na área na qual foi encontrado um microdiamante. Esse capítulo incluí ainda dados geoquímicos das rochas de composição basáltica, o condicionamento estrutural, os ambientes de sedimentação e a evolução geomorfológica e tectônica da área. $O$ capítulo 6 versa sobre os tipos de depósitos de diamantes, sua distribuição no espaço e no tempo, bem como os tipos de armadilhas desse mineral definidos na região. O Capítulo 7 trata dos minerais pesados presentes nos placeres atuais, nos conglomerados da Formação Quilombinho, nas rochas piroclásticas da Formação Paredão Grande e na intrusão Tamburi. No Capítulo 8 discutimos a origem do diamante da região levando em conta todos os conhecimentos até então existentes, bem como aqueles obtidos no decorrer desta Tese. $O$ volume encerra-se com as Conclusões Finais (Capítulo 9), os Agradecimentos (Capítulo 10) e as Referências Bibliográficas (Capítulo 11). 


\section{2 - MÉTODOS DE TRABALHO}

Os estudos que realizamos no decorrer deste trabalho podem ser divididos em trabalhos de campo e de laboratório. Os trabalhos de campo permitiram a obtenção e a interpretação de dados do arcabouço geológico das rochas hospedeiras do diamante que, aliadas às análises e identificações realizadas em diversos laboratórios permitiram a elaboração do texto ora apresentado.

\section{1 - Trabalhos de campo}

Os trabalhos desta tese constituem parte de um contexto maior que iniciamos bem antes do início formal dos nossos estudos de pós-graduação. Eles remontam ao período em que o autor desenvolveu atividades de prospecção de diamante em placeres na iniciativa privada, quando então entrou em contato com os problemas que iriam constituir os seus objetivos na vida acadêmica.

\subsection{1 - Mapeamento geológico}

As áreas de estudo (Figura 1) foram selecionadas por reunir simultaneamente diversidade litológica, condições favoráveis para um aprofundamento da geologia do diamante, relativa proximidade da capital do Estado e, por reunir diversas questões geológicas concernentes às mineralizações diamantíferas ainda não totalmente esclarecidas.

Inicialmente foram localizadas diversas áreas alvo nas quais foram realizados mapeamentos geológicos em escalas de 1:50.000 a 1:15.000, por alunos de graduação da UFMT nos semestres 91/2, 92/1 e 92/2. Foram usadas cartas topográficas da Diretoria de Serviço Geográfico do Ministério do Exército, na escala 1:100.000, com as seguintes denominações: Dom Aquino, SD. 21-Z-D-V, ano 1976; Poxoréu, SD. 21-Z-D-VI, ano 1976; Batovi, SD. 22Y-C-IV, ano 1977 e Colônia Meruri, SD. 22-Y-C-V, ano 1977. Fotografias aéreas da USAF 
em preto e branco de 1965-66 na escala 1:60.000, imagens de radar executadas pela LASAEngenharia e Prospecções S.A. na escala 1:250.000 de 1975/76 e imagens de satélite na escala de 1:100.000 de 1986/88/92, complementaram os trabalhos de interpretação fotogeológica e a produção dos mapas finais. As etapas de campo foram precedidas de um levantamento bibliográfico a respeito dos projetos executados anteriormente.

\subsection{2 - Amostragem}

Amostras de sedimentos de corrente com pesos de $20 \mathrm{~kg}$ foram obtidas nas drenagens ativas, preferencialmente em armadilhas como aquelas descritas por Weska et al. (1984) e Muggeridge (1986). Posteriormente, as amostras foram separadas granulometricamente em peneiras utilizadas em garimpos de diamantes, denominadas popularmente de refina $1,6 \mathrm{~mm}$; fina $2,0 \mathrm{~mm}$; média $3,6 \mathrm{~mm}$; grossa $6,0 \mathrm{~mm}$ e sururuca $20,0 \mathrm{~mm}$. O resíduo final abaixo de $1,6 \mathrm{~mm}$ foi concentrado em bateia.

A intrusão Tamburi foi amostrada por meio de 6 (seis) poços, com dimensões de $2 \times 2 \mathrm{~m}$, por até $3,5 \mathrm{~m}$ de profundidade em média, os quais forneceram descrições geológicas e amostras com pesos de $250 \mathrm{~kg}$. A mesma metodologia foi utilizada em afloramentos na obtenção de 6 (seis) amostras das rochas vulcanoclásticas e conglomerados da Formação Quilombinho. Destas 12 (doze) amostras, 8 (oito) - sendo 2 (duas) da intrusão Tamburi, 1 (uma) das rochas vulcanoclásticas e 5 (cinco) dos conglomerados, foram encaminhadas ao laboratório Nomos, Rio de Janeiro, para a separação e análise dos resistatos representados pelas granadas, ilmenitas e espinélios, bem como digestão em ácido para testar a presença ou não de microdiamante.

Foram amostradas também rochas intrusivas e extrusivas de Poxoréu, Dom Aquino e Paredão Grande para estudos microscópicos e análises químicas. Esse material, após devidamente selecionado, foi encaminhado para a Universidade de Durham, para as análises químicas pertinentes.

\section{2 - Trabalhos de laboratório}

Os trabalhos de laboratório incluíram diversos tipos de procedimentos, uma vez que estudamos rochas frescas (basaltos), minerais residuais de concentrados (acompanhantes do diamante) em sedimentos de corrente, além de minerais separados das rochas alteradas da 
intrusão Tamburi, de vulcanoclásticas associadas aos basaltos e de conglomerados da Formação Quilombinho do Grupo Bauru. Em virtude da variedade e diversidade dos problemas envolvidos na obtenção desses dados, discutiremos a seguir separadamente cada um dos métodos utilizados.

\subsection{1 - Preparação de amostras}

Durante os trabalhos de campo foram coletadas um grande número de amostras de rochas e de concentrados. As amostras de rochas do Grupo Bauru, dos basaltos e da intrusão Tamburi foram laminadas em seções delgadas, submetidas a descrições petrográficas e fotografadas em microscópios disponíveis na Universidade Federal de Mato Grosso (UFMT), Universidade de Durham e IG/USP. Apesar de várias tentativas, as amostras da intrusão Tamburi não forneceram lâminas de qualidade adequada para estudos petrográficos, devido a facilidade de alteração destas rochas frente ao forte intemperismo que se processa na região. Por esta razão, os dados aqui descritos a respeito deste corpo tem por base descrições macroscópicas e de química mineral dos minerais resistatos. Basaltos isentos de alteração compreendendo 17 (dezessete) amostras com peso médio de $200 \mathrm{~g}$ por amostra foram enviados à Universidade de Durham, sendo outras 2 (duas) encaminhadas à GEOLAB-Belo Horizonte. Todas as amostras foram analisadas para elementos maiores e menores. Entre aquelas encaminhadas à Inglaterra, 6 (seis) amostras foram analisadas pelos métodos $\mathrm{Sr}^{87} / \mathrm{Sr}^{86}$, $\mathrm{Nd}^{143} / \mathrm{Nd}^{144}, \mathrm{Ar}^{40} / \mathrm{Ar}^{39}$ (1) e $\mathrm{K}^{39} / \mathrm{Ar}^{40}$ (3). No estudo dos minerais satélites do diamante das amostras coletadas nos cascalhos, conglomerados, rochas vulcanoclásticas e na intrusão Tamburi, foram utilizadas as amostras concentradas em campo a partir de peneiras ou bateia, seguindo os intervalos granulométricos descritos anteriormente. Os grãos de granadas, espinélios e ilmenitas podem ser identificados no campo a partir de suas características fisicas. As granadas, por exemplo, foram reconhecidas pela sua cor castanha alaranjada, vermelha escura a vinho (púrpura), bem como pela sua borda fibrosa de kelifita, resultante do contato entre a matriz da rocha com o mineral; as ilmenitas por sua cor negra, brilho metálico e fratura conchoidal a subconchoidal; os espinélios, por sua vez, exibem textura fosca e quando fragmentados tornam-se transparentes de cor champanhe, podendo ocorrer também nas cores laranja a marrom avermelhada. Os minerais em questão foram separados em lupas binoculares Olimpus, com o auxílio de agulhas acondicionadas em tubos plásticos e posteriormente encaminhados ao 
laboratório Nomos para análises. Os pesados amostrados nos cascalhos quaternários foram estudados pelos métodos tradicionais compreendendo separação magnética com uso de imã, lupa binocular, lâminas delgadas, líquidos de densidade conhecida (bromofórmio) e luz uitravioleta, principalmente.

\subsection{2 - Microscopia óptica}

Essa técnica tradicional foi amplamente utilizada nas caracterizações petrográficas das várias litologias existentes na área de estudo. Como já mencionado anteriormente, foi útil também para a caracterização preliminar das fases mineralógicas componentes das assembléias de minerais pesados presentes nos conglomerados, na intrusão Tamburi e nas jazidas mineralizadas a diamante do Quaternário. No decorrer desses trabalhos fizemos uso de vários microscópios, entre eles os fotomicroscópios Zeiss Axioplan do Instituto de Geociências da USP e do Departamento de Recursos Minerais da UFMT, bem como o microscópio Olimpus binocular da Universidade de Durham, Inglaterra.

\subsection{3 - Difração de raios $X$.}

De forma análoga, também essa técnica clássica de identificação de minerais foi usada para comprovar a natureza do microdiamante encontrado na amostragem dirigida da intrusão Tamburi. Esse trabalho foi realizado na câmara Gandolfi do IG/USP com tempo de exposição de 12 horas.

\subsection{4 - Fluorescência de raios $X$.}

Trata-se de um dos métodos tradicionais de análise de rochas usadas na obtenção de dados de elementos maiores, menores e terras raras. Neste caso, as análises são efetuadas utilizando-se discos fundidos e peletes, ambos com diâmetro de $32 \mathrm{~mm}$, respectivamente para elementos maiores e traços. No caso dos peletes deve-se tomar cuidado com a homogeneização da amostra durante a preparação, fato que não ocorre com os discos fundidos onde a fusão naturalmente homogeniza. Um tubo de raios $X$ de ródio é usado normalmente para a análise 
tanto dos elementos maiores como menores. A calibração do equipamento é feita por um grupo internacional de rochas padronizadas variando de composição entre dunitos e granitos.

As concentrações de elementos traços são determinadas usando-se radiações com comprimentos de onda que variam de $0,75 \AA(\mathrm{NbK} \alpha)$ a $3,03 \AA(\mathrm{ScK} \alpha)$. Elementos mais pesados que o $\mathrm{Nb}(\mathrm{Ba}, \mathrm{La}, \mathrm{Ce}, \mathrm{Nd}, \mathrm{Pb}, \mathrm{U}$ e $\mathrm{Th})$ são medidos usando-se a radiação $\mathrm{L} \alpha$ com comprimento de onda variando entre 0,96-2,78 $\AA$. A efetiva penetração dos raios $X$ na amostra é uma função inversa do comprimento de onda e da granulometria do material geológico que varia de $100 \mu$ para o $\mathrm{ScK} \alpha$ até $3 \mathrm{~mm}$ para $\mathrm{NbK} \alpha$. Assim sendo, para alguns elementos traços como $\mathrm{Sc}, \mathrm{V}, \mathrm{Cr}$, $\mathrm{La}, \mathrm{Ce}$ e Nd o espectrometro somente consegue medir em granulometrias entre 100 a $200 \mu$. Por essa razão é importante que as amostras em peletes estejam homogeneizadas nesta escala, caso contrário, ocorrerão problemas de leitura do equipamento. Inicialmente as amostras com pesos entre 10 a $15 \mathrm{~g}$, foram separadas em dois grupos (amostra e contra-amostra) com pesos entre 4 a 5g. A pesagem foi feita em balança digital de precisão tipo AJ100 - Mettler e a seguir etiquetadas. Posteriormente, foram trituradas em prensa hidráulica e pulverizadas em moinho de bolas de ágata.

A confecção de peletes consiste resumidamente na colocação de uma porção de rocha em um becker, com 10 a 20 gotas de um impregnador (cola). A mistura é homogeneizada com a utilização de um pistilo, colocada em um molde de aço e levada a uma prensa submetida a 7-8 toneladas, sendo assim deixada entre 10 a 15 minutos. Finalizando, os peletes são retirados da forma e levados à secagem em temperatura de $100^{\circ} \mathrm{C}$ por 24 horas.

Para a análise dos elementos maiores, foram preparados discos de vidro fundidos obtidos a partir de amostras pesando entre 0,45 a $0,50 \mathrm{~g}$, previamente conservados no vácuo para evitar a umidade. As amostras foram misturadas com o fundente Spectroflux 100B, Johnson Matthey, que é uma mistura de metaborato e tetraborato de lítio, usando-se a proporção de 5 partes em peso de fundente para uma parte de amostra. A amostra é homogeneizada, colocada em cadinho de platina e tampada. Os cadinhos com as amostras são colocados no forno a $1050^{\circ} \mathrm{C}$ por um tempo mínimo de 20 minutos. O material fundido é retirado e rapidamente colocado em um molde, e prensado manualmente; todo procedimento final é realizado sobre uma chapa aquecida. Os discos de fusão são vítreos; se forem de cor amarela a champanhe escura normalmente correspondem a basalto; os incolores correspondem a granito e os verdes à rochas de natureza ultrabásica. 
Os elementos maiores foram determinados com a utilização de um espectrômetro de fluorescência de raios X Philips PW1400, incorporado com um alternador de amostras PW1500/10. Um tubo anódico de Rh foi usado para a excitação e um dispersador de picos $\mathbf{R h}$ Compton, foi utilizado para correções de absorção. Os elementos traços $\mathrm{Ba}, \mathrm{Cr}, \mathrm{Nb}, \mathrm{Ni}, \mathrm{Rb}, \mathrm{Sr}$, $\mathrm{V}, \mathrm{Y}, \mathrm{Zn}$ e $\mathrm{Zr}$, analizados a partir dos peletes foram determinados no mesmo aparelho. As correções apropriadas foram feitas com a sobreposição de $\mathrm{NbK} \alpha$ por $\mathrm{YK} \beta, \mathrm{ZrK} \alpha$ por $\operatorname{SrK} \beta$, YK $\alpha$ por $\mathrm{RbK} \beta$, BaL $\alpha$ por $\mathrm{TiK} \beta, \mathrm{NiK} \alpha$ por $\operatorname{CoK} \beta, \mathrm{VK} \alpha$ por TiK $\beta$ e CrK $\alpha$ por VK $\beta$. Em casos onde o $\mathrm{BaO}$ e o SrO são determinados como elementos maiores, devem ser efetuadas correções de intensidades de absorção de massa.

\subsection{5 - Microssonda eletrônica}

Trata-se do método mais importante de investigação de química mineral na atualidade. O uso da microssonda em problemas geológicos teve início no final dos anos sessenta, ampliouse nas duas últimas décadas de modo tão intenso, que hoje é praticamente o método isolado mais utilizado em análises químicas minerais. Os princípios fundamentais do método bem como um resumo das suas aplicações em questões geológicas foram apresentados por Gomes (1980).

No decorrer deste trabalho fizemos uso desta técnica para analisar minerais resistatos de três situações distintas: a) componentes pesados dos conglomerados da Formação Quilombinho; b) resistatos obtidos pela lavagem da brecha alterada constituinte de uma intrusão com características de kimberlito situada a sudeste de Poxoréu, e c) das fácies piroclásticas associadas aos diques e derrames de composição basáltica. Dentre os minerais recuperados nas situações descritas só foram analisadas fases com possibilidades de filiação kimberlítica, ou seja, granadas, ilmenitas e espinélios. Todas as análises foram executadas na microssonda eletrônica do Instituto de Geociências da Universidade de Brasília, que é um modelo Cameca, operado sob condições de 10 a $25 \mathrm{kV}$ e $30 \mathrm{nA}$. Durante as análises foram empregados os programas padrões usados na rotina do referido laboratório, individualizando inclusive $\mathrm{Fe}^{+3}$ do $\mathrm{Fe}^{+2}$. Ao todo foram realizadas 398 análises distribuídas entre 135 granadas, 116 ilmenitas e 147 espinélios. 


\subsection{6 - Espectrometria de massa}

Durante os trabalhos de campo defrontamos com alguns problemas que nos obrigaram a recorrer à determinações geocronológicas e isotópicas de diques e derrames localizados na área mapeada. Nesse sentido, os derrames basálticos da Raizinha que ocorrem na região de Poxoréu, foram datados pelo método $\mathrm{Ar}^{40} / \mathrm{Ar}^{39}$ na Open University, Inglaterra. Na Universidade McMaster, Ontário, Canadá, foram realizadas análises isotópicas $\mathrm{Sr}^{87} / \mathrm{Sr}^{86}$ e $\mathrm{Nd}^{143} \mathrm{Nd}^{144}$, utilizando-se um espectrômetro de massa modelo VG-354 existente naquela Universidade. Os diques de composição basáltica da região de Paredão Grande, por outro lado, foram datados na Universidade de New Castle, Inglaterra, utilizando-se o método $\mathrm{K}^{39} / \mathrm{Ar}^{40}$. Todas essas análises foram realizadas no âmbito de um projeto de pesquisa internacional que desenvolvemos em cooperação com os pesquisadores britânicos Drs. S.Gibson e R.N. Thompson e no Brasil Dr. O.H. Leonardos.

\subsection{7 - Digestão em ácido}

O método da digestão em ácido tem sido muito aplicado em trabalhos de prospeç̧ão de diamantes nos últimos anos e seu objetivo é verificar se as rochas que estão sendo estudas são portadoras ou não de microdiamantes. Por outro lado, a aplicação desse método aperfeiçoou os trabalhos de prospeç̧ão no que diz respeito ao uso do peso mínimo de amostragem. $\mathrm{Na}$ concepção de Davinson (1993), não existem "pipes" estéreis em macrodiamantes com quantidades elevadas de microdiamantes, da mesma forma que há casos conhecidos de "pipes" com macrodiamantes sem a presença de microdiamantes.

Microdiamantes, segundo Davinson (1993) e Coopersmith (1993), são definidos como pedras de tamanho menor que o limite de captura de plantas concentradoras de diamantes, isto é, medindo entre 1 a $0,5 \mathrm{~mm}$ correspondendo aproximadamente a 0,004 a $0,002 \mathrm{ct}$ em peso.

No estudo em questão, a presença de microdiamantes foi investigada na intrusão Tamburi, nos conglomerados do Grupo Bauru (Formação Quilombinho) e, nas rochas vulcanoclásticas relacionadas aos corpos intrusivos e extrusivos de composição basáltica na área. $O$ método consistiu na digestão em água régia + ácido fluorídrico, de certos volumes de amostras 
quarteadas a partir de $250 \mathrm{~kg}$. Como exemplo, da amostra RW-08 que possuia peso inicial de $181,6 \mathrm{~kg}, 64,7 \mathrm{~kg}$ foram submetidos a ataque por 303,0 litros de ácido durante 14 dias. Daí resultou uma fração de 37,23g que foi separada em bromofórmio, e posteriormente examinada em lupa binocular. Entre as oito amostras tratadas por esse método, no resíduo da RW-08 foi encontrado um microdiamante, cuja natureza foi confirmada por difração de raios $\mathbf{X}$. 


\section{3 - ASPECTOS FISIOGRÁFICOS}

No presente capitulo daremos ênfase ao clima, vegetação, relevo e drenagem da área de estudo. O clima atual reflete-se diretamente sobre a facilidade de alteração dos minerais satélites de kimberlitos. Tipos distintos de vegetação desenvolvem-se sobre corpos de natureza ultrabásica e são um critério importante para a prospeção dos corpos diamantíferos primários. $O$ relevo de áreas com jazidas quaternárias no Estado de Mato Grosso é normalmente muito acidentado individualizando-se em relação ao relevo regional, bem como compartimentando os inúmeros depósitos. As barreiras estruturais ou morfológicas, feições de relevo geradoras de armadilhas favoráveis à concentração do diamante aluvial, também registram peculiaridades na evolução das drenagens e na presença ou não de jazidas diamantíferas.

\section{1 - Clima}

O clima local é classificado nas categorias "AW" e "CW", segundo Köppen, havendo um certo predomínio do primeiro tipo (In: Baxter, 1988). As características dessas categorias climáticas são marcadas por duas estações bem definidas; uma seca, entre os meses de abril a outubro e outra chuvosa, entre os meses de novembro a março. A média de precipitação pluviométrica anual passa de $1600 \mathrm{~mm}$, com chuvas mais freqüentes no mês de dezembro.

A partir de informações extraídas da publicação do Instituto Brasileiro de Geografia e Estatística (IBGE, 1989), a temperatura média mensal local é de $30,1^{\circ} \mathrm{C}$, com médias máximas nos meses entre setembro a dezembro e médias mínimas entre junho a agosto. As médias mais frias $\left(10-15^{\circ} \mathrm{C}\right)$ são provocadas por massas de ar frio provenientes do sul da América do Sul, que penetram o vale do Rio Paraguai e rumam em direção às cabeceiras. Nos divisores de águas entre as bacias do Prata a sul, Amazônica à N-NW e a Araguaia à N-NE, são os locais onde essas frentes frias se dissipam. 


\section{2 - Vegetação}

Nos alvos PX, PG e DA, o contexto fitogeográfico pode ser dividido em dois domínios principais: de vegetação nativa e de vegetação artificial. $O$ primeiro tipo de vegetação, subdividese em cerrados, matas tropicais e matas galeria (matas ciliares). $O$ segundo, evidencia-se pela atividade agropecuária intensa e suas pastagens associadas.

Os cerrados (Fotografia 1), de um modo geral, constituem-se de árvores de pequeno a médio porte, de caules e galhos retorcidos, espaçadas, com folhas ásperas e associadas a gramíneas. A vegetação arbustiva representativa dos cerrados na região estudada compreende: lixeira (Curatella americana), pau-terra (Qualea sp.), pequizeiro (Caryocar brasiliensis),

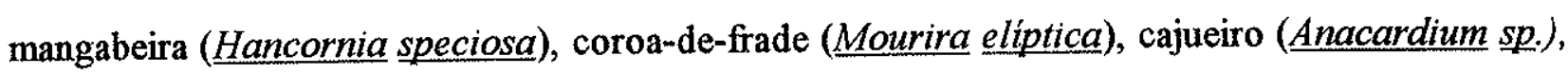
indaiá (Cocos petracea), ariticum (스ona coriácea), faveiro (Pteron pubescens), sobro (Roupala gardneri).

As matas tropicais compõem-se de árvores mais altas e mais largas, pouco retorcidas e de madeira rígida. Na região ora relatada, as matas tropicais transicionam com a vegetação do tipo cerrado até o domínio total da mata tropical na bacia amazônica, a aproximadamente $200 \mathrm{~km}$ à norte. A vegetação arbustiva característica de matas tropicais abrange: aroeira branca (Lithraea molleodes), aroeira vermelha (Schinus terebenthifolius), tamburi (Enterolobium contortisiligum) angico (Piptadenia sp.), pau-óleo (Copaifera langsdorffii), jequitibá (Cariniana sp.), ipês roxo e

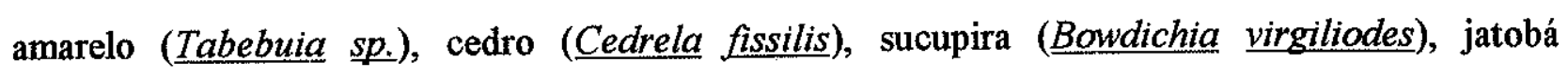
(Hymenaea sp.) e bacuri (Platonia insignis).

As matas ciliares (Fotografia 2) acompanham os traçados das drenagens representadas por córregos, ribeirões e rios da área estudada cujas principais espécies são: aroeira vermelha

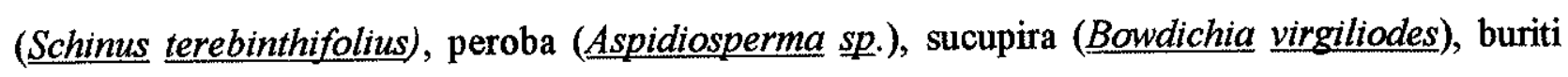
(Mauritea flexuosa), babaçu (Orbygnia martiana), angelim (Andira legalis) e jacareúba (Calophylum brasiliense).

As vegetações gramíneas e rasteiras comumente descritas de forma genérica são:

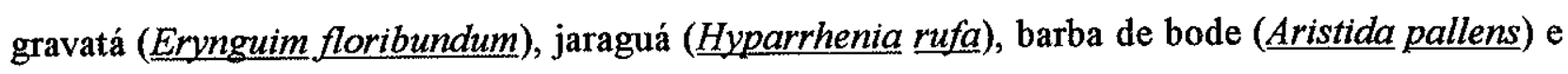
cansanção (Urera baccifera).

A vegetação da região, de acordo com Baxter (1988) reflete as unidades geológicas, afirmação essa que concordamos e acrescentamos alguns exemplos. Assim sendo, em solos 


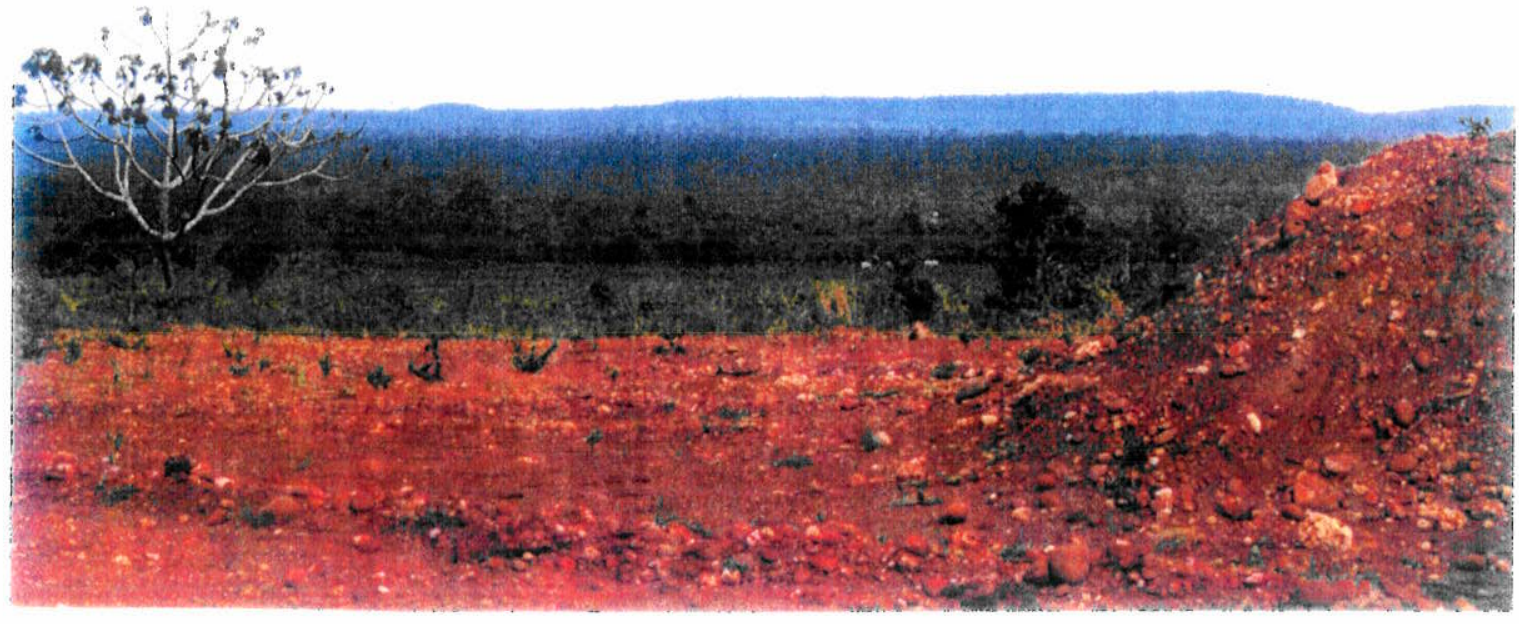

Fotografia $\mathbb{1}$ - Vegetação tipo cerrados predominam próximo aos basaltos da Raizinha. No segundo plano da fotografia o relevo plano (chapadões).

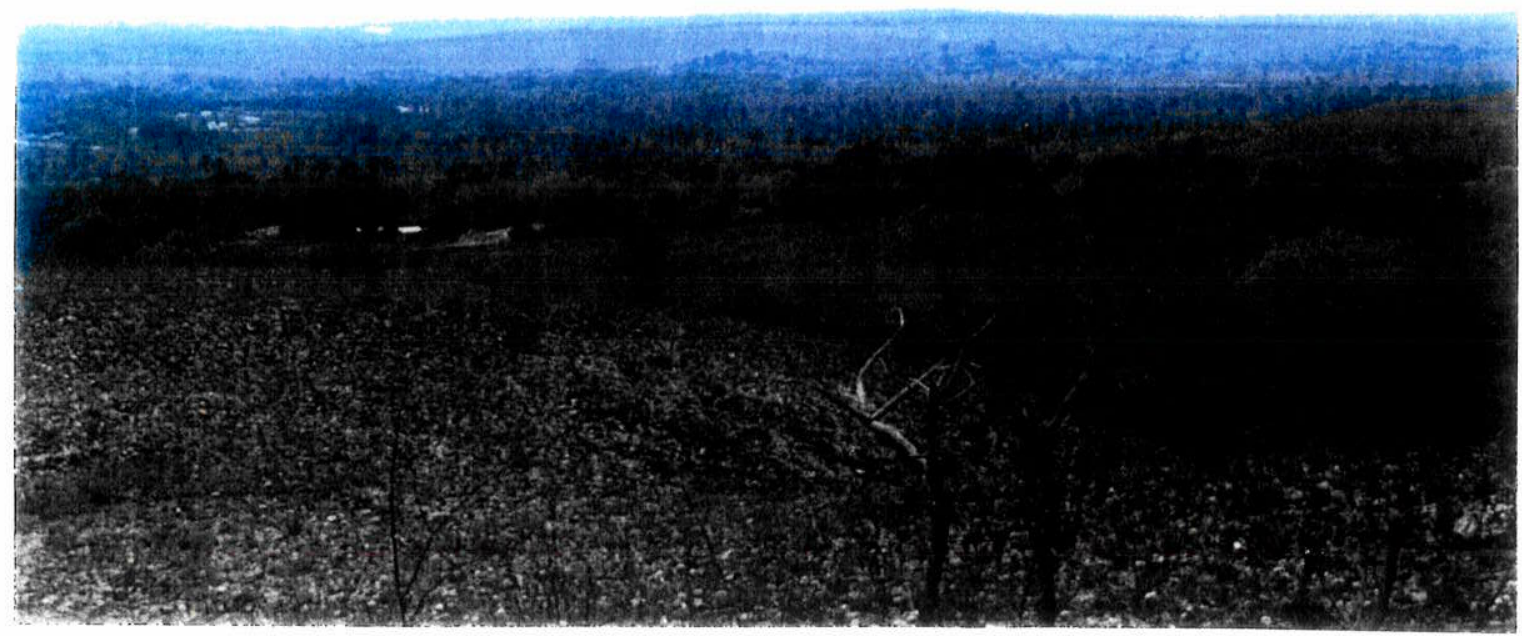

Fotografia 2 - Vegetação tipo matas ciliares associada a vegetação resultante da atividade pastoril evidenciam a bacia de drenagem. No primeiro plano da fotografia relevo de superficies residuais. 
pobres arenosos derivados de unidades litológicas areníticas predomina vegetação tipo cerrado. Nos solos ricos, originados da alteração de rochas básicas a ultrabásicas concentram-se matas tipo tropicais ou parte das matas ciliares. As árvores tipo babaçu, buriti e bacuri, denunciam lençol freático aflorante a subaflorante. A árvore tamburi destaca a brecha de características kimberlíticas Tamburi. Ressalta-se que a concentração dessa vegetação sobre o corpo foi fator decisivo para a localização e delimitação desta intrusão.

\section{3 - Relevo}

O relevo da área estudada é diversificado, predominando as formas planas, resultantes da esculturação por agentes exógenos (intemperísmo físico, químico e biológico), associados a formas de relevo desenvolvidas a partir da atuação de eventos endógenos (falhas e intrusões). As principais formas descritas em ordem de importância são chapadões (planaltos), escarpas, terraços e planícies aluviais, superfícies residuais, morros testemunhos, talus, altos topográficos, blocos basculados e a Estrutura de Alto Coité.

Os planaltos constituem a forma de relevo predominante (Fotografia 1); circunscrevem as bacias e estão situados em cotas topográficas mais elevadas. Ocorrem indistintamente sobre unidades litoestratigráficas como as Formações Cachoeirinha, Cambambe, Aquidauana e Palermo, assim como nos derrames da Raizinha (Formação Paredão Grande), principalmente. O planalto originado é resultante dos eventos de peneplanização terciária definida por King (1956) como superfície Sul-Americana.

As escarpas podem ser identificadas como de duas origens. O primeiro tipo é oriundo de falhamentos de rejeito vertical de até $150 \mathrm{~m}$ por $35 \mathrm{~km}$ de comprimento (Falha de Poxoréu). Escarpas de falhas foram descritas também nas regiões de Paredão Grande e no entorno da intrusão Tamburi (Serra da Saudade) onde são expostos paredões da Formação Aquidauana. O segundo tipo de escarpas é observado nas porções à norte de Poxoréu e Dom Aquino, como resultado da erosão por captura de cabeceiras (remontante) das bacias de drenagem. Além do controle estrutural-morfológico por sistemas de falhas e fraturas impressos nas rochas, tais escarpas são sustentadas por camadas de calcretes e silcretes das Formações Cachoeira do Bom Jardim e Cambambe, respectivamente, do Grupo Bauru. Essas escarpas estão sendo esculturadas pela bacia de drenagem terciária-quaternária do Pantanal. 
Os terraços são feições tabulares dispostas lateralmente às principais drenagens da área estudada, sendo geralmente mais jovens quanto mais próximos às drenagens. Os terraços mais altos, registram eventos deposicionais mais antigos e o conjunto está associado ao desenvolvimento da Bacia do Pantanal durante o Quaternário. No Estado de Mato Grosso, na região da bacia do Alto Paraguai, Weska et al. (1984) individualizaram quatro terraços denominando informalmente de $\mathrm{t} 4 \mathrm{o}$ mais jovem e $\mathrm{t} 1$ o mais antigo. A nível mundial, tais terraços (pedimentos) são registros dos 4 últimos ciclos glaciais. Com o rebaixamento do nível dos mares, uma nova base de erosão se estabelece, ocorrendo o aumento do gradiente, e como conseqüência a erosão mais intensa. Com o degelo a superfície marinha eleva-se, estabelecendo um novo nível base de erosão, definindo gradiente menor e consequentemente ciclos erosivos menos intensos, que propiciam então o predomínio da deposição em detrimento da erosão. Nas drenagens da região de Poxoréu além do encravamento vertical, houve intenso retrabalhamento lateral; entretanto, onde o "bedrock" é a Formação Aquidauana há predomínio da erosão vertical sobre a lateral. Estudando feições morfológicas deste tipo Almeida (1954) propôs o termo alcantilado para essa forma de relevo. Já nas áreas dos alvos DA e PG, há o predomínio da erosão vertical sobre a lateral. O resultado disso é que os terraços no alvo PX são mais expressivos quando comparados aos das demais áreas.

As planícies aluviais são superfícies planas associadas diretamente às drenagens atuais. A largura ou inexistência destas feições morfológicas estão diretamente relacionadas à erosão se predominantemente vertical ou com retrabalhamento lateral, ou ainda, se em posição de cabeceiras ou a jusante.

Superficies residuais (Fotografia 2) ocorrem extensivamente sobre as coberturas do terciário-quaternário indiviso em terraços, bem como sobre pacotes conglomeráticos nas unidades do Grupo Bauru e de cascalhos da Formação Cachoeirinha. Na verdade, essas superfícies residuais são depósitos de placeres tipo elúvio.

Os depósitos de talus maiores localizam-se junto aos sopés das escarpas, enquanto os menores internos às bacias estão associados às escarpas menores. As formas de relevo tipo talus constituem depósitos coluvionares hospedeiros de diamantes. A medida que a erosão remontante evolui sobre as escarpas, os talus mais jovens são aqueles mais próximos às escarpas atuais.

Morros testemunhos ocorrem tanto próximos aos paredões dos principais falhamentos (Fotografia 3), quanto próximos às escarpas localizadas a norte de Poxoréu e Dom Aquino, assim como no entorno da extrusão Tamburi. Tais formas de relevo são feições geomorfológicas 


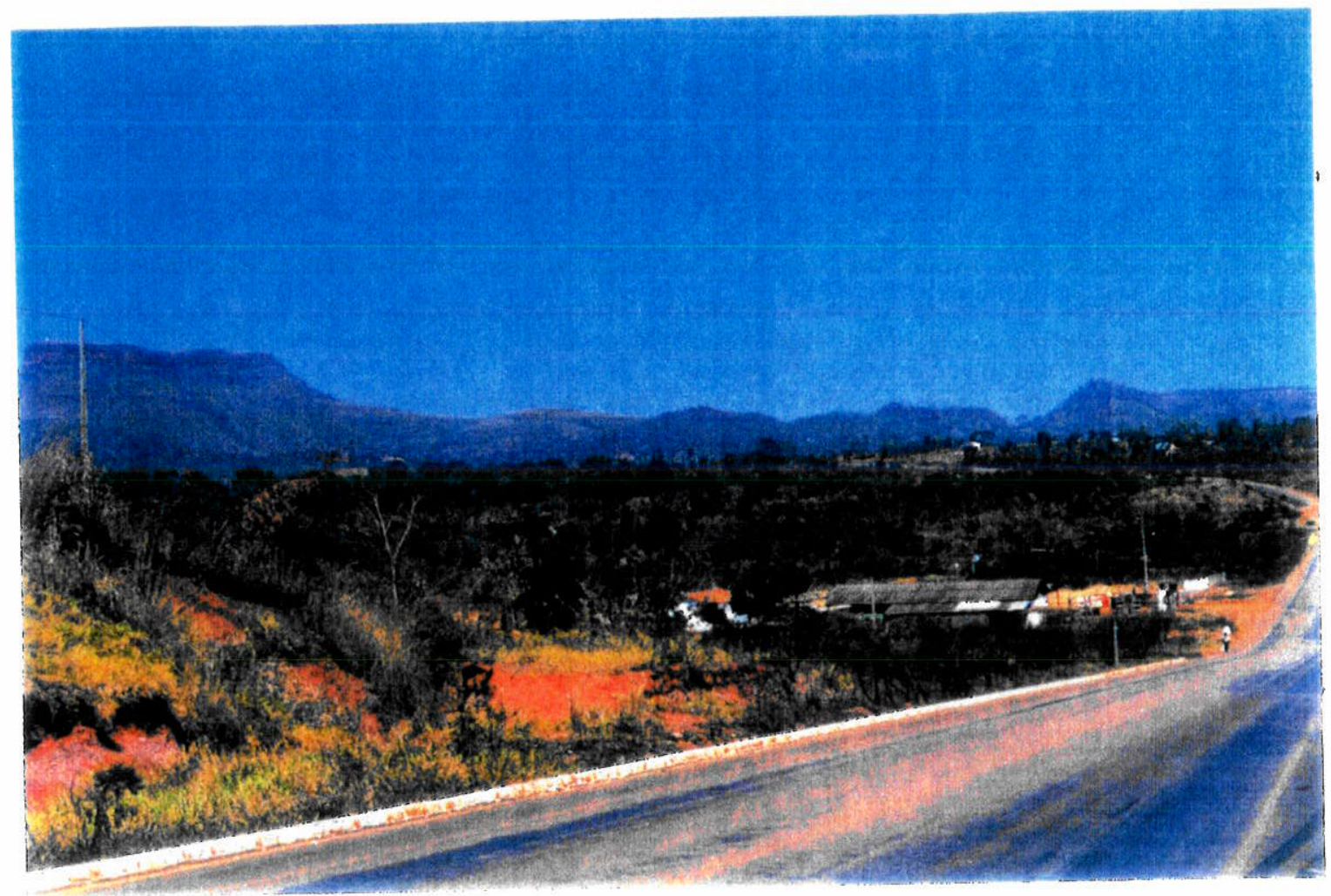

Fotografia 3 - Relevo tipo morro testemunho lado esquerdo e de blocos basculados, lado direito da fotografia, próximos a Falha de Poxoréu.

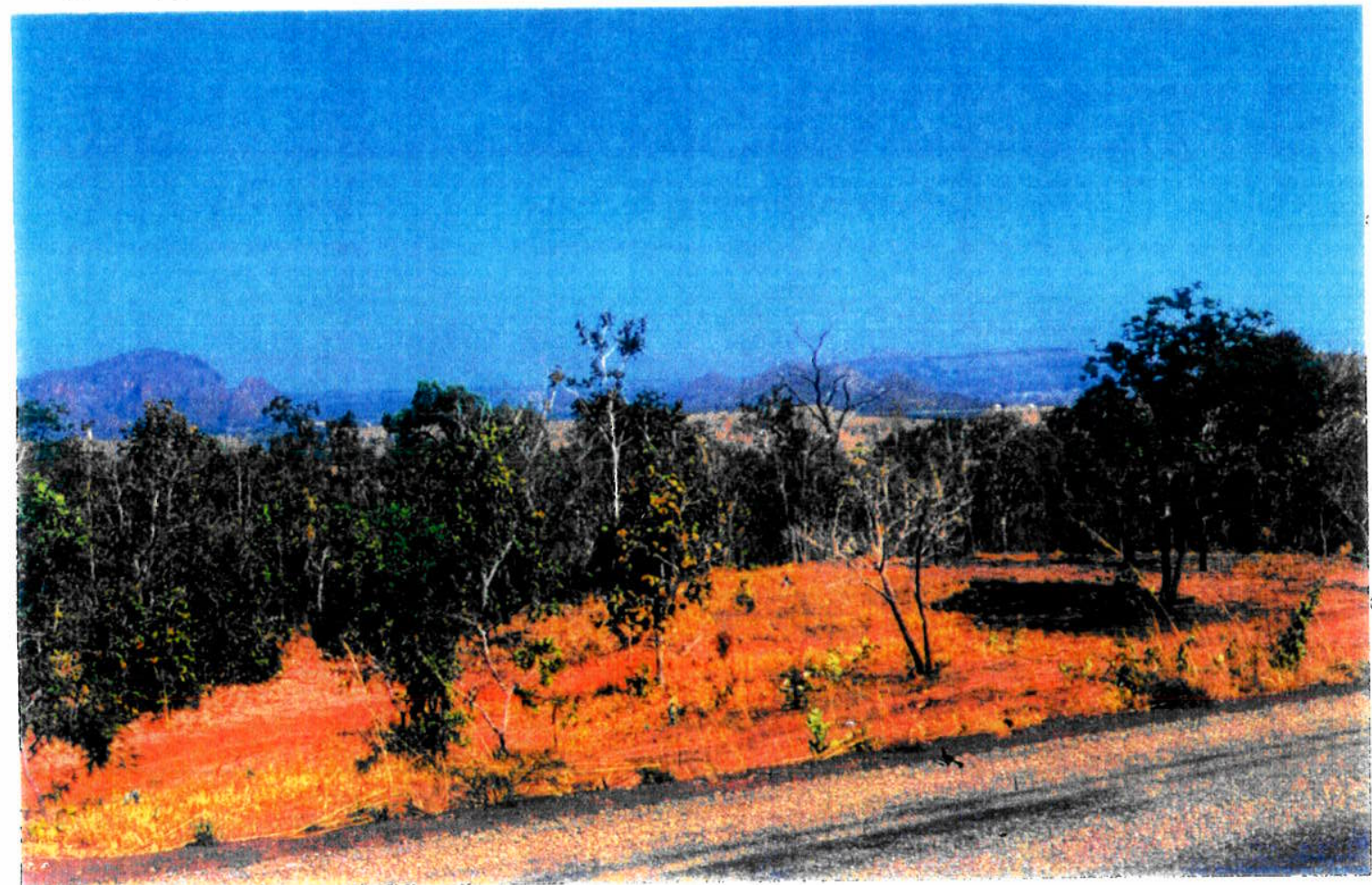

Fotografia 4 - Forma de relevo convexa nos diques da Formação Paredão Grande, porção intermediária da fotografia. 
importantes que evidenciam o recuo dessas escarpas, como resultado da erosão remontante das drenagens quaternárias.

No estudo em questão, denomina-se de altos topográficos as formas positivas de relevo (convexas) que ocorrem em parte dos diques da Formação Paredão Grande (Fotografia 4), silcretes da Formação Cambambe (Grupo Bauru) e a intrusão Tamburi. Destaca-se, que vários corpos de natureza kimberlítica descritos em alguns estados brasileiros por Svisero et al. (1984) e Gonzaga e Tompkins (1991) constituem via de regra baixos topográficos. A intrusão Tamburi, constitui exceção pelo relevo positivo, fato que facilitou também sua localização.

Blocos basculados são encontrados próximos à Falha de Poxoréu, bem como ao longo desse expressivo falhamento (Fotografia 3), e ainda no entorno da Estrutura do Alto Coité. Em ambas situações, essas feições com até $1 \mathrm{~km}$ de comprimento são preservadas por pacotes extremamente silicificados da Formação Palermo, fazendo parte da paisagem e sendo facilmente observáveis em torno de Poxoréu.

A Estrutura de Alto Coité, situada a NE da cidade de Poxoréu é uma feição geomorfológica em forma de semicírculo, lateral à Falha de Poxoréu em seu extremo NE, e cujas bordas estão arqueadas e dispostas com mergulhos divergentes. Apesar de não haver estudos geofísicos dessa estrutura, ela parece estar relacionada à intrusão de um corpo ígneo, que aparentemente não afetou o teto da falha, mas controla e condiciona a evolução do Córrego Poruba e, além disso, é também uma feição controladora de parte do paleorrelevo cretácico.

\section{4 - Hidrografia}

Segundo Baxter (1988), as primeiras grandes concentrações aluvionares de diamante foram encontradas no Rio das Pombas. Essa descoberta propiciou as condições necessárias à nucleação populacional do que seria posteriormente o Município de Poxoréu. Tal drenagem situase fora e a oeste do alvo PX.

No alvo PX ocorrem as porções de cabeceiras do Rio Poxoréu, representadas pelos Rios Poxoreuzinho e seu importante afluente de cabeceiras Córrego São João, à norte-noroeste de Poxoréu e, o Rio Alto Coité com seu afluente Córrego Poruba à nordeste. A confluência entre os Rios Poxoreuzinho e Alto Coité ocorre aproximadamente a $6,3 \mathrm{~km}$ à NE e à montante da cidade de Poxoréu. Os Córregos Areia e Bororó possuem confluência com o Rio Poxoreuzinho dentro do perímetro urbano dessa cidade, por onde o rio passa. A partir dessa cidade, em direção $\mathrm{SE}$, o rio assume o nome da cidade homônima. As principais jazidas aluvionares diamantíferas da 
região de Poxoréu, trabalhadas por atividades garimpeiras ao longo dos anos situam-se sobre os Rios Poxoreuzinho e Alto Coité, assim como nos Córregos Areia e São João.

$\mathrm{Na}$ região do alvo $\mathrm{DA}$ a drenagem mais importante é o Ribeirão Parnaíba, cujas cabeceiras situam-se nas porções do divisor de águas entre as drenagens pertencentes à Bacia do Prata e à Bacia do Araguaia. O Ribeirão Parnaíba, possui como tributários importantes os Córregos Lambança e Preto em sua margem direita e os Córregos Ribeirão, Lajinha e São José, formadores dos Córregos São Luiz e do Engano, como principais afluentes de margem esquerda. Esse ribeirão transforma-se no Rio São Lourenço a 3,3km à sudoeste de Dom Aquino.

Durante os trabalhos de mapeamento dessa área notou-se a ausência de atividades garimpeiras nas aluviões; além disso, quando elas existem são restritas, evidenciando em princípio a ausência de placeres diamantíferos importantes na área.

Sobre a cratera do Tamburi situam-se os Córregos do Tamburi (toponímia adotada nesse estudo) e o das Cobras, pertencentes à bacia do Rio Paraíso, em sua porção de cabeceiras, afluente de margem esquerda e pertencente à bacia do Rio Poxoréu, cuja confluência ocorre a $15,5 \mathrm{~km}$ a S-SE da cidade de Poxoréu. À jusante da intrusão existe um pequeno garimpo onde ocorrem minerais satélites semelhantes aqueles encontrados na intrusão Tamburi à montante.

As drenagens que escoam sobre a região onde ocorrem os diques de Paredão Grande pertencem à bacia do Rio das Garças, importante tributário da bacia do Rio Araguaia. A área em questão situa-se nas porções de cabeceiras do Rio Areado onde destacam-se os Córregos Revoltoso e João Batista, ambas drenagens intermitentes, onde não foram observadas atividades extrativas de diamantes.

Sobre a regiăo ocupada pelos diques na Colônia Meruri, a drenagem mais importante é o Rio Barreiro, afluente de margem direita do Rio das Mortes e da bacia hidrográfica do Araguaia. Os córregos de margem direita são denominados de Jeriguiga e Presenta. Na margem esquerda destaca-se o Merurizinho.

As drenagens de todos os alvos possuem condicionamento estrutural nítido em imagens de fotografias aéreas e de sensoriamento remoto, evidenciado por alinhamentos NW e NE ou secundariamente E-W e N-S. O mosaico hidrográfico resultante permitiu identificar drenagens com padrões retilíneo, retangular e subretangular. 


\section{4 - GEOLOGIA REGIONAL}

A área de estudo situa-se na borda extremo NW da Bacia do Paraná, pouco a sul da Faixa Paraguai. A Figura 2, mostra as principais unidades litoestratigráficas que circundam essa área. A coluna estratigráfica regional, compreendendo a região entre Dom Aquino, Poxoréu, Paredão Grande e Colônia Indígena Meruri, no Estado de Mato Grosso, foi edificada preservando parte da evolução e superposição das bacias sedimentares correspondentes ao Geossinclíneo Paraguai-Araguaia e, às bacias intracratônicas do Paraná, Bauru e Pantanal.

As unidades litoestratigráficas enquadradas no evento geossinclinal, são reconhecidas como os Grupos Cuiabá (Hennies, 1966) e Alto Paraguai (Almeida, 1964), além do Granito São Vicente (Almeida, 1954). O Grupo Cuiabá, corresponde à unidade aflorante mais antiga da coluna estratigráfica regional sendo sobreposta pelas unidades do Grupo Alto Paraguai, sendo finalmente intrudidas pelo Granito São Vicente. Datações realizadas por Almeida \& Mantovani (1975) e Barros et al. (1982) nas rochas graníticas, mostraram que os Grupos Cuiabá e Alto Paraguai possuem idade Proterozóica Superior.

Durante o Paleozóico, como parte dos eventos deposicionais relacionados ao desenvolvimento da Bacia Intracratônica do Paraná, do mais antigo para o mais jovem, temos as unidades litoestratigráficas do Grupo Paraná com as Formações Furnas e Ponta Grossa (Barros et al., 1982), recobertas discordantemente por litologias das Formações Aquidauana (Beurlen, 1956) e Palermo (White, 1908). Segundo Guirro (1991), a Formação Aquidauana é contemporânea aos eventos glaciogênicos que ocorrem em parte dos estados do Sul do Brasil, por esta razão esse autor incluiu a unidade Aquidauana no Grupo Itararé. A Formação Palermo foi também descrita por Guirro (1991) como pertencente ao Grupo Guatá.

Como unidades mesozóicas e de topo da Bacia do Paraná na região em questão, temos as rochas do Grupo São Bento (Mühlmann et al., 1974), com as Formações Botucatu e Serra Geral. Em virtude deste posicionamento de borda da área estudada, a coluna estratigráfica de muitos locais, como por exemplo, Chapada dos Guimarães, Poxoréu e Dom Aquino, não é completa. 


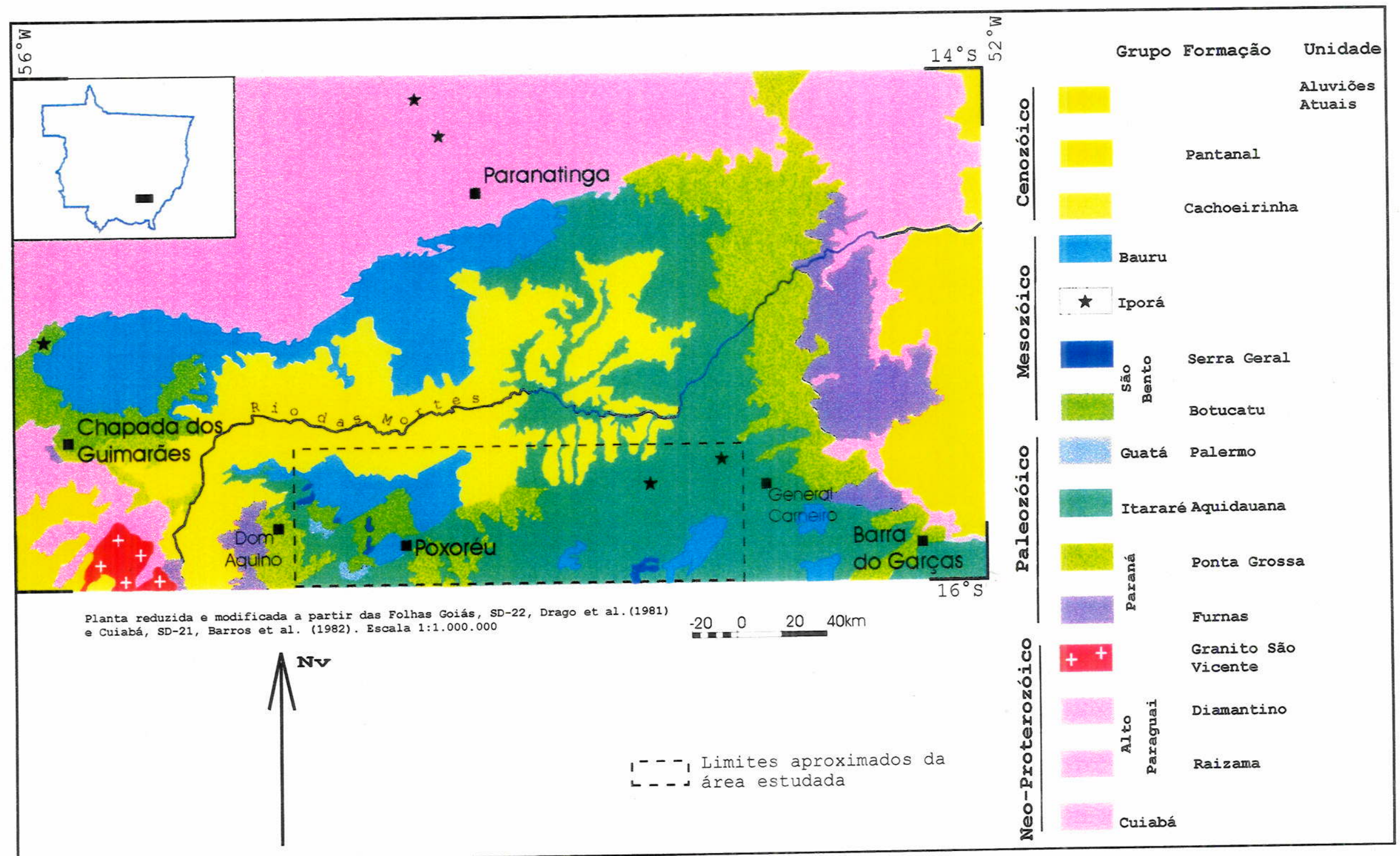

Figura 2 - Mapa geológico regional abrangendo a área estudada. 
Inúmeras intrusões e extrusões distintas do evento Serra Geral envolvendo rochas de natureza alcalina, básica e ultrabásica, ocorrem nas bordas da Bacia do Paraná, tendo sido consideradas como Grupo Iporá por autores tais como Schobbenhaus et al. $(1975,1979)$, Drago et al. (1981) e Weska et al. (1992) e, constituindo eventos magmáticos mais jovens que o Serra Geral. Durante o Cretáceo Superior, a região foi palco de eventos intrusivos, extrusivos e deposicionais, relacionados à bacias desenvolvidas também junto às bordas da Bacia Intracratônica do Paraná, como parte da Reativação Wealdeniana (Almeida, 1983,1986), que proporcionou nesta região o desenvolvimento de uma nova bacia sedimentar, de idade mais jovem que a da Bacia do Paraná. O conteúdo litológico dessas bacias foi caracterizado por Weska (1987) e Weska et al. (1988,1993), nas regiões de Chapada dos Guimarães e Poxoréu, respectivamente, e englobadas no Grupo Bauru. Da base para o topo, essa unidade litoestratigráfica foi subdividida nas Formações Quilombinho, Cachoeira do Bom Jardim e Cambdrmbe.

Coberturas inconsolidadas e/ou laterizadas que ocupam o topo da coluna geológica regional, são contemporâneas ao desenvolvimento da Bacia Intracratônica do Pantanal, a partir do Terciário até os dias atuais, recobrindo indistintamente as rochas anteriormente descritas. A unidade mais antiga é reconhecida regionalmente como Formação Cachoeirinha (Gonçalves e Schneider, 1970), cuja idade é Terciária. A Formação Pantanal (Oliveira e Leonardos, 1943) e as Aluviões Atuais (Barros et al., 1982), são ambas consideradas quaternárias.

\section{1 - Grupo Cuiabá}

O Grupo Cuiabá, que representa a base da coluna estratigráfica para o flanco noroeste da Bacia do Paraná encontra-se a norte, nordeste, noroeste e oeste da área mapeada (Figura 2), tendo os seus principais afloramentos na província geomorfológica Baixada Cuiabana (Almeida, 1964).

As rochas metamórficas de baixo grau intensamente dobradas, pelos eventos tectonoorogenéticos do Ciclo Brasiliano, receberam o primeiro nome de "Cuiabá Slates" por Evans (1894), tendo sido incorporada à literatura geológica a partir dos sucessivos trabalhos de Almeida (1948b, 1954, 1964, 1965a, 1974, 1984 e 1985). Vieira (1965) considerou que as rochas estudadas por Almeida (1964) constituíam um nível médio da "Série" Cuiabá; admitiu ainda a existência de pelo menos três unidades litoestratigráficas diferenciáveis entre si por suas 
caracteristicas litológicas, no trecho compreendido entre Cuiabá e Jangada. Luz et al. (1980) reconheceram a existência de oito subunidades, todas mapeáveis na escala 1:50.000, como parte do Projeto Coxipó. Alvarenga (1985), definiu as sub-unidades 3 e 5 (Luz et al., 1980), em duas fácies distintas, respectivamente: 1) canais de leques turbidíticos proximais e 2) canais anastomosados de leque médio. Recentemente, Alvarenga (1988) ponderou que a estratigrafia da Faixa Paraguai. quando comparada em colunas são conflitantes no que se refere às relações de contato entre o Grupo Cuiabá e a Formação Bauxi. Com base nesta questão e a partir de um estudo de fácies sedimentares, propôs uma subdivisão informal da Faixa Paraguai, incluindo as Formações Puga e Bauxi no topo do Grupo Cuiabá, pois segundo os seus dados, há somente variação lateral de fácies, sem a evidência da presença de discordância angular entre o Grupo Cuiabá e a Formação Bauxi, conforme anteriormente proposto por Figueiredo \& Olivati (1974), Ribeiro Fitho et al. (1975) e Almeida (1984).

Os tipos litológicos comuns ao Grupo Cuiabá, segundo Alvarenga (1988), são filitos grafitosos associados a filitos, quartzitos e dolomitos, em sua unidade inferior. $O$ topo, incluindo as Formações Puga e Bauxi, foi subdividido em 3 (três) fácies, quais sejam: a) proximal, constituída de diamictitos, com camadas de siltitos, arenitos, quartzitos e conglomerados intercaladas; b) intermediária, caracterizada pela presença de filitos com intercalações de quartzitos, microconglomerados e conglomerados, com granodecrescência para o topo; e c) distal, dominada por filitos, com eventuais intercalações de quartzitos e metassiltitos.

Com base no conteúdo litológico, Alvarenga (1988) sugeriu o ambiente deposicional de uma bacia marinha relativamente profunda, desenvolvida junto a uma borda cratônica, influenciada por glaciação e com aporte de sedimentação continental através de leques submarinos de noroeste para sudeste.

As rochas do Grupo Cuiabá possuem contatos térmicos com o Granito São Vicente e, contatos discordantes angulares e erosivos com as Formações Furnas, Botucatu e Cachoeirinha.

A idade do Grupo Cuiabá é considerada pré-cambriana superior, com base na datação do Granito São Vicente, cuja idade obtida pelo método $\mathrm{Rb} / \mathrm{Sr}$ é $500 \pm 4 \mathrm{Ma}$. (Barros et al, 1982). 


\section{2 - Grupo Alto Paraguai}

As rochas do Grupo Alto Paraguai situam-se à norte. nordeste. noroeste e oeste da área (Figura 2), ocorrendo principalmente na feição geomorfológica Província Serrana (Almeida, 1964).

A partir dos trabalhos realizados por Almeida (1964) na região centro-oeste matogrossense iniciaram-se as primeiras tentativas de empilhamento estratigráfico desse conjunto de rochas não metamórficas das estruturas brasilianas (Almeida, 1984), cabendo a esse autor a denominação de Grupo Alto Paraguai e a primeira subdivisão, da base para o topo, nas Formações Raizama, Sepotuba e Diamantino.

Inúmeros autores, entre eles Almeida (1964,1965,1968 e 1974), Vieira (1965), Hennies (1966), Corrêa \& Couto (1972), Guimarães \& Almeida (1972), Figueiredo et al. (1974), Olivatti \& Ribeiro Filho (1976), Montalvão et al. (1980), Barros et al. (1982) e Alvarenga (1988), realizaram trabalhos nessa região tentando prestar sua contribuição ao melhor entendimento deste contexto geológico. Apesar disso, até a presente data, muitos problemas de posicionamento estratigráfico ainda persistem e na atualidade este grupo é constituído somente pelas Formações Raizama (basal) e Diamantino (topo). Alvarenga (1988), excluiu desse grupo as Formações Puga, Bauxi e Araras. A Formação Sepotuba, a partir dos trabalhos de Barros et al. (1982) passou a ser considerada uma fácies da Formação Diamantino.

O conteúdo litológico da Formação Raizama é constituído de arenitos com intercalações de lentes de pelitos e de microconglomerados. Não raro, são encontradas estratificações planas e cruzadas, marcas de ondas simétricas e assimétricas, com o predomínio das primeiras. Segundo Almeida (1964), a Formação Raizama na Serra do Tombador possui uma espessura de $1600 \mathrm{~m}$.

A Formação Diamantino é constituída de uma intercalação de folhelhos, siltitos e arcósios, com espessura que pode atingir mais de $3.000 \mathrm{~m}$ de sedimentos, segundo Hennies (1966).

Os contatos entre as Formações Raizama e Araras, na porção basal do Grupo Alto Paraguai e no topo com a Formação Diamantino, são do tipo concordantes e gradacionais (Barros et al., 1982). De acordo com Alvarenga (1988), esse conjunto litológico, ao contrário do Grupo Cuiabá, aparentemente foi dobrado apenas por uma fase do ciclo orogenético Brasiliano, 
apresentando um decréscimo na intensidade dessas deformações em direção ao Cráton Amazônico situado à noroeste.

Datação de folhelhos da Formação Diamantino. revelou idade de $547 \pm 5 \mathrm{Ma}$. (Barros et al., 1982), mostrando que o Grupo Alto Paraguai é realmente Pré-Cambriano Superior.

\section{3 - Granito São Vicente}

As rochas graníticas da Serra de São Vicente encontram-se localizadas à oestesudoeste, como mostra o mapa geológico regional da Figura 2.

Os primeiros estudos a respeito destas rochas devem-se a Almeida (1954), quando utilizou a denominação de Granito São Vicente para as rochas intrusivas que ocorrem na serra homônima (Barros et al., 1982). Almeida (1954), propôs tratar-se de um batólito, parcialmente encoberto pela Formação Furnas e com tetos pendentes de massas filíticas e quartzíticas do Grupo Cuiabá. Esse granito possui granulação média a grossa, cristais de ortoclásio com mais de $1 \mathrm{~cm}$ de comprimento e, cores variáveis nos tons rosa, vermelho, amarelo e cinza.

Oliveira \& Mühlmann (1967), observaram que as rochas da Bacia do Paraná apresentam mergulho regional para SE ou para NW, a partir do corpo granítico caracterizando-o morfoestruturalmente como um arco de direção geral NE-SW.

Os efeitos termo-metamórficos provocados pela intrusão e notados por Almeida e Mantovani (1975), são identificados pela presença de nódulos de xistos e hornfels contendo cordierita, sillimanita, andaluzita, hornblenda e diopsídio, indicativos de metamorfismo de alta temperatura sob pressão moderada.

Segundo Luz et al. (1980), o Granito São Vicente é uma rocha de cor rosa, leucocrática e porfirítica, sendo cortada por diques de aplito e diabásio. Almeida et al. (1972), identificaram também rochas extrusivas do tipo riolitos e riodacitos, relacionadas à reativação magmática que ocorreu no batólito granítico, originadas a partir de falhas cônicas localizadas na câmara e na abóbada do corpo.

A grande dúvida levantada durante os estudos do Granito São Vicente foi em relação ao comportamento tectônico da intrusão. Seria ela sintectônica, conforme advogado por Bauer \& Largher (1958) e Almeida et al. (1972), ou póstectônica, como defendido pelos trabalhos realizados por Almeida (1968), Hasui \& Almeida (1970), Almeida \& Mantovani (1975), Luz et 
al. (1980) e Barros et al. (1982) Nos dias atuais. prevalece a posição de que o Granito São Vicente é na realidade um corpo intrusivo pós-tectônico.

Os contatos desse corpo granítico com os metassedimentos do Grupo Cuiabá são termometamórficos e, com os sedimentos Furnas. Cachoeirinha e Pantanal por discordâncias litológicas e erosivas (Barros et al., 1982).

Através dos dados analíticos $\mathrm{Rb} / \mathrm{Sr}$ conseguidos por Almeida e Mantovani (1975) e recalculados por Barros et al. (1982), foi obtida uma idade de $500 \pm 4$ Ma. para a intrusão desse maciço granítico, situando-o no limite entre o Cambriano e o Ordoviciano.

\section{4 - Grupo Paraná, Formação Furnas}

As rochas da Formação Furnas, ocorrem à noroeste (Chapada dos Guimarães), à sudoeste (Jaciara), à leste (Barra do Garças) e à nordeste (Nova Xavantina), conforme Figura 2. O termo "Arenito Furnas" foi utilizado, pela primeira vez por Oliveira (1912) para designar os arenitos das escarpas da Serra das Furnas e da Serrinha, descritos anteriormente por Derby (1878) e aflorantes desde o norte da estação de Serrinha, até as imediações de Itapeva, SP (In: Schobbenhaus et al.1984).

Os litotipos que representam esta unidade são principalmente arenitos, secundariamente conglomerados, argilitos e siltitos micáceos. Os arenitos são esbranquiçados e localmente arroxeados, com granulometria média a grossa, regularmente selecionados, possuindo grãos angulares a subangulares, quartzosos e com matriz caulínica (Schneider et al., 1974). Os conglomerados são monomíticos sendo constituídos exclusivamente por seixos de quartzo, que na grande maioria são bem arredondados. Raramente podem ser observados fragmentos de xistos e filitos do Grupo Cuiabá inseridos nos mesmos, a exemplo da seção descrita nas adjacências da cidade de Barra do Garças (Drago et al., 1981). A espessura da unidade em apreço, segundo Almeida (1954) é de 205m.

De acordo com Santos \& Freitas (1979) (In: Barros et al., 1982), as estruturas sedimentares predominantes são as estratificações cruzadas acanaladas, de pequeno a médio porte e, secundariamente, as estratificações planares e plano-paralelas.

$\mathrm{O}$ ambiente deposicional desta unidade é polêmico dentro da comunidade geológica. Almeida (1954), Sanford \& Lange (1960), Bigarella et al.(1966), Lange \& Petri (1967) e Bigarella \& Salamuni (1967), entre outros, advogam ambiente deposicional marinho. Outros 
como Ludwig \& Ramos (1965) e Schneider et al.(1974), defendem condições fluviais continentais ( $I n$ : Schobbenhaus et al., 1984).

Na região de Chapada dos Guimarães, as rochas da Formação Furnas assentam-se sobre epimetamorfitos do Grupo Cuiabá em nítida discordância angular, e sobre o Granito São Vicente em discordância litológica. O contato superior dessa formação com a Formação Ponta Grossa foi considerado concordante e gradacional por Barros et al. (1982). Na concepção de Schobbenhaus et al. (1984), ocorre contato discordante entre as Formações Furnas e Botucatu (Chapada dos Guimarães) e com o Grupo Bauru (sul de Rondonópolis).

Segundo Schobbenhaus et al. (1984), em relação à idade da Formação Furnas, podese afirmar apenas que a mesma é anterior ao Devoniano Inferior, idade essa da deposição da parte inferior da Formação Ponta Grossa obtida a partir de estudos paleontológicos.

\section{5 - Grupo Paraná, Formação Ponta Grossa}

Em relaçăo à área mapeada, esta unidade litoestratigráfica ocorre, predominantemente, à noroeste (Chapada dos Guimarães), à sudoeste (Dom Aquino-Jaciara), à sudeste de Poxoréu, à nordeste na região do Rio das Mortes e à leste, na região de General Carneiro e Barra do Garças (Figura 2).

O termo "Schistos Ponta Grossa" foi utilizado pela primeira vez por Oliveira (1912), para designar os pacotes de folhelhos aflorantes a oeste das escarpas da Serrinha, nos arredores da cidade de Ponta Grossa (PR), que já haviam sido descritos por Derby (1878) (In: Barros et al.1982). Litologicamente é constituída, segundo Schneider et al. (1974), de folhelhos, folhelhos síticos e siltitos cinza escuro a pretos, localmente carbonosos, fossilíferos, micáceos e com intercalações de arenitos cinza claro, finos a muito finos, formando bancos de até $5 \mathrm{~m}$ de espessura. Quando alteradas, estas rochas apresentam, cores variadas, onde predominam as amarelas, arroxeadas e castanhas.

As estruturas sedimentares mais freqüentes na Formação Ponta Grossa, de acordo com Barros et al. (1982) são as laminações plano-paralelas. De ocorrência mais rara, observa-se estratificação cruzada de pequeno porte, localmente acanalada, laminações cruzadas e "flaser", marcas onduladas, bioturbações e estruturas de escorregamento.

O contato entre as Formações Furnas e Ponta Grossa, é gradacional e concordante ou por falhas de gravidade (Barros et al, 1982). O contato superior ocorre por discordância 
crosiva ou por falhas com as Formações Aquidauana. Botucatu e Cachoeirinha ou com o Grupo Bauru (Schneider et al., 1974). Em um perfil geológico realizado por Barros et al. (1982), entre as cidades de Dom Aquino e Poxoréu, os autores constataram que a espessura da Formação Ponta Grossa é de $60 \mathrm{~m}$, próximo à primeira cidade.

$\mathrm{O}$ conteúdo fossilífero presente na unidade em questão é constituído por abundante fauna de trilobitas. braquiópodes e quitinozoários. que comprovam condições marinhas de deposição. A maior parte da unidade depositou-se em ambiente de águas rasas e parte considerável desta, em ambiente sob influência de marés (Gonçalves \& Schneider, 1968). Saes (1995, inf. verbal) considera o ambiente de deposição como sendo de mar raso epeirico, com sedimentos em suspensão associado a tempestades.

O conteúdo fossilífero indica idade Devoniana, fato aceito pela maioria dos autores tais como Oliveira \& Mühlmann (1965), Schneider et al. (1974), Barros et al. (1982) e Schobbenhaus et al. (1984).

\section{6 - Grupo Itararé, Formação Aquidauana}

A nível regional, essa unidade ocorre à sul-sudoeste, na região compreendida entre as cidades de Itiquira a Rondonópolis e, à sudeste, leste e nordeste, entre as cidades de Paranatinga e Barra do Garças. As rochas da Formação Aquidauana tem amplo predomínio na área mapeada, como por exemplo, nas regiões de Paredão Grande, Colônia Meruri e Poxoréu, onde ocorrem como encaixantes de inúmeros corpos intrusivos e extrusivos, bem como de sedimentos do Grupo Bauru estudados neste trabalho, como mostra o mapa geológico regional da Figura 2.

A sedimentação vermelha, essencialmente arenosa, que ocorre no vale do rio homônimo e que a estrada de ferro Noroeste do Brasil atravessou ao penetrar o Vale do Rio Aquidauana no Mato Grosso do Sul, foi denominada de Arenito Aquidauana por Lisboa (1909), tendo sido anteriormente correlacionada com a Seqüência Gondvânica do leste da Bacia do Paraná descrita por Derby (1895) (In: Barros et al., 1982).

A Formação Aquidauana (Gonçalves \& Schneider, 1970) consiste de sedimentos vermelhos e arroxeados, nos quais foram identificados três intervalos estratigráficos: o inferior, com arenitos médios a grossos, conglomerados e diamictitos subordinados; o médio, com siltitos estratificados e secundariamente diamictitos e folhelhos; e finalmente, o superior caracterizado pelo predomínio de sedimentos arenosos. 
A respeito do ambiente deposicional, o conteúdo litológico descrito por vários autores como por exemplo Almeida (1954), Gonçalves \& Schneider (1968), Schneider et al. (1974), Ribeiro Filho et al. (1975), Barros et al. (1982) e Drago et al. (1981), sugere um ambiente continental, a partir de sistemas fluviais associados a lacustres, com influência glacial próxima. No entanto, Vieira (1968), a partir da presença de fósseis marinhos encontrados em arenitos da porção inferior, argilitos basais e diamictitos da unidade em questão e na continuidade das camadas, propôs tratar-se de ambiente deposicional marinho associado a geleiras próximas (In: Barros et al., 1982).

Guirro (1991), concluiu que o conteúdo litológico dessa unidade entre as cidades de Pedra Preta a Alto Garças e Rondonópolis a Guiratinga, é caracterizado por arenitos intercalados com pelitos (siltitos) associados a ritimitos e diamictitos, tanto em superficie como em subsuperficie. Nesse segundo caso, os dados foram obtidos em testemunhos de sondagens realizadas pela Petrobrás na região de Alto Garças (MT), Taquari (MT) e Jataí (GO), assim como pela Paulipetro na região do Rio Aporé (MS). Nos pacotes arenosos predominam estratificações cruzadas acanaladas. Os siltitos refletem sedimentação por decantação enquanto os ritimitos são depósitos originados a partir de correntes de turbidez de baixa densidade. Já os diamictitos resultam da ressedimentação gerada por fluxos gravitacionais. Camadas arenosas intercaladas a siltitos e diamictitos foram interpretadas como depósitos originados por correntes de turbidez e fluxos mais coesos e liqüefeitos. Com base nesses e em outros inúmeros dados levantados, o referido autor concluiu que os intervalos arenosos representam tratos de sistema de progradação costeira que se desenvolveram durante os estágios de queda do nível relativo do mar. A deposição ocorreu sobretudo por fluxos gravitacionais de frentes deltaicas não tendo sido constatada a influência direta de geleiras sobre a sedimentação.

Saes et al. (1992) descreveram que a seção glaciogênica mais típica da Formação Aquidauana ocorre próximo à cidade homônima no Estado do. Mato Grosso do Sul. Os afloramentos localizados à leste de Rondonópolis são dominados por seqüências areno-argilosas fluviais com paleocorrentes dirigidas para SE. Pacotes de lamitos vermelhos, lacustres e espessos, ritimitos, diamictitos, conglomerados e freqüentes lobos arenosos associados à desembocadura de inúmeros pequenos deltas, bem como dunas eólicas foram registradas por esses autores.

$O$ contato inferior da Formação Aquidauana se faz discordantemente sobre a Formação Ponta Grossa. Nas proximidades do Rio Caiapó e a noroeste de Barra do Garças 
(Drago et al., 1981), o contato basal da Formação Aquidauana se faz por discordância erosiva e angular com o Grupo Cuiabá. A oeste e a sul de General Carneiro. o contato superior dessa unidade com as Formações Palermo, Botucatu. Serra Geral e o Grupo Bauru é discordante. erosivo ou por falha (Barros et al., 1982). A espessura no poço 2-AG-1-MT, na cidade de Alto Garças atingiu 799m (Guirro. 1991).

Estudos palinológicos e de microfósseis por Daemon \& Quadros (1970) (In: Gonçalves \& Schneider, 1970), encontrados nas proximidades de Tesouro, MT (a sul de Menuri), associados aos de Schobbenhaus et al., 1975a e Ribeiro Filho et al., 1975, mostraram que a idade da Formação Aquidauana situa-se no intervalo entre o Carbonífero Superior e o Permiano Inferior (In: Barros et al., 1982).

\section{7 - Grupo Guatá, Formação Palermo}

Regionalmente, a unidade em questão ocorre à oeste, muito próxima aos limites da área mapeada, tendo sido observada também na porção sudoeste, na estrada vicinal entre Poxoréu e Dom Aquino. Além disso, ocorre na porção à nordeste da cidade de Poxoréu e à sul capeando tipos litológicos da Formação Aquidauana.

O nome Palermo foi utilizado pela primeira vez na literatura geológica por White (1908), que retirou o nome da vila homônima do Município de Lauro Muller, SC, onde ocorre a seção-tipo dessa unidade litoestratigráfica (In: Barros et al., 1982). A inclusão dessa Formação e a Rio Bonito, no Grupo Guatá, coube a Gordon Jr.(1947) (In: Schobbenhaus et al., 1984).

Os tipos litológicos descritos na Formação Palermo, no Estado de Mato Grosso, são caracterizados por uma camada delgada de conglomerado basal, avermelhado, com seixos angulares, esparsos e matriz arenosa. Ocorrem ainda siltito vermelho arroxeado, arenoso, finamente estratificado, sílex esbranquiçado com estratificação ondulada, oolítico e/ou pisolítico, cinza esbranquiçado e, coquina silicificada esbranquiçada (Gonçalves \& Schneider, 1970). Os sedimentos dessa unidade apresentam uma silicificação intensa, que cimentou e destruiu, em grande parte, as características primárias de suas rochas.

A lenticularidade e as estruturas do tipo "flaser" são comuns nos leitos arenosos. Foram notadas também estruturas de sobrecarga e de deformação por compactação e, pelotas de argila (Petri \& Fúlfaro, 1988). 
Schneider et al. (1974) descreveram que as caracteristicas litológicas e sedimentares da Formação Palermo indicam deposição em ambiente marinho transgressivo de águas rasas, abaixo do nivel da ação das ondas.

$O$ contato inferior da Formação Palermo com a Aquidauana se faz através de discordância erosiva e por falhas de gravidade. Porém. Gonçalves \& Schneider (1970) relataram que esta discordância, além de erosiva para o centro-leste de Mato Grosso, é angular e marcada pela presença local de conglomerado basal, fato que não existe no centro da bacia. $O$ contato superior com a Formação Botucatu é por discordância erosiva. Com o Grupo Bauru o contato pode ser tanto erosivo como por falhamentos gravitacionais.

A idade de deposição da Formação Palermo, com base em estudos palinológicos e paleontológicos (microfósseis) desenvolvidos por Petri \& Fúlfaro (1966) e Daemon \& Quadros (1969) (In: Schobbenhaus et al., 1984), situa-se no Permiano.

\section{8 - Grupo São Bento, Formação Botucatu}

Os pacotes da Formação Botucatu ocorrem principalmente na região noroeste, Chapada dos Guimarães. Além disso, afloram, segundo Barros et al. (1982), na região da Estrutura do Alto Coité e à oeste da localidade de Coité, no Município de Poxoréu e dentro dos limites de mapeamento deste trabalho. Também ocorrem nas porções norte e nordeste do Município de Dom Aquino, como mostra o mapa geológico regional (Figura 2).

O nome Botucatu foi introduzido na literatura geológica da Bacia do .Paraná por Campos (1889) (In: Barros et al., 1982), denominando de "Grés Botucatu" os arenitos que constituem a serra de mesmo nome no Município de Botucatu, no Estado de São Paulo.

Os tipos litológicos comuns a esta unidade litoestratigráfica são constituídos, predominantemente, por arenitos vermelhos, resultantes da intensa cimentação por óxidos de ferro. Além disso apresentam seleção de regular a boa e classe modal de areia fina com pouca matriz (argila). Os grãos maiores de $0,5 \mathrm{~mm}$, possuem esfericidade alta, arredondamento bom, superficies foscas e esburacadas e, cimento silicoso ou ferruginoso.

Estratificações cruzadas, de médio a grande porte e plano-paralelas, são estruturas marcantes na Formação Botucatu. As características texturais, associadas às estruturas primárias observadas, indicam deposição eólica em ambiente desértico (Schneider et al., 1974). 
O contato inferior, observado por Weska (1987) na região da Chapada dos Guimarães, ocorre por discordância angular com o Grupo Cuiabá. O contato superior é litológico com a Formação Serra Geral, ou erosivo com o Grupo Bauru e com sedimentos inconsolidados quaternários. Barros et al. (1982), consideram que o contato inferior da Formação Botucatu pode ocorrer por falhas com o Grupo Cuiabá, bem como com as Formações Furnas, Ponta Grossa, Aquidauana e Palermo.

A idade do deserto Botucatu deve ser considerada como mais antiga do que o evento Serra Geral que lhe é sobreposto (Jurássico Superior) e, mais jovem que a idade dos pacotes de topo da Formação Rosário, que lhe são sotopostos, na porção sul da Bacia do Paraná (Triássico Superior). Esses fatos indicam que a idade da Formação Botucatu é jurássica (In: Schobbenhaus et al., 1984).

\section{9 - Grupo São Bento, Formação Serra Geral}

A denominação dessa unidade litoestratigráfica foi dada por White (1908), ao conjunto de corpos vulcânicos, indicando como seção-tipo as exposições que ocorrem na Serra Geral ao longo da estrada Lauro Muller - São Joaquim (SC). Este magmatismo é de extensão continental, segundo Melfi et al. (1988), atingindo os estados do sul e centro do país, bem como o noroeste do Uruguai, nordeste da Argentina e sudeste do Paraguai.

No Estado de Mato Grosso, os basaltos da Formação Tapirapuã (Evans, 1894), que ocorrem entre as cidades de Diamantino e Tangará da Serra, foram datados por Miniolli et al. (1971), resultando idades entre 112 a $126 \pm 4 \mathrm{Ma}$., que foram correlacionadas aos basaltos da Formação Serra Geral.

Na Folha Cuiabá, SD.21., basaltos correlacionados ao evento Serra Geral são de ocorrência restrita. Em relação a região estudada, situam-se à oeste de Poxoréu e à nordeste de Dom Aquino, conforme Figura 2.

Na região da Chapada dos Guimarães, à noroeste da área em apreço, Weska (1987) e Weska et al (1988), correlacionaram os diques da Mata e da Matinha, bem como o derrame da Passagem do Mamão ao evento Serra Geral. Tais diques estão encaixados na Formação Botucatu, tendo sido englobados por Schobbenhaus et al. (1979) no Grupo Iporá.

Segundo Gonçatves \& Schneider (1970), a Formação Serra Geral, no Estado de Mato Grosso é constituída de basaltos maciços, cinza escuros, com granulação fina a afanítica, por 
vezes amigdaloidais, contendo intercalações lenticulares de arenitos (intratraps). Barros et al. (1982) consideram que a Formação Serra Geral é constituída de basaltos, de cor cinza-escuro, com granulometria fina a afanítica e de ocorrência restrita na área mapeada. As rochas mapeadas como pertencentes a Formação Serra Geral apresentam contato basal do tipo litológico com a Formação Botucatu. O contato de topo por sua vez, é feito por discordância erosiva com rochas do Grupo Bauru ou com sedimentos inconsolidados de idades terciária ou quaternária.

A idade do evento vulcânico Serra Geral, segundo os trabalhos de datações realizados por Amaral et al. (1966), Melfi (1967), Umpierre (1966), Bossi \& Umpierre (1974), Sartori et al. (1975) e Cordani et al. (1980) (In: Schobbenhaus et al., 1984), está compreendida entre 130 e 150 Ma. Segundo Mantovani (1995), o tempo de duração desse magmatismo não teria excedido a $10 \mathrm{Ma}$.

Datações recentes de Montes-Lauar et al. (1994) dos basaltos Anari (RO) e Tapirapuã (MT), pelo método $\mathrm{Ar}^{40} / \mathrm{Ar}^{39}$ revelaram idades de $197 \mathrm{Ma}$. para ambos os corpos.

\subsection{0 - Grupo Iporá}

O Grupo Iporá, proposto por Schobbenhaus et al. $(1975,1979)$ no Estado de Mato Grosso, inclui rochas de composição basáltica de Paredão Grande, Colônia Meruri e Chapada dos Guimarães, assim como termos ultrabásicos como os kimberlitos da região de Paranatinga (Fragomeni, 1976; Costa, 1996). As rochas desse grupo foram descritas primeiramente por Guimarães et al. (1968), que reconheceram a existência de um complexo alcalino na região de Iporá,GO. Faria et al. $(1968,1969)$ (In: Drago et al., 1981), dividiram o Grupo Iporá em: a) rochas plutônicas constituídas de sienitos, essexitos, piroxenitos e dunitos; b) rochas hipoabissais compostas de traquiandesitos, basanitos, lamprófiros e tinguaitos; e c) rochas efusivas e piroclásticas.

Danni (1974,1978), ao estudar os complexos da região de Iporá, constatou a existência de dois episódios tecto-magmáticos. $O$ primeiro e mais importante, reúne intrusões zonadas do tipo central, caracterizadas pela série dunito, wehrlito, olivina-piroxenitos, metagabros alcalinos, teralitos, essexitos e nefelina-sienitos miaskíticos. Essas rochas originaramse a partir da cristalização fracionada cumulativa de olivinas, clinopiroxênios e plagioclásios, com a subsequente formação de líquidos residuais sieníticos. O segundo episódio é representado 
por uma reativação tectônica de falhas $\mathrm{NW}$ e $\mathrm{N} 70^{\circ} \mathrm{E}$, acompanhada por intrusões menores de magmas nefelinicos. leuciticos e analcimíticos. sob a forma de diques, sills e chaminés.

Pena et al. (1975), concluíram que as intrusões alcalinas do Grupo Iporá seriam uma extensão para NW do Arco do Alto Paranaiba (MG), tendo como feição estrutural principal falham̀entos de caráter normal, de direção $\mathrm{N} 50^{\circ} \mathrm{W}$ e idade Cretácea. Esses autores identificaram um eixo de arqueamento NW associado a importantes jazimentos minerais onde foram encontradas aproximadamente 80 intrusões consideradas como kimberlitos. Esses possíveis kimberlitos e intrusões alcalinas ( $I n$ : Schobbenhaus et al., 1984) localizam-se sobre importantes lineamentos que se estendem por centenas de quilômetros sobre o território brasileiro, com "trend" em torno de $\mathrm{N} 55^{\circ} \mathrm{W}$, em direção a Goiás, Mato Grosso e Rondônia, tendo sido denominados de Azimute $125^{\circ}$ por Bardet (1977).

Gonzaga \& Tompkins (1991) citam a ocorrência de dois corpos kimberlíticos situados no Segmento Brasiliano DL, sendo um deles localizado no "graben de Poxoréu".

Segundo Drago et al. (1981), na região compreendida entre a localidade de Paredão Grande e a Colônia Indígena Meruri, ocorrem corpos como pequenos afloramentos alongados e alinhados segundo E-NE, condicionados provavelmente pela falha Meruri. Os corpos alcalinos ocorrem também como pequenos "plugs" cônicos e foram incluídos no Grupo Iporá por esses autores.

Para Schobbenhaus et al. (1984), as manifestações do magmatismo cretáceo encontram-se balizadas por falhas gravitacionais de direções $\mathrm{NW}$ e $\mathrm{N} 70^{\circ} \mathrm{E}$. Um grande número de intrusões subvulcânicas foram reconhecidas através de levantamentos aero-geofísicos efetuados, respectivamente, pelos Projetos Iporá e Alto Garças. A maior parte desses corpos está encoberta por capeamentos sedimentares delgados do Grupo Bauru e da Formação Cachoeirinha.

Weska et al. (1992), na região entre a localidade de Paredão Grande e a Colônia Indígena do Meruri, mapearam 33 (trinta e três) corpos, que ocorrem encaixados na Formação Aquidauana sob a forma de diques. Esses corpos exibem características petrográficas similares, como textura porfiritica, fenocristais de plagioclásios, piroxênios e olivinas, e xenocristais de quartzo imersos em uma matriz muito fina a afanítica. Xenólitos de arenitos da Formação Aquidauana são comuns nas bordas e no topo dos diques, refletindo contaminação crustal importante. Como esses autores não dispunham de datações dessas rochas na época, elas foram incluídas no Grupo Iporá proposto por Guimarães et al. (1968). 
A idade das rochas alcalinas do Grupo lporá situa-se no intervalo 70 a 89 Ma., conforme datações pelo método K/Ar realizadas por Pena \& Figueiredo (1972), Danni (1974), Barbour et al. (1979) e Hasui et al. (1980) (In: Drago et al., 1981).

Os kimberlitos da região de Paranatinga, bem como os corpos intrusivos sob a forma de diques identificados como riolitos por Luz et al. (1980), na Chapada dos Guimarães, foram incluídos por Schobbenhaus et al. (1979) no Grupo Iporá, como está mostrado no mapa geológico da Folha Cuiabá SD.21. Um dos corpos de Paranatinga (B-9) foi datado por Davis (1977) por meio de traços de fissão revelando idade de 121,1 Ma. (In: Gonzaga \& Tomppkins, 1991); sendo, portanto, contemporâneo aos eventos do magmatismo Serra Geral.

\subsection{1 - Grupo Bauru}

Em relação à área mapeada, o Grupo Bauru ocorre à noroeste, na Chapada dos Guimarães e na porção extremo oeste e central, respectivamente em Dom Aquino e Poxoréu (Figura 2). A denominação pioneira de "Grês" Bauru coube a Campos (1905) ao batizar os sedimentos areno-calcáreos de uma seção cretácea do oeste de São Paulo (In: Barros et al., 1982). As primeiras citações a respeito da ocorrência destas rochas no Estado de Mato Grosso foram feitas por Bauer \& Largher (1958), nas proximidades do Rio Roncador (Chapada dos Guimarães), tendo sido consideradas como equivalentes ao Bauru. Oliveira \& Mülhmann (1965), subdividiram informalmente as rochas desse grupo nas seguintes unidades: "A" (inferior) e "B" (superior), correlacionando-as com a Formação Bauru. Gonçalves \& Schneider (1970) denominaram a unidade "B" de Membro Borolo.

Weska (1987) elaborou uma compartimentação faciológica do Grupo Bauru na região de Água Fria, Município de Chapada dos Guimarães, MT, caracterizando a existência de 3 (três) fácies que foram denominadas informalmente, da base para o topo de Quilombinho, Cachoeira do Bom Jardim e Cambambe. Posteriormente, essa proposta foi ratificada por Weska et al. (1988). A primeira, é constituída de rochas vulcanoclásticas basais, tendo em direção ao topo lentes de conglomerados, de arenitos e de argilas derivadas de eventos deposicionais cíclicos. A Fácies Cachoeira do Bom Jardim, definida por uma espessa e bem exposta seqüência de rochas detríticas, com granulação grossa na base, evolui progressivamente na porção intermediária para granulometria mais fina e sedimentos clasto-químicos no topo. Esta fácies foi caracterizada por cimento e crostas ricas em carbonatos (calcretes). A Fácies Cambambe, por sua vez, é 
constituída de conglomerados, arenitos finos a microconglomeráticos, silcretes, arenitos e microconglomerados. Os arenitos microconglomeráticos apresentam clastos de quartzo, são cíclicos e ocorrem preferencialmente no topo da fácies. Os conglomerados são cíclicos, sendo caracterizados por seixos de arenitos e quartzo. São destituídos de seixos de rochas vulcânicas básicas e ocorrem em lentes variando entre 1 e $3 \mathrm{~m}$. A matriz é arenosa e o cimento silicoso.

Estratificações cruzadas acanaladas de pequeno e médio porte, plano-paralelas e estruturas de corte e preenchimento são as principais estruturas sedimentares. $O$ Grupo Bauru na região, apresenta grande diversidade litológica e sua deposição foi grandemente influenciada por falhamentos (Gonçalves \& Schneider, 1970). Estes sedimentos resultam de deposição continental fluvial e lacustrina, representada por planícies de inundação, canais e deltas fluviais.

Bittencourt Rosa et al. (1991) relataram a ocorrência de minerais de sílica fibrosa nas rochas da Fácies Cambambe (Weska, 1987 e Weska et al., 1988), que foram descritas como as variedades mineralógicas de opala, megaquartzo, calcedonita, quartzina, lutecita e lussatita. Segundo esses autores a associação mineralógica descrita é típica de ambientes deposicionais evaporíticos.

A distribuição em área e a sucessão vertical dos estratos das três fácies, foram definidas a partir de um modelo deposicional de leques aluviais, desenvolvidos sob clima semiárido a árido e com variações laterais (Weska, 1987 e Weska et al., 1988). Coimbra (1991), com base nos trabalhos de Weska (1987) e Weska et al. (1988), e com suporte em uma coluna estratigráfica descrita por Oliveira \& Mülhmann (1965) na região de Dom Aquino, propôs que as Fácies Quilombinho e Cachoeira do Bom Jardim de Weska (1987) fossem englobadas em uma nova unidade litoestratigráfica denominada de Formação Córrego Ribeirão Boiadeiro.

Weska et al. (1993) mapearam na região de Poxoréu os litotipos das três fácies definidas na Chapada dos Guimarães e propuseram a formalização do Grupo Bauru no Estado de Mato Grosso, que ficou constituído pelas Formações Quilombinho (basal), Cachoeira do Bom Jardim (intermediária) e Cambambe (topo).

Os contatos deste grupo com as unidades inferiores mostram-se através de superficies discordantes erosivas marcantes, consolidadas por conglomerados basais espessos sobre as Formações Serra Geral, Botucatu, Palermo, Aquidauana e Ponta Grossa (In: Barros et al., 1982; Weska 1987; Weska et al., 1988). O contato de topo é discordante erosivo com as Formações Cachoeirinha, Pantanal e as Aluviões Atuais. 
A maior espessura medida no Grupo Bauru até o momento continua sendo aquela efetuada por Weska (1987), que encontrou 340m na região de Chapada dos Guimarães (MT).

A idade do Grupo Bauru, baseada em estudos de seu conteúdo fossilífero constituído de representantes das ordens Dinossauria e Quelônia, foi tratada inicialmente por Derby (1890) que propôs uma idade cretácea para esses litotipos. Estudos posteriores de Roxo (1937), permitiram conferir áos pacotes desta unidade a idade cretácea superior. Os jazigos dessas ossadas foram relocalizados por Weska (1987), no Morro do Cambambe, na Formação de mesmo nome, aflorante no Município de Chapada dos Guimarães.

\subsection{2 - Formação Cachoeirinha}

Os tipos litológicos da Formação Cachoeirinha possuem uma distribuição ampla no Estado de Mato Grosso, ocupando geralmente as cotas topográficas mais elevadas das superficies peneplanizadas resultantes da Superfície Sul-Americana de King (1956). Em relação à área, a unidade em questão ocorre à oeste, norte e nordeste, região do Rios das Mortes como está mostrado na Figura 2. No entanto, por uma questão de escala dos mapeamentos até agora executados, essa unidade não foi cartografada, uma vez que ocorre também nos quadrantes sul e leste, circundando a área como um todo, inclusive nas suas porções internas topograficamente mais elevadas.

A denominação dessa unidade litoestratigráfica deve-se a Gonçalves \& Schneider (1970), ao descreverem um material areno-argiloso inconsolidado com níveis de cascalhos interdigitados. O nome provém da localidade denominada Cachoeirinha, a cerca de $30 \mathrm{~km}$ à norte da cidade de Poxoréu, nas proximidades da BR-070. Entretanto, coube a Oliveira \& Mülhmann (1965) as primeiras descrições dessa unidade, tendo sido informalmente denominada de unidade "C".

Poucos foram os autores, além dos anteriormente descritos, que deram alguma atenção a estas coberturas em seus trabalhos no Estado de Mato Grosso, podendo-se destacar entre eles Luz et al. (1980), Drago et al. (1981), Barros et al. (1982), Weska (1987) e Weska et al (1991,1993), que descreveram, individualizaram e subdividiram essas coberturas em uma ou mais unidades informais.

Os tipos litológicos comuns na Formação Cachoeirinha são cascalhos inconsolidados, praticamente monomíticos por possuírem mais de $90 \%$ de seixos de quartzo, muito bem 
arredondados e de esfericidade alta, proporcionando a denominação local de "cascalhos ovos de pomba". Lentes arenosas, imaturas a maturas e argilosas, fortemente cimentados por óxidos de ferro, proporcionam cores avermelhadas a amareladas (limonitização) aos pacotes, formando muitas vezes verdadeiras crostas laterizadas que localmente são denominadas de "cangas".

Segundo Drago et al. (1981), esta unidade constitui-se de material areno-argiloso inconsolidado, que exibe cores vermelha-alaranjadas. ou, às vezes, rósea-claras. A granulometria varia de fina a média. com os grãos de quartzo em geral angulosos a subangulosos. Ocorrem vez ou outra, lentes de cascalhos, com seixos de quartzo ou sílex imersos em matriz arenosa, produto de depósitos residuais de canais. Níveis de concreções ferruginosas ou bolsões de cangas lateriticas são comumente encontrados na parte mais inferior.

Dois conjuntos litológicos foram individualizados nas Coberturas Terciárias da região da Chapada dos Guimarães, que se sobrepõem ao Grupo Bauru, segundo Weska (1987) e Weska et al. (1991). Estes conjuntos, que marcam os processos erosivos e deposicionais relacionados a evolução da Bacia Intracratônica do Pantanal, são a Formação Cachoeirinha (basal) e a Fácies Estiva (topo). A primeira é constituída predominantemente por clastos finos e a segunda por clastos grossos.

O ambiente deposicional na Chapada dos Guimarães é do tipo de leques aluviais (Weska, 1987), de climas úmidos, relacionados a altos topográficos próximos, sendo que a Formação Cachoeirinha é fluvial na base e lacustre no topo, originados a partir de deposições episódicas de fluxos de lama com raros detritos. A Fácies Estiva constitue o topo das coberturas terciárias na Chapada dos Guimarães, sendo caracterizada por clastos grossos com matriz arenoargilosa (debris flow).

A unidade litoestratigráfica, denominada de Formação Cachoeirinha, recobre quase todas as unidades da borda ocidental da Bacia do Paraná, sob as mais variadas formas de discordâncias. A do tipo erosivo predomina sobre as rochas dos Grupos Cuiabá e Alto Paraguai, Granito São Vicente, Formações Furnas, Ponta Grossa, Aquidauana, Palermo, Botucatu e Serra Geral (Barros et al, 1982), incluindo ainda o Grupo Bauru (Weska, 1987). O contato de topo é por discordância erosiva com a Fácies Estiva e Coberturas Quaternárias (Weska, 1987).

A Formação Cachoeirinha capeia uma superficie de aplainamento de idade pliocênica, sendo, portanto, segundo interpretação de Schobbenhaus et al.1984, também de idade pliocênica. 


\subsection{3 - Formação Pantanal}

Os sedimentos aluvionares inconsolidados e parcialmente laterizados da Formação Pantanal, ocorrem à oeste e sudoeste da área mapeada. nas proximidades de Cuiabá e Santo Antônio do Leverger, como se pode ver no mapa geológico regional da Figura 2.

A Formação Pantanal foi assim denominada por Oliveira \& Leonardos (1943), que a descreveram como constituída por vasas, areias e argilas de deposição sub-recente (In: Schobbenhaus et al., 1984). Segundo os autores referidos, essa unidade litoestratigráfica constitui os terraços mais elevados, parte do pediplano cuiabano e os leques aluviais que se espraiam no sopé das bordas da Bacia Intracratônica do Pantanal.

As litologias dessa unidade, na região do Pantanal Mato-grossense, são predominantemente areno-argilosas e síltico-argilosas; a granulometria dominante varia de fina a muito fina, podendo ocorrer também areias médias a cascalhosas, neste último caso proveniente da removimentação da drenagem atual (Barros et al., 1982), ou deposições resultantes de áreas fontes próximas. Weska et al. (1984), subdividiram informalmente os pacotes situados em terraços laterais às drenagens da Bacia do Alto Paraguai, na região entre Diamantino e Arenápolis, MT, em níveis T1, T2 e T3.

Para Weska (1987) e Weska et al. (1991), a Fácies Peba na Chapada dos Guimarães, possue como suas litologias, detritos inconsolidados de clastos finos no topo (areias e areias argilosas) e grossos na base (cascalhos com seixos de lateritas). Dado o seu posicionamento geográfico lateral às drenagens atuais, são rochas depositadas em ambiente fluvial, resultantes de vários ciclos erosivos e deposicionais, possuindo como área fonte o contexto geológico circunvizinho, sendo portadoras de mineralizações diamantíferas.

Figueiredo et al. (1974) estimaram a espessura da Formação Pantanal em no máximo $70 \mathrm{~m}$, com possança média de $40 \mathrm{~m}$. Segundo Barros et al. (1982), a Formação Pantanal recobre discordantemente rochas do Grupo Cuiabá e o Granito São Vicente, na Depressão Cuiabana, bem como outros tipos litológicos de rochas da Bacia do Paraná (Formação Botucatu) e do Grupo Bauru (Weska, 1987).

Com relação à sua idade, Almeida (1965a) referiu-se à presença de mamíferos fósseis na zona norte do Pantanal, fato este que viria comprovar o início das formações dos depósitos arenosos que constituem o Pantanal Mato-grossense, a partir do Pleistoceno (Quaternário) (In: Barros et al, 1982). 


\subsection{4 - Aluviões Atuais}

As Aluviões Atuais são encontradas junto aos canais atuais e às planícies de inundação das principais bacias de drenagem que escoam em direção à Bacia do Prata a sul e Amazônica à norte, como por exemplo, os Rios Cuiabá, das Mortes, Paraguai, Xingu e Teles Pires (Figura 2).

Segundo Barros et al. (1982), os depósitos atuais encontram-se ainda em fase de deposição nas planícies aluvionares dos grandes rios e seus tributários. Compõem-se de areias, siltes, argilas e cascalhos, reconhecendo-se depósitos de canal, depósitos de barra em pontal e transbordamento. Possuem pequena espessura, não atingindo $10 \mathrm{~m}$.

As aluviões fluviais do Holoceno, segundo Schobbenhaus et al. (1984), na Depressão Mato-grossense, representam o terraço atual que bordeja quase todos os rios e no qual há um remanejamento constante de sedimentos. A drenagem é de padrão labirintiforme e há grande quantidade de lagos de barragem e de meandros abandonados. Para esses autores, os maiores lagos da região estão associados a este terraço.

Weska et al. (1984), Weska (1987) e Weska et al. (1991), respectivamente entre as regiões de Diamantino a Arenápolis e Chapada dos Guimarães, definiram informalmente o nível "T4" e a Fácies Água Fria, unidades atuais informais, relacionadas à evolução da Bacia Intracratônica do Pantanal e em seus depósitos de cabeceira.

Litologicamente, na porção basal da Fácies Água Fria (Chapada dos Guimarães), ocorrem pacotes ricos em cascalhos portadores de diamantes. $O$ pacote de cascalhos foi descrito com seixos de arenitos, quartzo arenitos, quartzo, lateritas e silexitos. A matriz dos cascalhos é areno-argilosa e corresponde a $25 \%$ do pacote. As cores da fácies são vermelhas e amarelas. $O$ capeamento estéril sobre os cascalhos é de areias e areias argilosas, por vezes cascalhosas finas. As cores do capeamento são vermelhas, marrom avermelhadas e amarelas (Weska, 1987).

As características encontradas nos depósitos quaternários, segundo Weska (1987) e Weska et al. (1991), correspondem àquelas atribuídas às acumulações coluviais e ahuviais de ambiente fluvial, havendo estreita relação dos depósitos com a rede de drenagem local. 


\section{5 - GEOLOGIA LOCAL}

Conforme foi informado nos capítulos iniciais, um dos principais objetivos desta Tese diz respeito à geologia da região diamantífera, limitada aproximadamente pelas cidades de General Carneiro à leste e Dom Aquino à oeste (Figura 2).

Trata-se de uma faixa extensa onde os fenômenos geológicos, como seria de se esperar, estão distribuídos de forma heterogênea. $O$ próprio diamante, por exemplo, um dos objetivos centrais desse trabalho, ocorre de forma irregular concentrando-se de modo notável nos garimpos periféricos à cidade de Poxoréu (porção centro-oeste das áreas); e com teores menores ou inexistentes no restante da região estudada. Na porção centro-sul, por outro lado, mapeamos uma intrusão de possível natureza kimberlítica que foi o único corpo encontrado dentro dessa categoria de rochas. No extremo leste, próximo a Colônia Meruri, ocorre um conjunto de diques pertencentes ao Grupo Iporá (Drago et al., 1981 e Weska et al., 1992). No lado oposto da área, nos Alvos DA e PX, foram mapeados derrames básicos correlacionados anteriormente por Barros et al. (1982) e Weska et al. (1993) como da Formação Serra Geral. As colunas estratigráficas referentes a cada alvo mapeado estão mostradas nas Figuras 3,4 e 5 . Em todas elas a proposta desta Tese é mostrada em (b) de forma comparada com colunas (a) constantes da literatura (Barros et al., 1982; Drago et al., 1981; Coimbra, 1991; Weska et al., 1992; 1993).

Tendo em vista a escala de mapeamento de detalhe, tornou-se impossível apresentar os mapas geológicos em um conjunto único, por esta razão eles estão distribuídos nas Figuras 6, 7, 8, 9 e 10. Esses mapas foram elaborados durante os trabalhos de campo dos alunos de graduação do Curso de Geologia, do Instituto de Ciências Exatas e da Terra, da Universidade Federal de Mato Grosso, tendo como autores Pisani \& Arrais (1991), Araújo et al. (1991), Ribeiro \& Maciel (1991), Uggeri \& Costa (1991) e Oliveira et al. (1992). Esta base geológica foi ampliada posteriormente em direção à Paranatinga com os trabalhos de Pinho et al. (1994) e Macedo et al. (1995), tendo sido revisada por este autor em trabalhos de campo subsequentes, constituindo assim o produto ora apresentado. 


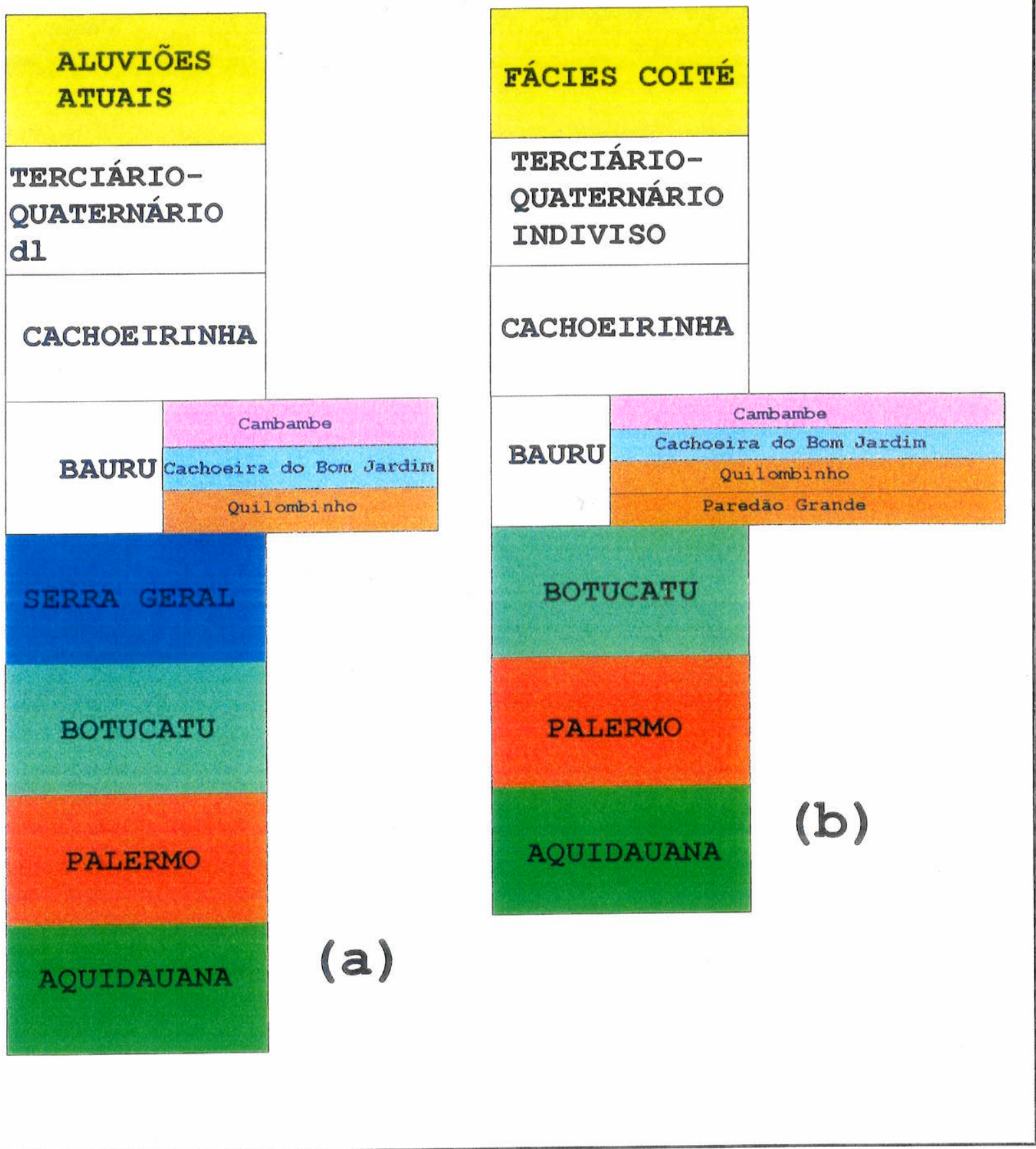

Figura 3 - Colunas estratigráficas comparativas da região de Poxoréu. Em (a), coluna vigente (Barros et al.,1982 e Weska et al.,1993); em (b), estratigrafia proposta nesta Tese. 

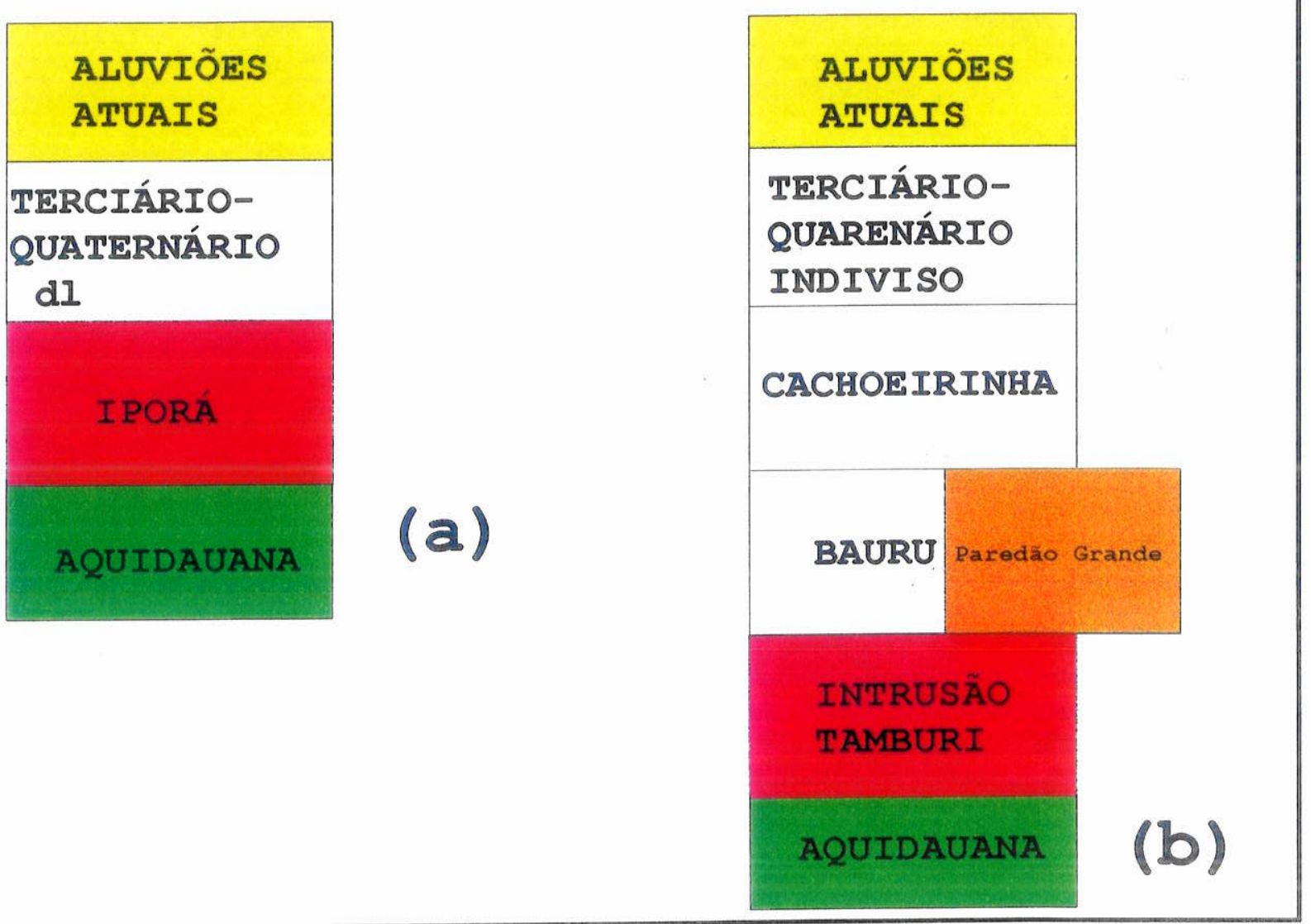

Figura 4 - Colunas estratigráficas comparativas da região abrangida pelo alvo PG. Em (a), coluna vigente (Drago et al.,1981); em (b), estratigrafia proposta nesta Tese.
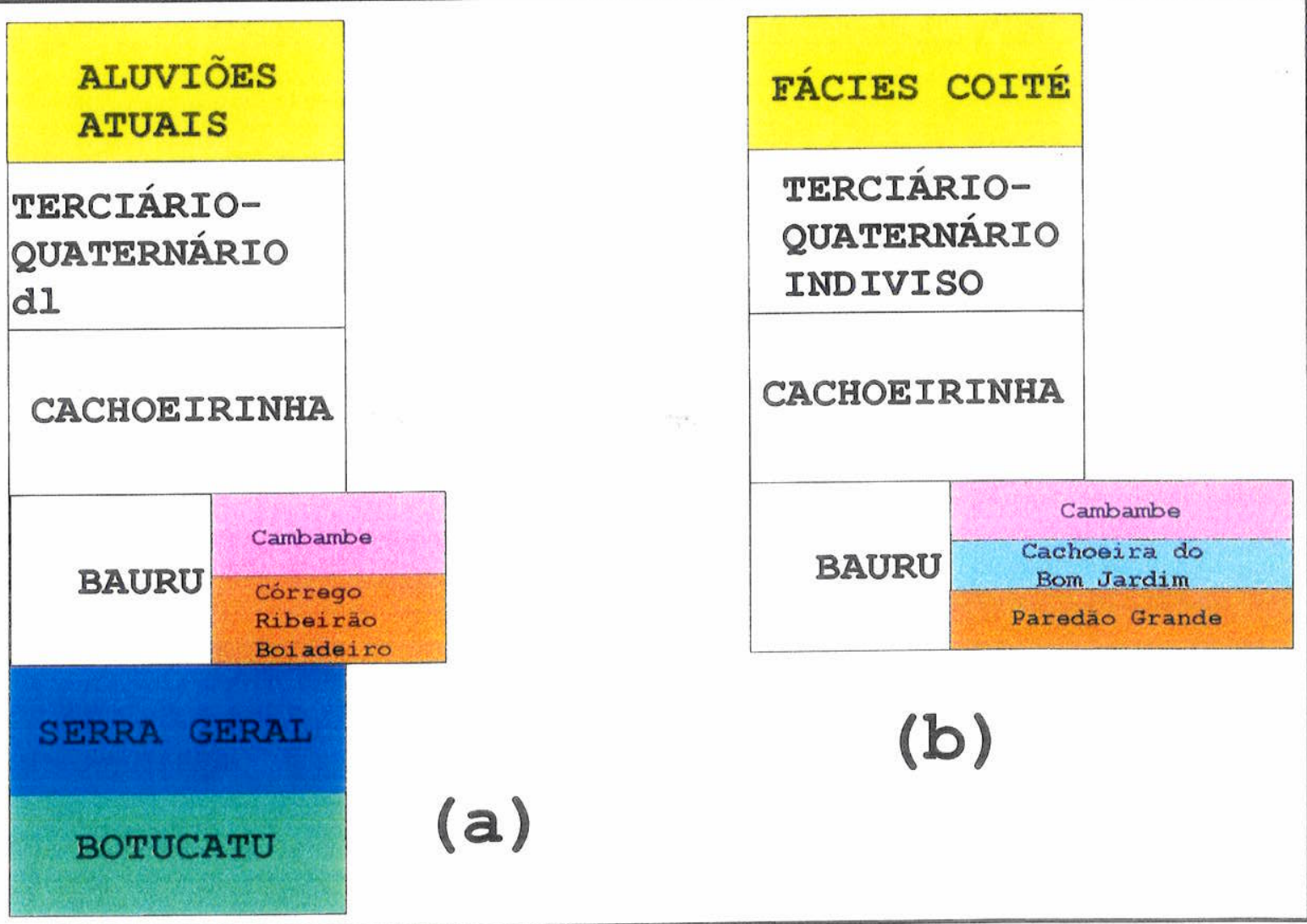

Figura 5 - Colunas estratigráficas comparativas da região do Alvo DA. Em (a), coluna vigente (Barros et al., 1982 e Coimbra, 1992); em (b), estratigrafia proposta nesta Tese. 
Figura 6 - Mapa geológico da região de Poxoréu (Alvo PX), VIDE ANEXO. 
Figura 7 - Mapa geológico da região adjacente à Intrusão Tamburi (Alvo PG), VIDE ANEXO. 
Figura 8 - Mapa geológico da região de Paredão Grande (Alvo PG), VIDE ANEXO. 
Figura 9 - Mapa geológico da região do Meruri (Alvo PG), VIDE ANEXO. 
Figura 10 - Mapa geológico da região de Dom Aquino (Alvo DA), VIDE ANEXO. 


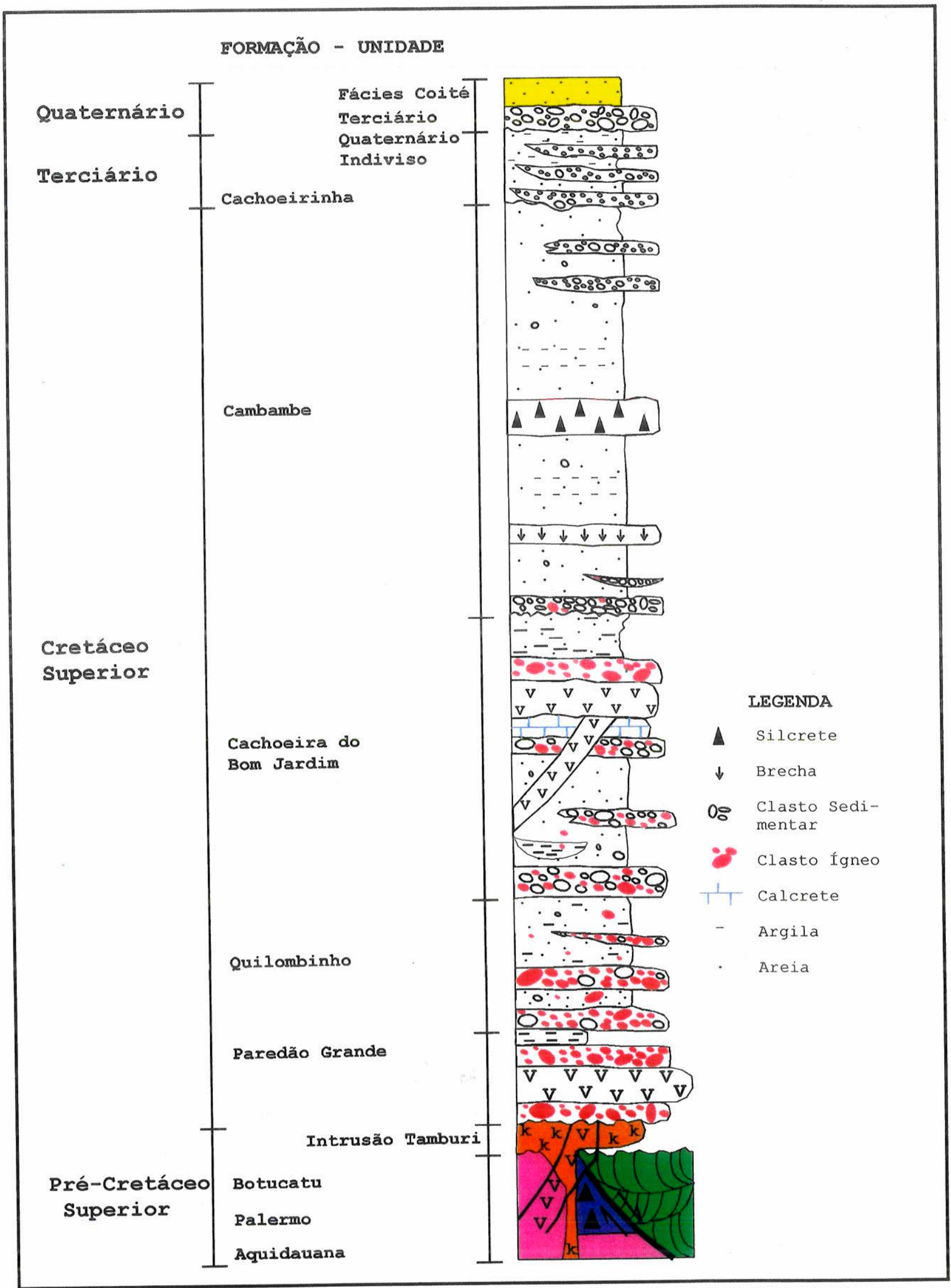

Figura 11 - Coluna estratigráfica da região compreendida entre os Municípios de Dom Aquino, General Carneiro, Paranatinga e Chapada dos Guimarães. 
Os estudos estratigráficos anteriormente colocados permitiram a inclusão de uma intrusão de possível natureza kimberlítica aqui denominada de Tamburi; a redefinição do Grupo Bauru no Estado de Mato Grosso, caracterizado da base para o topo pelas Formações Paredão Grande, Quilombinho, Cachoeira do Bom Jardim e Cambambe; bem como a proposição de uma unidade informal quaternária recente denominada de Fácies Coité. Tais estudos tornaramse necessários uma vez que o conhecimento da mineralização diamantífera nos depósitos tipo "placeres" só poderá ser desenvolvido a partir de uma base geológica consistente.

\section{1 - A Estratigrafia da região compreendida entre Dom Aquino e General Carneiro.}

A partir da composição das novas colunas estratigxáficas mostradas nas Figuras 3,4 e 5, a região compreendida entre Dom Aquino a General Carneiro, da base para o topo, é caracterizada pelas Formações Aquidauana, Palermo e Botucatu, Intrusão Tamburi, Formação Paredão Grande e Formações Quilombinho, Cachoeira do Bom Jardim e Cambambe, do Grupo Bauru; Formação Cachoeirinha, Unidade Terciário-Quaternário Indiviso e Fácies Coité /Aluviões Atuais (Figura 11). Nos capítulos subsequentes, discutiremos pormenorizadamente cada uma dessas unidades litoestratigráficas.

\subsection{1 - Formação Aquidauana}

A unidade litoestratigráfica em questão caracteriza-se como o substrato geológico mais antigo da região estudada (Figuras 2, 6 e 11), tendo sido mapeada nas porções sul, sudeste e sudoeste do Alvo PX, ao longo da falha de Poxoréu, na Estrutura de Alto Coité, como morros testemunhos e também como "bedrock" do Grupo Bauru, das Coberturas Terciário-Quaternário Indiviso e da Fácies Coité, conforme mostra a Figura 6. Nas áreas relativas ao Alvo PG, Figuras 7, 8 e 9, a Formação Aquidauana ocorre como rocha encaixante da Intrusão Tamburi e da Formação Paredão Grande. Ocupa as porções mais elevadas da área, com cotas topográficas de 680 a 400m em relação ao nível do mar. 
Os tipos litológicos constituintes da Formação Aquidauana mapeados em ambos alvos são caracterizados por arenitos grossos a finos, conglomeráticos, por vezes argilosos ou micáceos. Essas rochas ocorrem em bancos maciços ou friáveis, são intercaladas ciclicamente por lentes de arenitos microconglomeráticos. arenitos argilosos e argilitos. com concreções e cimento de óxidos de ferro, que predominam em direção ao topo. As cores predominantes do conjunto são vermelha e roxa. Nos pacotes conglomeráticos, os clastos de quartzo ( 1 a $4 \mathrm{~cm}$ ), estão dispersos em matriz areno-argilosa. Nos arenitos e arenitos argilosos, a cor pode ser amarela, branca e vermelha, sendo que a espessura pode variar de 1 a $30 \mathrm{~m}$. Os arenitos microconglomeráticos a conglomeráticos, possuem raros grânulos e seixos de quartzo $(0,3$ a $2 \mathrm{~cm})$, podendo chegar até a tamanho de matacões naqueles de argilitos $(0,5$ a $15 \mathrm{~cm})$; entretanto, há o predomínio da fração entre 0,5 a $1,5 \mathrm{~cm}$. O arredondamento é bom para os dois tipos de clastos, com esfericidade média para os de argilitos e média a alta nos de quartzo. A matriz é arenosa fina e compreende aproximadamente $60 \%$ do pacote descrito. A cor predominante nestas rochas é branca e a espessura pode variar no intervalo de 2 a $25 \mathrm{~m}$. No topo da coluna estratigráfica descrita para a Formação Aquidauana, ocorrem lentes de arenitos argilosos e argilitos, muito friáveis, com cores predominantes vermelhas e espessuras entre 2 a $20 \mathrm{~m}$. A espessura máxima medida nesta formação junto às escarpas da Falha de Poxoréu (Alvo PX), obtida através de diferenças de cotas no mapa topográfico foi de $150 \mathrm{~m}$.

Considerando-se o empilhamento proposto por Gonçalves \& Schneider (1970) para a Formação Aquidauana, há o predomínio de arenitos na base e de siltitos e folhelhos intermediários e arenitos na porção superior da coluna. Assim sendo, o empithamento ora descrito encaixa-se na porção basal descrita por aqueles autores.

Entre as estruturas primárias, foram observadas estratificações plano paralelas de médio porte, embora elas não sejam comuns. Outra estrutura identificada foi a sigmoidal nas áreas do Alvo PG, as quais desenvolvem-se por ocasião da diminuição abrupta da velocidade do meio transportador, com a conseqüente deposição em ambiente sub-aquoso.

Uma feição morfológica característica da Formação Aquidauana notada nos afloramentos nas proximidades das drenagens, são dissecações de forma hexagonal, lembrando casco de tartaruga, que já haviam sido descritas por Barros et al. (1982).

Por ocorrer associado ao muro da Falha de Poxoréu, o contato inferior da Formação Aquidauana não foi visualizado; entretanto, Oliveira \& Mühlmann (1965), descreveram esse contato como do tipo discordante erosivo com a Formação Ponta Grossa. O contato superior se 
dá por discordância angular com a Formação Palermo e erosiva com as unidades TerciárioQuaternário Indiviso e Coité (Aluviões Atuais). Os contatos entre a Formação Aquidauana com a Intrusão Tamburi e com os diques da Formação Paredão Grande, mostram metamorfismo térmico marcados por silicificação intensa, produzida durante o encaixamento desses corpos.

$O$ intervalo entre o Carbonífero Superior e o Permiano Inferior foi a idade definida para a Formação Aquidauana, a partir dos estudos palinológicos e de microfósseis, conforme dados de Daemon e Quadros (1970, In: Barros et al., 1982).

\subsection{2 - Formação Palermo}

A Formação Palermo (Figuras 2, 6 e 11), de igual modo a Aquidauana, ocupa as cotas topográficas mais elevadas, situando-se entre 720 a 400m em relação ao nível do mar. Esta unidade foi mapeada nas porções sul, sudeste e sudoeste da área do Alvo PX, onde ocorre recobrindo a Formação Aquidauana junto a Falha de Poxoréu e na Estrutura de Alto Coité (Figura 6).

Os litotipos que constituem a Formação Palermo são caracterizados por conglomerados basais oligomíticos, com seixos de quartzo $(4 \mathrm{a} 5 \mathrm{~cm})$, possuindo arredondamento ruim e esfericidade baixa. A matriz é areno-siltosa e o cimento silicoso. Calcarenitos oolíticos intercalam-se a pacotes de argila em direção ao topo na região da Estrutura do Alto Coité. Níveis oolíticos e silexitos, maciços, com laminações intercaladas de até $1 \mathrm{~cm}$ de espessura nas cores branca e vermelha ocorrem no topo do muro da Falha de Poxoréu. A morfologia desses pacotes é tabuliforme, estando as rochas intensamente silicificadas, sendo portanto, resistentes ao intemperismo.

As estruturas observadas nos afloramentos da Formação Palermo foram as laminações plano-paralelas, por vezes onduladas e os "tepees" (Fotografia 5a). A espessura da unidade em apreço varia de $5 \mathrm{~m}$ (Falha de Poxoréu) a $13 \mathrm{~m}$ na Estrutura do Alto Coité. O contato inferior localizado nesse alto ocorre com a Formação Aquidauana; já o contato superior é feito com as unidades Terciário-Quaternário Indiviso, sendo em ambos casos discordante erosivo.

Com base nas relações estratigráficas e nas coquinas que comumente ocorrem na Formação Palermo, Gonçalves e Schneider (1970) propuseram que a idade dessa unidade situa-se entre o Permiano Médio e o Superior. 


\subsection{3 - Formação Botucatu}

A Formaçāo Botucatu. conforme pode ser observado no mapa geológico regional (Figura 2), apresenta uma grande distribuição em área. Entretanto, com a conclusão dos mapeamentos geológicos realizados dentro dos limites dos Alvos DA e PX (Figuras 6 e 10), observou-se que afloramentos destas rochas são restritos ao Alvo PX (Figura 6), uma vez que tipos litológicos da Formação Cambambe (Grupo Bauru) foram indevidamente descritos como pertencentes a Formação Botucatu.

Afloramentos da Formação Botucatu foram identificados no centro e flanco norte da Estrutura do Alto Coité; à NE de Poxoréu (Fazenda Maringá) e à NW dessa cidade, conforme Figura 6, situando-se entre cotas topográficas de 500 a 400m em relação ao nível do mar.

As rochas características desta unidade litoestratigráfica correspondem a arenitos de granulometria fina a média, bem selecionados, com os grãos predominantemente foscos nas cores vermelha a amarela. Tais rochas em lâmina delgada são constituídas predominantemente por quartzo (90\%). Os grãos são arredondados a subarredondados, com tamanho variando de 0,3 a $0,7 \mathrm{~mm}$, possuindo como minerais acessórios rutilo, turmalina e zircão. $O$ cimento é silicoso e ferruginoso sendo a cor amarela resultante da introdução de água nos compostos de ferro (limonitização).

As estruturas primárias observadas são estratificações cruzadas de grande porte, próximo a Poxoréu (Fotografia 5b), e plano-paralelas na Estrutura do Alto Coité.

Não foi possivel definir o contato basal e nem a espessura da Formação Botucatu, uma vez que os afloramentos ocorrem nas porções topográficas baixas e por esta razão a base do Arenito Botucatu está encoberta por unidades mais jovens. Segundo Barros et al. (1982), o contato basal ocorre com as Formações Aquidauana e Palermo, por discordância erosiva ou falhas. O contato superior, descrito nas proximidades da cidade de Poxoréu (Weska et. al., 1993) é feito, com a Formação Quilombinho (Grupo Bauru) por discordância erosiva (Fotografia 5b).

A idade das rochas da Formação Botucatu, segundo Schobbenhaus et al. (1984) é Jurássica, considerando, segundo os referidos autores, que as mesmas são sotopostas pela Formação Rosário (Triássico Superior) e sobrepostas pelo vulcanismo Serra Geral (Jurássico Superior). 


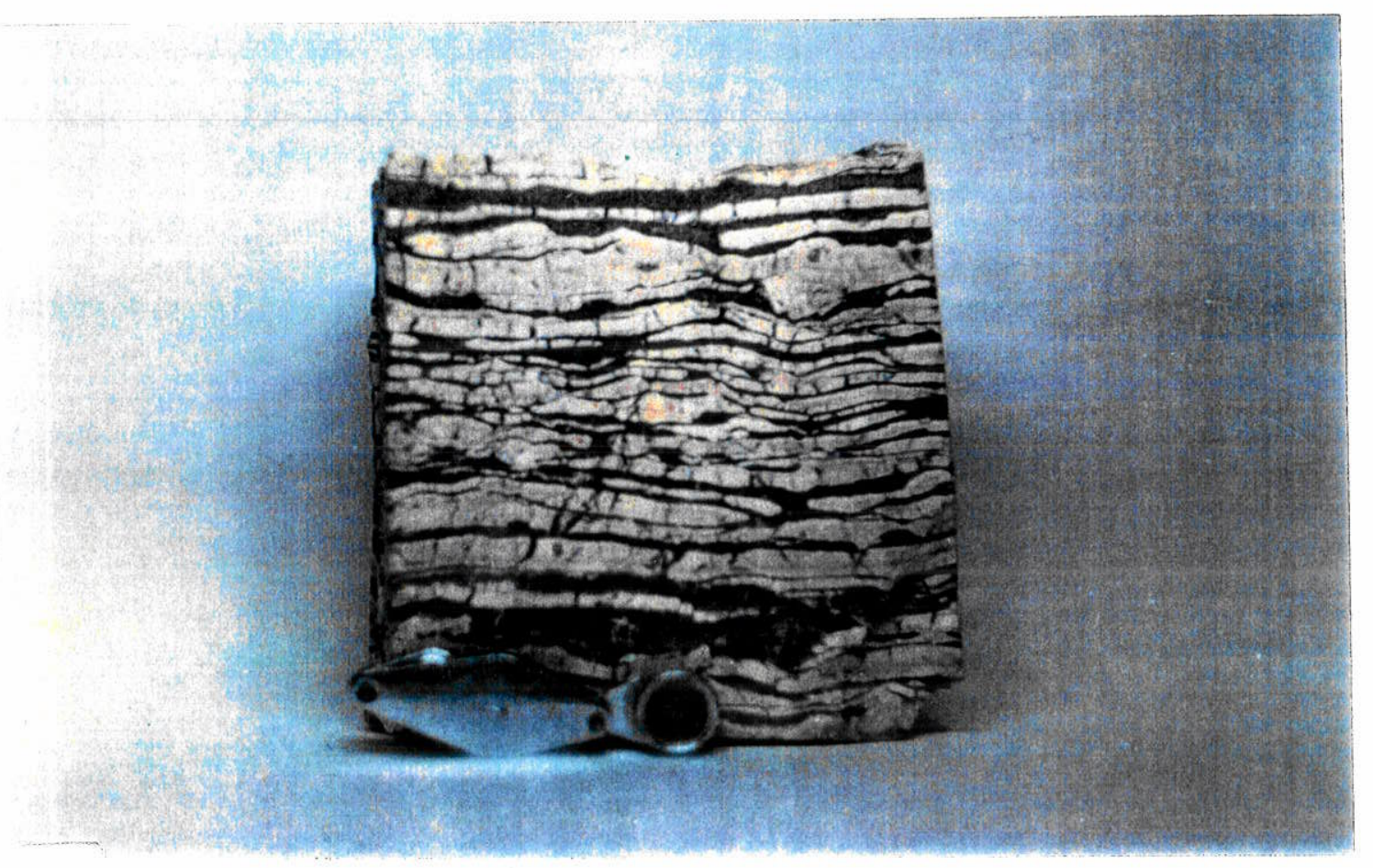

Fotografia 5a - Estruturas "tepees" na Formação Palermo.

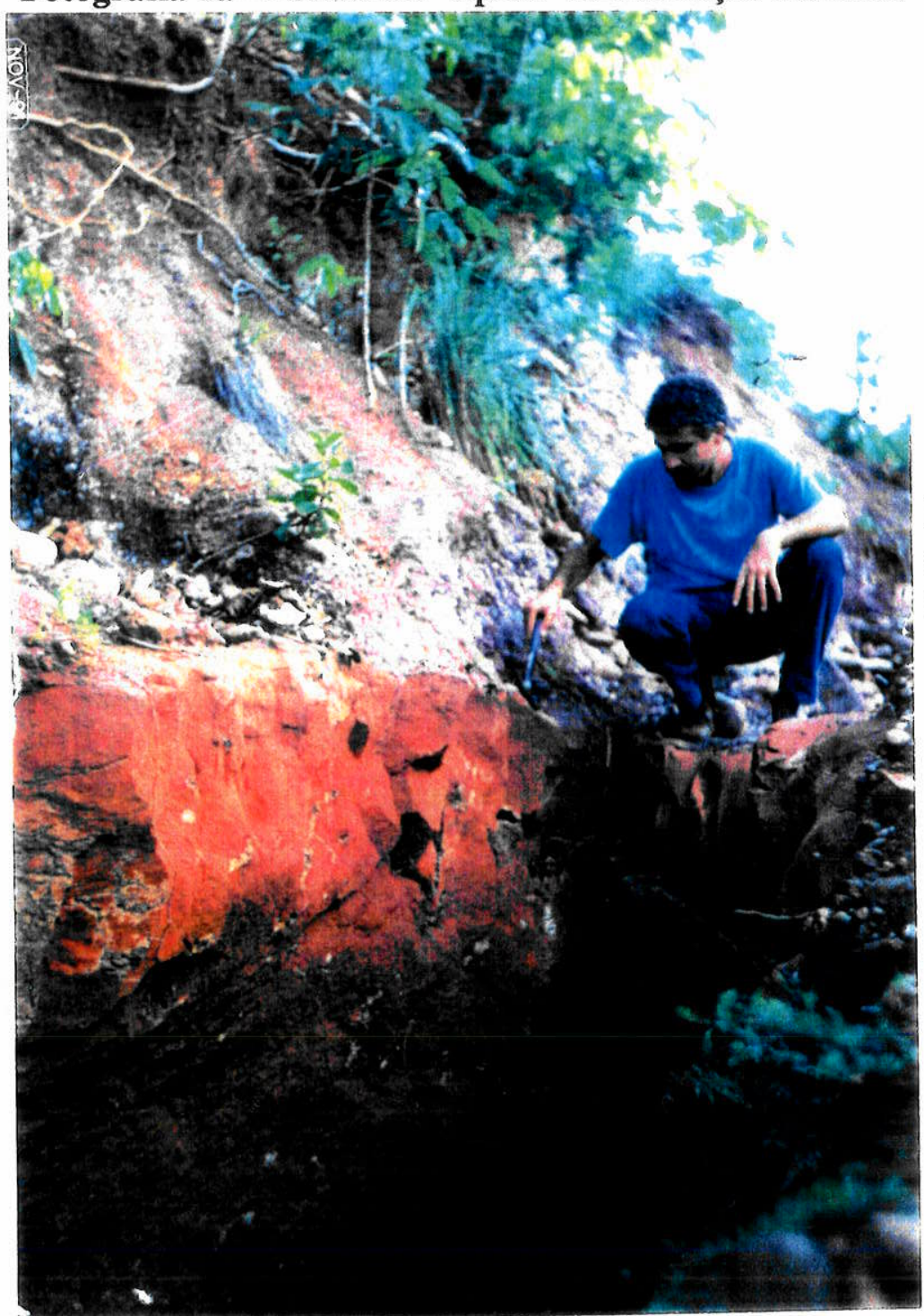

Fotografia 5b - Contato discordante erosivo entre as Formações Botucatu (base e Quilombinho (topo). 


\subsection{4 - Intrusão Tamburi}

A Intrusão Tamburi localiza-se na Fazenda Antão. cabeceiras de margem direita do Rio Paraíso (Córrego das Cobras e Tamburi), distante $50 \mathrm{~km}$ à SE de Poxoréu (Figuras le 7). O corpo está encaixado em rochas areníticas da Formação Aquidauana, possuindo, portanto, uma idade mais jovem do que estes sedimentos. Situa-se na borda NW da Bacia do Paraná, constituindo um quadro semelhante ao do kimberlito Redondão, que é intrusivo em sedimentos da Bacia do Parnaiba (Svisero et al., 1977). No Brasil, Almeida e Svisero (1991) verificaram que as principais áreas de ocorrência de intrusões de possível natureza kimberlítica situam-se justamente em faixas de dobramentos proterozóicas periféricas à áreas cratônicas. Assim sendo, as intrusões Tamburi e Redondão constituem dois corpos fora desse contexto tectônico, discordando também daquele do continente africano onde os kimberlitos situam-se nas bordas de crátons (Mitchell, 1986).

O nome Tamburi é originário de uma árvore denominada de Tamburi Enterrolobium contorstisiliquum), comum na Mata Atlântica, que possui tronco grosso, copa esgalhada sendo excelente para a fabricação de canoas (In: Novo Dicionário da Língua Portuguesa, Aurélio B. Holanda Ferreira, 1986). Esta vegetação arbustiva ocorre abundantemente sobre o corpo, o qual se destaca em relação à vegetação circundante onde predominam os cerrados (Fotografia 6).

Duas características chamam a atenção nessa intrusão: a) o relevo positivo e o fato de ocorrer de forma isolada. A primeira característica, resulta do fato da intrusão ter desenvolvido uma intensa carbonatação interna e silicificação da encaixante durante o episódio de colocação, fato que a preservou como alto topográfico frente aos processos intempéricos (Fotografia 6). 0 fato dela ocorrer de forma isolada também é incomum, visto que em geral intrusões kimberlíticas ou de filiação kimberítica normalmente aparecem em grupos ou mesmo enxames de algumas dezenas de intrusões, constituindo campos kimberlíticos, tal como definido por Mitchell (1986) no continente africano e em outros locais.

\subsubsection{1 - Características geológicas}

Trabalhos de mapeamento mostraram que a Intrusão Tamburi é um corpo de forma subelipsóidica, orientado na direção SE-NW, cujas dimensões principais são de aproximadamente $400 \mathrm{~m}$ segundo o eixo maior e de $200 \mathrm{~m}$ na direção perpendicular. O corpo possui uma área total de 5,9ha, constituindo, portanto, uma intrusão de porte médio a pequeno 


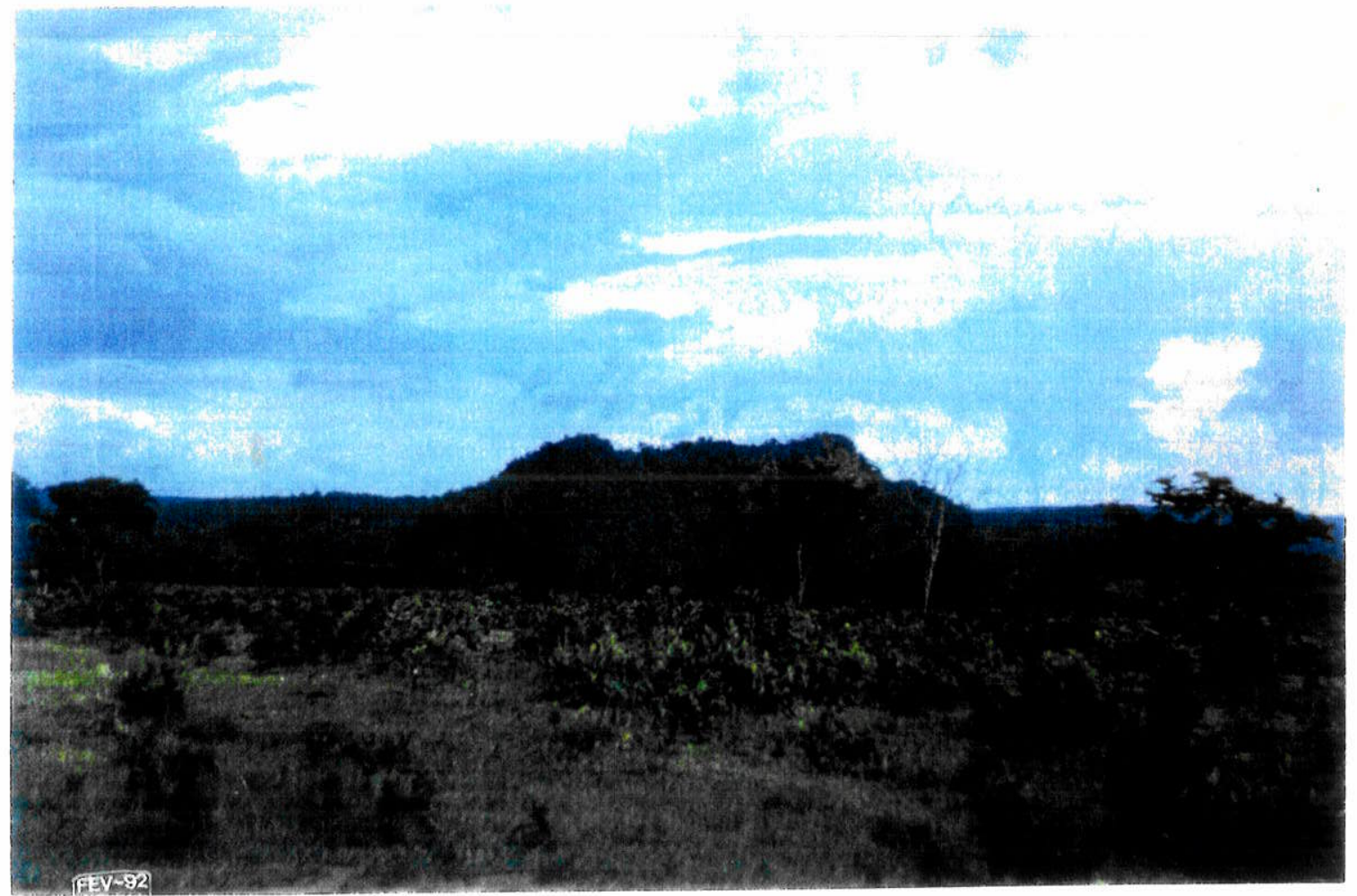

Fotografia 6 - Vista Geral da Intrusão Tamburi que se destaca na topografia em meio aos cerrados circundantes.

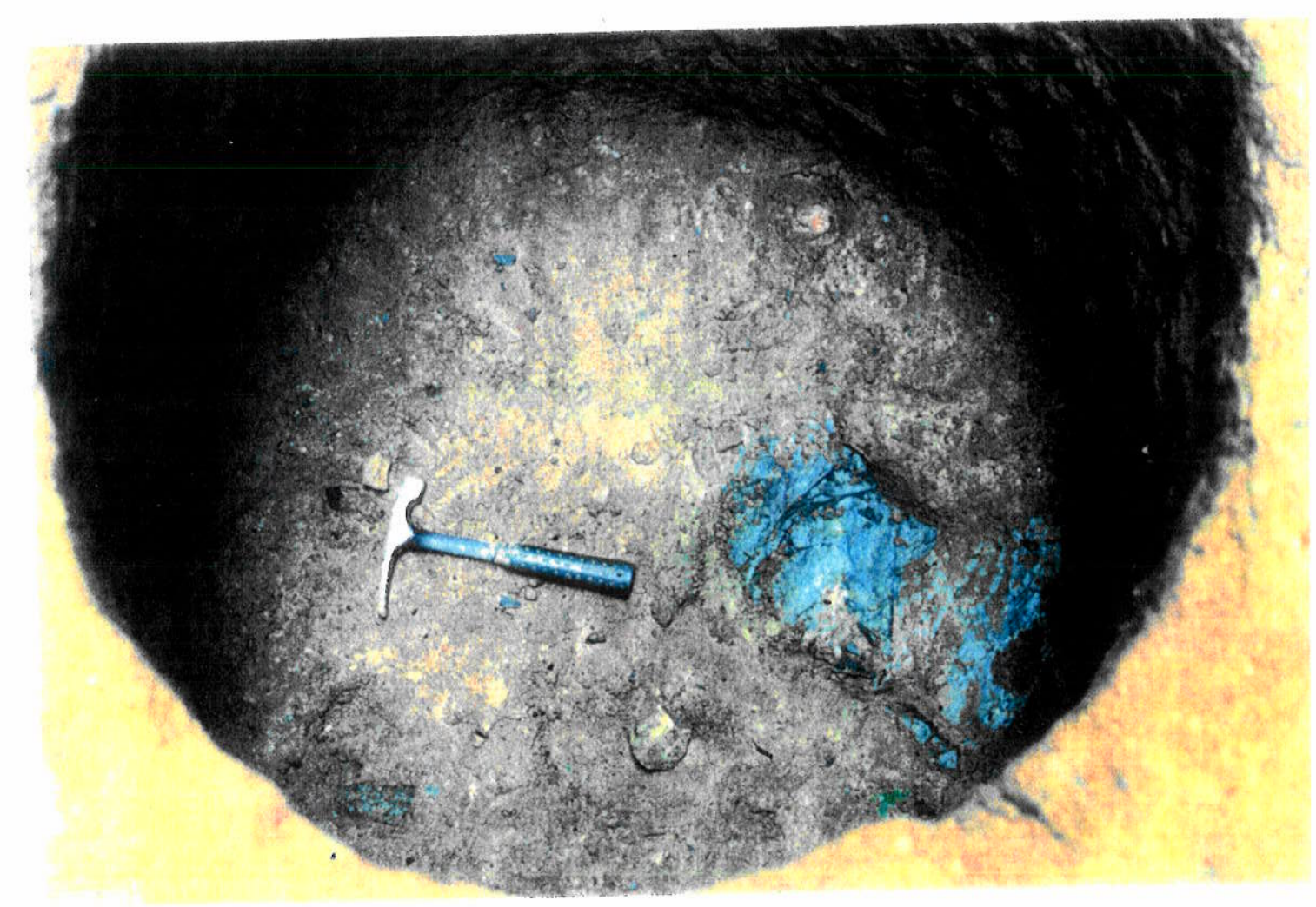

Fotografia 7 - Poço de amostragem de forma circular na Intrusão Tamburi. No fundo do poço destacam-se xenólitos sedimentares de tamanhos e natureza variada. 
(Mitchell, 1986). Outras feições locais que merecem destaque são a presença de uma escarpa lateral ao corpo na porção S e falhas NW-SE paralelas ao eixo da intrusão (Figura 12).

Comparações entre a Intrusão Tamburi e outras intrusões da região de Coromandel, no oeste de Minas Gerais (Meyer et al., 1994), estão apresentadas na Figura 13. Nota-se que o corpo Tamburi possue dimensões semelhantes à intrusão alcalina do Pântano, sendo ambas bem maiores que as intrusões kimberlíticas Limeira e Indaiá. Além disso, esses dois últimos corpos possuem intrusões satélites associadas, enquanto que o Pântano e Tamburi ocorrem isolados no terreno.

Como o corpo ígneo está muito alterado e em grande parte recoberto por fina $(0,2 \mathrm{~m})$ a espessa $(1,50 \mathrm{~m})$ cobertura quaternária, ele foi amostrado por 6 poços de $2 \times 2 \mathrm{~m}$, seguido de telescopagem circular de $90 \mathrm{~cm}$ de diâmetro, perfazendo uma profundidade total no poço mais profundo de 3,6m (Fotografia 7). Observações macroscópicas efetuadas revelaram a presença de uma quantidade grande de xenólitos de cores, dimensões, formas e naturezas variadas, tendo sido reconhecidos xenólitos dispersos em todas as paredes dos poços, os quais na sua grande maioria possuem bordas angulosas. Os tipos mais comuns são: a) arenitos com granulometria média a grossa, maciços a friáveis, cor vermelha e com bordas de alteração cinza (Fotografia 8a). 0 tamanho dos xenólitos situa-se entre 1 a $50 \mathrm{~cm}$, sendo originários de encaixantes da Formação Aquidauana; e b) rochas pelíticas, muito friáveis micáceas ou não, de cores bege ou cinza, com laminações plano-paralelas incipientes. Nesse caso possuem dimensões entre 0,5 a $12 \mathrm{~cm}$. em média, pertencendo provavelmente a tipos litológicos do Grupo Cuiabá, da Formação Ponta Grossa, e a corpos de natureza básica alterados da Formação Paredão Grande (Fotografia 8b).

Do ponto de vista petrográfico a rocha possue aspecto brechóide, sendo formada por uma matriz argilosa resultante do intemperismo profundo, no qual, além dos xenólitos já mencionados, ocorrem cristais de granadas de cor vermelha de até $3 \mathrm{~cm}$. Em lâminas delgadas (Fotomicrografia 1a), mostram-se na forma de cristais subidiomórficos, de relevo alto, cor vermelha, fracamente birrefringentes e com tamanhos entre 0,3 a $0,5 \mathrm{~mm}$. Flogopitas cloritizadas de até $2 \mathrm{~cm}$ ocorrem em amostras de mão, nas cores amarela a amarela ouro, inviabilizando a datação do corpo; em lâminas delgadas o tamanho situa-se entre 0,3 a $0,5 \mathrm{~mm}$ (Fotomicrografia 1b). Exibe hábito placóidal, pleocró́smo médio de verde pálido a marrom claro, zoneamentos de verde claro a escuro, extinção paralela às clivagens e caráter biaxial negativo. Pseudomorfos de olivina subedrais com tamanhos entre 0,2 a $1 \mathrm{~cm}$, totalmente serpentinizadas são freqüentes. $\mathrm{O}$ carbonato ocorre segundo cristais hipidiomórficos de dimensões entre 0,4 a $0,7 \mathrm{~mm}$, sendo incolores, com relevo alto, clivagem rômbica, ângulo entre os dois sistemas de clivagem de $75^{\circ}$ e 


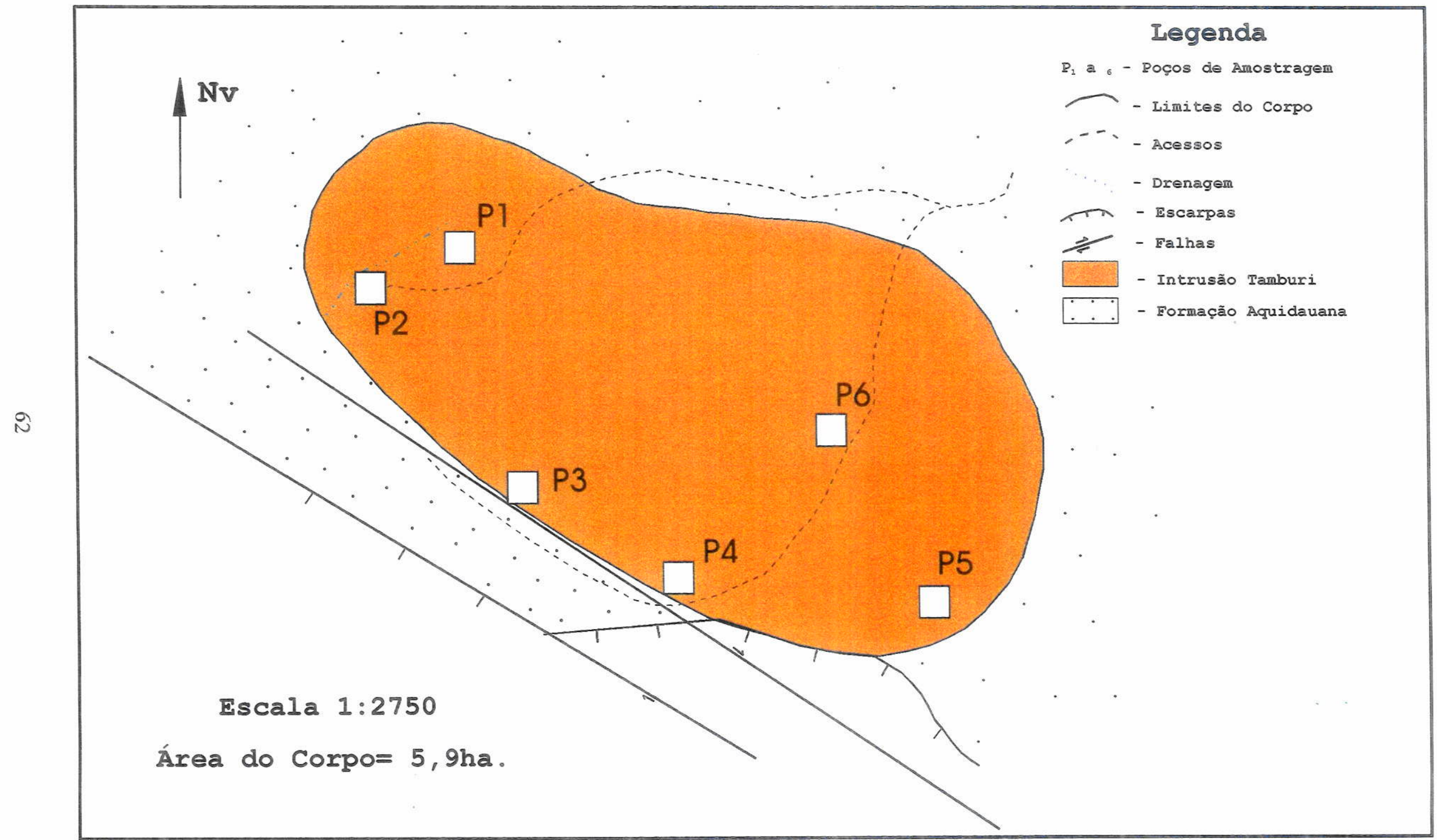

Figura 12 - Mapa geológico da Intrusãi Tamburi e a posição dos poços de amostragens $\left(P_{1}\right.$ a $\left.P_{6}\right)$. 


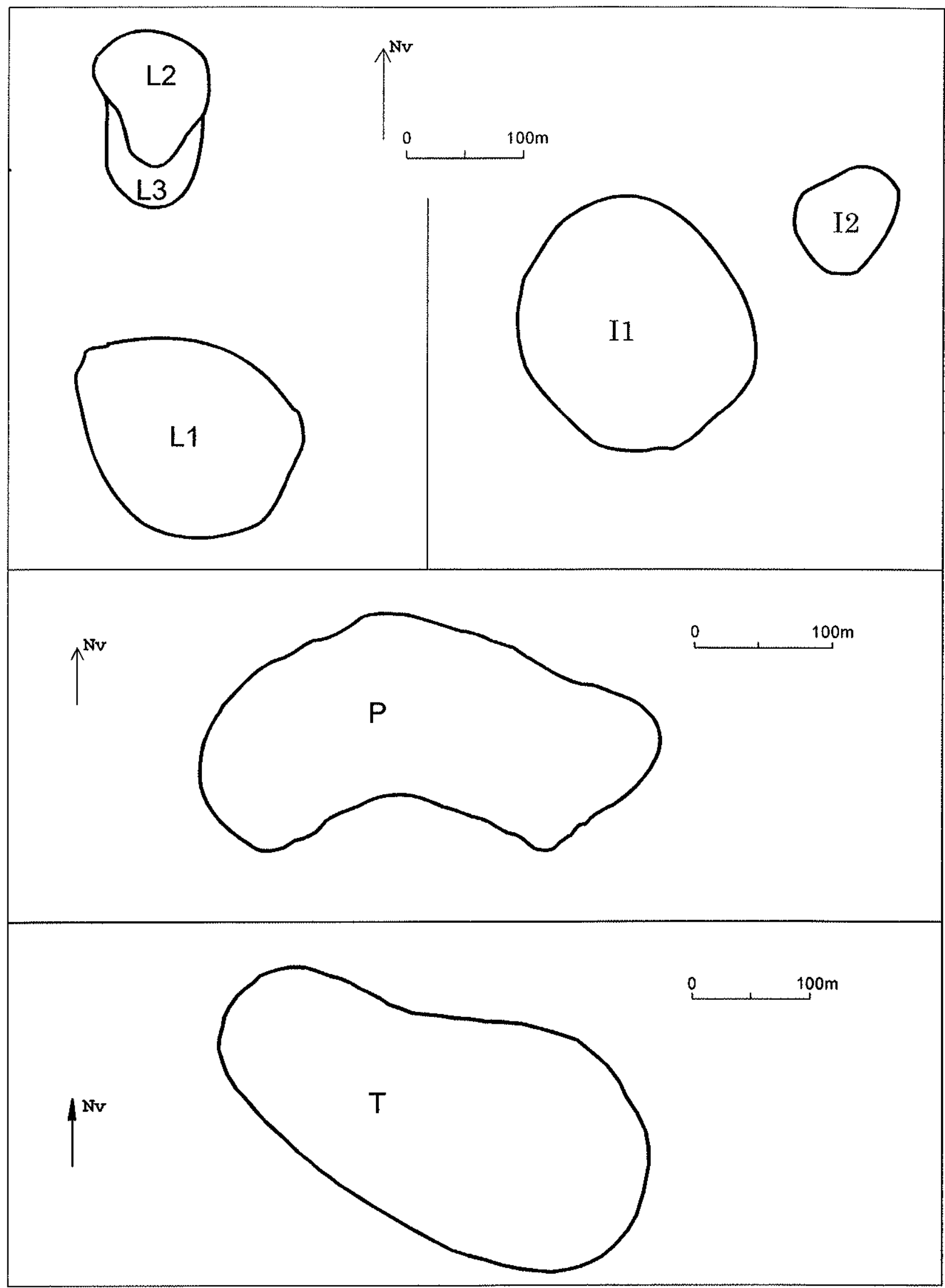

Figura 13 - Contornos em superfície da Intrusão Tamburi, comparado com as intrusões Limeiras (L1,L2 e L3), Indaiá (11 e 12) e Pântano (P), da região de Coromandel, Minas Gerais. Dados comparativos retirados de Meyer et al., (1994). 


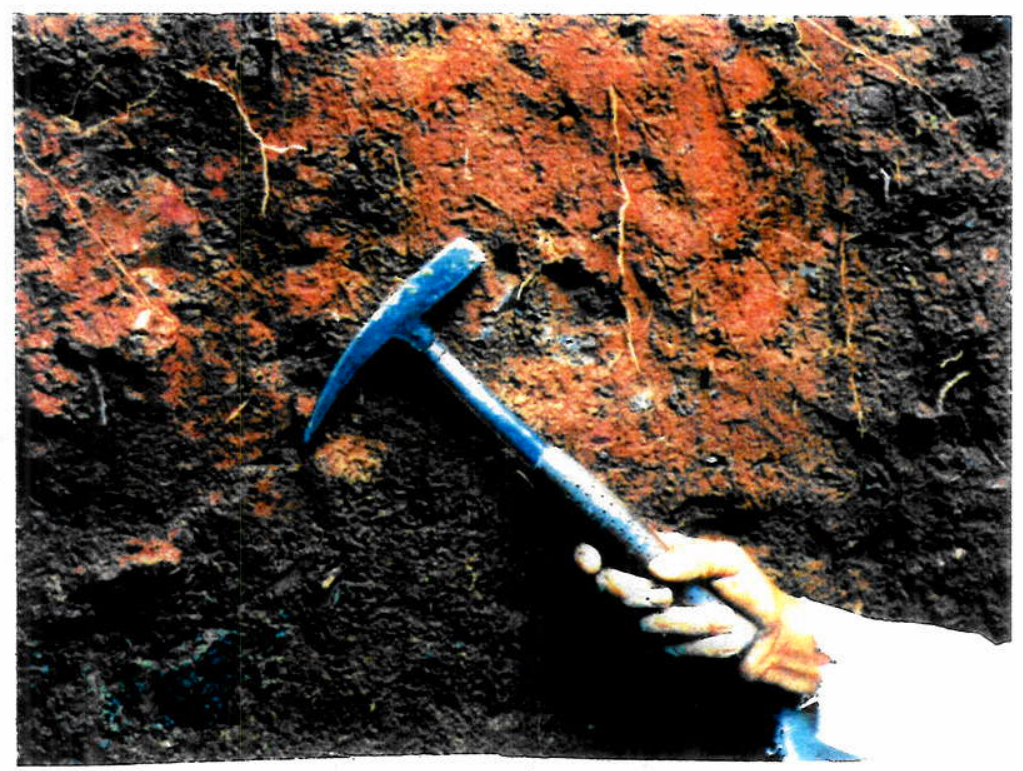

(a)

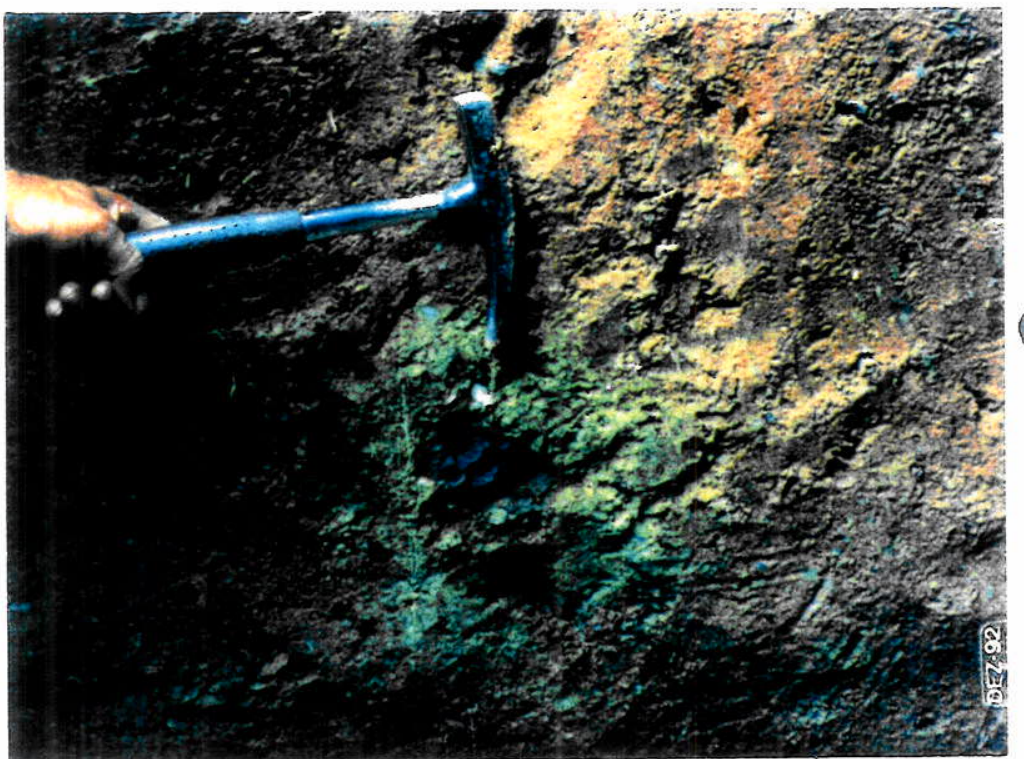

\& Fotografia 8 - Xenólitos na Intrusão Tamburi. Em (a), de rochas sedimentares das encaixantes; em (b), de rochas ígneas máficas alteradas.

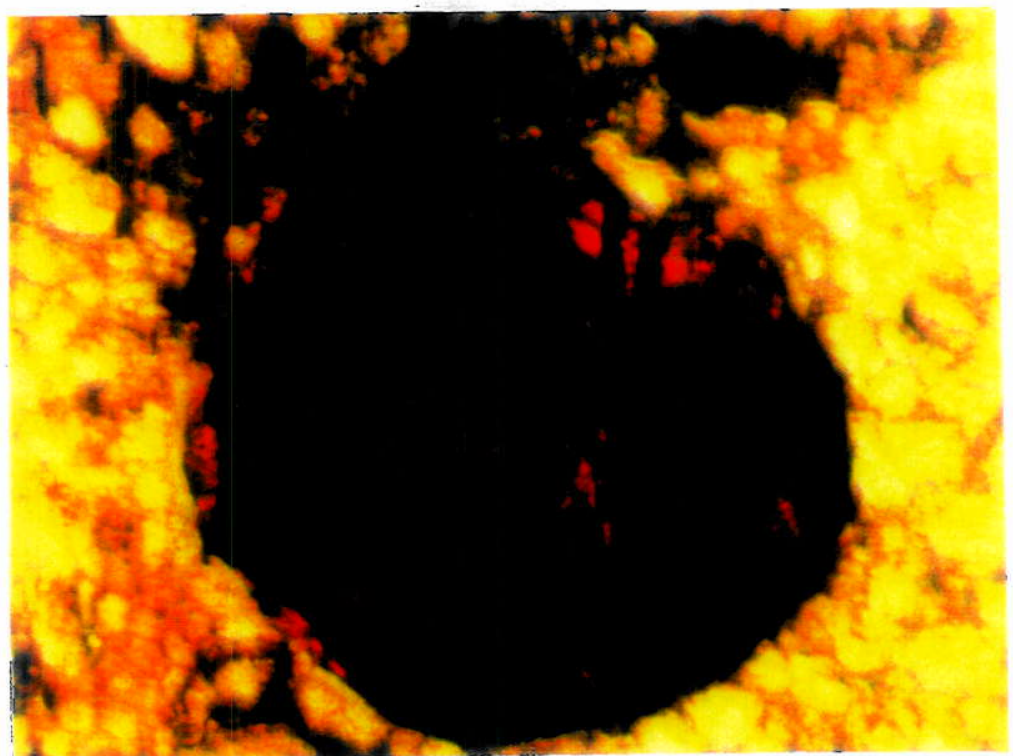

(ब)

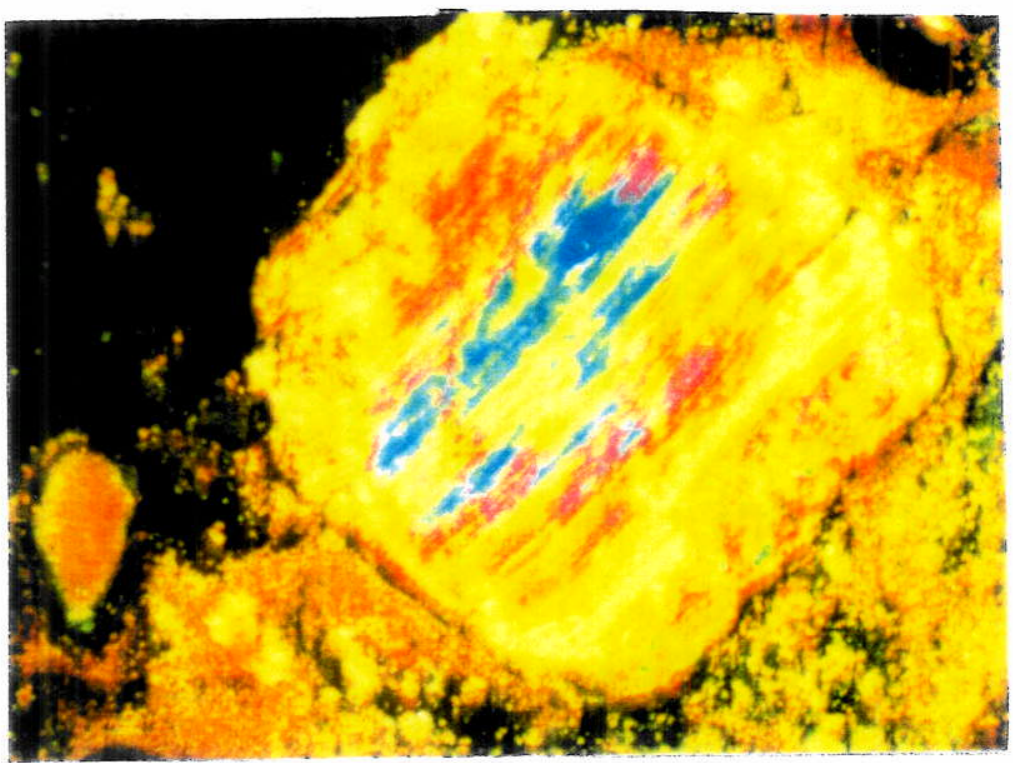

Fotomicrografia 1 - Características microscópicas da Intrusão Tamburi. Em (a), macrocristal de granada, com zoneamento, nicóis paralelos aumento 25x; e em (b), macrocristal de flogopita alterada, circundada por carbonatos e na auréola um cristal de perovskita, aumento 12,5x. 
extinção simétrica aos dois sistemas de clivagem. Os carbonatos ocorrem também abundantemente como agregado microcristalino compondo a matriz (Fotomicrografia 1b); na realidade, tais carbonatos são resultantes de segregações carbonáticas primárias do magma comuns a essas intrusões (Mitchell, 1986). Os opacos são freqüentes na matriz possuindo dimensões entre 0,1 a $0,3 \mathrm{~mm}$ e formas globulares. Entre eles, destaca-se a perovskita que apresenta dimensões da ordem de $0,05 \mathrm{~mm}$, hábito quadrático bem definido (Fotomicrografia $1 \mathrm{~b}$ ), cor castanha-avermelhada a castanha escuro, relevo alto e birrefringência anômala fraca. Segundo Svisero et al. (1982), nas intrusões da região oeste de Minas Gerais os cristais de perovskitas desenvolvem auréolas ou concentrações em torno de flogopitas, olivinas e outros macrocristais. A ilmenita ocorre na forma de monocristais de até $1 \mathrm{~cm}$ em afloramentos, possuindo capas de alteração de leucoxênio e fraturas subconchoidais.

O corpo apresenta macroscopicamente aspecto de rocha vulcanoclástica, textura brechóide e alteração intensa. Possui xenólitos de até $50 \mathrm{~cm}$, macrocristais de granadas $<3 \mathrm{~cm}$, flogopitas $<1,5 \mathrm{~cm}$, ilmenitas $<0,8 \mathrm{~cm}$ e olivinas $<1 \mathrm{~cm}$; imersos em uma matriz afanítica argilosa a areno-argilosa, constituída de minerais identificados em lupas binoculares $(30 \mathrm{x})$ como olivinas, flogopitas, ilmenitas e raramente granadas. Xenocristais de quartzo e feldspato caulinizados são relativamente comuns. $O$ conjunto foi submetido a intensa segregação carbonática, cujas evidências são macrocristais de carbonatos.

Segundo Cox (1978), "as erupções de magmas kimberlíticos são eventos vulcanogênicos explosivos, devido a presença excessiva de vapor d'água e dióxido de carbono que, quando atingem a superfície, causam a explosão. Com isso as paredes do conduto são despedaçadas e carreadas pelas lavas".

Dado a intensa alteração da Intrusão Tamburi, não foi possível obtermos amostras para datações geocronológicas. Entretanto, tomando-se como base a idade de 121,1Ma. obtida por Davis (1977) em zircão do Kimberlito B-9, Paranatinga (MT), a Intrusão Tamburi poderia ser contemporânea a esse magmatismo, sendo ambas por extensão correlacionadas ao vulcanismo Serra Geral da Bacia do Paraná, de iđade Jurássica.

Com base nestas características o corpo Tamburi pode em princípio ser classificado litologicamente como uma rocha de aspecto brechóide que, segundo a classificação de Mitchell (1986) reúne características comuns à fácies de cratera, na qual há predomínio de xenólitos de rochas provenientes das encaixantes sobre os de origem mantélica. Quanto as características químicas desse corpo, elas serão abordadas no Capítulo 8 conjuntamente com os resistatos dos 
conglomerados da Formação Quilombinho do Grupo Bauru, e com as rochas vulcanoclásticas da Formação Paredão Grande.

\subsection{5 - Formação Paredão Grande, Grupo Bauru.}

Corpos intrusivos e extrusivos aqui englobados na Formação Paredão Grande foram descritos em todos os alvos mapeados (Figuras 6,8,9 e 10). No Alvo PX (Figura 6), são representados por um conjunto de 10 (dez) pequenos derrames com localizações em pares de coordenadas e dimensões, segundo quadro da Tabela 1 . Situam-se a $25,5 \mathrm{~km}$ à NW da cidade de Poxoréu; comportam-se como altos topográficos e posicionam-se em altitudes que variam entre 700 a $600 \mathrm{~m}$ em relação ao nivel do mar (Fotografias 9a e 9b). Ocorrem alimhados segundo a direção aproximada $\mathrm{N}-\mathrm{S}$, tendo sido denominados primeiro e informalmente de Derrames da Raizinha por Pisani e Arrais (1991). Essa denominação também foi adotada por Weska et al. (1993) em referência ao nome da localidade onde afloram tais corpos.

Tabela 1 - Localização dos Derrames da Raizinha em pares de coordenadas e dimensões (largura $x$ comprimento). $O$ corpo $n^{\circ} 1$ situa-se no extremo sul e o $n^{\circ} 10$ no norte (Figura 6$)$. (**)coberto em parte pelo presente mapeamento.

\begin{tabular}{|c|c|c|c|c|}
\hline \multirow{2}{*}{$\begin{array}{c}\text { CORPO } \\
\text { NÚMERO }\end{array}$} & \multicolumn{2}{|c|}{ COORDENADAS } & \multicolumn{2}{|c|}{ DIMIENSÕES(m) } \\
\hline & LATITUDE SUL & LONGITUDE OESTE & LARGURA & COMPRIMENTO \\
\hline $1 * *$ & $15^{\circ} 49^{\prime} 27^{\prime \prime}$ & $54^{\circ} 33^{\prime} 40^{\prime \prime}$ & 600 & 2500 \\
\hline 2 & $15^{\circ} 47^{\prime} 40^{\prime \prime}$ & $54^{\circ} 33^{\prime} 22^{\prime \prime}$ & 200 & 400 \\
\hline 3 & $15^{\circ} 46^{\prime} 54^{\prime \prime}$ & $54^{\circ} 33^{\prime} 23^{\prime \prime}$ & 150 & 450 \\
\hline 4 & $15^{\circ} 46^{\prime} 38^{\prime \prime}$ & 54'33'42" & 200 & 1150 \\
\hline 5 & $15^{\circ} 46^{\prime} 09^{\prime \prime}$ & $54^{\circ} 33^{\prime} 49^{\prime \prime}$ & 150 & 250 \\
\hline 6 & $15^{\circ} 45^{\prime} 56^{\prime \prime}$ & 54'33'32" & 450 & 900 \\
\hline 7 & $15^{\circ} 45^{\prime} 04^{\prime \prime}$ & 54'33'39"' & 600 & 3500 \\
\hline 8 & $15^{\circ} 43^{\prime} 42^{\prime \prime}$ & $54^{\circ} 33^{\prime} 13^{\prime \prime}$ & 350 & 400 \\
\hline 9 & $15^{\circ} 43^{\prime} 15^{\prime \prime}$ & 54'33'59" & 700 & 950 \\
\hline 10 & 15०42'52" & $54^{\circ} 34^{\prime} 13^{\prime \prime}$ & 350 & 500 \\
\hline
\end{tabular}

$\mathrm{Na}$ área abrangida pelo Alvo PG foram descritos e estudados 34 corpos, sendo 25 localizados a SW, S, SE e E de Paredão Grande (Figura 8, Fotografia 10a); o dique Primavera localizado entre Primavera do Leste e Paredão Grande (Fotografia 10b), além de oito diques na Reserva Indígena Meruri (Figura 9, Fotografia 10c). Os corpos situados próximos a Paredão 
(a)

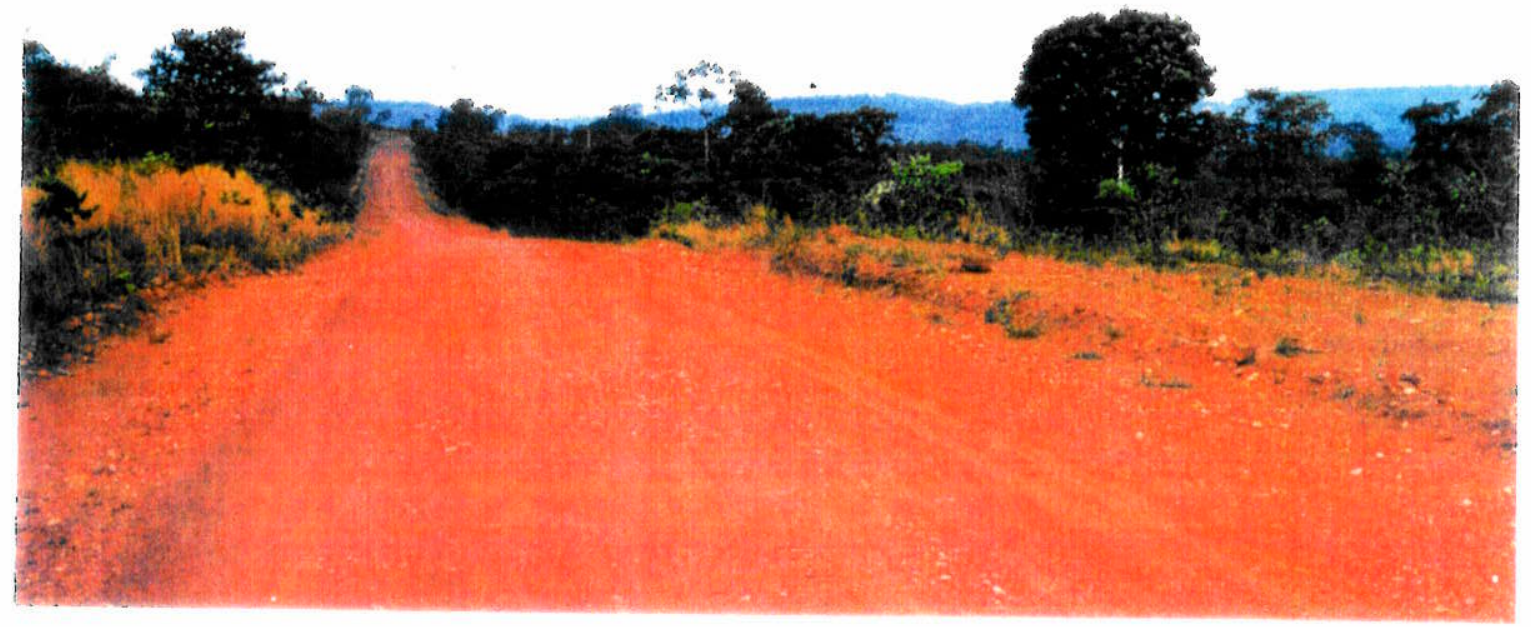

(b)

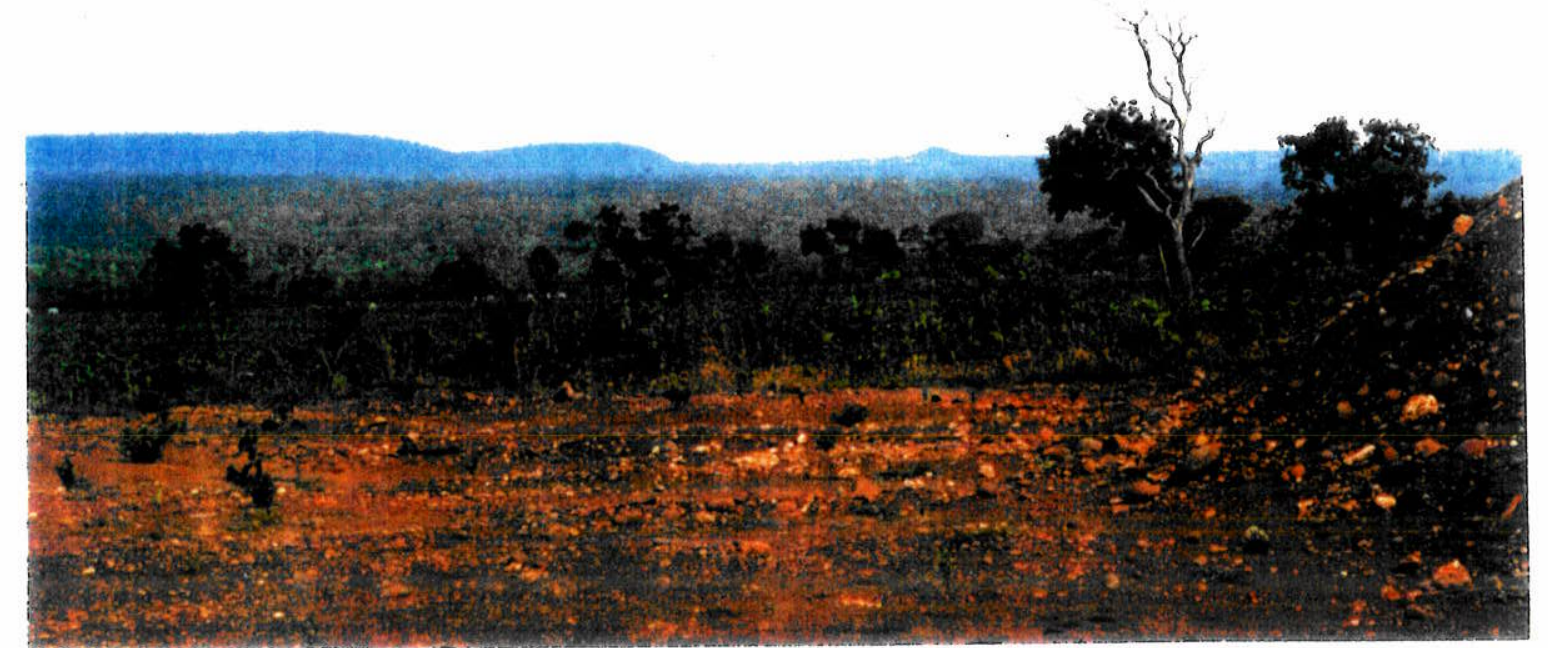

Fotografia 9 - Derrames da Raizinha como altos topográficos à Sul(a) e à Norte (b), Alvo PX. 
Grande comportam-se como altos (diques) e baixos topográficos sob a forma de derrames, além de um corpo da fácies piroclástica ( $\mathrm{n}^{\circ} 16$, Tabela 2$)$. Os demais, são os diques da região do Menuri e Primavera do Leste, os quais comportam-se como altos topográficos. Tais intrusões e extrusões situam-se em altitudes entre 600 a $520 \mathrm{~m}$ em relação ao nível do mar. Suas localizações em pares de coordenadas e dimensões são mostradas nas Tabelas 2 e 3 . A altura dos diques em Paredão Grande, situa-se entre o intervalo de 1 a $70 \mathrm{~m}$ (Weska et al., 1992), estando alinhados por aproximadamente $13 \mathrm{~km}$, segundo a orientação preferencial $\mathrm{N} 65^{\circ}-75^{\circ} \mathrm{E}$, mas encaixados segundo a direção $N 40^{\circ}-50^{\circ} \mathrm{W}$. Os diques na Colônia Indígena Meruri possuem altitudes que variam entre 30 e $80 \mathrm{~m}$, estando intrudidos segundo duas falhas distintas, paralelas e também de direção N65$75^{\circ} \mathrm{E}$. Nas bordas desses diques ocorrem depósitos de talus (Fotografia 10c) que configuram falsos corpos circulares em fotografias aéreas ou imagens de satélites.

A Formação Paredão Grande no Alvo DA (Figura 10) consiste de 7 pequenos derrames, sendo 5 situados na regiăo da Lajinha (Fotografia 10d) e 2 nas cercanias do Córrego Preto, com localizações em pares de coordenadas e dimensões segundo quadro da Tabela 4. Os Derrames da Lajinha e do Córrego Preto situam-se, respectiva e aproximadamente a 26 e a $30 \mathrm{~km}$ à NE de Dom Aquino. Ocorrem como altos e baixos topográficos em ambas regiões em altitudes que variam entre 640 a 500m em relação ao nível do mar. Os Derrames da Lajinha e do Córrego Preto foram primeiramente denominados por Oliveira et al. (1992), em referência á localização dos mesmos na região da Lajinha (porção $\mathrm{SW}$ ) e no vale do córrego homônimo, porção NW do mapa geológico (Figura 10), denominações estas que adotamos e que faremos referências no decorrer da Tese.

\subsubsection{1 - Características macro e microscópicas dos Derrames da Raizinha}

Em amostra de mão, as rochas vulcânicas dos Derrames da Raizinha (Alvo PX) apresentam-se maciças e de cores preta a cinza escuro predominantes. A rocha quando alterada é envolvida por uma capa de aiteração de cores amarela e alaranjada. $O$ solo desenvolvido nas proximidades e sobre os corpos são típicos daqueles oriundos de alterações de basaltos (terras roxas). Distingue-se dois tipos de texturas, sendo a primeira porfirítica, com fenocristais de olivinas, piroxênios e plagioclásios imersos em matriz afanítica e eventualmente com fragmentos de rocha (Fotografia 11a). O segundo tipo é a textura amigdaloidal, mais rara, encontrada na forma de blocos rolados e bastante alterados. Tais tipos texturais encontrados nos Derrames da 

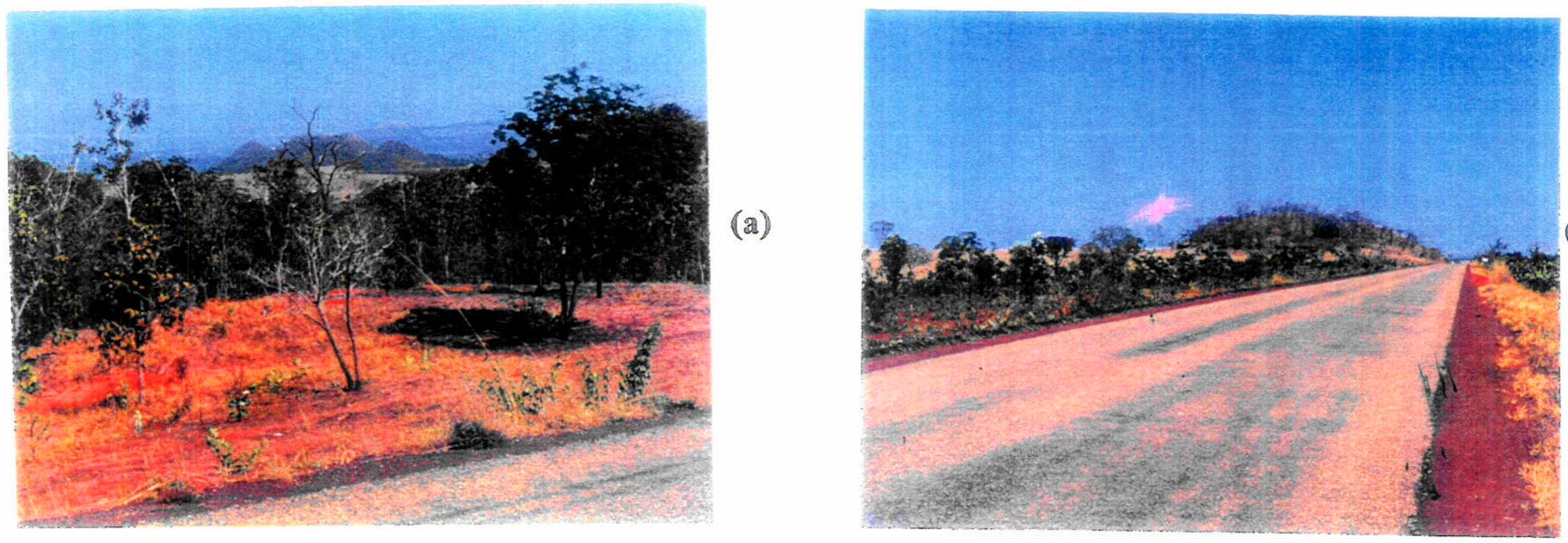

8
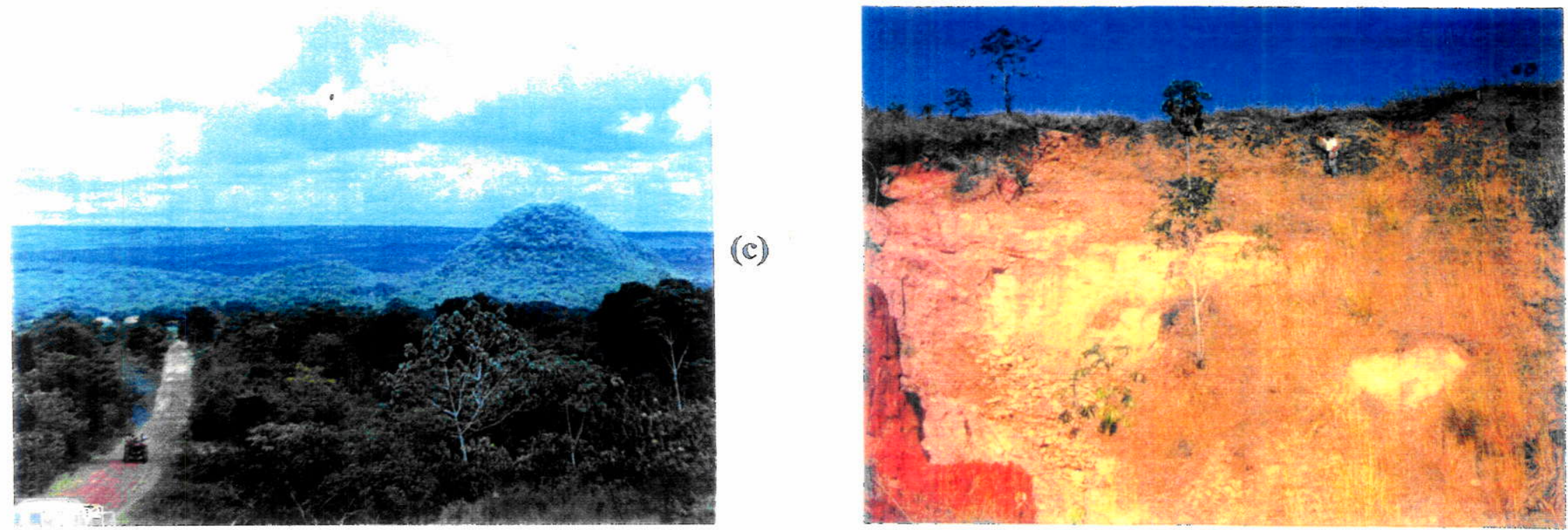

(d)

Fotografia 10 - Diques e outros derrames da Formação Paredão Grande. Em (a), diques de Paredão Grande; em (b), dique Primavera; em (c), diques na Colônia Indígena Meruri; e em (d) derrame de topo da Lajinha. 
Tabela 2 - Localização em pares de coordenadas e dimensões (largura x comprimento) das intrusões e extrusões na região de Paredão Grande. A intrusão l situa-se na porção extremo oeste e a 25 na leste (Figura 8). $\left({ }^{*}\right)$ - diques, $(+)$ - rochas piroclásticas e (\#) - derrames.

CORPO

NÚMERO

\section{COORDENADAS}

LATITUDE SUL

$\begin{array}{ll}1^{*} & 15^{\circ} 36^{\prime} 18^{\prime \prime} \\ 2^{*} & 15^{\circ} 36^{\prime} 17^{\prime \prime} \\ 3^{*} & 15^{\circ} 36^{\prime} 03^{\prime \prime} \\ 4^{*} & 15^{\circ} 36^{\prime} 05^{\prime \prime} \\ 5^{*} & 15^{\circ} 36^{\prime} 05^{\prime \prime} \\ 6^{*} & 15^{\circ} 36^{\prime} 06^{\prime \prime} \\ 7^{*} & 15^{\circ} 36^{\prime} 01^{\prime \prime} \\ 8^{*} & 15^{\circ} 35^{\prime} 57^{\prime \prime} \\ 9^{*} & 15^{\circ} 35^{\prime} 51^{\prime \prime} \\ 10^{*} & 15^{\circ} 35^{\prime} 51^{\prime \prime} \\ 11^{*} & 15^{\circ} 35^{\prime} 48^{\prime \prime} \\ 12^{*} & 15^{\circ} 35^{\prime} 47^{\prime \prime} \\ 13^{*} & 15^{\circ} 35^{\prime} 45^{\prime \prime} \\ 14^{*} & 15^{\circ} 35^{\prime} 44^{\prime \prime} \\ 15^{*} & 15^{\circ} 35^{\prime} 39^{\prime \prime} \\ 16+ & 15^{\circ} 35^{\prime} 29^{\prime \prime} \\ 17^{*} & 15^{\circ} 35^{\prime} 16^{\prime \prime} \\ 18 \# & 15^{\circ} 35^{\prime} 03^{\prime \prime} \\ 19 \# & 15^{\circ} 34^{\prime} 57^{\prime \prime} \\ 20 \# & 15^{\circ} 34^{\prime} 53^{\prime \prime} \\ 21 \# & 15^{\circ} 34^{\prime} 54^{\prime \prime} \\ 22 \# & 15^{\circ} 34^{\prime} 53^{\prime \prime} \\ 23 \# & 15^{\circ} 34^{\prime} 44^{\prime \prime} \\ 24 \# & 15^{\circ} 34^{\prime} 51^{\prime \prime} \\ 25 \# & 15^{\circ} 34^{\prime} 38^{\prime \prime}\end{array}$

\section{DIMENSÕ ES(m)}

LARGURA COMPRIMENTO

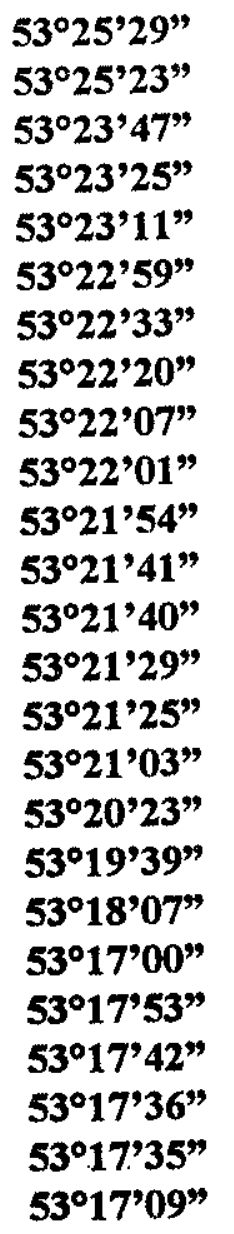

75

150

60

112

60

75

60

135

90

330

75

120

225

75

180

120

135

60

150

90

120

270

60

75

37

90

52

135

120

495

75

135

120

285

97

292

52

52

97

135

45

120

$90 \quad 330$

$45 \quad 150$

300

Tabela 3 - Localização em pares de coordenadas e dimensões (largura $x$ comprimento) dos diques da Colônia Indígena Meruri. $O \mathrm{n}^{\circ} 1$ situa-se no extremo oeste e o $\mathrm{n}^{\circ} 8$ à leste (Figura 9).

CORPO NORYO COORDENADAS

COORDENADAS

LATITUDE SUL LONGTTUDE OESTE
DIMENSÕES(m) LARGURA COMPRIMENTO

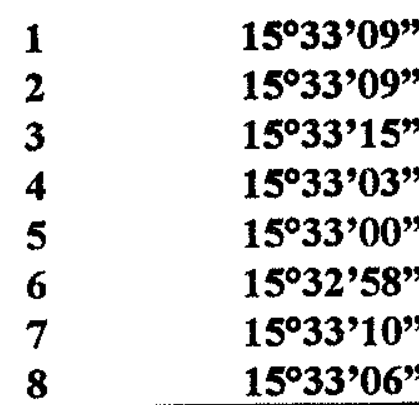

$53^{\circ} 04^{\prime} 49^{\prime \prime}$
$53^{\circ} 04^{\prime} 43^{\prime \prime}$
$53^{\circ} 04^{\prime} 41^{\prime \prime}$
$53^{\circ} 03^{\prime} 29^{\prime \prime}$
$53^{\circ} 03^{\prime} 17^{\prime \prime}$
$53^{\circ} 02^{\prime} 57^{\prime \prime}$
$53^{\circ} 02^{\prime} 56^{\prime \prime}$
$53^{\circ} 01^{\prime} 59^{\prime \prime}$

60

120

75

150

120

240

120

270

150

420

90

225

270

1050

90

120 
Tabela 4 - Localização em pares de coordenadas e dimensões (largura $x$ comprimento) dos Derrames da Lajinha ( 1 a 5) na porção Sul, e do Córrego Preto $(6,7)$ à Norte da Figura 10.

\begin{tabular}{|c|c|c|c|c|}
\hline CORPO & \multicolumn{2}{|c|}{ COORDENADAS } & \multicolumn{2}{|c|}{ DIMENSÕES(m) } \\
\hline NÚMERO & LATITUDE SUL & LONGITUDE OESTE & LARGURA & COMPRIMENTO \\
\hline 1 & $15^{\circ} 42^{\prime} 51^{\prime \prime}$ & $54^{\circ} 39^{\prime} 54^{\prime \prime}$ & 250 & 850 \\
\hline 2 & $15^{\circ} 43^{\prime} 26^{\prime \prime}$ & $54^{\circ} 41^{\prime} 24^{\prime \prime}$ & 400 & 1300 \\
\hline 3 & $15^{\circ} 43^{\prime} 26^{\prime \prime}$ & $54^{\circ} 42 \prime 53 \prime$ & 950 & 1500 \\
\hline 4 & $15^{\circ} 42^{\prime} 42^{\prime \prime}$ & $54^{\circ} 42^{\prime} 31^{\prime \prime}$ & 450 & 1950 \\
\hline 5 & $15^{\circ} 41^{\prime} 58^{\prime \prime}$ & $54^{\circ} 41^{\prime} 31^{\prime \prime}$ & 1000 & 2400 \\
\hline 6 & $15^{\circ} 36^{\prime} 26^{\prime \prime}$ & $54^{\circ} 43^{\prime} 36^{\prime \prime}$ & 750 & 4150 \\
\hline 7 & $15^{\circ} 36^{\prime} 00^{\prime \prime}$ & $54^{\circ} 45^{\prime} 00^{\prime \prime}$ & 400 & 750 \\
\hline
\end{tabular}

Raizinha já foram descritos (Weska, 1987 e Weska et al., 1988; 1993) sob a forma de clastos em conglomerados completamente alterados da Formação Quilombinho e Cachoeira do Bom Jardim (Grupo Bauru), e são evidências importantes de que esses derrames foram as áreas fontes principais desses conglomerados. Vale relembrar que os Derrames da Raizinha ocorrem como altos topográficos junto a borda da Bacia Bauru (Figura 6, Fotografia 9).

Suspeita-se de rochas piroclásticas da Formação Paredão Grande na região do garimpo do Buritizal, nas proximidades e à NE dos derrames números 7 a 10 (Figura 6, Tabela 1). Rochas piroclásticas finas a grossas que ocorrem na base do Grupo Bauru estão melhor preservadas na região da Chapada dos Guimarães, conforme descrito por Weska (1987) e Weska et al. (1988). A dúvida em relação à natureza . ígnea ou sedimentar dessas rochas é por que as mesmas estão completamente alteradas, ocorrendo como "bedrock" (piçarra) que são denominadas pelos garimpeiros locais como do tipo "amendoim" ou "pé de moleque". Com base no exposto anteriormente, no Alvo PX foram mapeados derrames e uma provável fácies explosiva associada.

Ao microscópio, a textura mais freqüente do vulcanismo máfico da Raizinha é a do tipo subofitica (Fotomicrografia 2a), tendo sido observadas secundariamente texturas traquítica (Fotomicrografias 2a, 2b) e microlítica. A composição mineralógica dessas rochas é constituída pelos seguintes minerais: plagioclásio (50\%), clinopiroxênio (25\%), opacos (16\%), olivina (4\%), epidoto (2\%), fragmentos de rocha (1\%) e acessórios $(2 \%)$. Os cristais de plagiociásio foram identificados como labradorita $\left(\mathrm{An}_{50-70}\right)$, são euédricos e ocorrem na forma de ripas alongadas de até $3 \mathrm{~mm}$, embora a média do tamanho do plagioclásio seja de $0,5 \mathrm{~mm}$. Os fenocristais desse mineral mostram bordas de reação com a matriz (Fotomicrografia $2 \mathrm{c}$ ). Os clinopiroxênios são 
representados por augita e titano-augita, em fenocristais de até $4 \mathrm{~mm}$ e tamanho médio de $0,3 \mathrm{~mm}$ em lâmina. A olivina alcança tamanho de até $5 \mathrm{~mm}$; os cristais estão muito alterados e como resultado disso, produziram minerais de alteração identificados como bowllingita e iddiginsita. Os opacos predominantes são magnetita, ilmenita e espinélio, observados em concentrados de batéia. A granulometria média dos opacos em lâmina é muito fina oscilando em torno de $1 \mathrm{~mm}$. Xenólitos de quartzo-arenitos $(0,5$ a $6 \mathrm{~cm})$, mostram bordas de reação com a matriz e estão envoltos por uma textura traquítica (Fotomicrografia $2 \mathrm{~d}$ ). Os acessórios são zircão, apatita e biotita (?).

\subsubsection{2 - Características macro e microscópicas das intrusões e extrusões de Paredão Grande e Meruri.}

Macroscopicamente, os diques de Paredão Grande e da Colônia Indígena Meruri (Alvo PG) apresentam variações texturais, sendo as mais finas geralmente próximas às zonas de contato com a Formação Aquidauana e as mais grossas nas porções mais internas aos corpos. A textura predominante é porfirítica, com fenocristais de plagioclásio + piroxênio + quartzo, rara olivina e fragmentos de rocha. Os fragmentos de rocha e a textura porfiritica ocorrem preferencialmente próximos às bordas e ao topo dessas intrusões, conforme já descrito por Weska (1987) na região da Chapada dos Guimarães. São comuns em afloramentos nos diques de Paredão Grande a estrutura de fluxo (Fotografia 11b), disjunção poliedral, fraturamentos (Fotografia 11c) e esfoliação esferoidal (Fotografia 11d). No corpo $\mathrm{n}^{\circ} 16$, próximo a entrada da Fazenda Toca da Onça pela BR-070 (Figura 8, Tabela 2), ocorrem seixos a matacões de composição basáltica, imersos em matriz argilosa e muito alterados, sugerindo a ocorrência de fácies piroclásticas associadas aos derrames e diques. Os clastos possuem cor castanha acinzentada e a alteração dos pórfiros de feldspato (caulinizado) resultam em pontos brancos dispersos em matriz afanítica. Estas rochas também são encontradas sob a forma de seixos e matacões muito alterados nos conglomerados das Formações Quilombinho e Cachoeira do Bom Jardim, descritos no Alvo PX (Weska et al, 1993) e também na Chapada dos Guimarães (Weska, 1987).

Em lâmina delgada, as rochas das regiões de Paredão Grande e Meruri são compostas essencialmente de plagioclásio (50\%), augita-titanaugita $(25 \%)$, opacos $(10 \%)$, ortoclásio (5\%), olivina (5\%), quartzo (3\%), acessórios $(1 \%)$ e produtos de alterações $(1 \%)$. Os plagioclásios identificados variam de andesina $\left(A n_{30-50}\right)$ até oligoclásio $\left(A n_{10-30}\right)$, ocorrendo em cristais euédricos a subédricos de hábito ripiforme; são incolores, com geminações simples e múltiplas 

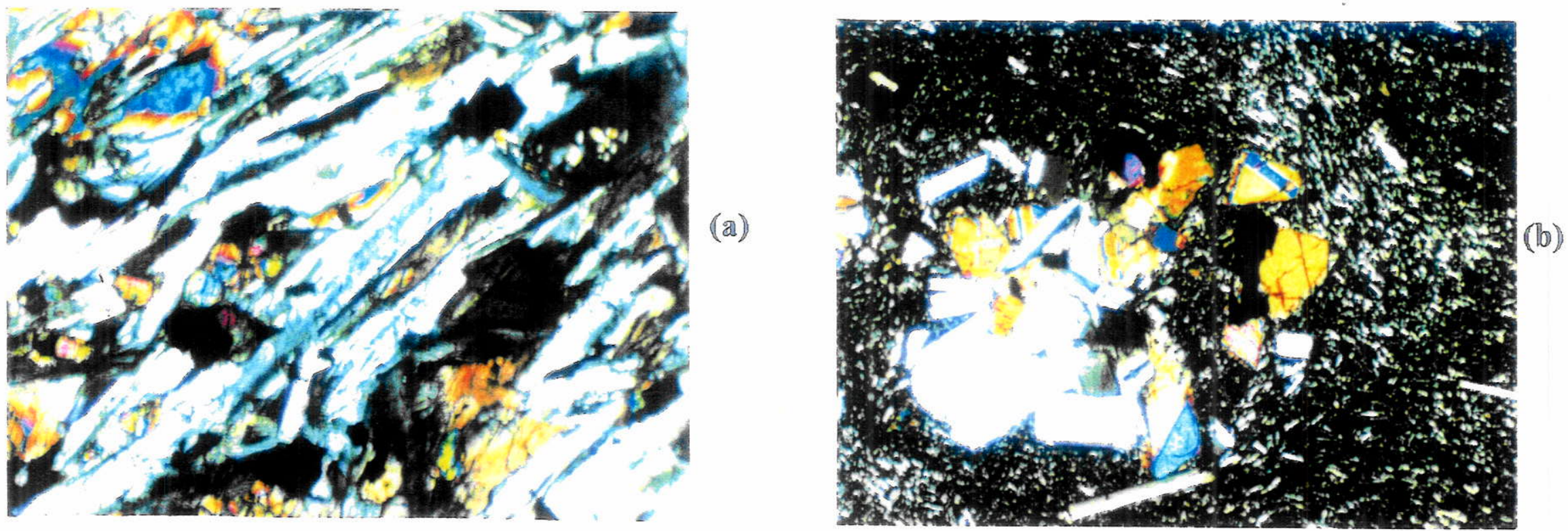

$\tilde{\omega}$
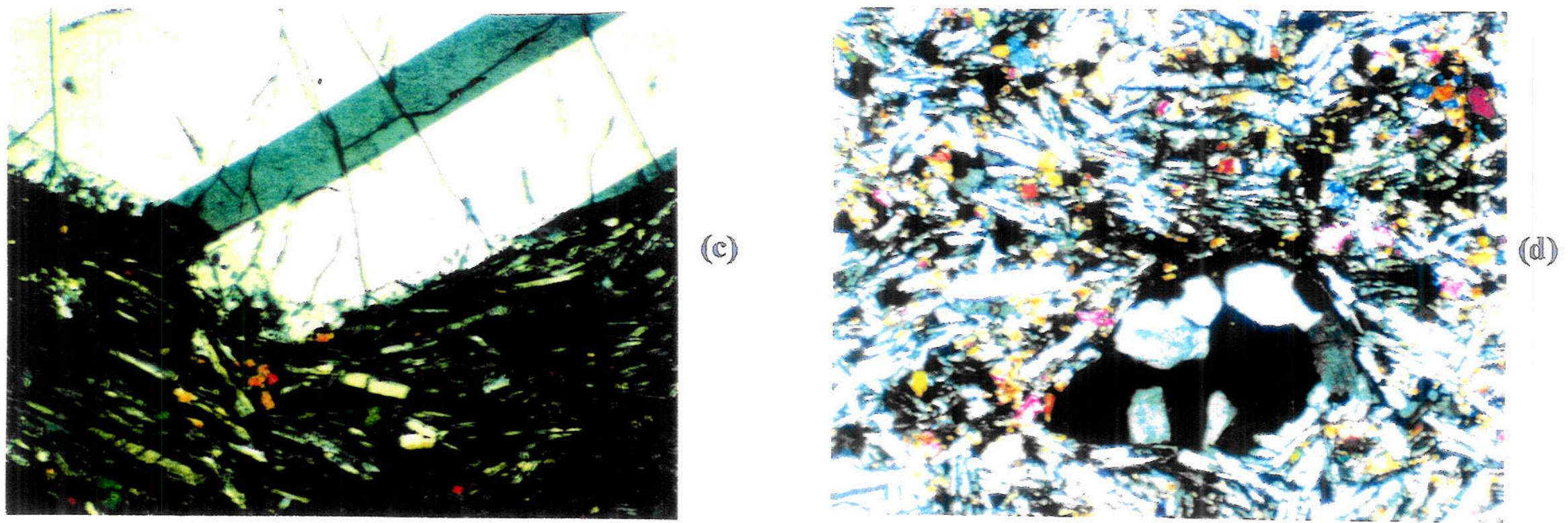

Fotomicrografia 2 - Características microscópicas da Formação Paredão Grande. Em (a), textura subofítica e traquítica, aumento 100x; em (b), textura glomeroporfirítica, aumento 40x; em (c), bordas de reação no plagioclásio, aumento de 40x; e em (d) fragmento de rocha reagindo com a matriz, aumento de 40x. 


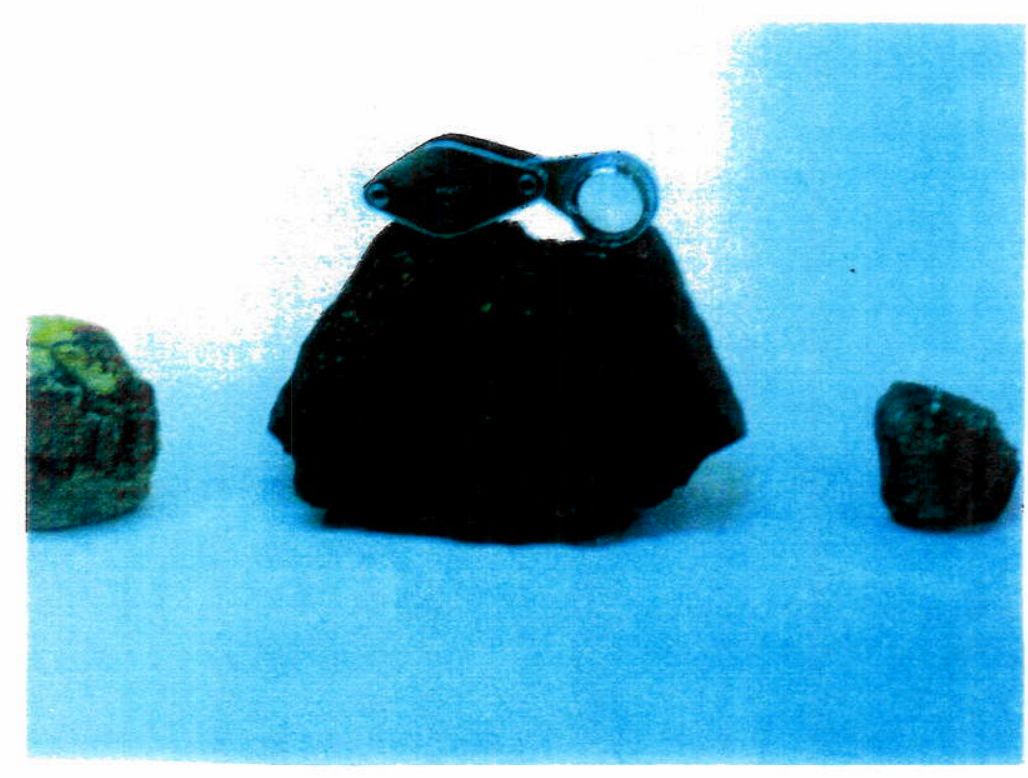

(a)

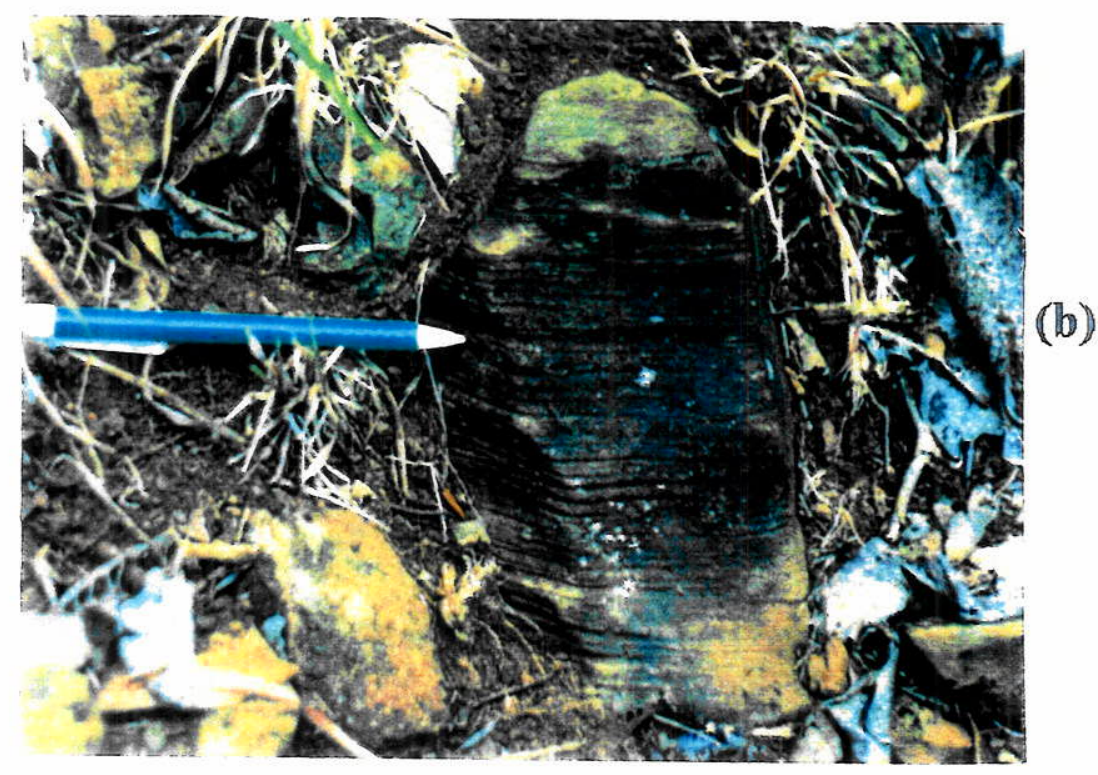

$\ddot{\perp}$

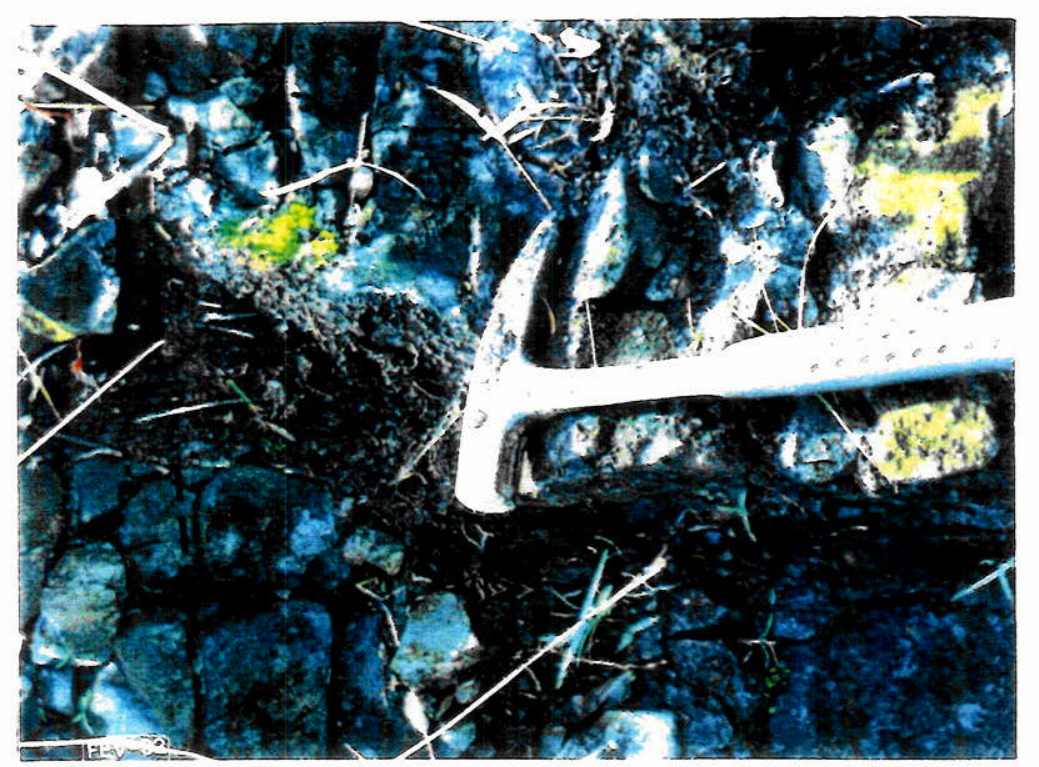

(c)

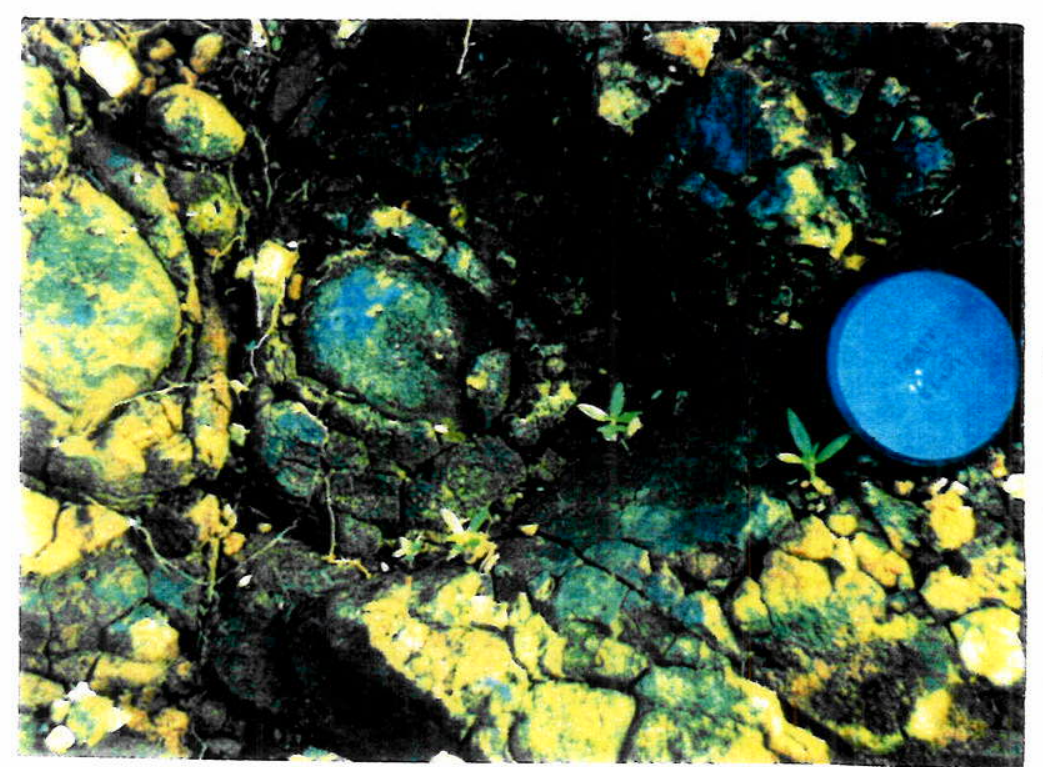

(d)

Fotografia 11 - Aspectos macroscópicos das rochas da Formação Paredão Grande. Em (a), textura porfirítica e fragmentos de rocha; em (b) estrutura de fluxo; em (c), fraturamento; e em (d), esfoliação esferoidal. 
(Carlsbad e Albita lamelar. Exibem freqüentemente bordas de reação com a matriz, tamanhos entre 1,0 a $4,0 \mathrm{~mm}$, e textura glomeroporfiritica com fenocristais de augita-titanaugita e opacos, tal como observado nos Derrames da Raizinha. Na matriz, as microlamelas de plagioclásio posicionam-se subparalelamente e, nos termos de granulação mais fina, estão dispostos em torno de fenocristais de augita-titanaugita e plagioclásio, localmente em linhas onduladas. As alterações freqüentemente observadas são de plagioclásio para sericita. Os clinopiroxênios são do tipo augita a titanaugita, que ocorrem como fenocristais euédricos a subeuédricos. A augita apresenta-se em prismas curtos, idiomorfos, com tamanho entre 0,5 a $1,0 \mathrm{~mm}$, cor castanha-esverdeada. pleocroismo fraco de verde pálido a castanho claro, extinção oblíqua às clivagens, geminações simples e mais raramente múltiplas. A titanaugita ocorre mais comumente como cristais longos hipidiomórficos, com tamanho oscilando entre 0,7 a $1,5 \mathrm{~mm}$, cor verde pálido, pleocroismo médio a forte, de verde-amarelado a violeta, apresentando zoneamento. Na matriz, a augita ocorre em microlamelas associadas com plagioclásio, opacos e vidro de sílica. A textura mais comum é subofitica entre os clinopiroxênios e os plagioclásios. Alguns cristais de augita encontram-se completamente alterados para uma massa de aspecto fibroso de cor castanha esverdeada, sendo provavelmente a uralita em estado de alteração avançado. $O$ feldspato alcalino (caulinizado) é o ortoclásio, o qual raramente ocorre como fenocristal, possuindo hábito tabular e tamanho variando entre 0,5 a $2,0 \mathrm{~mm}$. Associa-se ao plagioclásio que ocorre na forma de cristais hipidiomórficos, incolores, com clivagem boa, geminação tipo Carlsbad e mais raramente Baveno. A olivina (Fotomicrografia 3a) constitui fenocristais de dimensões entre 0,7 a $1,0 \mathrm{~mm}$, ocorrendo em hábitos euédricos a subeuédricos, cor amarela esverdeada, pleocroismo fraco em tons pálidos de verde a amarelo, com freqüentes fraturas, extinção reta, cores de interferência forte (verde, azul, etc...), contendo comumente inclusões de opacos. Na matriz, a olivina ocorre como microcristais idiomorfos à hipidiomorfos disseminados, às vezes sob forma de esqueletos de cristais parcialmente alterados para bowlingita e iddiginsita. $O$ quartzo ocorre como xenocristal evidenciando contaminação do magma pela encaixante arenítica. Os xenocristais de quartzo apresentam aspecto límpido, incolor, algumas vezes fraturados, extinção ondulante e caráter uniaxial positivo. Nas bordas dos cristais de quartzo ocorrem microlamelas de augita em disposição radial, subparalelas e englobadas por auréolas concêntricas de cor laranja a amarela, opticamente isótropas, com textura de devitrificação, sendo provavelmente vidro vulcânico (Fotomicrografias $3 \mathrm{~b}$ e $3 \mathrm{c}$ ). Os fragmentos de rocha presentes nas bordas e topo dos diques, mostram-se sob formas variadas, como por exemplo esféricas, retangulares, elipsóides e de 
bastonetes. Em lâminas delgadas. o tamanho situa-se entre 0.5 a $1.0 \mathrm{~mm}$; contudo, em afloramento foram descritos fragmentos de rocha de até $16 \mathrm{~cm}$. A apatita ocorre como acessório na maioria das amostras, em microcristais idiomorfos a hipidiomorfos. incolores. com relevo médio e extinção reta. apresentando dimensões entre 0.1 a $0.3 \mathrm{~mm}$. O carbonato. de ocorrência localizada. forma agregados microcristalinos incolores. fazendo parte do produto de alteração do plagioclásio e do piroxênio. Ocorre também preenchendo vesículas circulares, com dimensões variando entre 0,5 a $0,7 \mathrm{~mm}$. Os minerais opacos são abundantes em todas as amostras, ocorrendo como fenocristais idiomorfos a hipidiomorfos, com hábito triangular, cúbico e esqueletos de cristais com tamanho entre 0,4 a $1,0 \mathrm{~mm}$, de cor marrom escura a preta. opticamente isotrópicos, tratando-se provavelmente de magnetita (Fotomicrografia $3 \mathrm{~d}$ ). Em afloramento entre os diques números 7 e 17 (Tabela 2), a bússola quando colocada sobre o corpo ficava fora de controle. A matriz é formada predominantemente por microlamelas de plagioclásio em microcristais idiomorfos, microlamelas de augita, globulitos de opacos e microcristais idiomorfos de apatita. $O$ vidro vulcânico apresenta-se em formatos irregulares, de cor marrom alaranjada, por vezes com textura hialopilítica com micrólitos de plagioclásio.

\subsubsection{3 - Características macro e microscópicas dos Derrames da Lajinha e do Córrego Preto.}

As amostras de mão das rochas dos Derrames da Lajinha e do Córrego Preto (Alvo DA) apresentam-se maciças, nas cores cinza escura, com textura afanítica e estruturas de fluxo.

Em lâminas delgadas caracterizam-se pela presença de plagioclásio (50\%), clinopiroxênio (30\%), opacos $(15 \%)$ e acessórios (5\%). A textura predominante é subofitica e secundariamente a traquítica. O plagioclásio tipo oligoclásio $\left(\mathrm{An}_{10-30}\right)$, apresenta-se geralmente em cristais idiomórficos $(0,05 \mathrm{~mm})$, na forma de ripas associadas aos clinopiroxênios. Os clinopiroxênios são augita (lmm) e raramente titano-augita. Os fenocristais destes minerais são raros quando comparados aos da Raizinha (Alvo PX). Os opacos predominantes são do tipo magnetita, muitos em elevado estágio de alteração, transformando-se em óxidos de ferro que produzem alterações nos cristais de plágioclásio e de clinopiroxênio. Os minerais acessótios predominantes são formas secundárias de sílica (lussatita) que formam mosaicos geralmente envolvendo o quartzo microcristalino (daumoritização). Na concepção de Roubalt (1982), daumoritização é um tipo de alteração de plagioclásio que permite a geração de quartzo, epidoto, clorita e calcita. Os demais 

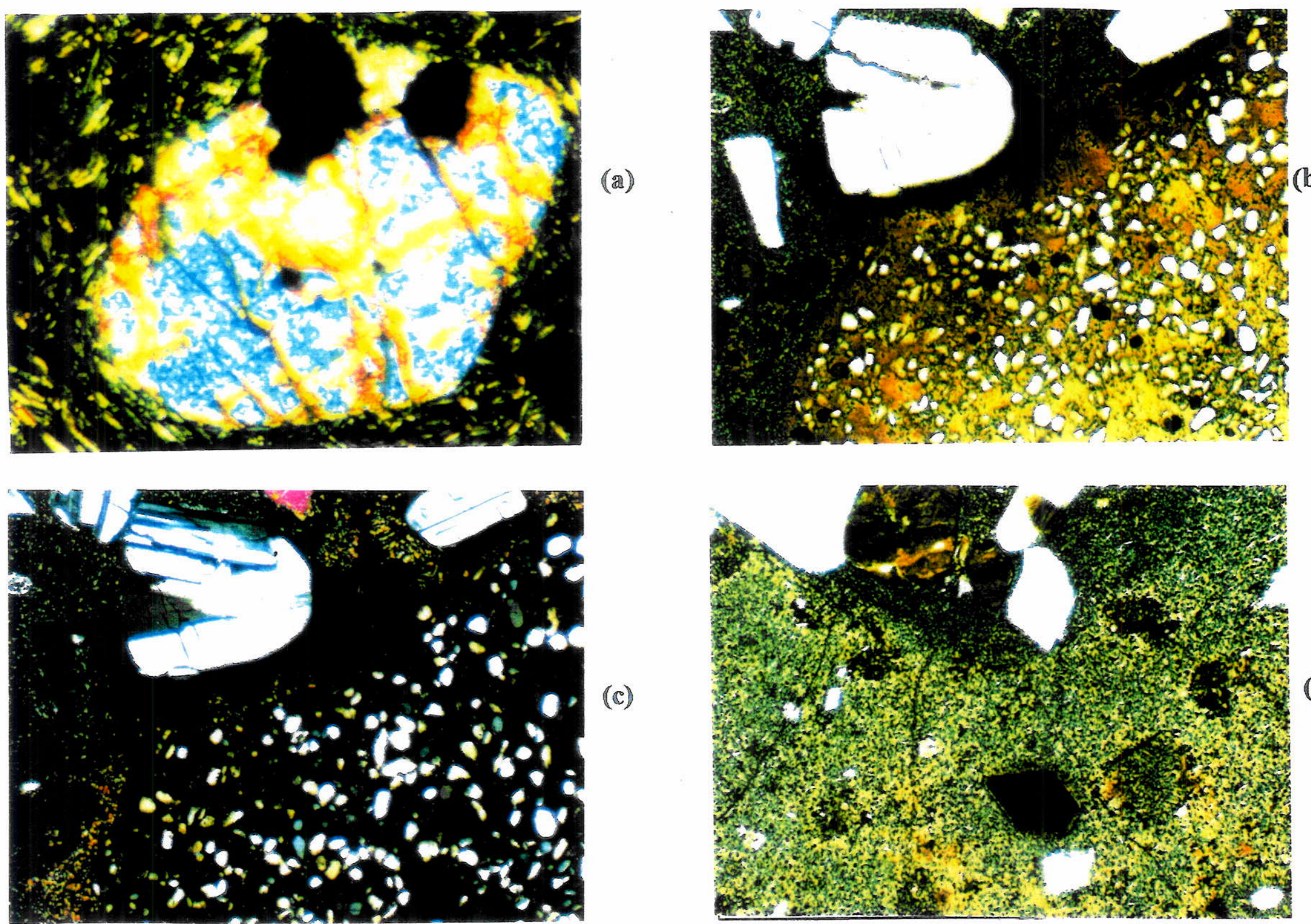

(d)

Fotomicrografia 3 - Características microscópicas dos diques de Paredão Grande e Colônia Indígena Meruri (Formação Paredão Grande), com aumento de 40x. Em (a), fenocristal de olivina; em (b), vidro vulcânico sob nicóis paralelos; em (c), ídem com nicóis cruzados; e em (d), cristais de magnetita. 
minerais acessórios foram descritos como calcita. epidoto e mais raramente apatita.

A partir das descrições petrográficas realizadas. foi possivel definir-se duas associações mineralógicas para os fenocristais presentes na Formação Paredão Grande. A primeira, descrita para as vulcânicas máficas da Raizinha é caracterizada por olivina + clinopiroxênio + plagioclásio (labradorita); a segunda. com clinopiroxènio + plagioclásio (andesina. oligoclásio) descrita nos diques de modo geral e nos Derrames da Lajinha e Córrego Preto. Nos diques em particular. ocorrem freqüentemente xenocristais de quartzo o que permite caracterizar a associação de fenocristais como clinopiroxênio + plagioclásio + quartzo.

Com base nas associações descritas de fenocristais em conjunto com o restante das características mineralógicas dessas rochas e, considerando-se ainda as diferenças petrográficas entre basaltos toleíticos e alcalinos propostas por Hughes (1982, In: Wilson, 1994) (Tabela 5), as rochas pertencentes à Formação Paredão Grande enquadram-se na categoria de basaltos alcalinos. O termo mais primitivo é caracterizado por olivina basalto o qual, por diferenciação magmática, produziu rochas de composição álcali feldspato riolito encontrados como seixos e matacões nos conglomerados do Grupo Bauru (Weska, 1987). A diferenciação magmática em questão, pode ter sido resultado da intensa contaminação crustal e da assimilação pelo magma primitivo, sendo facilmente observável desde a escala de afloramentos até lâminas delgadas, traduzindo-se por xenólitos a microxenólitos das Formações Aquidauana e Botucatu, principalmente, além de xenocristais de quartzo (Fotomicrografias $3 b$ e $3 c$ ).

\subsubsection{4 - Posicionamento estratigráfico, contatos e idades}

O posicionamento estratigráfico dos Derrames da Raizinha é duvidoso quando utilizados os métodos de mapeamento geológico tradicionais, uma vez que os contatos inferiores não são aflorantes, apesar de se comportarem como altos topográficos; todavia, depósitos coluvionares recentes recobrem as porções onde poderiam estar localizados tais contatos. Trabalhos de pesquisa com sondagem realizados pela Mineração Noroeste Ltda. (1984), consideraram esses corpos como sendo pós-Grupo Bauru e de provável idade Terciária. Um furo de sondagem para água realizado pela Empresa Geoeste Ltda. sobre o corpo 2 (Tabela 1) a cujos dados tivemos acesso, permitiram confirmar que na realidade os Derrames da Raizinha (espessura de $17,5 \mathrm{~m}$ ) estão intercalados nas rochas da Formação Quilombinho (base do Grupo Bauru, segundo Weska et al., 1993). Os contatos entre os diques 5 a 15 (Tabela 2), assim como o dique 
Primavera, são feitos com a Formação Aquidauana (Figura 8). Nos diques de Paredão Grande os contatos mostram metamorfismo térmico, exposto por intensa silicificação. Já os Derrames da Lajinha e do Córrego Preto, ocorrem intercalados e cíclicos, desde a base até a porção intermediária na Formação Cachoeira do Bom Jardim (unidade intermediária do Grupo Bauru, segundo Weska, 1987 e Weska et al., 1993), ocorrendo provavelmente em 3 ciclos. Dois desses ciclos são claramente observadas na região da Lajinha (Figura 10), e um terceiro é provável (Derrames do Córrego Preto), pois os contatos de topo desses últimos derrames não foram observados em campo, enquanto que o basal é feito com a Formação Cachoeira do Bom Jardim, mostrado na Figura 14. Esse terceiro ciclo é admitido em função da proximidade entre esses derrames e espessos afloramentos da Formação Cambambe (topo do Grupo Bauru). Os contatos entre os Derrames da Lajinha e a Formação Cachoeira do Bom Jardim, são discordantes, dos tipos litológico e erosivo, sendo o último evidenciado por conglomerados possantes sobrepostos às lavas (Figura 11). A espessura do derrame inferior da Lajinha foi medida em $20 \mathrm{~m}$ e a de topo em 7,5m, ambos em média. A espessura de $\sim 9 \mathrm{~m}$ de um dos derrames do Córrego Preto, é mostrada na Figura 15 em contato com com rochas da Formação Cachoeira do Bom Jardim. sobreposto em discordância erosiva por cascalhos da Unidade Terciário-Quaternário Indiviso.

A idade obtida por Gibson et al. (no prelo) para o corpo 3 (Tabela 1), sugere que o resfriamento magmático dos Derrames da Raizinha ocorreu a 83,9 $\pm 0,4 \mathrm{Ma}$., conforme dados obtidos através do método $\mathrm{Ar}^{40} / \mathrm{Ar}^{39}$ a laser. Os diques Primavera e Toca da Onça, datados pelo método K/Ar em rocha total, forneceram idades de 83 e $66 \mathrm{Ma}$., respectivamente. A despeito das limitações de aplicação do método (contaminação crustal), é possível admitir que a de idade de resfriamento desses corpos é Cretácea Superior. Os Derrames da Lajinha e do Córrego Preto não foram datados; entretanto, com base no posicionamento estratigráfico dos mesmos, intercalados

ciclicamente desde a porção intermediária para topo da Formação Cachoeira do Bom Jardim, em relação aos Derrames da Raizinha, eles são mais jovens, porém, com idade de colocação Cretácea Superior.

\subsubsection{5 - Características geoquímicas e isotópicas.}

Estudos introdutórios a respeito das características geoquímicas destas rochas foram apresentados por Weska (1987), para os diques da Mata e da Matinha e os Derrames da Passagem do Mamão (Chapada dos Guimarães), assim como para os diques de Paredão Grande 
Tabela 5 - Diferenças petrográficas entre basaltos toleíticos e alcalinos (Hughes, 1982; In: Wilson 1994).

\section{BASALTOS}

\section{TOLEÍTICOS}

\section{ALCALINOS}

\section{a) Fenocristais}

- fenocristais grandes de olivina pouco - fenocristais de olivina de tamanho médio freqüentes, sem zoneamento. podendo comuns, muitas vezes fortemente zonados com mostrar anéis de reação de ortopiroxênio.

- podem ocorrer fenocristais de ortopiroxênio.

- fenocristais de plagioclásio muitas vezes aparecem nos estágios iniciais da cristalização.

- olivina < plagioclásio < augita

- fenocristais de augita castanho claro.

\section{b) Matriz}

- granulação relativamente fina, com textura intergranular.

- olivina ausente.

- o piroxênio varia entre augita subcálcica ou augita \pm pigeonita.

- feldspatos alcalinos ou analcita ausentes.

- vidro intersticial relativamente comum.

c) Rochas Associadas

- xenólitos ultramáficos muito raros anéis mais ricos em ferro.

- ortopiroxênio ausente.

- fenocristais de plagioclásio menos comuns, sendo tardios na seqüência de cristalização.

- olivina $<$ augita $<$ plagioclásio

- fenocristais de augita titanifera, fortemente zonados com bordas de reação roxa a castanha.

- relativamente grossa, com textura variando entre intergranular a ofitica.

- olivina na matriz.

- somente espécies de clinopiroxênios ricos em $\mathrm{Ca}$ (salita titanífera).

- feldspato alcalino e analcita podem ocorrer na matriz.

- vidro intersticial é raro ou ausente.

- xenólitos ultramáficos muito comuns, composições duníticas ou wehrlíticas predominam.

- rochas acumulativas associadas são picritos - rochas acumulativas associadas são (oceanitos), ricos em fenocristais de olivina. ankaramitos, ricos em fenocristais de olivina e augita.

(Weska et al., 1992), concluindo-se que essas rochas seriam de composição basalto-andesítica derivadas de um magma parental toleítico.

Durante os trabalhos de campo para essa Tese houve a necessidade de desenvolver estudos a respeito do magmatismo da Formação Paredão Grande caracterizado por rochas piroclásticas grossas (aglomerados e vulcanoclásticas epiclásticas) a finas (tufos), derrames e diques associados. Entretanto, só conseguimos realizar coletas de materiais para análises em derrames e diques, porque as demais rochas estão completamente alteradas. Simultaneamente, participamos de um projeto de pesquisa internacional cujos objetivos foram estudos geoquímicos e isotópicos dessas rochas e que culminaram com o trabalho de Gibson et al. (no prelo). Nesse 


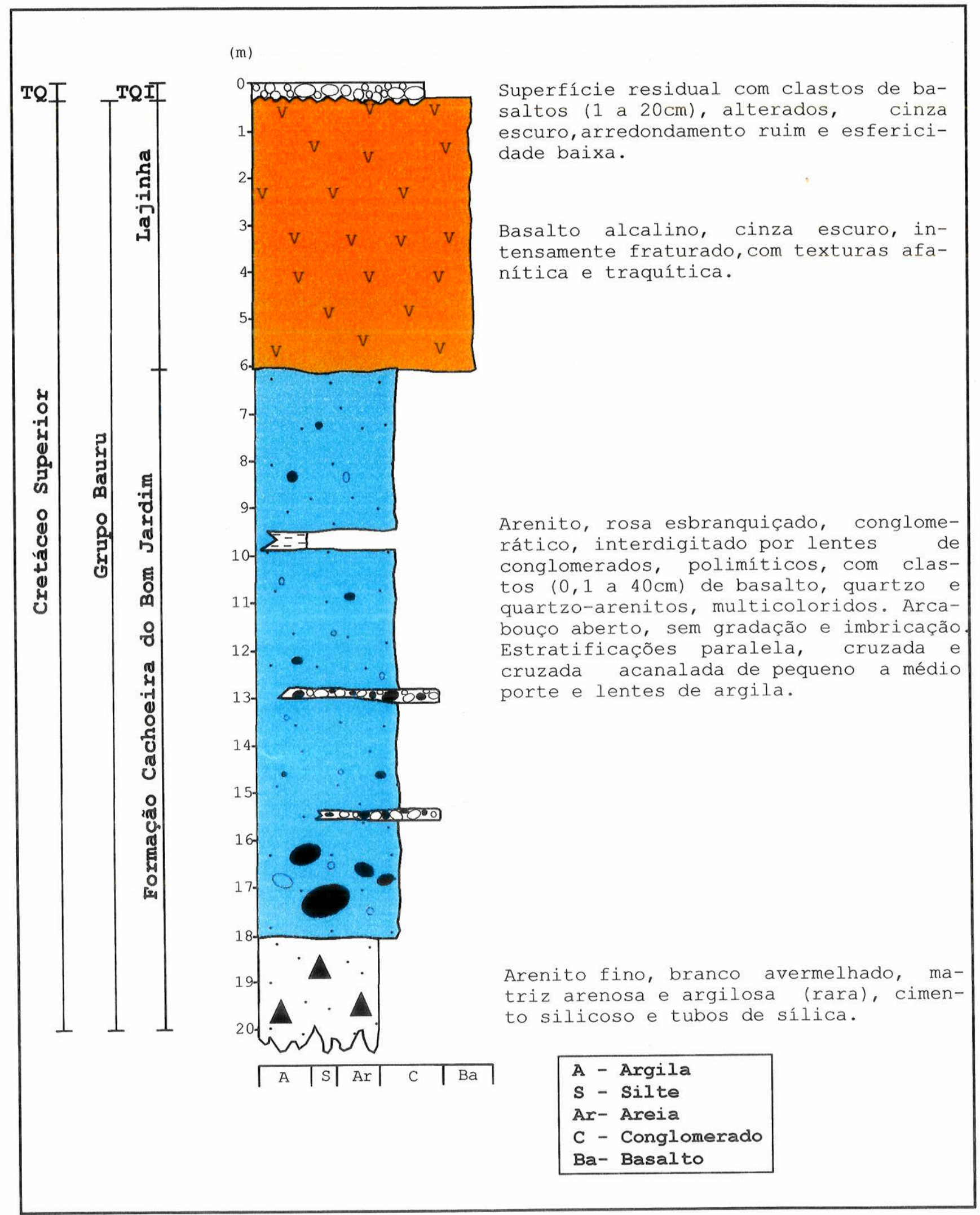

Figura 14 - Coluna estratigráfica mostrando o contato entre a Paredão Grande e a Formação Cachoeira do Bom Jardim, região da Lajinha, Alvo DA. 


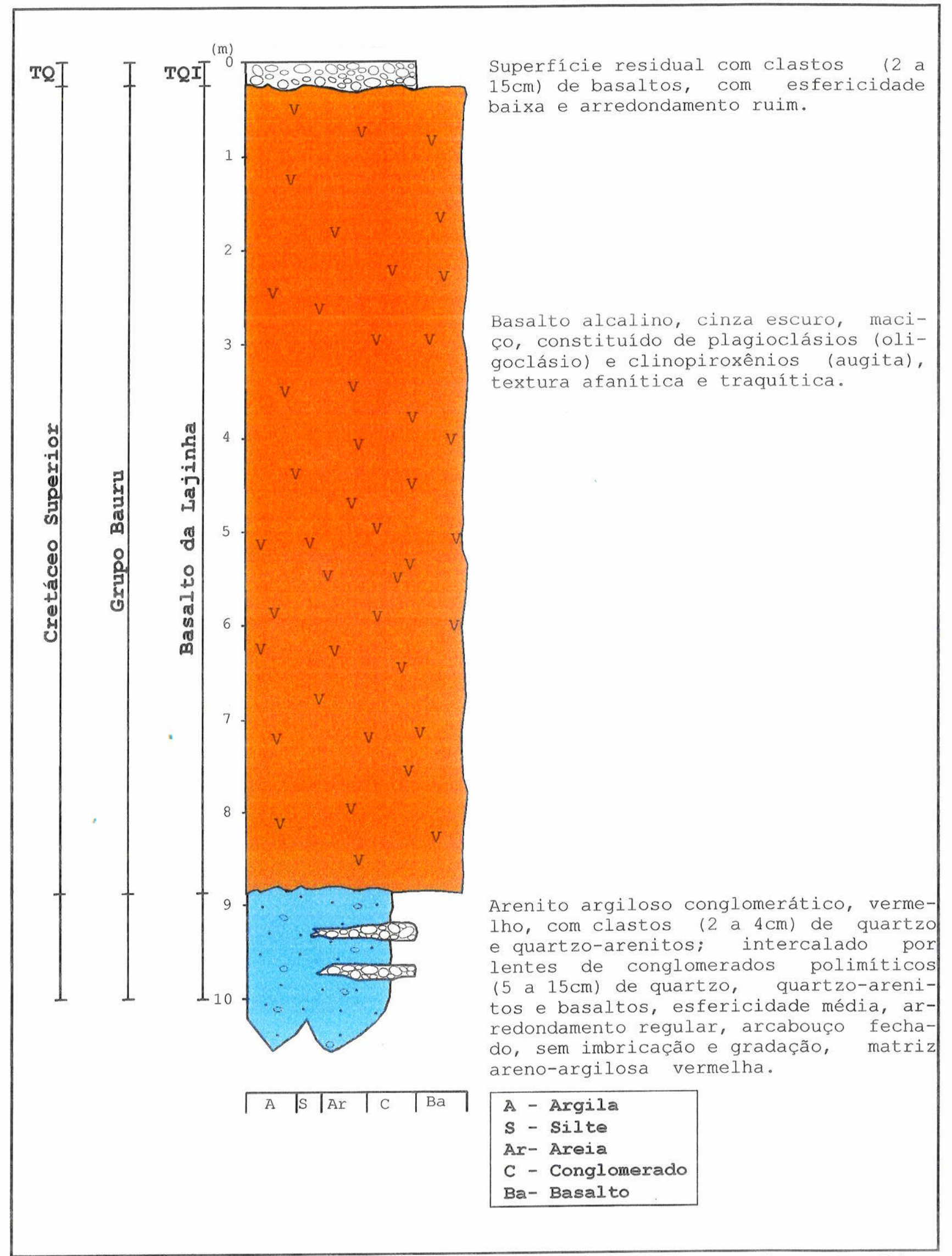

Figura 15 - Coluna estratigráfica da Formação Paredão Grande no Córrego Preto - Alvo DA. 
projeto. foram estudadas rochas sob a forma de derrames que incluíram Raizinha (PX), Lajinha e Córrego Preto (DA) e Passagem do Mamão, Chapada dos Guimarães (Weska. 1987); bem como os diques de Paredão Grande, Meruri. da Mata e da Matinha. Chapada dos Guimarães (Weska, 1987) e a intrusão alcalina da Ponta do Morro (Mimoso) que foram englobadas na Provincia Ígnea de Poxoréu (PIP), contemporânea as de Iporá e do Alto Paranaiba (Figura 16), porém com características petrográficas e geoquimicas particulares.

Não é objetivo desta Tese o detalhamento do magmatismo da PIP, por essa razão utilizaremos apenas parte dos dados geoquimicos e isotópicos, como por exemplo as análises de elementos maiores, traços e as razões de $\mathrm{Sr}^{87} / \mathrm{Sr}^{86}$ e $\mathrm{Nd}^{143} \mathrm{Nd}^{144}$. A caracterização do magmatismo em apreço introduz dados para futuras discussões nessa Tese a respeito de questões, como por exemplo: a) o magmatismo no contexto da bacia do Grupo Bauru no Estado de Mato Grosso; b) sedimentos dele derivados (áreas fontes); e c) discriminações de associações de minerais pesados (satélites do diamante), pontos que se constituem nos objetivos principais dessa pesquisa.

Nas Tabelas 6 e 7a estão plotados os resultados das análises litogeoquímicas e de CIPW de rochas da Formação Paredão Grande. Além das características mineralógicas anteriormente descritas, os Derrames da Raizinha possuem em peso $-48 \%$ de $\mathrm{SiO}_{2}$ e $5 \%$ de $\mathrm{Na}_{2} \mathrm{O}+\mathrm{K}_{2} \mathrm{O}$, enquanto que os da Lajinha e do Córrego Preto possuem valores que variam de 54 $\mathrm{a} \sim 61 \%$ para a $\mathrm{SiO}_{2} \mathrm{e} \sim 4 \%$ para $\mathrm{Na}_{2} \mathrm{O}+\mathrm{K}_{2} \mathrm{O}$. Os diques de Paredão Grande, Meruri e Primavera são caracterizados por valores de $\mathrm{SiO}_{2}$ entre $53-56 \%$ e $\mathrm{Na}_{2} \mathrm{O}+\mathrm{K}_{2} \mathrm{O}$ da ordem de 5 a 7\% em peso. Esses dados plotados no gráfico álcalis versus sílica (Le Bas et al., 1986) são mostrados na Figura 17, onde se pode observar, ainda que de forma incipiente, a presença de dois trendes. $O$ primeiro de natureza alcalina, representa um magma mais primitivo (basalto alcalino) sendo exemplificado pelos Derrames da Raizinha. Os termos intermediários desse magma possuem composições desde basalto traquiandesito até traquiandesito, sendo representado pelos diques Primavera, Paredão Grande e Meruri. O segundo trende, corresponde a um magma parental de composição toleítica variando entre basalto andesítico nos Derrames da Passagem do Mamão e da Lajinha e o dique da Matinha; a dacito, como nos Derrames do Córrego Preto.

Segundo Gibson et al. (no prelo), os magmas máficos da PIP contêm $<6 \%$ em peso de $\mathrm{MgO}$, que associado à assembléia de fenocristais indica evolução do magma por cristalização fracionada. Para estimar o grau desse fracionamento, os estudos experimentais de composição normativa (CIPW) mostram que os derrames e os diques da PIP exibem variação ampla no grau 
de saturação em sílica, com basalto desde nefelina (Derrames da Raizinha), até quartzo-normativo nas demais intrusões e extrusões. As amostras analisadas dos Derrames da Raizinha (basalto alcalino) comportam-se desde nefelina até hiperstênio normativas e variam através do plano crítico de saturação em sílica. Elas também situam-se próximas à curva cotética para líquidos basálticos em equilíbrio com olivina, plagioclásio e clinopiroxênio a $9 \mathrm{kbar}$, comportando-se de modo similar às séries de lavas de Skye Main e o Grupo Mull Plateau que foram equilibradas na base da crosta (Thompson et al., 1983). Em contraste, os basaltos traquiandesíticos da PIP são todos quartzo normativos e quando plotados situam-se proximos ao cotético anidro de 1 atmosfera, definido por líquidos basálticos e toleíticos andesíticos em equilibrio com olivina, plagiocásio e clinopiroxênio (Thompson et al., 1983).

Estudos de contaminação crustal realizados por Dungan et al. (1986), In: Wilson (1994), no Taos Plateau Volcanic Field (Rift Rio Grande), a partir da utilização de razões de elementos traços incompatíveis (Tabela 6) tais como $\mathrm{Y} / \mathrm{Nb}$ versus $\mathrm{Zr} / \mathrm{Nb}$ coincidem com o trende obtido para as rochas da Formação Paredão Grande que foram plotadas na Figura 18, caracterizando contaminação crustal dessas rochas em direção crescente para os termos mais primitivos (Derrames da Raizinha).

O grau de contaminação crustal dos magmas máficos da PIP, de acordo com Gibson et al. (no prelo), são evidentes a partir das razões isotópicas de Sr e Nd. Segundo esse trabalho, as rochas de composição traquiandesito basalto são caracterizadas por razões iniciais mais altas de $\mathrm{Sr}^{87} / \mathrm{Sr}^{86}(0,7060-0,7101)$ e baixas razões iniciais de $\mathrm{Nd}^{143} / \mathrm{Nd}^{144}(0,51252-0,51236)$ (Tabela $7 \mathrm{~b}$ e Figura 19), quando comparadas as de basalto alcalino, que possuem razões iniciais baixas $\mathrm{Sr}^{87} / \mathrm{Sr}^{86}(0,7040)$ e altas de $\mathrm{Nd}^{143} / \mathrm{Nd}^{144}(0,51274)$. Tais dados isotópicos projetam-se no mesmo campo de magmatismo tipo OIB (ocean island basaits) convencional para isótopos de $\mathrm{Sr}$ e $\mathrm{Nd}$. Para estimar o grau de contaminação crustal dos traquiandesitos basalticos, foram determinadas as razões isotópicas de $\mathrm{Sr}$ e $\mathrm{Nd}$ de uma das rochas encaixantes desses corpos (Formação Botucatu). A Figura 19 mostra que as rochas traquibasálticas caem no campo da curva compreendida entre uma rocha pouco contaminada da PIP (Derrames da Raizinha) e a Formação Botucatu. Nestas condições, a assinatura isotópica dos traquibasaltos pode ser explicada por um modelo que envolve a assimilação de $50 \%$ de sedimentos das rochas encaixantes (Botucatu ou Aquidauana). Para Gibson et al. (no prelo) a estimativa parece uma taxa alta quando comparada à soma modal de xenocristais de quartzo nas amostras da rocha, pois se a contaminação crustal ocorreu durante o fracionamento magmático a soma deverá ser significativamente menor. 


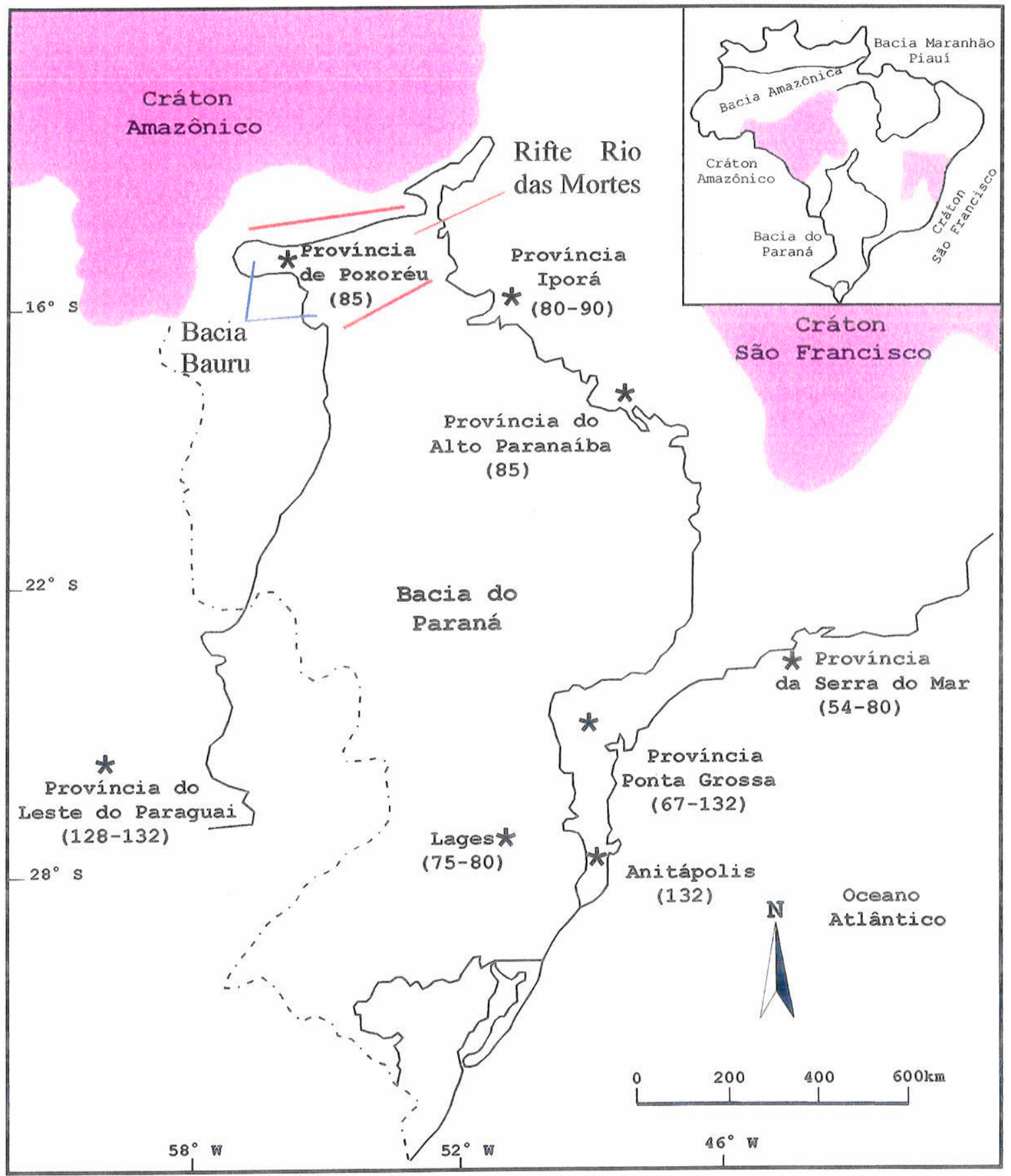

Figura 16 - O posicionamento da Província Ígnea de Poxoréu (PIP), na Bacia Bauru, no Rifte Rio das Mortes, no Estado de Mato Grosso, em relação às Províncias Iporá e Alto Paranaíba, além de outras províncias no Barasil e no Paraguai e suas respectivas idades. Modificado de Gibson et al. (1995). 
Tabela 6 - Elementos maiores e traços da Formação Paredão Grande (PIP); dos Derrames da Raizinha (PX); Passsagem do Mamão (Chapada dos Guimarães); da Lajinha e do Córrego Preto (DA); e Diques Primavera, Paredão Grande e Meruri (PG); e da Matinha (Chapada dos Guimarães). (*) Fe total expresso como $\mathrm{Fe}_{2} \mathrm{O}_{3}$. Os elementos maiores são apresentados em bases voláteis livres. Amostras SOB, fonte (Gibson et al., 1996 - no prelo) e a 24a Uggeri \& Costa, 1992.

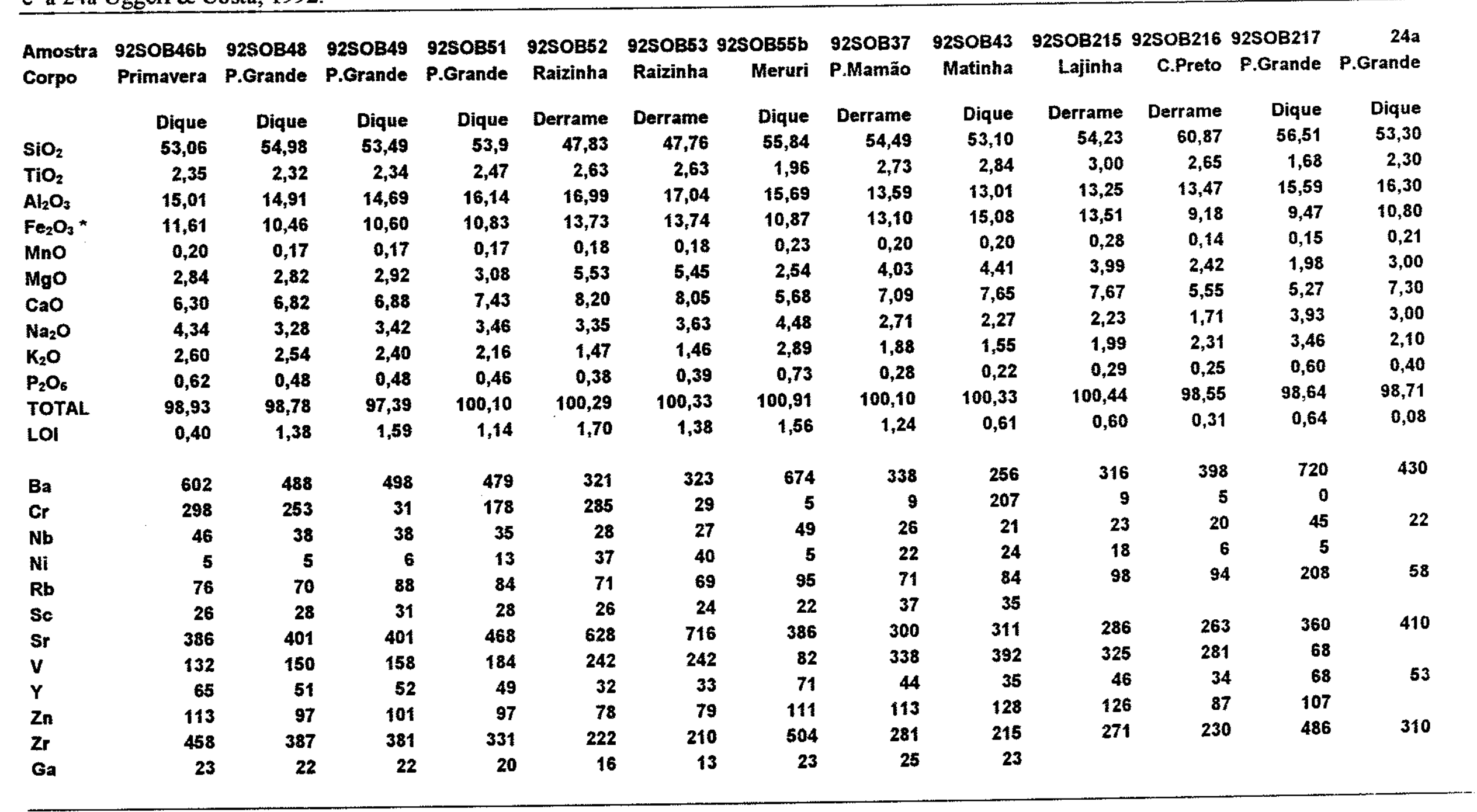


Tabela 7 - CIPW (a) e análises isotópicas (b) de $\mathrm{Nd}^{143} / \mathrm{Nd}^{144} \mathrm{e} \mathrm{Sr}^{87} / \mathrm{Sr}^{86}$ em valores medidos (m) e com valores iniciais (i) corrigidos para 85 Ma. de parte da Formação Paredão Grande (PIP); dos Derrames da Raizinha (PX); Passsagem do Mamão (Chapada dos Guimarães); da Lajinha e do

Córrego Preto (DA); e Diques Primavera, Paredão Grande e Meruri (PG); e da Matinha (Chapada dos Guimarães). Amostras SOB, fonte Gibson et al. (1996 - no prelo) e a 24a Uggeri \& Costa, 1992.

(a)

\begin{tabular}{|c|c|c|c|c|c|c|c|c|c|c|c|c|c|}
\hline $\begin{array}{l}\text { Amostra } \\
\text { Corpo }\end{array}$ & $\begin{array}{l}\text { 92soB46b } \\
\text { Primavera }\end{array}$ & $\begin{array}{l}925 O B 48 \\
\text { P.Grande }\end{array}$ & $\begin{array}{l}\text { 92SOB49 } \\
\text { P.Grande }\end{array}$ & $\begin{array}{l}9250 B 51 \\
\text { P.Grande }\end{array}$ & $\begin{array}{l}92 S O B 52 \\
\text { Raizinha }\end{array}$ & $\begin{array}{c}925 O B 53 \\
\text { Raizinha }\end{array}$ & $\begin{array}{r}\text { 9250B55b } \\
\text { Meruri }\end{array}$ & $\begin{array}{l}\text { 92SOB37 } \\
\text { P.Mamäo }\end{array}$ & $\begin{array}{r}92 S O B 43 \\
\text { Matinha }\end{array}$ & $\begin{array}{r}925 O B 215 \\
\text { Lajinha }\end{array}$ & $\begin{array}{r}925 O B 216 \\
\text { C.Preto }\end{array}$ & $\begin{array}{r}9250 B 217 \\
\text { P.Grande }\end{array}$ & $\begin{array}{r}24 a \\
\text { P.Grande }\end{array}$ \\
\hline $\mathbf{Q}$ & $\begin{array}{r}\text { Dique } \\
1,01\end{array}$ & $\begin{array}{r}\text { Dique } \\
\mathbf{8 , 5 2}\end{array}$ & $\begin{array}{r}\text { Dique } \\
6,64\end{array}$ & $\begin{array}{r}\text { Dique } \\
5,96\end{array}$ & Derrame & Derrame & $\begin{array}{r}\text { Dique } \\
2,91\end{array}$ & $\begin{array}{r}\text { Derrame } \\
9,84\end{array}$ & $\begin{array}{c}\text { Dique } \\
9,28\end{array}$ & $\begin{array}{r}\text { Derrame } \\
9,91\end{array}$ & $\begin{array}{r}\text { Derrame } \\
25,94\end{array}$ & $\begin{array}{r}\text { Dique } \\
9,8\end{array}$ & $\begin{array}{r}\text { Dique } \\
8,81\end{array}$ \\
\hline Or & 15,37 & 15,01 & 14,18 & 12,77 & 8,69 & 8,63 & 17,08 & 11,11 & 9,16 & 11,76 & 13,65 & 20,45 & 12,41 \\
\hline $\mathbf{A b}$ & 36,72 & 27,75 & 28,94 & 29,28 & 28,35 & 29,81 & 37,91 & 22,93 & 19,21 & 18,87 & 14,47 & 33,25 & 25,39 \\
\hline An & 13,80 & 18,46 & 17,65 & 22,13 & 26,98 & 25,89 & 14,17 & 19,37 & 20,73 & 20,27 & 22,26 & 14,68 & 24,81 \\
\hline Di & 11,15 & 10,09 & 11,00 & 9,64 & 9,21 & 9,45 & 7,73 & 11,54 & 13,12 & 13,01 & 2,97 & 6,09 & 7,25 \\
\hline Hy & 9,79 & 8,27 & 8,24 & 9,21 & 3,03 & & 11,03 & 13,76 & 17,07 & 12,57 & 8,40 & 3,91 & 9,64 \\
\hline OI & & & & & 12,59 & 14,59 & & & ' & & & & \\
\hline $\begin{array}{l}\text { Ne } \\
\text { Mt }\end{array}$ & & & & & & 0,49 & & & & & & & \\
\hline $\begin{array}{l}\text { Mit } \\
\text { il }\end{array}$ & $\begin{array}{l}5,68 \\
4,46\end{array}$ & $\begin{array}{l}5,54 \\
4,41\end{array}$ & $\begin{array}{l}5,57 \\
4,44\end{array}$ & $\begin{array}{l}5,76 \\
4,69\end{array}$ & $\begin{array}{l}5,99 \\
5,00\end{array}$ & $\begin{array}{l}5,99 \\
5,00\end{array}$ & $\begin{array}{l}5,02 \\
3,72\end{array}$ & $\begin{array}{l}6,13 \\
5,18\end{array}$ & $\begin{array}{l}6,29 \\
5,39\end{array}$ & $\begin{array}{l}6,83 \\
5,70\end{array}$ & $\begin{array}{l}6,18 \\
5,03\end{array}$ & $\begin{array}{l}7,80 \\
3,19\end{array}$ & $\begin{array}{l}5,14 \\
4,37\end{array}$ \\
\hline Ap & 1,44 & 1,11 & 1,11 & 1,07 & 0,88 & 0,90 & 1,69 & 0,65 & 0,51 & 0,67 & 0,58 & 1,39 & 0,93 \\
\hline Total & 99,32 & 99,16 & $\mathbf{9 7 , 7 7}$ & 100,51 & 100,72 & 100,75 & 101,26 & 100,51 & 100,76 & 99,59 & 99,48 & 100,5 & 99,35 \\
\hline
\end{tabular}

(b)

$\begin{array}{lrrrrrr}\text { AMOSTRA } & \mathbf{9 2 S O B 4 6 b} & \mathbf{9 2 S O B 5 2} & \mathbf{9 2 S O B 4 9} & \mathbf{9 2 S O B 5 1} & \mathbf{9 2 S O B 4 3} & \mathbf{9 2 S O B 5 5 b} \\ \mathbf{8 7 S r / 8 6 S r m} & 0,706670 & 0,704426 & 0,706750 & 0,706755 & 0,711008 & 0,707078 \\ 143 \mathrm{Nd} / 144 \mathrm{Ndm} & 0,512600 & 0,512815 & 0,512584 & 0,512589 & 0,512445 & 0,512581 \\ \mathbf{8 7 S r / 8 6 S r i} & 0,705981 & 0,704033 & 0,705983 & 0,706130 & 0,710068 & 0,706220 \\ 143 N d / 144 N d i & 0,512523 & 0,512735 & 0,512491 & 0,512514 & 0,512363 & 0,512473\end{array}$




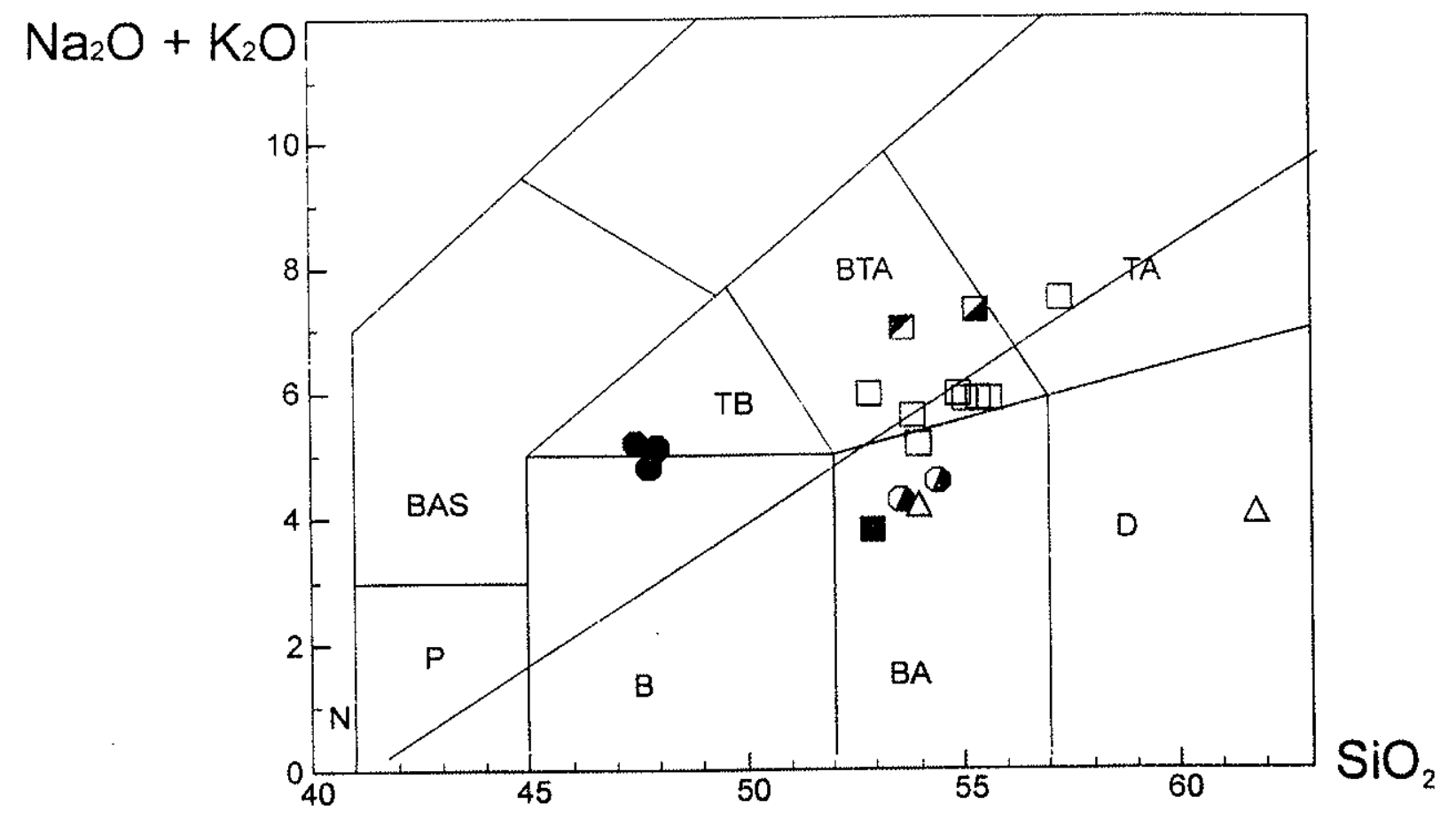

Figura 17 - Gráfico Na2O + K2O, em \% em peso, extraído de Le Bas et al. 1986, com dados plotados dos Derrames da Raizinha, PX ( ), da Passagem do Mamão, - Chapada dos Guimarãe,s- ( ( ) ), Lajinha e Córrego Preto, DA $(\triangle)$ e os Diques de Paredão Grande, PG ( $\square$ ), Primavera, - PG ( $\nabla$ ), Meruri ( $\square$ ) e da Mata e da Matinha ( $)$ ), Chapada dos Guimarães. Fonte: Gibson et al. (1996, in press). O limite tolético-alcalino extraído de MacDonald \& Katsura (1964).

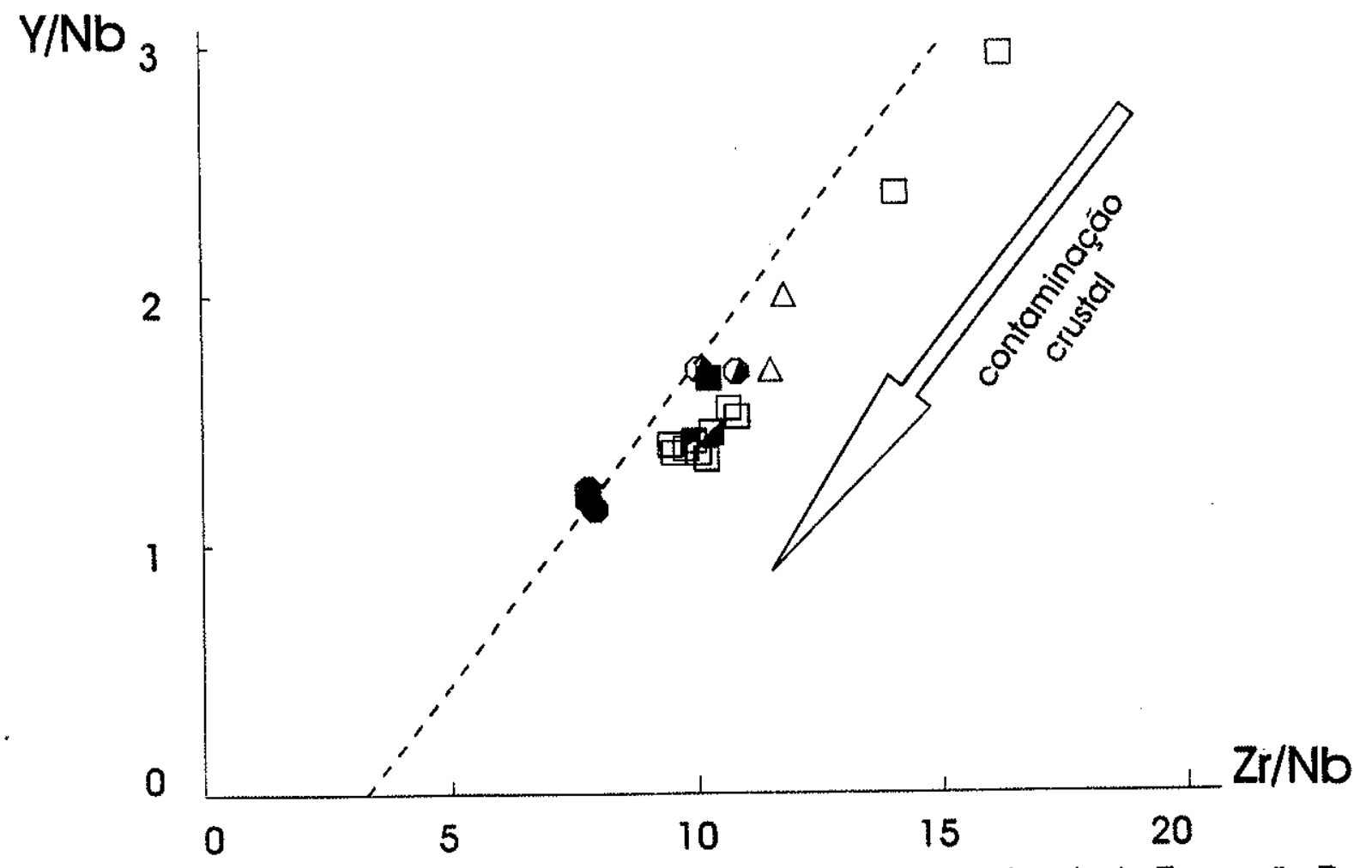

Figura 18 - Variação de $\mathrm{Y} / \mathrm{Nb}$ versus $\mathrm{Zr} / \mathrm{Nb}$ para basaltos transicionais da Formação Paredão Grande. Extraído de Dungan et al., 1986; In: Wilson, 1994. 


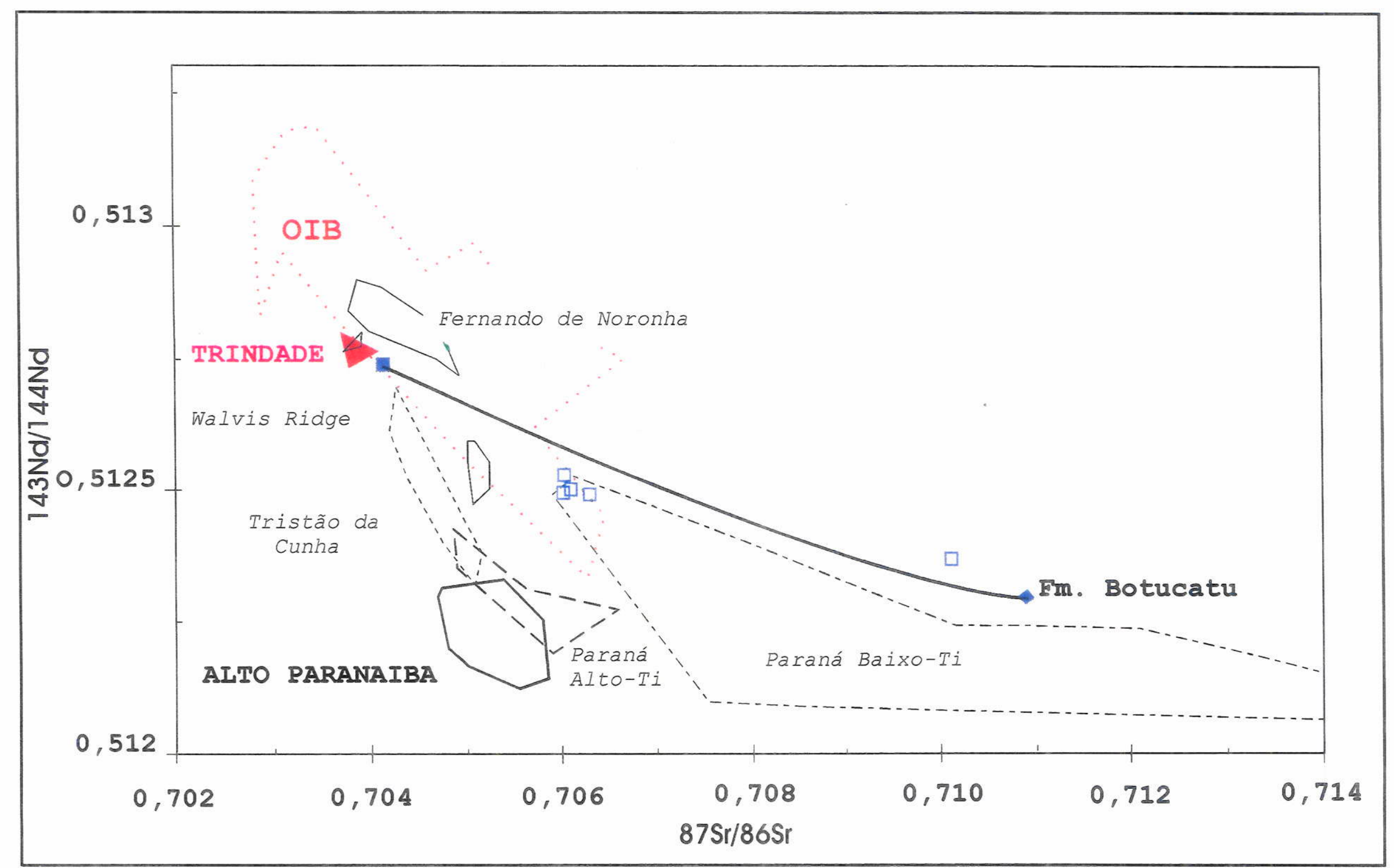

Figura 19 - Razões isotópicas $\mathrm{Nd}^{143} / \mathrm{Nd}^{144}$ versus $\mathrm{Sr}^{87} / \mathrm{Sr}^{86}$ da Formação Paredão Grande em comparação com Alto Paranaíba, magmas tipo OIB e basaltos de alto e baixo Ti. ( " ) Derrames da Raizinha; ( $\square$ ) Diques de Paredão Grande; e ( • ) Formação Botucatu. 


\subsection{6 - Formação Quilombinho, Grupo Bauru}

A Formação Quilombinho aflora somente no Alvo PX, nas porções SW e NW do mapa geológico (Figuras 6 e 11 ). Há um predominio de afloramentos desta unidade litoestratigráfica no entorno do perímetro urbano do Município de Poxoréu e ao longo da porção SW do plano de falha de mesmo nome. Na porção NW, envolvendo os garimpos da região do Buritizal, a unidade Quilombinho foi descrita em afloramentos e como "bedrock" nas frentes de lavra dos garimpos. Da base para o topo, foram identificados os seguintes litotipos na unidade litoestratigráfica em questão: conglomerados, argilitos e arenitos conglomeráticos, argilitos e arenitos (Figura 11).

Três tipos de conglomerados podem ser descritos na Formação Quilombinho, sendo o primeiro monomítico (Fotografia 12) e os demais polimíticos (Figura 20, Fotografias 13 e 14). Os conglomerados basais da Formação Quilombinho possuem predominantemente seixos e matacões de rochas de composição basáltica $(>90 \%)$. Os clastos possuem esfericidade média a alta, arredondamento bom a muito bom e tamanho médio entre 2 a $10 \mathrm{~cm}$; entretanto, matacões de tamanho superior a $50 \mathrm{~cm}$ podem ser encontrados (Fotografia 15). A espessura desse tipo de conglomerado varia desde 0,20 até $1,50 \mathrm{~m}$.

Os conglomerados intermediários são polimíticos e constituídos de seixos e matacões $(>40 \mathrm{~cm})$ de rochas basálticas, arenitos e silexitos. Esses conglomerados já evidenciam a incorporação das Formações Aquidauana e Palermo como importantes áreas fontes, contudo há predomínio de até $90 \%$ de clastos de composições basálticas variadas. Os clastos de rochas ígneas apresentam esfericidade média a alta, arredondamento bom a muito bom e tamanho entre 1 a $20 \mathrm{~cm}$ em média. Os clastos de origem sedimentar (arenitos e quartzo-arenitos), por sua vez, apresentam tamanho entre de 3 a $40 \mathrm{~cm}$ e os de silexitos dimensões entre 4 a $15 \mathrm{~cm}$. A esfericidade dos clastos sedimentares varia entre baixa a alta, o arredondamento de regular a muito bom, enquanto as espessuras situam-se entre $20 \mathrm{~cm}$ até $5 \mathrm{~m}$. Os conglomerados de topo da Formação Quilombinho (Figura 21) são similares aos intermediários, no entanto, o tamanho dos seixos e matacões em tnédia é menor. Os clastos de rochas vulcânicas básicas possuem dimensões de 2 a $6 \mathrm{~cm}$ em média, alguns alcançam até $30 \mathrm{~cm}$ e, os de origem sedimentar, de 2 a $18 \mathrm{~cm}$, segundo o eixo maior. A espessura dessas lentes de conglomerados situa-se no intervalo de 5 a $50 \mathrm{~cm}$. 


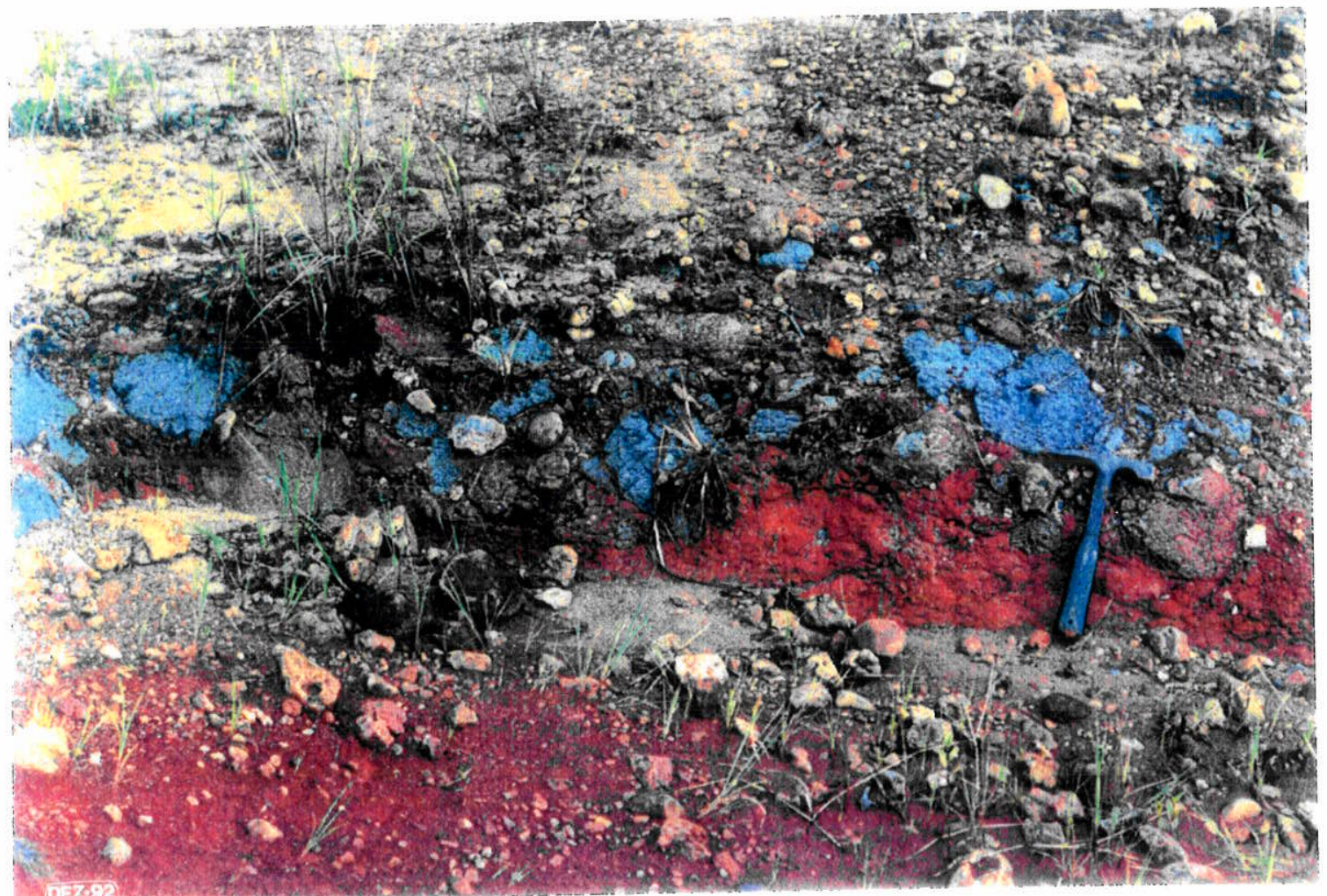

Fotografia 12 - Detalhe de conglomerados tipo basal da Formação Quilombinho, interdigitados por lentes de argilito conglomerático. O conglomerado possue mais que $90 \%$ de clastos vulcânicos.

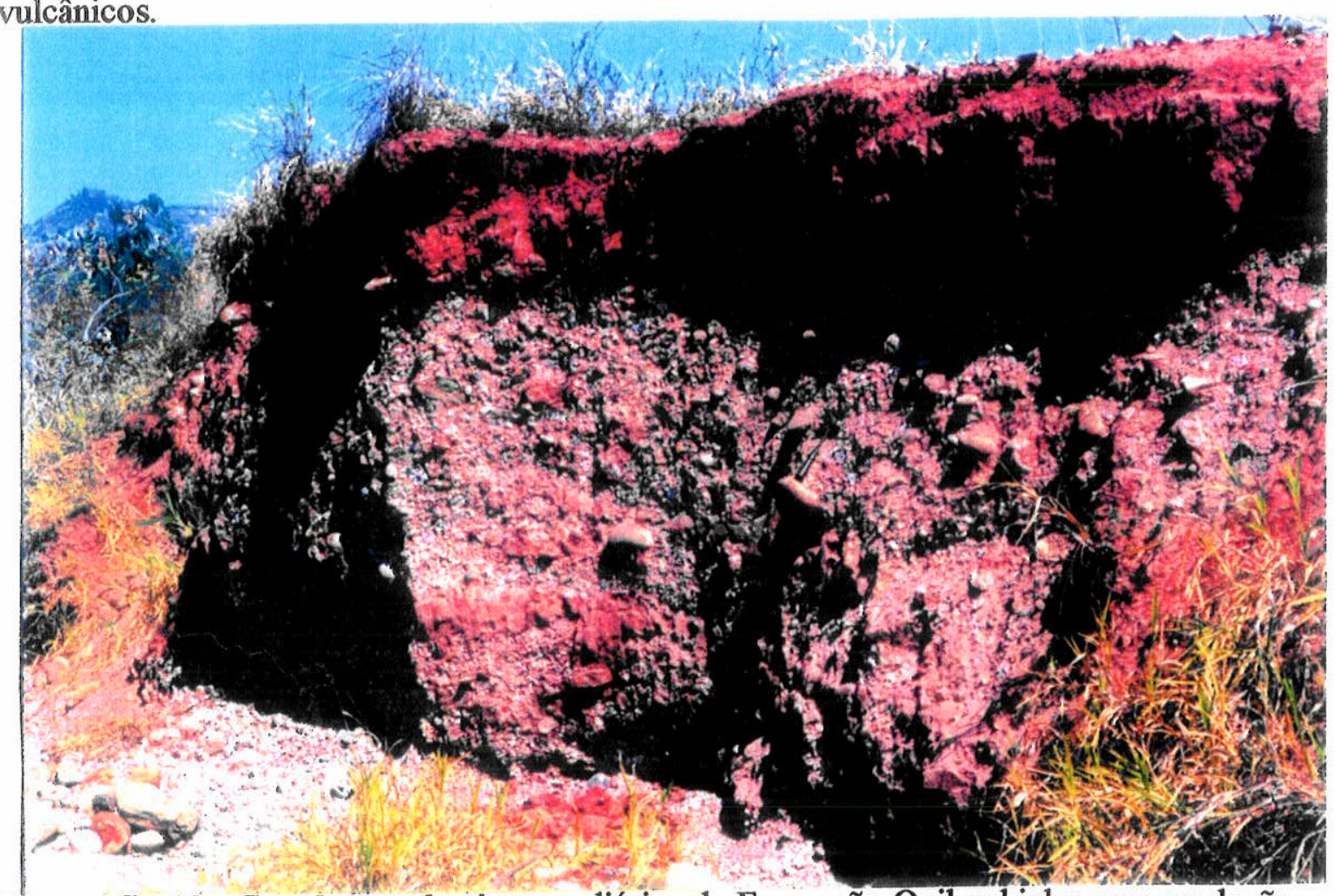

Fotografia 13 - Conglomerados intermediários da Formação Quilombinho com gradação inversa. 


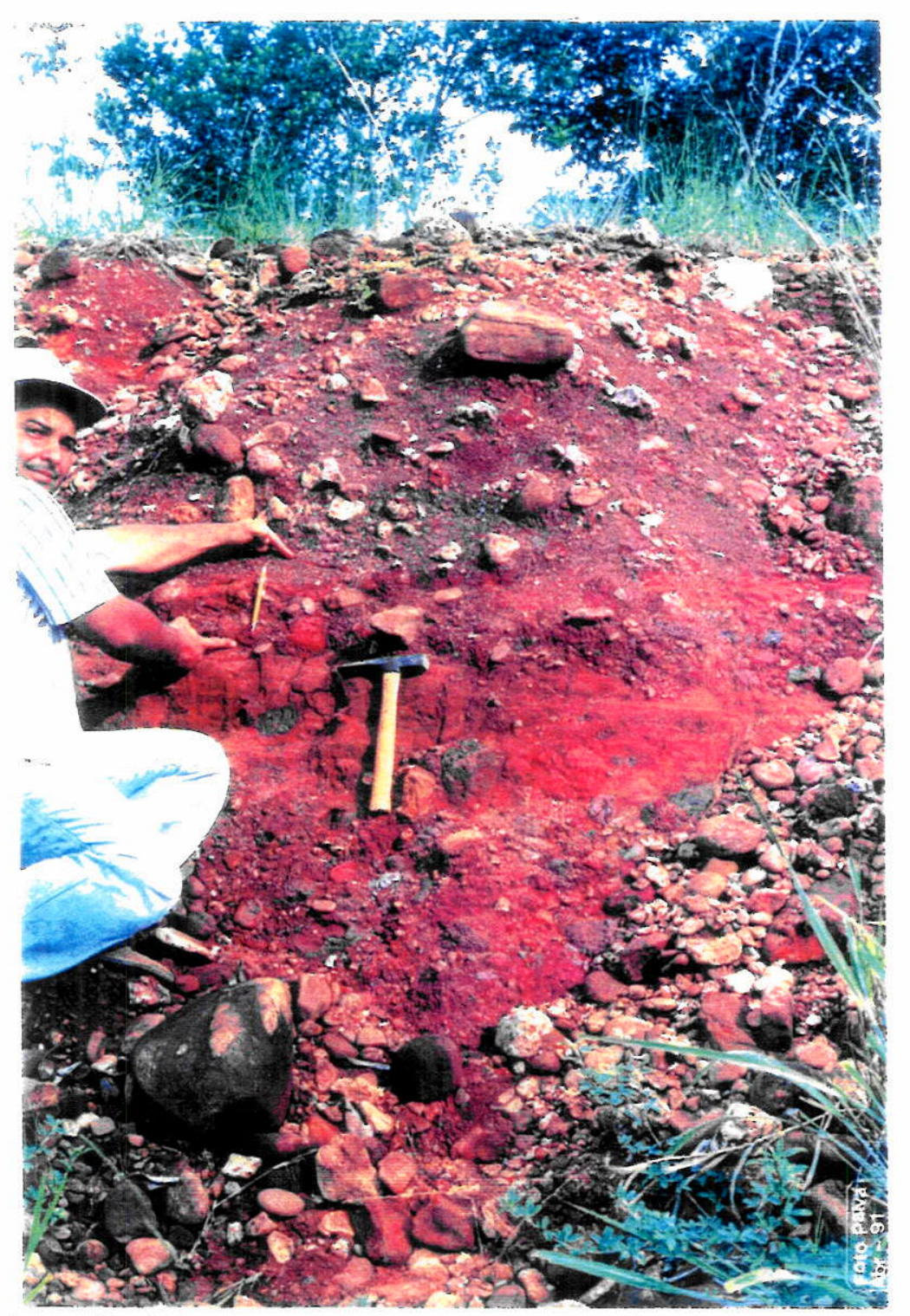

Fotografia 14 - Conglomerados intermediários da Formação Quilombinho interdigitados por lentes de argilito conglomerático.

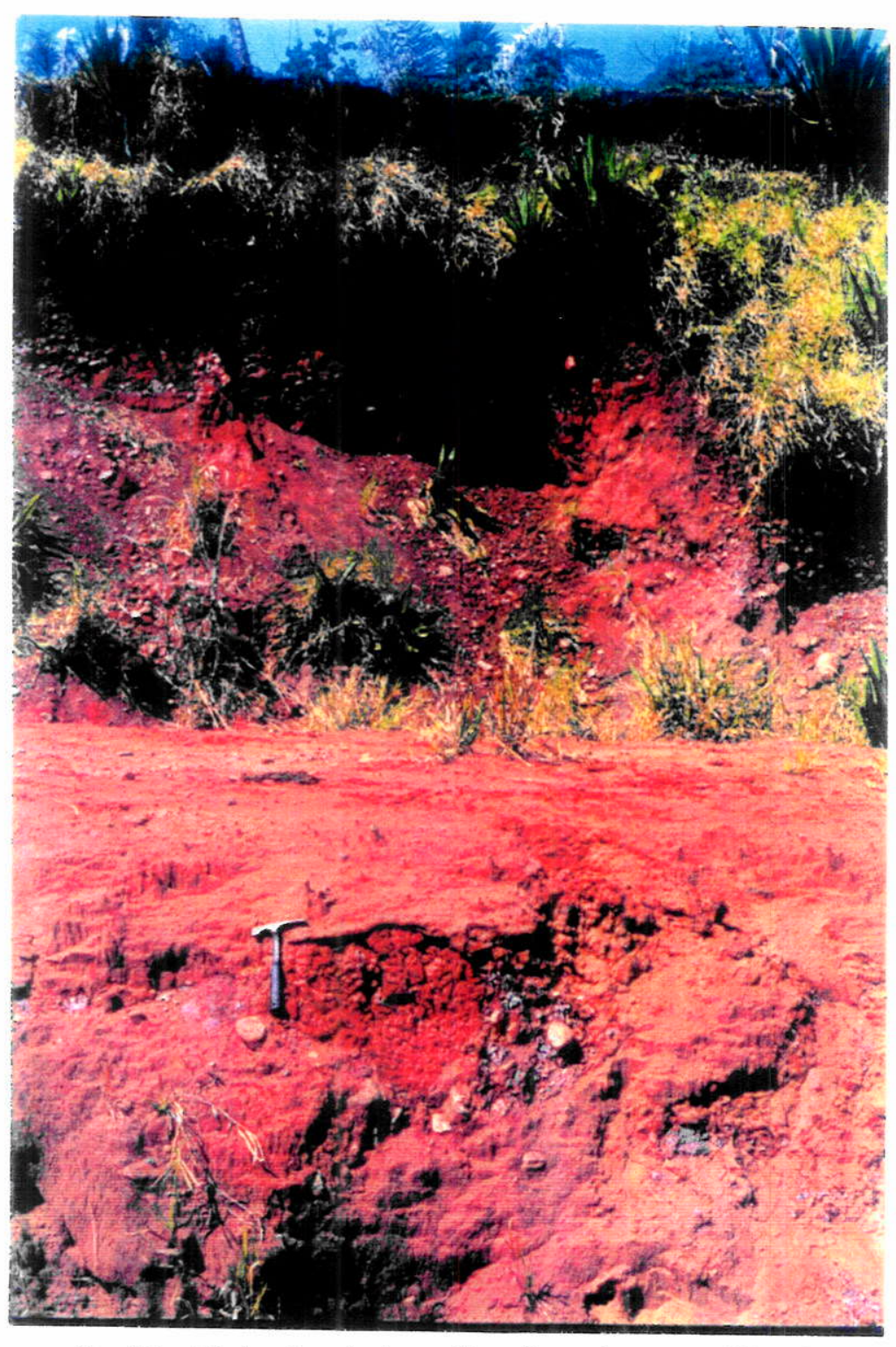

Fotografia 15 - Matacão de basalto alterado com diâmetro maior que $50 \%$, segundo o eixo maior, em conglomerados intermediários da Formação Quilombinho. 


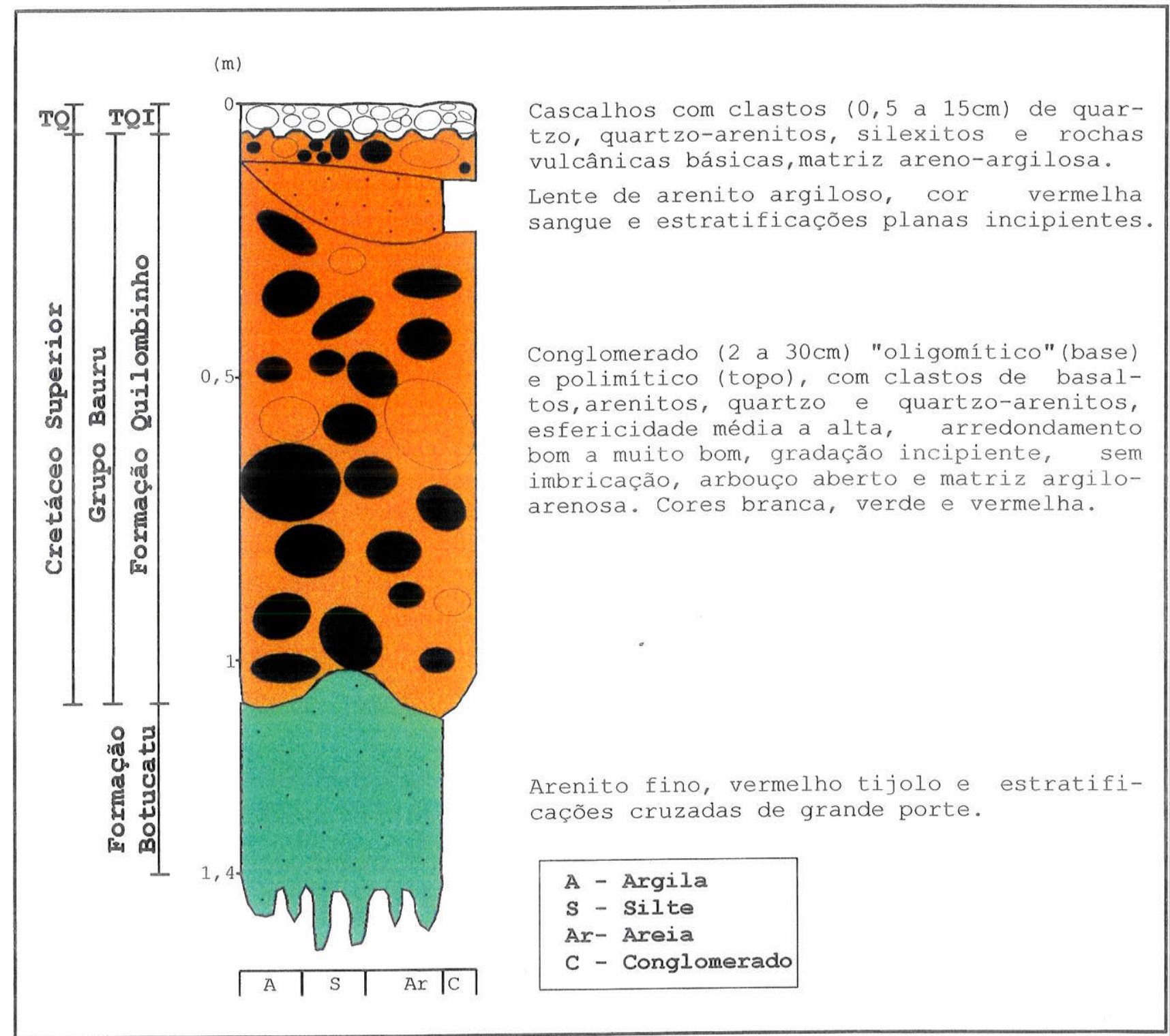

Figura 20 - Conglomerados intermediários da Formação Quilombinho, sotoposto pela Formação Botucatu (?) e sobreposto pela Unidade Terciário-Quaternário Indiviso, em discordância erosiva, MT-309 (Alvo PX). 
(m)
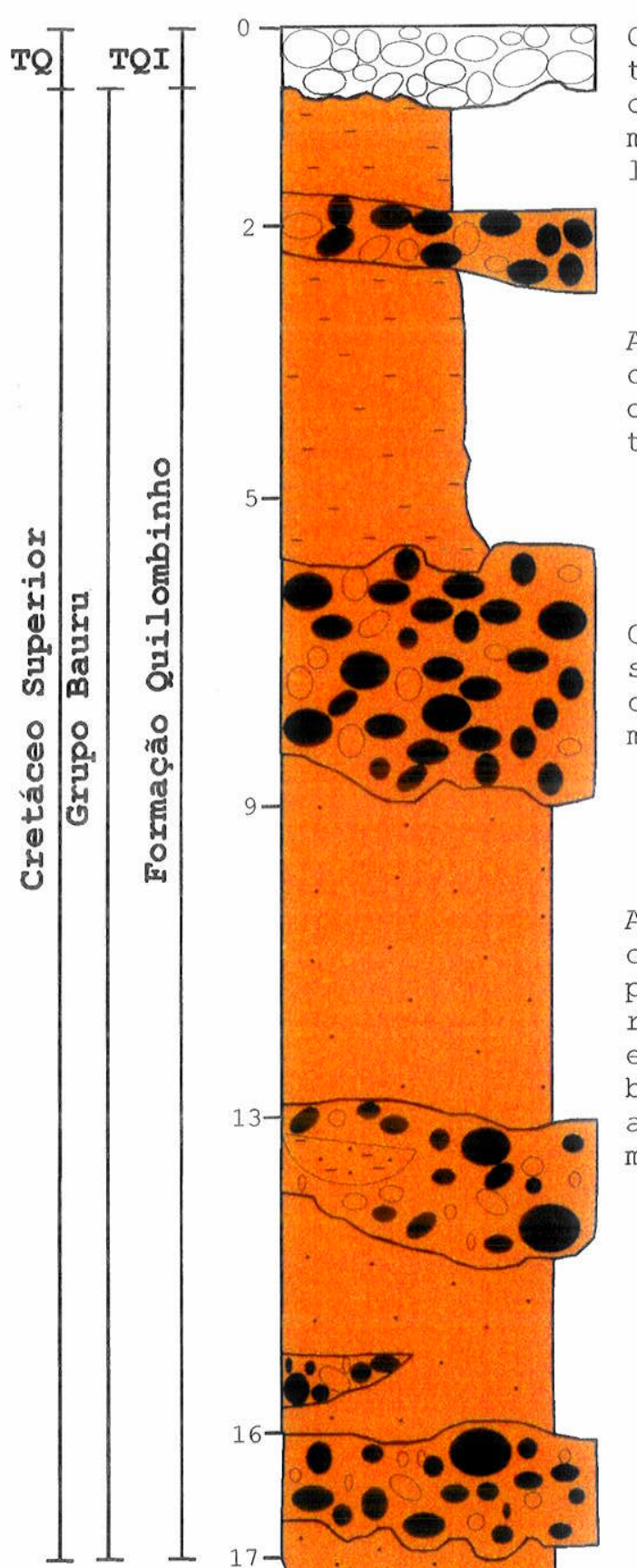

Cascalhos ( 1 a $10 \mathrm{~cm}$ ) com clastos de quartzo, quartzo-arenitos e basaltos, esfericidade média, arredondamento bom a muito bom, matriz areno-argilosa. Interdigitado por lentes de argila.

Argila siltosa vermelha com manchas brancas, interdigitada por lente de conglomerado (2 a $8 \mathrm{~cm}$ ) com clastos de basaltos, quartzo e quartzo-arenitos.

Conglomerado (2 a $20 \mathrm{~cm}$ ) com clastos de basaltos, quartzo e quartzo-arenitos, esfericidade média a alta, arredondamento bom a muito bom e matriz argilosa.

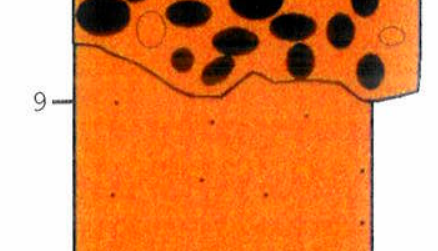

Arenito fino, cor vermelha, roxa com manchas brancas, estratificações planas no topo e interdigitado por lentes de conglomerados ( $1 \mathrm{a} 20 \mathrm{~cm}$ ) com clastos de basaltos, esfericidade média a alta, arredondamento bom a muito bom e matriz argilosa. Lente de arenito argiloso interdigita-se ao conglomerado.

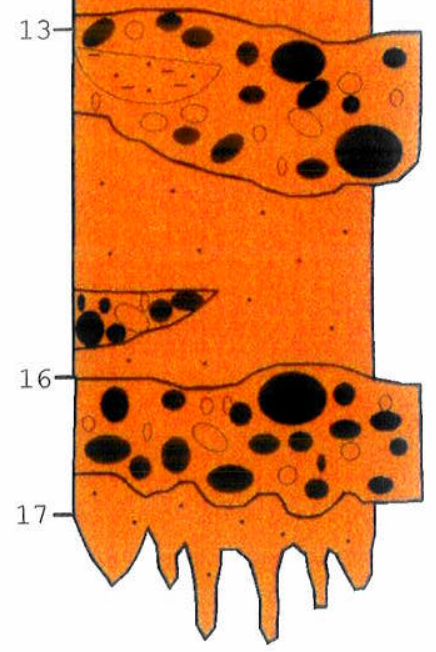

$$
\begin{aligned}
& \text { A - Argila } \\
& \text { S - Silte } \\
& \text { Ar- Areia } \\
& \text { C - Conglomerado }
\end{aligned}
$$

Figura 21- Interdigitações cíclicas de conglomerados em lentes de arenitos (base) e argilitos siltosos (topo) da Formação Quilombinho, Grupo Bauru, Fazenda Jataí. 
Nos três tipos de conglomerados descritos na Formação Quilombinho, a matriz varia desde argilosa até areno-argilosa. sendo a granulação da areia fina a grossa. A matriz argilosa predomina junto aos conglomerados basais. enquanto que a areno-argilosa ocorre nos conglomerados intermediários e de topo. O arcabouço varia desde fechado (clastos suportados) até aberto (matriz suportando clastos), segundo a classificação de Walker (1975). A gradação, quando observado o conjunto de lentes de conglomerados é do tipo inversa entre o conglomerado basal e o intermediário (Fotografia 13) e, normal entre o conglomerado intermediário e o de topo.

Os pacotes conglomeráticos possuem forma lenticular, são cíclicos e as cores predominantes são vermelha, roxa, branca, cinza e rosa. Quando observada a distribuição espacial desses conglomerados, o tipo monomítico ocorre muito próximo à área fonte; aqueles mais próximos à falha de Poxoréu são mais grossos, enquanto que os que ocorrem mais distantes à NW dessa falha, são mais finos (garimpos do Buritizal). Esses conglomerados, como de resto o conjunto da unidade litoestratigráfica ora descrita estão muito alterados e por essa razão é comum observar-se disjunção esferoidal nos clastos das rochas vulcânicas básicas.

Lentes de argilitos conglomeráticos (Fotografia 13) e de argilitos (raros), friáveis, interdigitam-se aos conglomerados descritos da base ao topo da Formação Quilombinho. Os clastos englobados nas lentes argilosas basais são predominantemente de rochas vulcânicas básicas, com tamanhos que podem variar desde 1 até $50 \mathrm{~cm}$, segundo o eixo maior. A espessura dessas lentes varia de $5 \mathrm{~cm}$ próximas a base, a $2 \mathrm{~m}$ no topo.

Lentes de arenitos e arenitos argilosos (Fotografias 16 e 17), microconglomeráticos a conglomeráticos, bem como raras lentes de arenitos, ocorrem entre a porção intermediária e de topo da Formação Quilombinho estando intemperizadas. Nestes pacotes ocorrem estratificações plana e cruzada acanalada (rara). As cores predominantes são vermelha, rosa e por vezes branca; a espessura dessas lentes cíclicas, por sua vez, situa-se dentro do intervalo de 0,30 a $2 \mathrm{~m}$, com espessamento em direção ao topo.

A espessura total estimada para a Formação Quilombinho no Alvo PX é de $21 \mathrm{~m}$. $O$ contato inferior é do tipo discordante erosivo com a Formação Botucatu (Fotografia 5) e por falha com a Formação Aquidauana; com a Formação Paredão Grande que lhe é intercalada, o contato é do tipo litológico e/ou erosivo. O contato superior foi observado com a Formação Cambambe (Figura 6), Unidades Terciário-Quaternário Indiviso (Figuras 20 e 21) e a Fácies Coité. Com essas duas últimas unidades o contato é por discordância erosiva, sendo que com a primeira a Quilombinho faz contato tipo transgressivo. 


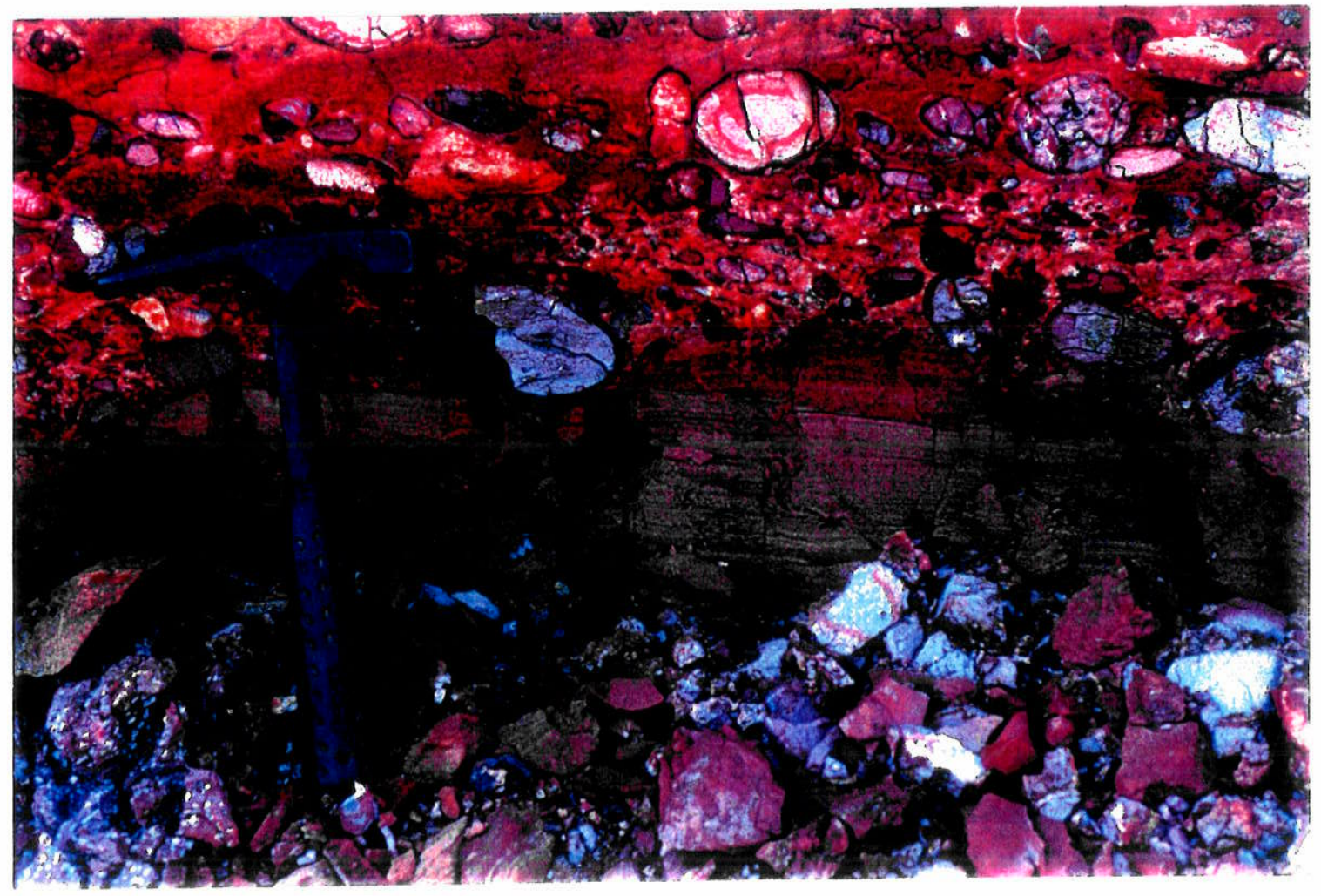

Fotografia 16 - Lente de arenito argiloso com estratificação plana, interdigitada com conglomerados monomíticos da Formação Quilombinho.

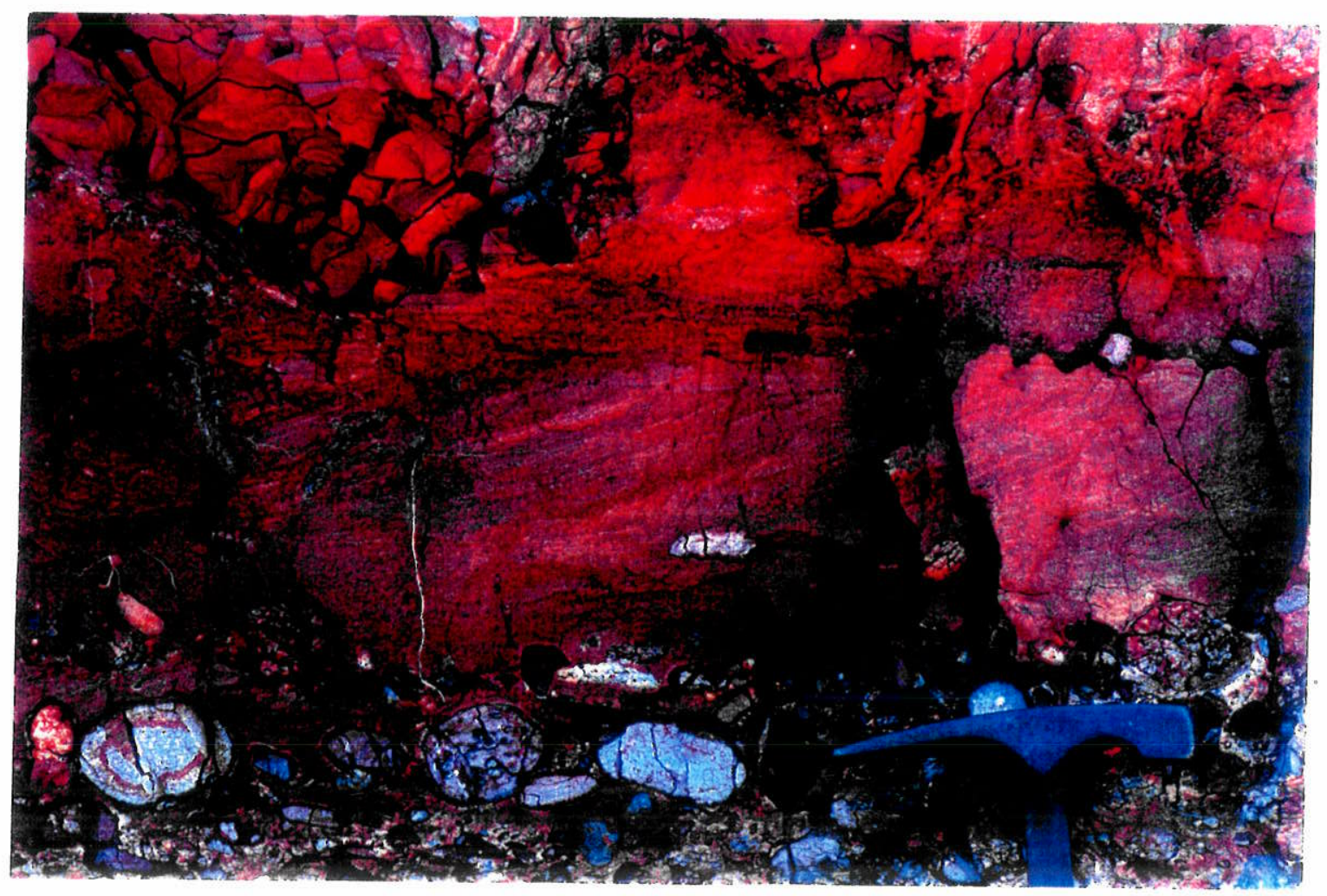

Fotografia 17 - Lente de arenito argiloso com estratificação cruzada interdigitada em conglomerados monomíticos da Formação Quilombinho. 
Datação de um dos Derrames da Raizinha efetuada por Gibson et al. (no prelo) pelo método $\mathrm{Ar}^{40} / \mathrm{Ar}^{39}$, revelaram idade de resfriamento de $83.9 \pm 0,4 \mathrm{Ma}$. Levando-se em conta a intercalação dos Derrames da Raizinha na Formação Quilombinho. conclui-se que a porção basal da unidade Quilombinho é mais antiga do que esses corpos vulcânicos e que o topo é mais jovem. $O$ conjunto enquadra-se no Cretáceo Superior.

\subsubsection{Formação Cachoeira do Bom Jardim, Grupo Bauru}

A Formação Cachoeira do Bom Jardim (FCBJ) foi mapeada nos Alvos PX e DA. Na região de Poxoréu (Alvo PX, Figura 6), ela aflora à NW-SW da cidade de Poxoréu, no local Caieira Rocha (Figura 22), à NE no entorno da Estrutura de Alto Coité e à NW nas proximidades do Distrito de Alto Coité (Figura 6). No Alvo DA (Figura 10), a unidade litoestratigráfica em questão aflora nas Fazendas Santa Maria (Figura 23), Lajinha, Lavrinha Verde, Primavera (Figura 24), Velha, Aroeira, bem como nas proximidades dos Córregos São José e Preto, ocupando principalmente as porções centro-sul (Figura 10). Da base para o topo, caracteriza-se pelos seguintes litotipos: conglomerados, arenitos argilosos, arenitos, arenitos conglomeráticos a microconglomeráticos, argilas conglomeráticas e argilas, friáveis, calcretes e silcretes raros (Figura 22).

A porção basal da Formação Cachoeira do Bom Jardim nas regiões abrangidas pelos dois alvos é caracterizada por arenitos argilosos conglomeráticos com clastos (2 a $4 \mathrm{~cm})$ de rochas vulcânicas básicas, quartzo-arenitos e quartzo. A esfericidade dos clastos é média a baixa e o arredondamento é regular a bom em média. A cor dos clastos vulcânicos é roxa, e dos demais tipos litológicos a cor é branca e amarela, apresentando-se muito alterados, em especial os primeiros.

Os pacotes basais até o topo dessa unidade litoestratigráfica são interdigitados por conglomerados, cíclicos e lenticulares. Os conglomerados são petromíticos, compostos por seixos e matacões de arenitos, quartzo, quartzo-arenitos e rochas de natureza básica (Fotografia 18). O tamanho dos clastos varia em média de 4 a $15 \mathrm{~cm}$ (base), e de 5 a $10 \mathrm{~cm}$ (topo). As espessuras das lentes situam-se entre 0,10 a $1,5 \mathrm{~m}$; o arredondamento é bom a muito bom e a esfericidade é média a alta (clastos vulcanogênicos). Em contrapartida, o arredondamęto pode ser regular e com esfericidade baixa nos clastos sedimentares. A proporção de clastos ígneos 
(m)

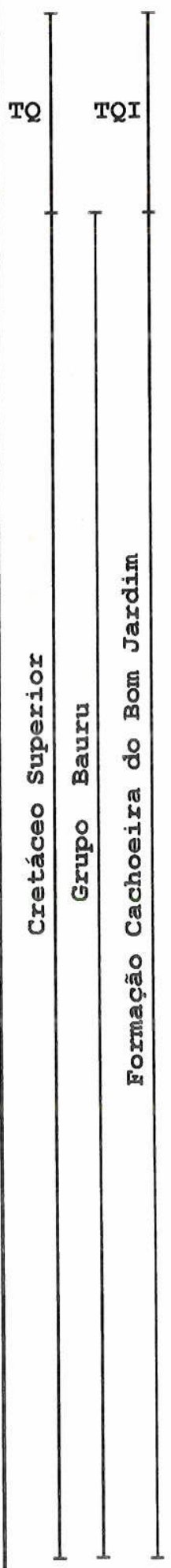

Areias e areias argilosas (topo) e cascalho (base) com clastos (1 a $10 \mathrm{~cm}$ ) de quartzo e quartzoarenitos, esfericidade média, arredondamento bom, matriz areno-argilosa e cor vermelha a marrom.

Arenito argiloso conglomerático a microconglomerático com clastos $(0,5 \mathrm{a} 3 \mathrm{~cm})$ quartzo e quartzoarenitos, esfericidade média a alta e arredondamento bom a muito bom. Interdigitado por lentes de conglomerados e calcretes. Os conglomerados são constituídos de clastos $(0,5$ a $14 \mathrm{~cm})$ de quartzo, quartzo-arenitos e rochas vulcânicas básicas e ácidas, esfericidade média, arredondamento bom, matriz arenosa e cimento carbonático.

Intercalação de calcretes tipo favo de mel, maciço e nodular. No calcrete maciço ocorrem lentes de arenitos.

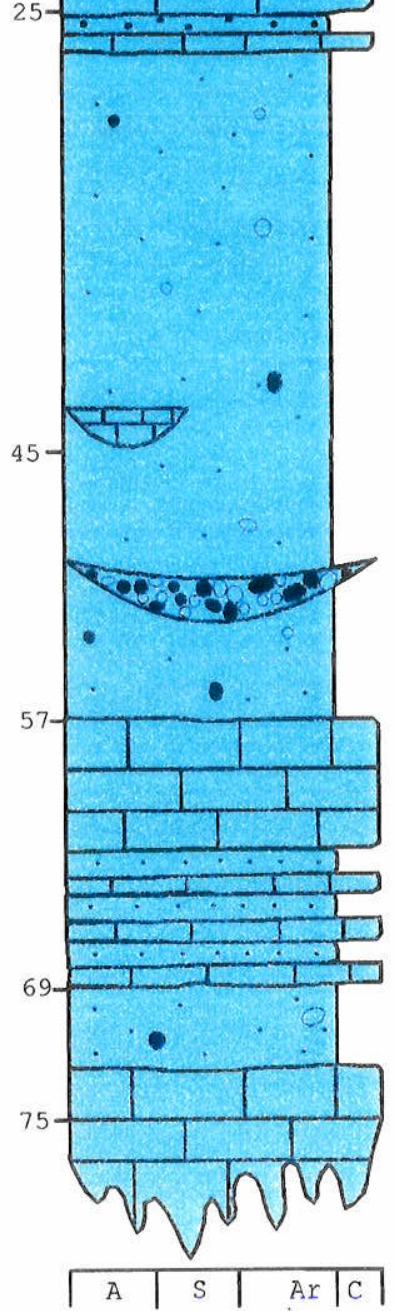

Intercalações de calcretes com arenito fino e arenitos conglomeráticos com cimento carbonático.
A - Argila
S - Silte
Ar- Areia
C - Conglomerado

Figura 22 - Coluna Estratigráfica da Formação Cachoeira do Bom Jardim, Grupo Bauru, Caieira Rocha. 


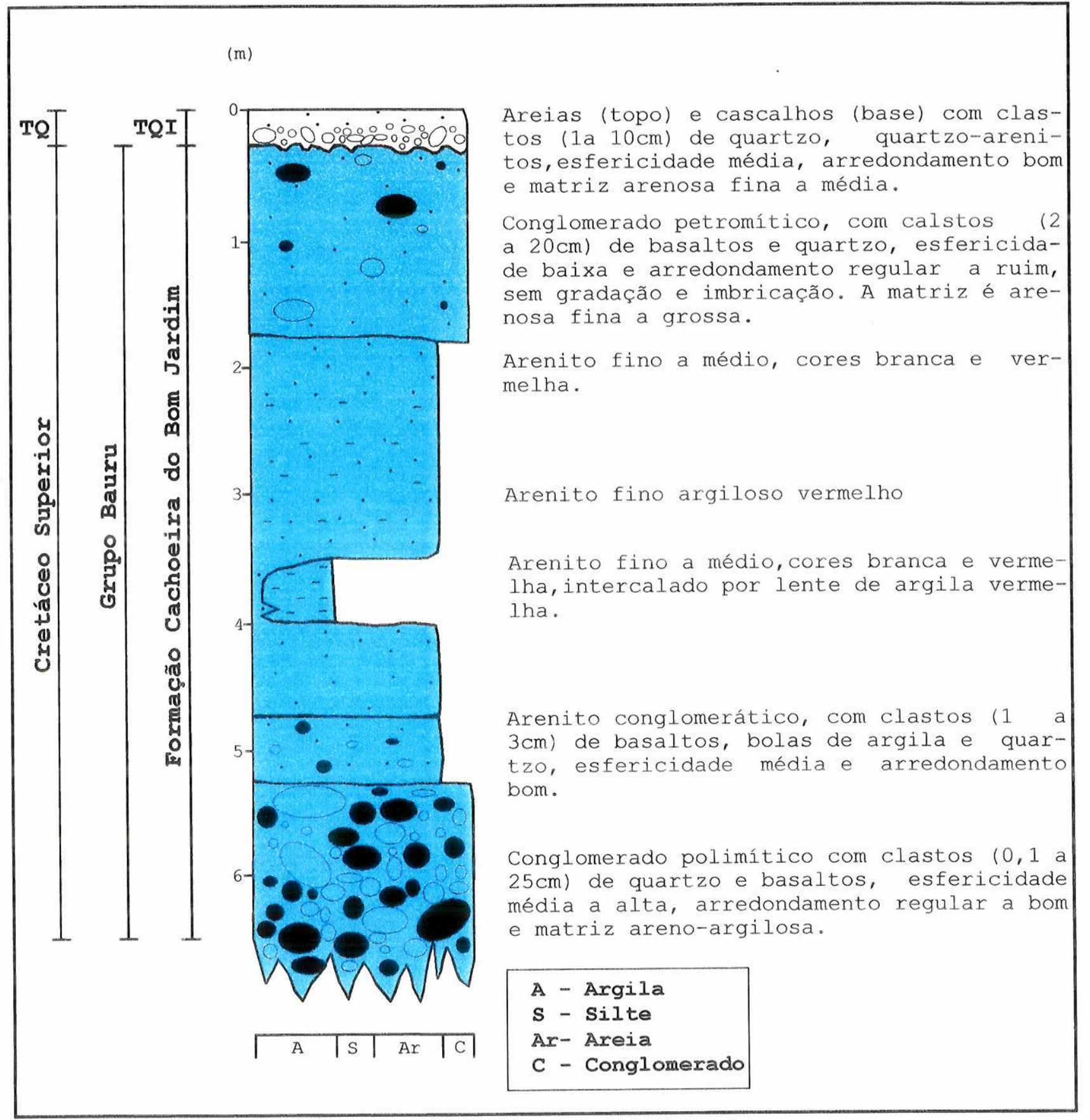

Figura 23 - Coluna estratigráfica da Formação Cachoeira do Bom Jardim, Grupo Bauru (Fazenda Santa Maria). 

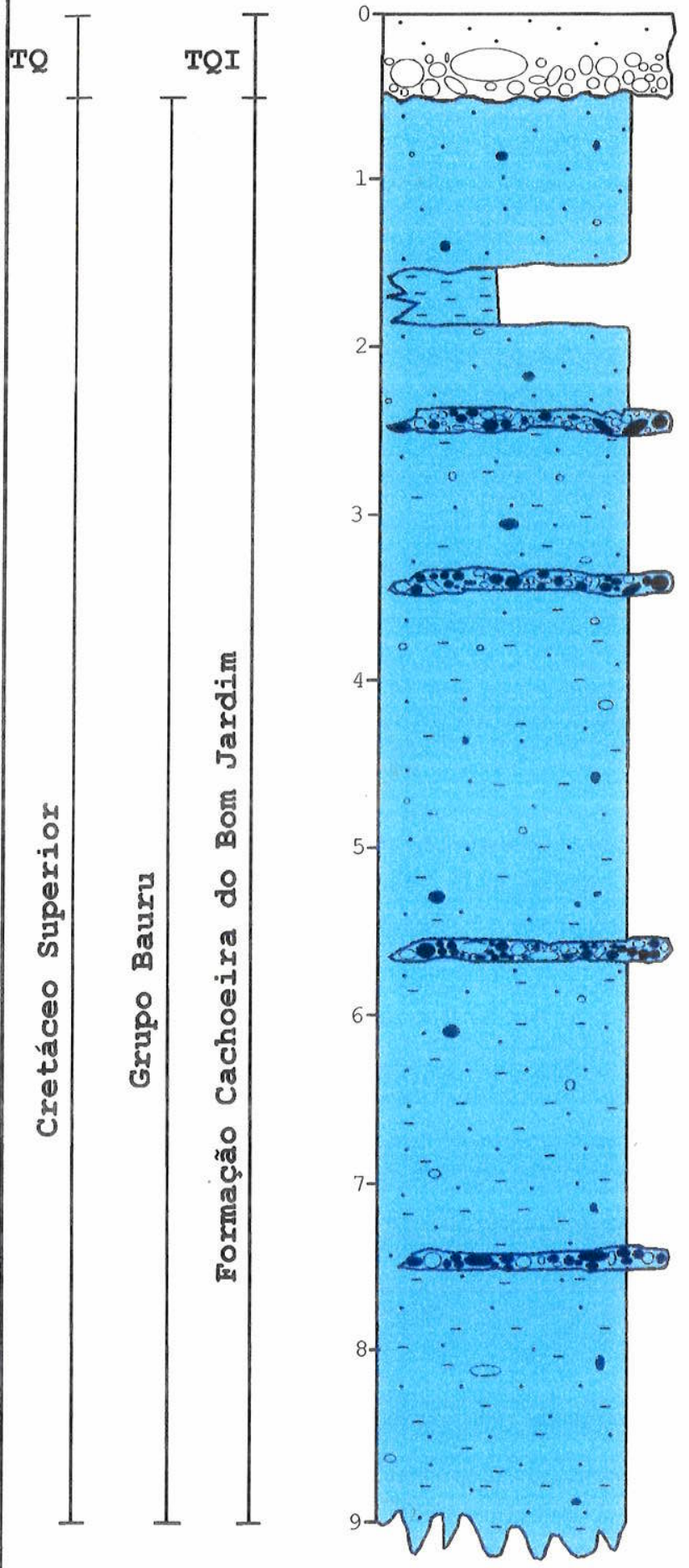

Arenito conglomerático, argiloso, cor vermelha; interdigitado por lentes de conglomerados petromíticos, com clastos (1 a $15 \mathrm{~cm}$ ) de basaltos, quartzo e silexitos, esfericidade média a baixa, arredondamento bom, sem imbricação e gradação. Matriz arenosa fina.

$$
\begin{aligned}
& \text { A - Argila } \\
& \text { S - Silte } \\
& \text { Ar- Areia } \\
& \text { C - Conglomerado }
\end{aligned}
$$

Figura 24 - Coluna estratigráfica da Formação Cachoeira do Bom Jardim, Grupo Bauru (Fazenda Primavera). 
para sedimentares apresenta razões de 2:3, 1:1 a 3:2 com média geral de 1:1, enquanto o arcabouço pode se aberto a fechado. A matriz é arenosa. grossa a fina e o cimento quando existente é de $\mathrm{CaCO}_{3}$. Na região de Dom Aquino foram descritos conglomerados com mais de $90 \%$ de clastos derivados de rochas vulcanogènicas até então desconhecidos nessa formação (Figura 11). Esses conglomerados situam-se próximos e sobre os Derrames da Lajinha e Córrego Preto, tendo como área fonte esses derrames. Os conglomerados em questão, constituem-se de clastos $(3$ a $60 \mathrm{~cm})$ de basaltos, de arredondamento bom a regular e esfericidade média a baixa, matriz argilo-arenosa, arcabouço fechado, espessura de 1 a $3 \mathrm{~m}$ e cores vermelha esverdeada a vermelha. Os conglomerados de topo da FCBJ são de composição e características similares aos inferiores dessa unidade, cujas cores variam entre o vermelho claro a rosa (Fotografia 19). No conjunto cíclico na unidade, até a porção intermediária a gradação é inversa (granocrescente), porém, da base ao topo, o conjunto cíclico das lentes conglomeráticas são granodecrescentes, conforme anteriormente observado por Weska (1987) na Chapada dos Guimarães. O arcabouço é do tipo matriz suportando clastos a clastos suportados de acordo com a classificação de Walker (1975).

Arenitos conglomeráticos a microconglomeráticos com estratificações planas de grande porte, cruzadas tabulares de médio porte e cruzadas acanaladas (raras), ocupam a porção intermediária da coluna estratigráfica da Formação Cachoeira do Bom Jardim no Alvo DA (Fotografias 20 e 21). Os clastos são de fontes variadas (polimíticos), sendo constituídos de quartzo, silexitos, quartzo-arenitos e rochas de composição basáltica, com dimensões variando entre 0.5 a $15 \mathrm{~cm}$, embora alguns cheguem a atingir até $40 \mathrm{~cm}$ de diâmetro. $\mathrm{O}$ arredondamento tende a bom nos clastos de natureza ígnea sendo regular nos de origem sedimentar. A esfericidade por outro lado, varia de média a baixa, respectivamente. A matriz é constituída de arenitos imaturos, com granulometria grossa a fina e cimento carbonático. As cores dessas rochas são vermelha, rosa, amarela e branca, sendo a espessura de aproximadamente $50 \mathrm{~m}$ nas proximidades da Caieira Rocha e, de 70m no entorno do Alto Coité.

Arenitos argilosos de cores avermelhadas intensas, e arenitos finos por vezes imaturos, de tonalidade rosa ocorrem interdigitados aos arenitos conglomeráticos em lentes que variam entre 0,5 a $8 \mathrm{~m}$, ocupando o topo da coluna da formação em questão (Figuras 23 e 24).

As crostas duras carbonáticas (Fotografias 22a, b, c e d) foram mapeadas na Formação Cachoeira do Bom Jardim em bancos espessos interdigitados aos conglomerados basais, arenitos, arenitos argilosos e arenitos conglomeráticos. Nas frentes de lavra de calcário calcítico da Caieira 


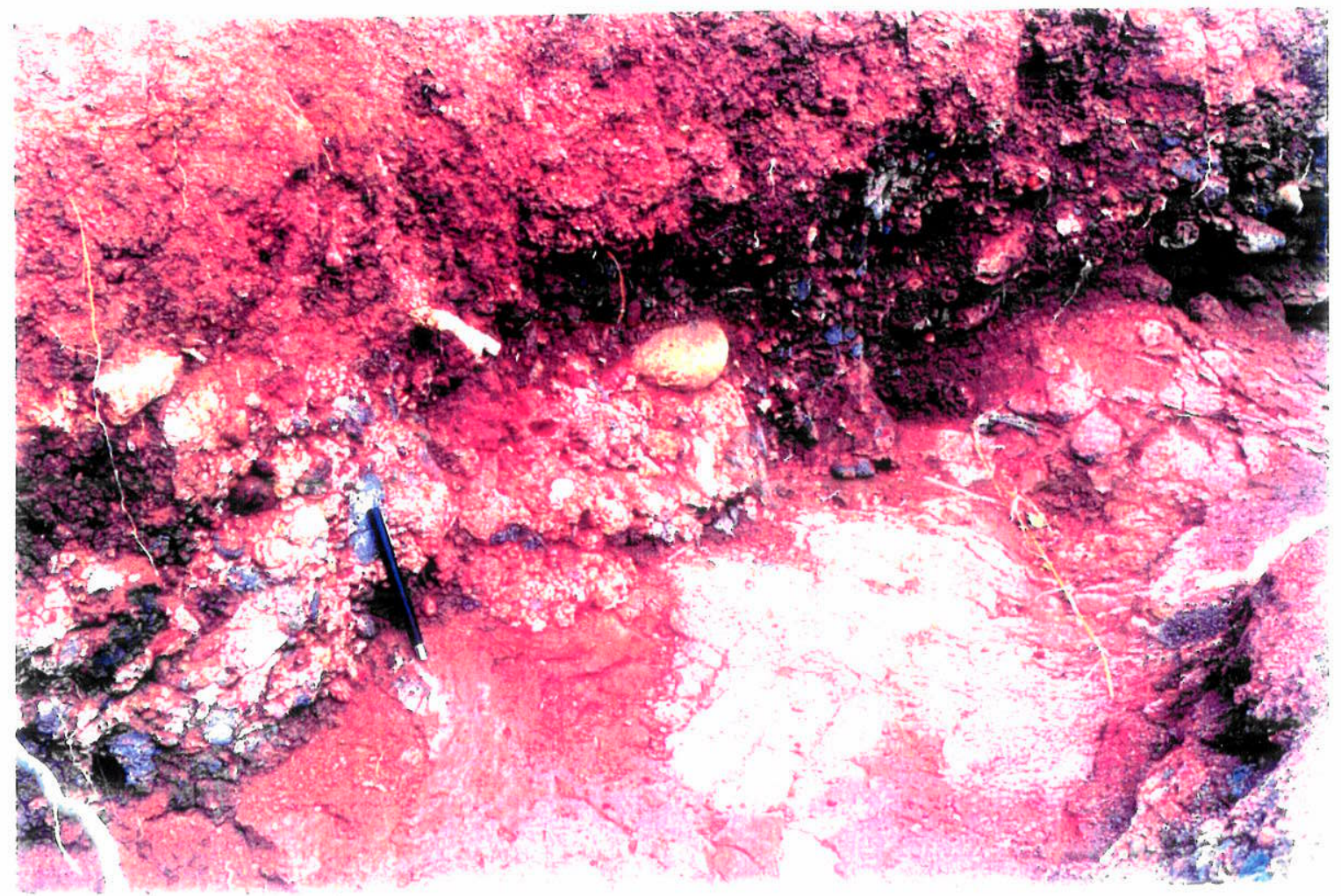

Fotografia 18 - Conglomerados da Formação Cachoeira do Bom Jardim sobrepostos a arenitos argilosos conglomeráticos.

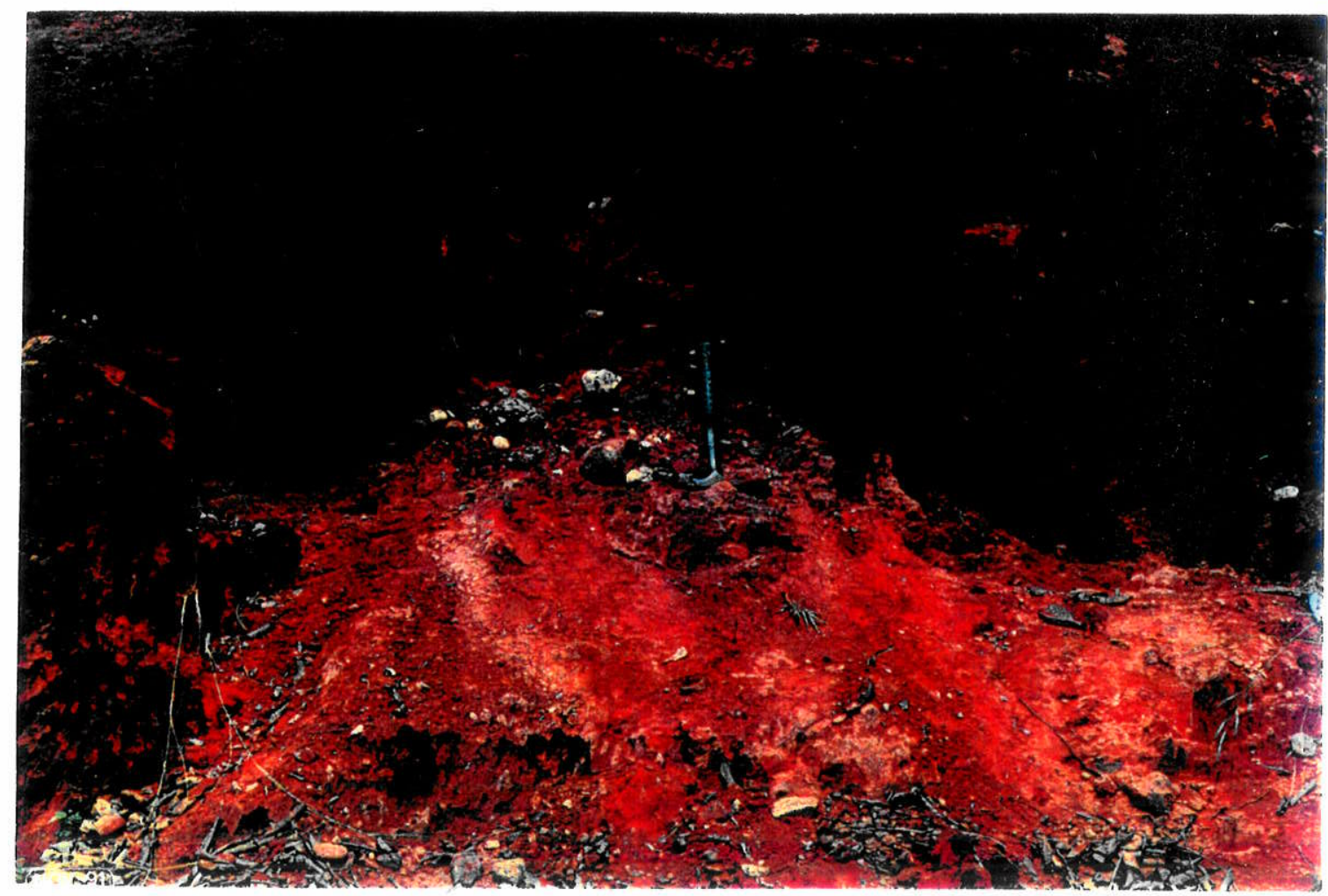

Fotografia 19 - Lentes de arenitos argilosos da Formação Cachoeira do Bom Jardim interdigitados por lentes de conglomerados. 


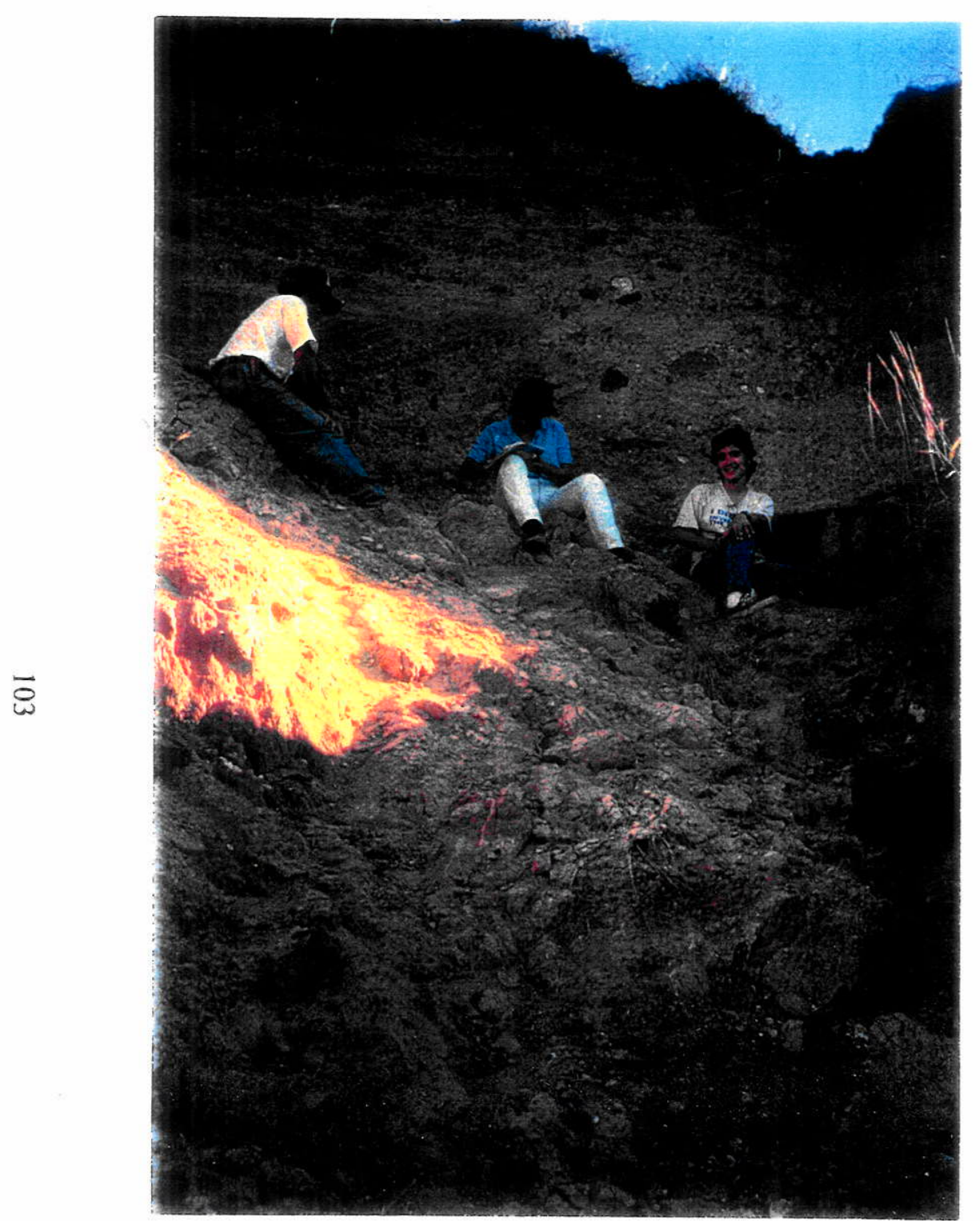

Fotografia 20 - Arenito conglomerático da Formação Cachoeira do Bom Jardim, Lajinha, Alvo DA, com estratificação cruzada e o Derrame da Lajinha no topo.

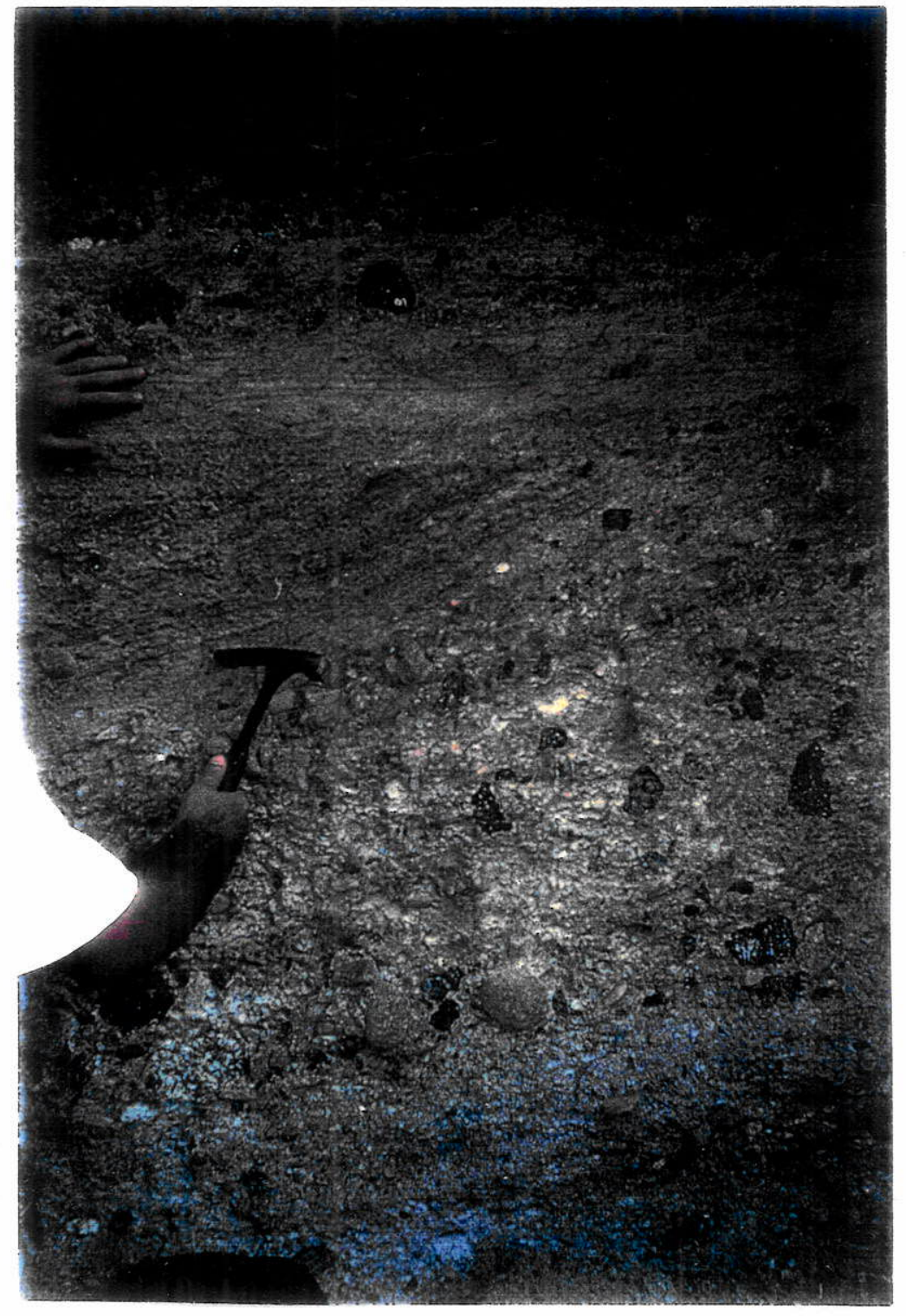

Fotografia 21 - Detalhe da estratificação plana e cruzada acanalada da Fotografia 20. 
Rocha (Alvo PX), ocorrem as meihores exposições de calcretes (Fotografia 22a). Foram descritos quatro tipos texturais distintos. quais sejam: nodular (Fotografia 22b e 22d), maciço, favo de mel. laminar (Fotografia 22c), de acordo com classificação proposta por Goudie (1973). Da base para o topo, consistem de carbonatos nodulares. nas cores rosa e branca, com espessura média de $20 \mathrm{~cm}$. e com pelotas de argila (Fotografia 22d). As crostas carbonáticas são cíclicas, interdigitadas nos arenitos e conglomerados. onde podem ser observadas inúmeras fases de dissoluções, precipitações e recristalizações de carbonatos (Fotografia 22b). Calcretes maciças ocorrem com espessuras variando entre 20 a $50 \mathrm{~cm}$, podendo estar associadas às calcretes nodulares ou aos do tipo favo de mel, que situam-se nos arenitos conglomeráticos de topo. A maior espessura descrita das caicretes pode atingir $\sim 19 \mathrm{~m}$, em conjuntos cíclicos de $11 \mathrm{~m}$.

As espessuras totais obtidas para a Formação Cachoeira do Bom Jardim, foram de $60 \mathrm{~m}$ na Caieira Rocha (Alvo PX), de $110 \mathrm{~m}$ no entorno da Estrutura de Alto Coité (Alvo PX) e de $58 \mathrm{~m}$ (Atvo DA) incluindo os Derrames da Lajinha.

Os contatos inferior e superior, respectivamente com as Formações Quilombinho e Cambambe, ambas do Grupo Bauru, não foram possiveis de serem observados. Weska (1987), descreveu esses contatos como discordantes erosivos na Chapada dos Guimarães em ambas situações. Entretanto, o contato da FCBJ com os Derrames da Lajinha, é por discordância litológica e erosiva (Figuras 14 e 15). Já o contato entre a FCBJ e as unidades TerciárioQuaternário e com a Fácies Coité é por discordância erosiva. A forma geral dos pacotes cíclicos dos variados tipos litológicos é lenticular ou tabular (calcretes). Segundo Oliveira et al. (1992), o metamorfismo de contato provocado pelos Derrames da Lajinha em rochas da Formação Cachoeira do Bom Jardim é inexpressivo.

A idade da Formação Cachoeira do Bom Jardim, levando em conta a idade de 83,9 \pm 0,4Ma. (Gibson et al, no prelo) dos Derrames da Raizinha, bem como a existência de fósseis de répteis do Cretáceo Superior (Roxo, 1937), é Cretácea Superior.

\subsection{8 - Formação Cambambe, Grupo Bauru}

No Alvo PX a unidade litoestratigráfica em questão ocorre preferencialmente nas porções extremo NE, N e NW em relação a Poxoréu (Figura 6), mantendo o mesmo comportamento no Alvo DA, localizando-se nas porções à norte (Figura 10). Contudo, existem afloramentos localizados mais a sul, como aqueles à N-NW de Poxoréu, ou aqueles mapeados nas 


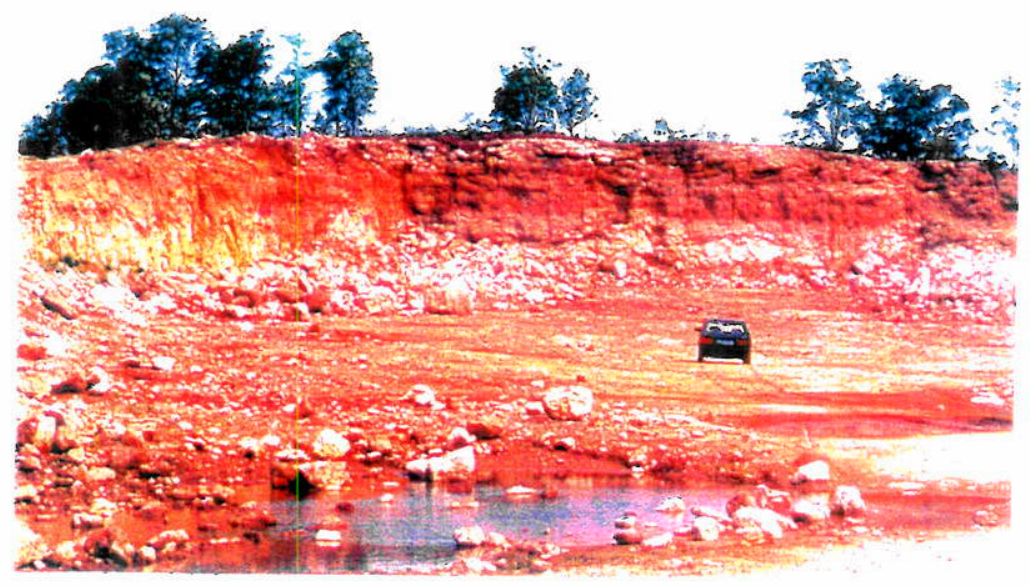

(a)

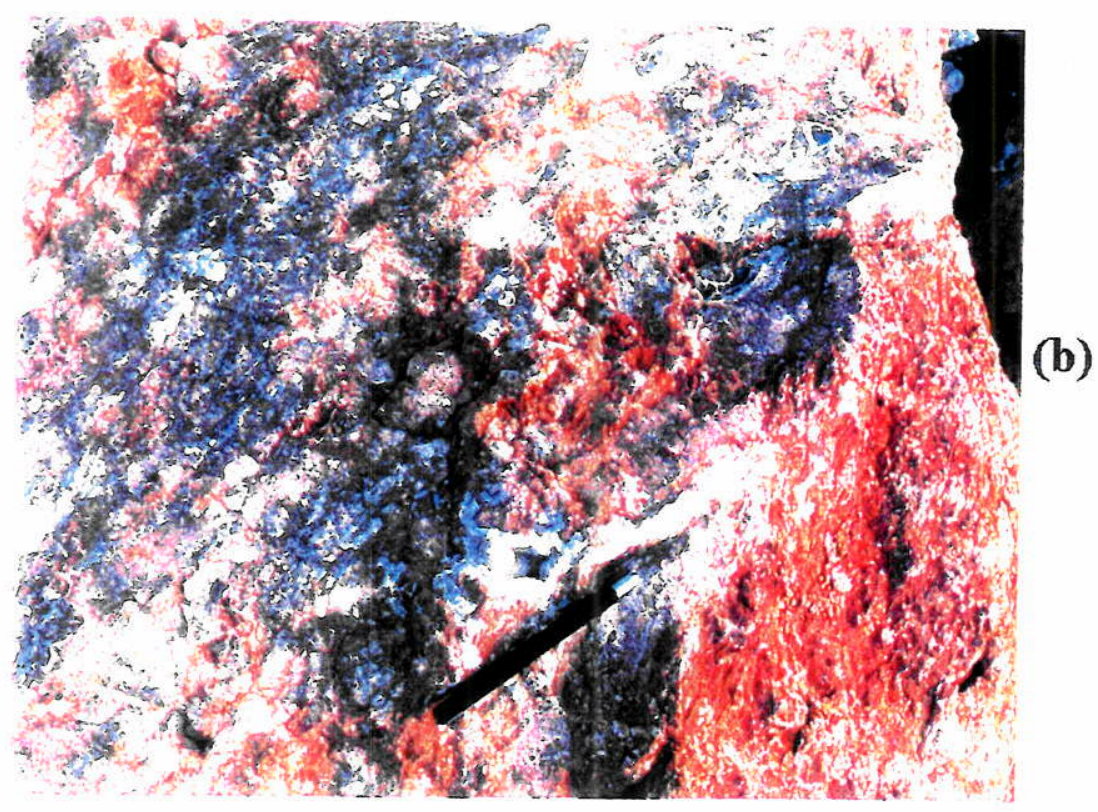

$\overline{8}$

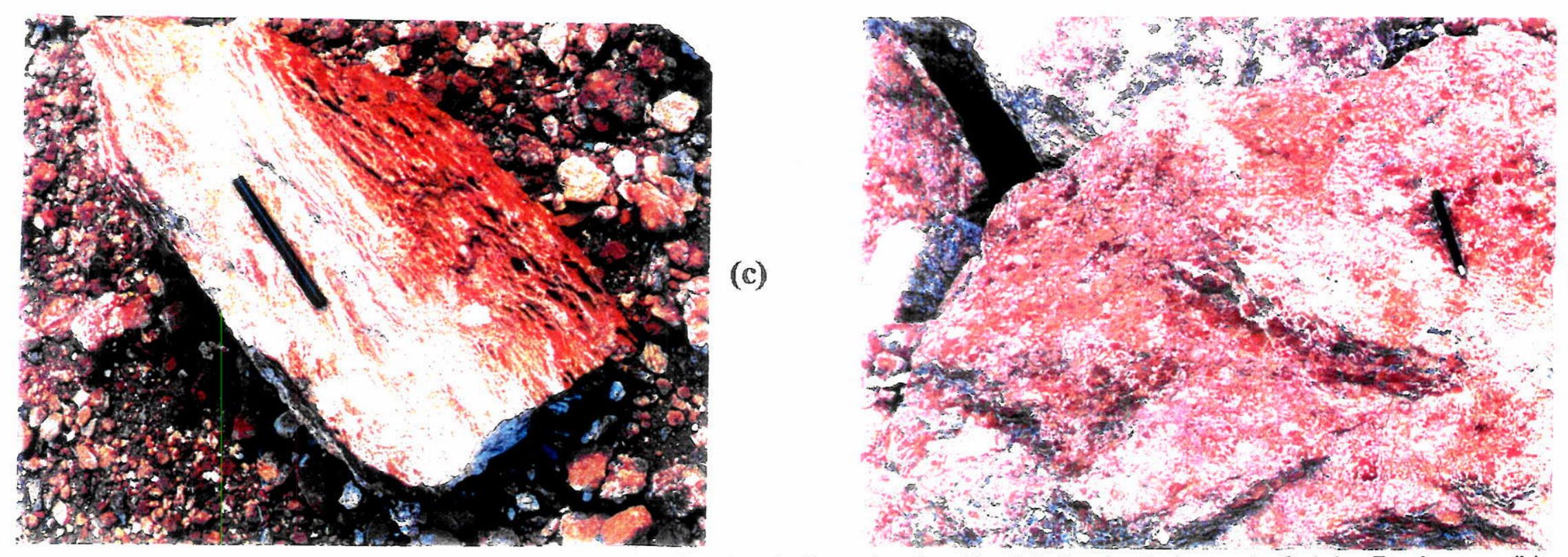

(d)

Fotografia 22 - Aspectos das calcretes da Formação Cachoeira do Bom Jardim. Em (a), frente de lavra da Caieira Rocha; em (b), calcrete nodular com recristalização de calcitas em geôdos; em (c), calcrete laminar e favo de mel; e em (d), calcrete nodular com pelotas de argilas. 
porções S do Alvo DA, como podem ser observados nas Figuras 6 e 10. Em relação ao nível do mar, a Formação Cambambe ocupa cotas topográficas entre 620 a $500 \mathrm{~m}$.

Da base para o topo, a unidade litoestratigráfica que ocupa o topo da coluna para o Grupo Bauru no Estado de Mato Grosso (Figura 11), constitui-se de arenitos e arenitos argilosos microconglomeráticos a congiomeráticos, interdigitados por lentes de conglomerados e microconglomerados, brechas intraformacionais, arenitos de granulometria fina a média a microconglomeráticos, silcretes e raros siltitos argilosos. As Figuras 25 a 28 mostram partes dessa coluna.

Os pacotes de arenitos conglomeráticos (Fotografia 23) caracterizam-se como o tipo litológico predominante na coluna estratigráfica da Formação Cambambe. Os arenitos são finos a grossos e os clastos presentes são de quartzo, quartzo arenitos e pelotas de argila. A granulometria dos clastos varia entre 0,5 a $15 \mathrm{~cm}$, o arredondamento é bom e a esfericidade é média. Os arenitos conglomeráticos constituem as lentes também mais espessas chegando a medir até $30 \mathrm{~m}$

As lentes de conglomerados ocorrem desde a porção intermediária das colunas descritas até o topo, onde predominam (Figuras 25 e 26, Fotografias 23 e 24). Os conglomerados são constituídos por mais de $95 \%$ de clastos de quartzo e quartzo arenitos, além dos seixos de composição basáltica $(<2 \%)$, de silexitos e de formas secundárias de quartzo. $O$ arredondamento é regular a muito bom, a esfericidade baixa a média, enquanto o tamanho varia de 1 até $15 \mathrm{~cm}$. segundo o eixo maior. A matriz é arenosa imatura, raramente argilosa e o cimento silicoso. No contato entre essa unidade e a Cachoeira do Bom Jardim (inferior), pode ocorrer cimento carbonático, conforme descrito por Weska (1987) na região da Chapada dos Guimarães. A espessura dos conglomerados de forma lenticular varia entre $10 \mathrm{~cm}$ a $2 \mathrm{~m}$. Seu arcabouço inclui os tipos clastos suportados a matriz suportando os clastos, segundo a classificação de Walker (1975). Na região do Alvo PX não foi possível mapear os pacotes basais dessa unidade, assim como no Alvo DA em razão do recobrimento das coberturas terciárias e quaternárias. Gradações inversas entre lentes de conglomerados são comuns, contudo, no conjunto cíclico dos variados tipos de conglomerados ocorre granodecrescência em direção ao topo. Os conglomerados também apresentam-se sem gradação e imbricação.

Lentes de arenitos maturos, de siltitos e de argilitos (Fotografia 24), com pelotas de argila interdigitam-se aos tipos litológicos anteriores, podendo medir até $10 \mathrm{~m}$ de espessura. 


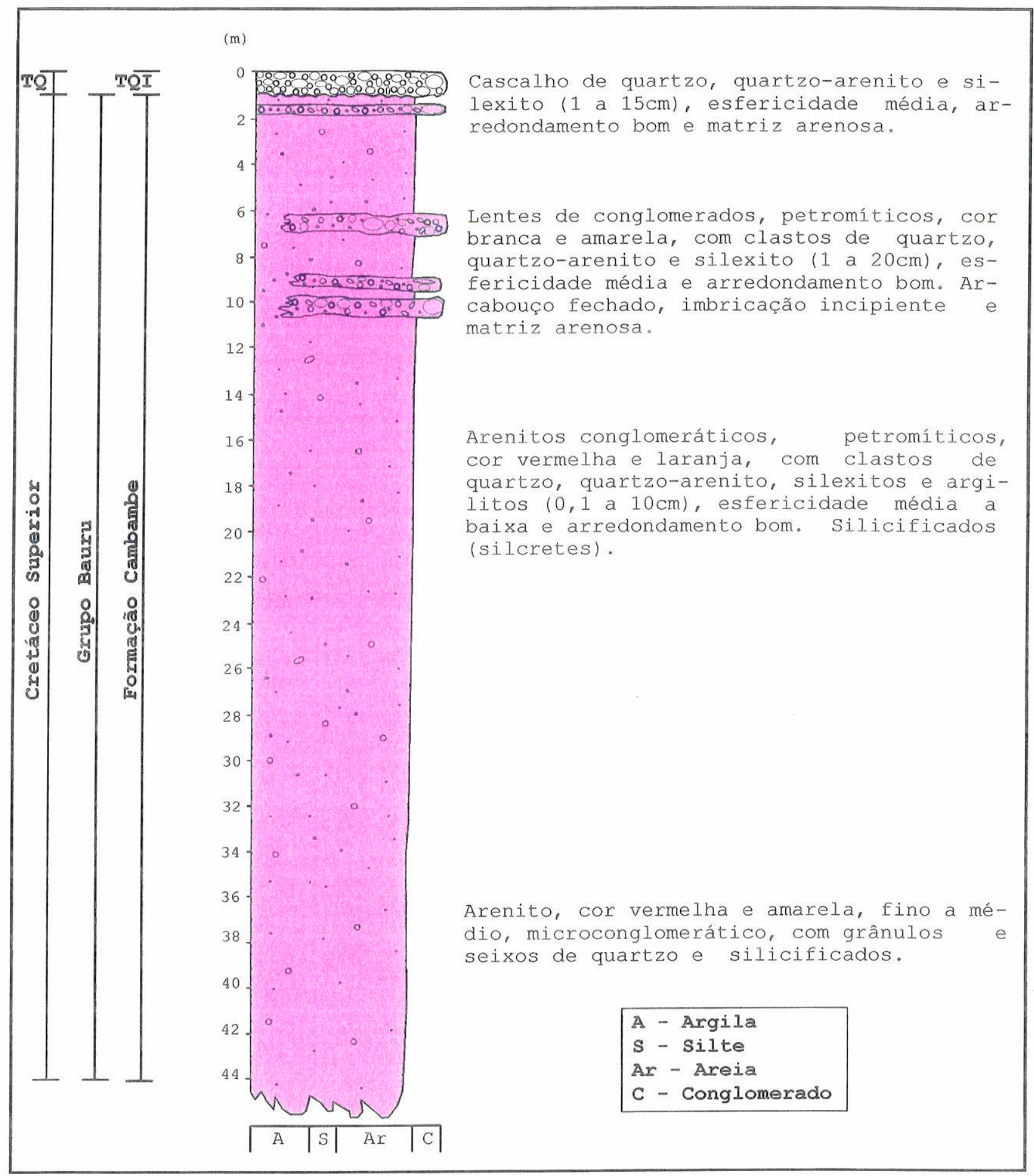

Figura 25 - Coluna estratigráfica da Formação Cambambe, Grupo Bauru, Morro do Quati. 


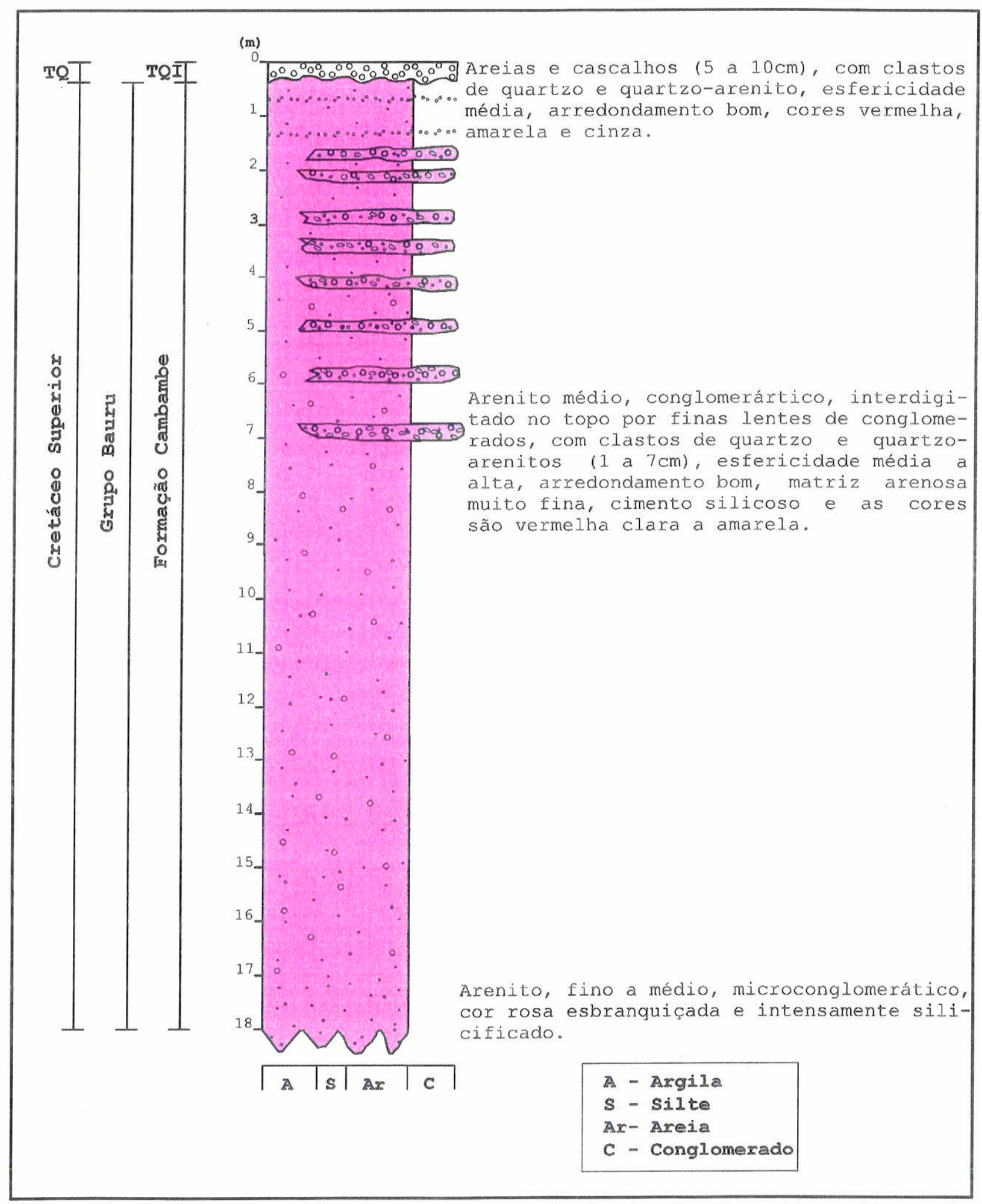

Figura 26 - Coluna estratigráfica do topo da Formação Cambambe, Grupo Bauru, Morro do Carvão, Alvo DA. 
(m)

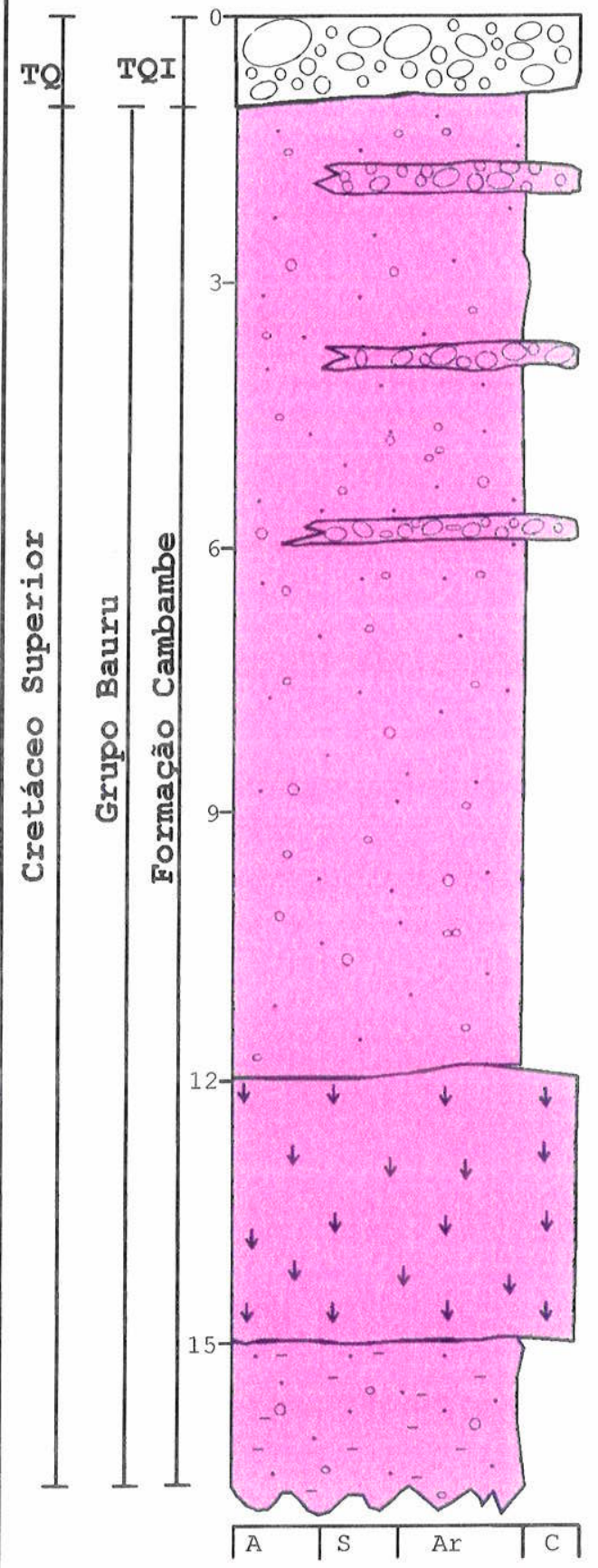

Superficie residual com clastos (até $20 \mathrm{~cm}$ ) de quartzo, quartzo-arenito, esfericidade média, arredondamento bom.
Arenito conglomerático, branco avermelhado, com seixos de quartzo e quartzo-arenitos (1 a $3 \mathrm{~cm})$, intercalado por lentes de conglomerados polimíticos, com clastos (10 a $15 \mathrm{~cm}$ ) de quartzo e quartzo-arenitos. Esfericidade média, arredondamento bom, arcabouço aberto, sem gradação e imbricação. A matriz é arenosa fina a grossa e o cimento é silicoso.

Arenito argiloso, conglomerático (2 a $10 \mathrm{~cm}$ ), com clastos de quartzo e quartzo-arenitos, esfericidade média e arredondamento bom a muito bom. A matriz é areno-argilosa e o cimento é silicoso.

$$
\begin{aligned}
& \text { A - Argila } \\
& \text { S - Silte } \\
& \text { Ar - Areia } \\
& C \text { - Conglomerado }
\end{aligned}
$$

Figura 27 - Coluna estratigráfica da Formação Cambambe, Grupo Bauru, Fazenda Chico Nunes. 


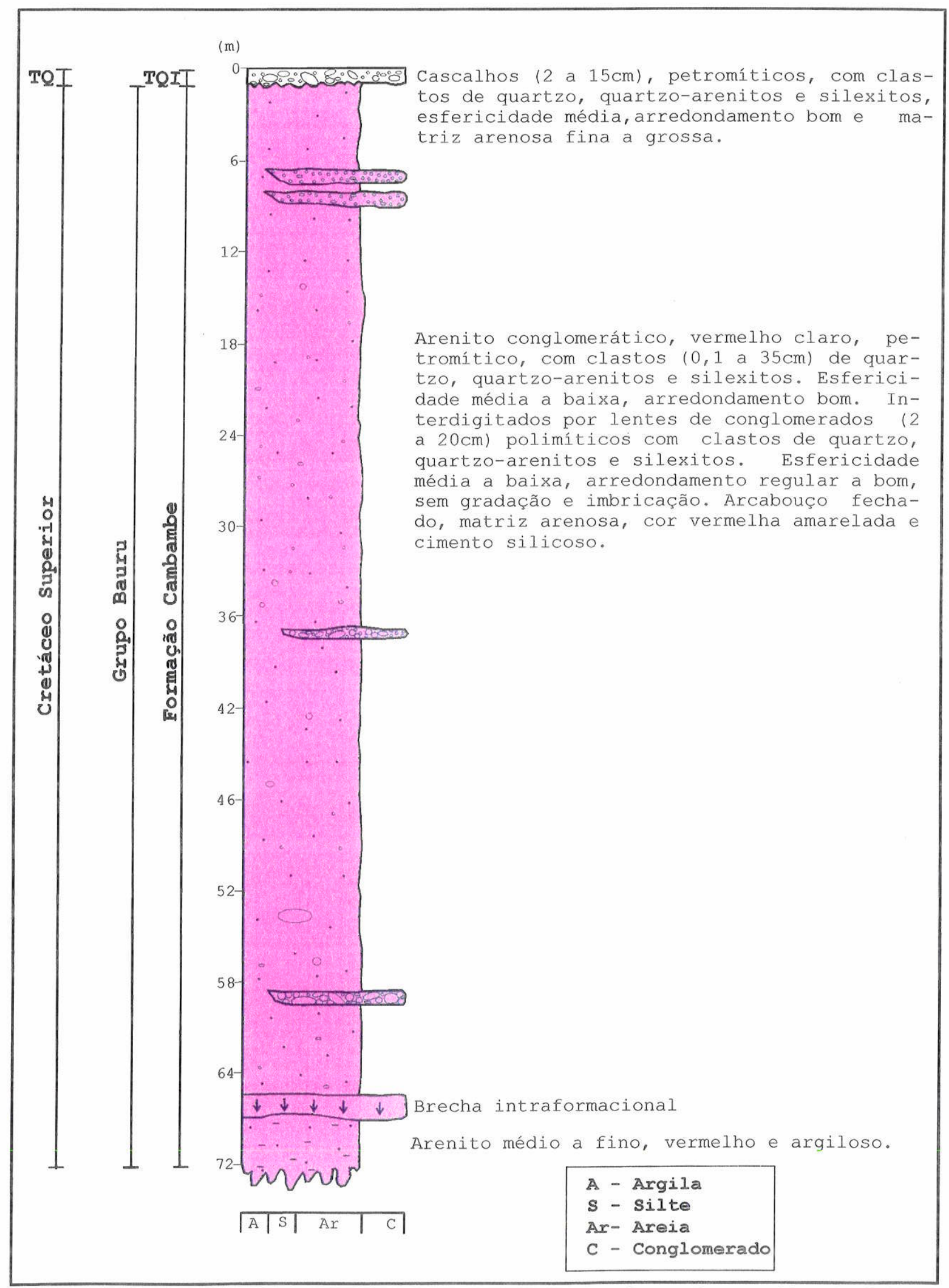

Figura 28 - Coluna estratigráfica da Formação Cambambe, Grupo Bauru, 3km à SW da Fazenda Primavera. 


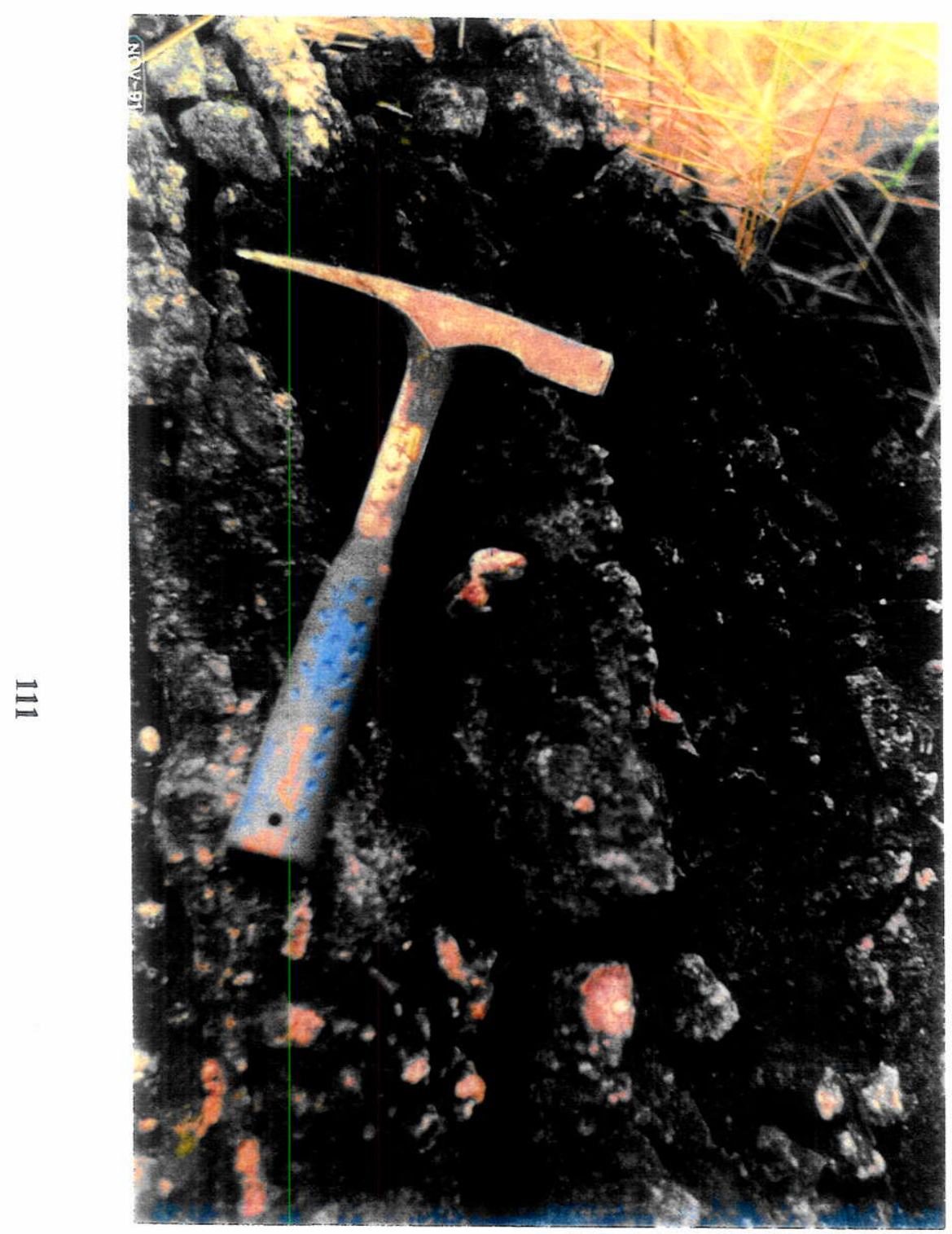

Fotografia 23 - Arenito conglomerático da Formação Cambambe, Alvos DA e PX.

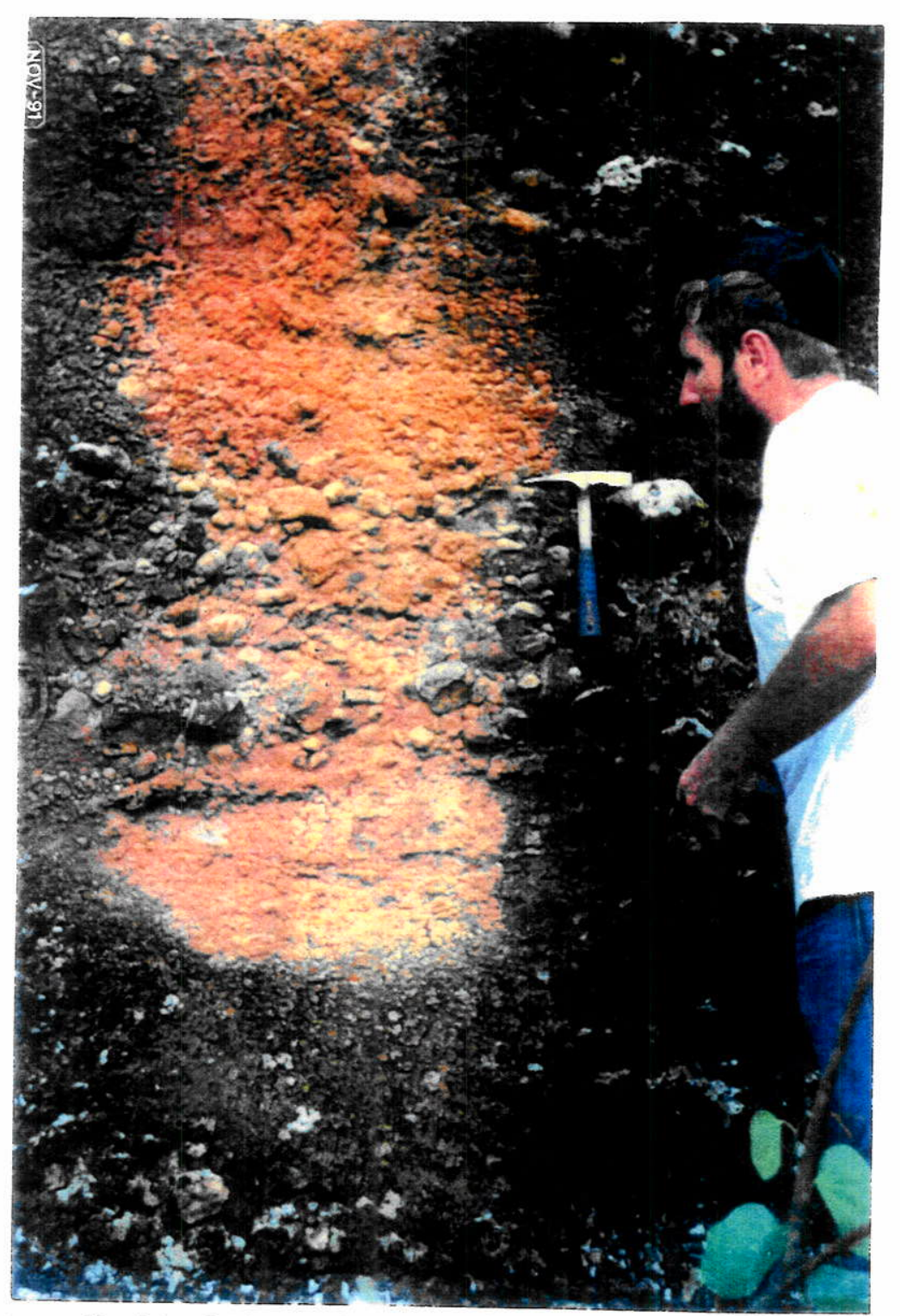

Fotografia 24 - Siltito argiloso silicificado, interdigitado em conglomerados intermediários da Formação Cambambe, Morro do Quati. 
As silcretes caracterizam-se por constituirem pacotes espessos de carapaças silicosas de até $6 \mathrm{~m}$, de aspecto rugoso, onde destacam-se tubos de sílica características da Formação Cambambe. Além dos tubos, outras formas bizarras resultantes da cristalização da sílica também são comuns. Os pacotes de silcretes são tabulares, cíclicos e suas cores predominantes são branca, vermelha clara e amarela (Fotografias 25 e 26).

As rochas da Formação Cambambe geralmente são destituídas de estruturas primárias, e com raras exceções podem ser vistas laminações planas nos tipos litológicos mais finos. Todavia, a existência das silcretes cíclicas intercaladas à seqüência, por serem resistentes aos processos intempéricos, facilitam a observação de uma estratificação plano-paralela decamétrica no conjunto da unidade em questão.

O contato basal da Formação Cambambe não foi possível de ser observado na presente área; entretanto, na região da Chapada dos Guimarães essa feição foi descrita por Weska (1987) como sendo por discordância erosiva com a Formação Cachoeira do Bom Jardim. No Alvo PX, o contato entre a Formação Cambambe (topo) e Quilombinho (basal), foi caracterizado como sendo do tipo transgressivo. Esse tipo de contato não é restrito a Poxoréu, tendo sido observado também na Chapada dos Guimarães sobre os Derrames da Passagem do Mamão, onde também é do tipo litológico (Weska, 1987). Na região de Paranatinga a Formação Cambambe possue contato transgressivo, erosivo e angular sobre rochas da Formação Raizama do Grupo Alto Paraguai. Os contatos de topo da Formação Cambambe são também por discordância erosiva com a Formação Cachoeirinha (Fotografia 27), as Coberturas Terciário-Quaternário Indiviso e a Fácies Coité.

A partir das várias colunas descritas, a espessura da Formação Cambambe no Alvo PX é de $120 \mathrm{~m}$ e no Alvo DA de $94 \mathrm{~m}$. Deve-se considerar que somente parte dessa unidade litoestratigráfica foi mapeada, uma vez que a cobertura terciário-quaternária tampona a porção basal da mesma. Para a região da Chapada dos Guimarães, Weska (1987) registrou uma espessura de $300 \mathrm{~m}$ para essa unidade litoestratigráfica

O conteúdo fossilífero constituído por representantes das ordens Crocodilia, Dinossauria e Chelonia, permitiram a Roxo (1937) propor uma idade cretácea superior para as rochas da então unidade cretácea na região da Chapada dos Guimarães. Hoje, a partir dos trabalhos de subdivisão estratigráfica do Grupo Bauru no Estado de Mato Grosso propostos por Weska (1987) e Weska et al. (1993), tais jazigos fossilíferos ocorrem na Formação Cambambe, unidade de topo do Grupo Bauru, conferindo, portanto, idade cretácea superior à esta unidade. 


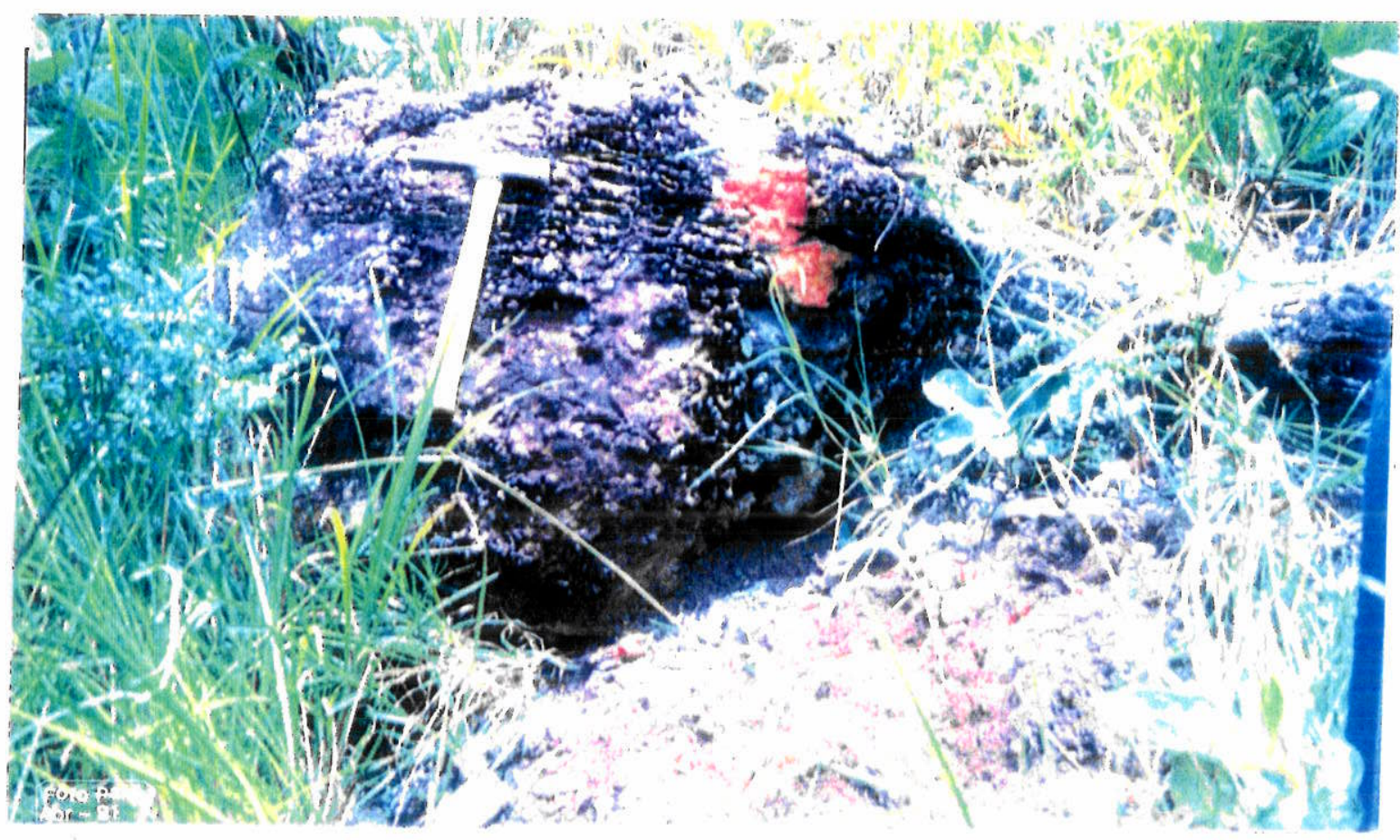

Fotografia 25 - Tubos de sílica, características nas silcretes da Formação Cambambe.

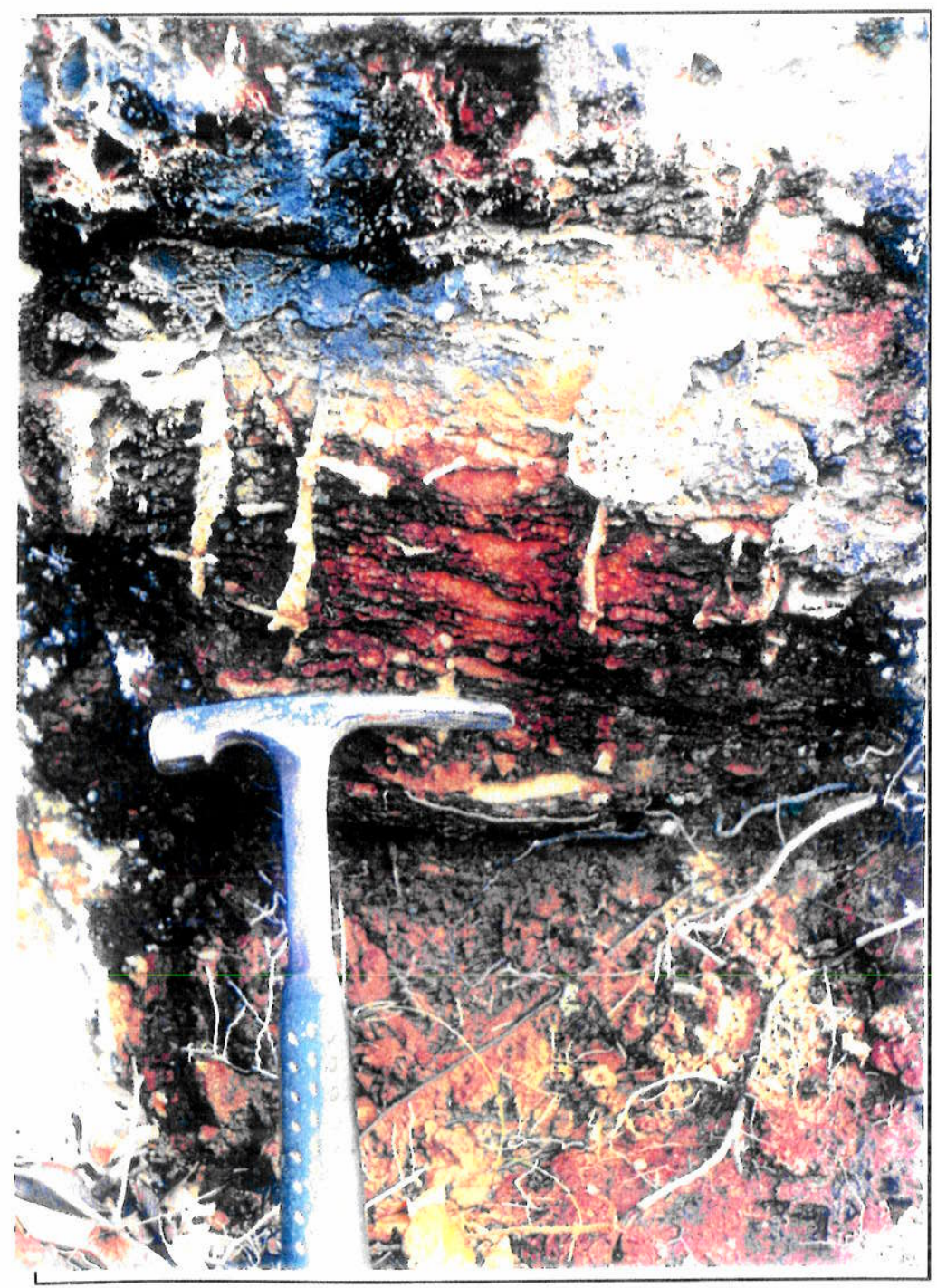

Fotografia 26 - Formas bizarras de silcretes na Formação Cambambe. 


\subsection{9 - Formação Cachoeirinha}

A Formação Cachoeirinha (Figura 11) situa-se nas porções topograficamente mais elevadas, entre 650 e 600m em relação ao nível do mar. desde a cidade de Primavera do Leste até a Serra de São Vicente (Cuiabá), coincidindo com o alinhamento da BR-070, ocupando preferencialmente as porções $\mathrm{N}$ dos Alvos PX e DA (Figuras 6 e 10). Ocorre também em cotas topográficas mais altas no entorno das áreas mapeadas no Alvo PG.

A seção tipo da Formação Cachoeirinha descrita por Gonçalves e Schneider (1970), localiza-se a aproximadamente $30 \mathrm{~km}$ à $\mathrm{N}$ da cidade de Poxoréu, região norte-noroeste do Alvo PX. Seu conteúdo litológico é composto de sedimentos inconsolidados a consolidados, caracterizados por areias argilosas, argilas e areias cascalhosas, parcialmente laterizadas.

No Alvo PX a Formação Cachoeirinha, da base para o topo é constituída de cascalhos, areias cascalhosas e crostas lateríticas (ferricretes). No Alvo DA, além desses tipos litológicos mencionados no Alvo PX, também ocorrem areias argilosas e areias (Figura 29). Os cascalhos são basais e compostos por clastos de lateritas, de tamanho entre 0,5 a $5 \mathrm{~cm}$ segundo o eixo maior, com arredondamento ruim e esfericidade baixa. $O$ arcabouço desses cascalhos é do tipo matriz suportando clastos, de acordo com a classificação de Walker (1975), sem gradação e imbricação. A matriz é arenosa, imatura e o cimento de óxido de ferro. Os cascalhos interdigitados próximos ao topo são polimíticos, sendo compostos por seixos e matacões de quartzo, quartzo-arenitos e fragmentos lateríticos. O tamanho dos clastos situa-se no intervalo de 2 a $18 \mathrm{~cm}, 0$ arredondamento varia de bom a regular e a esfericidade de média a baixa. A presença de clastos lateríticos condiciona o arredondamento como regular e a esfericidade baixa. A matriz é arenosa, imatura, e o cimento quando presente é de óxidos de ferro. Os cascalhos de topo, caracterizamse por seixos de quartzo ( $2 \mathrm{~cm}$ em média) e raros matacões de quartzo arenitos de até $12 \mathrm{~cm}$. $O$ arredondamento é muito bom e a esfericidade é alta, a matriz é arenosa a areno-argilosa, e o cimento quando ocorre é de óxido de ferro. Esses cascalhos são denominados pelos garimpeiros no Estado de Mato Grosso como do típo "ovos de pombas".

Areias a argilas cascalhosas, com clastos de 1 a $8 \mathrm{~cm}$ de quartzo, quartzo arenitos e fragmentos lateríticos interdigitam-se aos cascalhos da base ao topo da coluna descrita na Formação Cachoeirinha. $\mathrm{O}$ arredondamento dos clastos varia de bom a regular, a esfericidade de média a baixa, sendo a matriz arenosa imatura. Lentes de areias e areias argilosas interdigitam-se aos tipos litológicos anteriores. Pacotes litológicos maturos, de outro lado constituem exceções. 


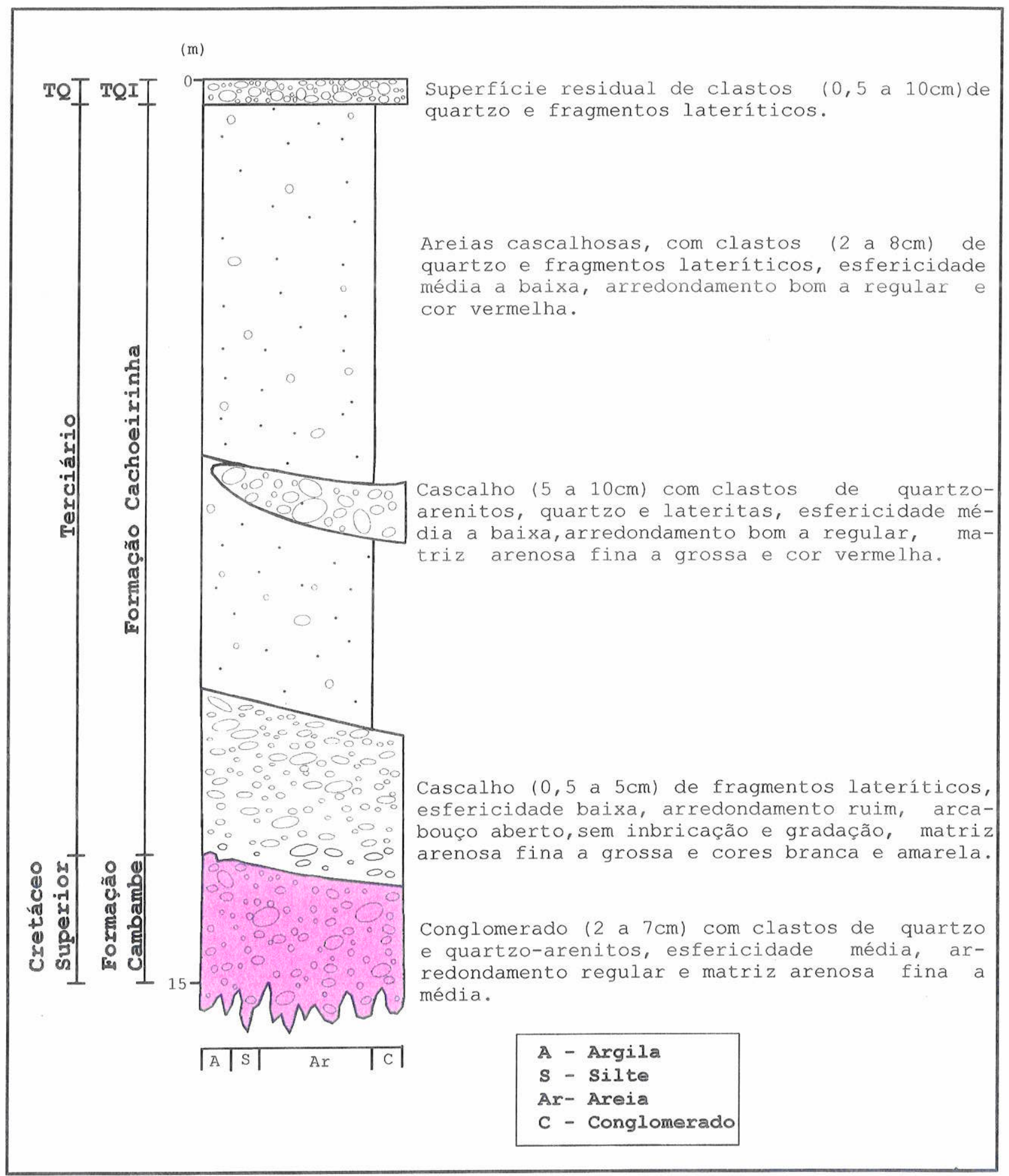

Figura 29 - Coluna estratigráfica mostrando o contato basal da Formação Cachoeirinha com a Formação Cambambe, Grupo Bauru. No topo, o contato da Formação Cachoeirinha com a Unidade Terciário Quaternário Indiviso, próximo ao entroncamento entre a BR-070 e a MT 130, Alvo PX. 


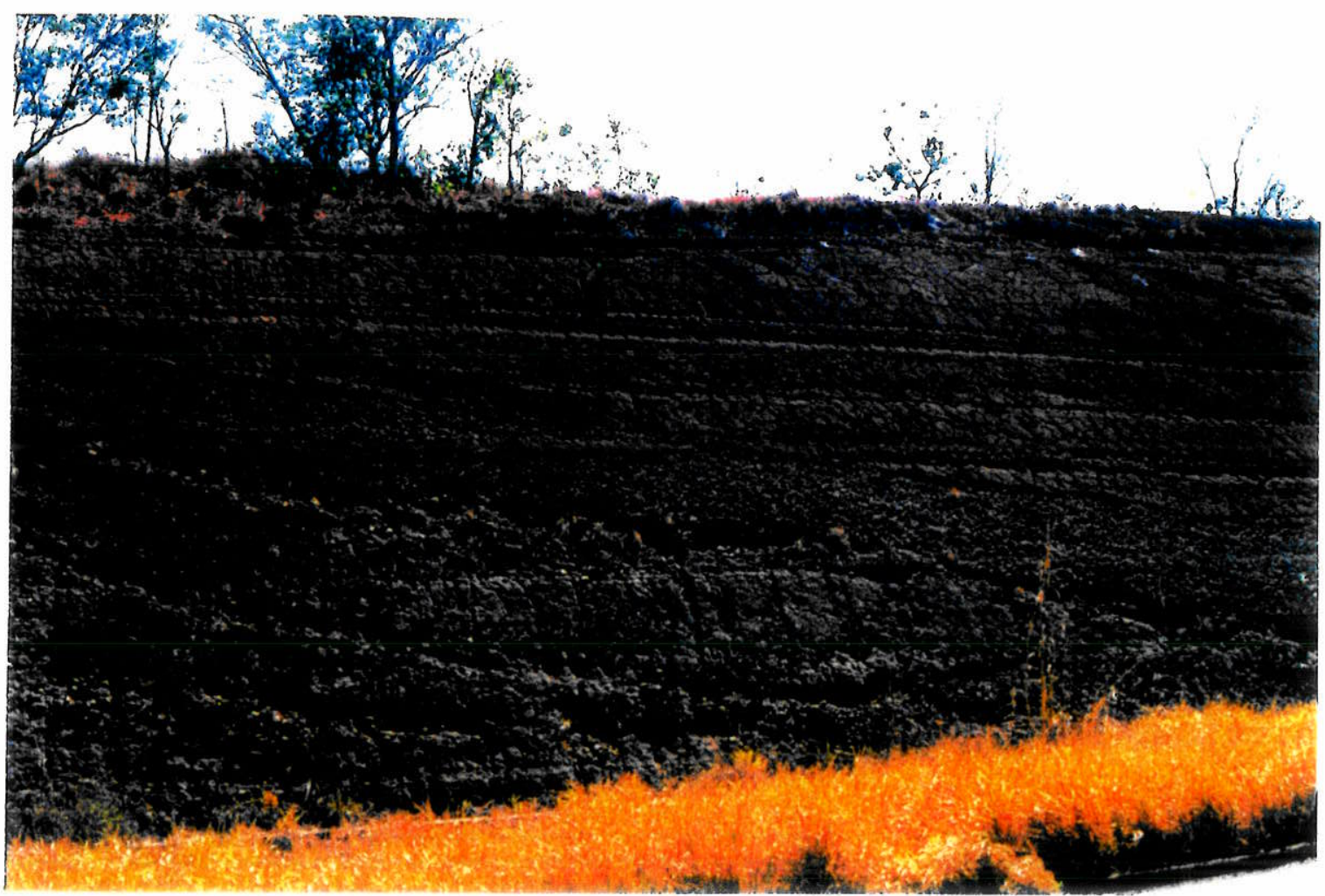

Fotografia 27 - Contato entre as Formações Cambambe e Cachoeirinha.

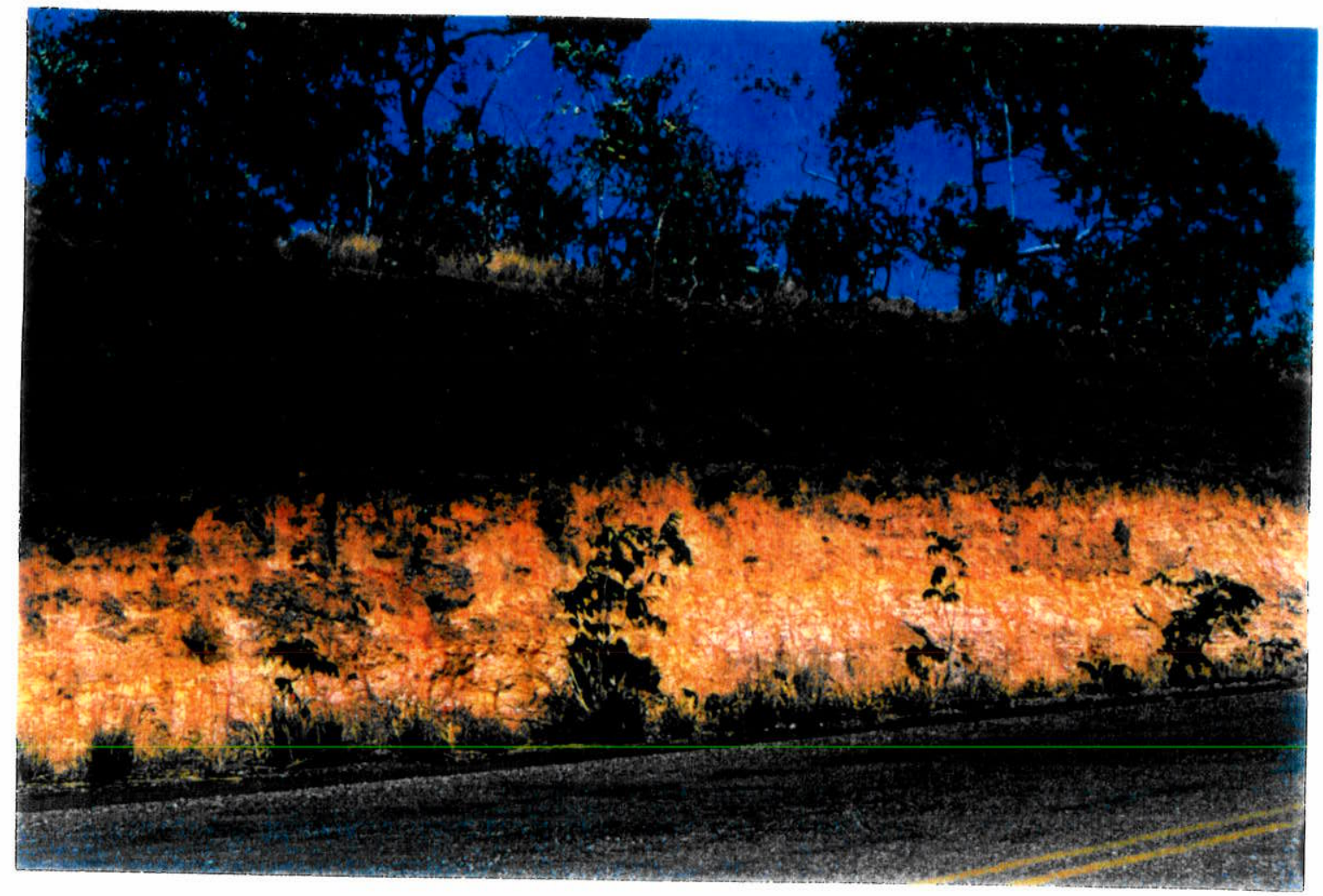

Fotografia 28 - Crostas lateríticas da Formação Cachoeirinha. 
As crostas lateriticas (Fotografia 28) ocorrem sob as mais variadas formas, individualizando-se em camadas definidas e até permeando como cimento os tipos litológicos que constituem a unidade litoestratigráfica em questão. uma vez que a deposição do óxido de ferro foi condicionada pela flutuação do lençol freático. As ferricretes mais comuns são maciças, todavia, ocorrem também com textura nodular e diversas outras formas bizarras.

Os pacotes são cíclicos. de formato lenticular e com granodecrescência para o topo. As espessuras medidas das camadas de cascalhos variam de 0,2 a $\mathrm{lm}$, as de areias e argilas cascalhosas variam de 0,5 a $10 \mathrm{~m}$ e as das ferricretes de 0,5 a $3 \mathrm{~m}$. As cores predominantes são vermelha e amarela, essa última pela introdução de $\mathrm{H}_{2} \mathrm{O}$ na estrutura do óxido de ferro transformando-o em limonita (goethita), e consequentemente a cor vermelha passa a amarela.

O contato basal e de topo da Formação Cachoeirinha ocorre por discordância erosiva, respectivamente com as Formações Aquidauana e Cambambe (principalmente), bem como com as unidades informais Terciário-Quaternário Indiviso e a Fácies Coité (Aluviões Atuais).

A idade dessa unidade litoestratigráfica, de acordo com o proposto por Gonçalves e Schneider (1970) é terciária.

\subsubsection{0 - Unidade Terciário-Quaternário Indiviso}

A unidade informal em apreço, situa-se nos terraços das porções laterais e de interflúvios das bacias de drenagens do Rio Poxoréu (Alvo PX, Figura 6) e Ribeirão Parnaiba (Alvo DA, Figura 10), ocupando cotas topográficas que variam entre 600 a $400 \mathrm{~m}$. Nas bacias de drenagem dos Rios Paraíso, Batovi e das Garças (Alvo PG, Figuras 7,8 e 9), ocupam cotas topográficas entre 720 a $450 \mathrm{~m}$ em relação ao nível do mar.

Da base para o topo (Figuras 30 e 31 ), as Coberturas Terciário-Quaternário Indiviso compõem-se de cascalhos grossos a finos, com tamanhos compreendidos no intervalo de 1 a $50 \mathrm{~cm}$, exibindo arredondamento bom a muito bom e esfericidade média a alta. Os tipos litológicos identificados nos seixos e matacões constituintes dos cascalhos são: quartzo ( 1 a $7 \mathrm{~cm}$ ), quartzoarenitos $(3-8 \mathrm{~cm})$, arenitos $(4$ a $50 \mathrm{~cm})$, silexitos $(3$ a $18 \mathrm{~cm})$, fragmentos lateríticos $(5$ a $30 \mathrm{~cm})$ e raros clastos de rochas de composição basáltica. Contudo, alguns clastos da Fácies Estiva chegam a alcançar $7 \mathrm{~m}$ de diâmetro segundo o eixo maior (Weska, 1987). O arredondamento é bom, com exceção dos lateríticos e silexíticos onde é regular a ruim. A esfericidade é média na maioria dos tipos de clastos sendo baixa nos clastos lateríticos e silexíticos. A espessura dos cascalhos varia de 


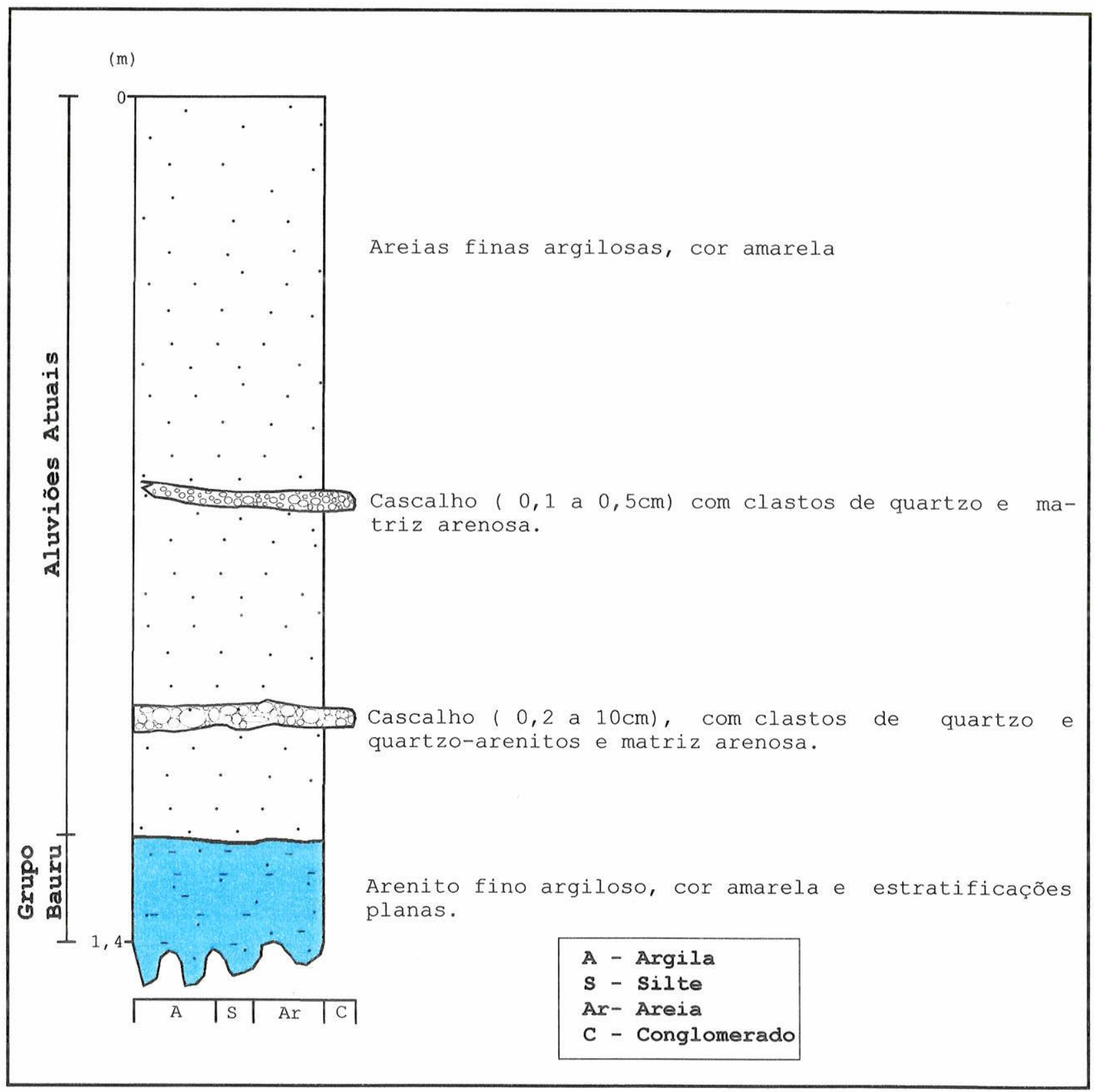

Figura 30 - Coluna estratigráfica mostrando o contato da Unidade Terciário Quatenário Indiviso com arenitos argilosos da Formação Cachoeira do Bom Jardim. Fazenda Juraci Macedo Alvo DA . 


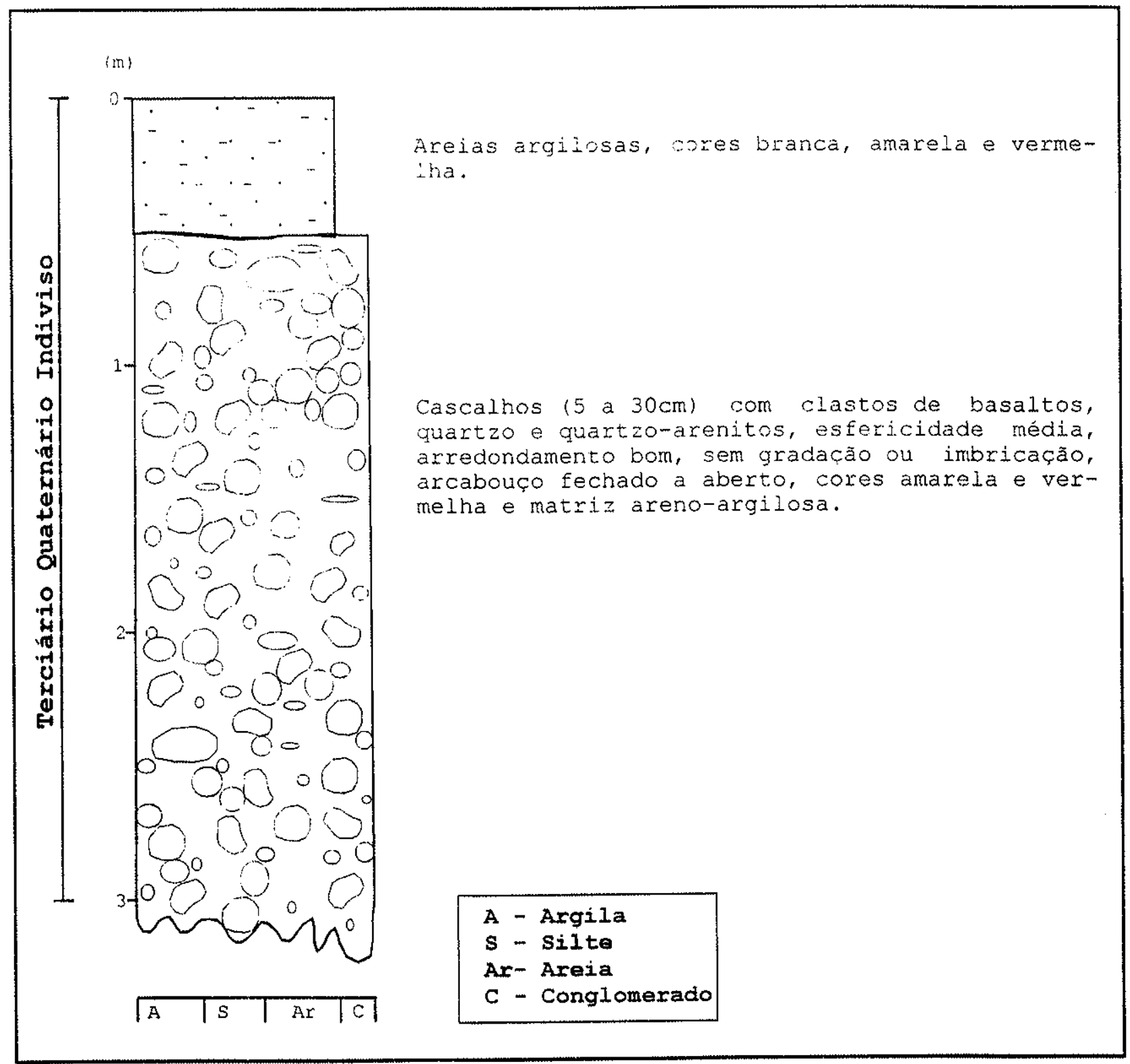

Figura 31 - Coluna estratigráfica da Unidade Terciário Quaternário Indiviso no Alvo DA. 


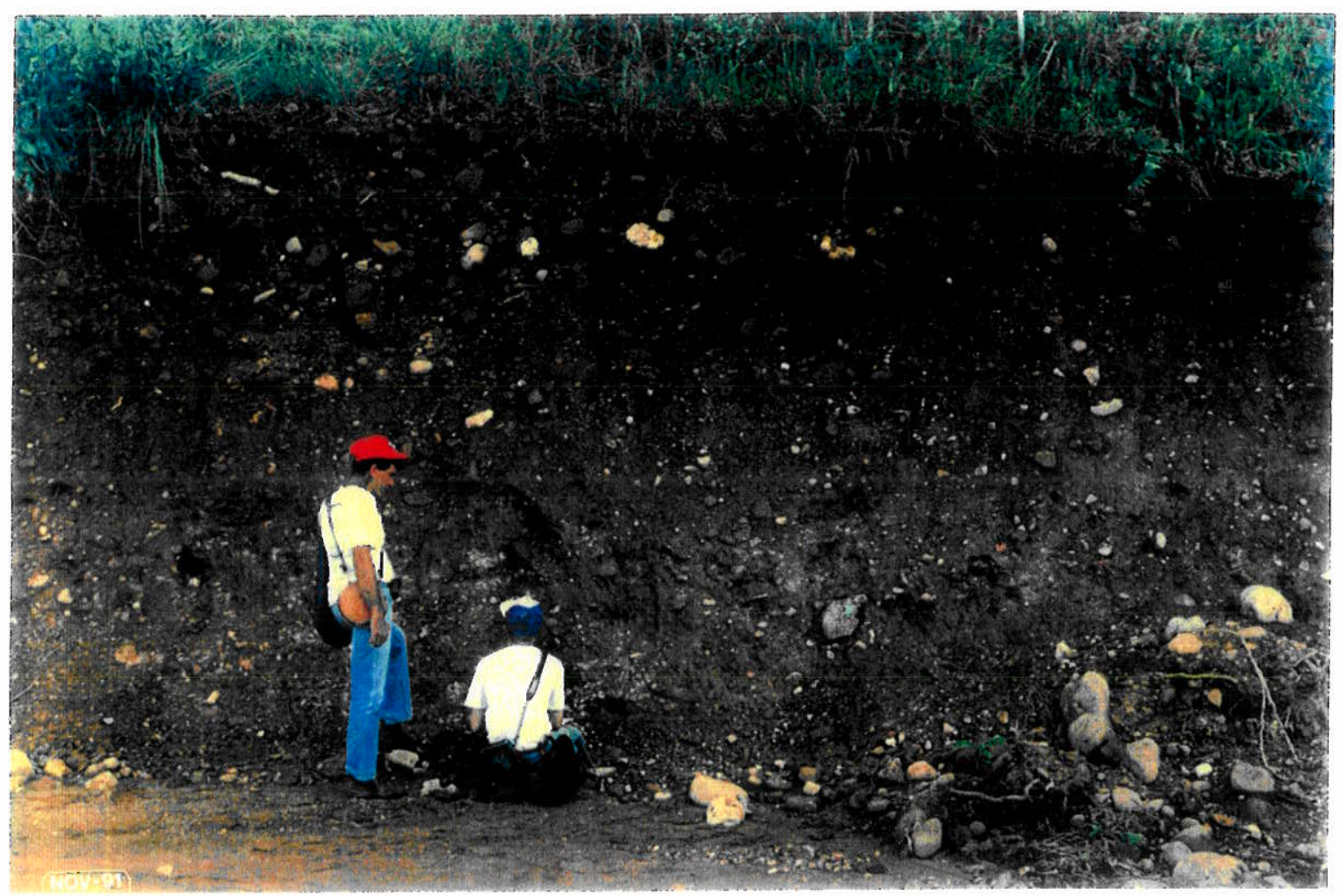

Fotografia 29 - Cascalhos da Unidade Terciário Quaternário Indiviso, com arcabouço aberto e um canal de corte e preenchimento no topo.

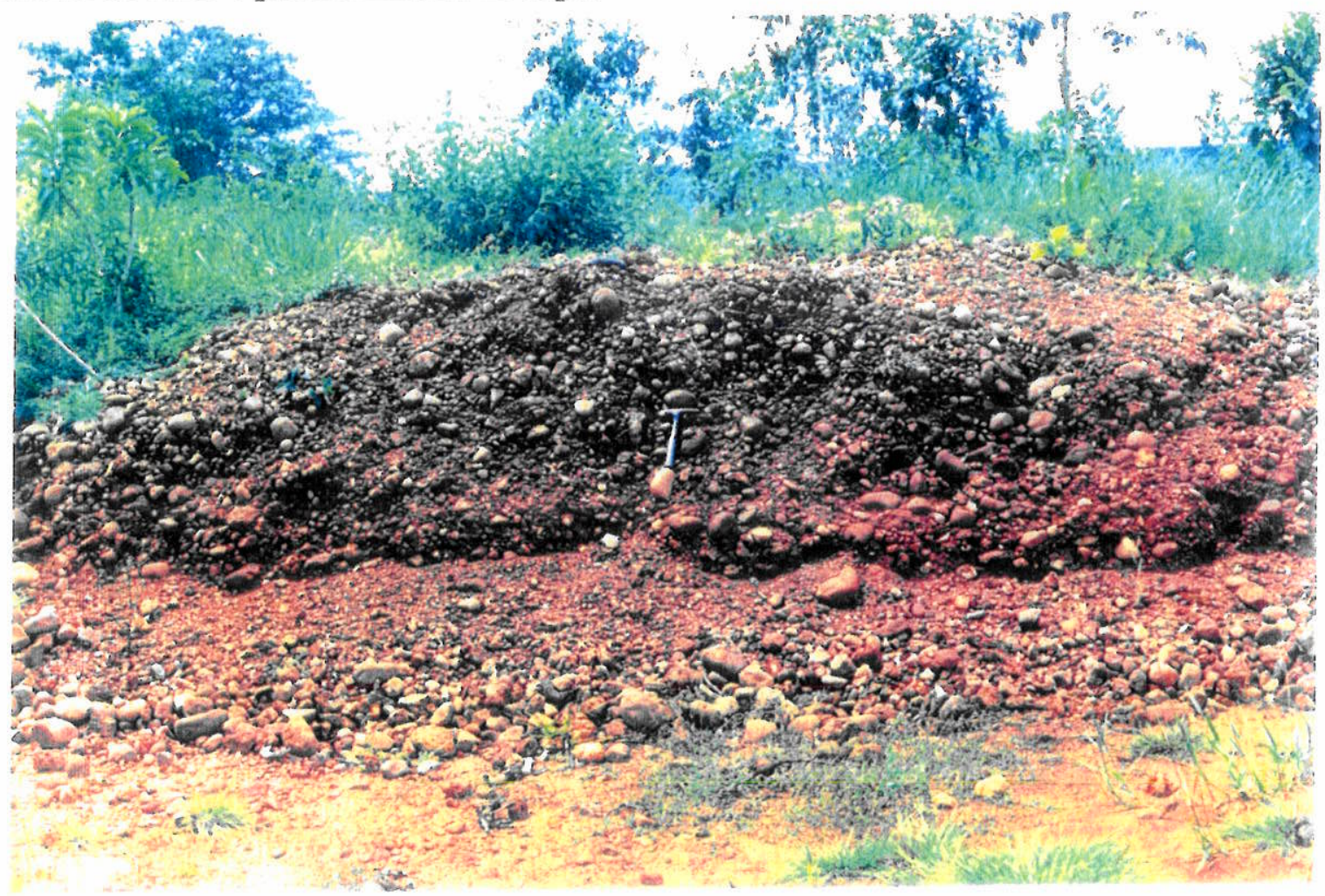

Fotografia 30 - Cascalhos da Unidade Terciário Quaternário Indiviso em superficie residual. 
0,1 a $5 \mathrm{~m}$ (Fotografia 29), e a do capeamento de ausente em superficies residuais (Fotografia 30 ) de cascalhos a $10 \mathrm{~m}$. O arcabouço dos cascallos é do tipo matriz suportando clastos (aberto) até clastos suportados (fechado), segundo a classificação de Walker (1975). Apresentam-se com ou sem gradação, quando existente normal ou inversa e com imbricação incipiente ou inexistente. A matriz é arenosa imatura (grossa a fina), areno-argilosa e até argilosa, ocorrendo cimento de óxido de ferro.

Os capeamentos estéreis dos cascalhos são compostos por areias grossas a finas, com grânulos de quartzo e fragmentos lateríticos (solo transportado); por vezes também os cascalhos são recobertos por areias argilosas e raramente argilas, sendo o conjunto cimentado por óxidos de ferro.

Estruturas primárias não foram observadas, entretanto, os clastos areníticos mostram em suas superficies marcas de impacto evidenciando choques entre os clastos resultantes do ambiente deposicional turbulento, em função da alta capacidade de carga do meio transportador, bem como canais de corte e preenchimento.

Os formatos dos pacotes são lenticulares, com seqüências de cascalhos basais capeados por areias ou até argilas e assim sucessivamente até o terraço mais jovem. A medida que o pacote cascalhoso situa-se em terraceamento mais elevado em relação à drenagem atual e, portanto, mais antigo, a média do tamanho de clastos diminui. Entretanto, são mais grossos quanto mais próximos às drenagens e topograficamente mais baixos (mais jovens). As cores predominantes desses pacotes são vermelha e amarela, sendo raras as cores branca e cinza. Analisados individualmente apresentam granodecrescência para o topo, todavia, quando observados no conjunto dos vários ciclos apresentam granocrescência em direção aos cascalhos de topo.

$O$ contato entre os pacotes de cascalhos e areias da Unidade Terciário-Quaternário Indiviso com os demais pacotes similares, dispostos em terraços, é por nítida discordância erosiva, assim como é também o contato basal dos mesmos quando ocorrem com todos os tipos litológicos descritos anteriormente nesse capítulo. A discordância litológica ocorre quando essa unidade faz contato sobre litotipos da Formação Paredão Grande. A Fácies Coité (Alvo PX) ou Aluviões Atuais (Alvos DA e PG) que recobrem essa unidade, possuem também contato discordante erosivo.

Dado o posicionamento geográfico desses terraços intimamente relacionados à drenagem que escoa em direção à Bacia do Pantanal de idade Terciário-Quaternário, a idade desses cascalhos e areias dispostos em terraços é correlata à própria evolução do Pantanal. 
Nessas condições. os cascalhos e areias situados em terraços mais elevados topograficamente são os mais antigos. enquanto que aqueles mais baixos topograficamente e mais próximos à drenagem atual são os mais jovens.

\subsubsection{1 - Fácies Coité (Aluviões Atuais)}

Neste estudo, propomos informalmente a Fácies Coité que em função da existência de inúmeras frentes de garimpos nas circunvizinhanças de Poxoréu (Alvo PX, Figura 6) facilitaram o empilhamento e a descrição dos tipos litológicos destas rochas. Nos demais Alvos DA e PG (Figuras 7, 8, 9 e 10), em função da reduzida ou inexistente atividade extrativa de garimpos, adotaremos a denominação também informal de Aluviões Atuais, corrente na literatura geológica regional para as planícies de inundação e fundos de canais, predominantemente recobertos por areias, argilas e raros afloramentos de cascalhos. As unidades contemporâneas, contudo, de nomes distintos, englobam também depósitos eluviais, caracterizados por inúmeras superficies residuais que ocorrem tanto nos terraços mais jovens quanto nos antigos e, depósitos coluviais, situados ao longo das escarpas da região de Paredão Grande, no entorno da Intrusão Tamburi (Figura 7), circundando os diques de Paredão Grande (Figura 8), Meruri (Figura 9) e Primavera (Tabela 2), bem como ao longo das escarpas à $\mathrm{N}$ de Dom Aquino (Figura 10) e no entorno de morros testemunhos.

A Fácies Coité, informalmente denominada neste trabalho, corresponde aos depósitos do canal atual das principais drenagens ativas da região, como por exemplo os Rios Poxoréuzinho, Coité e Poxoréu, além de seus afluentes, bem como as suas planícies de inundação (Figura 6). Engloba também depósitos eluviais caracterizados por inúmeras superficies residuais, que ocorrem tanto nos terraços mais jovens quanto nos antigos, bem como depósitos coluviais situados ao longo da falha de Poxoréu, junto às escarpas da Formação Cambambe à N,NE e NW de Poxoréu, e circundando morros testemunhos situados nas porções internas à bacia de drenagem atual (Figura 6). Tais depósitos interdigitam-se aos depósitos de canal (Fotografias $31 \mathrm{e}$ 32) e planícies de inundação. Topograficamente, tal unidade ocorre entre 640 a $350 \mathrm{~m}$ em relação ao nível do mar.

Da base para o topo, a Fácies Coité é caracterizada por cascalhos, areias, areias cascalhosas, areias argilosas e argilas (Figura 32). Os cascalhos são constituídos de seixos e 
matacões de quartzo, arenitos, quartzo arenitos, silexitos, fragmentos lateriticos e seixos raros de composição basáltica, como ocorre nas imediações dos garimpos Balaio de Gato (Buritizal) e Raizinha. O tamanho dos clastos situa-se entre o intervalo de 1 a $40 \mathrm{~cm}$, sendo os maiores de arenitos e quartzo arenitos e os menores de quartzo e de lateritas. $O$ arredondamento é bom a muito bom para os seixos e matacões de quartzo. arenitos, quartzo-arenitos e os de origem ígnea, tornando-se regular a ruim para os silexitos e os clastos de ferricretes. A esfericidade é média a alta para os primeiros e, média a baixa, para os últimos, respectivamente. A matriz dos cascalhos varia desde areias grossas a finas, até o extremo argiloso, com composições intermediárias variáveis. $\mathrm{O}$ cimento quando ocorre é de óxido de ferro. $\mathrm{O}$ arcabouço varia entre os extremos aberto a fechado; quanto a gradação, essa pode ser normal, inversa ou inexistente e com imbricação incipiente. A espessura desses pacotes situa-se no intervalo entre 0,1 a $2 \mathrm{~m}$ (Fotografias 33 e 34).

O capeamento dos cascalhos é feito por areias cascalhosas até finas. Quando cascalhosas, a composição dos clastos predominantes coincide com aqueles descritos para os cascalhos. O tamanho dos mesmos em média é menor $(0,5$ a $3 \mathrm{~cm})$. Areias argilosas e argilas ocorrem capeando os cascalhos em especial nas planícies de inundações. A espessura do capeamento situa-se entre 0 a $5 \mathrm{~m}$, sendo raras espessuras maiores.

O formato dos pacotes é lenticular e as cores são predominantemente branca, cinza, amarela e raramente vermelha ou cinza azulada. Marcas de impacto ocorrem na superfície dos clastos, não tendo sido observadas estruturas primárias.

O contato basal da Fácies Coité com os tipos litológicos de todas as unidades anteriormente descritas nesse capítulo é por discordância erosiva, com exceção se o "bedrock" é da Formação Paredão Grande, quando então a discordância é litológica. A superfície de contato da base do cascalho com o "bedrock", normalmente é irregular o que em muitas vezes desenvolve armadilhas para o diamante, conforme discutido por Weska et al. (1984).

$\mathrm{Na}$ falta de restos fósseis passíveis de fornecer uma idade, e considerando o posicionamento geográfico dessas rochas junto aos canais ativos atuais e bordas de escarpamentos, a idade, mais provável é quaternária. 


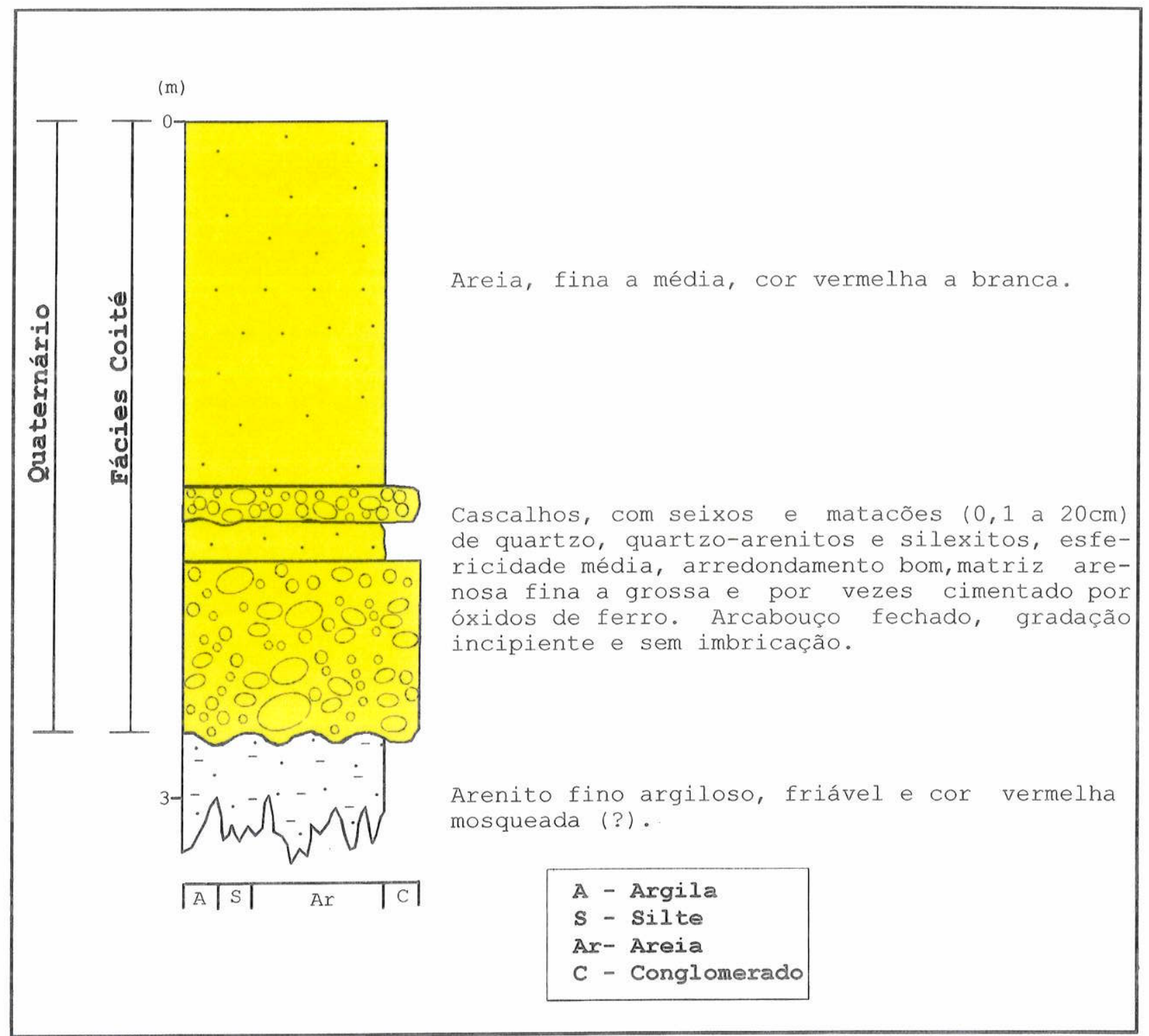

Figura 32 - Coluna estratigráfica da Fácies Coité, Alvo PX. 


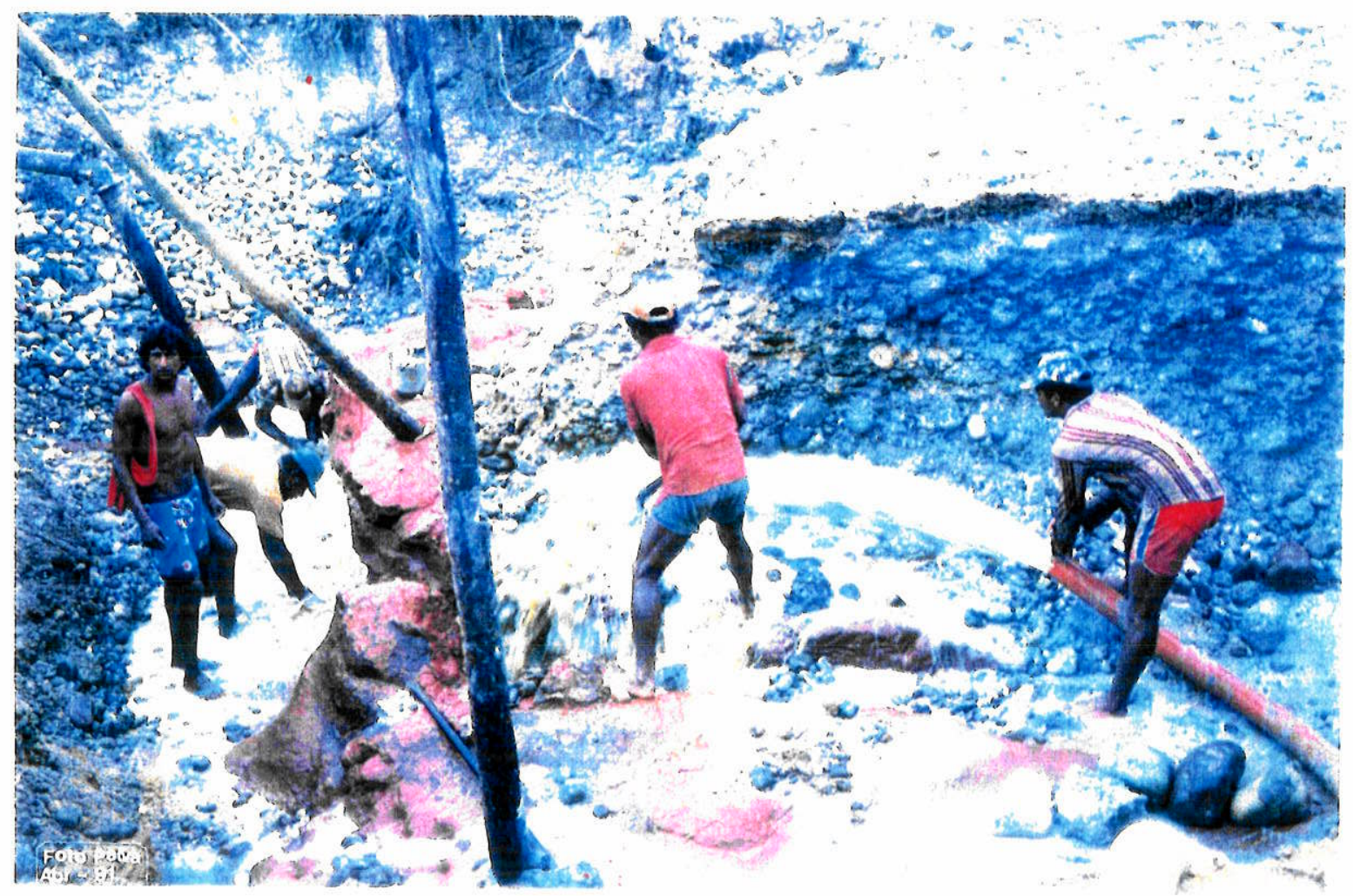

Fotografia 31 - Cascalhos de canal da Fácies Coité em discordância erosiva sobre rochas do Grupo Bauru.

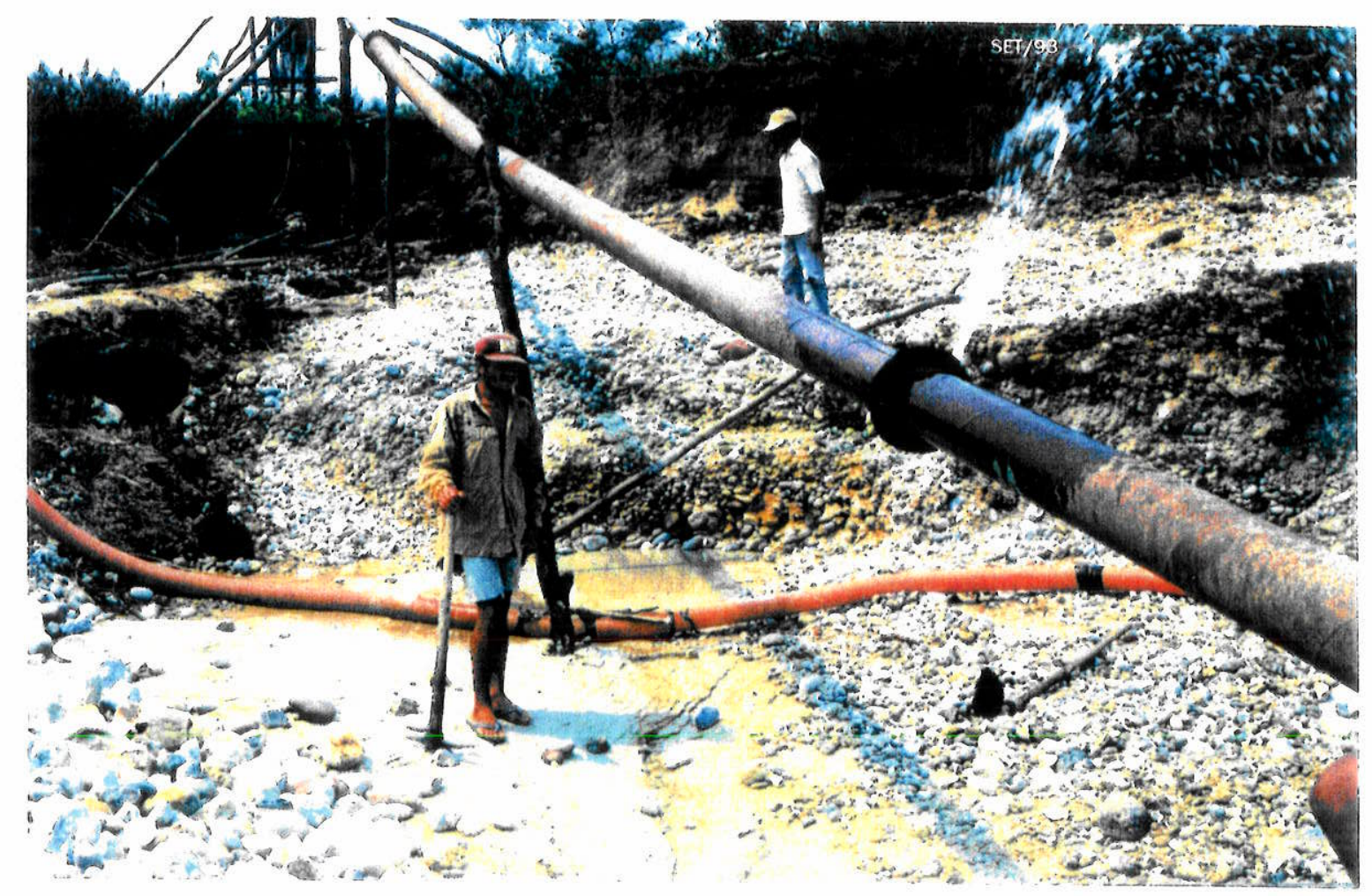

Fotografia 32 - Cascalhos de canal da Fácies Coité recobertos por capeamento areno-argiloso.. 


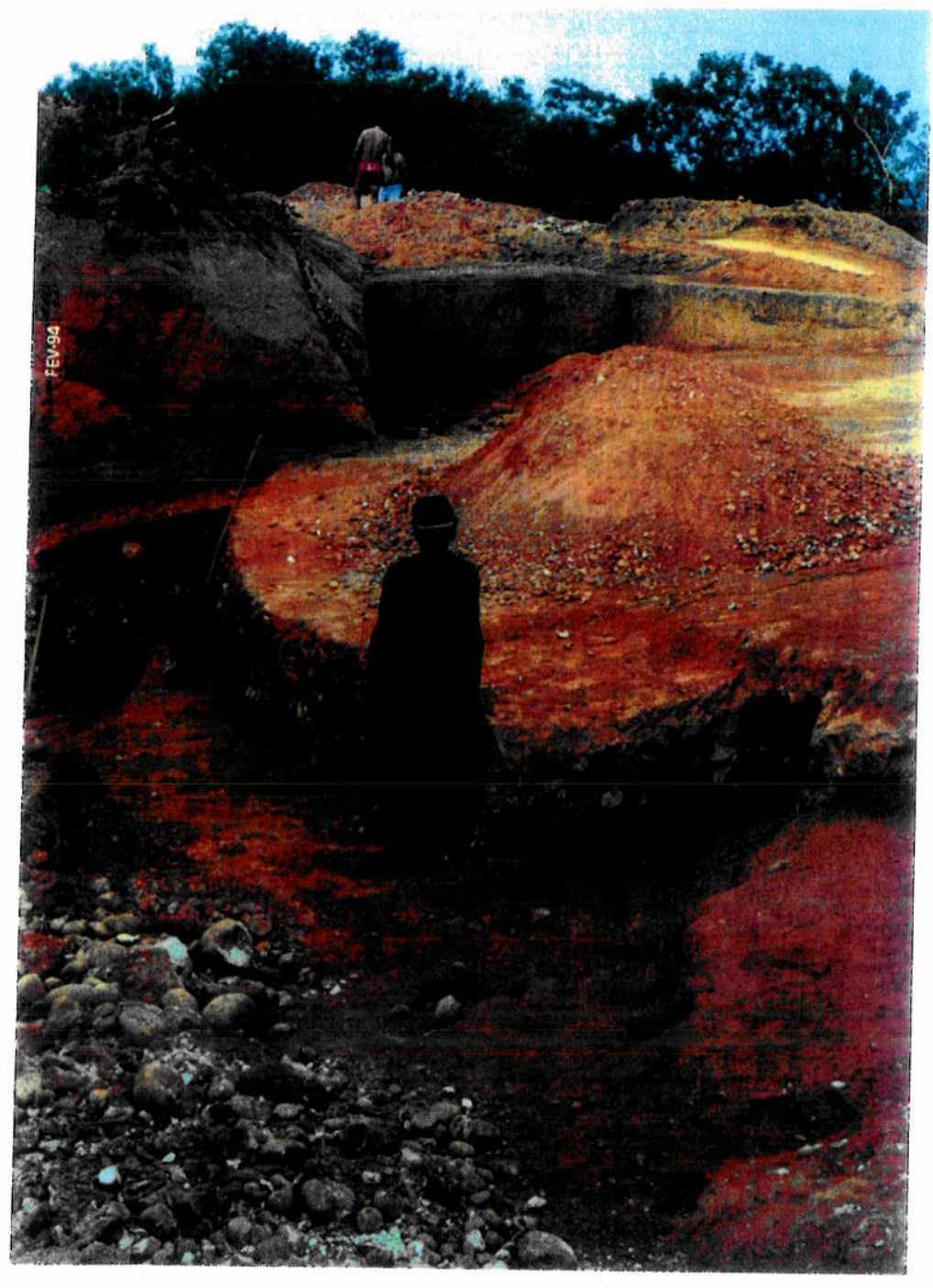

Fotografia 33 - Cascalhos da Fácies Coité depositados sobre "bedrock" irregular e recobertos por areias argilosas.

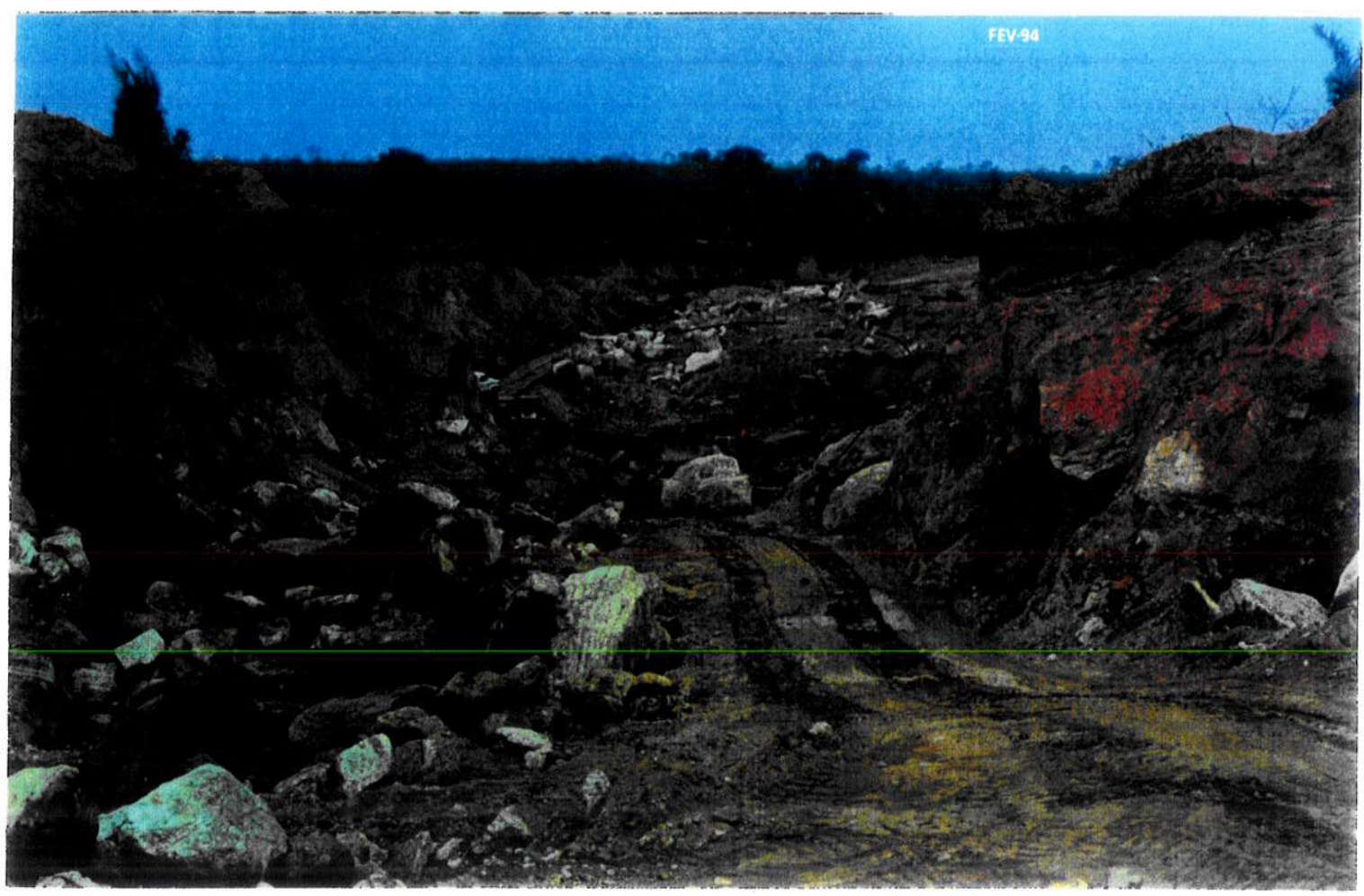

Fotografia 34 - Cascalhos coluviais da Fácies Coité em armadilha do tipo bolsão. 


\section{2 - O ambiente deposicional do Grupo Bauru e da Fácies Coité.}

O estudo do ambiente deposicional refere-se principalmente as rochas do Grupo Bauru que ocorre com a sua coluna estratigráfica completa (Weska et al., 1996) na região de Poxoréu (Alvo PX), e com parte dela (unidades de topo) à norte de Dom Aquino (Alvo DA), como já anteriormente exposto no Capítulo 5. Além disso. analisaremos também a Fácies Coité dado a sua importância como hospedeira das principais mineralizações diamantíferas na região.

Em relação ao modelo deposicional dessas rochas do Cretáceo Superior nos Estados de Minas Gerais, São Paulo e Mato Grosso, (Pires, 1982; Fernandes \& Coimbra, 1996; Weska 1987), há um consenso de que a deposição ocorreu por leques aluviais, em condicionamento climático variando de árido a semi-árido. No Estado de Mato Grosso, na região da Chapada dos Guimarães, coube a Weska (1987) caracterizar o ambiente de sedimentação dos tipos litológicos do Grupo Bauru.

A bacia deposicional cretácea em apreço situa-se à SE do Arco de São Vicente, sendo delimitada a SE pela Falha de Poxoréu, fonte principal dos materiais detríticos depositados nos tempos terciários e quaternários, incluindo o diamante

A identificação dos eventos da Formação Paredão Grande $(83,9 \pm 0,4 \mathrm{Ma}$ ), posicionados estratigraficamente tanto na base como intercalados ciclicamente nas Formaçöes Quilombinho e Cachoeira do Bom Jardim, diferentes portanto do evento magmático Serra Geral de 125Ma., provoca modificações conceituais na Bacia Bauru no Estado de Mato Grosso, sem contudo, alterar substancialmente o modelo deposicional geral conhecido hoje. Entretanto, com base em dados levantados nos mapeamentos de campo, discutiremos algumas questões que consideramos importantes.

Além dos derrames, como por exemplo aqueles da Raizinha, Lajinha e Córrego Preto, assim como os diques associados Primavera, Paredão Grande e Meruri, destacamos as rochas piroclásticas grossas a finas e cíclicas, que em função do elevado estágio de alteração, muitas vezes foram confundidas como rochas sedimentares grossas (conglomerados) pertencentes à Formação Quilombinho (Weska et al., 1993). No campo, essa rochas vulcanoclásticas podem ser identificadas pelo caráter quase oligomítico, 
contendo em muitos casos até $100 \%$ de fragmentos com composição de rochas máficas. Nos tipos litológicos finos (tufos), observa-se em alguns casos estruturas de fluxo incipientes. Além disso, os clastos sedimentares quando presentes exibem silicificação nas bordas. $O$ contato desses tipos litológicos com o substrato rochoso da Formação Botucatu, também é em muitos casos caracterizado por silicificação intensa, bem como por feições similares a marcas de onda sugerindo o escorrimento eventual desse evento explosivo (rios de lavas) sobre superficies arenosas pouco litificadas, tal como já observado na região da Chapada dos Guimarães (Weska, 1987).

A Formação Quilombinho é a unidade sedimentar basal do Grupo Bauru derivada dos eventos magmáticos da Formação Paredão Grande. Situa-se espacialmente próxima aos Derrames da Raizinha (Alvo PX) e a Falha de Poxoréu (Figura 33). A proximidade da área fonte é denunciada pelo tamanho dos clastos, podendo alcançar até $50 \mathrm{~cm}$ de diâmetro (Fotografia 15). A unidade é constituida por um conjunto de lentes cíclicas de conglomerados, argilitos e arenitos conglomeráticos, argilitos e arenitos. As lentes de conglomerados são basais enquanto as de argilitos e de arenitos situam-se no topo. A espessura e a envergadura das lentes de conglomerados são maiores na base e menores em direção ao topo, enquanto que as dos pelitos são menores na base $(10 \mathrm{X}$ $50 \mathrm{~cm}$, Fotografias 16 e 17) e maiores em direção ao topo. As estruturas primárias existentes são caracterizadas por estratificações planas e cruzadas incipientes (raras). Os conglomerados de arcabouço aberto (matriz suportando os clastos, Walker, 1975), ocorrem em conglomerados posicionados próximos a altos topográficos como a Falha de Poxoréu, e os de arcabouço fechado (clastos suportados) junto aos paleocanais restritos. Os conglomerados são granocrescentes em direção ao topo (Fotografia 13), evidenciando reativações tectônicas sin-deposicionais, bem como progradação do leque aluvial em direção às porções centrais da bacia deposicional, com características similares às fácies do tipo "Gms" de Rust (1980). O aumento de clastos sedimentares em direção ao topo denuncia diversificação da área fonte, neste caso caracterizadas como sendo as Formações Aquidauana (arenitos) e Palermo (silexitos oolíticos e pisolíticos). As lentes de lamitos conglomeráticos sugerem condições deposicionais sujeitas a corridas de lamas 


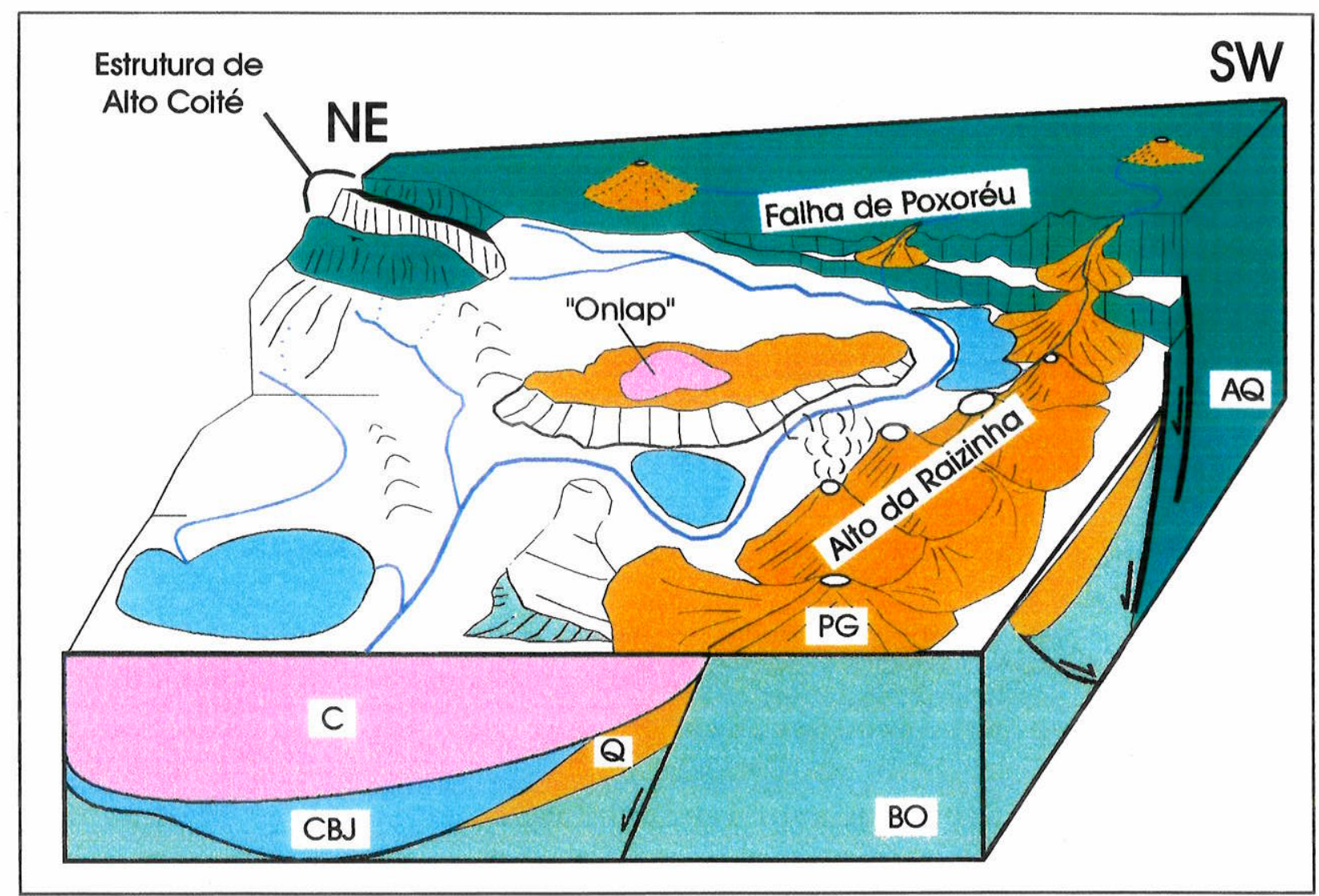

Figura 33 - Diagrama esquemático de paleorelevo e evolução durante o Cretáceo Superior na região de Poxoréu (Alvo PX). Formações (AQ) - Aquidauana, (BO) - Botucatu, (PG) Paredão Grande, (Q) Quilombinho, (CBJ) Cachoeira do Bom Jardim e (C) Cambambe; região de Poxoréu (Alvo $P X$ ). Sequência de eventos magmáticos e de sedimentação $P G-Q$ - PG (Alto da Raizinha ) - CBJ - C ("onlap") e drenagem plano axial à Falha de Poxoréu. 
(movimentos de massa), e as lentes de arenitos com estruturas primárias, sugerem ambiente seletivo e perene (fluvial). $O$ conjunto dos variados tipos litológicos, com predomínio de grossos na base e de finos em direção ao topo, caracterizam a granodecrescència em direção ao topo da unidade. As cores de tonalidades vermelhas, por outro lado. evidenciam a influência de óxidos de ferro resultantes da alteração dos tipos litológicos vulcânicos derivados da Formação Paredão Grande.

A Formação Cachoeira do Bom Jardim é constituída de lentes de conglomerados, arenitos e argilitos conglomeráticos, arenitos, argilitos e calcretes. Essas lentes, bem como as calcretes resultantes da precipitação química de $\mathrm{CaCO}_{3}$ são cíclicas. Há predomínio dos pacotes de conglomerados na porção basal da unidade (Weska,1987), com arcabouço variando entre matriz suportando os clastos a clastos suportados. Ocorre ainda, gradação inversa (Walker, 1975) e granocrescência em direção ao topo, pressupondo reativações tectônicas da área fonte sin-deposicionais e com progradação em direção ao depocentro da bacia. No caso da área estudada envolvendo os Alvos PX e DA, os conglomerados próximos à porção basal, mostram a instalação de um novo ciclo erosivo e deposicional, diversificação de área fonte, além de incremento dos clastos sedimentares em detrimento dos de composição basáltica, sendo a relação de clastos ígneos/sedimentares em média 1:1. A intercalação dos Derrames da Lajinha e do Córrego Preto em arenitos conglomeráticos próximos ao topo, evidenciam a recorrência dos eventos vulcânicos na região de Dom Aquino (Alvo PX), internos à bacia. Tais derrames, apesar de não datados, são mais jovens e como altos vulcânicos proporcionaram a deposição de conglomerados oligomíticos similares macroscopicamente àqueles da Formação Quilombinho, embora composicionalmente diferenciados (traquibasaltos), conforme observado no Capítulo 5.1.5.5. Esses arenitos conglomeráticos são de granulometria média a fina, apresentando estratificações plano-paralelas, cruzadas tabulares e acanaladas características de sistemas fluviais com alternância de regimes de fluxos aquosos intensos a calmos. Estão interdigitados com argilitos, argilitos conglomeráticos e argilas em direção ao topo. $\mathrm{O}$ conjunto encerra fácies similares a 'Fm + C", "Sh" e "St" de Rust (1980). Segundo Goudie (1973), as calcretes (crostas carbonáticas) são resultantes da deposição seletiva de $\mathrm{CaCO}_{3}$ que se depositou em 
periodos secos mais severos sobre as areias e argilas do fundo de lagoas antigas, característica de ambiente evaporítico (sabkhas interioranas) de clima árido. Cimentação carbonática intensa manifesta-se também ciclicamente e de forma gradacional em direção ao predominio das silcretes da Formação Cambambe (topo). A sequência de eventos deposicionais descrita caracteriza as porções intermediárias de leques aluviais (Figura 33), e o conjunto litológico apresenta granodecrescência em direção ao topo.

O empilhamento estratigráfico que caracteriza a Formação Cambambe nas regiões dos alvos PX e DA, é constituído de arenitos finos a conglomeráticos, interdigitados por lentes de conglomerados, brechas intraformacionais e silcretes. $\mathrm{Na}$ região da Chapada dos Guimarães, Weska (1987) descreveu também conglomerados basais, que na interpretação do referido autor significa uma importante reativação tectônica, com rejuvenescimento das áreas fontes e uma nova progradação dos leques em direção às porções internas da bacia. As lentes dos variados tipos litológicos,assim como as silcretes resultantes da precipitação química de $\mathrm{SiO}_{2}$ são cíclicas. Ocorre predomínio dos pacotes de conglomerados na porção basal da unidade (Weska,1987), com o arcabouço variando entre matriz suportando os clastos a clastos suportados, além de gradação inversa (Walker, 1975) e granocrescência em direção ao topo, pressupondo reativações tectônicas da área fonte pré e sin-deposicionais, com progradação do leque em direção ao depocentro da bacia. $O$ maior espessamento e os clastos maiores estão restritos aos pacotes inferiores, uma vez que os conglomerados superiores são pouco espessos e são constituidos de clastos muito pequenos (Figura 26). No conjunto cíclico de conglomerados há o predomínio de $>90 \%$ de clastos sedimentares sendo os $10 \%$ restantes de clastos ígneos (dimensões $<5 \mathrm{~cm}$ ), principalmente quanto mais próximos dos Derrames da Lajinha e do Córrego Preto ( Alvo DA). Na região da presente Tese, nos alvos PX e DA, foram descritos os conglomerados intermediários e os de topo da Formação Cambambe. Os conglomerados intermediários e de topo possuem gradação inversa incipiente e o conjunto cíclico de lentes está interdigitado em arenitos, siltitos, argilitos e arenitos conglomeráticos. Os conglomerados de topo possuem clastos de dimensões menores (torrentes em lençol), são menos espessos sugerindo planação da área fonte. $O$ arcabouço varia de matriz suportando os clastos a clastos suportados. Os arenitos 
conglomeráticos são depósitos imaturos originados por movimentações bruscas de massas sendo destituídos de estruturas primárias. As brechas intraformacionais (Figuras 27 e 28) denunciam reativações tectônicas internas à Bacia Bauru local, de modo similar à Chapada dos Guimarães (Weska, 1987). As silcretes ocorrem na porção intermediária ressaltando a morfologia do conjunto de pacotes em estratificações planas decamétricas, sendo resultantes do clima extremamente árido. responsável pelo desenvolvimento dos tubos e estruturas exóticas de sílica. No conjunto litológico pertencente à Formação Cambambe, predomina cimento silicoso, porém mais próximo a base o cimento silicoso interdigita-se com cimento carbonático constituíndo depósitos distais de leques aluviais (Figura 33).

Com base nos dados anteriormente colocados, o Grupo Bauru mapeado na região de Poxoréu constitue uma sequência de eventos intrusivos e extrusivos localizados no alto lateral das porções E-SE de Poxoréu. Na borda da bacia, junto à Falha de Poxoréu temos a Formação Quilombinho, intercalada pelos Derrames da Raizinha, representando as porções proximais de leques aluviais. Em direção à $\mathrm{N}-\mathrm{NW}$ aparecem deposições detríticas intercaladas por outros derrames (Lajinha e Córrego Preto), seguidas de precipitação de $\mathrm{CaCO}_{3}$ (calcretes). Tal conjunto corresponde às porções intermediárias dos leques aluviais. As porções internas da bacia, por sua vez, correspondem às porções distais dos leques aluviais, compostas de detritos e precipitações de $\mathrm{SiO}_{2}$ (silcretes). Calcretes e silcretes formaram-se em ambiente evaporítico, sendo a primeira produto de clima árido e a segunda de extremo árido. Esse conjunto mostra que a Bacia Bauru da região de Poxoréu é uma bacia vulcano-clasto-química, depositada em paleosuperficie de meio graben e cujo depocentro situa-se à N-NE sob o vale do Rio das Mortes.

A Fácies Coité caracterizamse por cascalhos basais grossos, com esfericidade média a alta e arrendondamento bom a muito bom, sugerindo transporte a longas distâncias em ambiente fluvial. São destituídos totalmente de clastos de rochas ígneas da Formação Paredão Grande, exceto quando o sistema de drenagem captura algum derrame ou dique, tal como observado no entorno dos Derrames da Raizinha, Lajinha e Córrego Preto e os Diques de Paredão Grande. Os cascalhos variam entre arcabouço aberto a fechado, alguns sem gradação e outros com gradação inversa, ambos sem imbricação. $O$ capeamento areno-argiloso que se sobrepõe aos cascalhos em conjunto com o cascalho 
basal encerra o ciclo deposicional atual. Argilas predominam nas planícies de inundação, enquanto nos canais ativos predominam os cascalhos. Junto às bordas das escarpas de falha ou de erosão, assim como no entorno de morros testemunhos, desenvolvem-se depósitos de talus. Nesses depósitos. o ambiente é de baixa selitividade quando comparado aos depósitos de canais atuais. 


\section{ASPECTOS ESTRUTURAIS, GEOMORFOLÓGICOS E TECTÔNICOS}

No presente capítulo, como suporte para questões relativas às evoluções geomorfológicas e tectônicas, discutiremos inicialmente os principais elementos estruturais identificados nos alvos PX, PG e DA. No final, tentaremos integrar esses elementos com aqueles relativos às sequências litológicas apresentadas no Capítulo 5 , a fim de elaborar um modelo das evoluções geomorfológica e tectônica da área estudada, com ênfase a partir do Cretáceo Superior.

\subsection{O Condicionamento estrutural}

A região estudada situa-se no truncamento do Lineamento Transbrasiliano (Schobbenhaus et al., 1975b) com o Lineamento $125^{\circ} \mathrm{Az}$ (Bardet, 1977). Com relação ao Lineamento Transbrasiliano, trata-se de uma extensa faixa intensamente falhada do território brasileiro com direção em torno de $\mathrm{N}^{\circ} 5^{\circ} \mathrm{E}$, que atravessa os Estados de Mato Grosso, Goiás, Piauí e Ceará. O Lineamento $125^{\circ} \mathrm{Az}$, também de expressão continental, corta os Estados do Rio de Janeiro, Minas Gerais, Goiás, Mato Grosso e Rondônia.

A região da Tese em apreço, apresenta enormes dificuldades para estudos de geologia estrutural em função da espessa e extensa cobertura terciário-quaternário. Por outro lado, trata-se de um arcabouço geológico da borda extremo noroeste da Bacia do Paraná onde os registros tectônicos estão impressos em parte dos dos tipos litológicos desta bacia intracratônica (Formações Furnas, Ponta Grossa, Aquidauana, Palermo e Botucatu). Esse contexto geológico representou o substrato geológico regional para a deposição das rochas do Grupo Bauru durante o Cretáceo Superior, tendo sido afetado posteriormente por eventos tectônicos relativos ao desenvolvimento da Bacia do Pantanal durante o Terciário e o Quaternário. Por esta razão, ainda 
não dispomos de elementos estruturais que permitam elucidar o seu condicionamento estrutural em detalhe. Entretanto, a distribuição e o posicionamento geográfico dos tipos litológicos cretáceos e do magmatismo basáltico associado, permitiram a individualização do Rifte Rio das Mortes, a ser proposto neste capítulo.

\subsection{Os elementos estruturais}

Os principais elementos estruturais estudados nos mapeamentos geológicos são falhamentos e fraturamentos. Parte dos falhamentos são preenchidos pela Intrusão Tamburi e por diques, como por exemplo o da Mata e da Matinha (Weska, 1987), além daqueles inseridos na área ora relatada, como os diques Primavera, Paredão Grande e Meruri ( Fotografia 10b e Figuras 8 e 9) . Como visto no Capítulo 5, esses diques foram englobados na Formação Paredão Grande. Secundariamente, temos feições estruturais regionais e locais como o Arco de São Vicente (Oliveira \& Muhlmann, 1967), a Antéclise de Rondonópolis (Coimbra, 1991), a Estrutura de Alto Coité (Alvo PX), e os Altos da Raizinha (Alvo PX) e da Passagem do Mamão na Chapada dos Guimarães (Figura 33 e 34). Tais elementos estruturais além de registrarem a história tectônica da região, constituem também feições importantes no desenvolvimento de armadilhas do diamante, que serão tratada no capítulo seguinte.

Nas áreas dos Alvos PX, DA e PG, há predomínio de falhamentos de direção NE-SW, paralelos a sub-paralelos entre si e com o Arco de São Vicente. De forma menos evidente, temos falhamentos perpendiculares $(\mathrm{NW})$ ou oblíquos (N-S) às falhas de direção NE. Os fallhamentos NE mais expressivos são a Falha de Poxoréu (Alvo PX) e, secundariamente, as falhas denominadas de Jaciara-Serra Grande (Alvos DA e PX) e a região falhada das Parnaíbas (Alvo DA), conforme denominações de Barros et al. (1982). Tais falhamentos, associados a outros de menor envergadura, condicionam a rede de drenagem da região.

A Falha de Poxoréu (Figuras 6 e 33), é uma falha normal que coloca os sedimentos da Bacia do Paraná (Formações Aquidauana e Palermo) topograficamente elevados em relação aos litotipos do Grupo Bauru, cuja linha de fraqueza localiza-se junto à cidade que lhe emprestou o nome. Essa falha possue rejeito de $250 \mathrm{~m}$ na porção sul e de $30 \mathrm{~m}$ na porção norte. Tal situação de rejeitos distintos, muito provavelmente, foi 


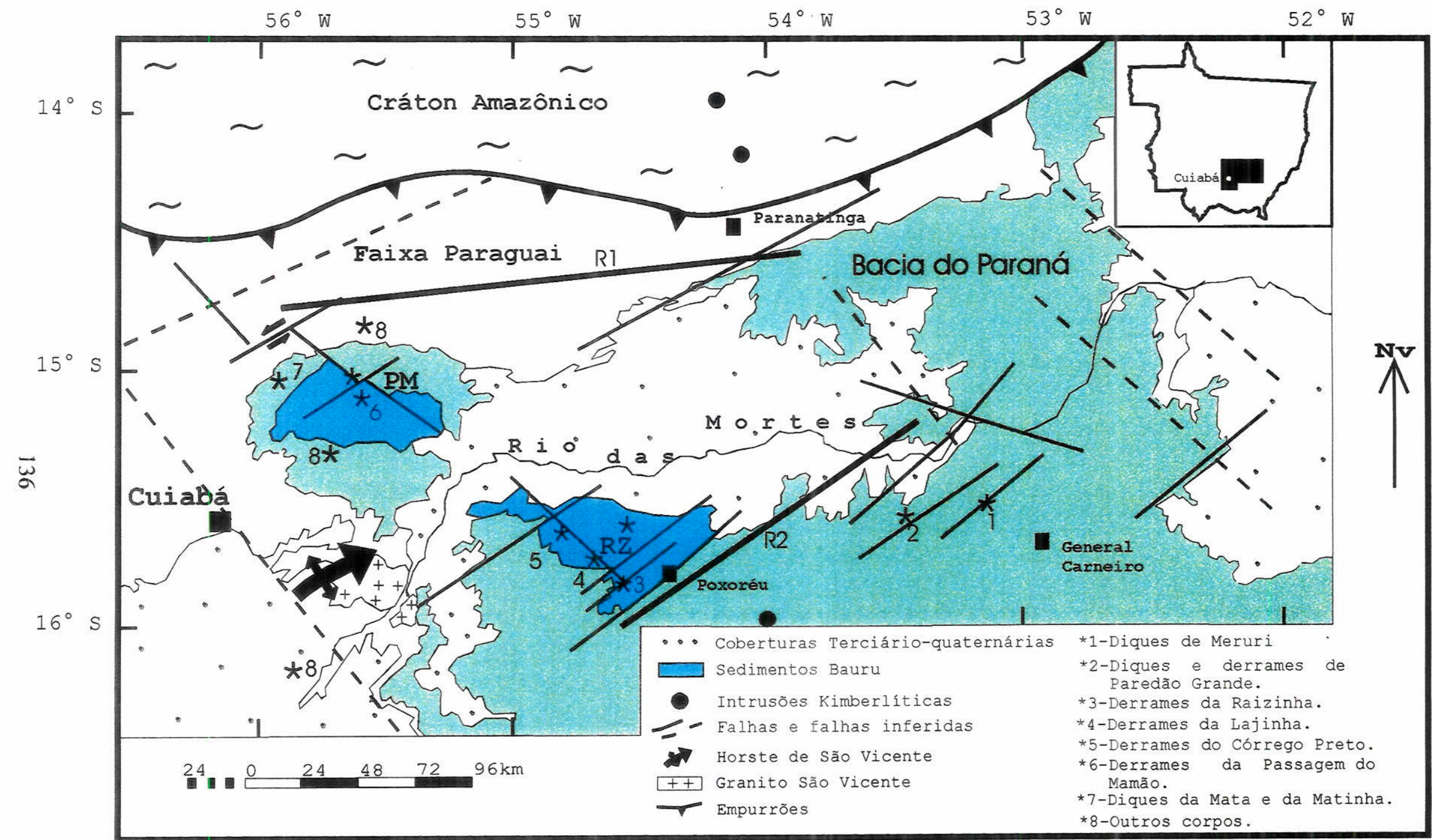

Figura 34 - Localização da bacia do Grupo Bauru situada entre o Cráton Amazônico à NW-NE e a Bacia do Paraná à S-SE. Os números caracterizam as intrusões e extrusões da Formação Paredão Grande. PM-Alto da Passagem do Mamão e RZ- Alto da Raizinha. O rifte Rio das Mortes é delimitado aproximadamente pelos alinhamentos R1-R2. 
provocada por interferência do que hoje identifica-se como Estrutura de Alto Coité, que condicionou também a deposição da Formação Quilombinho, pois onde o rejeito é menor tal unidade litoestratigráfica inexiste, passando a ocorrer em direção ao sul onde o rejeito aumenta. Os esforços direcionais desse falhamento foram registrados através de dobras de arrasto (drag folds); além disso, zonas brechadas e diáclases sub-perpendiculares à falha são comuns.

A Estrutura de Alto Coité (Figura 6 e 33) está associada ao bloco baixo da Falha de Poxoréu, situada a $10 \mathrm{~km}$ a NE da localidade de Alto Coité. As falhas nessa estrutura são normais, de envergadura pequena e rejeito considerável, e suas cristas alinhadas obedecem a direção preferencial E-W, estando suportadas por silicificação intensa na Formação Palermo. No conjunto, a Estrutura de Alto Coité possue o formato semi-circular sugerindo uma provável intrusão.

As falhas das Parnaibas (Figura 10), segundo Barros et al. (1982), constituem um conjunto de falhas normais e sub-paralelas, situadas a $15 \mathrm{~km}$ à norte de Dom Aquino. Possuem direção NE e segundo os referidos autores, essas falhas seriam testemunhos da intensa fase de ativação relacionadas e contemporâneas em idade às Falhas de Poxoréu e Jaciara-Serra Grande. A Falha Jaciara-Serra Grande situa-se à SE entre a região falhada das Parnaibas e a Falha de Poxoréu, com direção concordante às mesmas. Em função da proximidade e paralelismo às falhas anteriormente descritas, Barros et al. (1982) considerou essa falha evoluída a partir de reflexos do Lineamento Transbrasiliano.

Na região do Alvo PG (Figura 8), existem inúmeros alinhamentos observáveis em imagens de fotografias aéreas e de radar, que são coincidentes com o Lineamento Transbrasiliano. Entretanto, os diques de Paredão Grande estão encaixados segundo as direções $\mathrm{N} 40^{\circ}-50^{\circ} \mathrm{W}$ proporcionando no conjunto um padrão "en echelon" (Weska et al., 1992). O encaixamento NW também foi observado no Dique Primavera (Fotografia 10b). Segundo Milani (1988, In: Gabaglia \& Milani, 1990) dentre os elementos chave para o diagnóstico do estilo estrutural, o arranjo espacial das estruturas é de particular importância. No caso, uma distribuição "en echelon" consiste numa organização de elementos paralelos uns aos outros, mas posicionados obliquamente em relação à zona de deformação. Já os diques da Mata e da Matinha na região da Chapada dos Guimarães, estão encaixados segundo a direção NE (Weska, 1987). Na região do Alvo PG, Uggeri \& Costa (1992) registraram que os falhamentos NW truncam os de direção NE. Na região da Chapada dos Guimarães, Weska (1987) descreveu que falhamentos NW são truncados pelos de direção NE. 
O Alto da Raizinha (Figuras 33 e 34) é caracterizado por um total de 10 pequenos derrames (Tabela 1), estando situado próximo à Falha de Poxoréu no Alvo PX e possuindo alinhamento oblíquo aproximadamente N-S. O Alto da Passagem do Mamão na Chapada dos Guimarães, apesar de recoberto pela cobertura terciário-quaternária, sugere também direção N-S para o encaixamento daqueles corpos.

O Arco de São Vicente (Figura34), segundo Oliveira \& Mühlmann (1967) é um soerguimento alongado de direção NE, situado na serra homônina no Estado de Mato Grosso. De acordo com Almeida (1983), este arco iniciou a sua atividade ascencional provavelmente durante o Paleozóico, sendo contudo, difícil apreciar sua atividade tectônica no Mesozóico.

A Antéclise de Rondonópolis (Coimbra, 1991), encerra elementos estruturais importantes relacionados ao denominado "Lineamento Transbrasiliano". Segundo o referido autor, a Antéclise de Rondonópolis seria um alto topográfico situado entre as Bacias Bauru à SE e Parecis à NW.

Com base nos elementos estruturais anteriormente descritos, destaca-se o Arco de São Vicente e a Antéclise de Rondonópolis como elementos estruturais regionais pré sedimentação da Bacia Bauru. A Estrutura de Alto Coité e os Altos da Raizinha e da Passagem do Mamão, destacam-se como elementos estruturais sin deposicionais e internos à bacia. Os falhamentos NE preenchidos pelos diques da Mata e da Matinha, são relacionados a eventos distensivos. Já os falhamentos NW que permitiram o encaixamento dos diques com padrão "en echelon" resultam de eventos compressivos. Os falhamentos e fraturamentos N-S e E-W, parecem estar relacionados aos falhamentos NE. No conjunto, a tectônica rígida é resultado da reativação dos alinhamentos estruturais mais antigos e em termos cronólógicos, os dados até então existentes em relação aos truncamentos NE-NW (Uggeri \& Costa, 1992) e NW-NE (Weska, 1987) não permitem estabelecer uma sequência clara de eventos rúpteis desde os mais antigos até os mais recentes. Entretanto, a variedade de situações de truncamentos de falhas evidenciam atividades tectônicas cíclicas desde o cretáceo superior até o quaternário (Bacia do Pantanal). 


\section{3 - Evolução geomorfológica}

Estudos geomorfológicos de caracterização das formas de relevo já foram apresentados no Capítulo 3. Esses estudos são de grande importância à prospecção e à pesquisa de depósitos do tipo placeres ou paleoplaceres diamantíferos, permitindo ao geólogo definir critérios e guias (Weska et al., 1984), sendo úteis também para a descoberta de jazidas de Au, Sn, assim como outros tipos de minérios detríticos.

Na região estudada nesta Tese, pretende-se tratar da evolução geomorfológica do Cretáceo Superior ao Quaternário, como forma de melhor entender a paisagem modelada observada nos dias atuais. Trata também dos fatores endógenos e exógenos que combinados atuaram na formação de jazidas aluviais quaternárias recentes, dispostas em canais e planícies de inundação (Facies Coité) e em terraços laterais (Unidade Terciário-Quaternário Indiviso).

Os primeiros estudos regionais relativos à evolução geomorfológica do Cretáceo Superior ao Quaternário, abrangendo uma área de aproximadamente $350.000 \mathrm{~km}^{2}$ e englobando as regiões de Dom Aquino, Poxoréu, Paredão Grande e Meruri, estudadas nessa Tese, foram realizados por Brunsden et al. (1981). Nesse trabalho, os referidos autores estudaram uma região de aproximadamente $1.150 \mathrm{~km}$ segundo sentido E-W ao longo do divisor de águas atual entre as Bacias Amazônica à norte e a do Prata à sul, que são mostradas na Figura 35. Entre outras questões, tal estudo mostra dados a respeito de cotas topográficas que caracterizam a Superficie Sul Americana (King, 1956), denotando um caimento superficial nas direções NW, N e NE. Mostra também, a evolução dos Rios Cuiabá, Paraguai, Arinos, Teles Pires e das Mortes durante - Terciário e o Quatemário, bem como a captura de cabeceiras desenvolvida pela Bacia do Prata sobre a Amazònica (Figura 35).

Os estudos a respeito da evolução geomorfológica de Brunsden et al. (1981), foram utilizados por Weska (1987) na região da Chapada dos Guimarães, permitindo ao autor caracterizar a nível de detalhe uma das cabeceiras do Rio Cuiabá, bem como os depósitos do tipo placeres de idade Quaternária (Fácies Água Fria e Peba), o leque aluvial na Fazenda Três Casais de idade terciária (Fácies Estiva), e por último o meio graben desenvolvido durante o Cretáceo Superior. Esse graben constiuiu a paleosuperficie substrato para a deposição de rochas do Grupo Bauru, hospedeiras intermediárias de diamantes entre os depósitos recentes e as prováveis áreas fontes primárias. 


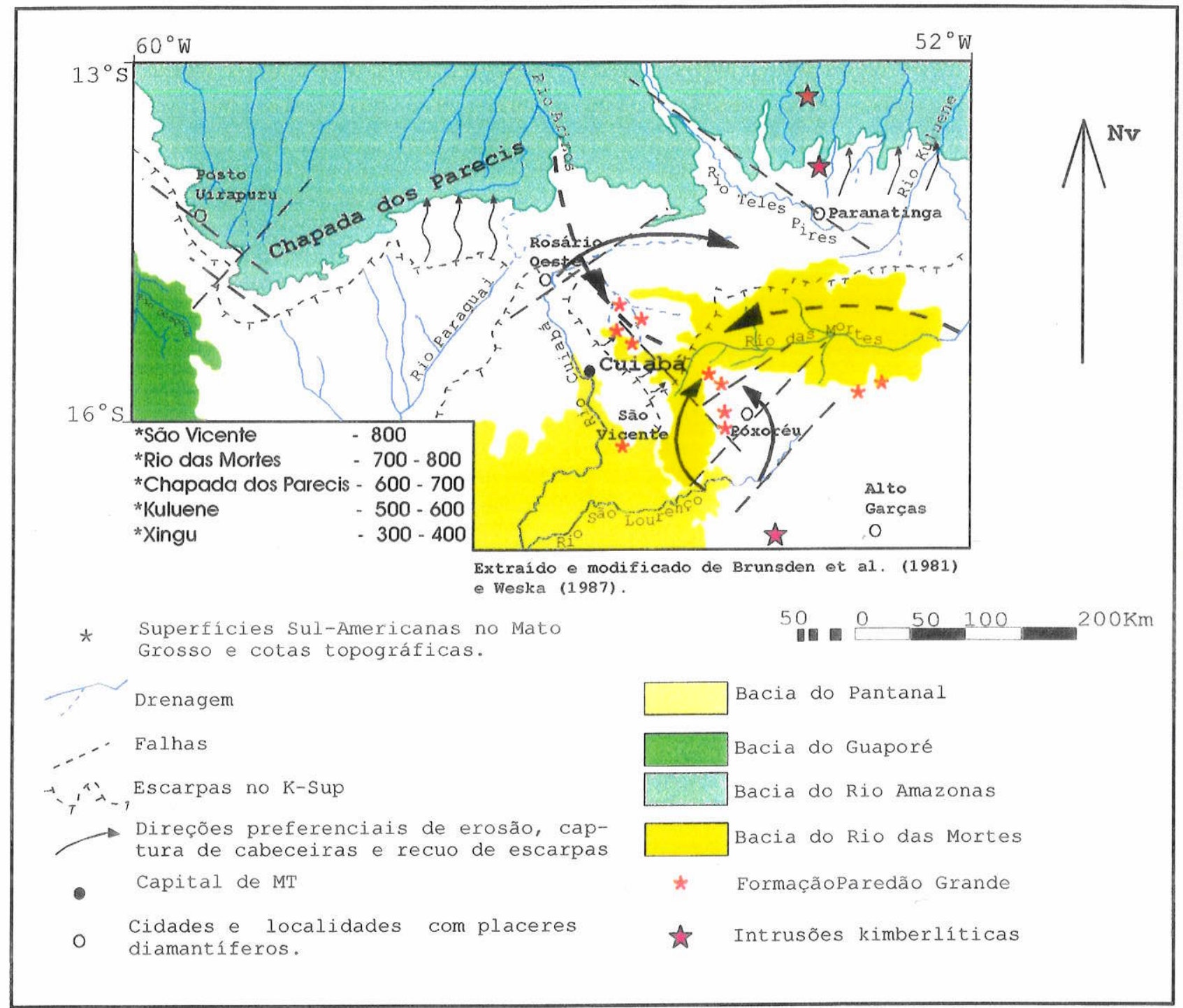

Figura 35 - Evolução geomorfológica de parte do Estado de Mato Grosso do Cretáceo Superior ao Quaternário. As setas com traços inercalados mostram a captura de cabeceiras durante 0 Terciário e as linhas cheias a captura desenvolvinda pela drenagem que escoa em direção à Bacia do Pantanal. 
No Cretáceo Superior a área em apreço foi palco de epirogênese positiva, como parte do arqueamento superficial imposto pela Pluma de Trindade (Gibson et al., 1996 - in press). Essa área, registra vocação para a epirogênese positiva, fato esse facilmente explicável através do seu posicionamento paleogegráfico de provável divisor de águas entre as Bacias do Paraná à SE e a Amazônica à NW. Por outro lado, a sua coluna estratigráfica é incompleta em Chapada dos Guimarães e Poxoréu, evidenciando que na região predominaram erosões em detrimento de sedimentação. Gonçalves \& Schneider (1970), pressupõem epirogênese positiva final para o Arco de São Vicente coincidindo com o início da sedimentação dos desertos Botucatu no Mesozóico.

Cessado o arqueamento superficial, tensores distensivos de direções NW e SE riftearam a região invertendo o relevo, uma vez que a faixa entumecida e antes área de erosão, desenvolveu baixos topográficos que transformam-se em sitios de deposição das Formações Quilombinho, Cachoeira do Bom Jardim e Cambambe. Tal bacia deposicional foi delimitada à SE pelo horste Rondonópolis e, internamente entre Chapada dos Guimarães e Poxoréu, pelo horste de São Vicente (Figura 36). O paleorelevo cretáceo por conseguinte, a partir desses eventos, por complexa e cíclica tectônica rúptil pré e sin-deposicional, desenvolveu escarpamentos acentuados delimitados lateralmente por baixos topográficos. Com base nas sequências grossas basais a finas no topo, registradas nas unidades litoestratigráficas do Grupo Bauru, pressupõe-se além da fase tectônica principal, no mínimo mais dois rejuvenescimentos importantes caracterizados pelos contatos discordantes erosivos das Formaçòes Cachoeira do Bom Jardim e Cambambe.

Weska (1987), correlacionando topograficamente afloramentos da Formação Botucatu que bordejam as porções SW,S e SE da Chapada dos Guimarães com aqueles que ocorrem na porção interna rebaixada no Campestre (Passagem do Mamão), considerou que rejeitos de falhas com 250 a $400 \mathrm{~m}$ devem ter ocorrido durante esta fase de evolução do relevo cretáceo, pressupondo que acima das superficies Sul.

Americana os relevos escarpados poderiam ter atingido tais diferenças topográficas positivas. Entretanto, os processos de aplainamento foram tão acentuados que resultaram em chapadões. Tais chapadões (planaltos) portanto, são testemunhos morfológicos da peneplanização Sul Americana, marcando em termos litológicos uma discordância erosiva regional importante que aplainou completamente a paleosuperfície cretácea. Segundo Vieira (1965), esses eventos constituiriam o terceiro ciclo erosivo em escala regional no Estado de Mato Grosso. 


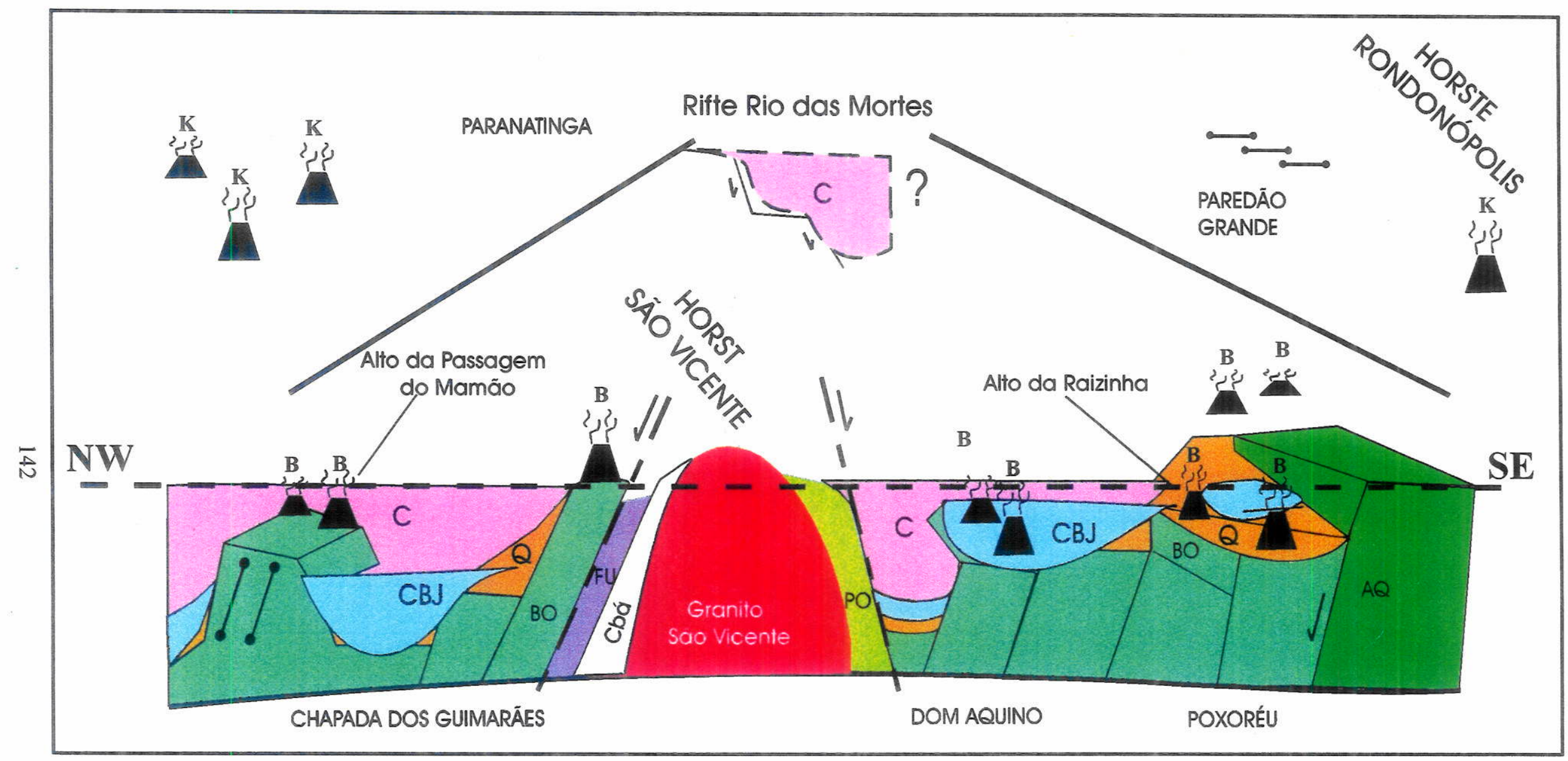

Figura 36 - Esboço tectônico do Rifte Rio das Mortes em corte SE-NW. Grupo Bauru (B e / ) com rochas das Formações Paredão Grande; e Formações (Q) Quilombinho, (CBJ) Cachoeira do Bom Jardim e (C) Cambambe; e Botucatu (BO), Aquidauana (AQ), Ponta Grossa (PO), Furnas (FU), Granito São Vicente e o Grupo Cuiabá ( Cbá ). 
$\mathrm{Na}$ área compreendida entre Dom Aquino a General Carneiro, uma segunda inversão de relevo ocorreu já dentro do Terciário, correspondendo aos eventos erosivos e deposicionais relativos à Bacia Intracratônica do Pantanal. Essa área, uma bacia de deposição durante o Cretáceo Superior e parte do Terciário, torna-se área fonte de sedimentos da Bacia do Pantanal a partir do Terciário até os dias atuais.

Com base em dados do autor ainda não publicados, é provavel que durante os tempos terciários as cabeceiras dos Rios Arinos e das Mortes tenham estado localizadas na Chapada dos Guimarães e a SE da Serra de São Vicente, respectivamente, conforme mostram as setas interrompidas da Figura 35. Em contrapartida, durante o Quaternário o Rio Cuiabá capturou o Rio Arinos por erosão remontante, evoluindo até as cabeceira atuais em Paranatinga (Córrego Cavalo) e Chapada dos Guimaràes (Rios Manso, Roncador e Quilombo). O Rio Paraguai evoluiu em direção as cidades do Alto Paraguai e Diamantino. Ambos exumaram e esculturaram as suas cabeceiras resultando em superficies rebaixadas em relação à Superficie Sul Americana que ocupa posições de interflúvios entre essas bacias hidrográficas. Essas capturas estão mostradas na Figura 35 por meio de setas contínuas.

Na área estudada, o Rio Poxoréu (Alvo PX), o Ribeirão Parnaíba e o Córrego Lambança (Alvo DA), o Rio Barreiro e Córregos Aroeira, João Batista e Revoltoso (Alvo PG), entre outros, evidenciam forte controle estrutural segundo as direções NW e NE, e secundariamente N-S e E-W. São comuns a essas drenagens padrões retangulares e subretangulares. Destaca-se a captura de cabeceiras desenvolvida durante o Quaternário pela bacia hidrográfica do Rio São Lourenço, através do Rio Poxoréu; Ribeirão Parnaíba e Córrego Lambança (Figuras 6 e 10). Desses processos de exumação e esculturação resultaram por processos endógenos, o Alto da Raizinha, a Estrutura de Alto Coité que provavelmente registra a morfologia de uma intrusão junto a Falha de Poxoréu, os blocos basculados e as escarpas de falha. Processos exógenos, por outro lado, produziram terraços laterais às bacias de drenagens, morros testemunhos derivados da captura de cabeceiras por erosão remontante, escarpas erosivas controladas por fraturas e falhas reativadas no cretáceo e os depósitos de talus junto as escarpas (depósitos aluviais).

A Estrutura de Alto Coité, de provável origem endógena, parece ter controlado a paleosuperficie junto à Falha de Poxoréu do cretáceo até os dias atuais. Assim sendo, a ausência de depósitos da Formação Quilombinho próximos a esse alto pode ser explicada pelo nivelamento da escarpa de falha com esse alto. Por outro lado, essa feição comportou-se como cabeceiras de 
drenagem paralelas à falha. Nos dias atuais, o formato semi-circular do Córrego Poruba que circunda o alto, registra forte controle estrutural exercido por essa feição sobre a evolução desse córrego (Figuras 6, 33, 34 e 36).

Entre a região mapeada nos Alvos DA e PX, o Alto da Raizinha constitue um divisor de águas atual entre as cabeceiras do Ribeirão Parnaíba e do Rio Poxoreuzinho (Figura 6). Esse alto parece ter se comportado também como barreira geomorfológica durante o Cretáceo Superior (Figura 33 ).

A Intrusão Tamburi sofre nos dias atuais, a captura desenvolvida pelas porções de cabeceiras do Rio Paraíso (Córregos Tamburi e das Cobras). A erosão remontante dessas drenagens sobre a Superficie Sul Americana que encerra essa intrusão, ressalta o corpo por erosão diferencial do mesma. Nesse caso, o alto topográfico é sustentado por arenitos silicificados da Formação Aquidauana resistentes aos processos erosivos atuais (Fotografia 6). De igual modo, tais processos erosivos exumaram os diques de Paredão Grande, o Primavera e os da região do Meruri, destacando-os também como altos topográficos (Fotografias 10a, b e c, respectivamente).

\subsection{Evolução geotectônica}

A bacia cretácea estudada, é constituída por um conjunto de eventos magmáticos, detríticos (grossos a finos) e químicos (carbonático e silicoso), sendo limitada à norte pelo Cráton Amazônico recoberto pela Faixa de Dobramentos Paraguai; e a sul, pelos sedimentos da borda extremo noroeste da Bacia Intracratônica do Paraná. A Figura 34, ressalta esse posicionamento, bem como outros elementos estruturais internos à essa bacia, já descritos no Capitulo 6.2.

O primeiro modelo geotectônico evolutivo dessa bacia foi proposto por Coimbra (1991), que a partir de elementos estruturais importantes a nível de Plataforma Sul- Americana, individualizou a Antéclise de Rondonópolis, feição tectônica controladora da sedimentação no Cretáceo Superior. Tal estrutura, concide com a Zona de Falhas Transbrasiliano (Zalán et al.,1986) englobando as bacias denominadas de Cambambe, Poxoréu e Itiquira, de noroeste para sudeste (Coimbra, 1991). Tal compartimentação, segundo o referido autor, tornou-se necessária uma vez que as principais bacias cretáceas brasileiras alojam-se sobre áreas cratônicas, como por exemplo a Parecis à noroeste e Bauru à sudeste, enquanto que as bacias Cambambe, Poxoréu e Itiquira estariam situadas no domínio de terrenos brasilianos. 
Detalhando a evolução tectônica, Coimbra (1991) concluiu: "a Antéclise de Rondonópolis é uma feição de direção ENE de marcada atividade no Mesozóico. No Cretáceo Superior, como ressultado dos esforços compressivos na borda oeste da Placa Sul-Americana, falhamentos ENE, longitudinais à feiçào, foram reativados com características transtracionais (transcorrência sinistral), ensejando a deposição de significativa espessura de sedimentos continentais em bacias romboidais, tipo "pull apart", em arranjo lazy - Z (bacias do Cambambe, Poxoréu e Itiquira). Entre o Cretáceo Superior e o Terciário, com o predomínio de esforços compressivos vindos de leste (Cadeia Meso-Atlântica) sobre os Andinos, a região sofre transpressão (transcorrência dextral), com soerguimento e erosão, possível separação entre as bacias anteriormente ligadas (bacias Cambambe e Poxoréu e bacias de Itiquira e Bauru), e geração da discordância pré-Formação Cachoeirinha."

Weska et al. (1993) e Fleischer (1993) propuseram modelos semelhantes do tipo rifte, no qual predominaram esforços tectônicos distensivos em detrimento de esforços trasncorrentes.

A partir do referido quadro tectônico, procuramos aprofundar a questão relativa à evolução tectono-sedimentar da região compreendida entre Chapada dos Guimarães, Poxoréu e Paranatinga, tomando por base os estudos de fácies e de sistemas deposicionais de Weska (1987) na região da Chapada dos Guimarães, das regiões de Dom Aquino, Poxoréu, Paredão Grande e Meruri englobadas por essa Tese, bem como os trabalhos Pinho et al. (1994) e Macedo et al. (1995) para a região de Paranatinga. Tais estudos, permitiram a elaboração do diagrama esquemático da Figura 36. Conforme mostrado nessa figura, o paleorelevo do tipo meio graben, com caimento em direção norte, repetiu-se na região de Poxoréu, onde o mapeamento realizado no Alvo PX evidenciou eventos deposicionais e magmáticos alcalinos de borda do rifte. No Alvo DA, ocorrem eventos similares aos descritos no PX, porém, internos ao rifte. No Alvo PG, eventos intrusivos e extrusivos de mesma composição àqueles mapeados nos Alvos PX e DA, situam-se no horste lateral ao rifte, já definidos como pertencentes a Formação Paredão Grande. Assim sendo, para o estudo da evolução geotectônica, os dados relativos aos sistemas deposicionais foram complementados por informações a respeito do magmatismo associado a esse rifte.

No horste Rondonópolis mapeamos também uma intrusão de natureza kimberlítica aqui denominada de Tamburi, intrudida portanto, em ambiente geotectônico de borda de uma bacia intracratônica (Bacia do Paraná), diferentemente das intrusões kimberlíticas de Paranatinga 
que parecem (Pinho et al., 1994) situar-se nas bordas S-SE do Cráton Amazônico (Figuras34 e $36)$.

Os registros geotectônicos mais antigos estão representados à norte pela Faixa de Dobramentos Paraguai que atingiram o estágio de ortoplataforma no final do Ciclo Brasiliano (Weska et al, 1993). Durante o Paleozóico, a região passou por uma relativa estabilidade crustal que prosseguiu até meados do Mesozóico, quando então inúmeras intrusões kimberlíticas intrudiram a região constituíndo a Província Kimberlítica de Paranatinga (Fragomeni, 1976), com encaixamentos segundo as direções NW e secundariamente NE. A Intrusão Tamburi (Alvo PG) encaixou-se segundo a direção NW (Figura 12). Tais eventos são cronocorrelatos aos estágios iniciais da separação continental dos continentes africano e sul-americano e aos extensos derrames de composição basáltica da Formação Serra Geral (Peccirillo \& Melfi, 1988).

Segundo Gibson et al. (1996 - in press), no Cretáceo Superior o magmatismo da Formação Paredão Grande foi resultado da atuação da Pluma de Trindade (Figuras 37 e 38) sob o oeste brasileiro. Os referidos autores sugerem também que esta mesma pluma, além de ter sido responsável pelos eventos magmaticos relativos a Província Ígnea de Poxoréu, também foi responsável pelos eventos magmáticos ocorridos na Província Iporá e do Alto Paranaíba, conforme mostrado na Figura 38, com idade em torno de 85Ma..

Conforme Wilson (1994), a instalação da pluma produz adelgaçamento e entumecimento crustal, resultantes de movimentos convectivos mantélicos. Essa fase de arqueamento superficial é seguida por uma tectônica rúptil de natureza distensiva, proporcionando assim o surgimento de áreas elevadas, como por exemplo feições de horste, associadas a regiões topograficamente rebaixadas os grabens. No presente caso, o horste Rondonópolis constitue as porções laterais elevadas em direção SE e o horste São Vicente, um alto topográfico interno ao rifte de direção NE que comportou-se de forma rígida a tectônica distensiva para o desenvolvimento dos meio-grabens de Chapada dos Guimarães (Weska, 1987) e Poxoréu (Weska et al., 1993) Figura 36. Com relação ao adelgaçamento crustal, os estudos petrogenéticos de modelamentos inversos de elementos do grupo das terras raras realizados por Gibson et al. (1.996 - in press), sugerem que a fusão magmática dos tipos litológicos da Formação Paredão Grande ocorreu a profundidades entre 50 a $105 \mathrm{~km}$, aproximadamente. Essa fusão teria ocorrido no limite entre a litosfera subcontinental e o manto superior convectivo a temperaturas da ordem de $1.500{ }^{\circ} \mathrm{C}$. Quando comparamos esses dados com aqueles reportados por Gibson et al. (1995) para o magmatismo cronocorrelato da Província Ígnea do Alto 


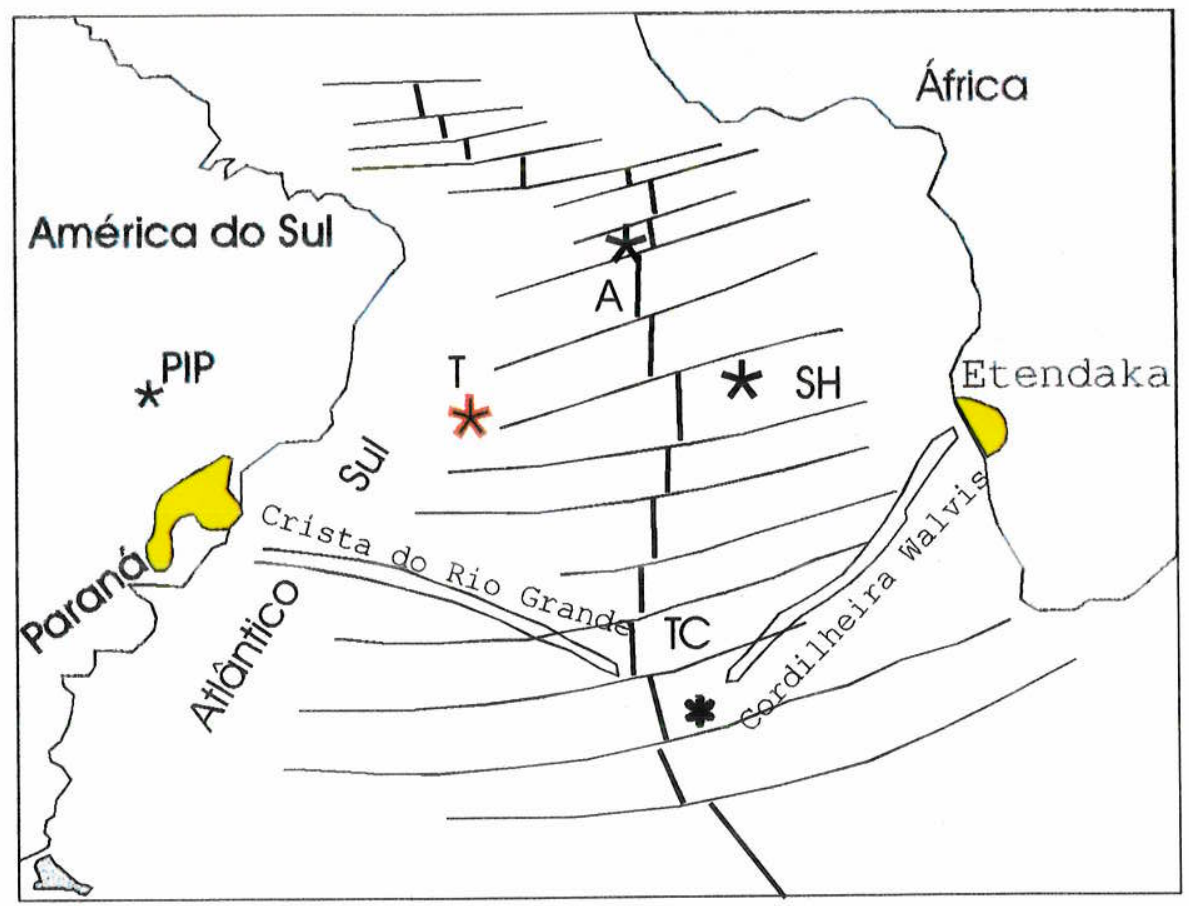

Figura 37 - A Província de Ígnea de Poxoréu (PIP) e as plumas de, A- Ascenção; SH- Santa Helena; TC- Tristão da Cunha e T-Trindade. Modificado a partir de Wilson(1994).

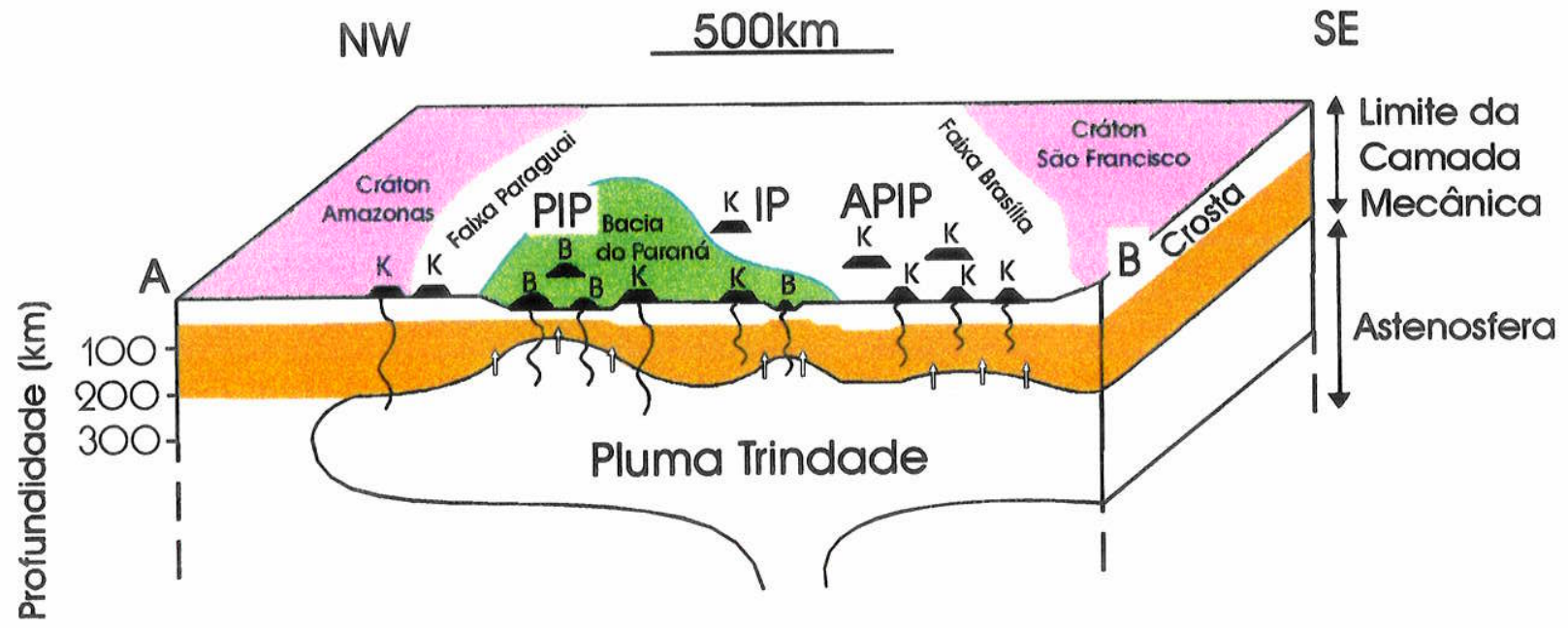

Figura 38 - Diagrama mostrando a atuação da Pluma de Trindade sob o oeste do Brasil. K Intrusões de natureza kimberlítica; B - basaltos; PIP - Província Ígnea de Poxoréu; IP - Província de Iporá e APIP - Província do Alto Paranaíba. Extraído de Gibson et al. (1996 in press). 
Paranaiba, conclue-se que o adelgaçamento crustal do oeste brasileiro é maior quando comparado ao oeste mineiro (Figura 38). Em consequência desse fato, tanto o magmatismo como a litosfera subcontinental da Província Ígnea de Poxoréu são menos profundos do que aqueles do Alto Paranaíba (Figura 38).

Os efeitos da Pluma de Trindade manifestaram-se na região estudada através do magmatismo descrito no Capítulo 5 (Formação Paredão Grande), exemplificado e posicionado em relação ao rifte, por um perfil SE-NW com a seguinte distribuição: Diques de Meruri, Paredão Grande e Primavera encaixados segundo a direção $N 40^{\circ}-50^{\circ} \mathrm{W}$; Derrames da Raizinha segundo o alinhamento N-S; Derrames da Lajinha e do Córrego Preto segundo a direção NE (?); Derrames da Passagem do Mamão segundo a direção N-S (?), e finalmente os diques da Mata e da Matinua com direções $\mathrm{N} 45^{\circ} \mathrm{E}$.

A partir desse arcabouço de padrão de encaixamento variado, a princípio, poderíamos considerar que os diques da Mata e da Matinha e os Derrames da Lajinha e

do Córrego Preto, seriam contemporâneos à fase distensiva NW-SE de geração do rifte. Por outro lado, os diques Paredão Grande e Primavera de direções NW seriam resultantes de uma fase distensiva NE-SW. Já os Derrames da Raizinha e da Passagem do Mamão com direções N-S (?), seriam resultantes de reativações cretáceas segundo falhamentos mais antigos do embasamento. Na verdade esse quadro tectônico simples não corresponde a realidade. Assim sendo, mesmo que analisados com reservas a datação $\mathrm{K} / \mathrm{Ar}$ do dique da Matinha forneceu a idade de 72 Ma. Os Derrames da Raizinha forneceram idade de 83.9 \pm 0.4 Ma. Os Derrames da Lajinha e do Córrego Preto, estratigraficamente são superiores aos da Raizinha, sendo portanto mais jovens, além de serem composicionalmente mais diferenciados que os primeiros. A Estrutura do Alto Coité situada junto à falha de Poxoréu sugere uma intrusão de encaixamento similar aos da Lajinha e do Córrego Preto. Já os diques de Paredão Grande, a partir do seu padrão de encaixamento "en echelon" sugerem movimentos transcorrentes dextrais a partir de esforços compressivos oblíquos à zona de falhamentos NE. Mostra-se, portanto, no conjunto que tais estruturas de falhamentos regionais NW, NE e N-S foram reativadas em vários cíclos, posteriormente à fase distensiva principal geradora do rifte. Vemos portanto, a partir dos dados existentes, que no momento não existem condições adequadas para definirmos uma sequência cronológica detalhada dos inúmeros eventos tectônicos relacionados a esse rifte. Os dados 
conhecidos permitiram definir uma fase distensiva principal do rifte com tensores NW-SE, associada a movimento transcorrente dextral (Diques de Paredão Grande).

Os sedimentos derivados de áreas fontes resultantes desse magmatismo, originaram os pacotes rudáceos a pelitos da Formação Quilombinho, unidade essa tipicamente vulcano-derivada. que no conjunto apresentam granodecrescência em direção ao topo. Os registros de gradação inversa registrados por Weska (1987) na Chapada dos Guimarães, foram observados no Alvo PX evidenciando reativações tectônicas sin-sedimentação. A continuação destes eventos também é registrada pela ciclicidade da intercalação de conglomerados grossos em detritos finos da Formação Cachoeira do Bom Jardim. As calcretes resultantes de atividades evaporíticas (sabkhas interioranas), são também evidências de períodos de relativa estabilidade tectônica. Esses registros no conjunto representam a fase termo mecânica e de subsidência do rifte.

A Formação Cambambe, topo dessa sequência, constituida por um conjunto de conglomerados basais (Weska, 1987) que variam de grossos na base a finos no topo, representam nova retomada da atividade tectônica na bacia, com rejuvenescimento das áreas fontes. $\mathrm{A}$ ausência de magmatismo de composição basáltica, associado aos contatos transgressivos (onlap) observados nessa unidade, constituem evidências da fase de resfriamento desse rifte, marcando também o encerramento da atividade da Pluma de Trindade na região. As silcretes, são resultantes da retomada da fase evaporitica de tendência ao extremo árido.

Os trabalhos realizados por Pinho et al. (1994) e Macedo et al. (1995) na região de Paranatinga, mostraram que a situação de meio grabem se repete nessa área. Entretanto, o caimento da paleosuperficie é de sentido oposto, sendo para SE. Os dados até então obtidos sugerem que esse rifte seja assimétrico. Tendo em vista esses elementos, propomos a denominação de Rifte Rio das Mortes (Weska et al., 1996) para essa estrutura desenvolvida no Cretáceo Superior, em referência ao rio homônimo, cujo leito acompanha aproximadamente a maior dimensão do rifte.

Durante o Terciário e o Quaternário, a área estudada foi provavelmente afetada pela tectônica relativa ao desenvolvimento da Bacia Intracratônica do Pantanal, muito embora não existam registros nas rochas dessa neotectônica. Aqui, o problema é similar aos que ocorrem nos pacotes cretáceos, onde a presença de coberturas espessas mascaram tais registros. 


\section{7 - TIPOS DE DEPÓSITOS E ARMADILHAS DO DIAMANTE}

A nível mundial, a prospecção e a pesquisa do diamante desenvolvem-se segundo duas linhas principais, ou seja: em fontes primárias representadas por kimberlitos e lamproitos, ou em fontes secundárias do tipo aluviões ou paleoaluviões. Em relação às fontes primárias kimberlíticas, destacam-se o continente africano, a plataforma siberiana, assim como os lamproitos na Austrália. O Brasil, em especial o Estado de Mato Grosso, tem se mostrado ao longo dos anos um campo fértil para o desenvolvimento de projetos com vistas à delimitação de jazidas do tipo "placer", como por exemplo, as minas do Arranha Céu de NortelândiaArenápolis, porção de cabeceiras do Rio Paraguai, Rio Santana em Nortelândia, Rio Coité (Poxoréu), bem como os placeres da região de Juína. Com exceção de Juína onde os diamantes são do tipo indústria, nas demais áreas predomina o diamante gemológico com tamanho médio da ordem de $3: 1(3: 1=3$ pedras de diamante em um quilate; 1 quilate (ct) é igual a 100 pontos $=$ $0,2 \mathrm{~g}$ ). Corpos primários de natureza kimberlítica localizados estudados no Brasil por empresas internacionais de minereção até a presente data não resultaram em jazidas primárias economicamente viáveis, como por exemplo as intrusões kimberlíticas de Paranatinga e Juína. Com relação à Intrusão Tamburi estudada nessa Tese, a presença de um microdiamante em amostragem por digestão ácida (Capítulo 5.1.4), não gera expectativas positivas a respeito da economicidade do corpo. Esse dado informa apenas a presença do diamante na rocha, sem contudo permitir o conhecimento do teor do corpo.

O Município de Poxoréu destaca-se no Estado desde a sua fundação pelas descobertas cíclicas de depósitos aluvionares diamantíferos através dos garimpeiros. No final da década de 70, a Mineração São José Ltda. foi responsável pela descoberta de um depósito aluvial diamantífero no Rio Coité. Infelizmente, tal projeto industrial foi interrompido por invasões de garimpeiros, como já relatado anteriormente, assim como outros projetos, com exceção daquele desenvolvido pelo Grupo Camargo Correia, Mineração Morro Vermelho Ltda., em operação no Município de Nortelândia. 
Os dados anteriormente relatados conduzem a concluir que o potencial de diamantes no Estado de Mato Grosso restringe-se somente às jazidas quaternárias recentes. Entretanto, como mostraremos no decorrer desse Capítulo, existe um potencial muito grande em depósitos de placeres e paleoplaceres entre o Quạternário e o Cretáceo Superior.

\section{1 - Distribuição no espaço e no tempo}

A avaliação econômica de um jazimento aluvionar diamantífero é revestida de inúmeras particularidades que escapam aos objetivos desse trabalho; contudo, algumas dessas peculiaridades merecem referência. Por exemplo, a distribuição do diamante nas aluviões é da ordem de ppb, enquanto que a do ouro é de ppm; a área mínima para a avaliação do diamante em amostragem é de $2 \times 2 \mathrm{~m}$, enquanto que a de ouro pode ser no máximo de $1 \times 1 \mathrm{~m}$, de tal forma que o teor resultante de uma avaliação econômica pode ser expresso $\mathrm{em} \mathrm{m}^{2}$ (Sichel, 1966). Esse fato é explicado pela distribuição heterogênea ou errática do diamante nos placeres.

Independentemente dessas questões, observa-se que as principais atividades extrativas desse mineral no Estado de Mato Grosso, ao longo dos tempos, tem se desenvolvido junto às principais drenagens da região, em seus terraços laterais de idade terciária (Exemplo: Fazenda Três Casais, Chapada dos Guimarães, Weska, 1987 e Weska et al., 1991), ou em conglomerados cretácicos das bacias Parecis e Bauru. $\mathrm{Na}$ bacia ora estudada, foram descritas atividades extrativas (garimpos) em conglomerados das Formações Quilombinho e Cachoeira do Bom Jardim, respectivamente basal e intermediária do Grupo Bauru (Weska et al., 1993 e Fleischer, 1993), como por exemplo, os garimpos da Raizinha e Balaio de Gato (Figura 6). Na Bacia Parecis, conglomerados de topo da Formação Parecis, intensamente silicificados e equivalentes à Formação Cambambe, topo do Grupo Bauru, constituem as principais áreas fontes intermediárias dos depósitos lavrados pela Mineração Morro Vermelho Ltda. (Grupo Camargo Correia).

O potencial diamantífero na área dessa Tese caracteriza-se pela existência de depósitos recentes (Fácies Coité ) a subrecentes (Unidade Terciário Quaternário Indiviso), assim como em conglomerados depositados durante o Cretáceo Superior. Não foram observadas atividades extrativas ou exploratórias em conglomerados da Formação Cachoeirinha, tal como descrito para a Fácies Estiva, de idade terciária (Weska, 1987 e Weska et al., 1991). Assim sendo, considerando todas as ocorrências estudadas neste trabalho, os depósitos detríticos de diamantes 
da região da Chapada dos Guimarães, Poxoréu e Nortelândia, espalham-se do Cretáceo Superior ao Quaternário.

\section{2 - Os tipos de depósitos}

Os placeres e paleoplaceres, quaternários a cretácicos, subdividem-se em dois tipos principais: o primeiro caracterizado por depósitos de canais de rios e terraços laterais resultantes do retrabalhamento lateral e encravamento vertical da drenagem, como parte da evolução da Bacia Intracratônica do Pantanal. O segundo tipo, de leques aluviais, são característicos de paleoplaceres cretáceos; entretanto, tais tipos de depósitos ocorrem também em menor escala no Terciário como na Fazenda Três Casais, Chapada dos Guimarães, e na jazida do Arranha Céu, Nortelândia-Arenápolis.

Os depósitos tipo placeres na área estudada subdividem-se ainda em depósitos eluviais, coluviais e aluviais. Os depósitos eluviais são aqueles caracterizados pelas superficies residuais descritas no Capítulo 5 referente à geologia local, em tipos litológicos cretácicos e na Unidade Terciário-Quaternário Indiviso mostrados nas Fotografias 30 e 35 . Os elúvios caracterizam-se pela concentração vertical do diamante, resultante da erosão a que essas áreas fontes intermediárias foram submetidas, com o transporte dos tipos litológicos mais finos (areias e argilas), porém sem capacidade de carga suficiente para transportar os seixos, matacões e o próprio diamante. Tais depósitos podem produzir concentrações significativas de diamante, entretanto, como possuem volume pequeno, tornam-se inviáveis à explorações industriais. Os depósitos coluviais nos Alvos PX, PG e DA, posicionam-se junto às escarpas de falha ou de erosão e nos morros testemunhos internos à bacia, sendo depósitos resultantes de pequeno transporte, produzidos por movimentos bruscos de massa (depósitos de talus). A distribuição do diamante neste tipo de depósito é errática devido a ausência de seleção (Fotografia 36). Os depósitos aluviais e principalmente aqueles de canais, ocorrem na região de Poxoréu, assim como de resto em todas bacias diamantíferas no Estado de Mato Grosso constituindo as jazidas mais importantes no tocante aos teores. Tais depósitos resultam de transportes a longa distância que associados a gradiente elevado e a capacidade de carga do meio transportador, proporcionam as condições adequadas à concentração do diamante (Fotografias 37 e 38). A jazida descoberta pela 


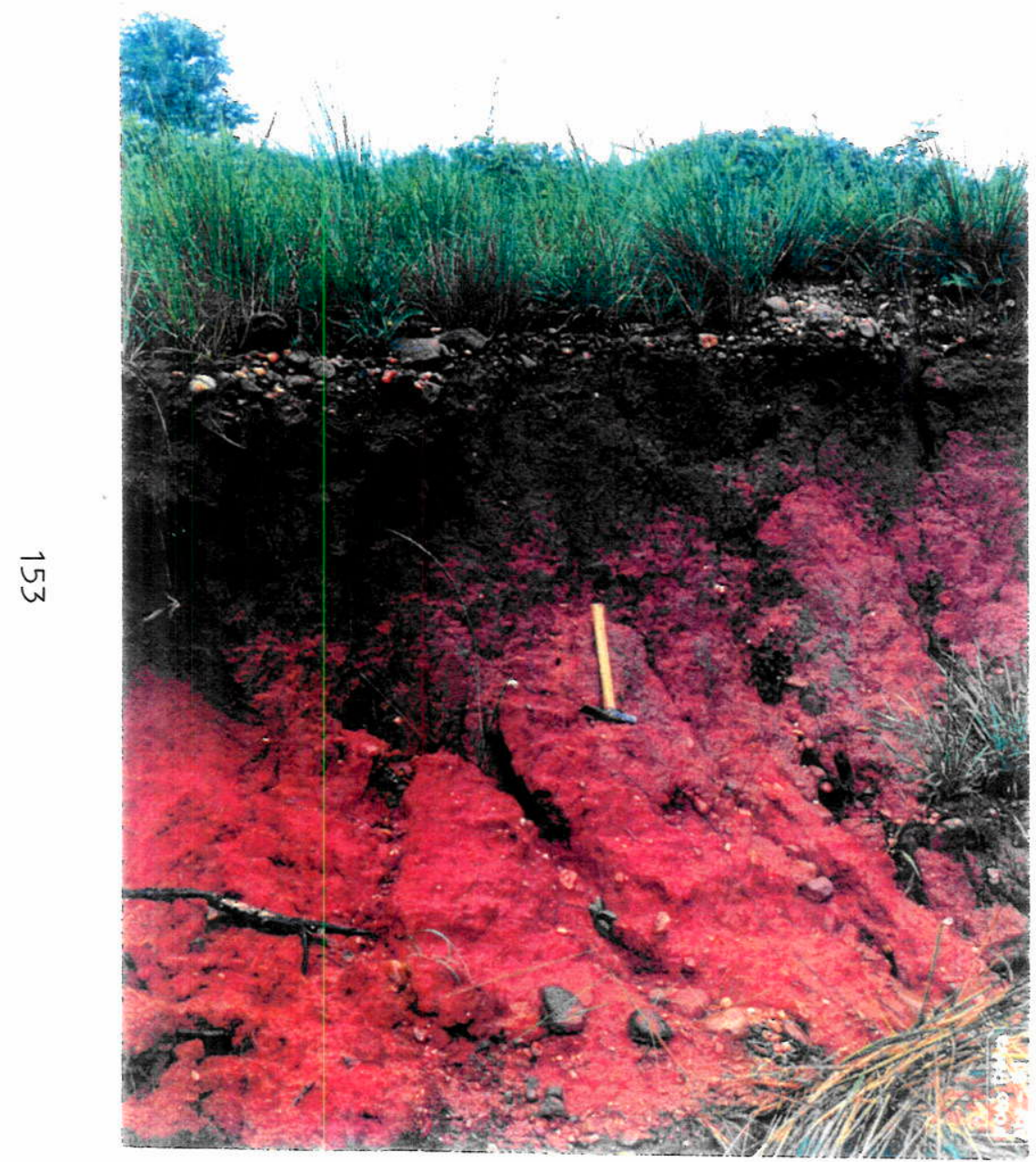

Fotografia 35 - Elúvio sobre o capeamento da Unidade Terciário Quaternário Indiviso UTQI (Alvo DA).

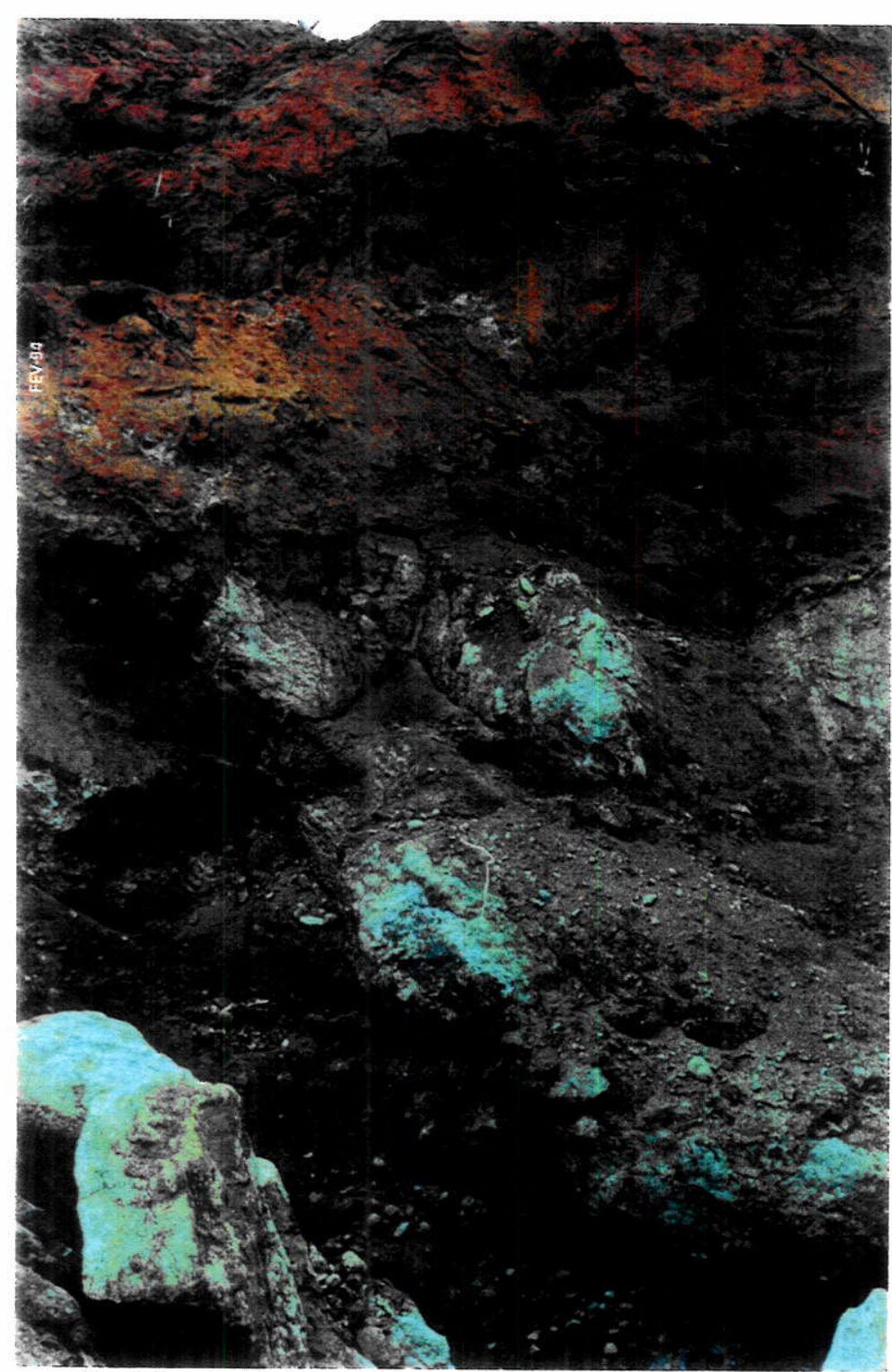

Fotografia 36 - Colúvio na Unidade Terciário Quaternário Indiviso Alvo PX. 


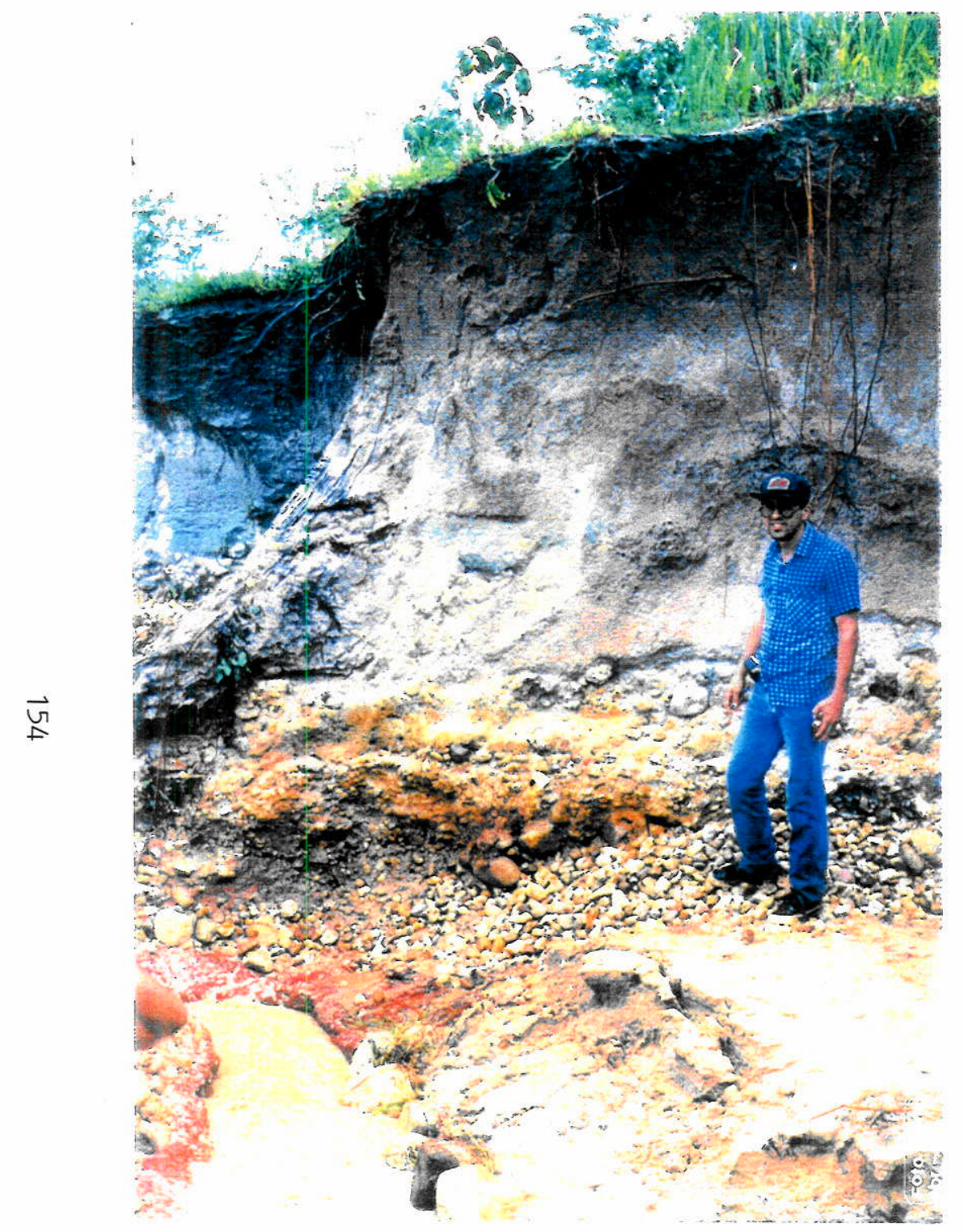

Fotografia 37 - Depósitos aluviais situados nas cabeceiras do Rio Coité (Alvo PX).

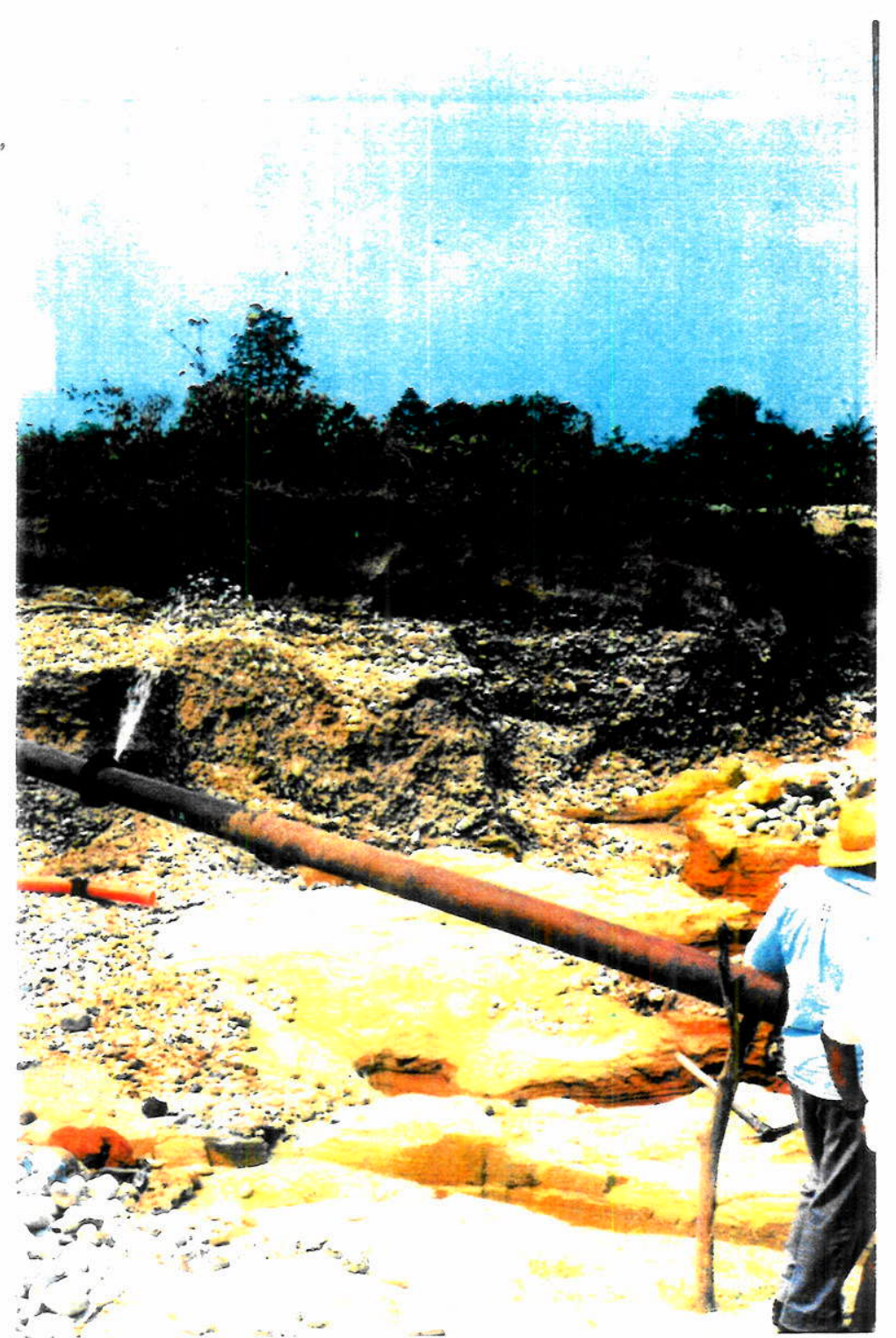

Fotografia 38 - Placeres aluviais recentes na região da Raizinha (Alvo PX). 
empresa Mineração São José Ltda. no Rio Coité, é o exemplo clássico deste tipo de depósito no Alvo PX (Figura 39 e Fotografia 39).

Nos depósitos de leques aluviais, as principais concentrações do diamante ocorrem nos paleocanais em detrimento das porções laterais onde a distribuição é errática. Nesse caso, a distribuição é mais errática do que aquela de depósitos quaternários.

\section{3 - As armadilhas (traps)}

A metodologia de prospecção do diamante em placeres a partir de suas armadilhas, representa uma importante ferramenta para a avaliação do potencial desse mineral durante as etapas de prospecção e pesquisa. Entretanto, a literatura nacional e internacional que trata do tema é restrita; assim sendo Smirnov (1976) trata do assunto parcialmente, tal como tratado por Muggeridge $(1986,1995)$ e Beckel (1984). Weska et al. (1984), descreveram as armadilhas dos depósitos aluviais terciários e quaternários da região de Alto Paraguai (MT); posteriormente, Weska (1987) e Weska et al. (1991) retomaram o tema na região da Chapada dos Guimarães (MT).

As armadilha (traps) descritas a seguir, são feições morfológicas concentradoras de diamantes originadas durante os eventos deposicionais, em ambiente aluvial a paleoaluvial, e que são resultantes de condicionamentos variados. Entre esses condicionamentos, destacam-se a hidrodinâmica do meio transportador, os tipos litológicos de "bedrocks", a tectônica e a evolução geomorfológica da bacia deposicional.

As armadilhas constituem-se importantes pontos preferenciais de concentração de diamantes a partir da perda brusca da capacidade de carga do meio transportador. Possuem dimensões variando entre centímetro a quilômetros, como por exemplo no Rio Itiquira na divisa entre MT/MS, onde ocorre um travessão originado de uma "cuesta" com mais de $20 \mathrm{~km}$ de comprimento. $O$ tamanho da armadilha também está diretamente relacionado ao tipo litológico do "bedrock". Assim sendo, arenitos imaturos são mais susceptíveis de desenvolverem "traps" quando comparados em ordem de importância com arenitos maturos, siltitos e argilitos.

O entendimento das armadilhas permite ao geólogo de prospecção a localização dos pontos prováveis de maior concentração de diamantes, a análise rápida do provável teor de um determinado "placer", bem como a obtenção de amostras representativas de volume reduzido. 


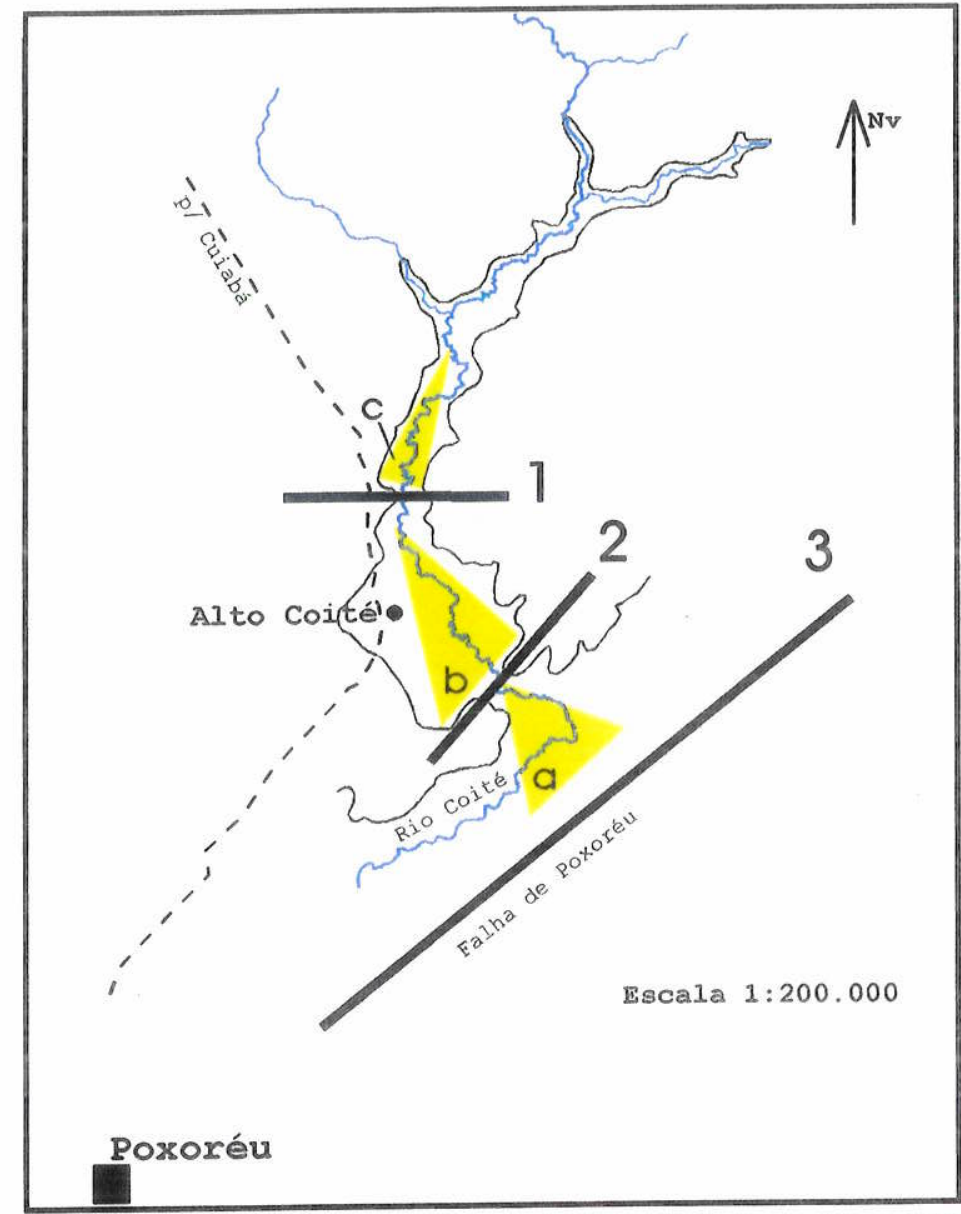

Figura 39-Armadilhas tipo travessão (1, 2 e 3$)$ controladoras das principais mineralizações aluviais ( $a, b$ e c) no Rio Coité (Alvo PX).

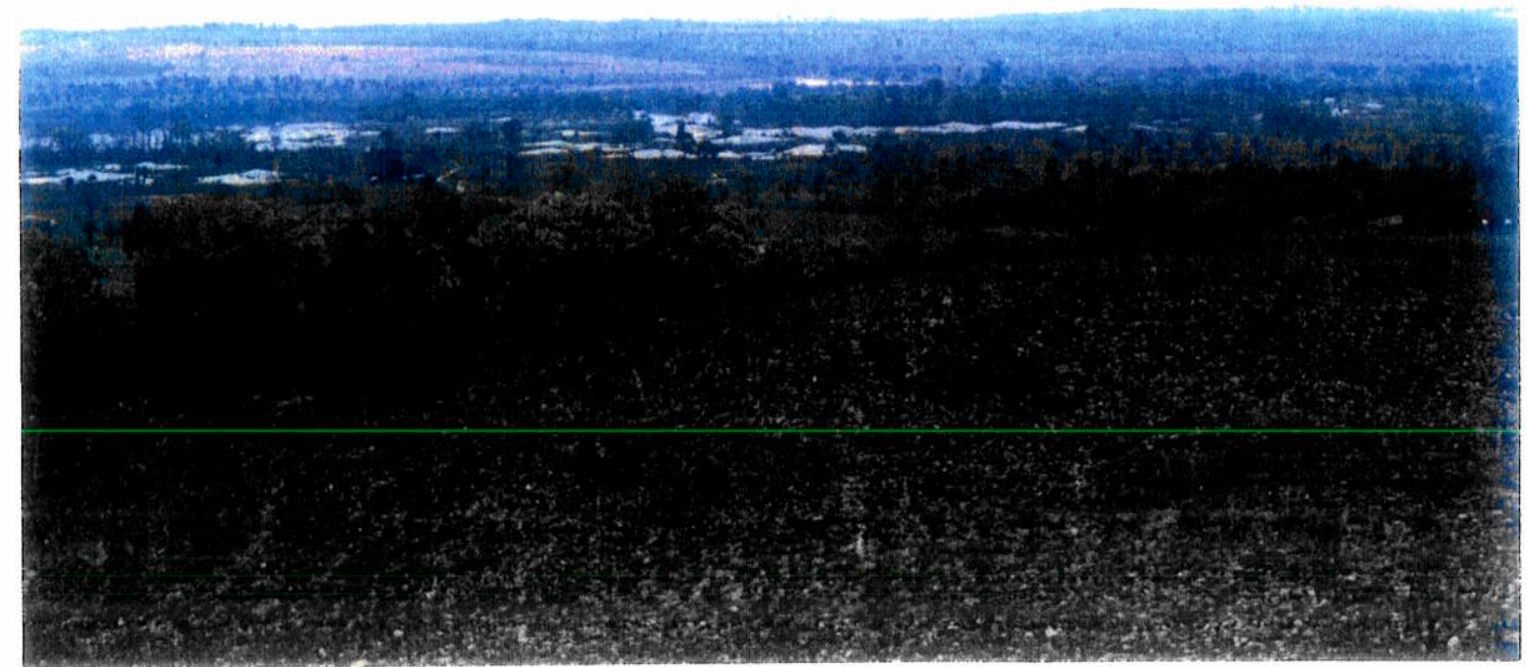

Fotografia 39 - Vista geral do Rio Coité nos depósitos formados à montante do travessão 1 mostrado na Figura 35. 
A terminologia dos tipos de armadilhas (traps) que utilizaremos nas áreas estudadas nesta Tese, possuem como base os trabalhos de Weska et al. (1984). Dentre os diversos tipos de armadilhas observados, nos Alvos PX, PG e DA, discutiremos por ordem de importância aqueles conhecidos na nomenclatura garimpeira por travessão, canoão, bolsão, ajogo, panela e veias.

Os "travessões" são barreiras geomorfológicas que se interpõem perpendicularmente ao canal do rio. Eles são originados a partir da erosão diferencial dos tipos litológicos que constituem o "bedrock", por condicionamento estrutural de falhamentos e dobramentos (mais raros), ou ainda por "cuestas" com mergulho de camada contrário ao escoamento da drenagem. Os principais depósitos ocorrem à montante da barreira geomorfológica, sendo exemplificados pelos depósitos recentes do Rio Coité, condicionados por 3 três travessões de médio porte, conforme mostrado na Figura 39. Os travessões 1 e 2 desenvolveram-se sobre litotipos da Formação Cachoeira do Bom Jardim, Grupo Bauru, enquanto o $3 \mathrm{em}$ tipos litológicos da Formação Aquidauana.

As armadilhas do tipo "canoão", são representadas por canais de corte e preenchimento (cut and fill) recentes a antigos, que podem ser identificados no campo a partir da observação da superfície onde ocorreu a deposição, podendo ser plana, ondulada ou irregular (Fotografia 29). Superficies onduladas ou irregulares denunciam sempre a presença de uma armadilha. Em uma situação mais sutil, o canal de corte e preenchimento pode ocorrer sobreposto a um pacote cascalhoso ou conglomerático; neste caso, dados a respeito do tamanho dos seixos e dos matacões, assim como o seu arcabouço, permitem a individualização da armadilha. Na realidade, os canoões representam o paleocanal e os tributários da bacia de drenagem. Quando de menor envergadura são chamadas de armadilhas do tipo "veias" (Fotografia 40).

Os bolsões são feições desenvolvidas pela ação erosiva da queda d'água sobre as rochas. A profundidade do bolsão e a velocidade da água são fatores importantes na concentração do diamante. A Fotografia 41 mostra um bolsão na Unidade Terciário-Quaternário Indiviso, localizado à SW da Raizinha, próximo ao Rio das Pombas, onde a porção achuriada ressalta a cascalheira sobreposta por colúvios recentes.

A armadilha do tipo "ajogo" é um concentrador de diamantes que ocorre durante o meandramento do canal do rio (barras de pontal). A concentração de diamantes tenderá ocorrer na margem do rio oposta àquela que está sendo submetida à erosão. A observação do traçado das bacias de drenagem dos alvos PX, PG e DA, permite a individualização deste tipo de armadilha em pequena a média escala. 


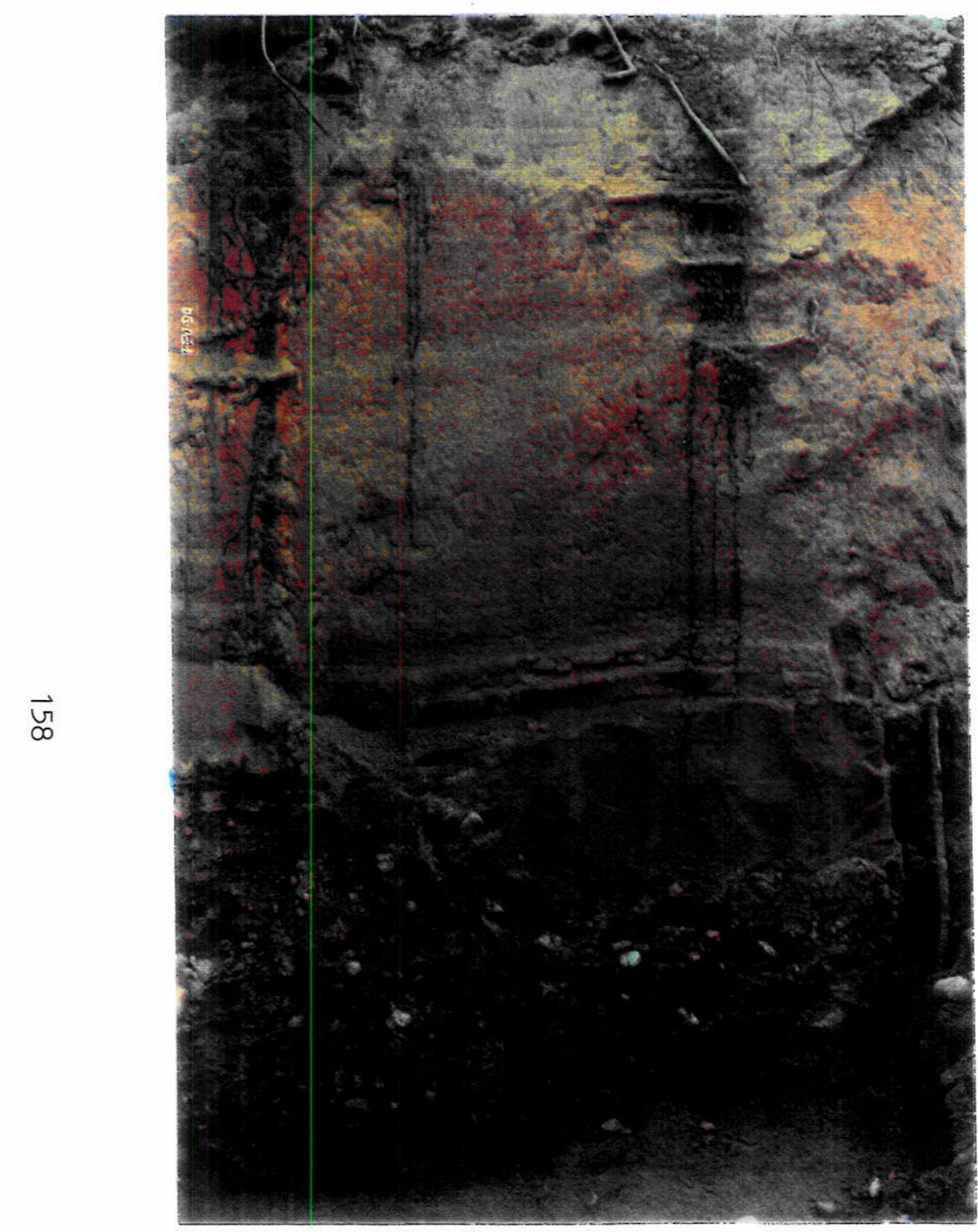

Fotografia 40 - Armadilha tipo veia na UTQI, Rio Coité (Alvo PX).

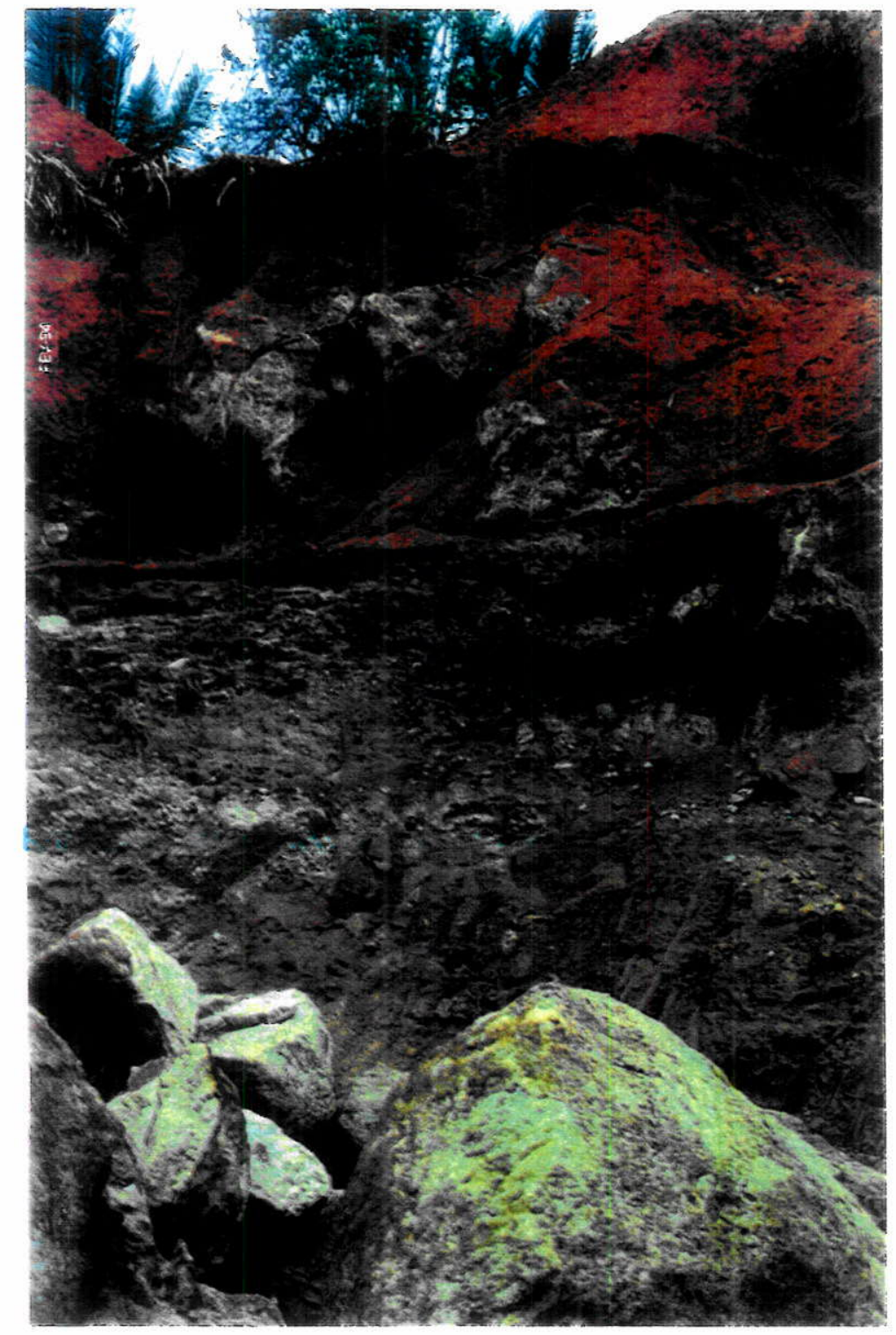

Fotografia 41 - Armadilha tipo bolsão na UTQI, na região da da Raizinha (Alvo PX). 
As panelas são armadilhas geradas quando o fluxo das águas do canal assumem movimento composto circular-helicoidal, comuns em zonas de remanso dos rios. $O$ tamanho dessas estrutura está associado ao grau de maturidade litológica do "bedrock". Estas armadilhas também dependem da profundidade e da velocidade das águas do rio. $O$ formato normalmente é circular ou quadrático por interferência de fraturas e falhas. 


\section{8 - ESTUDO DOS MINERAIS PESADOS}

Em áreas portadoras de depósitos diamantíferos do tipo placeres, desenvolvem-se tradicionalmente campanhas de amostragens para o estudo de minerais pesados (Weska, et al., 1984; Coopersmith, 1993; Marshall \& Baxter-Brown, 1995; Muggeridge, 1995). Nesses estudos e em especial em áreas quaternárias, procura-se definir a assembléia dos minerais pesados, conhecidos também pela denominação satélites ou acompanhantes, e ao mesmo tempo, caracterizar-se aqueles minerais que poderiam indicar fonte primária proxima. Por exemplo, minerais do tipo granada piropo, crômio espinélios e ilmenitas magnesianas, em geral indicam área fonte kimberlítica; por outro lado minerais tipo waadeíta, priderita; zircão, cromita e granada andradita, indicam área fonte primária lamproítica (Gold, 1984).

Na região da Bacia do Alto Paraguai, Mato Grosso, Weska et al., (1984) registraram que as aluviões diamantíferas são destituídas de minerais satélites, uma vez que os grãos mono e poliminerálicos não apresentam qualquer filiação à fontes primárias conhecidas. Por esta razão, utilizaram o termo "acompanhantes" como forma de caracterizar os minerais e grãos de rochas que acompanham o diamante, sem contudo estarem relacionados a kimberlitos e/ ou lamproítos. A associação nesse caso, resulta de similaridade entre os pesos específicos das fases mineralógicas e os grãos de rochas associadas sem haver qualquer relação genética entre as fases. Na região da Chapada dos Guimarães (Weska, 1987), descreveu que os depósitos aluviais recentes são também constituídos de minerais e grãos de rochas, tendo identificado turmalinito (pretinha), concreções e nódulos de óxido de ferro, magnetita, zircão, ilmenita (pretinha), leucoxênios (faceiras), topázio, pirita, safira (azulinha), coríndon verde ? (verdinha), rutilo, anătásio, brookita, turmalina $\mathrm{e}$ hematita. Em Poxoréu, Araujo et al. (1991) e Ribeiro \& Maciel (1991), descreveram safiras azuis e verdes, grãos de óxidos de ferro limonitizados (amarelinha mole), turmalinito, óxidos de ferro (feijão vermelho), topázio, leucoxênio, hematita e ouro. Uggeri \& Costa (1992), na região abrangida pelo Alvo PG, descreveram uma assembléia de grãos mono e poliminerálicos similares aos descritos na região de Poxoréu. Reportaram também as primeiras informações sobre rastreamento de minerais pesados da Intrusão Tamburi (Capítulo 5.1.4).

Em todas as assembléias de minerais pesados já descritas no Estado, abrangendo as regiões de Nortelândia, Chapada dos Guimarães, Poxoréu e Paredão Grande, é flagrante, em 
primeiro lugar, uma certa regularidade nos tipos de grãos de minerais e rochas que acompanham o diamante nesses depósitos. Em segundo lugar é notória a ausência de minerais indicadores de fontes primárias próximas.

Nos trabalhos prospectivos de geologia do diamante, uma das etapas mais importantes é a obtenção correta de amostras que representam de fato a situação definida teoricamente no laboratório. Tratando-se de rastreamento de fontes primárias (kimberlitos e/ou lamproítos), a amostragem deve ser conduzida de modo a cobrir todas as variáveis geológicas do terreno. Qualquer falha pode produzir resultados negativos falsos que por si só provocam até o abandono de um projeto de pesquisa. Tendo em vista esses fatos, discutiremos a seguir os pormenores das etapas de amostragens realizadas no decorrer dessa Tese, uma vez que se trata de tema pouco discutido na literatura. Além disso, os poucos exemplos encontrados, referem-se em geral à situações de clima temperado onde o contexto geológico é diferente daquele de áreas tropicais como é o caso da área ora estudada.

\subsection{O significado geológico da amostragem.}

Os minerais pesados paragenéticos indicadores de fontes primárias de diamantes possuem características químicas de rochas básicas/ultrabásicas, que associadas às condições climáticas tropicais reinantes na região são facilmente alterados. Entre os espinélios, granadas e ilmenitas, esse último é o mineral pesado que a partir do momento que é liberado do corpo primário consegue alcançar as maiores distâncias; as granadas alcançam distâncias intermediárias, enquanto que os espinélios são pouco transportados por não resistirem à intemperização. Tomando-se como, exemplo o Rio Paraíso que captura a Intrusão Tamburi, ilmenitas liberadas por este corpo, com dimensões de $1 \mathrm{~mm}$, foram encontradas em abundância até a distância de $\sim 5 \mathrm{~km}$; a partir daí esses minerais tendem a reduzir sua frequência. As granadas parecem resistir transporte até $\sim 2 \mathrm{~km}$ do corpo, enquanto os espinélios resistem ainda menos o transporte. Em relação as micas do tipo flogopita descritas na intrusão, estas restringen-se ao corpo. Comportamento similar ao da flogopita ocorre com os diopsídios cromíferos, descritos em alguns corpos kimberlíticos da região de Paranatinga. Nestas condições, ao encontrar-se minerais de flogopita e de diopsídio isto significa dizer que estamos sobre o corpo kimberlítico. $\mathrm{O}$ diamante 
destaca-se neste contexto pelo fato de possuir propriedades fisicas (dureza máxima) e químicas (insolúvel) especiais quando comparado aos seus acompanhantes.

Como já colocado no Capítulo 7, o diamante de Poxoréu, bem como dos Municípios entre Alto Paraguai - Arenápolis, Paranatinga, Barra do Garças e Chapada dos Guimarães, o diamante distribui-se em sedimentos que variam do Cretáceo ao Quaternário. A localização de uma básica/ultrabásica isolada na área, não explica as concentrações anômalas conhecidas nos placeres quaternários da região de Poxoréu. $O$ aprofundamento dos estudos petrográficos e geoquímicos dos derrames e dos diques da Formação Paredão Grande, evidenciaram por outro lado a natureza alcalina dessas rochas. Os estudos de empilhamento estratigráfico aliados aos de ambiente deposicional do Grupo Bauru na região evidenciaram que a Formação Quilombinho é vulcanogênica, tendo em média até $90 \%$ de detritos grossos a finos derivados das rochas da Formação Paredão Grande. Segundo Janse (1991), além das fontes tradicionalmente conhecidas, o diamante ocorre também em certos lamprófiros, peridotitos, ofiolitos e até em gnaisses gerados em zonas de subducção.

Com base no anteriormente exposto, em detrimento de uma amostragem extensiva, optamos por amostragem seletiva, e ao mesmo tempo procuramos estudar os minerais pesados presentes nos corpos Tamburi e Paredão Grande, correlacionando-os com os minerais pesados encontrados na Formação Quilombinho. A comparação com essa última unidade foi feita em razão da sua baixa contaminacão $(<10 \%)$ de detritos derivados de outras áreas fontes, excetuando-se a Formação Paredão Grande. A contaminação da Formação Cachoeira do Bom Jardim é da ordem de 50\% e da Formação Cambambe de $90 \%$. Em função do exposto, estas duas últimas unidades não foram amostradas para minerais pesados.

Os resultados da amostragem de minerais pesados estão reunidos na Tabela 8 , incluindo informações referentes aos tipos litológicos e unidades geológicas amostradas. Foi dada atenção especial aos minerais do grupo das granadas, ilmenitas e espinélios, em virtude do interesse que esses minerais possuem na prospecção de kimberlitos e lamproítos. Além desses minerais, foi investigada também a presença de microdiamantes nas amostras. 
Tabela 8 - Minerais pesados identificados nas oito amostras selecionadas para estudos de laboratório.

\begin{tabular}{|c|c|c|c|c|}
\hline AMOSTRA & $\begin{array}{l}\text { TIPO DE } \\
\text { ROCHA }\end{array}$ & ALVO & $\begin{array}{l}\text { UNIDADE/ } \\
\text { FORMAÇÃO }\end{array}$ & RESULTADOS \\
\hline RW 01 & Intrusão & PG & Tamburi & espinélios + granadas + ilmenitas \\
\hline RW 02 & Piroclástica (?) & PG & Paredão Grande & granadas \\
\hline RW 03 & Conglomerado & PX & Quilombinho & ilmenitas \\
\hline RW 04 & Conglomerado & PX & Quilombinho & - \\
\hline RW 05 & Conglomerado & PX & Quilombinho & espinélios \\
\hline RW 06 & Conglomerado & PX & Quilombinho & ilmenita + espinélios \\
\hline RW 07 & Conglomerado & PX & Quilombinho & granadas \\
\hline RW 08 & Intrusão & PG & Tamburi & $\begin{array}{c}\text { espinélios }+ \text { granadas }+ \text { ilmenitas }+ \\
\text { microdiamante }\end{array}$ \\
\hline
\end{tabular}

\subsection{Dados Geoquímicos}

Como já foi informado nos capítulos iniciais, a região de Poxoréu destaca-se entre os principais distritos produtores de diamante detrítico do País. Nessa área, o diamante é lavrado a partir de cascalhos quaternários da Fácies Coité, e sua origem, a exemplo de outros locais do País permanece desconhecida. Tendo em vista esse fato, foram realizados estudos de química mineral de concentrados da Intrusão Tamburi, de rochas piroclásticas alteradas da Formação Paredão Grande e de conglomerados da Formação Quilombinho, unidades litoestratigráficas mapeadas nesta Tese.

\subsubsection{Granada}

A granada é um dos minerais resistatos característicos de kimberlitos, e por essa razão vem sendo utilizado na prospecção dessa rocha há longa data. Exibe coloração vermelha característica com tonalidades variáveis incluíndo os tons de vinho, violeta, laranja e castanho esverdeado. As dimensões, variam desde alguns $\mathrm{mm}$ até decímetros em casos excepcionais (Mitchell, 1986). Estudos composicionais desenvolvidos intensivamente nos últimos anos culminaram com a classificação estatística de Dawson \& Stephens (1975), onde as granadas 
kimberlíticas foram divididas em doze grupos distintos referidos na literatura pela simbologia G1 a G12. Entre esses grupos, destaca-se o grupo G10 (cromiopiropos pobres em cálcio) considerado um guia de prospecção e de avaliação da presença ou não de diamante em fontes primárias.

A Tabela 9 apresenta 62 análises representativas de um total de 135, escolhidas por apresentarem fechamento mais satisfatório. Observa-se pela referida tabela que entre os elementos principais, o $\mathrm{MgO}$ varia de 4,26 a 20,89\%; $\mathrm{FeO}$ de 7,33 a 33,95\%; $\mathrm{CaO}$ de 0,0 a $10,34 \% ; \mathrm{Al}_{2} \mathrm{O}_{3}$ de 19,51 a $53,35 \%$ e $\mathrm{Cr}_{2} \mathrm{O}_{3}$ de 0,0 a $5,44 \%$ em peso.

A Tabela 10 mostra 11 análises de granadas da Formação Paredão Grande. Nesse caso, os elementos maiores apresentam as seguintes variações em peso: $\mathrm{MgO}$ : 19,52-21,77\%; FeO: 5,62-8,46\%; $\mathrm{CaO}: 4,36-6,48 \% ; \mathrm{Al}_{2} \mathrm{O}_{3}: 17,48-23,54 \%$ e $\mathrm{Cr}_{2} \mathrm{O}_{3}: 0,74-7,05 \%$.

Analogamente, a Tabela 11 reune 05 granadas da Formação Quilombinho, cujos elementos principais exibem as seguintes variações composicionais em peso: $\mathrm{MgO}$ : 19-0320,12\%; FeO: 5,57-8,01\%; $\mathrm{CaO}: 5,46-6,52 \% ; \mathrm{Al}_{2} \mathrm{O}_{3}: 17,39-20,14 \%$ e $\mathrm{Cr}_{2} \mathrm{O}_{3}: 4,49-7,02 \%$.

Esses dados mostram que entre os três tipos de litologias, a maior variação composicional ocorre nas granadas da Intrusão Tamburi, enquanto nas outras duas litologias, as variações são menores. Além disso, observa-se que existem similaridades entre as variações exibidas pelas granadas das Formações Paredão Grande e Quilombinho, distinguindo-as da Intrusão Tamburi. Levando em conta as variações observadas, podemos dizer de forma resumida que as granadas Tamburi são relativamente mais pobres em $\mathrm{MgO}$ e $\mathrm{Cr}_{2} \mathrm{O}_{3}$, sendo enriquecidas em $\mathrm{FeO}, \mathrm{CaO}$ e $\mathrm{Al}_{2} \mathrm{O}_{3}$. Em contrapartida, as granadas das Formações Paredão Grande e Quilombinho são enriquecidas em $\mathrm{MgO}$ e $\mathrm{Cr}_{2} \mathrm{O}_{3}$ e empobrecidas em $\mathrm{FeO}, \mathrm{CaO}$ e $\mathrm{Al}_{2} \mathrm{O}_{3}$.

Para efeitos de interpretações, esses valores foram projetados em diagramas convencionais da literatura. Na Figura 40, as granadas estão projetadas em um diagrama ternário $\mathrm{Ca}-\mathrm{Mg}$-Fe, onde estão delineados os campos correspondentes a inclusões de diamantes, xenólitos de lherzolitos e de eclogitos, megacristais, além de dados referentes ao kimberlito Poço Verde, todos extraídos de Svisero et al. (1987). Observa-se nesse diagrama que as granadas das Formações Paredão Grande e Quilombinho projetam-se junto com a maior parte das amostras da Intrusão Tamburi, sendo que uma boa parte dessas caem no campo dos eclogitos. Algumas amostras da Formação Paredão Grande caem dentro do campo dos megacristais, enquanto que parte das granadas Tamburi espalham-se pelo diagrama em direção ao Fe sủgerindo possível filiação a basaltos alcalinos. 
Tabela 9 - Composição química de granadas (\% em peso) presentes na Intrusão Tamburi., amostra RW 01, Alvo PG.

\begin{tabular}{|c|c|c|c|c|c|c|c|c|c|c|c|c|c|}
\hline AMOSTRA & RW102 & RW103 & RW104 & RW105 & RW106 & RW107 & RW108 & RW109 & RW110 & RW111 & RW115 & RW117 & RW118 \\
\hline $\mathrm{SiO}_{2}$ & 40,67 & 41,01 & 40,89 & 40,87 & 40,99 & 41,30 & 41,26 & 40,65 & 40,81 & 40,92 & 40,66 & 41,07 & 40,69 \\
\hline $\mathrm{TiO}_{2}$ & 0,17 & 0,04 & 0,03 & 0,13 & 0,08 & 0,05 & 0,05 & 0,11 & 0,18 & 0,11 & 0,11 & 0,09 & 0,02 \\
\hline $\mathrm{Al}_{2} \mathrm{O}_{3}$ & 20,18 & 21,28 & 20,93 & 20,82 & 21,08 & 21,11 & 20,92 & 21,11 & 21,47 & 21,58 & 21,38 & 20,82 & 19,51 \\
\hline $\mathrm{Fe}_{2} \mathrm{O}_{3}$ & 0,19 & 0,22 & 0,48 & 0,56 & 0,62 & 0,45 & 0,34 & 0,00 & 0,00 & 0,30 & 0,27 & 0,00 & 0,10 \\
\hline FeO & 8,39 & 8,63 & 7,85 & 8,44 & 7,33 & 7,92 & 8,22 & 8,61 & 8,77 & 8,67 & 8,09 & 7,86 & 7,57 \\
\hline Mno & 0,50 & 0,49 & 0,46 & 0,39 & $0, \mathbf{4 0}$ & 0,45 & 0,46 & 0,48 & 0,48 & 0,45 & 0,40 & 0,39 & 0,41 \\
\hline Mgo & 19,08 & 19,32 & 19,77 & 19,55 & 20,89 & 20,09 & 19,40 & 19,25 & 19,30 & 19,25 & 19,78 & 18,49 & 18,49 \\
\hline $\mathrm{CaO}$ & 5,76 & 5,72 & 5,69 & 5,54 & 4,87 & 5,57 & 5,80 & 5,62 & 5,53 & 5,28 & $\mathbf{5 , 5 0}$ & 6,41 & 6,69 \\
\hline $\mathrm{Na}_{2} \mathrm{O}$ & 0,02 & 0,00 & 0,00 & 0,01 & 0,01 & 0,01 & 0,00 & 0,00 & 0,04 & 0,01 & 0,02 & 0,02 & 0,00 \\
\hline $\mathrm{Cr}_{2} \mathrm{O}_{3}$ & 4,49 & 3,27 & 3,48 & 3,47 & 3,27 & 3,57 & 3,71 & 3,76 & 3,09 & 2,41 & 2,84 & 4,26 & 5,44 \\
\hline $\mathrm{V}_{2} \mathrm{O}_{6}$ & 0,06 & 0,01 & 0,03 & 0,04 & 0,07 & 0,05 & 0,02 & 0,00 & 0,10 & 0,04 & 0,04 & 0,06 & 0,08 \\
\hline TOTAL & 99,51 & 99,99 & 99,61 & 99,82 & 99,61 & 100,57 & 100,18 & 99,59 & 99,77 & 99,02 & 99,09 & 99,47 & 99,00 \\
\hline $\mathrm{Cr}_{2} \mathrm{O}_{3} / \mathrm{Cr}_{2} \mathrm{O}_{3}+\mathrm{Al}_{2} \mathrm{O}_{3}$ & 18,20 & 13,32 & 14,26 & 14,29 & 13,43 & 14,47 & 15,06 & 15,12 & 12,58 & 10,05 & 11,73 & 16,99 & 21,80 \\
\hline MgO/MgO+FeO & 69,46 & 69,12 & 71,58 & 69,85 & 74,03 & 71,72 & 70,24 & 69,10 & 68,76 & 68,95 & 70,97 & 70,17 & 70,95 \\
\hline \multicolumn{14}{|c|}{ Número de cátions com base em 12 átomos de oxigênio. } \\
\hline $\mathbf{S i}$ & 19,01 & 19,17 & 19,11 & 19,10 & 19,16 & 19,30 & 19,28 & 19,00 & 19,07 & 19,13 & 19,00 & 19,20 & 19,02 \\
\hline Tì & 0,10 & 0,02 & 0,02 & 0,08 & 0,05 & 0,03 & 0,03 & 0,07 & 0,11 & 0,07 & 0,07 & 0,05 & 0,01 \\
\hline Al & 10,68 & 11,26 & 11,08 & 11,02 & 11,16 & 11,17 & 11,07 & 11,17 & 11,36 & 11,42 & 11,32 & 11,02 & 10,33 \\
\hline $\mathrm{Fe}^{+3}$ & 0,13 & 0,15 & 0,34 & 0,39 & 0,43 & $\mathbf{0 , 3 1}$ & 0,24 & 0,00 & 0,00 & 0,21 & 0,19 & 0,00 & 0,07 \\
\hline $\mathrm{Fe}^{+2}$ & 6,52 & 6,71 & 6,10 & 6,56 & 5,70 & 6,16 & 6,39 & 6,69 & 6,82 & 6,74 & 6,29 & 6,11 & 5,88 \\
\hline $\mathbf{M n}$ & 0,39 & 0,38 & 0,36 & 0,30 & 0,31 & 0,35 & 0,36 & 0,37 & 0,37 & 0,35 & 0,31 & 0,30 & 0,32 \\
\hline Mg & 11,51 & 11,65 & 11,92 & 11,79 & 12,60 & 12,12 & 11,70 & 11,61 & 11,64 & 11,61 & 11,93 & 11,15 & 11,15 \\
\hline $\mathbf{C a}$ & 4,12 & 4,09 & 4,07 & 3,96 & 3,48 & 3,98 & 4,15 & 4,02 & 3,95 & 3,77 & 3,93 & 4,58 & 4,78 \\
\hline $\mathrm{Na}$ & 0,01 & 0,00 & 0,00 & 0,01 & 0,01 & 0,01 & 0,00 & 0,00 & 0,03 & 0,01 & 0,01 & 0,01 & 0,00 \\
\hline Cr & 3,07 & 2,24 & 2,38 & 2,37 & 2,24 & 2,44 & 2,54 & $\mathbf{2 , 5 7}$ & 2,11 & 1,65 & 1,94 & 2,91 & 3,72 \\
\hline $\mathbf{V}$ & 0,04 & 0,01 & 0,02 & 0,03 & 0,05 & 0,03 & 0,01 & 0,00 & 0,07 & 0,03 & 0,03 & 0,04 & 0,05 \\
\hline 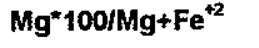 & 63,83 & 63,46 & 66,15 & 64,25 & 68,86 & 66,31 & 64,68 & 63,43 & 63,07 & 63,27 & 65,48 & 64,60 & 65,46 \\
\hline $\mathrm{Cr} / \mathrm{Cr}+\mathrm{Al}$ & 0,22 & 0,17 & 0,18 & 0,18 & 0,17 & 0,18 & 0,19 & 0,19 & 0,16 & 0,13 & 0,15 & 0,21 & 0,26 \\
\hline
\end{tabular}


(continuação da Tabela 9)

RW119

$\mathrm{SiO}_{2}$

$\mathrm{TiO}_{2}$

$\mathrm{Al}_{2} \mathrm{O}_{3}$

$\mathrm{Fe}_{2} \mathrm{O}_{3}$

$\mathrm{FeO}$

Mno

Mgo

$\mathrm{CaO}$

$\mathrm{Na}_{2} \mathrm{O}$

$\mathrm{Cr}_{2} \mathrm{O}_{3}$

$\mathrm{V}_{2} \mathrm{O}_{6}$

TOTAL

$\mathrm{Cr}_{2} \mathrm{O}_{3} / \mathrm{Cr}_{2} \mathrm{O}_{3}+\mathrm{Al}_{2} \mathrm{O}_{3}$

$\mathrm{MgO} / \mathrm{MgO}+\mathrm{FeO}$

40,99

0,10

21,55

0,00

8,41

0,45

18,96

$\mathbf{5 , 5 1}$

0,02

3,10

0,06

99,15

12,58

69,27

RW120

41,73

0,05

21,19

1,04

7,49

0,42

20,00

5,42

0,00

2,77

0,00

100,11

11,56

72,75

Número de cátions com base em 12 átomos de oxigênio.

$\mathrm{Si}$
$\mathrm{Ti}$
$\mathrm{Al}$
$\mathrm{Fe}^{+3}$
$\mathrm{Fe}^{+2}$
$\mathrm{Mn}$
$\mathrm{Mg}$
$\mathrm{Ca}$
$\mathrm{Na}$
$\mathrm{Cr}$
$\mathrm{V}$
$\mathrm{Mg}+100 / \mathrm{Mg}+\mathrm{Fe}^{42}$
$\mathrm{Cr} / \mathrm{Cr}+\mathrm{Al}$

19,16
0,06
11,41
0,00
6,54
0,35
11,43
3,94
0,01
2,12
0,04
63,63

19,50

0,03
11,22

19,22

$$
\begin{array}{r}
0,08 \\
11,54
\end{array}
$$

11,22

0,73
5,82

0,33

12,06

3,87

0,00

1,90

0,00

67,45

0,14
$\begin{array}{rrr}R W 124 & R W 125 \\ 41,01 & 41,24\end{array}$

41,13

$0,14 \quad 0,13$

21,80

$0,00 \quad 0,38$

8,85

18,79

5,34

0,01
2,79

0,10

$\mathbf{9 9 , 4 2}$

11,35

67,98

8,12

0,42

20,08
5,08

0,02

2,59

0,05

99,47

10,71

71,21

9,72
RW127 RW128 RW

$\begin{array}{rrr}40,86 & 40,54 & 41,47 \\ 0,16 & 0,06 & 0,15\end{array}$

$21,81 \quad 21,82 \quad 22,08$

$\begin{array}{lll}0,20 & 0,51 & 0,00\end{array}$

$8,50 \quad 7,95 \quad 8,33$

$0,43 \quad 0,44 \quad 0,49$

$19,63 \quad 20,43 \quad 18,91$

$\begin{array}{lll}\mathbf{5 , 2 6} & \mathbf{5 , 2 2} & \mathbf{5 , 7 8}\end{array}$

$\begin{array}{lll}0,00 & 0,02 & 0,02\end{array}$

$2,25 \quad 2,21 \quad 2,75$

$0,05 \quad 0,05 \quad 0,02$

$99,15 \quad 99,25 \quad 100,00$

$9,35 \quad 9,20 \quad 11,08$

69,42

69,78

71,99
0,16

$\begin{array}{rrr}19,17 & 19,28 & 19,10 \\ 0,08 & 0,05 & 0,10 \\ 11,43 & 11,55 & 11,54 \\ 0,27 & 0,30 & 0,14 \\ 6,31 & 6,36 & 6,61 \\ 0,33 & 0,38 & 0,33 \\ 12,11 & 12,00 & 11,84 \\ 3,63 & 3,81 & 3,76 \\ 0,01 & 0,00 & 0,00 \\ 1,77 & 1,61 & 1,54 \\ 0,03 & 0,06 & 0,03 \\ 65,74 & 65,37 & 64,18 \\ 0,13 & 0,12 & 0,12\end{array}$

69,42

RW133

RW134

RW135

41,11

40,93

RW137

RW138

$\begin{array}{lllll}0,22 & 0,17 & 0,15 & 0,06 & 0,10\end{array}$

$\begin{array}{lllll}21,54 & 21,67 & 22,21 & 21,34 & 21,80\end{array}$

$\begin{array}{lllll}0,43 & 0,47 & 0,00 & 0,34 & 0,29\end{array}$

$\begin{array}{lllll}8,68 & 8,33 & 9,32 & 7,80 & 8,50\end{array}$

$\begin{array}{lllll}0,48 & 0,39 & 0,50 & 0,37 & 0,44\end{array}$

$\begin{array}{lllll}19,44 & 19,98 & 19,07 & 20,28 & 19,84\end{array}$

$\begin{array}{lllll}5,25 & 4,67 & 5,25 & 4,72 & 4,82\end{array}$

$\begin{array}{lllll}0,02 & 0,04 & 0,01 & 0,02 & 0,02\end{array}$

$\begin{array}{lllll}2,43 & 2,21 & 1,96 & 3,01 & 2,35\end{array}$

$\begin{array}{lllll}0,03 & 0,08 & 0,07 & 0,02 & 0,09\end{array}$

$\begin{array}{lllll}99,61 & 99,12 & 99,47 & 99,31 & 99,48\end{array}$

$\begin{array}{lllll}10,14 & 9,25 & 8,11 & 12,36 & 9,73\end{array}$

$\begin{array}{lllll}69,13 & 70,58 & 67,17 & 72,22 & 70,01\end{array}$

$\begin{array}{rr}18,95 & 19,38 \\ 0,04 & 0,09 \\ 11,55 & 11,69 \\ 0,36 & 0,00 \\ 6,18 & 6,47 \\ 0,34 & 0,38 \\ 12,32 & 11,40 \\ 3,73 & 4,13 \\ 0,01 & 0,01 \\ 1,51 & 1,88 \\ 0,03 & 0,01 \\ 66,60 & 63,79 \\ 0,12 & 0,14\end{array}$

19,21

19,13

19,33

0,04

11,30

0,24

11,40

11,47

11,76

0,00

6,06

0,29

12,23

3,37

0,01

2,06

0,01

66,86

0,15

19,27

0,06

11,54

0,20

6,61

0,34

11,97

3,44

0,01

0,01
1,61

0,06

$63,47 \quad 65,05 \quad 61,35$

0,10

0,12 
(continuação da Tabela 9)

\begin{tabular}{|c|c|c|c|c|c|c|c|c|c|c|c|c|c|}
\hline AMOSTRA & RW139 & RW140 & RW141 & RW142 & RW143 & RW145 & RW146 & RW147 & RW148 & RW149 & RW150 & RW188 & RW189 \\
\hline $\mathrm{SiO}_{2}$ & 40,98 & 41,06 & 41,21 & 41,30 & 40,96 & 41,48 & 41,15 & 40,97 & 40,89 & 40,84 & 40,83 & 39,82 & 40,64 \\
\hline $\mathrm{TiO}_{2}$ & 0,10 & 0,15 & 0,08 & 0,13 & 0,11 & 0,02 & 0,19 & 0,09 & 0,11 & 0,06 & 0,06 & 0,07 & 0,06 \\
\hline $\mathrm{Al}_{2} \mathrm{O}_{3}$ & 21,58 & 22,28 & 22,33 & 20,99 & 20,76 & 21,56 & 20,74 & 22,65 & 21,91 & 21,67 & 21,58 & 22,74 & 23,57 \\
\hline $\mathrm{Fe}_{2} \mathrm{O}_{3}$ & 0,00 & 0,00 & 0,00 & 1,13 & 0,31 & 0,00 & 0,00 & 0,00 & 0,20 & 0,00 & 0,00 & 0,00 & 0,00 \\
\hline FeO & 8,64 & 8,80 & 8,44 & 7,59 & 8,28 & 8,36 & 7,90 & 9,32 & 8,92 & 8,89 & 9,25 & 18,91 & 12,74 \\
\hline Mno & 0,41 & 0,42 & 0,48 & 0,42 & 0,48 & 0,51 & 0,48 & 0,41 & 0,53 & 0,46 & 0,47 & 0,37 & 0,14 \\
\hline $\mathrm{MgO}$ & 19,25 & 19,33 & 20,13 & 20,09 & 19,27 & 19,54 & 20,22 & 18,72 & 19,13 & 18,29 & 18,69 & 11,63 & 16,40 \\
\hline $\mathrm{CaO}$ & 5,51 & 5,06 & 5,02 & 5,04 & 5,74 & 5,19 & 5,30 & 5,36 & 5,33 & 6,30 & 6,11 & 6,38 & 6,23 \\
\hline $\mathrm{Na}_{2} \mathrm{O}$ & 0,01 & 0,03 & 0,00 & 0,02 & 0,03 & 0,00 & 0,03 & 0,00 & 0,02 & 0,00 & 0,00 & 0,06 & 0,00 \\
\hline $\mathrm{Cr}_{2} \mathrm{O}_{3}$ & 3,04 & 2,25 & 2,31 & 2,68 & 3,75 & 3,22 & 4,52 & 1,78 & 2,07 & 3,00 & 3,18 & 0,02 & 0,16 \\
\hline $\mathbf{V}_{2} \mathbf{O}_{6}$ & 0,05 & 0,03 & 0,03 & 0,05 & 0,01 & 0,00 & 0,05 & 0,07 & 0,02 & 0,15 & 0,00 & 0,02 & 0,00 \\
\hline TOTAL & 99,57 & 99,41 & 100,03 & 99,44 & 99,70 & 99,88 & 100,58 & 99,37 & 99,13 & 99,66 & 100,17 & 100,02 & 99,94 \\
\hline $\mathrm{Cr}_{2} \mathrm{O}_{3} / \mathrm{Cr}_{2} \mathrm{O}_{3}+\mathrm{Al}_{2} \mathrm{O}_{3}$ & 12,35 & 9,17 & 9,37 & 11,32 & 15,30 & 12,99 & 17,89 & 7,29 & 8,63 & 12,16 & 12,84 & 0,09 & 0,67 \\
\hline $\mathrm{MgO} / \mathrm{MgO}+\mathrm{FeO}$ & 69,02 & 68,72 & 70,46 & 72,58 & 69,95 & 70,04 & 71,91 & 66,76 & 68,20 & 67,29 & 66,89 & 38,08 & 56,28 \\
\hline
\end{tabular}

Número de cátions com base em 12 átomos de oxigênio.

\begin{tabular}{|c|c|c|c|c|c|c|c|c|c|c|c|c|c|}
\hline Si & 19,15 & 19,19 & 19,26 & 19,30 & 19,14 & 19,39 & 19,23 & 19,15 & 19,11 & 19,09 & 19,08 & 18,61 & 19,00 \\
\hline $\mathbf{T i}$ & 0,06 & 0,09 & 0,05 & 0,08 & 0,07 & 0,01 & 0,11 & 0,05 & 0,07 & 0,04 & 0,04 & 0,04 & 0,04 \\
\hline Al & 11,42 & 11,79 & 11,82 & 11,11 & 10,99 & 11,41 & 10,98 & 11,99 & 11,60 & $11, \mathbf{4 7}$ & 11,42 & 12,04 & 12,48 \\
\hline $\mathrm{Fe}^{+3}$ & 0,00 & 0,00 & 0,00 & 0,79 & 0,22 & 0,00 & 0,00 & 0,00 & 0,14 & 0,00 & 0,00 & 0,00 & 0,00 \\
\hline $\mathrm{Fe}^{+2}$ & 6,72 & 6,84 & 6,56 & 5,90 & 6,44 & 6,50 & 6,14 & 7,24 & 6,93 & 6,91 & 7,19 & 14,70 & 9,90 \\
\hline $\mathrm{Mn}$ & 0,32 & 0,33 & 0,37 & 0,33 & 0,37 & 0,39 & 0,37 & 0,32 & 0,41 & 0,36 & 0,36 & 0,29 & 0,11 \\
\hline $\mathbf{M g}$ & 11,61 & 11,66 & 12,14 & 12,12 & 11,62 & 11,78 & 12,19 & 11,29 & 11,54 & 11,03 & 11,27 & 7,01 & 9,89 \\
\hline Ca & 3,94 & 3,62 & 3,59 & 3,60 & 4,10 & 3,71 & 3,79 & 3,83 & 3,81 & 4,50 & 4,37 & 4,56 & 4,45 \\
\hline $\mathbf{N a}$ & 0,01 & 0,02 & 0,00 & 0,01 & 0,02 & 0,00 & 0,02 & 0,00 & 0,01 & 0,00 & 0,00 & 0,04 & 0,00 \\
\hline Cr & 2,08 & 1,54 & 1,58 & 1,83 & 2,57 & 2,20 & 3,09 & 1,22 & 1,42 & 2,05 & 2,18 & 0,01 & 0,11 \\
\hline $\mathbf{V}$ & 0,03 & 0,02 & 0,02 & 0,03 & 0,01 & 0,00 & 0,03 & 0,05 & 0,01 & 0,10 & 0,00 & 0,01 & 0,00 \\
\hline $\mathrm{Mg} * 100 / \mathrm{Mg}+\mathrm{Fe}^{+2}$ & 63,35 & 63,02 & 64,92 & 67,25 & 64,36 & 64,46 & 66,51 & 60,91 & 62,46 & 61,48 & 61,05 & 32,30 & 49,97 \\
\hline $\mathrm{Cr} / \mathrm{Cr}+\mathrm{Al}$ & 0,15 & 0,12 & 0,12 & 0,14 & 0,19 & 0,16 & 0,22 & 0,09 & 0,11 & 0,15 & 0,16 & 0,00 & 0,01 \\
\hline
\end{tabular}


(continuação da Tabela 9)

\begin{tabular}{|c|c|c|c|c|c|c|c|c|c|c|}
\hline AMOSTRA & RW190 & RW191 & RW191 & RW192 & RW194 & RW195 & RW196 & RW198 & RW199 & RW200 \\
\hline $\mathrm{SiO}_{2}$ & 39,41 & 40,20 & 40,43 & 41,93 & 41,57 & 41,13 & 41,04 & 39,17 & 41,61 & 41,67 \\
\hline $\mathrm{TiO}_{2}$ & 0,09 & 0,11 & 0,06 & 0,11 & 0,14 & 0,11 & 0,15 & 0,05 & 0,10 & 0,17 \\
\hline $\mathrm{Al}_{2} \mathrm{O}_{3}$ & 22,78 & 23,15 & 22,77 & 24,46 & 22,80 & 22,91 & 22,52 & 22,76 & 23,52 & 23,52 \\
\hline $\mathrm{Fe}_{2} \mathrm{O}_{3}$ & 0,00 & 0,00 & 0,43 & 0,00 & 0,00 & 0,00 & 0,10 & 0,00 & 0,01 & 0,00 \\
\hline FeO & 15,48 & 14,27 & 14,83 & 9,00 & 8,98 & 9,37 & 9,64 & 21,66 & 9,11 & 9,33 \\
\hline Mno & 0,31 & 0,28 & 0,19 & 0,32 & 0,47 & 0,43 & 0,44 & 0,56 & 0,18 & 0,32 \\
\hline Mgo & 11,55 & 13,08 & 12,64 & 20,16 & 19,36 & 19,71 & 19,21 & 13,79 & 15,44 & 20,26 \\
\hline $\mathrm{CaO}$ & $\mathbf{9 , 5 0}$ & 9,07 & 9,25 & 4,81 & 5,18 & 4,73 & 4,80 & 1,72 & 10,34 & 4,19 \\
\hline $\mathrm{Na}_{2} \mathrm{O}$ & 0,03 & 0,05 & 0,04 & 0,02 & 0,04 & 0,03 & 0,03 & 0,00 & 0,00 & 0,04 \\
\hline $\mathrm{Cr}_{2} \mathrm{O}_{3}$ & 0,06 & 0,08 & 0,09 & 0,11 & 1,40 & 1,22 & 1,32 & 0,03 & 0,03 & 0,63 \\
\hline $\mathrm{V}_{2} \mathrm{O}_{6}$ & 0,00 & 0,00 & 0,00 & 0,06 & 0,00 & 0,05 & 0,05 & 0,04 & 0,02 & 0,06 \\
\hline TOTAL & 99,21 & 100,29 & 100,73 & 100,98 & 99,94 & 99,69 & 99,30 & 99,78 & 100,36 & 100,19 \\
\hline $\mathrm{Cr}_{2} \mathrm{O}_{3} / \mathrm{Cr}_{2} \mathrm{O}_{3}+\mathrm{Al}_{2} \mathrm{O}_{3}$ & 0,26 & 0,34 & 0,39 & 0,45 & 5,79 & 5,06 & 5,54 & 0,13 & 0,13 & 2,61 \\
\hline MgO/MgO+FeO & 42,73 & 47,82 & 46,01 & 69,14 & 68,31 & 67,78 & 66,59 & 38,90 & 62,89 & 68,47 \\
\hline
\end{tabular}

Número de cátions com base em 12 átomos de oxigênio.

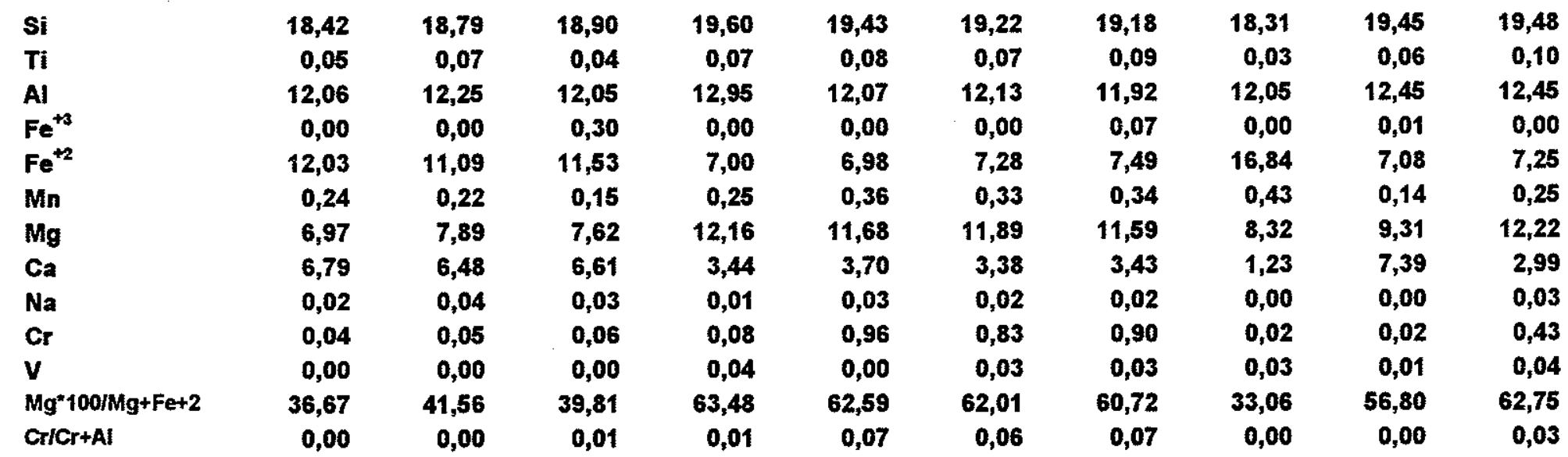


continuação da Tabela 9)

\begin{tabular}{|c|c|c|c|c|c|c|c|c|c|c|c|c|c|}
\hline AMOSTRA & RW800 & RW801 & RW802 & RW803 & RW804 & RW806 & RW807 & RW810 & RW811 & RW812 & RW813 & RW814 & RW814 \\
\hline $\mathrm{SiO}_{2}$ & 41,03 & 40,77 & 40,78 & 40,91 & 41,24 & 41,04 & 40,87 & 40,63 & 40,66 & 40,99 & 40,80 & 40,89 & 40,87 \\
\hline $\mathrm{TiO}_{2}$ & 0,17 & 0,14 & 0,21 & 0,13 & 0,11 & 0,09 & 0,12 & 0,16 & 0,17 & 0,11 & 0,18 & 0,19 & 0,12 \\
\hline $\mathrm{Al}_{2} \mathrm{O}_{3}$ & 20,58 & 20,52 & 20,94 & 21,88 & 20,91 & 21,00 & 21,13 & 21,21 & 21,02 & 21,49 & 21,67 & 21,68 & 21,45 \\
\hline $\mathrm{Fe}_{2} \mathrm{O}_{3}$ & 0,00 & 0,17 & 0,03 & 0,22 & 0,08 & 0,24 & 0,07 & 0,06 & 0,19 & 0,00 & 0,00 & 0,00 & 0,00 \\
\hline FeO & 8,07 & 8,37 & 8,34 & 8,52 & 8,21 & 8,05 & 8,30 & 8,48 & 9,07 & 9,05 & 8,59 & 8,52 & 7,79 \\
\hline Mno & 0,46 & 0,48 & 0,42 & 0,45 & 0,47 & 0,44 & 0,41 & 0,42 & 0,48 & 0,51 & 0,42 & 0,38 & 0,47 \\
\hline $\mathrm{MgO}$ & 19,12 & 18,99 & 19,48 & 19,40 & 18,93 & 19,47 & 19,35 & 19,14 & 19,30 & 19,08 & 20,08 & 20,17 & 19,92 \\
\hline $\mathrm{CaO}$ & 5,56 & 5,64 & 5,57 & 5,50 & 6,05 & 5,64 & $5, \mathbf{5 0}$ & 5,83 & 5,24 & 5,31 & 4,84 & 4,77 & 5,31 \\
\hline $\mathrm{Na}_{2} \mathrm{O}$ & 0,02 & 0,00 & 0,01 & 0,01 & 0,00 & 0,00 & 0,01 & 0,01 & 0,01 & 0,01 & 0,02 & 0,02 & 0,01 \\
\hline $\mathrm{Cr}_{2} \mathrm{O}_{3}$ & 4,04 & 3,91 & 3,63 & 2,15 & 3,74 & 3,47 & 3,30 & 3,13 & 3,34 & 2,96 & 2,82 & 2,78 & 3,06 \\
\hline $\mathrm{V}_{2} \mathrm{O}_{6}$ & 0,02 & 0,02 & 0,04 & 0,04 & 0,06 & 0,03 & 0,02 & 0,05 & 0,05 & 0,05 & 0,06 & 0,02 & 0,08 \\
\hline TOTAL. & 99,07 & 99,02 & 99,45 & 99,21 & 99,81 & 99,47 & 99,08 & 99,12 & 99,53 & 99,56 & 99,48 & 99,42 & 99,08 \\
\hline $\mathrm{Cr}_{2} \mathrm{O}_{3} / \mathrm{Cr}_{2} \mathrm{O} 3+\mathrm{Al}_{2} \mathrm{O}_{3}$ & 16,41 & 16,00 & 14,77 & 8,95 & 15,17 & 14,18 & 13,51 & 12,86 & 13,71 & 12,11 & 11,51 & 11,37 & 12,48 \\
\hline $\mathrm{MgO} / \mathrm{MgO}+\mathrm{FeO}$ & 70,32 & 69,41 & 70,02 & 69,48 & 69,75 & 70,75 & 69,98 & 69,30 & 68,03 & 67,83 & 70,04 & 70,30 & 71,89 \\
\hline \multicolumn{14}{|c|}{ Número de cátions com base em 12 átomos de oxigênio. } \\
\hline Si & 19,18 & 19,06 & 19,06 & 19,12 & 19,28 & 19,18 & 19,10 & 18,99 & 19,00 & 19,16 & 19,07 & 19,11 & 19,10 \\
\hline $\mathrm{Ti}$ & 0,10 & 0,08 & 0,13 & 0,08 & 0,07 & 0,05 & 0,07 & 0,10 & 0,10 & 0,07 & 0,11 & 0,11 & 0,07 \\
\hline Al & 10,89 & 10,86 & 11,08 & 11,58 & 11,07 & 11,12 & 11,18 & 11,23 & 11,13 & 11,37 & 11,47 & 11,48 & 11,35 \\
\hline $\mathrm{Fe}^{+3}$ & 0,00 & 0,12 & 0,02 & 0,15 & 0,06 & 0,17 & 0,05 & 0,04 & 0,13 & 0,00 & 0,00 & 0,00 & 0,00 \\
\hline $\mathrm{Fe}^{+2}$ & 6,27 & 6,51 & 6,48 & 6,62 & 6,38 & 6,26 & 6,45 & 6,59 & 7,05 & 7,03 & 6,68 & 6,62 & 6,06 \\
\hline Mn & 0,36 & 0,37 & 0,33 & 0,35 & 0,36 & 0,34 & 0,32 & 0,33 & 0,37 & 0,39 & 0,33 & 0,29 & 0,36 \\
\hline $\mathbf{M g}$ & 11,53 & 11,45 & 11,75 & 11,70 & 11,42 & 11,74 & 11,67 & 11,54 & 11,64 & 11,51 & 12,11 & 12,16 & 12,01 \\
\hline $\mathrm{Ca}$ & 3,97 & 4,03 & 3,98 & 3,93 & 4,32 & 4,03 & 3,93 & 4,17 & 3,75 & 3,80 & 3,46 & 3,41 & 3,80 \\
\hline $\mathrm{Na}$ & 0,01 & 0,00 & 0,01 & 0,01 & 0,00 & 0,00 & 0,01 & 0,01 & 0,01 & 0,01 & 0,01 & 0,01 & 0,01 \\
\hline $\mathrm{Cr}$ & 2,76 & 2,68 & 2,48 & 1,47 & 2,56 & 2,37 & 2,26 & 2,14 & 2,29 & 2,03 & 1,93 & 1,90 & 2,09 \\
\hline $\mathbf{v}$ & 0,01 & 0,01 & 0,03 & 0,03 & 0,04 & 0,02 & 0,01 & 0,03 & 0,03 & 0,03 & 0,04 & 0,01 & 0,05 \\
\hline $\mathrm{Mg}^{*} 100 / \mathrm{Mg}+\mathrm{Fe}^{+2}$ & 64,77 & 63,77 & 64,44 & 63,86 & 64,14 & 65,24 & 64,40 & 63,65 & 62,28 & 62,06 & 64,46 & 64,75 & 66,49 \\
\hline $\mathrm{Cr} / \mathrm{Cr}+\mathrm{Al}$ & 0,20 & 0,20 & 0,18 & 0,11 & 0,19 & 0,18 & 0,17 & 0,16 & 0,17 & 0,15 & 0,14 & 0,14 & 0,16 \\
\hline
\end{tabular}


(continuação da Tabela 9)

\begin{tabular}{|c|c|c|c|c|c|c|c|c|c|}
\hline AMOSTRA & RW815 & RW818 & RW818 & RW819 & RW819 & POX540 & POX541 & POX24 & POX24R \\
\hline $\mathrm{SiO}_{2}$ & 41,02 & 40,80 & 41,10 & 37,00 & 36,59 & 40,93 & 36,51 & 37,66 & 26,75 \\
\hline $\mathrm{TiO}_{2}$ & 0,19 & 0,15 & 0,08 & 0,02 & 0,00 & 0,12 & 0,00 & 0,00 & 0,57 \\
\hline $\mathrm{Al}_{2} \mathrm{O}_{3}$ & 21,22 & 21,78 & 22,39 & 21,51 & 21,38 & 22,47 & 21,44 & 22,44 & 53,35 \\
\hline $\mathrm{Fe}_{2} \mathrm{O}_{3}$ & 0,00 & 0,24 & 0,00 & 0,00 & 0,00 & 0,00 & 0,00 & 0,00 & 0,00 \\
\hline FeO & 8,72 & 8,64 & 8,88 & 32,62 & 33,95 & 8,76 & 32,68 & 25,12 & 11,54 \\
\hline Mno & 0,45 & 0,45 & 0,51 & 0,85 & 1,29 & 0,40 & 2,66 & 0,63 & 0,57 \\
\hline Mgo & 19,04 & 19,88 & 19,59 & 6,09 & 5.05 & 19,37 & 4,26 & 10,58 & 7,02 \\
\hline CaO & 5,48 & 4,96 & 5,05 & 1,31 & 1,09 & 5,21 & 1,91 & 2,49 & 0,00 \\
\hline $\mathrm{Na}_{2} \mathrm{O}$ & 0,03 & 0,02 & 0,00 & 0,00 & 0,00 & 0,03 & 0,01 & 0,00 & 0,00 \\
\hline $\mathrm{Cr}_{2} \mathrm{O}_{3}$ & 3,24 & 2,34 & 1,85 & 0,01 & 0,00 & 2,04 & 0,02 & 0,06 & 0,01 \\
\hline $\mathbf{V}_{2} \mathbf{O}_{6}$ & 0,05 & 0,06 & 0,03 & 0,01 & 0,03 & 0,05 & 0,05 & 0,03 & 0,01 \\
\hline TOTAL & 99,44 & 99,32 & 99,48 & 99,42 & 99,38 & 99,39 & 99,53 & 99,02 & 99,82 \\
\hline $\mathrm{Cr}_{2} \mathrm{O}_{3} / \mathrm{Cr}_{2} \mathrm{O} 3+\mathrm{Al}_{2} \mathrm{O}_{3}$ & 13,25 & 9,70 & 7,63 & 0,05 & 0,00 & 8,32 & 0,08 & 0,29 & 0,02 \\
\hline $\mathrm{MgO} / \mathrm{MgO}+\mathrm{FeO}$ & 68,59 & 69,71 & 68,81 & 15,73 & 12,95 & 68,86 & 11,52 & 29,63 & 37,81 \\
\hline
\end{tabular}

Número de cátions com base em 12 átomos de oxigênio.

\begin{tabular}{|c|c|c|c|c|c|c|c|c|c|}
\hline Si & 19,17 & 19,07 & 19,21 & 17,29 & 17,10 & 19,13 & 17,06 & 17,60 & 12,50 \\
\hline $\mathrm{Ti}$ & 0,11 & 0,09 & 0,05 & 0,01 & 0,00 & 0,07 & 0,00 & 0,00 & 0,34 \\
\hline Al & 11,23 & 11,53 & 11,85 & 11,39 & 11,32 & 11,89 & 11,35 & 11,88 & 28,24 \\
\hline $\mathrm{Fe}^{+3}$ & 0,00 & 0,17 & 0,00 & 0,00 & 0,00 & 0,00 & 0,00 & 0,00 & 0,00 \\
\hline $\mathrm{Fe}^{+2}$ & 6,78 & 6,72 & 6,90 & 25,36 & 26,39 & 6,81 & 25,40 & 19,53 & 8,97 \\
\hline Mn & 0,35 & 0,35 & 0,39 & 0,66 & 1,00 & 0,31 & 2,06 & 0,49 & 0,44 \\
\hline $\mathbf{M g}$ & 11,48 & 11,99 & 11,81 & 3,67 & 3,05 & 11,68 & 2,57 & 6,38 & 4,23 \\
\hline $\mathbf{C a}$ & 3,92 & 3,54 & 3,61 & 0,94 & 0,78 & 3,73 & 1,36 & 1,78 & 0,00 \\
\hline $\mathrm{Na}$ & 0,02 & 0,01 & 0,00 & 0,00 & 0,00 & 0,02 & 0,01 & 0,00 & 0,00 \\
\hline Cr & 2,22 & 1,60 & 1,27 & 0,01 & 0,00 & 1,39 & 0,01 & 0,04 & 0,01 \\
\hline $\mathbf{V}$ & 0,03 & 0,04 & 0,02 & 0,01 & 0,02 & 0,04 & 0,03 & 0,02 & 0,0 \\
\hline $\mathrm{Mg}^{*} 100 / \mathrm{Mg}+\mathrm{Fe}^{+2}$ & 62,88 & 64,10 & 63,12 & 12,65 & 10,35 & 63,18 & 9,18 & 24,62 & \\
\hline $\mathrm{Cr} / \mathrm{Cr}+\mathrm{Al}$ & 0,16 & 0,12 & 0,10 & 0,00 & 0,00 & & & & \\
\hline
\end{tabular}


Tabela 10 - Composição química de granadas (\% em peso) presentes em rochas da Formação Paredão Grande, Grupo Bauru, amostra RW 02, Alvo PG.

\begin{tabular}{|c|c|c|c|c|c|c|c|c|c|c|c|}
\hline AMOSTRA & RW201 & RW202 & RW203 & RW204 & RW205 & RW206 & RW207 & RW208 & RW209 & RW210 & RW243 \\
\hline $\mathrm{SiO}_{2}$ & 41,35 & 41,02 & 41,29 & 41,06 & 40,76 & 40,84 & 40,90 & 41,65 & 41,22 & 41,68 & 41,84 \\
\hline $\mathrm{TiO}_{2}$ & 0,78 & 0,95 & 0,83 & 0,45 & 0,24 & 0,24 & 0,53 & 0,32 & 0,89 & 0,30 & 0,14 \\
\hline $\mathrm{Al}_{2} \mathrm{O}_{3}$ & 20,72 & 20,79 & 21,29 & 18,90 & 19,07 & 19,42 & 17,48 & 20,76 & 20,16 & 20,82 & 23,54 \\
\hline $\mathrm{Fe}_{2} \mathrm{O}_{3}$ & 1,27 & 1,45 & 0,92 & 0,40 & 0,40 & 0,72 & 1,29 & 0,85 & 0,93 & 0,60 & 0,00 \\
\hline $\mathrm{FeO}$ & 7,04 & 8,46 & 8,27 & 7,00 & 7,00 & 5,91 & 5,73 & 5,62 & 5,75 & 5,68 & 8,14 \\
\hline MnO & 0,28 & 0,33 & 0,30 & 0,37 & 0,37 & 0,25 & 0,30 & 0,26 & 0,27 & 0,24 & 0,32 \\
\hline Mgo & 20,64 & 19,52 & 19,92 & 19,72 & 19,95 & 20,76 & 19,89 & 21,77 & 21,57 & 21,62 & 21,16 \\
\hline $\mathrm{CaO}$ & 5,10 & 5,38 & 4,95 & 5,92 & 5,66 & 5,74 & 6,48 & 5,05 & 5,02 & 5,01 & 4,36 \\
\hline $\mathrm{Na}_{2} \mathrm{O}$ & 0,04 & 0,06 & 0,05 & 0,02 & 0,03 & 0,01 & 0,01 & 0,01 & 0,05 & 0,01 & 0,01 \\
\hline $\mathrm{Cr}_{2} \mathrm{O}_{3}$ & 2,51 & 1,90 & 1,84 & 6,03 & 5,89 & 5,21 & 7,05 & 3,56 & 3,60 & 3,64 & 0,74 \\
\hline $\mathrm{V}_{2} \mathrm{O}_{6}$ & 0,11 & 0,15 & 0,11 & 0,09 & 0,05 & 0,08 & 0,10 & 0,06 & 0,10 & 0,08 & 0,04 \\
\hline TOTAL & 99,84 & 100,01 & 99,77 & 99,96 & 99,42 & 99,18 & 99,76 & 99,91 & 99,56 & 99,68 & 100,29 \\
\hline $\mathrm{Cr}_{2} \mathrm{O}_{3} / \mathrm{Cr}_{2} \mathrm{O} 3+\mathrm{Al}_{2} \mathrm{O}_{3}$ & 10,80 & 8,37 & 7,96 & 24,19 & 23,60 & 21,15 & 28,74 & 14,64 & 15,15 & 14,88 & 3,05 \\
\hline $\mathrm{MgO} M \mathrm{MgO}+\mathrm{FeO}$ & 74,57 & 69,76 & 70,66 & 73,80 & 74,03 & 77,84 & 77,63 & 79,48 & 78,95 & 79,19 & 72,22 \\
\hline \multicolumn{12}{|c|}{ Número de cátions com base em 12 átomos de oxigênio. } \\
\hline Si & 19,33 & 19,17 & 19,30 & 19,19 & 19,05 & 19,09 & 19,12 & 19,47 & 19,27 & 19,48 & 19,56 \\
\hline$\pi i$ & 0,47 & 0,57 & 0,50 & 0,27 & 0,14 & 0,14 & 0,32 & 0,19 & 0,53 & 0,18 & 0,08 \\
\hline A & 10,97 & 11,00 & 11,27 & 10,00 & 10,09 & 10,28 & 9,25 & 10,99 & 10,67 & 11,02 & 12,46 \\
\hline $\mathrm{Fe}^{+3}$ & 0,89 & 1,01 & 0,64 & 0,28 & 0,28 & 0,50 & 0,90 & 0,59 & 0,65 & 0,42 & 0,00 \\
\hline $\mathrm{Fe}^{+2}$ & 5,47 & 6,58 & 6,43 & 5,44 & 5,44 & 4,59 & 4,45 & 4,37 & 4,47 & 4,42 & 6,33 \\
\hline Mn & 0,22 & 0,26 & 0,23 & 0,29 & 0,29 & 0,19 & 0,23 & 0,20 & 0,21 & 0,19 & 0,25 \\
\hline $\mathrm{Mg}$ & 12,45 & 11,77 & 12,01 & 11,89 & 12,03 & 12,52 & 12,00 & 13,13 & 13,01 & 13,04 & 12,76 \\
\hline $\mathrm{Ca}$ & 3,64 & 3,85 & 3,54 & 4,23 & 4,05 & 4,10 & 4,63 & 3,61 & 3,59 & 3,58 & 3,12 \\
\hline $\mathrm{Na}$ & 0,03 & 0,04 & 0,04 & 0,01 & 0,02 & 0,01 & 0,01 & 0,01 & 0,04 & 0,01 & 0,01 \\
\hline $\mathrm{Cr}$ & 1,72 & 1,30 & 1,26 & 4,13 & 4,03 & 3,56 & 4,82 & 2,44 & 2,46 & 2,49 & 0,51 \\
\hline V & 0,07 & 0,10 & 0,07 & 0,06 & 0,03 & 0,05 & 0,07 & 0,04 & 0,07 & 0,05 & 0,03 \\
\hline $\mathrm{Mg}^{*} 100 \mathrm{Mg}+\mathrm{Fe}^{+2}$ & 69,46 & 64,16 & 65,14 & 68,61 & 66,86 & 73,16 & $\mathbf{7 2 , 9 2}$ & 75,03 & 74,43 & 74,70 & 66,85 \\
\hline $\mathrm{Cr} / \mathrm{Cr}+\mathrm{Al}$ & 0,14 & 0,11 & 0,10 & 0,29 & 0,29 & 0,26 & 0,34 & 0,18 & 0,19 & 0,18 & 0,04 \\
\hline
\end{tabular}


Tabela 11 - Composição química de granadas (\% em peso) presentes na Formação Quilombinho, Grupo Bauru; amostra RW 07 (Balaio de Gato), Alvo PX.

\begin{tabular}{|c|c|c|c|c|c|}
\hline AMOSTRA & RW701 & RW702 & RW703 & RW704 & RW705 \\
\hline $\mathrm{SiO}_{2}$ & 40,74 & 40,89 & 40,78 & 40,86 & 40,82 \\
\hline $\mathrm{TiO}_{2}$ & 0,07 & 0,19 & 0,13 & 0,60 & 0,34 \\
\hline $\mathrm{Al}_{2} \mathrm{O}_{3}$ & 20,14 & 19,35 & 20,06 & 17,39 & 18,57 \\
\hline $\mathrm{Fe}_{2} \mathrm{O}_{3}$ & 0,25 & 0,31 & 0,43 & 1,38 & 0,67 \\
\hline FeO & 8,01 & 7,03 & 7,11 & 5,67 & 6,31 \\
\hline Mno & 0,46 & 0,38 & 0,37 & 0,30 & 0,30 \\
\hline Mgo & 19,03 & 20,05 & 20,11 & 19,75 & 20,12 \\
\hline $\mathrm{CaO}$ & 5,88 & 6,62 & 5,46 & 6,62 & 5,64 \\
\hline $\mathrm{Na}_{2} \mathrm{O}$ & 0,03 & 0,03 & 0,04 & 0,05 & 0,05 \\
\hline $\mathrm{Cr}_{2} \mathrm{O}_{3}$ & 4,49 & 5,66 & 4,63 & 7,02 & 6,16 \\
\hline $\mathbf{V}_{2} \mathbf{O}_{6}$ & 0,05 & 0,03 & 0,03 & 0,10 & 0,09 \\
\hline TOTAL & 99,16 & 99,44 & 99,05 & 99,44 & 99,06 \\
\hline $\mathrm{Cr}_{2} \mathrm{O}_{3} / \mathrm{Cr}_{2} \mathrm{O}_{3}+\mathrm{Al}_{2} \mathrm{O}_{3}$ & 18,23 & 22,63 & 18,42 & 28,76 & 24,88 \\
\hline $\mathrm{MgO} / \mathrm{MgO}+\mathrm{FeO}$ & 70,38 & 74,04 & 73,88 & 78,00 & 76,13 \\
\hline
\end{tabular}

Número de cátions com base em 12 átomos de oxigênio.

\begin{tabular}{|c|c|c|c|c|c|}
\hline Si & 19,04 & 19,11 & 19,06 & 19,10 & 19,08 \\
\hline $\mathbf{T i}$ & 0,04 & 0,11 & 0,08 & 0,30 & 0,20 \\
\hline Al & 10,66 & 10,24 & 10,62 & 9,20 & 9,83 \\
\hline $\mathrm{Fe}^{+3}$ & 0,17 & 0,22 & 0,30 & 0,97 & 0,47 \\
\hline $\mathrm{Fe}^{+2}$ & 6,23 & 6,46 & 6,63 & 4,33 & 4,90 \\
\hline$M n$ & 0,36 & 0,29 & 0,29 & 0,23 & 0,23 \\
\hline $\mathbf{M g}$ & 11,48 & 12,09 & 12,13 & 11,91 & 12,13 \\
\hline $\mathrm{Ca}$ & 4,20 & 3,95 & 3,90 & 4,66 & 4,03 \\
\hline $\mathrm{Na}$ & 0,02 & 0,02 & 0,03 & 0,04 & 0,04 \\
\hline Cr & 3,07 & 3,87 & 3,10 & 4,80 & 4,21 \\
\hline v & 0,03 & 0,02 & 0,02 & 0,07 & 0,06 \\
\hline $\mathrm{Mg}^{* 1} 100 / \mathrm{Mg}+\mathrm{Fe}^{+2}$ & 64,83 & 68,88 & 68,70 & 73,34 & 71,21 \\
\hline CriCr+Al & 0,22 & 0,27 & 0,23 & 0,34 & 0,30 \\
\hline
\end{tabular}


A presença ou não de granadas G10 nas amostras estudadas foi testada pelo diagrama $\mathrm{CaO} \times \mathrm{Cr}_{2} \mathrm{O}_{3}$ de Gurney (1984), mostrado na Figura 41. Observa-se que as granadas estudas caem no campo das granadas G9, a maior parte no campo das granadas de peridotitos, e as demais no campo dos eclogitos. Todas as amostras situam-se fora do campo das granadas G10, afastando qualquer possibilidade da Intrusão Tamburi conter mineralizações significativas de diamante.

\subsubsection{Ilmenita}

A ilmenita magnesiana é um dos minerais mais característicos de kimberlitos, podendo alcançar proporções de até $5, \%$ em peso em alguns corpos. Desempenha um papel chave na prospecção dessas rochas tendo em vista as facilidades de concentração e a resistência ao imtemperísmo físico e químico. Do ponto de vista químico, são constituídos por soluções sólidas entre as moléculas de $\mathrm{FeTiO}_{3}$ (ilmenita), $\mathrm{MgTiO}_{3}$ (geikielita) e $\mathrm{Fe}_{2} \mathrm{O}_{3}$ (hematita). Além dos elementos principais ferro e titânio, possuem magnésio com teores de $\mathrm{MgO}$ de até $25 \%$ em peso, além de crômio, cujos teores de $\mathrm{Cr}_{2} \mathrm{O}_{3}$ alcançam até $5 \%$ em peso (Bardet, 1977; Mitchell, 1986).

A Tabela 12 apresenta 47 análises químicas de ilmenitas de conglomerados da Formação Quilombinho, escolhidas a partir de um lote de 116 análises, onde o $\mathrm{TiO}_{2}$ varia de 48,27 a 54,04\%; $\mathrm{Fe}_{2} \mathrm{O}_{3}$ de 1,72 a 10,14\%; $\mathrm{FeO}$ de 24,29 a 44,82\%; $\mathrm{MgO}$ de 0,34 a $13,02 \%$ e $\mathrm{Cr}_{2} \mathrm{O}_{3}$ de 0,0 a $0,84 \%$ em peso.

Analogamente, na Tabela 13 apresentamos 13 análises referentes à Intrusão Tamburi onde o $\mathrm{TiO}_{2}$ varia de 10,35 a 53,28; $\mathrm{Fe}_{2} \mathrm{O}_{3}$ de 5,47 a 69,97; FeO de 13,46 a 33,$72 ; \mathrm{MgO}$ de 0,08 a 9,46 e o $\mathrm{Cr}_{2} \mathrm{O}_{3}$ de 0,04 a 2,41\% em peso.

Repetindo comportamento já observado nas granadas, as ilmenitas da Intrusão Tamburi apresentam variações composicionais maiores do que as suas correspondentes da Formação Quilombinho. Com relação às ilmenitas dessa formação, observa-se a existência de dois grupos bem distintos: a) um com teores de magnésio e crômio baixos ( $\mathrm{MgO}$ de 0,34 a 3,17 e $\mathrm{Cr}_{2} \mathrm{O}_{3}$ de 0,0 a 0,04\% em peso) e outro em que esses elementos apresentam-se enriquecidos ( $\mathrm{MgO}$ de 11,27 a 13,02 e $\mathrm{Cr}_{2} \mathrm{O}_{3}$ de 0,39 a 0,84\% em peso). 


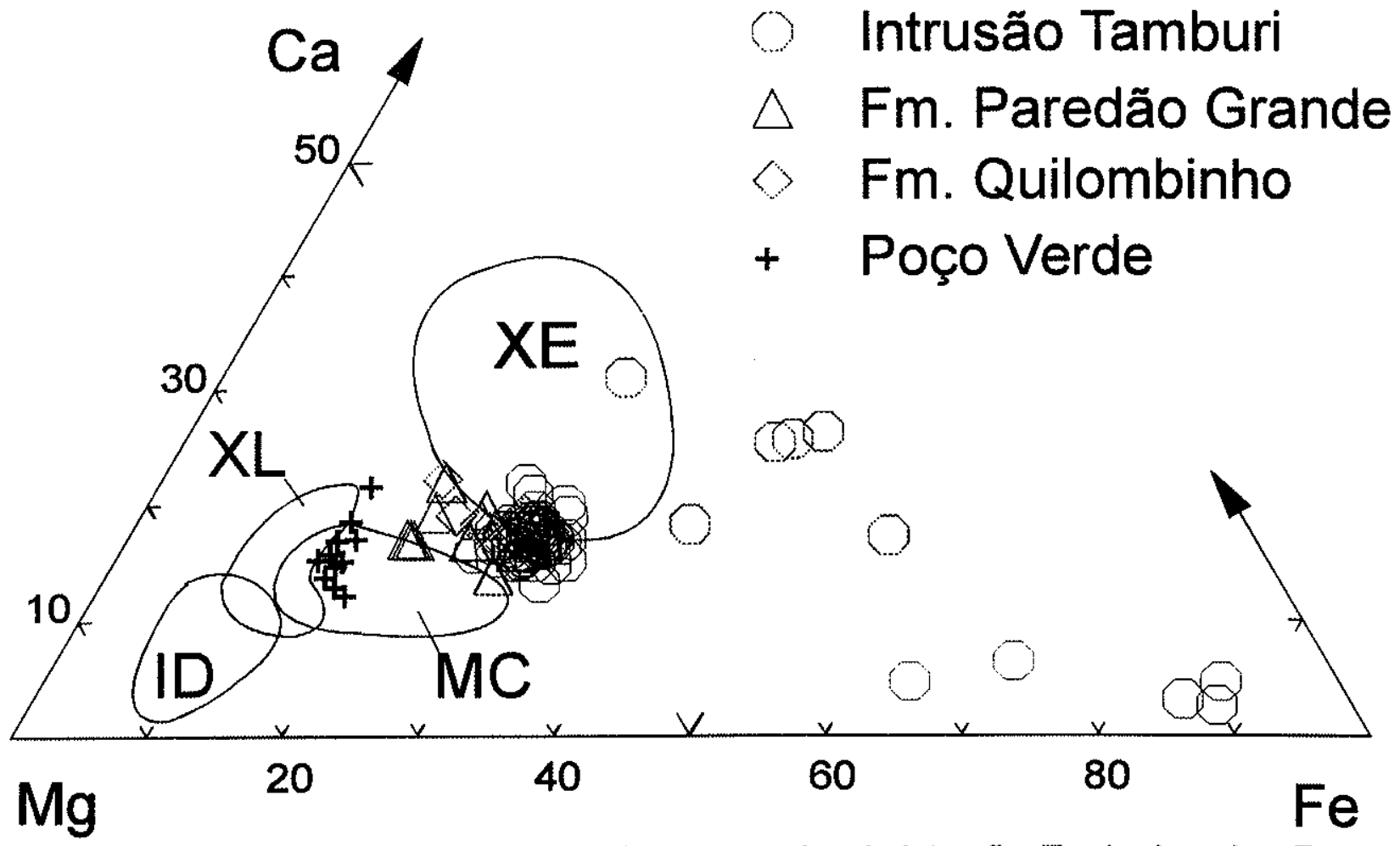

Figura 40 - Diagrama Ca-Mg-Fe mostrando as granadas da Intrusão Tamburi e das Formações Paredão Grande e Quilombinho. Os campos comparativos ID (Inclusões em diamantes), MC (Mega cristais), XL. (Xenólitos de lherzolitos), XE (Xenólitos de eclogitos) e os pontos referentes ao kimberlito Poço Verde, foram extraidos de Svisero et al. (1987).

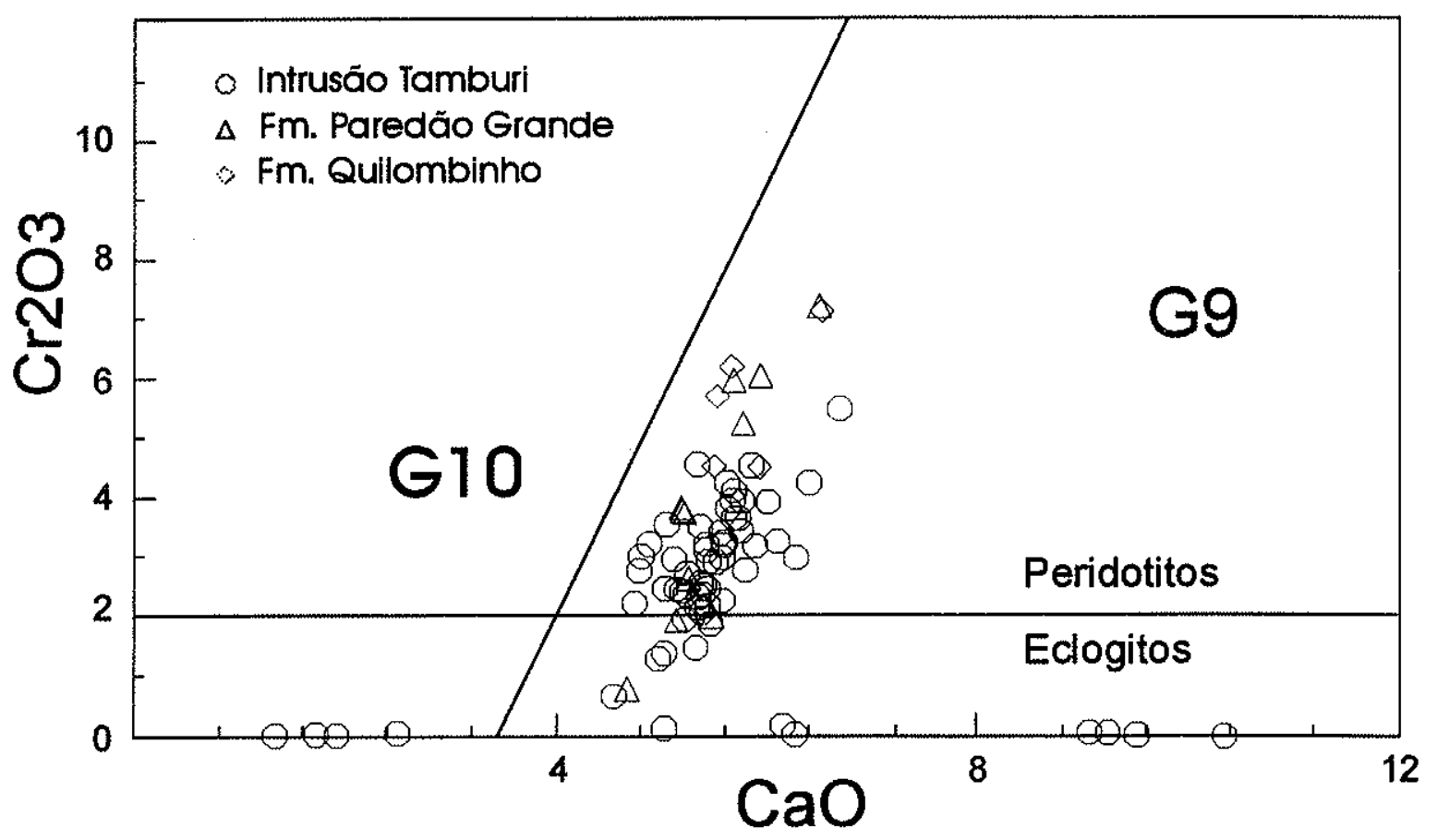

Figura 41 - Diagrama $\mathrm{Cr}_{2} \mathrm{O}_{3} \times \mathrm{CaO}$ de granadas da Intrusão Tamburi e das Formações Paredão Grande e Quilombinho. Todas as amostras analisadas caem fora do campo das granadas G10. Diagrama base segundo Gumey (1984). 
Tabela 12 - Composição química de ilmenitas (\% em peso) presentes em conglomerados da Formação Quilombinho, Grupo Bauru, amostra RW 03, Alvo PX.

\begin{tabular}{|c|c|c|c|c|c|c|c|c|c|c|c|c|c|}
\hline AMOSTRA & RW302 & RW303 & RW305 & RW306 & RW307 & RW308 & RW309 & RW310 & RW311 & RW313 & RW314 & RW316 & RW317 \\
\hline $\mathrm{SiO}_{2}$ & 0,00 & 0,01 & 0,00 & 0,00 & 0,02 & 0,01 & 0,01 & 0,00 & 0,01 & 0,00 & 0,00 & 0,04 & 0,01 \\
\hline $\mathrm{TiO}_{2}$ & 49,64 & 51,69 & 50,74 & 51,71 & 51,23 & 51,58 & 51,23 & 51,40 & 49,25 & 51,57 & 50,60 & 50,96 & 51,97 \\
\hline $\mathrm{Al}_{2} \mathrm{O}_{3}$ & 0,10 & 0,04 & 0,11 & 0,11 & 0,04 & 0,08 & 0,09 & 0,07 & 0,09 & 0,05 & 0,13 & 0,08 & 0,05 \\
\hline $\mathrm{Fe}_{2} \mathrm{O}_{3}$ & 6,67 & 2,39 & 4,17 & 2,77 & 2,65 & 2,18 & 3,02 & 2,67 & 6,23 & 2,37 & 4,82 & 3,90 & 2,36 \\
\hline $\mathrm{FeO}$ & 40,72 & 43,14 & 43,29 & 43,32 & 44,82 & 43,65 & 43,34 & 43,34 & 42,06 & 42,57 & 41,48 & 42,36 & 43,34 \\
\hline Mno & 0,84 & 0,57 & 0,54 & 0,61 & 0,65 & 0,50 & 0,60 & 0,56 & 0,66 & 0,61 & 0,51 & 0,54 & 0,57 \\
\hline MgO & 1,76 & 1,57 & 1,05 & 1,49 & 0,34 & 1,29 & 1,23 & 1,33 & 0,91 & 1,82 & 2,02 & 1,68 & 1,60 \\
\hline $\mathrm{CaO}$ & 0,00 & 0,01 & 0,00 & 0,02 & 0,00 & 0,01 & 0,00 & 0,01 & 0,00 & 0,00 & 0,01 & 0,00 & 0,00 \\
\hline $\mathrm{Cr}_{2} \mathrm{O}_{3}$ & 0,00 & 0,03 & 0,01 & 0,01 & 0,00 & 0,04 & 0,01 & 0,01 & 0,00 & 0,02 & 0,02 & 0,02 & 0,02 \\
\hline TOTAL & 99,73 & 99,45 & 99,91 & 100,04 & 99,75 & 99,34 & 99,53 & 99,39 & 99,21 & 99,01 & 99,59 & 99,58 & 99,92 \\
\hline \multicolumn{14}{|c|}{ Número de cátions com base em 3 átomos de oxigênio. } \\
\hline Si & 0,00 & 0,00 & 0,00 & 0,00 & 0,01 & 0,00 & 0,00 & 0,00 & 0,00 & 0,00 & 0,00 & 0,02 & 0,00 \\
\hline $\mathbf{T i}$ & 29,76 & 30,99 & 30,42 & 31,00 & 30,71 & 30,92 & 30,71 & 30,81 & 29,53 & 30,92 & 30,33 & 30,55 & 31,16 \\
\hline Al & 0,05 & 0,02 & 0,06 & 0,06 & 0,02 & 0,04 & 0,05 & 0,04 & 0,05 & 0,03 & 0,07 & 0,04 & 0,03 \\
\hline $\mathrm{Fe}^{+3}$ & 4,66 & 1,67 & 2,92 & 1,94 & 1,85 & 1,52 & 2,11 & 1,87 & 4,36 & 1,66 & 3,37 & 2,73 & 1,65 \\
\hline $\mathrm{Fe}^{+2}$ & 31,65 & 33,53 & 33,65 & 33,67 & 34,84 & 33,93 & 33,69 & 33,69 & 32,69 & 33,09 & 32,24 & 32,93 & 33,69 \\
\hline Mn & 0,65 & 0,44 & 0,42 & 0,47 & $\mathbf{0 , 5 0}$ & 0,39 & 0,46 & 0,43 & 0,51 & 0,47 & 0,39 & 0,42 & 0,44 \\
\hline $\mathbf{M g}$ & 1,06 & 0,95 & 0,63 & 0,90 & 0,21 & 0,78 & 0,74 & 0,80 & 0,55 & 1,10 & 1,22 & 1,01 & 0,96 \\
\hline $\mathbf{C a}$ & 0,00 & 0,01 & 0,00 & 0,01 & 0,00 & 0,01 & 0,00 & 0,01 & 0,00 & 0,00 & 0,01 & 0,00 & 0,00 \\
\hline $\mathrm{Cr}$ & 0,00 & 0,02 & 0,01 & 0,01 & 0,00 & 0,03 & 0,01 & 0,01 & 0,00 & 0,01 & 0,01 & 0,01 & 0,01 \\
\hline
\end{tabular}


(continuação da Tabela 12)

\begin{tabular}{|c|c|c|c|c|c|c|c|c|c|c|c|c|c|}
\hline AMOSTRA & RW318 & RW319 & RW320 & RW321 & RW322 & RW324 & RW325 & RW326 & RW328 & RW329 & RW330 & RW331 & RW332 \\
\hline $\mathrm{SiO}_{2}$ & 0,00 & 0,00 & 0,01 & 0,00 & 0,01 & 0,00 & 0,01 & 0,00 & 0,00 & 0,00 & 0,00 & 0,03 & 0,00 \\
\hline $\mathrm{TiO}_{2}$ & 50,08 & 51,60 & 50,74 & 51,67 & 51,17 & 51,05 & 48,27 & 51,38 & 51,24 & 52,00 & 50,89 & 50,67 & 50,70 \\
\hline $\mathrm{Al}_{2} \mathrm{O}_{3}$ & 0,08 & 0,06 & 0,08 & 0,04 & 0,02 & 0,07 & 0,10 & 0,07 & 0,19 & 0,06 & 0,07 & 0,13 & 0,09 \\
\hline $\mathrm{Fe}_{2} \mathrm{O}_{3}$ & 5,16 & 2,21 & 3,33 & 2,20 & 3,03 & 3,33 & 10,14 & 2,86 & 3,58 & 1,72 & 3,77 & 4,31 & 3,68 \\
\hline $\mathrm{FeO}$ & 42,85 & 43,76 & 43,96 & 43,55 & 43,72 & 43,42 & 37,39 & 42,83 & 42,06 & 43,97 & 43,47 & 41,64 & 42,75 \\
\hline Mno & 0,52 & 0,56 & 0,54 & 0,74 & 0,59 & 0,53 & 0,44 & 0,53 & 0,48 & 0,61 & 0,72 & 0,47 & 0,56 \\
\hline Mgo & 0,97 & 1,19 & 0,66 & 1,23 & 0,96 & 1,12 & 3,17 & 1,62 & 2,06 & 1,24 & 0,91 & 1,99 & 1,32 \\
\hline $\mathrm{CaO}$ & 0,00 & 0,01 & 0,00 & 0,01 & 0,00 & 0,00 & 0,00 & 0,01 & 0,00 & 0,00 & 0,00 & 0,00 & 0,00 \\
\hline $\mathrm{Cr}_{2} \mathrm{O}_{3}$ & 0,02 & 0,00 & 0,00 & 0,00 & 0,00 & 0,02 & 0,04 & 0,00 & 0,02 & 0,01 & 0,03 & 0,03 & 0,02 \\
\hline TOTAL & 99,68 & 99,39 & 99,32 & 99,44 & 99,50 & 99,54 & 99,56 & 99,30 & 99,63 & 99,61 & 99,86 & 99,27 & 99,12 \\
\hline \multicolumn{14}{|c|}{ Número de cátions com base em 3 átomos de oxigênio. } \\
\hline $\mathbf{S i}$ & 0,00 & 0,00 & 0,00 & 0,00 & 0,00 & 0,00 & 0,00 & 0,00 & 0,00 & 0,00 & 0,00 & 0,01 & 0,00 \\
\hline Ti & 30,02 & 30,93 & 30,42 & 30,98 & 30,68 & 30,60 & 28,94 & 30,80 & 30,72 & 31,17 & 30,51 & 30,38 & 30,39 \\
\hline Al & 0,04 & 0,03 & 0,04 & 0,02 & 0,01 & 0,04 & 0,05 & 0,04 & 0,10 & 0,03 & 0,04 & 0,07 & 0,05 \\
\hline $\mathrm{Fe}^{+3}$ & 3,61 & 1,55 & 2,33 & 1,54 & 2,12 & 2,33 & 7,09 & 2,00 & 2,50 & 1,20 & 2,64 & 3,01 & 2,57 \\
\hline $\mathrm{Fe}^{+2}$ & 33,31 & 34,01 & 34,17 & 33,85 & 33,98 & 33,75 & 29,06 & 33,29 & 32,69 & 34,18 & 33,79 & 32,37 & 33,23 \\
\hline Mn & 0,40 & 0,43 & 0,42 & 0,57 & 0,46 & 0,41 & 0,34 & 0,41 & 0,37 & 0,47 & 0,56 & 0,36 & 0,43 \\
\hline Mg & 0,59 & 0,72 & 0,40 & 0,74 & 0,58 & 0,68 & 1,91 & 0,98 & 1,24 & 0,75 & 0,55 & 1,20 & 0,80 \\
\hline $\mathrm{Ca}$ & 0,00 & 0,01 & 0,00 & 0,01 & 0,00 & 0,00 & 0,00 & 0,01 & 0,00 & 0,00 & 0,00 & 0,00 & 0,00 \\
\hline $\mathrm{Cr}$ & 0,01 & 0,00 & 0,00 & 0,00 & 0,00 & 0,01 & 0,03 & 0,00 & 0,01 & 0,01 & 0,02 & 0,02 & 0,01 \\
\hline
\end{tabular}


(continuação da Tabela 12)

\begin{tabular}{|c|c|c|c|c|c|c|c|c|c|c|c|c|c|}
\hline AMOSTRA & RW334 & RW335 & RW337 & RW338 & RW339 & RW340 & RW341 & RW342 & RW343 & RW344 & RW345 & RW346 & RW347 \\
\hline $\mathrm{SiO}_{2}$ & 0,02 & 0,00 & 0,00 & 0,00 & 0,00 & 0,01 & 0,00 & 0,00 & 0,01 & 0,01 & 0,00 & 0,03 & 0,00 \\
\hline $\mathrm{TiO}_{2}$ & 50,40 & 51,02 & 51,69 & 51,21 & 51,17 & 51,75 & 50,66 & 50,72 & 50,82 & 51,21 & 50,55 & 51,54 & 51,52 \\
\hline $\mathrm{Al}_{2} \mathrm{O}_{3}$ & 0,14 & 0,04 & 0,10 & 0,07 & 0,08 & 0,05 & 0,03 & 0,11 & 0,05 & 0,07 & 0,08 & 0,10 & 0,07 \\
\hline $\mathrm{Fe}_{2} \mathrm{O} 3$ & 4,72 & 3,91 & 2,31 & 3,11 & 3,02 & 1,87 & 3,26 & 3,57 & 3,59 & 3,37 & 4,29 & 2,76 & 2,33 \\
\hline $\mathrm{FeO}$ & 41,78 & 42,85 & 43,84 & 43,24 & 43,78 & 43,23 & 43,86 & 42,77 & 43,53 & 42,51 & 42,78 & 43,75 & 43,59 \\
\hline Mno & 0,53 & 0,52 & 0,53 & 0,53 & 0,54 & 0,53 & 0,64 & 0,54 & 0,76 & 0,52 & 0,53 & 0,59 & 0,56 \\
\hline MgO & 1,74 & 1,42 & 1,22 & 1,30 & 0,98 & 1,59 & 0,60 & 1,33 & 0,80 & 1,72 & 1,24 & 1,17 & 1,25 \\
\hline $\mathrm{CaO}$ & 0,02 & 0,00 & 0,01 & 0,00 & 0,00 & 0,00 & 0,00 & 0,00 & 0,00 & 0,00 & 0,00 & 0,01 & 0,01 \\
\hline $\mathrm{Cr}_{2} \mathrm{O}_{3}$ & 0,00 & 0,01 & 0,01 & 0,01 & 0,00 & 0,03 & 0,00 & 0,00 & 0,00 & 0,01 & 0,02 & 0,03 & 0,02 \\
\hline TOTAL. & 99,35 & 99,77 & 99,71 & $99, \mathbf{4 8}$ & 99,57 & 99,06 & 99,05 & 99,04 & 99,56 & 99,42 & 99,49 & 99,98 & 99,35 \\
\hline \multicolumn{14}{|c|}{ Número de cátions com base em 3 átomos de oxigênio. } \\
\hline $\mathbf{S i}$ & 0,01 & 0,00 & 0,00 & 0,00 & 0,00 & 0,00 & 0,00 & 0,00 & 0,00 & 0,00 & 0,00 & 0,01 & 0,00 \\
\hline $\mathrm{Ti}$ & 30,21 & 30,59 & 30,99 & 30,70 & 30,68 & 31,02 & 30,37 & 30,41 & 30,47 & 30,70 & 30,30 & 30,90 & 30,89 \\
\hline Al & 0,07 & 0,02 & 0,05 & 0,04 & 0,04 & 0,03 & 0,02 & 0,06 & 0,03 & 0,04 & 0,04 & 0,05 & 0,04 \\
\hline $\mathrm{Fe}^{+3}$ & 3,30 & 2,73 & 1,62 & 2,18 & 2,11 & 1,31 & 2,28 & 2,50 & 2,51 & 2,36 & 3,00 & 1,93 & 1,63 \\
\hline $\mathrm{Fe}^{+2}$ & 32,48 & 33,31 & 34,08 & 33,61 & 34,03 & 33,60 & 34,09 & 33,25 & 33,84 & 33,04 & 33,25 & 34,01 & 33,88 \\
\hline Mn & 0,41 & 0,40 & 0,41 & 0,41 & 0,42 & 0,41 & 0,50 & 0,42 & 0,59 & 0,40 & 0,41 & 0,46 & 0,43 \\
\hline Mg & 1,05 & 0,86 & 0,74 & 0,78 & 0,59 & 0,96 & 0,36 & 0,80 & 0,48 & 1,04 & 0,75 & 0,71 & 0,75 \\
\hline $\mathrm{Ca}$ & 0,01 & 0,00 & 0,01 & 0,00 & 0,00 & 0,00 & 0,00 & 0,00 & 0,00 & 0,00 & 0,00 & 0,01 & 0,01 \\
\hline Cr & 0,00 & 0,01 & 0,01 & 0,01 & 0,00 & 0,02 & 0,00 & 0,00 & 0,00 & 0,01 & 0,01 & 0,02 & 0,01 \\
\hline
\end{tabular}


(continuação da Tabela 12)

\begin{tabular}{|c|c|c|c|c|c|c|c|c|}
\hline AMOSTRA & RW349 & RW350 & RW600 & RW601 & RW602 & RW602 & RW603 & RW605 \\
\hline $\mathrm{SiO}_{2}$ & 0,00 & 0,00 & 0,02 & 0,02 & 0,02 & 0,03 & 0,02 & 0,04 \\
\hline $\mathrm{TiO}_{2}$ & 49,28 & 50,18 & 53,23 & 54,04 & 54,46 & 53,77 & 52,75 & 53,67 \\
\hline $\mathrm{Al}_{2} \mathrm{O}_{3}$ & 0,09 & 0,07 & 0,47 & 0,63 & 0,71 & 0,73 & 0,34 & 0,65 \\
\hline $\mathrm{Fe}_{2} \mathrm{O}_{3}$ & 6,34 & 4,55 & 5,47 & 3,47 & 3,69 & 3,66 & 7,50 & 3,91 \\
\hline FeO & 42,48 & 43,10 & 28,09 & 26,40 & 27,48 & 27,49 & 24,29 & 27,48 \\
\hline Mno & 0,56 & 0,44 & 0,27 & 0,26 & 0,24 & 0,20 & 0,36 & 0,26 \\
\hline Mgo & 0,76 & 0,91 & 11,27 & 12,78 & 12,40 & 12,08 & 13,02 & 11,97 \\
\hline $\mathrm{CaO}$ & 0,00 & 0,00 & 0,00 & 0,02 & 0,03 & 0,01 & 0,03 & 0,02 \\
\hline $\mathrm{Cr}_{2} \mathrm{O}_{3}$ & 0,03 & 0,02 & 0,52 & 0,84 & 0,77 & 0,75 & 0,39 & 0,75 \\
\hline TOTAL. & 99,63 & 99,27 & 99,34 & 98,46 & 99,79 & 98,62 & 98,70 & 98,74 \\
\hline
\end{tabular}

Número de cátions com base em 3 átomos de oxigênio.

$\begin{array}{lrrrrrrrr}\text { Si } & \mathbf{0 , 0 0} & \mathbf{0 , 0 0} & \mathbf{0 , 0 1} & \mathbf{0 , 0 1} & \mathbf{0 , 0 1} & \mathbf{0 , 0 1} & \mathbf{0 , 0 1} & \mathbf{0 , 0 2} \\ \mathrm{Ti} & \mathbf{2 9 , 6 4} & \mathbf{3 0 , 0 8} & \mathbf{3 1 , 9 1} & \mathbf{3 2 , 4 0} & \mathbf{3 2 , 6 4} & \mathbf{3 2 , 2 4} & \mathbf{3 1 , 6 2} & \mathbf{3 2 , 1 8} \\ \mathrm{Al} & \mathbf{0 , 0 5} & \mathbf{0 , 0 4} & \mathbf{0 , 2 5} & \mathbf{0 , 3 3} & \mathbf{0 , 3 8} & \mathbf{0 , 3 9} & \mathbf{0 , 1 8} & \mathbf{0 , 3 4} \\ \mathrm{Fe}^{+3} & \mathbf{4 , 4 3} & \mathbf{3 , 1 8} & \mathbf{3 , 8 3} & \mathbf{2 , 4 3} & \mathbf{2 , 5 8} & \mathbf{2 , 4 9} & \mathbf{5 , 2 5} & \mathbf{2 , 7 3} \\ \mathrm{Fe}^{+2} & \mathbf{3 3 , 0 2} & \mathbf{3 3 , 5 0} & \mathbf{2 1 , 8 3} & \mathbf{2 0 , 5 2} & \mathbf{2 1 , 3 6} & \mathbf{2 1 , 3 7} & \mathbf{1 8 , 8 8} & \mathbf{2 1 , 3 6} \\ \mathrm{Mn} & \mathbf{0 , 4 3} & \mathbf{0 , 3 4} & \mathbf{0 , 2 1} & \mathbf{0 , 2 0} & \mathbf{0 , 1 9} & \mathbf{0 , 1 5} & \mathbf{0 , 2 8} & \mathbf{0 , 1 9} \\ \mathrm{Mg} & \mathbf{0 , 4 6} & \mathbf{0 , 6 5} & \mathbf{6 , 8 0} & \mathbf{7 , 7 1} & \mathbf{7 , 4 8} & \mathbf{7 , 2 9} & \mathbf{7 , 8 5} & \mathbf{7 , 2 2} \\ \mathrm{Ca} & \mathbf{0 , 0 0} & \mathbf{0 , 0 0} & \mathbf{0 , 0 0} & \mathbf{0 , 0 1} & \mathbf{0 , 0 2} & \mathbf{0 , 0 1} & \mathbf{0 , 0 2} & \mathbf{0 , 0 1} \\ \mathrm{Gr} & \mathbf{0 , 0 2} & \mathbf{0 , 0 1} & \mathbf{0 , 3 6} & \mathbf{0 , 6 7} & \mathbf{0 , 6 3} & \mathbf{0 , 6 1} & \mathbf{0 , 2 7} & \mathbf{0 , 6 1}\end{array}$


Tabela 13 - Composição química de ilmenitas (\% em peso) derivadas de coletas pontuais de amostras de solo e de drenagem sobre a Intrusão Tamburi., Alvo PG.

\begin{tabular}{|c|c|c|c|c|c|c|c|c|c|c|c|c|c|}
\hline AMOSTRA & POX510 & POX513 & POX516 & POX528 & POX530 & POX532 & POX27 & POX29 & POX42 & POX131 & POX132 & POX133 & POX135 \\
\hline $\mathrm{SiO}_{2}$ & 0,03 & 0,03 & 0,01 & 0,02 & 0,02 & 0,03 & 0,02 & 0,05 & 0,04 & 0,04 & 0,01 & 0,01 & 0,04 \\
\hline $\mathrm{TiO}_{2}$ & 51,95 & 51,42 & 50,92 & 52,76 & 53,28 & 52,94 & 20,38 & 10,35 & 50,60 & 37,55 & 51,87 & 15,12 & 21,92 \\
\hline $\mathrm{Al}_{2} \mathrm{O}_{3}$ & 0,13 & 0,21 & 0,19 & 0,15 & 0,15 & 0,14 & 0,15 & 0,20 & 0,18 & 0,15 & 0,17 & 0,18 & 0,13 \\
\hline $\mathrm{Fe}_{2} \mathrm{O}_{3}$ & 6,06 & 6,80 & 7,44 & 5,03 & 4,82 & 5,47 & 60,58 & 79,78 & 5,83 & 27,45 & 6,98 & 69,97 & 57,66 \\
\hline FeO & 29,87 & 30,70 & 30,26 & 30,80 & 28,83 & 30,68 & 18,10 & 9,37 & 29,81 & 33,72 & 31,21 & 13,46 & 19,33 \\
\hline Mno & 0,35 & 0,37 & 0,34 & 0,31 & 0,34 & 0,35 & 0,21 & 0,03 & 0,32 & 0,04 & 0,30 & 0,11 & 0,44 \\
\hline Mgo & 9,46 & 8,68 & 8,77 & 9,39 & 10,66 & 9,41 & 0,08 & 0,05 & 9,33 & 0,08 & 8,63 & 0,11 & 0,05 \\
\hline $\mathrm{CaO}$ & 0,02 & 0,00 & 0,02 & 0,00 & 0,01 & 0,02 & 0,00 & 0,00 & 0,03 & 0,00 & 0,01 & 0,00 & 0,01 \\
\hline $\mathrm{Nb}_{2} \mathrm{O}_{6}$ & 0,47 & 0,50 & 0,49 & 0,43 & 0,47 & 0,42 & 0,06 & 0,00 & 0,38 & 0,03 & 0,40 & 0,04 & 0,00 \\
\hline $\mathrm{Cr}_{2} \mathrm{O}_{3}$ & 0,58 & 0,35 & 0,64 & 0,62 & 0,35 & 0,23 & 0,06 & 0,07 & 2,41 & 0,04 & 0,28 & 0,08 & 0,12 \\
\hline NiO & 0,11 & 0,00 & 0,07 & 0,06 & 0,05 & 0,02 & 0,00 & 0,00 & 0,12 & 0,01 & 0,04 & 0,02 & 0,02 \\
\hline Zno & 0,00 & 0,00 & 0,10 & 0,00 & 0,02 & 0,00 & 0,06 & 0,00 & 0,00 & 0,01 & 0,06 & 0,00 & 0,06 \\
\hline TOTAL & 99,04 & 99,08 & 99,25 & 99,59 & 99,01 & 99,71 & 99,69 & 99,88 & 99,04 & 99,11 & 99,96 & 99,10 & 99,79 \\
\hline \multicolumn{14}{|c|}{ Número de cátions com base em 3 átomos de oxigênio. } \\
\hline $\mathbf{S i}$ & 0,02 & 0,01 & 0,00 & 0,01 & 0,01 & 0,02 & 0,01 & 0,02 & 0,02 & 0,02 & 0,01 & 0,01 & 0,02 \\
\hline $\mathbf{T i}$ & 31,14 & 30,82 & 30,52 & 31,63 & 31,94 & 31,74 & 12,22 & 6,20 & 30,33 & 22,51 & 31,10 & 9,06 & 13,14 \\
\hline Al & 0,07 & 0,11 & 0,10 & 0,08 & 0,08 & 0,07 & 0,08 & 0,11 & 0,09 & 0,08 & 0,09 & 0,10 & 0,07 \\
\hline $\mathrm{Fe}^{+3}$ & 4,24 & 4,76 & 5,21 & 3,52 & 3,37 & 3,83 & 42,37 & 55,80 & 4,08 & 19,20 & 4,88 & 48,93 & 40,33 \\
\hline $\mathrm{Fe}^{+2}$ & 23,22 & 23,86 & 23,52 & 23,94 & 22,41 & 23,85 & 14,07 & 7,28 & 23,17 & 26,21 & 24,26 & 10,46 & 15,02 \\
\hline $\mathrm{Mn}$ & 0,27 & 0,28 & 0,26 & 0,24 & 0,26 & 0,27 & 0,16 & 0,02 & 0,25 & 0,03 & 0,23 & 0,09 & 0,34 \\
\hline $\mathbf{M g}$ & 5,70 & 5,24 & 5,29 & 5,66 & 6,43 & 5,68 & 0,05 & 0,03 & 5,63 & 0,05 & 5,21 & 0,06 & 0,03 \\
\hline $\mathrm{Ca}$ & 0,01 & 0,00 & 0,02 & 0,00 & 0,01 & 0,01 & 0,00 & 0,00 & 0,02 & 0,00 & 0,01 & 0,00 & 0,00 \\
\hline Nb & 0,33 & 0,35 & 0,34 & 0,30 & 0,33 & 0,29 & 0,04 & 0,00 & 0,26 & 0,02 & 0,28 & 0,03 & 0,00 \\
\hline Cr & 0,40 & 0,24 & 0,44 & 0,42 & 0,24 & 0,15 & 0,04 & 0,05 & 1,65 & 0,02 & 0,19 & 0,05 & 0,09 \\
\hline $\mathbf{N i}$ & 0,09 & 0,00 & 0,08 & 0,00 & 0,01 & 0,00 & 0,00 & 0,00 & 0,10 & 0,01 & 0,03 & 0,02 & 0,02 \\
\hline$Z_{n}$ & 0,00 & 0,00 & 0,05 & 0,05 & 0,04 & 0,01 & 0,05 & 0,00 & 0,00 & 0,01 & 0,05 & 0,00 & 0,05 \\
\hline
\end{tabular}


$\mathrm{Na}$ Figura 42, as ilmenitas estudadas estão projetadas no diagrama binário $\mathrm{MgO}$ $x \mathrm{FeO}$, onde constituem duas populações distintas, conforme já notado no caso das granadas. A maior parte das amostras, tanto da Intrusão Tamburi quanto da Formação Quilombinho, apresentam correlação negativa bem destacada, além disso, algumas ilmenitas Tamburi projetadas na base do diagrama possuem teores variáveis de $\mathrm{FeO}$ e ausência total de $\mathrm{MgO}$.

Comparações com o diagrama ternário $\mathrm{FeTiO}_{3}-\mathrm{MgTiO}_{3}-\mathrm{Fe}_{2} \mathrm{O}_{3}$ estão mostradas na Figura 43, onde estão assinalados os campos referentes a kimberlitos, carbonatitos, basaltos alcalinos e toleíticos, extraídos de Mitchell (1986). As ilmenitas referentes aos conglomerados da Formação Quilombinho concentram-se no campo dos carbonatitos, enquanto aquelas da Intrusão Tamburi exibem espalhamento notável em direção ao vértice $\mathrm{Fe}_{2} \mathrm{O}_{3}$. Uma das amostras cai no campo dos kimberlitos e as demais fora dos campos assinalados.

\subsubsection{Espinélios}

Importante grupo de minerais opacos de kimberlitos, lamproítos, basaltos e outras rochas básica e ultrabásicas. Nos kimberlitos, além de constituir uma fase importante na matriz, ocorre também sob a forma de macrocristais, produtos resultantes da serpentinização das olivinas, em intercrescimentos com a ilmenita, e como produto de decomposição da ilmenita. Possuem composição química extremamente complexa descrita por um sistema de oito componentes: $\mathrm{MgCr}_{2} \mathrm{O}_{4}$ (magnésiocromita), $\mathrm{FeCr}_{2} \mathrm{O}_{4}$ ( cromita), $\mathrm{MgAl}_{2} \mathrm{O}_{4}$ (espinélio), $\mathrm{FeAl}_{2} \mathrm{O}_{4}$ (hercinita), $\mathrm{Mg}_{2} \mathrm{TiO}_{4}$ (magnésio ulvöespinélio), $\mathrm{FeTiO}_{4}$ (ulvöespinélio), $\mathrm{MgFeO}_{4}$ (magnésioferrita) e $\mathrm{Fe}_{3} \mathrm{O}_{4}$ (magnetita). Os espinélios são relativamente estáveis ao intemperismo químico, e desta forma são utilizados também na prospeç̧ão kimberlitos e lamproítos.

No decorrer desse trabalho analisamos 147 amostras de espinélios, entre as quais selecionamos 78 para interpretações. A Tabela 14 apresenta 52 análises da Intrusão Tamburi e a Tabela 15, 26 análises referentes aos conglomerados da Formação Quilombinho.

Os espinélios da Intrusão Tamburi possuem composição variável sendo constituídos essencialmente de crômio, ferro, alumínio e magnésio, com valores baixos de titânio. Assim sendo, $\mathrm{Cr}_{2} \mathrm{O}_{3}$ varia de 13,86 a 69,07; $\mathrm{FeO}$ de 6,82 a 23,49; $\mathrm{Fe}_{2} \mathrm{O}_{3}$ de 0,0 a 12,$09 ; \mathrm{MgO}$ de 6,06 a 18,$34 ; \mathrm{Al}_{2} \mathrm{O}_{3}$ de 9,61 a 52,73 e $\mathrm{TiO}_{2}$ de 0,0 a $4,47 \%$ em peso. 


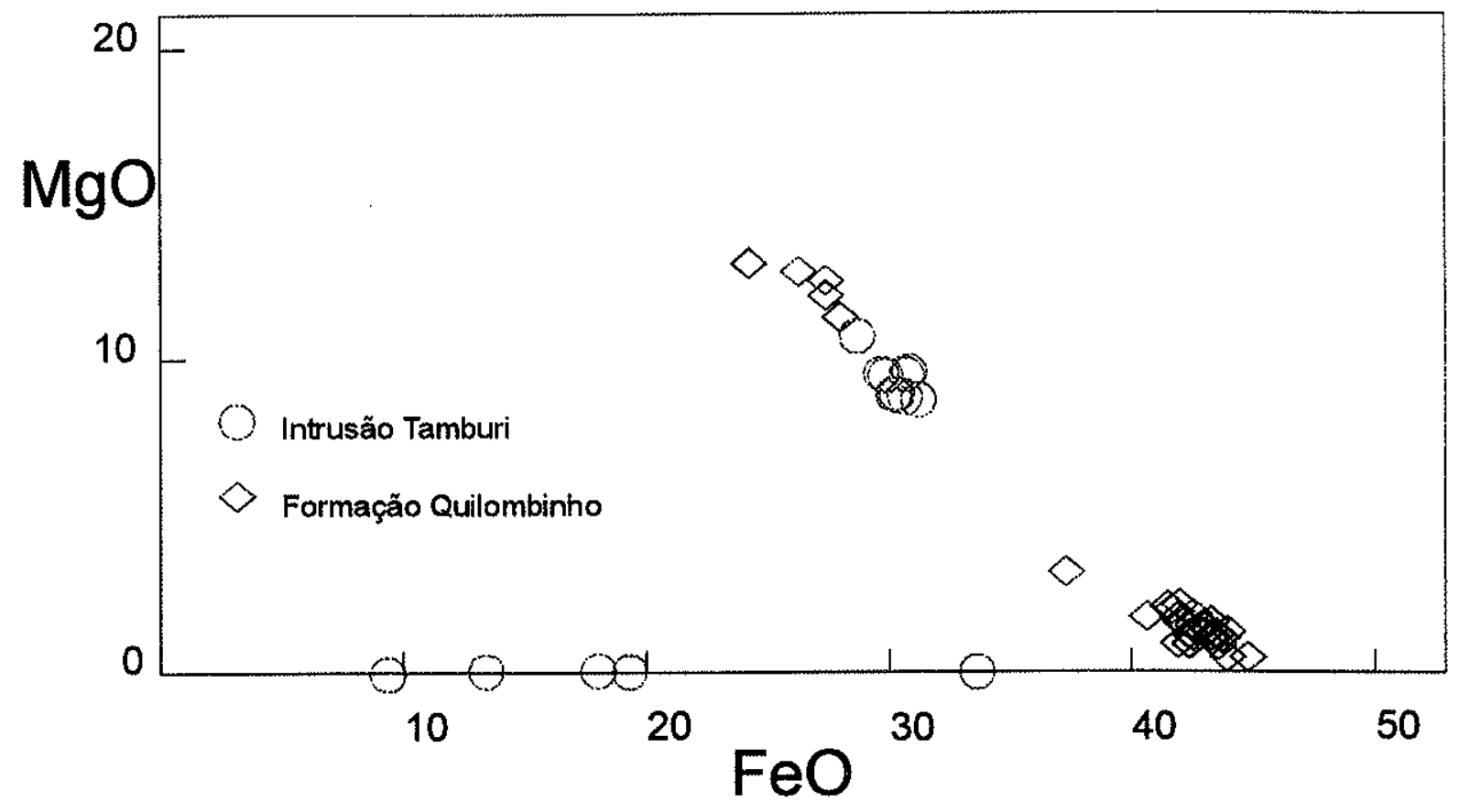

Figura 42 - Diagrama binário $\mathrm{MgO}$ x FeO mostrando que existe uma relação linear negativa entre algumas ilmenitas da Intrusão Tamburi e da Formação Quilombinho. Um segunda população da Intrusão Tamburi é totalmente desprovida de magnésio e constitue um campo a parte.

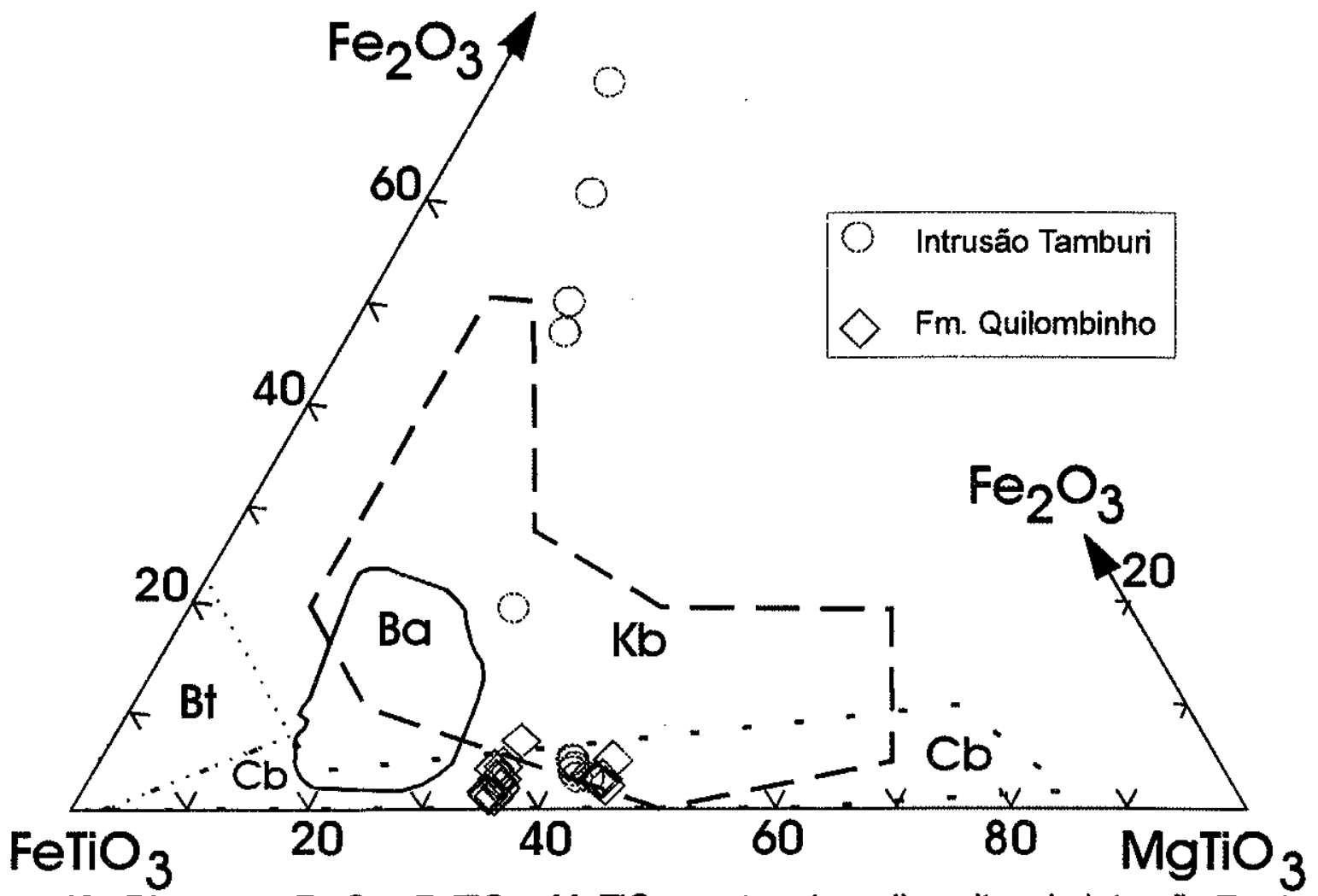

Figura 43. Diagrama $\mathrm{Fe}_{2} \mathrm{O}_{3}-\mathrm{FeTIO}_{3}-\mathrm{MgTiO}_{3}$ mostrando as ilmenitas da Intrusão Tamburi e da Formação Quilombinho. Os Campos referentes a kimberlitos $(\mathrm{Kb})$, carbonatitos (Cb), basaltos alcalinos (Ba) e basaltos toleíticos (Bt), foram extraídos de Mitchell (1986). Algumas ilmenitas Tamburi caem no campo $(\mathrm{Kb})$, e as demais espalham-se em direção ao vértice da hematita. As ilmenitas Quilombinho situam-se nos campos $\mathrm{Kb}$ e $\mathrm{Cb}$. 
Com relação aos conglomerados da Formação Quilombinho foram observadas as seguinte variações: $\mathrm{Cr}_{2} \mathrm{O}_{3}, 15,14-44,23$; $\mathrm{FeO}, 0,0-14,60 ; \mathrm{Fe}_{2} \mathrm{O}_{3}, 11,62-28,49$; $\mathrm{MgO}, 7,66-$ 17,$31 ; \mathrm{Al}_{2} \mathrm{O}_{3}, 13,22-52,69$ e $\mathrm{TiO}_{2}, 0,07-7,86 \%$ em peso.

Sintetizando, os espinélios da Intrusão Tamburi são em média mais ricos em crômio e magnésio, sendo empobrecidos em ferro e titânio. Nos conglomerados da Formação Quilombinho, invertem-se essas relações, uma vez que esses espinélios são enriquecidos em ferro e titânio e empobrecidos em crômio e magnésio.

No diagrama $\mathrm{Cr} / \mathrm{Cr}+\mathrm{Al} \times \mathrm{Fe} / \mathrm{Fe}+\mathrm{Mg}$, os espinélios estudados estão comparados com espinélios constituintes de kimberlitos, de basaltos de cadeias dorsais oceânicas e com inclusões encontradas em diamante (Mitchell, 1986). Nota-se pela Figura 44 que os espinélios Tamburi apresentam variações significativas projetando-se fora dos campos comparativos mostrados. Os espinélios da Formação Quilombinho caem também fora desses campos, porém, exibem variações composicionais bem menores.

$\mathrm{Na}$ Figura 45, os espinélios estão projetados em um diagrama binário $\mathrm{Fe} / \mathrm{Fe}+\mathrm{Mg} \mathrm{x} \mathrm{Fe}{ }^{3+}$ + Ti, e nele estão delineados os campos dos kimberlitos Koidu (K) e Libéria (L). De modo semelhante ao anterior, observa-se novamente variações amplas para os espinélios Tamburi. Além disso, nota-se que os espinélios Quilombinho caem no campo das titanomagnetitas, enquanto que a maior parte das amostras do Tamburi distribuem-se no campo das cromitas.

\subsubsection{Diamante}

Conforme já informado anteriormente, todas as oito amostras estudadas (Tabela 8), foram submetidas à digestão ácida, com o intuito de testar a presença de microdiamante. Concluídos os experimentos, foi encontrado um microdiamante no resíduo final da amostra RW08 proveniente da Intrusão Tamburi. Observações à lupa binocular, mostraram tratar-se de um cristal de $0,6 \mathrm{~mm}$, incolor, transparente, de hábito irregular, com faces curvas e arestas sinuosas.

Para comprovar a natureza verdadeira desse material, o cristal foi submetido à difração de raios $\mathrm{X}$ em uma câmara de Gandolfi durante 12 horas. $\mathrm{O}$ diagrama resultante está apresentado na Figura 46 e nele estão destacadas as três reflexões características do diamante: $2,06 \AA ; 1,26 \AA$ e $1,08 \AA$. 
Tabela 14 - Composição química de espinélios (\% em peso) presentes na Intrusão Tamburi, amostra de poço (RW 01), Alvo PG.

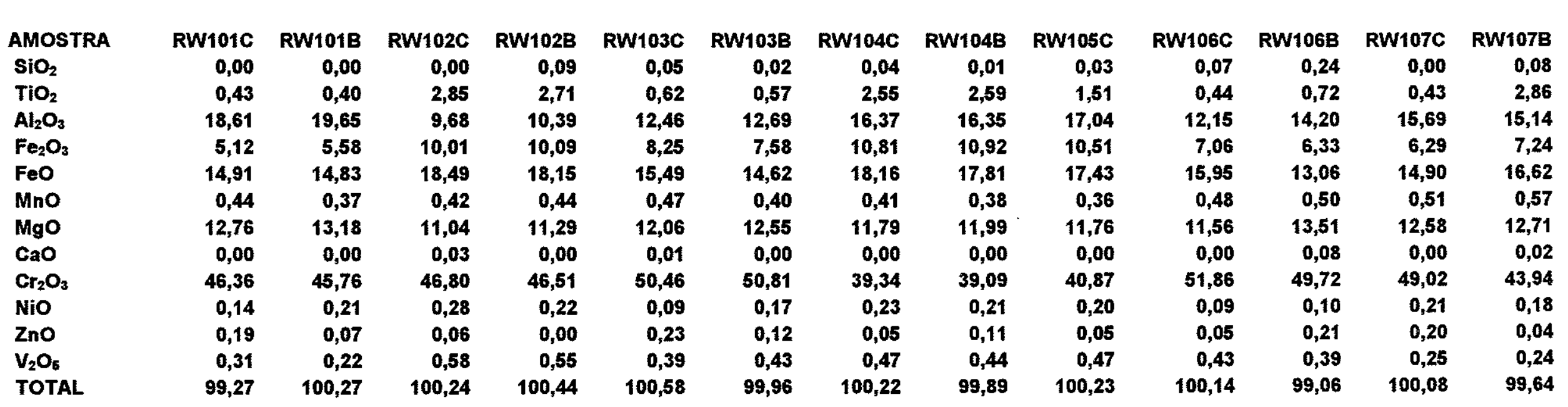

Número de cátions com base em 4 átomos de oxigênio.

\begin{tabular}{|c|c|c|c|c|c|c|c|c|c|c|c|c|c|}
\hline Si & 0,00 & 0,00 & 0,00 & 0,04 & 0,02 & 0,01 & 0,02 & 0,00 & 0,01 & 0,03 & 0,11 & 0,00 & 0,04 \\
\hline $\mathbf{T i}$ & 0,26 & 0,24 & 1,71 & 1,62 & 0,37 & 0,34 & 1,53 & 1,55 & 0,91 & 0,26 & 0,43 & 0,26 & 1,71 \\
\hline Al & 9,85 & 10,40 & 5,12 & 5,50 & 6,60 & 6,72 & 8,66 & 8,65 & 9,02 & 6,43 & 7,52 & 8,30 & 8,01 \\
\hline $\mathrm{Fe}^{+3}$ & 3,58 & 3,90 & 7,00 & 7,06 & 5,77 & 5,30 & 7,56 & 7,64 & 7,35 & 4,94 & 4,43 & 4,40 & 5,06 \\
\hline $\mathrm{Fe}^{+2}$ & 11,59 & 11,53 & 14,37 & 14,11 & 12,04 & 11,36 & 14,12 & 13,84 & 13,55 & 12,40 & 10,15 & 11,58 & 12,92 \\
\hline Mn & 0,34 & 0,29 & 0,33 & 0,34 & 0,36 & 0,31 & 0,32 & 0,29 & 0,28 & 0,37 & 0,39 & 0,39 & 0,44 \\
\hline $\mathbf{M g}$ & 7,70 & 7,95 & 6,66 & 6,81 & 7,27 & 7,57 & 7,11 & 7,23 & 7,09 & 6,97 & 8,15 & 7,59 & 7,67 \\
\hline $\mathrm{Ca}$ & 0,00 & 0,00 & 0,02 & 0,00 & 0,01 & 0,00 & 0,00 & 0,00 & 0,00 & 0,00 & 0,06 & 0,00 & 0,01 \\
\hline $\mathbf{C r}$ & 31,72 & 31,31 & 32,02 & 31,82 & 34,52 & 34,76 & 26,92 & 26,75 & 27,96 & 35,48 & 34,02 & 33,54 & 30,06 \\
\hline $\mathbf{N i}$ & 0,11 & 0,16 & 0,22 & 0,17 & 0,07 & 0,13 & 0,18 & 0,16 & 0,16 & 0,07 & 0,08 & 0,16 & 0,14 \\
\hline $\mathrm{Zn}$ & 0,15 & 0,06 & 0,05 & 0,00 & 0,18 & 0,10 & 0,04 & 0,09 & 0,04 & 0,04 & 0,17 & 0,16 & 0,03 \\
\hline $\mathbf{v}$ & 0,17 & 0,12 & 0,32 & 0,31 & 0,22 & 0,24 & 0,26 & 0,25 & 0,26 & 0,24 & 0,22 & 0,14 & 0,13 \\
\hline $\mathrm{Cr} / \mathrm{Cr}+\mathrm{Al}$ & 0,76 & 0,75 & 0,86 & 0,85 & 0,84 & 0,84 & 0,76 & 0,76 & 0,76 & 0,85 & 0,82 & 0,80 & 0,79 \\
\hline
\end{tabular}




\begin{tabular}{|c|c|c|c|c|c|c|c|c|c|c|c|c|c|}
\hline $\begin{array}{l}\text { AMOSTRA } \\
\mathrm{SiO}_{2}\end{array}$ & $\begin{array}{r}\text { RW108C } \\
0,02\end{array}$ & $\begin{array}{r}\text { RW109C } \\
0,03\end{array}$ & $\begin{array}{r}\text { RW109B } \\
0,08\end{array}$ & $\begin{array}{r}\text { RW110C } \\
0,10\end{array}$ & $\begin{array}{r}\text { RW111B } \\
0,09\end{array}$ & $\begin{array}{r}\text { RW112C } \\
0,08\end{array}$ & $\begin{array}{r}\text { RW112B } \\
0,08\end{array}$ & $\begin{array}{r}\text { RW113C } \\
0,03\end{array}$ & $\begin{array}{r}\text { RW113B } \\
0,01\end{array}$ & $\begin{array}{r}R W 114 C \\
0,00\end{array}$ & $\begin{array}{r}\text { RW114B } \\
0,09\end{array}$ & $\begin{array}{r}\text { RW115C } \\
0,00\end{array}$ & $\begin{array}{r}\text { RW116C } \\
0,00\end{array}$ \\
\hline $\mathrm{TiO}_{2}$ & 1,23 & 0,81 & 0,90 & 4,25 & 1,39 & 0,84 & 1,57 & 0,16 & 0,21 & 1,86 & 2,06 & 0,13 & 0,20 \\
\hline $\mathrm{Al}_{2} \mathrm{O}_{3}$ & 15,80 & 18,88 & 19,03 & 12,78 & 12,18 & 17,02 & 9,86 & 44,34 & 45,08 & 9,61 & 10,40 & 38,88 & 42,70 \\
\hline $\mathrm{Fe}_{2} \mathrm{O}_{3}$ & 8,92 & 9,59 & 8,87 & 11,44 & 7,80 & 8,05 & 6,50 & 2,25 & 2,26 & 11,00 & 9,41 & 2,20 & 1,92 \\
\hline FeO & 16,39 & 15,85 & 15,96 & 19,12 & 16,37 & 15,62 & 16,79 & 10,74 & 10,84 & 17,86 & 16,25 & 13,53 & 12,33 \\
\hline Mno & 0,48 & 0,37 & 0,36 & 0,41 & 0,49 & 0,50 & 0,57 & 0,24 & 0,21 & 0,50 & 0,44 & 0,32 & 0,20 \\
\hline Mgo & 12,05 & 12,39 & 12,38 & 11,66 & 11,84 & 12,51 & 11,28 & 18,09 & 18,31 & 10,82 & 12,05 & 15,84 & 16,94 \\
\hline $\mathrm{CaO}$ & 0,01 & 0,00 & 0,01 & 0,00 & 0,00 & 0,01 & 0,07 & 0,00 & 0,00 & 0,02 & 0,00 & 0,01 & 0,01 \\
\hline $\mathrm{Cr}_{2} \mathrm{O}_{3}$ & 44,41 & 40,67 & 40,98 & 39,19 & 49,47 & 45,07 & 52,42 & 22,61 & 22,28 & 47,73 & 48,46 & 28,52 & 24,16 \\
\hline NiO & 0,14 & 0,19 & 0,22 & 0,28 & 0,16 & 0,26 & 0,12 & 0,29 & 0,28 & 0,18 & 0,19 & 0,16 & 0,23 \\
\hline Zno & 0,12 & 0,11 & 0,01 & 0,05 & 0,04 & 0,13 & 0,09 & 0,17 & 0,23 & 0,11 & 0,13 & 0,21 & 0,28 \\
\hline $\mathrm{V}_{2} \mathrm{O}_{6}$ & 0,36 & 0,33 & 0,38 & 0,58 & 0,40 & 0,40 & 0,35 & 0,14 & 0,08 & 0,54 & 0,45 & 0,13 & 0,19 \\
\hline TOTAL & 99,93 & 99,22 & 99,18 & 99,86 & 100,23 & 100,49 & 99,70 & 99,06 & 99,79 & 100,23 & 99,93 & 99,93 & 99,16 \\
\hline \multicolumn{14}{|c|}{ Número de cátions com base em 4 átomos de oxigênio. } \\
\hline Si & 0,01 & 0,01 & 0,64 & 0,05 & 0,04 & 0,04 & 0,04 & 0,01 & 0,00 & 0,00 & 0,04 & 0,00 & 0,00 \\
\hline $\mathbf{T i}$ & 0,74 & 0,49 & 0,54 & 2,55 & 0,83 & 0,50 & 0,94 & 0,10 & 0,13 & 1,12 & 1,23 & 0,08 & 0,12 \\
\hline Al & 8,36 & 9,99 & 10,07 & 6,76 & 6,45 & 9,01 & 5,22 & 23,47 & 23,86 & 5,09 & 5,50 & 20,58 & 22,60 \\
\hline $\mathrm{Fe}^{+3}$ & 6,24 & 6,71 & 6,20 & 8,00 & 5,46 & 5,63 & 4,55 & 1,57 & 1,58 & 7,69 & 6,58 & 1,54 & 1,34 \\
\hline $\mathrm{Fe}^{+2}$ & 12,74 & 12,32 & 12,41 & 14,86 & 12,72 & 12,14 & 13,05 & 8,35 & 8,43 & 13,88 & 12,63 & 10,52 & 9,58 \\
\hline Mn & 0,37 & 0,29 & 0,28 & 0,32 & 0,38 & 0,39 & 0,44 & 0,19 & 0,16 & 0,39 & 0,34 & 0,25 & 0,15 \\
\hline $\mathbf{M g}$ & 7,27 & 7,47 & 7,47 & 7,03 & 7,14 & 7,54 & 6,80 & 10,91 & 11,04 & 6,53 & 7,27 & 9,55 & 10,22 \\
\hline $\mathrm{Ca}$ & 0,01 & 0,00 & 0,01 & 0,00 & 0,00 & 0,01 & 0,05 & 0,00 & 0,00 & 0,01 & 0,00 & 0,01 & 0,01 \\
\hline Cr & 30,39 & 27,83 & 28,04 & 26,81 & 33,85 & 30,84 & 35,87 & 15,47 & 15,24 & 32,66 & 33,16 & 19,51 & 16,53 \\
\hline $\mathbf{N i}$ & 0,11 & 0,15 & 0,17 & 0,22 & 0,13 & 0,20 & 0,09 & 0,23 & 0,22 & 0,14 & 0,15 & 0,13 & 0,14 \\
\hline $\mathbf{Z n}$ & 0,10 & 0,09 & 0,01 & 0,04 & 0,03 & 0,10 & 0,07 & 0,14 & 0,18 & 0,09 & 0,10 & 0,17 & 0,22 \\
\hline v & 0,20 & 0,18 & 0,21 & 0,32 & 0,22 & 0,22 & 0,20 & 0,08 & 0,04 & 0,30 & 0,25 & 0,07 & 0,11 \\
\hline $\mathrm{Cr} / \mathrm{Cr}+\mathrm{Al}$ & 0,78 & 0,74 & 0,74 & 0,80 & 0,84 & 0,77 & 0,87 & 0,40 & 0,39 & 0,87 & 0,86 & 0,49 & 0,42 \\
\hline
\end{tabular}




\begin{tabular}{|c|c|c|c|c|c|c|c|c|c|c|c|c|c|}
\hline AMOSTRA & RW117C & RW117B & RW118C & RW119C & RW119B & RW120C & RW801 & RW804 & RW812 & RW813 & RW818 & RW819 & RW821 \\
\hline $\mathrm{SiO}_{2}$ & 0,00 & 0,22 & 0,01 & 0,02 & 0,04 & 0,00 & 0,00 & 0,01 & 0,05 & 0,01 & 0,06 & 0,03 & 0,00 \\
\hline $\mathrm{TiO}_{2}$ & 0,14 & 0,15 & 0,02 & 0,10 & 0,15 & 0,10 & 0,04 & 0,10 & 1,33 & 0,31 & 1,37 & 0,28 & 0,84 \\
\hline $\mathrm{Al}_{2} \mathrm{O}_{3}$ & 47,78 & 44,75 & 42,28 & 50,12 & 50,39 & 32,91 & 49,96 & 52,73 & 15,67 & 32,92 & 18,07 & 14,30 & 21,19 \\
\hline $\mathrm{Fe}_{2} \mathrm{O}_{3}$ & 1,02 & 0,98 & 1,17 & 2,91 & 2,90 & 1,40 & 0,48 & 0,25 & 3,97 & 0,00 & 5,42 & 1,57 & 0,00 \\
\hline FeO & 11,52 & 11,17 & 10,89 & 11,55 & 11,75 & 15,11 & 12,59 & 12,04 & 20,72 & 16,27 & 20,55 & 18,65 & 18,15 \\
\hline $\mathrm{MnO}$ & 0,17 & 0,26 & 0,28 & 0,28 & 0,16 & 0,34 & 0,21 & 0,17 & 0,45 & 0,31 & 0,36 & 0,40 & 0,37 \\
\hline $\mathrm{MgO}$ & 17,98 & 16,79 & 17,71 & 18,14 & 18,34 & 14,03 & 17,11 & 17,83 & 8,81 & 11,85 & 9,24 & 9,47 & 10,27 \\
\hline $\mathrm{CaO}$ & 0,00 & 0,02 & 0,00 & 0,00 & 0,00 & 0,00 & 0,00 & 0,01 & 0,01 & 0,00 & 0,00 & 0,00 & 0,00 \\
\hline $\mathrm{Cr}_{2} \mathrm{O}_{3}$ & 19,81 & 19,27 & 26,24 & 15,56 & 15,91 & 34,82 & 16,49 & 13,86 & 45,84 & 35,05 & 41,79 & 52,15 & 46,03 \\
\hline NiO & 0,26 & 0,24 & 0,16 & 0,29 & 0,23 & 0,08 & 0,32 & 0,33 & 0,14 & 0,19 & 0,20 & 0,16 & 0,14 \\
\hline Zno & 0,21 & 0,23 & 0,30 & 0,22 & 0,29 & 0,29 & 0,21 & 0,21 & 0,11 & 0,24 & 0,07 & 0,06 & 0,17 \\
\hline $\mathbf{V}_{2} \mathbf{O}_{6}$ & 0,16 & 0,21 & 0,12 & 0,10 & 0,06 & 0,09 & 0,11 & 0,07 & 0,45 & 0,34 & 0,36 & 0,32 & 0,44 \\
\hline TOTAL & 99,05 & 94,29 & 99,18 & 99,29 & 100,22 & 99,17 & $\mathbf{9 7 , 5 2}$ & 97,61 & 97,55 & 97,49 & 97,49 & 97,39 & $\mathbf{9 7 , 6 0}$ \\
\hline \multicolumn{14}{|c|}{ Número de cátions com base em 4 átomos de oxigênio. } \\
\hline Si & 0,00 & 0,10 & 0,00 & 0,01 & 0,02 & 0,00 & 0,00 & 0,00 & 0,02 & 0,00 & 0,03 & 0,01 & 0,00 \\
\hline $\mathrm{Ti}$ & 0,08 & 0,09 & 0,01 & 0,06 & 0,09 & 0,06 & 0,02 & 0,06 & 0,80 & 0,19 & 0,82 & 0,17 & 0,50 \\
\hline Al & 25,29 & 23,69 & 22,38 & 26,53 & 26,67 & 17,42 & 26,44 & 27,91 & 8,29 & 17,42 & 9,56 & 7,57 & 11,22 \\
\hline $\mathrm{Fe}^{+3}$ & 0,71 & 0,69 & 0,82 & 2,04 & 2,03 & 0,98 & 0,34 & 0,17 & 2,78 & 0,00 & 3,79 & 1,10 & 0,00 \\
\hline $\mathrm{Fe}^{+2}$ & 8,95 & 8,68 & 8,46 & 8,98 & 9,13 & 11,75 & 9,79 & 9,36 & 16,11 & 12,65 & 15,97 & 14,50 & 14,11 \\
\hline Mn & 0,13 & 0,20 & 0,22 & 0,22 & 0,12 & 0,26 & 0,16 & 0,13 & 0,35 & 0,24 & 0,28 & 0,31 & 0,29 \\
\hline $\mathbf{M g}$ & 10,84 & 10,13 & 10,68 & 10,94 & 11,06 & 8,46 & 10,32 & 10,75 & 5,31 & 7,15 & 5,57 & 5,71 & 6,19 \\
\hline $\mathrm{Ca}$ & 0,00 & 0,01 & 0,00 & 0,00 & 0,00 & 0,00 & 0,00 & 0,01 & 0,01 & 0,00 & 0,00 & 0,00 & 0,00 \\
\hline $\mathrm{Cr}$ & 13,55 & 13,18 & 17,95 & 10,65 & 10,89 & 23,82 & 11,28 & 9,48 & 31,36 & 23,98 & 28,59 & 35,68 & 31,49 \\
\hline $\mathbf{N i}$ & 0,20 & 0,19 & 0,13 & 0,23 & 0,18 & 0,06 & 0,25 & 0,26 & 0,11 & 0,15 & 0,16 & 0,13 & 0,11 \\
\hline $\mathrm{Zn}$ & 0,17 & 0,18 & 0,24 & 0,18 & 0,23 & 0,23 & 0,17 & 0,17 & 0,09 & 0,19 & 0,06 & 0,05 & 0,14 \\
\hline v & 0,09 & 0,12 & 0,07 & 0,06 & 0,03 & 0,05 & 0,06 & 0,04 & 0,25 & 0,19 & 0,20 & 0,18 & 0,25 \\
\hline $\mathrm{Cr} / \mathrm{Cr}+\mathrm{Al}$ & 0,35 & 0,36 & 0,45 & 0,29 & 0,29 & 0,58 & 0,30 & 0,25 & 0,79 & 0,58 & 0,75 & 0,82 & 0,74 \\
\hline
\end{tabular}




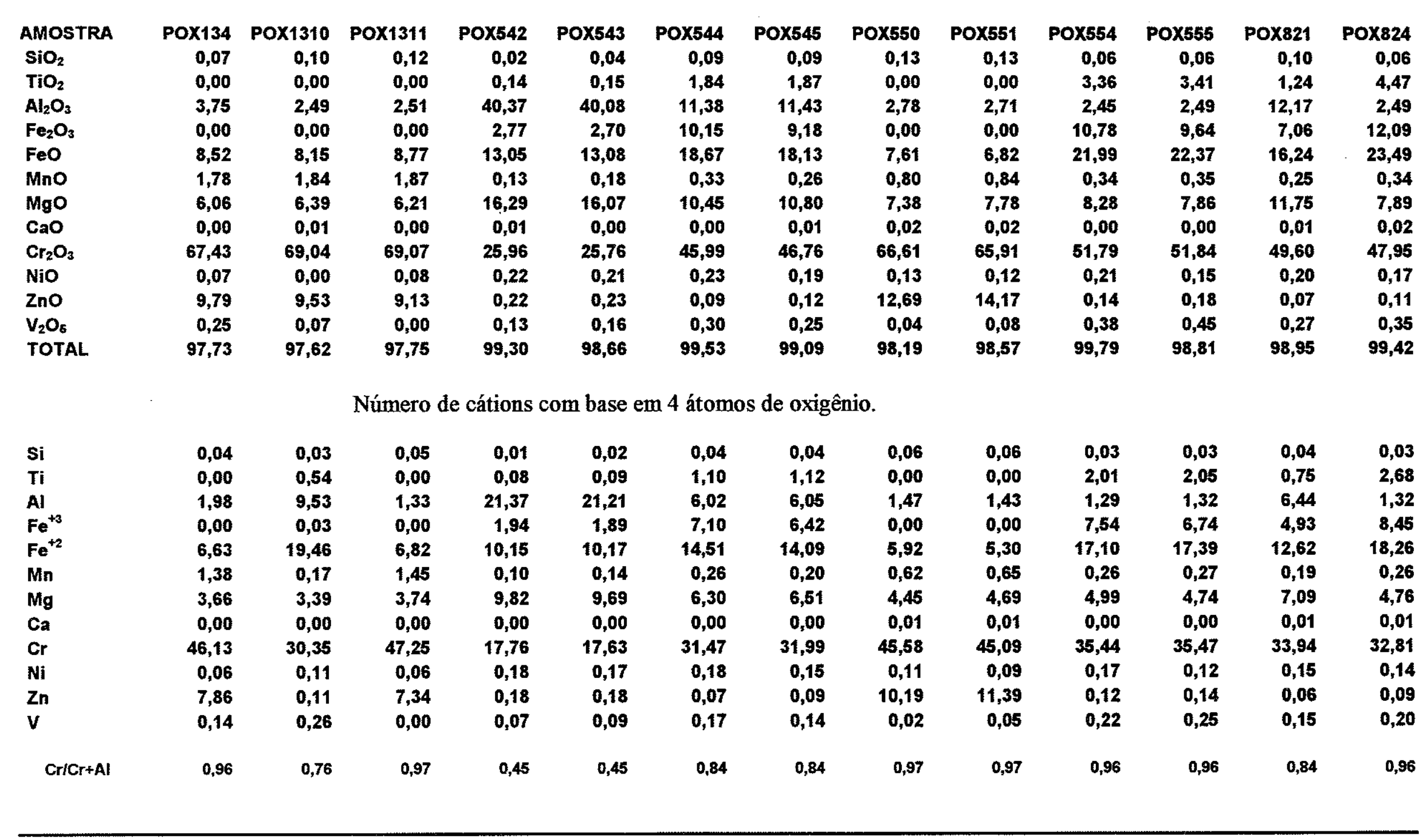


Tabela 15 - Composição química de espinélios, centro e borda (\% em peso) presentes eñ conglomerados da Formação Quilombinho, Grupo Bauru; amostra RW 06, Alvo PX.

\begin{tabular}{|c|c|c|c|c|c|c|c|c|c|c|c|c|c|c|}
\hline $\begin{array}{l}\text { AMOSTRA } \\
\mathrm{SiO}_{2}\end{array}$ & $\begin{array}{r}\text { RW601C } \\
0,14\end{array}$ & $\begin{array}{r}\text { RW601B } \\
0,18\end{array}$ & $\begin{array}{r}\text { RW602C } \\
0,23\end{array}$ & $\begin{array}{r}\text { RW602B } \\
0,11\end{array}$ & $\begin{array}{r}\text { RW603C } \\
0,21\end{array}$ & $\begin{array}{r}\text { RW603B } \\
0,20\end{array}$ & $\begin{array}{r}\text { RW604C } \\
0,22\end{array}$ & $\begin{array}{r}\text { RW604B } \\
0,06\end{array}$ & $\begin{array}{r}\text { RW605C } \\
0,19\end{array}$ & $\begin{array}{r}\text { RW605B } \\
0,12\end{array}$ & $\begin{array}{c}\text { RW606C } \\
0,11\end{array}$ & $\begin{array}{r}\text { RW606B } \\
0,11\end{array}$ & $\begin{array}{c}\text { RW607C F } \\
0,01\end{array}$ & $\begin{array}{r}\text { RW607B } \\
0,02\end{array}$ \\
\hline $\mathrm{TiO}_{2}$ & 0,88 & 1,01 & 0,79 & 0,81 & 0,47 & 0,46 & 0,44 & 7,86 & 0,95 & 0,94 & 0,88 & 0,93 & 0,08 & 0,07 \\
\hline $\mathrm{Al}_{2} \mathrm{O}_{3}$ & 25,89 & 25,65 & 20,83 & 22,68 & 27,86 & 26,67 & 27,52 & 13,22 & 26,67 & 26,76 & 33,54 & 33,68 & 52,69 & 52,59 \\
\hline $\mathrm{Fe}_{2} \mathrm{O}_{3}$ & 16,03 & 17,06 & 16,07 & 19,32 & 13,21 & 18,18 & 16,89 & 28,49 & 16,97 & 19,82 & 14,57 & 19,19 & 11,62 & 11,97 \\
\hline FeO & 1,77 & 1,71 & 2,19 & 0,50 & 0,27 & 0,00 & 1,22 & 14,60 & 2,86 & 0,94 & 1,24 & 0,00 & 0,00 & 0,00 \\
\hline Mno & 0,33 & 0,35 & 0,35 & 0,40 & 0,36 & 0,38 & 0,39 & 0,47 & 0,30 & 0,42 & 0,27 & 0,30 & 0,17 & 0,16 \\
\hline $\mathrm{MgO}$ & 12,96 & 12,25 & 12,10 & 10,17 & 14,50 & 11,21 & 12,47 & 7,66 & 12,52 & 10,59 & 14,80 & 11,55 & 17,31 & 17,23 \\
\hline $\mathrm{CaO}$ & 0,00 & 0,00 & 0,01 & 0,00 & 0,00 & 0,00 & 0,00 & 0,02 & 0,00 & 0,02 & 0,00 & 0,00 & 0,00 & 0,00 \\
\hline $\mathrm{Cr}_{2} \mathrm{O}_{3}$ & 39,84 & 39,33 & 44,23 & 42,68 & 39,79 & 40,16 & 39,73 & 26,63 & 37,65 & 38,42 & 32,71 & 31,91 & 15,18 & 15,14 \\
\hline NiO & 0,21 & 0,25 & 0,20 & 0,13 & 0,27 & 0,24 & 0,23 & 0,13 & 0,25 & 0,22 & 0,26 & 0,24 & 0,36 & 0,31 \\
\hline Zno & 0,05 & 0,09 & 0,13 & 0,08 & 0,04 & 0,10 & 0,09 & 0,07 & 0,06 & 0,12 & 0,06 & 0,10 & 0,15 & 0,22 \\
\hline $\mathbf{V}_{2} \mathbf{O}_{5}$ & 0,21 & 0,21 & 0,21 & 0,20 & 0,18 & 0,19 & 0,19 & 1,02 & 0,27 & 0,24 & 0,23 & 0,24 & 0,08 & 0,09 \\
\hline TOTAL & 98,31 & 98,09 & $\mathbf{9 7 , 3 4}$ & 97,08 & 97,16 & 97,79 & 99,39 & 100,23 & 98,69 & 98,61 & 98,67 & 98,25 & 97,65 & 97,80 \\
\hline \multicolumn{15}{|c|}{ Número de cátions com base em 4 átomos de oxigênio. } \\
\hline $\mathbf{S i}$ & 0,07 & 0,08 & 0,11 & 0,05 & 0,10 & 0,09 & 0,10 & 0,03 & 0,09 & 0,06 & 0,05 & 0,05 & 0,00 & 0,01 \\
\hline $\mathbf{T i}$ & 0,53 & 0,61 & 0,47 & 0,49 & 0,28 & 0,28 & 0,26 & 4,71 & 0,57 & 0,56 & 0,63 & 0,56 & 0,05 & 0,04 \\
\hline Al & 13,70 & 13,58 & 11,03 & 12,00 & 14,75 & 14,12 & 14,57 & 7,00 & 14,12 & 14,16 & 17,75 & 17,83 & 27,89 & 27,84 \\
\hline $\mathrm{Fe}^{+3}$ & 11,21 & 11,93 & 11,24 & 13,51 & 9,24 & 12,72 & 11,81 & 19,93 & 11,87 & 13,86 & 10,19 & 13,42 & 8,13 & 8,37 \\
\hline $\mathrm{Fe}^{+2}$ & 1,38 & 1,33 & 1,70 & 0,39 & 0,21 & 0,00 & 0,95 & 11,35 & 2,22 & 0,73 & 0,96 & 0,00 & 0,00 & 0,00 \\
\hline$M n$ & 0,26 & 0,27 & 0,27 & 0,31 & 0,28 & 0,29 & 0,30 & 0,36 & 0,23 & 0,33 & 0,21 & 0,23 & 0,13 & 0,12 \\
\hline $\mathbf{M g}$ & 7,82 & 7,39 & 7,30 & 6,13 & 8,74 & 6,76 & 7,52 & 4,62 & 7,55 & 6,39 & 8,93 & 6,97 & 10,44 & 10,39 \\
\hline $\mathrm{Ca}$ & 0,00 & 0,00 & 0,01 & 0,00 & 0,00 & 0,00 & 0,00 & 0,01 & 0,00 & 0,01 & 0,00 & 0,00 & 0,00 & 0,00 \\
\hline Cr & 27,26 & 26,91 & 30,26 & 29,20 & 27,22 & 27,48 & 27,18 & 18,22 & 25,76 & 26,29 & 22,38 & 21,83 & 10,39 & 10,36 \\
\hline $\mathrm{Ni}$ & 0,16 & 0,20 & 0,16 & 0,10 & 0,21 & 0,19 & 0,18 & 0,10 & 0,20 & 0,17 & 0,20 & 0,19 & 0,28 & 0,24 \\
\hline $\mathbf{Z n}$ & 0,04 & 0,07 & 0,10 & 0,06 & 0,03 & 0,08 & 0,07 & 0,06 & 0,05 & 0,10 & 0,05 & 0,08 & 0,12 & 0,18 \\
\hline$v$ & 0,12 & 0,12 & 0,12 & 0,11 & 0,10 & 0,11 & 0,11 & 0,57 & 0,15 & 0,13 & 0,13 & 0,13 & 0,04 & 0,05 \\
\hline $\mathrm{Cr} / \mathrm{Cr}+\mathrm{Al}$ & 0,67 & 0,66 & 0,73 & 0,71 & 0,65 & 0,66 & 0,65 & 0,72 & 0,65 & 0,65 & 0,56 & 0,55 & 0,27 & 0,27 \\
\hline
\end{tabular}




\begin{tabular}{|c|c|c|c|c|c|c|c|c|c|c|c|c|}
\hline $\begin{array}{l}\text { AMOSTRA } \\
\mathrm{SiO}_{2}\end{array}$ & $\begin{array}{r}\text { RW501C } \\
0,15\end{array}$ & $\begin{array}{r}\text { RW501B } \\
0,17\end{array}$ & $\begin{array}{r}\text { RW502C } \\
0,15\end{array}$ & $\begin{array}{r}\text { RW502B } \\
0,18\end{array}$ & $\begin{array}{r}\text { RW503C } \\
0,11\end{array}$ & $\begin{array}{r}\text { RW503B } \\
0,18\end{array}$ & $\begin{array}{r}\text { RW504C } \\
0,15\end{array}$ & $\begin{array}{r}\text { RW504B } \\
0,08\end{array}$ & $\begin{array}{r}\text { RW505c } \\
0,14\end{array}$ & $\begin{array}{r}\text { RW505B } \\
0,14\end{array}$ & $\begin{array}{r}\text { RW506C } \\
0,15\end{array}$ & $\begin{array}{r}\text { RW506B } \\
0,10\end{array}$ \\
\hline $\mathrm{TiO}_{2}$ & 0,81 & 0,79 & 0,94 & 0,90 & 0,83 & 0,88 & 0,84 & 0,86 & 0,96 & 0,97 & 0,85 & 0,83 \\
\hline $\mathrm{Al}_{2} \mathrm{O}_{3}$ & 26,21 & 26,59 & 33,31 & 35,31 & 26,82 & 26,81 & 26,77 & 27,09 & 25,08 & 27,05 & 24,51 & 24,45 \\
\hline $\mathrm{Fe}_{2} \mathrm{O}_{3}$ & 16,65 & 16,17 & 15,92 & 20,12 & 15,70 & 18,52 & 21,24 & 21,47 & 17,31 & 24,23 & 20,40 & 20,64 \\
\hline $\mathrm{FeO}$ & 1,56 & 1,62 & 2,58 & 1,50 & 1,47 & 0,84 & 0,00 & 0,36 & 1,34 & 0,35 & 0,00 & 0,00 \\
\hline Mno & 0,31 & 0,36 & 0,29 & 0,29 & 0,31 & 0,35 & 0,36 & 0,36 & 0,34 & 0,40 & 0,31 & 0,39 \\
\hline $\mathrm{MgO}$ & 12,55 & 12,85 & 13,72 & 11,18 & 13,23 & 11,50 & 9,49 & $\mathbf{9 , 5 8}$ & 12,04 & 7,84 & 9,60 & 9,30 \\
\hline $\mathrm{CaO}$ & 0,01 & 0,00 & 0,01 & 0,00 & 0,00 & 0,00 & 0,01 & 0,00 & 0,00 & 0,01 & 0,00 & 0,00 \\
\hline $\mathrm{Cr}_{2} \mathrm{O}_{3}$ & 39,60 & 39,23 & 30,35 & 27,85 & 39,23 & 39,18 & 38,68 & 38,28 & 40,43 & 37,35 & 42,14 & 41,84 \\
\hline NiO & 0,22 & 0,24 & 0,25 & 0,29 & 0,26 & 0,20 & 0,24 & 0,22 & 0,19 & 0,16 & 0,28 & 0,19 \\
\hline Zno & 0,02 & 0,05 & 0,03 & 0,14 & 0,04 & 0,07 & 0,07 & 0,07 & 0,07 & 0,11 & 0,02 & 0,12 \\
\hline $\mathbf{V}_{2} \mathbf{O}_{6}$ & 0,18 & 0,23 & 0,24 & 0,19 & 0,22 & 0,24 & 0,19 & 0,26 & 0,25 & 0,21 & 0,22 & 0,22 \\
\hline TOTAL & 98,27 & 98,30 & 97,79 & 97,95 & 98,22 & 98,77 & 98,04 & 98,63 & 98,15 & 98,82 & 98,48 & 98,08 \\
\hline
\end{tabular}

Número de cátions com base em 4 átomos de oxigênio.

\begin{tabular}{|c|c|c|c|c|c|c|c|c|c|c|c|c|}
\hline Si & 0,07 & 0,08 & 0,07 & 0,08 & 0,05 & 0,08 & 0,07 & 0,04 & 0,07 & 0,07 & 0,07 & 0,05 \\
\hline $\mathrm{Ti}$ & 0,49 & 0,47 & 0,56 & 0,54 & 0,50 & 0,53 & 0,50 & 0,52 & 0,58 & 0,58 & 0,51 & 0,50 \\
\hline Al & 13,87 & 14,07 & 17,63 & 18,69 & 14,20 & 14,19 & 14,17 & 14,34 & 13,27 & 14,32 & 12,97 & 12,94 \\
\hline $\mathrm{Fe}^{+3}$ & 11,65 & 11,31 & 11,13 & 14,07 & 10,98 & 12,95 & 14,86 & 15,02 & 12,11 & 16,95 & 14,27 & 14,44 \\
\hline $\mathrm{Fe}^{+2}$ & 1,21 & 1,26 & 2,01 & 1,17 & 1,14 & 0,65 & 0,00 & 0,28 & 1,04 & 0,27 & 0,00 & 0,00 \\
\hline $\mathrm{Mn}$ & 0,24 & 0,28 & 0,22 & 0,22 & 0,24 & 0,27 & 0,28 & 0,28 & 0,26 & 0,31 & 0,24 & 0,30 \\
\hline $\mathbf{M g}$ & 7,57 & 7,75 & 8,27 & 6,74 & 7,98 & 6,94 & 5,72 & 5,78 & 7,26 & 4,73 & 5,79 & 5,61 \\
\hline $\mathrm{Ca}$ & 0,01 & 0,00 & 0,01 & 0,00 & 0,00 & 0,00 & 0,01 & 0,00 & 0,00 & 0,01 & 0,00 & 0,00 \\
\hline $\mathrm{Cr}$ & 27,09 & 26,84 & 20,77 & 19,05 & 26,84 & 26,81 & 26,46 & 26,19 & 27,66 & 25,55 & 28,83 & 28,63 \\
\hline Ni & 0,17 & 0,19 & 0,20 & 0,23 & 0,20 & 0,16 & 0,19 & 0,17 & 0,15 & 0,13 & 0,22 & 0,15 \\
\hline $\mathrm{Zn}$ & 0,02 & 0,04 & 0,02 & 0,11 & 0,03 & 0,06 & 0,06 & 0,06 & 0,06 & 0,09 & 0,02 & 0,10 \\
\hline v & 0,10 & 0,13 & 0,13 & 0,11 & 0,12 & 0,13 & 0,11 & 0,15 & 0,14 & 0,12 & 0,12 & 0,12 \\
\hline $\mathrm{Cr} / \mathrm{Cr}+\mathrm{Al}$ & 0,66 & 0,66 & 0,54 & 0,50 & 0,65 & 0,65 & 0,65 & 0,65 & 0,68 & 0,64 & 0,69 & 0,69 \\
\hline
\end{tabular}




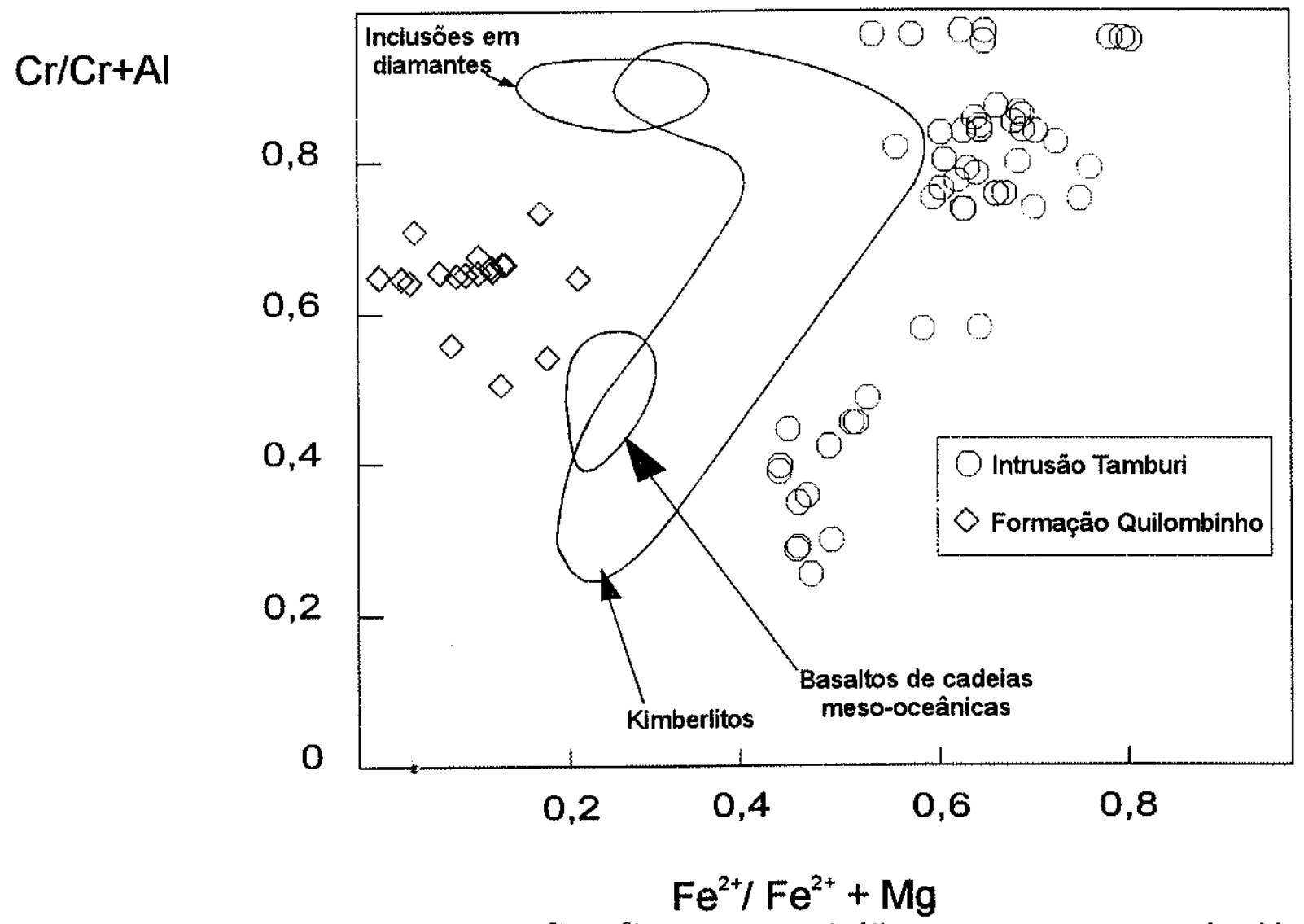

Figura 44 - Diagrama $\mathrm{Cr} / \mathrm{Cr}+\mathrm{Al} \times \mathrm{Fe}^{2+} / \mathrm{Fe}^{2+}+\mathrm{Mg}$ de espinélios com os campos de kimberlitos, basaltos meso-oceânicos e inclusões de diamantes,conforme Mitchell (1986). Os espinélios Tamburi mostram variações significativas maiores do que os da Formação Quilombinho. Ambos caem fora dos campos mostrados no desenho.

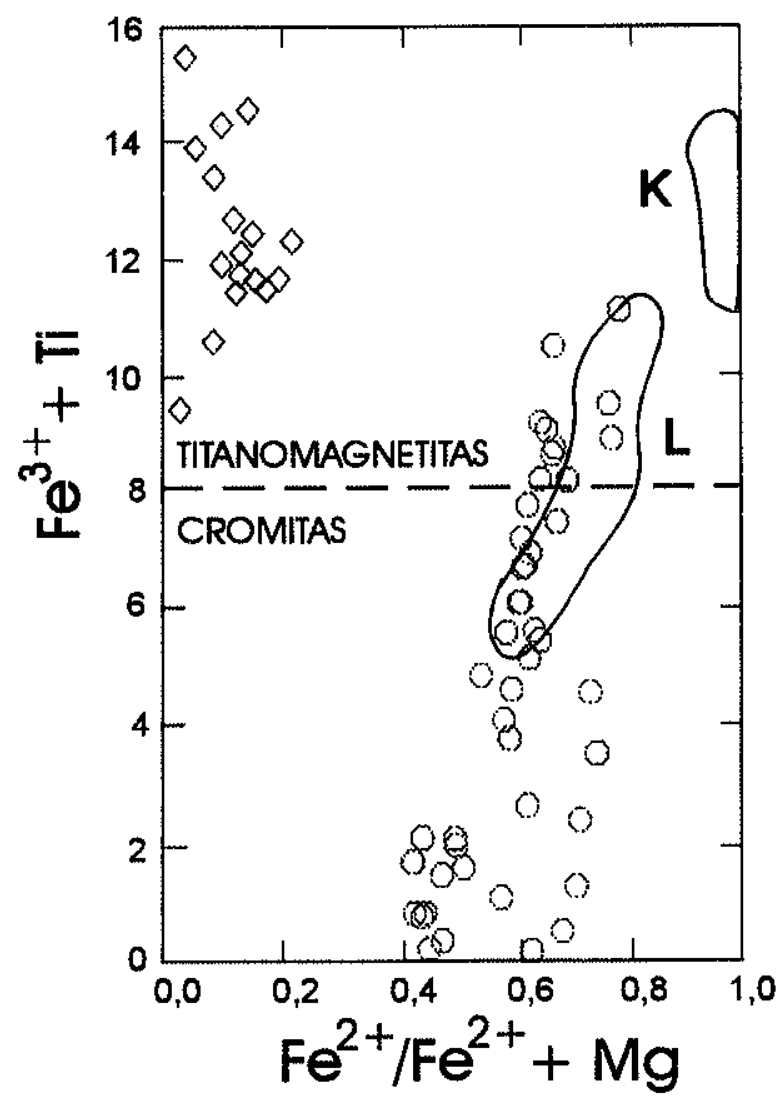

Figura 45 - Diagrama $\mathrm{Fe}^{3+}+\mathrm{Ti} \times \mathrm{Fe}^{2+} / \mathrm{Fe}^{2+}+\mathrm{Mg}$ de espinélios ressaltando os campos dos kimberlitos Koidu (K) e Libéria (L), e os campos das cromitas e das titanomagnetitas, segundo Haggerty \& Tompkins (1984). Os espinélios Tamburi concentram-se no campo das cromitas e os da Formação Quilombinho no campo das titanomagnetitas. Legenda para as amostras estudadas igual a da figura anterior. 
$2 \theta=0^{\circ}$

$2 \theta=180^{\circ}$

$\uparrow$
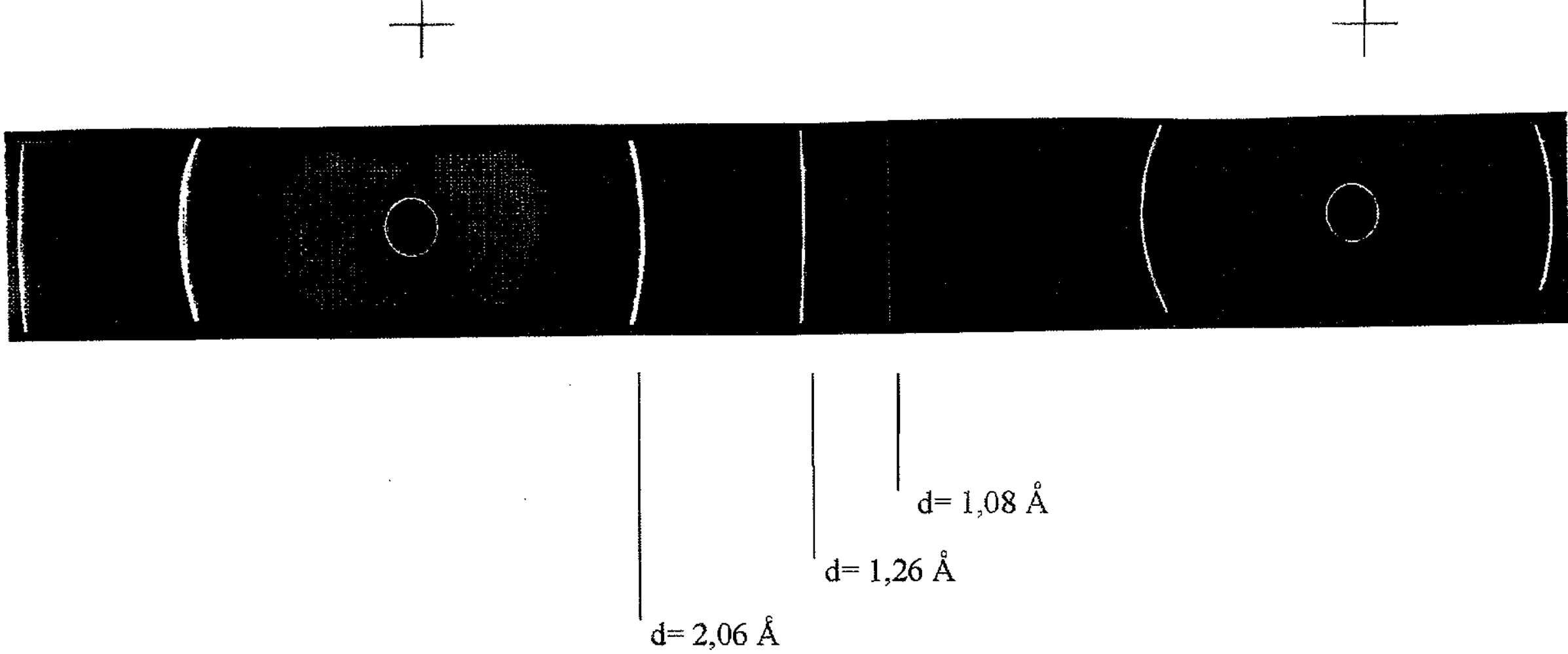

Figura 46 - Difratograma de raios $X$ de um microdiamante recuperado pela digestão ácida da rocha alterada constituinte da Intrusão Tamburi (Amostra RW - 08). Câmara de Gandolfi, radiação CuK $\alpha=1,54 \AA$, 12 horas de exposição. 


\section{9 - CONCLUSÕES}

Os estudos realizados nesta Tese, abrangendo as regiões compreendidas entre os Municípios de Dom Aquino a General Carneiro, incluindo os garimpos diamantíferos de Poxoréu, abordaram dados históricos, metodológicos, caracterização e evolução de relevo, o empilhamento estratigráfico, dados geoquímicos e isotópicos de rochas de natureza básica/ ultrabásica, elementos estruturais e tectônicos, bem como a distribuição e os tipos de jazimentos do diamante, além dos minerais pesados amostrados em sedimentos de corrente, conglomerados e nos tipos litológicos primários mencionados. Entre as conclusões principais alcançadas neste trabalho, destacamos aquelas enumeradas a seguir.

1) A região de Poxoréu vem se destacando nos últimos 50 anos como um dos mais importantes centros produtores de diamantes do Estado de Mato Grosso. As atividades de garimpagem são cíclicas, e desenvolveram-se principalmente ao longo do Rio Poxoréu e seus afluentes. Nas demais regiões, abrangendo à leste Dom Aquino e à oeste General Carneiro, a extração do diamante é segnificativamente menor a inexistente, quando comparada a Poxoréu.

2) No decorrer desses trabalhos utilizamos metodologia diversificada, tendo em vista a variedade dos tópicos abordados. Além dos métodos tradicionais de investigação mineralógica e petrológica (fluorescência de raios $\mathrm{X}$, microssonda eletrônica, entre outros), utilizamos também o método da digestão ácida de uso corrente em empresas de mineração envolvidas na prospecção de diamantes. Com relação ao método de amostragem dos minerais pesados, considerando o tamanho da área estudada (60 x 100 km aproximadamente), utilizamos amostragem seletiva baseada em fundamentos geológicos e feições morfológicas concentradoras de diamantes. Considerando o alto grau de alteração de algumas rochas estudadas, parte da amostragem dos minerais pesados foi realizada por poços de $2 \times 2 \mathrm{~m}$, finalizando-se com telescopagem de $90 \mathrm{~cm}$ de diâmetro, alcançando profundidades entre 3 a $4 \mathrm{~m}$.

3) A paisagem que circunda os depósitos diamantíferos na área estudada é caracterizada por altos topográficos, associados a regiões baixas, acompanhando o padrão 
topográfico de outras regiões mato-grossenses, como por exemplo Chapada dos Guimarães e Nortelândia-Arenápolis. Tais relevos tem sido exumados e esculturados por drenagens de forte encravamento vertical e/ou grande retrabalhamento lateral, resultando em terraços laterais extensos, morros testemunhos e escarpamentos nas bordas e no interior da bacia hidrográfica. A superfície de cimeira é plana (chapadões), tendo sido modelada durante os eventos de peneplanização da Superfície Sul Americana. Essa superfície possue idade Terciária e está em processo de captura por parte das drenagens pertencentes a Bacia do Prata, cujos eventos deposicionais fazem parte dos processos relativos à Bacia Intracratônica do Pantanal.

4) Com base na compilação e na interpretação das inúmeras colunas estratigráficas levantadas, nas litologias do Cretáceo Superior ao Quaternário, nas regióes de Poxoréu (Alvo PX), Paredão Grande (Alvo PG) e Dom Aquino (Alvo DA), foi elaborada uma nova coluna estratigráfica, apresentada na Figura 11. Da base para o topo, essa coluna é constituída pelas Formações Aquidauana (Grupo Itararé), Palermo (Grupo Guatá) e Botucatu (Grupo São Bento), Intrusão Tamburi, Formações Paredão Grande, Quilombinho, Cachoeira do Bom Jardim e Cambambe (Grupo Bauru), Formação Cachoeirinha, Unidade Terciário Quaternário Indiviso e Fácies Coité (Aluviões Atuais).

5) Durante o mapeamento, foi localizado um corpo subelíptico de $400 \times 200 \mathrm{~m}$ aproximadamente, encaixado segundo a direção SE-NW, constituído por uma rocha de natureza básica/ultrabásica alterada, de matriz areno-argilosa à argilosa, denominado neste trabalho Intrusão Tamburi (Figura 7). São comuns na intrusão segregações carbonáticas internas, silicificação intensa nas bordas provocada durante o encaixamento, fato que ajudou a preservar o corpo como alto topográfico. Esse corpo tem como rochas hospedeiras a Formação Aquidauana, possuindo textura brechóide em escala macro e microscópica, xenólitos de rochas básicas e tipos litológicos das encaixantes de composições areníticas a pelíticas. Os minerais separados nos concentrados incluem macro a microcristais de granadas, flogopita, ilmenitas e espinélios.

6) A Formação Paredão Grande foi aqui caracterizada como constituída de eventos explosivos grossos a finos, derrames e diques associados, intercalados ciclicamente na base e nas porções intermediárias do Grupo Bauru, representadas pelas Formações Quilombinho e Cachoeira do Bom Jardim, respectivamente. Na região compreendida entre Dom Aquino a General Carneiro, foram localizados e estudados 51 corpos, sendo 26 derrames (corpos da Raizinha, Lajinha e do Córrego Preto), 24 diques (corpos de Paredão Grande, Meruri e Primavera) e 1 corpo de rochas piroclásticas alteradas (Paredão Grande, corpo $\mathbf{n}^{\circ} 16$, Tabela 2). 
Tais intrusões e extrusões descritas nos Alvos PX, DA e PG, adicionados aos existentes na Chapada dos Guimarães (derrames da Passagem do Mamão e os diques da Mata e da Matinha), fazem parte de um conjunto de eventos magmáticos pertencentes à Província Ígnea de Poxoréu (PIP). Essas rochas possuem textura afanítica a porfirítica, e estruturas maciça e de fluxo. Nos termos mais primitivos representados pelos Derrames da Raizinha, ocorrem fenocristais de olivina, clinopiroxênios (titanoaugitas) e plagioclásio (labradorita). Nos termos mais diferenciados, exemplificados pelos diques de Paredão Grande, Meruri e Primavera, além de olivina (rara) e clinopiroxênios, ocorrem plagioclásios (andesina, oligoclásio) e xenocristais de quartzo provenientes das rochas hospedeiras. Fragmentos de encaixantes são raros nos termos mais primitivos (Derrames da Raizinha), sendo comuns nos termos diferenciados (Diques de Paredão Grande). Essas feições mineralógicas são comuns em rochas de composição basáltica alcalina. Datação $\operatorname{Ar}^{40} / \mathrm{Ar}^{39}$ a laser realizada no corpo 3 dos Derrames da Raizinha, revelou uma idade de 83,9 \pm 0,4 Ma., mostrando que essas rochas estão posicionadas no Cretáceo Superior. Diagrama $\mathrm{Na}_{2} \mathrm{O}+\mathrm{K}_{2} \mathrm{O}$ versus $\mathrm{SiO}_{2}$ desses e de outros litotipos existentes na Chapada dos Guimarães, mostra a existência de dois prováveis trendes, sendo o primeiro alcalino e o segundo tolético. $O$ trende alcalino é caracterizado por olivina basaltos que representam o magmatismo mais primitivo (Derrames da Raizinha, Figura 6), enquanto os termos intermediários (diques de Paredão Grande, Primavera e Meruri, Figuras 8 e 9), possuem composição entre basalto traquiandesito a traquandesito. $O$ segundo trende, corresponde a um magma parental de composição toleítica, variando entre basalto andesito (derrames Passagem do Mamão e Lajinha e o dique da Mata), a dacito (derrames do Córrego Preto). Diagrama relacionando dados isotópicos $\mathrm{Nd}^{143} / \mathrm{Nd}^{144}$ versus $\mathrm{Sr}^{87} / \mathrm{Sr}^{86}$, mostra que os basaltos alcalinos dos Derrames da Raizinha projetam-se no campo de magmas do tipo OIB (Ocean Island Basalts), constituíndo portanto, o primeiro registro desse tipo de rocha na região oeste do Brasil. Assim sendo, os eventos da Formação Paredão Grande são distintos daqueles da Formação Serra Geral, de idade em torno de 125 Ma.. O modo de ocorrência e a idade obtida mostram que os litotipos da Formação Paredão Grande constituem parte integrante do Grupo Bauru na região.

6) A Formação Quilombinho é a unidade imediatamente sobreposta a Formação Paredão Grande, caracterizando a porção basal do Grupo Bauru na região. Ela é constituída de conglomerados cíclicos, interdigitados por lentes pequenas (base) a grandes (topo), de argilitos e arenitos conglomeráticos a argilitos e arenitos, com raras estratificações plana, cruzada e cruzada acanalada. Os conglomerados possuem em média mais de $90 \%$ de clastos derivados de 
rochas da unidade Paredão Grande, sendo os $10 \%$ restantes das Formações Aquidauana, Palermo e Botucatu. Os clastos possuem tamanho entre 0,5 a $50 \mathrm{~cm}$, arcabouço aberto a fechado, gradação inversa no conjunto das lentes, sendo a unidade litoestratigráfica, entretanto, granodecrescente em direção ao topo. Essa unidade ocorre junto às escarpas da Falha de Poxoréu, ou nas circunvizinhanças de eventos magmáticos da Formação Paredão Grande. Esse conjunto representa portanto, depósitos de borda da Bacia Bauru, desenvolvidos por sistema fluvial restrito.

7) A unidade seguinte Formação Cachoeira do Bom Jardim, é constituída de conglomerados, arenitos a argilitos conglomeráticos, arenitos e argilas, além de precipitações químicas de carbonato de cálcio (calcretes). Está situada espacialmente entre os eventos deposicionais de borda e de centro da Bacia Bauru, ocorrendo desde o Alvos PX (Figura 6) até o DA (Figura 10). Os conglomerados ocorrem junto às porções basais, interdigitando-se em lentes de argilitos a arenitos, por vezes conglomeráticos e que predominam em direção ao topo. Os conglomerados são petromíticos, variam de grossos a finos, possuem arcabouço aberto a fechado, ausência de gradação ou gradação inversa, sendo constituídos em média por $50 \%$ de clastos da Formação Paredão Grande e os $50 \%$ restantes, por rochas sedimentares (Formações Aquidauana, Palermo e Botucatu). Tais rochas são fortemente cimentadas por carbonatos, formando depósitos de calcretes espessos resultantes de ambientes evaporíticos. As estruturas primárias presentes são estratificações plana, cruzada e cruzada acanalada em arenitos a arenitos conglomeráticos, assim como gretas de contração observadas em argilas em contato com calcretes. A unidade litoestratigráfica em apreço é intercalada pelos Derrames da Lajinha e do Córrego Preto (Alvo DA). Esses derrames comportaram-se como áreas fontes das lentes mais jovens dos conglomerados grossos próximos ao topo da unidade. Os tipos litológicos e as estruturas primárias descritas, mostram que essa rochas foram depositadas por sistema fluvial amplo, associado a depósitos lacustres e evaporíticos (restrito). $O$ conjunto descrito apresenta granodecrescência em direção ao topo.

8) O topo do Grupo Bauru (Figuras 6, 10 e 11) na área estudada é representado pela Formação Cambambe, que ocorre com espessura menor em direção às bordas Sul a Sudeste da bacia, e espessura maior em direção à Norte e Noroeste. A unidade litoestratigráfica em questão caracteriza-se predominantemente por arenitos conglomeráticos interdigitados por lentes de conglomerados. Ao conjunto anterior, interdigitam-se lentes de argilitos e siltitos. Grande parte dessas rochas foram intensamente cimentadas por sílica, formando precipitados químicos 
espessos típicos de ambientes evaporíticos (silcretes), que ocorrem ciclicamente da base para o topo da unidade. Brechas intraformacionais complementam os tipos litológicos da Formação Cambambe. Os conglomerados grossos ocorrem mais próximos à base e os finos no topo, onde predominam. São petromíticos, possuíndo mais de $90 \%$ de clastos de rochas sedimentares variadas provenientes das Formações Aquidauana, Palermo e Botucatu. Clastos da Formação Paredão Grande são raros. O arcabouço dos conglomerados pode ser aberto a fechado, com ou sem gradação. Tubos ou outras formas bizarras de sílica são comuns. Não foram registradas estruturas primárias e corpos intrusivos ou extrusivos da Formação Paredão Grande nesta unidade. Os tipos litológicos descritos na Formação Cambambe na área estudada, permitiram identificar rochas originadas de sistema fluvial restrito à lacustre amplo. $O$ conjunto mostra granodecrescência em direção ao topo.

9) $O$ conjunto das unidades descritas na região, mostra que o Grupo Bauru, no Estado de Mato Grosso, constitue uma bacia vulcano-clasto-química (calcretes e silcretes), equivalente à Bacia Bauru dos Estados de São Paulo e Minas Gerais. A idade de 83,9 \pm 0,4 Ma. dos eventos vulcânicos basais no Grupo Bauru (Derrames da Raizinha), associada à presença de répteis estudados anteriormente em rochas da Formação Cambambe, indicam que a Bacia Bauru no Estado de Mato Grosso foi depositada durante o Cretáceo Superior.

10) A Formação Cachoeirinha é de idade terciária e recobre discordantemente rochas do Grupo Bauru. Ocupa as porções à norte dos Alvos PX e DA (Figuras 6 e 10), sendo constituída de cascalhos, argilas e areias, por vezes conglomeráticas, cimentadas por óxidos de ferro. Ferricretes ocorrem de forma extensiva. Os cascalhos são cíclicos, com clastos de fragmentos lateríticos, quartzo e quartzo-arenitos, principalmente. Essa unidade registra os eventos de peneplanização da Superfície Sul Americana.

11) A Unidade Terciário-Quaternário Indiviso permitiu a agregação de pacotes lenticulares e cíclicos de cascalhos capeados por areias a areias argilosas, por vezes cascalhosas. Ocorre disposta em terraços laterais às bacias de drenagem da região estudada, tendo como áreas fontes os tipos litológicos da Bacia Bauru. Essa unidade é portadora de importantes mineralizações diamantíferas, situando-se entre áreas fontes detríticas do Cretáceo Superior e o Quaternário.

12) A Fácies Coité, Alvo PX e as Aluviões Atuais nos demais Alvos PG e DA, correspondem aos depósitos de canal e planícies de inundação de idade quaternária. Constituemse de cascalhos capeados por areias e areias argilosas, por vezes cascalhosas. A Fácies Coité é 
aqui proposta por encerrar, além de suas características litológicas particulares, as principais mineralizações diamantíferas, em detrimento aos depósitos similares e contemporâneos (Aluviões Atuais), destituídos de afloramentos, estéreis ou fracamente mineralizados.

13) $O$ ambiente deposicional do Grupo Bauru é caracterizado por depósitos proximais (Formação Quilombinho), intermediários (Formação Cachoeira do Bom Jardim) e distais (Formação Cambambe), formados por leques aluviais desenvolvidos em clima árido a semi-arido. Os conglomerados, assim como os demais tipos litológicos nas três unidades sedimentares são cíclicos e possuem forma lenticular. Esses conglomerados, possuem arcabouço entre aberto a fechado e gradação inversa, denunciando reativações tectônicas pré e sindeposicionais, bem como a progradação do leque em direção ao depocentro da bacia. $\mathrm{Na}$ unidade basal eles mostram que a área fonte foi essencialmente o magmatismo da Formação Paredão Grande, enquanto que os das Formações Cachoeira do Bom Jardim e Cambambe revelam áreas fontes diversificadas. As lentes de lamitos e arenitos conglomeráticos sugerem condições deposicionais desenvolvidas por movimentos abruptos de massas. Lentes de argilitos e arenitos ocorrem com pequena envergadura e espessura, interdigitadas nos conglomerados basais, sendo de maior porte e espessura em direção ao topo de cada unidade. As estruturas primárias observadas são raras e incluem estratificações planas, cruzadas e acanaladas, presentes nas unidades basal e intermediária. $\mathrm{Na}$ unidade intermediária ocorrem calcretes, enquanto na distal silcretes. Tais precipitações químicas são evidências de ciclos evaporíticos associados ao desenvolvimento desses leques. $O$ conjunto de clastos grossos a finos em cada unidade mostra que as mesmas são granodecrescentes em direção ao topo. $O$ condicionamento de paleorelevo a partir dos conteúdos litológicos descritos e a distribuição em área, evidencia estruturas de meio graben, de modo similar à Chapada dos Guimarães.

14) A região estudada situa-se no truncamento do Lineamento Transbrasiliano com o Lineamento $125^{\circ} \mathrm{Az}$, que foram ciclicamente reativados durante o Cretáceo Superior no desenvolvimento do Rifte Rio das Mortes e da Bacia Intracratônica do Pantanal. Os elementos estruturais marcantes são falhamentos de direção NE e NW, que possuem complexa relação de truncamentos; ora os falhamentos NW são cortados pelos NE e vice e versa. Com base no encaixamento dos diques, aqueles de direção NE caracterizam fases distensivas NW-SE, enquanto que os diques "en echelon" de Paredão Grande, com encaixamento segundo a direção NW denunciam transcorrência no desenvolvimento desse rifte. $O$ horste de Rondonópolis delimita o rifte em sua porção SE, enquanto que o horste de São Vicente situado entre o meio 
graben de Poxoréu à SE e o da Chapada dos Guimarães à NW, ambos com caimento de superficie para NW, evidenciam uma distribuição assimétrica do rifte. Essa estrutura possue altos topográficos internamente, aqui identificados como da Raizinha e da Passagem do Mamão. A evolução geomorfológica do Cretáceo Superior ao Quaternário mostra que a paleosuperficie cretácea foi arrasada pelos eventos de peneplanização da Superficie Sul Americana. Com o desenvolvimento da Bacia Intracratônica do Pantanal do Terciário até os dias atuais, intensos processos erosivos capturaram, exumaram e modelaram a paisagem atual. A evolução geotectônica da área tem por modelo a interferência da Pluma de Trindade sob essa porção do Estado de Mato Grosso. Os efeitos da atuação dessa pluma, iniciaram-se com o soerguimento da área, seguindo-se o rifteamento, acompanhado de intrusões e extrusões (Formação Paredão Grande) e sedimentação derivada (Formações Quilombinho e Cachoeira do Bom Jardim), caracterizando a fase termo mecânica e de subsidência do rifte. A fase de resfriamento do rifte está registrada pelos tipos litológicos da Formação Cambambe destituída de vulcanismo e pelos contatos transgressivos ("onlap") desenvolvidos por essa unidade sobre as bordas da bacia.

15) Os principais depósitos mineralizados a diamante são aqueles relacionados às drenagens atuais (Fácies Coité) e, secundariamente os paleoplaceres da Unidade TerciárioQuaternário Indiviso (UTQI). Em menor escala de importância foram observadas atividades de garimpos nos conglomerados das Formações Quilombinho e Cachoeira do Bom Jardim. A concentração do diamante em depósitos do tipo placeres está intimamente relacionada a ambientes fluviais seletivos. Tal ambiente ocorre principalmente nos tipos litológicos pertencentes à UTQI e à Fácies Coité. Já os depósitos de leques aluviais do Grupo Bauru, mostram ambiente fluvial restrito nas Formações Quilombinho e Cachoeira do Bom Jardim (mais desenvolvido). Nesses casos a distribuição do diamante possui comportamento mais errático (heterogêneo) quando comparados aos depósitos quaternários (Fácies Coité). Feições geomorfológicas de origem endógena ou exógena provocadoras de perda brusca da capacidade de carga do meio transportador em ambientes aluviais a paleoaluviais, constituem barreiras geomorfológicas ao escoamento natural dos canais de drenagens atuais e antigos, resultando em armadilhas para a concentração do diamante. $\mathrm{Na}$ área estudada, os expressivos depósitos de diamantes do Rio Coité foram controlados por três armadilhas do tipo travessão de grande porte (Figura 39). Em menor escala, foram identificadas armadilhas do tipo canoão, veias, bolsões, ajogo e panelas. 
16) $O$ estudo de minerais pesados foi realizado com o intuito de investigar as possíveis fontes primarias do diamante da área estudada. As amostragens realizadas revelaram a presença de granadas, ilmenitas e espinélios na Intrusão Tamburi e nos conglomerados da Formação Quilombinho, enquanto que nas rochas piroclásticas da Formação Paredão Grande foram encontradas somente granadas. Estudos químicos desses minerais mostraram sistematicamente a existência de duas populações distintas. No caso das granadas, algumas amostras da Formação Paredão Grande apresentam certas similaridades com megacristais de kimberlitos, enquanto que aquelas da Formação Quilombinho e a maior parte das amostras da Intrusão Tamburi guardam certas semelhanças com xenólitos de eclogitos. Contudo, a maior parte das amostras estudadas caem fora dos campos dos materiais de natureza kimberlítica indicando que tais granadas possuem pouca ou nenhuma afinidade com kimberlitos (Figura 40). Testadas no diagrama $\mathrm{Cr}_{2} \mathrm{O}_{3} \times \mathrm{CaO}$ de Gurney (1984), todas as granadas analisadas caem no campo das granadas G9, concentrando-se na região dos peridotitos e subordinadamente no campo dos eclogitos (Figura 41). A ausência de granadas G10 indica que a Intrusão Tamburi, as áreas fontes dos conglomerados e as rochas piroclásticas, não possuem potencial mineralizante para diamante. Com relação às ilmenitas, as amostras da Formação Quilombinho guardam similaridades com ilmenitas de carbonatitos; por outro lado, as ilmenitas da Intrusão Tamburi mostram variações amplas, sendo algumas semelhantes à ilmenitas de carbonatitos, outras semelhantes à ilmenitas de kimberlitos, havendo também amostras desprovidas de qualquer relação com fontes primárias tradicionais (Figura 43). Os espinélios confirmam parte das observações relatadas anteriormente, porém mostram comportamento complexo. Em um diagrama $\mathrm{Cr} / \mathrm{Cr}+\mathrm{Al} \times \mathrm{Fe}^{2+} / \mathrm{Fe}^{2+}+\mathrm{Mg}$, não exibem semelhanças com materiais kimberlíticos (Figura 44). Contudo, em diagrama $\mathrm{Fe}^{3+}+\mathrm{Ti} \times \mathrm{Fe}^{2+} / \mathrm{Fe}^{2+}+\mathrm{Mg}$, os espinélios da Intrusão Tamburi mostram variações de cromitas a titanomagnetitas sendo parte das amostras semelhantes a espinélios de kimberlitos. Espinélios da Formação Quilombinho, por outro lado, são constituídas por titanomagnetitas e isentos de semelhanças com kimberlitos. As características reveladas pelos minerais pesados, afastam em princípio a possibilidade de haver kimberlitos na área. Por outro lado, a presença de um microdiamante na Intrusão Tamburi, revela pelo menos que existem fontes primárias desse mineral na área. Essa intrusão poderia ter mineralizado drenagens adjacentes; entretanto, esse corpo somente, ainda que contivesse alto teor de diamante não poderia explicar os ricos depósitos diamantíferos garimpados na região de Poxoréu. 


\section{0 - AGRADECIMENTOS}

Encerrando esta etapa profissional tenho a nítida sensação e clara compreensão de não estar concluindo, simplesmente iniciando. Não é fácil mudar conceitos em Geociências, também não é essa a pretensão. Tendo percorrido esse caminho, viandante do tempo, desde os depósitos diamantíferos aluvionares quaternários ao estudo do magmatismo associado a uma bacia cretácea no Estado de Mato Grosso, em consonância com tecnologias de ponta paralelas às primitivas, passaram-se 20 anos. Dificil é absorver e digerir as mais profundas informações do interior da Terra até as jazidas quaternárias superficiais e porque o diamante está ali e não aqui; a desinformação, os tabus, os segredos industriais e tecnológicos, até admirar a beleza de um diamante lapidado no busto de uma mulher. Por esta razão, sinto-me mensageiro e não posseiro de uma parte desse conhecimento e, o ato de agora agradecer, é também, o meu sentir e reconhecimento com as pessoas que compuseram as equipes, que me permitiram acesso e que sinto orgulho termos convivido questões relativas ao tema diamante, assim como aquelas pessoas que contribuíram pessoal e profissionalmente. Sinto-me, portanto, na obrigação de não omitir esse cenário em respeito a paciência, a compreensão, as discussões, a motivação, aos desafios, as sugestões, as críticas e a coragem, proporcionadas pelas pessoas relacionadas abaixo, a quem externo os meus sinceros agradecimentos.

\section{Orientador}

Prof. Dr. Darcy Pedro Svisero - IG/USP

\section{Co-orientador}

Prof. Dr. Othon Henry Leonardos -IG/UNB

\section{Professores Doutores}

José Caruso Moresco Danni - IG/UNB

Robert N. Thompson - University of Durhan

Armando Márcio Coimbra - IG/USP
Marcel Auguste Dardenne - IG/UNB

Sally A. Gibson - University of Cambridge

Dharani Sundaram - DGG/ICET/UFMT 
Deocleciano Bittencourt Rosa - DGG/ICET/UFMT Caetano Juliani - IG/USP

Antônio Romailino S. Fragoso Cesar - IG/USP Hardy Jost - IG/UNB

Bernardino R de Figueiredo- IG/UNICAMP Benjamim Bley de Brito Neves - IG/USP

\section{Geólogos e Professores}

Noel Marsden - (in memorian)

Nelson Marinho - (in memorian)

Gustavo Gomes - RTZ Mineração Ltda

Marcus Diógenes - RTZ Mineração Ltda

Vagner Roberto Elis - DGG/ICET/UFMT

Francisco Rubens Alves - IG/USP

Dr. Ronald Fleischer

Osvaldo Weissel - RTZ Mineração Ltda

Paulo Zini - RTZ Mineração Ltda

Vanderlei Maniesi - DRM/ICET/UFMT

Itsuo Tsuda - PROMISA S/A

Alexandre de Souza - Geólogo Consultor
Rogério Silvestre Pereira - SOPEMI S/A

Mauro Coppola - Geólogo Consultor

Alfredo Luiz Perin - Geólogo Consultor

Sérgio Amaro Aquino - Geólogo Consultor

Gerson Souza Saez - DRM/ICET/UFMT

Gergely A.J. Szabó - IG/USP

Guilherme Gonzaga - Geólogo Consultor

Edízio Rocha - Geólogo Consultor

Rui Schiffer - DRM/ICET/UFMT

João Matos - DRM/ICET/UFMT

Márcia Pinho - DRM/ICET/UFMT

Leonice Lotufo - DGG/ICET/UFMT

\section{Técnicos e Servidores}

Francisco Silva (in memorian)

Cláudio Roberto de Carvalho

José Romão da Silva

Álvaro Elias Silva - DRM/UFMT

José Licínio da Silva

Reginaldo J. R. da Silva - DRM/UFMT

Nilson Santana Botelho - DGG-UFMT
Ervino Ritter Jr. (in memorian)

Roberto Crispim

Luis Ferreira de Oliveira

Alexandrino Leite Nascimento - DRM/UFMT

Benedito Augusto de Oliveira - DRM/UFMT

$D^{\text {a }}$ Chiquinha - IG/USP 


\section{Colegas de Pós-Graduação}

Anabel Perez Aguilar (IG/USP)

Wellington Ferreira da Silva (IG/USP)

Afonso Brod (DURHAM UNIVERSITY)

Flávio Machado de Souza Carvalho (IG/USP)

Tereza Cristina J.Brod (DURHAN UNIVERSITY)
Marco Aurélio Bonfá Martin (IG/USP)

Dioniso Tadeu de Azevedo (IG/USP)

Jaime Presser Báez (IG/USP)

Rita Parisi Conde (IG/USP)

José Portocarrero (IG/UNB)

Roberto Viseu Lima Pinheiro (DURHAN UNIVERSITY)

\section{Alunos do Curso de Geologia, ICET/UFMT e IG-USP}

Maria Sibonei Neme

José Romualdo Morcelli

Suzana Shizuko Hirooka

José Eustáquio da Cunha

Shelma Lúcia Roman Kato

Salatiel Alves de Araújo

Marcos Augusto Costa Maciel

José Ricardo Thibes Pisani

Vicente Sérgio Costa

André Luís Árabe Martins de Oliveira

Carla Rosane da Rocha Barbosa

Marcelo Jung Pinho

Celso F. Macedo

Everaldo Arioldi

Marilene Gouvea Oliveira
Antônio Carlos Neme Borges

José Carlos da Silva D' Oliveira

Cláudio A. Neme

Flávio Henrique Toledo

Ubirajara Alves Pires

Antônio Rosestolato Filho

José Maurício C. Ribeiro

Júlio César de Pinheiro Arrais

Alexandro R. Uggeri

Terezinha de Almeida Costa

Wilson Thibes Pisani Jr.

Nara Rúbia Coelho

Cleiri Freitas Pisani

Edmar V.G. Silveira

Isabel A.A. dos Santos

Agradeço também à Universidade Federal de Mato Grosso, através do Departamento de Recursos Minerais e o Programa de Capacitação de Pessoal Docente (CAPES); a RTZ Mineração Ltda patrocinadora de parte das questões relativas tanto ao mestrado (UNB), quanto o doutorado (USP); ao Conselho Britânico que patrocinou minha estada na Universidade de 
Durhan, Inglaterra, processo $\mathrm{CNPq}^{\circ}$ 91.0021/91-0; ao povo de Poxoréu, através de sua Prefeitura que nos concedeu parte do suporte durante os trabalhos de mapeamento geológico dos alvos PX e DA; à Família Carloto, em especial Mauri Luiz Carloto (Intrusão Tamburi), ao Sr. Constâncio (Paredão Grande) e ao povo indígena das Nações Xavante e Bororos, através de seus representantes Caciques Alexandre Tsereptse e Eveldino Cucotchereu, respectivamente, que durante os trabalhos de campo prestaram-nos apoio.

A todos, MUITO OBRIGADO !!! 


\section{1 - REFERÊNCIAS BIBLIOGRÁFICAS}

ABREU, S.F. (1973) - Recursos minerais do Brasil, 2 ed. , São Paulo, Edgard Blücher, Ed. da Universidade de São Paulo, v. 1, 324p.

ALMEIDA, F.F.M. de (1948b) - Reconhecimento geomórfico nos planaltos divisores das Bacias Amazônica e do Prata, entre os meridianos $51^{\circ}$ e $56^{\circ}$ WGr., Revista Brasileira de Geografia, 10(3) : 397-440.

ALMEIDA, F.F.M. de (1954) - Geologia do centro-leste mato-grossense, Divisão de Geologia e Mineralogia, Departamento Nacional da Produção Mineral, Rio de Janeiro, Boletim n ${ }^{\circ} 150,97 \mathrm{p}$.

ALMEIDA, F.F.M. de (1964) - Geologia do centro-oeste mato-grossense, Divisão de Geologia e Mineralogia, Departamento Nacional da Produção Mineral, Rio de Janeiro, Boletim $\mathbf{n}^{\circ} 215$, $133 p$.

ALMEIDA, F.F.M. de (1965a) - Geologia da Serra de Bodoquena (Mato Grosso), Boletim da Divisão de Geologia e Mineralogia, Departamento Nacional da Produção Mineral, Boletim n ${ }^{\circ}$ $219,96 \mathrm{p}$.

ALMEIDA, F.F.M. de (1968) - Evolução tectônica do centro-oeste brasileiro no Proterozóico Superior, Anais da Academia Brasileira de Ciências, 40 : 285-96.

ALMEIDA, F.F.M. de (1974) - Antefossa do Alto Paraguai, In: Congresso Brasileiro de Geologia, 28, Porto Alegre, Anais...Porto Alegre, Sociedade Brasileira de Geologia, 4: 3-6. 
ALMEIDA, F.F.M. de (1974) - Sistema tectônico marginal do Cráton do Guaporé, In: Congresso Brasileiro de Geologia, 28, Porto Alegre, Anais...Porto Alegre, Sociedade Brasileira de Geologia, $4: 9-17$.

ALMEIDA, F.F.M. de (1983) - Relações tectônicas das rochas alcalinas mesozóicas da região meridional da Plataforma Sul-Americana, Revista Brasileira de Geociências, 13(3) : 139-58.

ALMEIDA, F.F.M. de (1984) - Província Tocantins - Setor Sudeste, In: Almeida F.F.M. de \& Hasui, Y., Coords. O Pré-Cambriano no Brasil, São Paulo, Ed. Edgard Blücher, p. 265-281.

ALMEIDA, F.F.M. de (1985) - Alguns problemas das relações geológicas entre o Cráton Amazônico e as faixas de dobramentos marginais a leste. In: Simpósio de Geologia do Centro-Oeste, 2, Goiânia, Anais...Goiânia, Núcleo Centro-Oeste da Sociedade Brasileira de Geologia, p. 3-14.

ALMEIDA, F.F.M. de (1986) - Distribuição regional e relações tectônicas do magmatismo póspaleozóico no Brasil, Revista Brasileira de Geociências, 16 (4) : 325-49.

ALMEIDA, F.F.M. de \& MANTOVANI, M.S.M. (1975) - Geologia e geocronologia do Granito de São Vicente, Mato Grosso, Anais da Academia Brasileira de Ciências, 47(3/4) : 451-8.

ALMEIDA, L.F.C. de; MELO, S.C.; FRIAÇA, G.C. (1972) - A Geologia e as perspectivas econômico-minerais da estrada de integração nacional Cuiabá-Santarém (Trecho Cuiabá Cachimbo), In: Congresso Brasileiro de Geologia, 26, Belém, Anais...Belém, Sociedade Brasileira de Geologia, $1:$ 121-8.

ALMEIDA, F. F. M. de \& SVISERO, D.P. (1991) - Structural setting and tectonic control of kimberlite and associated rocks of Brazil, In: International Kimberlite Conference, 5th, Extended Abstracts, CPRM Special Publication 2/91: 3-5. 
ALVARENGA, C.J.S. de (1985) - Evidências de fácies turbidíticas grosseiras no Grupo Cuiabá, MT, In: Simpósio de Geologia do Centro-Oeste, 2, Goiânia, Atas da Sociedade Brasileira de Geologia, Núcleo Centro-Oeste, p. 256-66.

ALVARENGA, C.J.S. de (1988) - Turbiditos e a glaciação do final do Proterozóico Superior no Cinturão Paraguai, Mato Grosso, Revista Brasileira de Greociências, 18(3) : 323-27.

AMARAL, V.L. do (no prelo) - Amazônia: a Fronteira do Ouro, Instituto Ecologista de Desenvolvimento, Chapada dos Guimarães, Fundo Nacional do Meio Ambiente, 272p..

ARAÚJO, S.A.; KATO, S.L.R; ROSESTOLATO FILHO, A. (1991) - Uma Contribuição à Geologia do Grupo Bauru na Folha SD-21-Z-D-VI, Poxoréu, Mato Grosso, Cuiabá, Departamento de Recursos Minerais, Instituto de Ciências Exatas e da Terra, Universidade Federal de Mato Grosso, 103p., Monografia de Graduação em Geologia (inédito).

BARDET, M.G. (1977) - Gélogie du Diamant, Trosieme Partie: Gisements de Diamants d'Asie, d'Amérique, d'Europe et d'Australasie, Memoires du B.R.G.M, n 83, 169p.

BARROS, A.M.; DA SILVA, R.H.; CARDOSO, O.R.F.A.; FREIRE, F.A.; DE SOUZA Jr., J.J.; RIVETTI, M.; DA LUZ, D.S.; PALMEIRA, R.C. de B.; TASSINARI, C.C.G. (1982) - Folha Cuiabá, SD. 21, Projeto RadamBrasil, Ministério das Minas e Energia, Rio de Janeiro, 26: 540p.

BAUER, A.M. \& LARGHER, G.N. (1958) - A Preliminary report of the eastern central part of the State of Mato Grosso and a portion of the western part of the State of Goiás, Brasil, Ponta Grossa, Petrobrás-DEBSP, $\mathfrak{n}^{\circ} 837$, ( Relatório Técnico Interno ), inédito.

BAXTER, M. (1988) - Garimpeiros de Poxoréu, Mineradores de Pequena Escala de Diamantes e seu Meio Ambiente no Brasil, Brasília, Centro Gráfico do Senado Federal, 301p. 
BECKEL, J. (1984) -Prospecção Aluvionar Para Ouro - Modelos e Aplicações, Petrobrás Mineração S.A. - Petromisa, Gerência de Exploração, 67p. (inédito).

BEURLEN, K.A. (1956) - A Geologia pós-algonquiana do sul do Estado de Mato Grosso, Boletim da Divisão de Geologia e Mineralogia, Departamento Nacional da Produção Mineral, Rio de Janeiro, $\mathrm{n}^{\circ} 163,137 \mathrm{p}$.

BITTENCOURT ROSA, D.; WESKA, R. K; LIMA, P.R.M. (1991) - Formas de sílicas fibrosas associadas a evaporitos em rochas pertencentes à Fácies Cambambe (Grupo Bauru), na região de Água Fria, Chapada dos Guimarães, MT, In: Simpósio de Geologia do Centro-Oeste, $3^{\circ}$, Cuiabá, Anais... Cuiabá, Sociedade Brasileira de Geologia, Núcleo Centro-Oeste, 1: 211 221.

BRUNSDEN, D.; DOORNKAMP, J.C.; JONES, D.K.C.; RUSSEL, R.; DONWNEY, J. (1981) Riofinex reconnaissance study Braziil, interpretation of slar images of Project Radam Amazônia, Londres, 34p.

COIMBRA, A.M. (1991) - Bacias Continentais Cretáceas do Centro-Sul da Plataforma SulAmericana, Sistematização da Obra, São Paulo, Universidade de São Paulo, Instituto de Geociências, Tese de Livre Docência, 54p.

COOPERSMITH, H.G. (1993)- Diamond Mine Discovery, In: Diamonds: Exploration, Sampling and Evaluation, Proceedings of a Short Course, Toronto, Ontario, Canada, Prospectors and Developers Association of Canada, p. 73-108.

CORRÊA, J.A. \& COUTO, E.A. do (1972) - Projeto Aluviões Diamantíferos de Mato Grosso, Convênio Departamento Nacional da Produção Mineral/ Companhia de Recursos Minerais, Goiânia, Relatório Final, 2v.

COX, K.G. (1978) - Pipes kimberlites, Scientific Americam, 238: 120-132. 
DANNI, J.C.M. (1974) - Geologie des Complexes Ultrabasiques Alcalins de la Region d' Iporá, Goiás, Brésil, Paris, Université de Paris Sud, Centre D’ Orsay, 104p.

DANNI, J.C.M. (1978) - Magmatic differentiation of the alkaline ultrabasic intrusions of the Iporá region, south west Goiás, Brazil, In: Proceedings of the First International Symposium on Carbonatites, Poços de Caldas, MG, Brasil, p. 149-167.

DAVIS, G. L. (1977) - The age and uranium contents of zircons from kimberlites and associated rocks, In: F.R. BOYD Jr. \& H.O.A. MEYER (eds), Proceedings of International Kimberlite Conference, 2th, Extended Abstracts, Santa Fé, U.S.A., p. 67-69.

DAVISON, J.G. (1993) - Laboratory exploration samples: laboratory processing, In: Diamonds: Exploration, Sampling and Evaluation, Proceedings of a Short Course, Toronto, Ontario, Canada, Prospectors and Developers Association of Canada, p. 315-342.

DAWSON, J.B. \& STEPHENS, W.E. (1975) - Statistical analysis of garnets from kimberlites and associated xenoliths. Journal of Geology, 83: 589-607.

DERBY, O.A. (1890) - Notas sobre a geologia e paleontologia de Matto Grosso, Archivos do Museu Nacional, 9 : 59-88.

DRAGO, V.A.; PINTO, A.C.; DE MONTALVÃO, R.M.G.; DOS SANTOS, RO.B.; SIMÕES, M.A.; OLIVEIRA, I.C.; BEZERRA, P.E.L.; PRADO, P.; FERNANDES, C.A.C. \& TASSINARI, C.C.G. (1981) - Folha Goiás, SD. 22, Projeto RadamBrasil, Ministério de Minas e Energia, Rio de Janeiro, $25: 636 \mathrm{p}$.

EVANS, S.W. (1894) - The geology of Mato Grosso particulary the region drained by the upper Paraguay, Quarterly Journal of the Geological Society of London, 50 : 85-104. 
FERNANDES, L.A. \& COIMBRA, A.M. (1996) - A Bacia Bauru (Cretáceo Superior, Brasil). Anais da Academia Brasileira de Ciências, 68: 195 - 205.

FERREIRA, A. B. de H. (1986) - Novo Dicionário da Língua Portuguesa, $2^{\text {a }}$ ed., Editora Nova Fronteira, Rio de Janeiro, 1838p..

FIGUEIREDO, A.J. de A. \& OLIVATTI, O. (1974) - Projeto Alto Guaporé, Goiânia, Convênio Departamento Nacional da Produção Mineral/ Companhia de Pesquisa de Recursos Minerais, Relatório Final Integrado, $11: 173 \mathrm{p}$.

FLEISCHER, R. (1993) - Um modelo "rift" para os depósitos sedimentares de diamante do Brasil, In: Simpósio Brasileiro de Geologia do Diamante, 1, Cuiabá, MT, Anais...Cuiabá, Ed. UFMT - Gráfica Universitária, p. 165-197.

FRAGOMENI, P.R.P. (1976) - Controle tectônico da Província Quimberlítica de Paranatinga, Boletim Informativo da Sociedade Brasileira de Geologia, Goiânia, Núcleo Centro-Oeste, 5: 3-10.

FUNDAÇÃO INSTITUTO BRASILEIRO DE GEOGRAFIA E ESTATÍSTICA -IBGE (1989) Informações básicas municipais: Município de Poxoréo, MT, Cuiabá, 7p.

GABAGLIA, G.P.R \& MILANI, E.J. (1990) - Origem e evolução de bacias sedimentares, Petrobrás, 415p.

GARFIELD, L. (1980) - Diamonds in Angola and Zaire, Londres, RioFinex - Rio Tinto Finance Exploration, 30p. (inédito).

GIBSON, S.A.; THOMPSON, R.N.; LEONARDOS, O.H.; DICKIN, A.P., MITCHEL, J.G. ( 1995) - The Late Cretaceous impact of the Trindade mantle plume: Evidence from large-volume, mafic potassic magmatism in SE Brazil. Journal Petrology, 36(1): 189 - 229. 
GIBSON, S.A.; THOMPSON, R.N.; WESKA, R.K.; DICKIN, A.P. \& LEONARDOS, O.H. ( 1996) - Late Cretaceous rift-related upwelling and melting of the Trindade starting mantle plume head beneath western Brazil. Contribution to Mineralogy and Petrology (In Press).

GOLD, D.P. (1984) - Properties and tectonic setting for diamond bearing rocks, In: Exploration Roundp, New York, Engineering \& Mining Journal, p.9-10.

GOMES, C.B. (1984) - Técnicas Analíticas Instrumentais Aplicadas à Geologia, São Paulo, Edgard Blücher: Pró-minério, 218p.

GONÇALVES, A. \& SCHNEIDER, R.L. (1968) - Geologia de semi-detalhe da região de Sangradouro, Batovi-Tesouro e Guiratinga, Mato Grosso, Ponta Grossa, Petrobrás-DESUL, $n^{\circ} 370$, 35p. ( Relatório Técnico Interno ), inédito.

GONÇALVES, A. \& SCHNEIDER, R.L. (1970) - Geologia do centro-leste de Mato Grosso, Ponta Grossa, Petrobrás - DESUL, $\mathrm{n}^{\circ}$ 394, 43p. ( Relatório Técnico Interno ), inédito.

GONZAGA, G.M. (1993) - Diamantes da região sul do Estado do Piaú: Quais são suas origens? In: Simpósio Brasileiro de Geologia do Diamante, 1º, Cuiabá, MT, Anais...Cuiabá, Ed. UFMT - Gráfica Universitária, p. 42-56.

GONZAGA, G.M. \& TOMPKINS, L.A. (1991) - Geologia do diamante, In: Schobbenhaus, C. Queiroz, E.T. \& Coelho, C.E. - Principais Depósitos Minerais do Brasil, v. 4, parte A, Companhia de Pesquisa de Recursos Minerais, p. 53-116.

GOUDIE, A. (1973) - Duricrusts in Tropical and Subtropical Landscapes, London, Oxford University Press, 174p. 
GuimarÃES, G. \& ALMEIDA, L.F.G. de (1972) - Projeto Cuiabá, Departamento Nacional da Produção Mineral, Cuiabá, Relatório Final, Relatório do Arquivo Técnico do DGM, $\mathrm{n}^{\circ} 1872$.

GUIMARÃES, G.; GLASER, I.; MARQUES, V.J. (1968) - Sobre a ocorrência de rochas alcalinas na região de Iporá, Goiás, Mineração e Metalurgia, 48 (283) : 11-5.

GUIRRO, A.C. (1991) - Análise de fácies dos sedimentos da Formação Aquidauana (Neocarbonífero) no sudeste de Mato Grosso e nos poços da borda norte da Bacia do Paraná, Ouro Preto, MG, Universidade Federal de Ouro Preto, Departamento de Geologia da Escola de Minas, Dissertação de Mestrado em Geologia, 187p.

HAGGERTY, S.E. \& TOMPKINS, L.A. (1984) - Subsolidus reaction in kimberlitic ilmenites: Exolution, redution and the redox state of the mantle, 3th International Kimberlite Conference, 1: 335-357.

HASUI, Y. \& ALMEIDA, F.F.M. de (1970) - Geocronologia do centro-oeste brasileiro, Boletim da Sociedade Brasileira de Geologia, 19 (1) : 5-26.

HENNIES, W.T. (1966) - Geologia do centro-norte mato-grossense. São Paulo, Universidade de São Paulo, Escola Politécnica, Tese de Doutoramento em Engenharia, 65p.

JANSE, A.J.A. (1991) - Non-kimberlitic diamonds source rocks. Extended Abstracts 5th International Kimberlite Conference, CPRM Special Publication, 2/91: 199-201.

KING, L.C. (1956) - A geomorfologia do Brasil oriental, Revista Brasileira de Geografia, 18(12) : $147-265$.

LE BAS, M.J.; LE MAITRE, R.W.; STRECKEISEN, A.; ZANETTIN, B. (1986) - A Chemical classification of volcanic rocks based on the total alkali-silica diagram. Journal of Petrology, 27: 745-750. 
LUZ, J. da S.; ARAÚJO, E.S.; GODÓI, H. de O. (1980) - Projeto Coxipó, Convênio Departamento Nacional da Produção Mineral/ Companhia de Pesquisa de Recursos Minerais, Goiânia, Relatório Final, Fase 1, $1:$ 136p.

MACDONALD, G.A. \& KATSURA, T. (1964) - Chemical composition of Hawaiian lavas. Journal of Petrology, 5: 82 -133.

MACEDO, F.C.; FREITAS, C.I.; SILVEIRA, E.V.G.; ARIOLDI, E. (1995) - Contribuição à Geologia Regional e o Kimberlito Alabama, Paranatinga-Mato Grosso, Cuiabá, Departamento de Recursos Minerais, Instituto de Ciências Exatas e da Terra, Universidade Federal de Mato Grosso, 45p., Monografia de Graduação em Geologia (inédito).

MANTOVANI, M.S.M.; STEWART, K.; TURNER, S.; HAWKESWORTH, C.J. (1995) - Duration of Paraná magmatism and implications for the evolution and source regions of continental flood basalts. Anais da Academia Brasileira de Ciências, 67(1), no prelo.

MARSHALL, T. R \& BAXTER-BROWN, R (1995) - Basic principles of alluvial diamond exploration. Journal of Geochemical Exploration, 53: 277-292.

MELFI, A.J.; PICCIRILLO, E.M.; NARDY, A.J.R. (1988) - Geological and magmatic aspects of the Paraná basin: An introduction, In: E.M. Piccirillo \& A.J. Melfi (Eds.), The Mesozoic Flood Colcanism of the Paraná Basin: Petrogenetic and Geophysical Aspects. Ed. IAG, University of São Paulo, p. 1 - 13.

MEYER, H, O. A.; GARWOOD, B. L.; SVISERO, D. P. ; SMITH, C.B. (1994) - Alkaline ultrabasic intrusions in Western Minas Gerais, Brazil. Proceedings 5th International Kimberlite Conference, v. 1, p. 140-155, CPRM \& CNPq Special Publication. 
MILANI, J. E. (1990) - Estilos estruturais em bacias sedimentares - revisão conceitual, In: GABAGLIA, G.P.R. \& MLLANI, E.J. (coords) - Origem e evolução de bacias sedimentares, Petrobrás, p. 75-96.

MINIOLI, B.; PONÇANO, W.L.; OLIVEIRA, S.M.B. de (1971) - Extensão geográfica do vulcanismo basáltico do Brasil meridional, Anais da Academina Brasileira de Ciências, 43(2): 433-7.

MITCHEL, R.H. (1986) - Kimberlites: mineralogy, geochemistry, and petrology. Plenum Press, New York, 442p..

MONTALVÃO, R.M.G. de \& BEZERRA, P.E.L. (1980) - Geologia e tectônica da Plataforma Amazônica (Parte da Amazônia Legal Brasileira), Revista Brasileira de Geociências, 10(1) : $1-27$.

MONTES-LAUAR, C.R.; PACCA, I.G.; MELFI, A.J., PICCIRILlO, E.M.; BELlIENI, G.; PETRINE, R; RIZZIERI, R. (1994) - The Anari and Tapirapuã jurassic formations, western Brazil: paleomagnetism, geochemistry and geochronology, Earth and Planetary Science Letters, Elsevier Science B.V., 128: 357-71.

MUGGERIDGE, M.T. (1986) - The efficiency of fluvial trap sites to concentrate kimberlitic minerals: an experimental sampling programme, In: Fourth International Kimberlite Conference, Geological Society of Australia, Abstracts Series, 16: 481 - 483.

MUGGERIDGGE, M.T. (1995) - Pathfinder sampling techniques for locating primary sources os diamond: Recovery of indicator minerals, diamonds and geochemical signatures, Journal of Geochemical Exploration, 53: 183 - 204.

MÜHLMANN, H. (1974) - Revisão Estratigráfica da Bacia do Paraná, Ponta Grossa, PetrobrásDESUL, $\mathfrak{n}^{\circ} 444,186 \mathrm{p}$. (Relatório Técnico Interno), inédito. 
OLIVATTI, O. \& RIBEIRO FILHO, W. (1976) - Revisão da geologia do centro-norte de Mato Grosso, Projetos centro-oeste de Mato Grosso, Alto Guaporé e Serra Azul, Goiânia, Convênio Departamento Nacional da Produção Mineral/Companhia de Pesquisa de Recursos Minerais, 51p.

OLIVEIRA, A.I. de \& LEONARDOS, O.H. (1943) - Geologia do Brasil, $2^{a}$ Edição com Revisão Atualizada, Rio de Janeiro, Serviço de Informação Agrícola, 813p. (Série Didática, 2).

OLIVEIRA, A.L.A.M. de, BARBOSA, C.R. da R.; COSTA T. de A. (1992) - Sequência ClastoVulcano-Química do Grupo Bauru e as Unidades Terciárias e Quaternárias da Região de Dom Aquino, MT, Cuiabá, Departamento de Recursos Minerais, Instituto de Ciências Exatas e da Terra, Universidade Federal de Mato Grosso, 150p., Monografia de Graduação em Geologia (inédito).

OLIVEIRA, M.A.M. de \& MÜLHMANN, H. (1965) - Geologia de semi-detalhe da região de Mutum, Jaciara, São Vicente e Chapada dos Guimarães, Ponta Grossa, Petrobrás - DEBSP, $\mathrm{n}^{\circ} 300,62 \mathrm{p}$. ( Relatório Técnico Interno), inédito.

OLIVEIRA, M.A.M. de \& MÜLHMANN, H. (1967) - Observation on the geology of Chapada dos Guimarães, Mato Grosso, Petrobrás, $n^{\circ} 362,5 p$. (Relatório Técnico Interno).

PEATE, D. W.; HAWKESWORTH, C. J.; MANTOVANI, M.S.M. (1992) - Chemical stratigraphy of the Paraná lavas (South America): classification of magma types and their spatial distribution. Bulletin of Vulcanology, 55: 119 -139.

PECCIRILLO, E. M. \& MELFI, A.J. (1988) - The mesozoic flood volcanism of the Paraná Basin: petrogenetic and geophysical aspects. Instituto Astronômico e Geofísico da USP, 600p. 
PENA, G.S.; PEREIRA, A.D.C.; TAKAHASHI, A.T.; OGUINO, K; NETO, M.H.F.; ARAÚJO, V.A. de (1975) - Projeto Goiânia II, Relatório Final, Convênio Departamento Nacional da Produção Mineral/Companhia de Pesquisa Recursos Minerais, 5v.

PETRI, S. \& FÚLFARO, V. J. (1966) - Sobre a geologia da área balizada pelas cidades de Barra dos Garças e Guiratinga, Mato Grosso e Jataí e Amorinópolis, Goiás. Boletim da Sociedade Brasileira de Geologia, 15: 59 -80.

PETRI, S. \& FÚlFARO, V.J. (1988) - Geologia do Brasil, T.A. Queiroz Editor Ltda., São Paulo, Editora da Universidade de São Paulo, 631p.

PINHO, M.J.; COÊLHO, N.R; PISANI Jr. W.T. (1994) - Dados Geológicos e Geofísicos das Intrusões Kimberlíticas na Província de Paranatinga, MT, Cuiabá, Departamento de Recursos Minerais, Instituto de Ciências Exatas e da Terra, Universidade Federal de Mato Grosso, 65p, Monografia de Graduação em Geologia (inédito).

PIRES, F.R.M. (1982) - Formação Bauru: Controvérsias, Anais da Academia Brasileira de Ciências, 54(2): 369 -393.

PISANI, J.R.T. \& ARRAIS, J.C. de P. (1991) - Contribuição ao Estudo do Grupo Bauru, Unidades Terciárias-Quaternárias e o Diamante na Região de Poxoréu, MT, Área 1, Cuiabá, Departamento de Recursos Minerais, Instituto de Ciências Exatas e da Terra, Universidade Federal de Mato Grosso, 129p., Monografia de Graduação em Geologia (inédito) .

RIBEIRO, J.M.C. \& MACIEL, M.A.C. (1991) - Contribuição ao Estudo do Grupo Bauru, Unidades Terciárias-Quaternárias e o Diamante na Regiāo de Poxoréu, MT, Área 2, Cuiabá, Departamento de Recursos Minerais, Instituto de Ciências Exatas e da Terra, Universidade Federal de Mato Grosso, 65p., Monografia de Graduação em Geologia (inédito). 
RIBEIRO FILHO, W.; LUZ, J. da S.; ABREU FILHO, W. (1975) - Projeto Serra Azul, Convênio Departamento Nacional da Produção Mineral/Companhia de Pesquisa de Recursos Minerais, Relatório Final, $1: 104 p$.

ROUBAUlT, M. (1982) - Determination Des Mineráux Des Roches au Microscope Polarisant, Editions Lamarre-Poinat, $3^{\mathrm{a}}$ ed., Paris, $311 \mathrm{p}$.

ROXO, M.G.O. (1937) - Notas geológicas sobre a Chapada do Mato Grosso, Notas Preliminares e Estudos do Serviço Geológico e Mineralógico, Ministério da Agricultura, Rio de Janeiro, 15 : 4-7.

RUST, B. R. (1980) - Coarse Alluvial Deposits, In: WALKER, R.G., Facies Models, 2, Ontario, Geoscience Canada, p. 9 -22 (Reprint Series 1).

SAEZ, G.S.; SUNDARAN, D.; OLIVEIRA. N.M. (1992) - O registro glacial permo-carbonífero em Mato Grosso e Mato Grosso do Sul, In: Congresso Brasileiro de Geologia, 37, São Paulo, Anais...São Paulo, Sociedade Brasileira de Geologia, 1 : 535-36.

SCHNEIDER, R.L.; MÜHLMANN, H.; TOMMASI, E.; MEDEIROS, R.A.; DAEMON, R.F.; NOGUEIRA, A.A. (1974) - Revisão estratigráfica da Bacia do Paraná, In: Congresso Brasileiro de Geologia, 28, Porto Alegre, Anais...Porto Alegre, Sociedade Brasileira de Geologia, $1: 41-65$.

SCHOBBENHAUS, C.; CAMPOS, D. de A. ; DERZE, G.R.; ASMUZ, H.E. (1984) - Geologia do Brasil - Texto explicativo do mapa geológico do Brasil e da área oceânica adjacente, incluindo depósitos minerais, Ministério das Minas e Energia, Departamento Nacional da Produção Mineral, Brasília, DF, 465p.

SCHOBBENHAUS, C.; OLIVA, L.A.; OLIVATTI, O.; RIBEIRO FILHO, W.; TAKANOHASHI, J.T.; MINGNON, R.A.; CAMPOS, D.A.; DERZE, G.R. (1979) - Folha SD.21 - Cuiabá, 
Carta Geológica do Brasil ao Milionésimo, Ministério das Minas e Energia, Departamento Nacional da Produção Mineral, Brasília, DF.

SCHOBBENHAUS, C.; RIBEIRO, C.L.; OLIVA, L.A.; TAKANOHASHI, J.T.; LINDENMAYER, Z.G.; VASCONCELOS, J.B.; ORLANDI, V.; DERZE, G.R.; RIBEIRO, E.P. (1975) - Folha SD.22 - Goiás, Carta Geológica do Brasil ao Milionésimo, Ministério das Minas e Energia, Departamento Nacional da Produção Mineral, Brasília, DF.

SICHEL, H.S. (1966) - The estimation of means and associated confidence limits for small samples from lognormal populations. Journal of the South African Institute of Mining and Mettallurgy, 4: 1-17.

SMIRNOV, V.I. (1976) - Geology of Mineral Deposits, Ed. Mir Publishers, Moscow, 520p.

SVISERO, D.P. (1994) - Distribution and origin of diamonds in Brazil: An overview, In: International Symposium on the Physics and Chemistry of the Upper Mantle, São Paulo, SP, Invited Lectures, p. 257-287.

SVISERO, D.P.; DRUMOND, D.; HARALY, N.L.E.; MORAES, A. (1987) - Mineralogia e geologia do kimberlito Poço Verde, Município de Coromandel, Minas Gerais, Atas do $6^{\circ}$ Simpósio Regional de Geologia, 1: 97-111.

SVISERO, D.P.; HARALY, N.L.E.; FEITOSA, V.M.N. (1982) - Geologia e geofísica do Kimberlito Sucuri, Monte Carmelo, Minas Gerais. In: Congresso Brasileiro de Geologia, 32, Salvador, Anais.....Salvador, Sociedade Brasileira de Geologia, 2: 465-474.

SVISERO, D.P. \& MEYER, H.O.A ( 1986) - New occurrences of kimberlites in Brazil. Extended Abstracts 4th International Kimberlite Conference, 16: 145147. 
SVISERO, D.P., MEYER, H.O.A., HARALY, N.L.E.; HASUI, Y. (1984) - A note on the geology of some brazilian kimberlites, Journal of Geology, 92: 331-338.

SVISERO, D.P.; MEYER, H.O.A.; TSAI, H.M. (1977) - Kimberlite minerals from Vargem (Minas Gerais) and Redondão (Piauí) diatremes, Brazil; and garnet therzolite xenolith from Redondão diatreme, Revista Brasileira de Geociências, 7 (1): 1-13.

THOMPSON, R.N.; MORRINSON, M.A.; DICKIN, A.P.; HENDRY, G.L. (1983) - Continental flood basalts....Arachnids rule OK? In: Continental Basalts and Xenoliths, (Eds.) C.J. Hawkesworth \& M.J. Norry, Shiva, Cambridge, Mass. pp 158-185.

UGGERI, A.R. \& COSTA, V.S. (1991) - O Kimberlito Tamburi e os Diques de Textura Lamprofírica de Paredão Grande e Meruri, Cuiabá, Departamento de Recursos Minerais, Instituto de Ciências Exatas e da Terra, Universidade Federal de Mato Grosso, 172p., Monografia de Graduação em Geologia (inédito).

VIEIRA, A.J. (1965) - A Geologia do centro-oeste de Mato Grosso, Ponta Grossa, Petrobrás DEBSP, $\mathrm{n}^{\circ} 303,79 \mathrm{p}$. (Relatório Técnico Interno), inédito.

WALKER, R.G. (1975) - Conglomerate: sedimentary Structures and facies models, Chapter 7, In: HARN, J.C.; SOUTHARD, J. B.; SPEARING, D.R. \& WALKER, R.G., Depositional Enviroments as Interpreted From primary Sedimentary Structures and Stratifications Sequences, Texas, Econ. Paleont., Short Course 2, p. 133-161.

WESKA, R.K (1987) - "Placers" diamantíferos da região de Água Fria, Chapada dos Guimarães, MT, Universidade de Brasilia, Departamento de Geociências, Tese de Mestrado em Geologia Econômica e Prospecção, 170 p.

WESKA, R.K; BITTENCOURT ROSA, D.; PISANI, J.R.T.; ARRAIS,J. C. de P.; MACIEL, M.A.C.; RIBEIRO, J.M.; KATO, S.L.R.; ARAÚJO, S.A. de; ROSESTOLATO FILHO, A. 
(1993) - A estratigrafia, a evolução tectônica e o diamante do Grupo Bauru da região de Poxoréo, MT, Brasil, In: Simpósio Brasileiro de Geologia do Diamante, $1^{\circ}$, Cuiabá, MT, Anais...Cuiabá, Ed. UFMT - Gráfica Universitária, p. 208-228.

WESKA, RK; BITTENCOURT ROSA, D.; UGGERI, A.R; COSTA, V.S. (1992) - Diques da região entre Paredão Grande e a Colônia Indígena Meruri, General Carneiro, MT, Brasil, In: Congresso Brasileiro de Geologia, 37, São Paulo, Boletim de Resumos Expandidos....São Paulo, Sociedade Brasileira de Geologia, $1: 515$.

WESKA, R.K; DANNI, J.C.M.; DARDENNE, M.A.; PERIN, A.L.(1988) - Contribuição à estratigrafia do Grupo Bauru da Chapada dos Guimarães, MT, In: Congresso Brasileiro de Geologia, 35, Belém, Anais ... Belém, Sociedade Brasileira de Geologia , 2 : 905 - 16.

WESKA, R.K; PERIN, A.L.; BITTENCOURT ROSA, D. (1991) - "Placers" diamantíferos na Chapada dos Guimarães, Mato Grosso, Brasil, In: Simpósio de Geologia do Centro-Oeste, $3^{0}$, Cuiabá, Anais... Cuiabá, Sociedade Brasileira de Geologia, Núcleo Centro-Oeste, 1 : 200 - 210.

WESKA, R.K, PERIN,L.A.; FERREIRA, I.A. (1984) - Placers diamantíferos da bacia do Alto Paraguai-MT, Caracterização geológica como critérios e guias de prospecção, In: Congresso Brasileiro de Geologia, 33, Rio de Janeiro, Anais... Rio de Janeiro, Sociedade Brasileira de Geologia, $8: 3.877$ - 87 .

WESKA, R.K; SAES, G.S.; ANDREAZZA, P; WEISSEL, O.; BORGES, R.M.K. (1993) - O Grupo Bauru e as unidades terciário-quaternárias das regiões da Chapada dos Guimarães e Poxoréo e os kimberlitos de Paranatinga, MT, Brasil. In: R.K. WESKA; O.H. LEONARDOS \& G.M. GONZAGA (eds.). $1^{\circ}$ Simpósio Brasileiro de Geologia do Diamante, Cuiabá, Roteiro de excursão, Publicação especial - UFMT 1/93, p. 3 -18. 
WESKA, R.K.; SVISERO, D.P.; LEONARDOS, H.O. (1996) - Contribuição so conhecimento do Grupo Bauru no Estado de Mato Grosso, Brasil, Boletin do $4^{0}$ Simpósio sobre o Cretáceo do Brasil, Rio Claro, UNESP, p. 289 - 295.

WILSON, M. (1994) - Igneous Petrogenesis, Unwin Hyman, London, 466p.

WHITE, I.C. (1908) - Relatório final da comissão das minas de carvão de pedra do Brasil, Rio de Janeiro, Imprensa Nacional, 607p.

ZALAN, P.V.; CONCEIÇÃO, J.C.J.; WOLFF, S.; ASTOLFI, M.A.M.; VIEIRA, I.S.; APPI, V.I.; NETO, E.V.S.; CERQUEIRA, J.R.; ZANOTTO, D.A.; PAUMAR, M.L. (1968) - Análise regional integrada da Bacia do Paraná, PETROBRÁS, Rio de Janeiro. Relatório interno, s/n ${ }^{\circ}$ , 69p. (inédito).......... 
FIGURA 6 MAPA - GEOLÓGICO DA REGIÃO DE POXORÉU (ALVO PX)

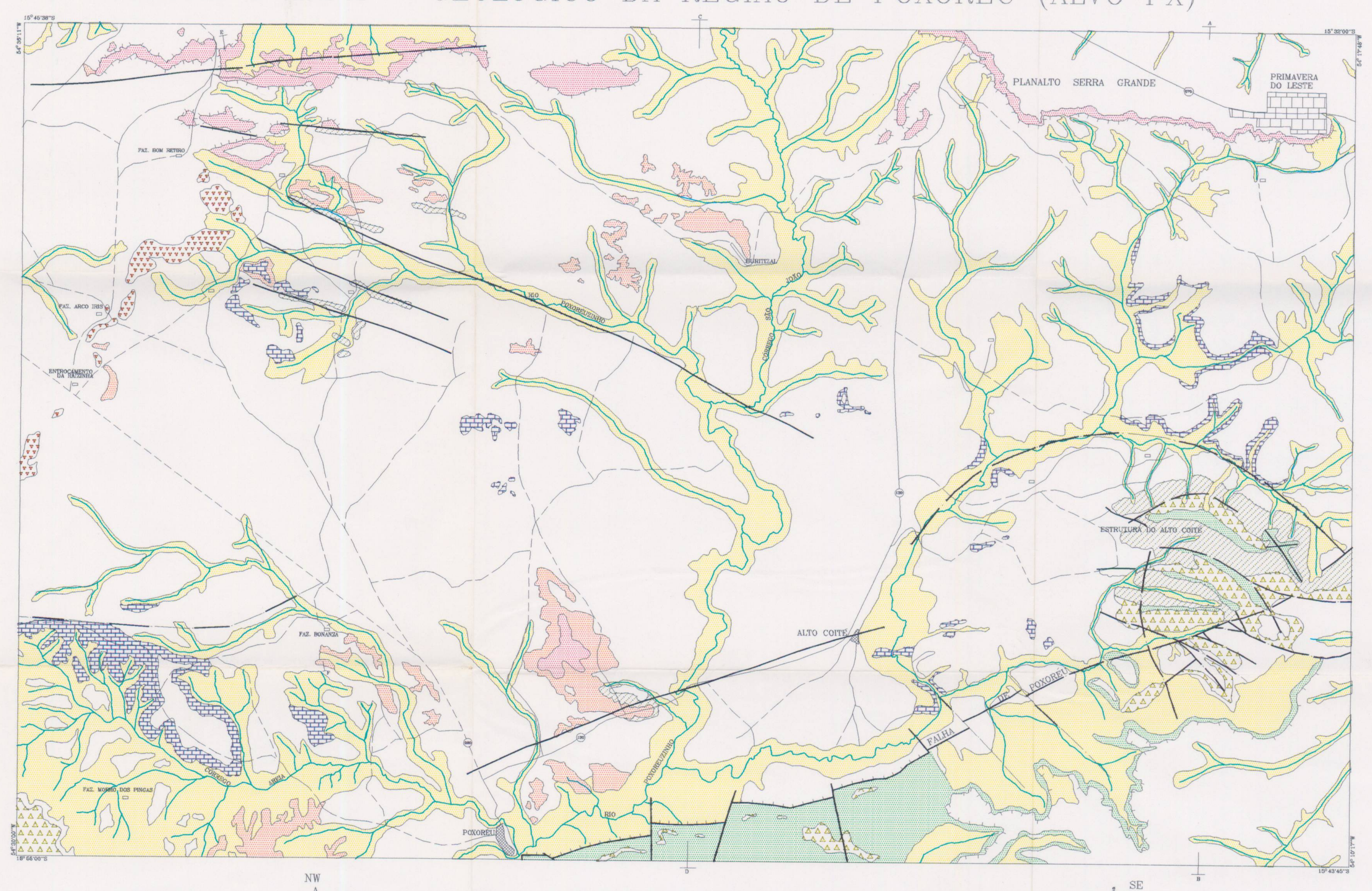

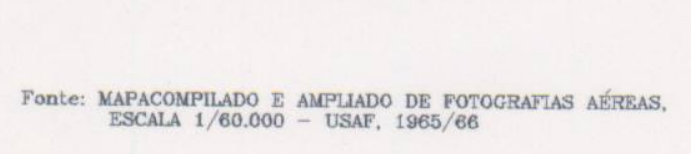

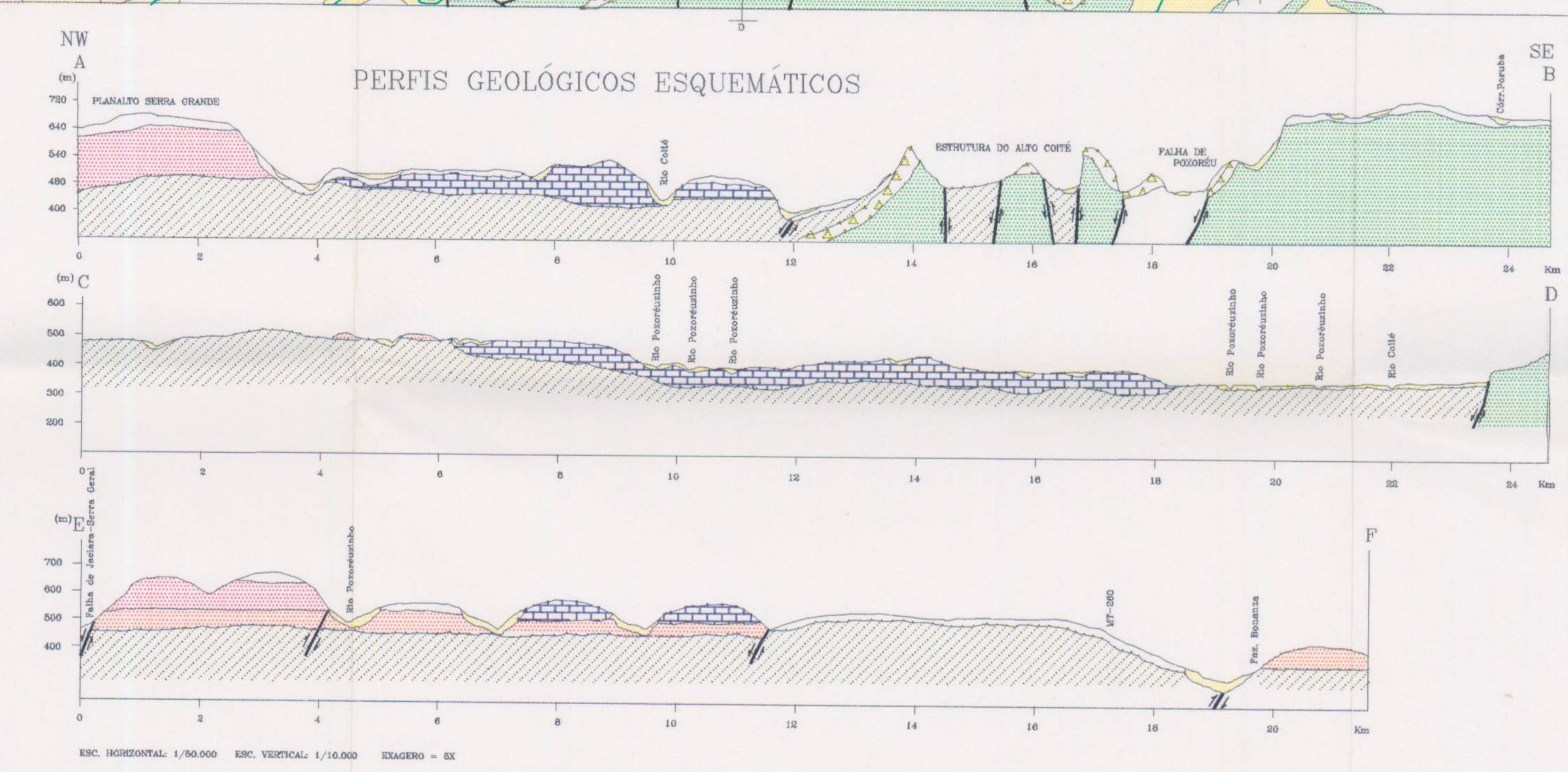

COLUNA ESTRATIGRÁFICA

\begin{tabular}{|c|c|c|c|c|}
\hline \multirow{4}{*}{ 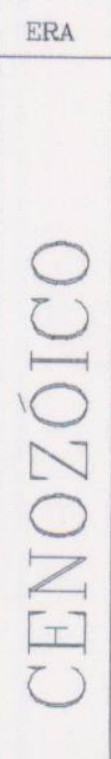 } & \multicolumn{2}{|c|}{ PEŔ́ODO GRUPO } & \multirow{2}{*}{\begin{tabular}{|l|} 
FoRnaÃ̃o \\
FÁCIES COITÉ
\end{tabular}} & $D E S C R I C O_{0}$ \\
\hline & 敢 & & & 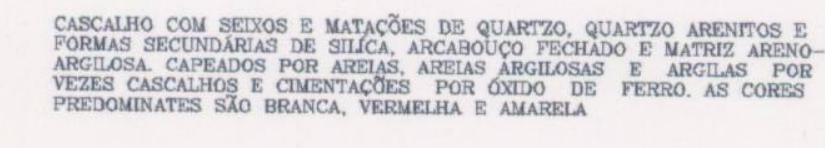 \\
\hline & 商 & & $\begin{array}{l}\text { TERCIÁRIO } \\
\text { QUATERNÁRIO } \\
\text { INDIVISO }\end{array}$ & 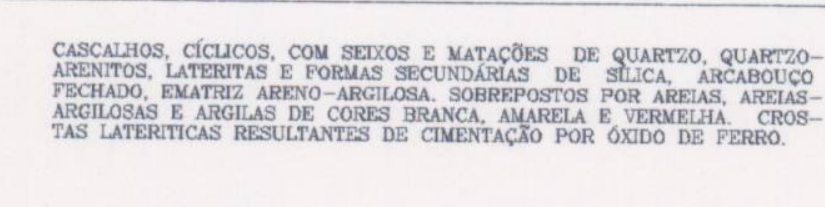 \\
\hline & 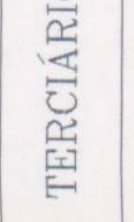 & & CACHOERINHA & 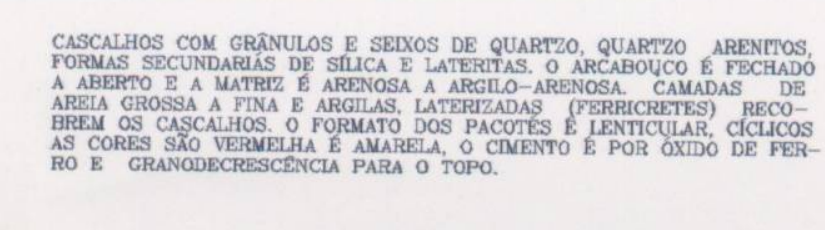 \\
\hline & 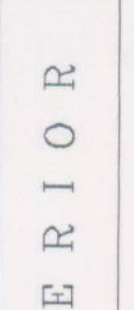 & & CAMBAMBE & 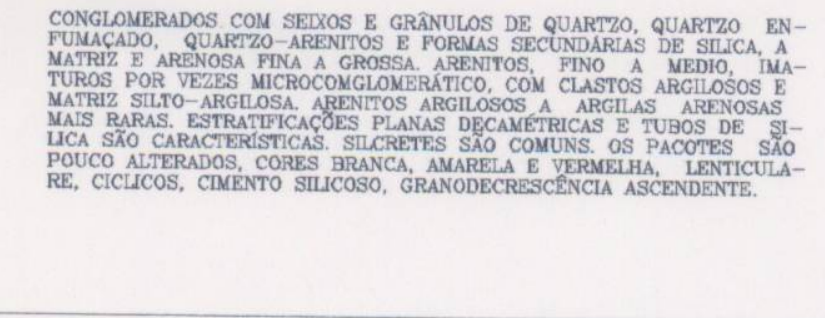 \\
\hline 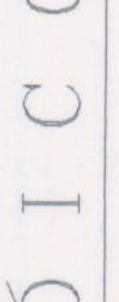 & $\begin{array}{l}a \\
0 \\
i \\
0 \\
0\end{array}$ & $\begin{array}{l}D \\
2 \\
2 \\
D\end{array}$ & $\begin{array}{l}\text { CACHOEIRA DO } \\
\text { BOM JARDIM } \\
\\
\end{array}$ & 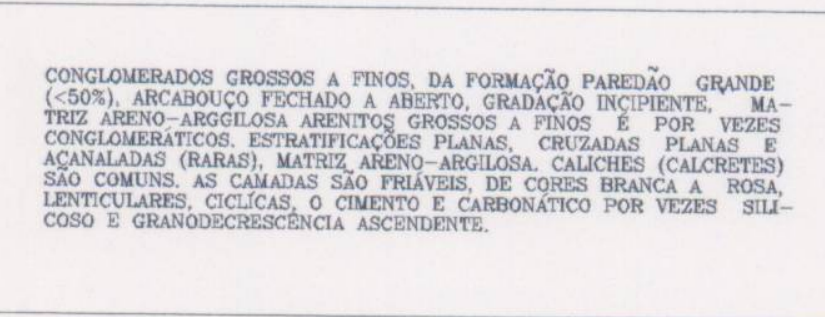 \\
\hline $\begin{array}{l}N \\
0\end{array}$ & 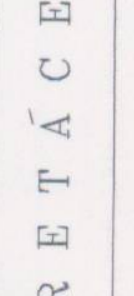 & $m$ & QULLOMBINHO & 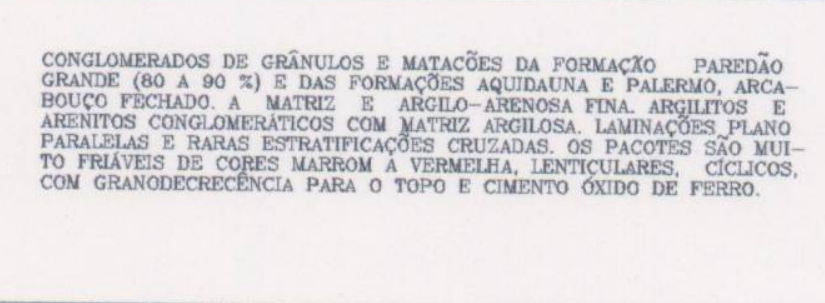 \\
\hline $\begin{array}{l}\text { IS } \\
{[\tau]}\end{array}$ & $\stackrel{2}{0}$ & & \begin{tabular}{|l|l|} 
PAREDÃO \\
GRANDE
\end{tabular} & 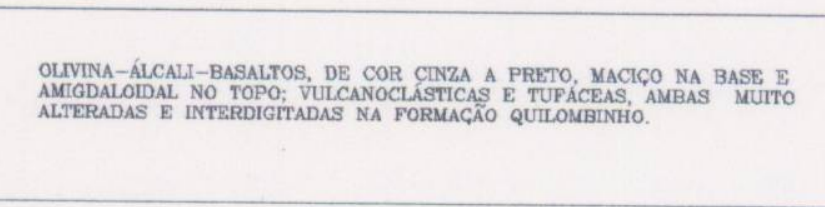 \\
\hline$\Sigma$ & 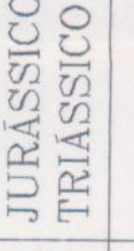 & 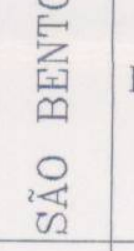 & BOTUCATU & 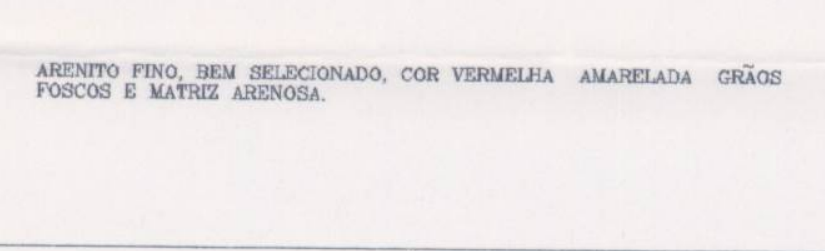 \\
\hline $\begin{array}{l}0 \\
0 \\
0 \\
0 \\
\end{array}$ & 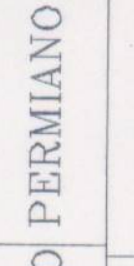 & 蕮 & PALERMO & 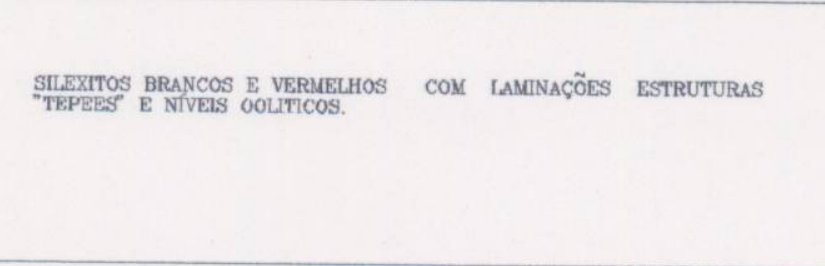 \\
\hline 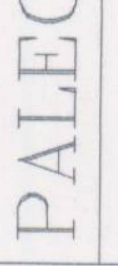 & 㝘 & 通 & AQUIDAUANA & 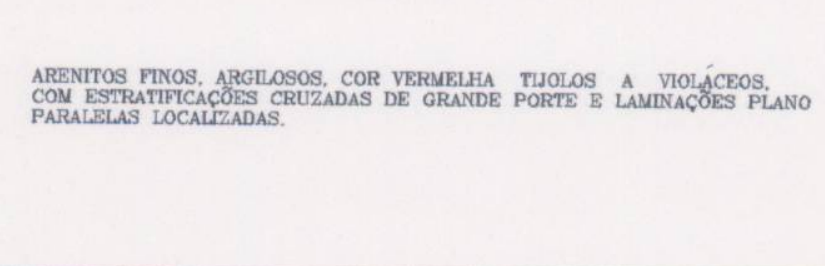 \\
\hline
\end{tabular}

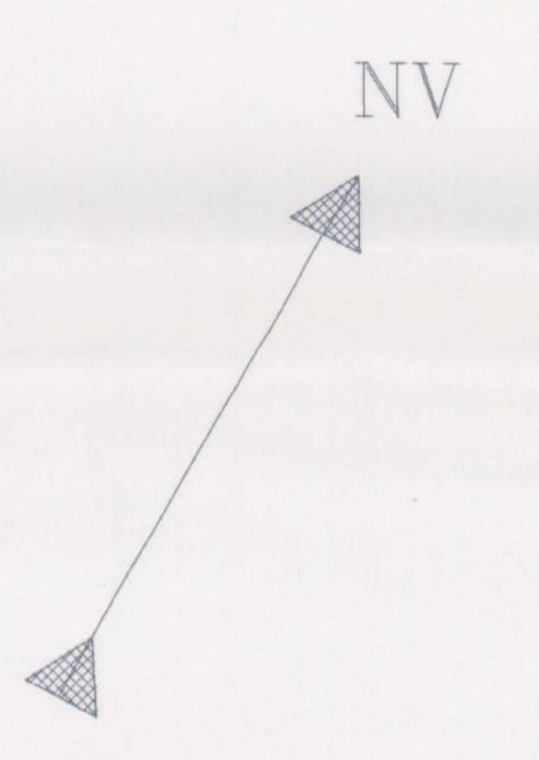


FIGURA 7 - MAPA GEGLǴGICD DA REGIÃU DA INTRUSÃ
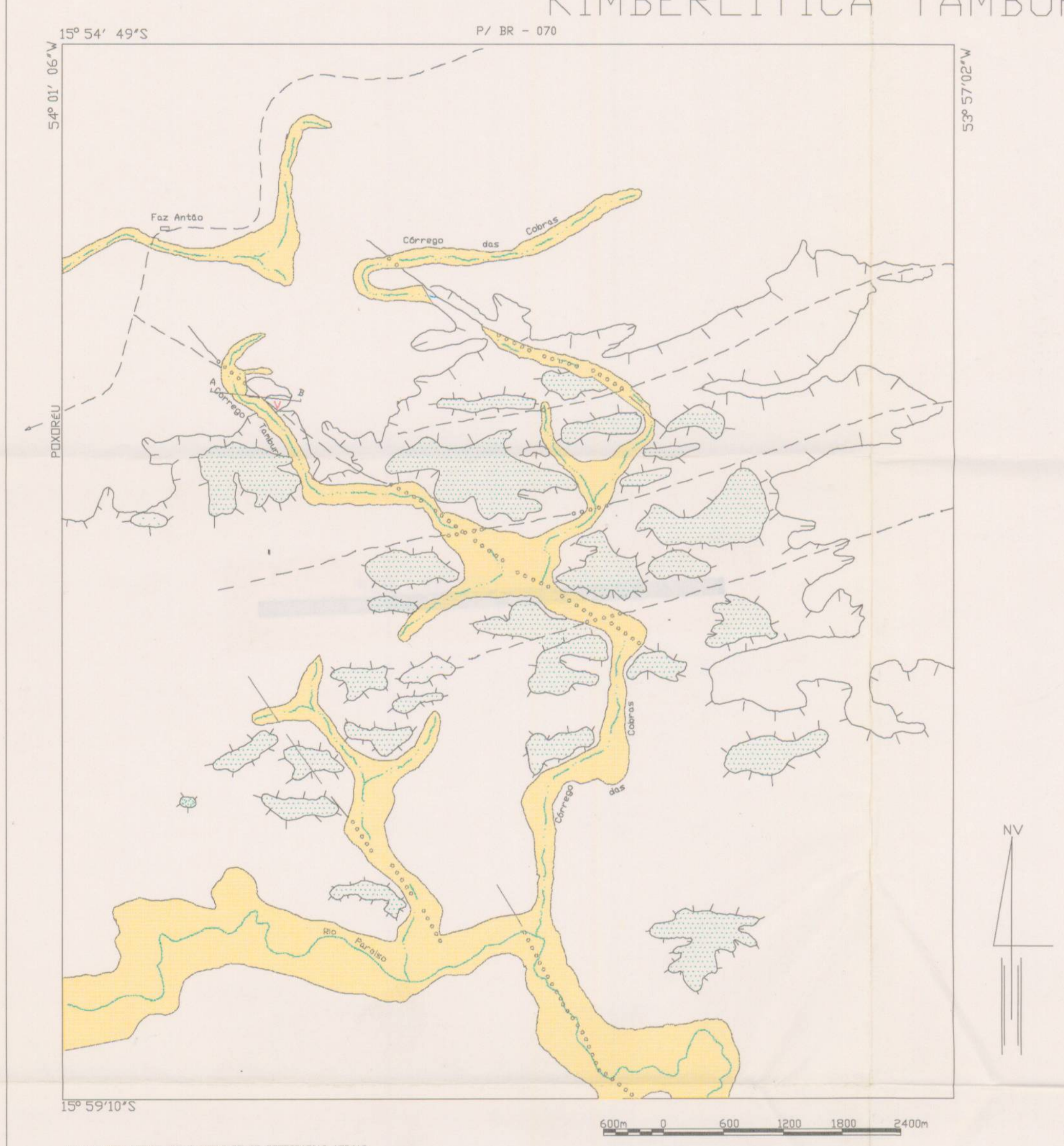

\section{CILUNA ESTRATIGRÁFICA}

\begin{tabular}{|c|c|c|c|c|}
\hline Era & Períodd & Grupd & $\begin{array}{l}\text { Formação/ } \\
\text { Unidade }\end{array}$ & Descrição \\
\hline $\begin{array}{l}\square \\
\cup \\
\mapsto \\
\square\end{array}$ & 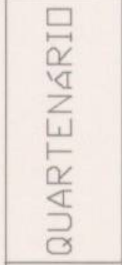 & & $\begin{array}{l}\text { ALUVIธ̃ES } \\
\text { ATUAIS }\end{array}$ & $\begin{array}{l}\text { Cascalho basal, fino a grosso, com } \\
\text { grânulos e seixos de quartzo hia- } \\
\text { lino, quartzo leltoso e arenltos, } \\
\text { arredondados a subarredondados } \\
\text { e matriz areno-argilosa a arenosa } \\
\text { Arelas, arelas cascallosas e arel- } \\
\text { as argilosas no topo, nas cores } \\
\text { branca, cinza e por vezes amarela. }\end{array}$ \\
\hline $\begin{array}{l}N \\
\square \\
z \\
\omega \\
u\end{array}$ & 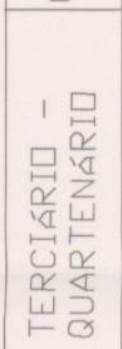 & & $\begin{array}{l}\text { TERCIáRID } \\
\text { QUARTENÁRID } \\
\text { INDIVISL }\end{array}$ & $\begin{array}{l}\text { Cascalhos basals, flinos a grossos, } \\
\text { de quartzo, quartzo arenitos, are } \\
\text { nitos e fragmentos de laterita, ma } \\
\text { triz arenosa e por vezes argilosa. } \\
\text { Forte cimentaçao de oxidos de fer } \\
\text { ro (ferricretes). No topo arelas e } \\
\text { areias argilosas, por vezes casca- } \\
\text { lhosas. As camadas são lenticula- } \\
\text { res, cicllcas dispostas em ter- } \\
\text { raços laterais as drenagens. Cores } \\
\text { vermelha, amarela, branca e cinza. }\end{array}$ \\
\hline $\begin{array}{l}\text { 号 } \\
\text { 号 } \\
\text { 号 } \\
\text { 岁 }\end{array}$ & & & $\begin{array}{l}\text { INTRUSĨ̃ } \\
\text { KIMBERLIIICA } \\
\text { TAMBURI }\end{array}$ & $\begin{array}{l}\text { Macrocristals de granadas, llmeni- } \\
\text { tas, ollivinas e micas, xenbitos de } \\
\text { arenitos, pelitos e pelitos micáceos } \\
\text { matriz areno-argolosa, friávels, In- } \\
\text { segregação carbonática. Cor ver- } \\
\text { melha tjjolo. }\end{array}$ \\
\hline 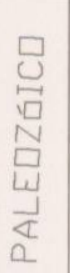 & 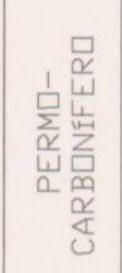 & 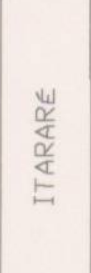 & AQUIDAUANA & $\begin{array}{l}\text { Arenitos finos, argilosos com es- } \\
\text { tratificaçoses plano-paralelas e e } \\
\text { cruzadas. As cores săo vermelha } \\
\text { e branca. }\end{array}$ \\
\hline
\end{tabular}

Fonter MAPA CDMPILADD E AMPLLADD DE FOTTGRAF FAS AEREAS,
ESCALA $1 / 60.000-$ USAF $1965 / 66$.

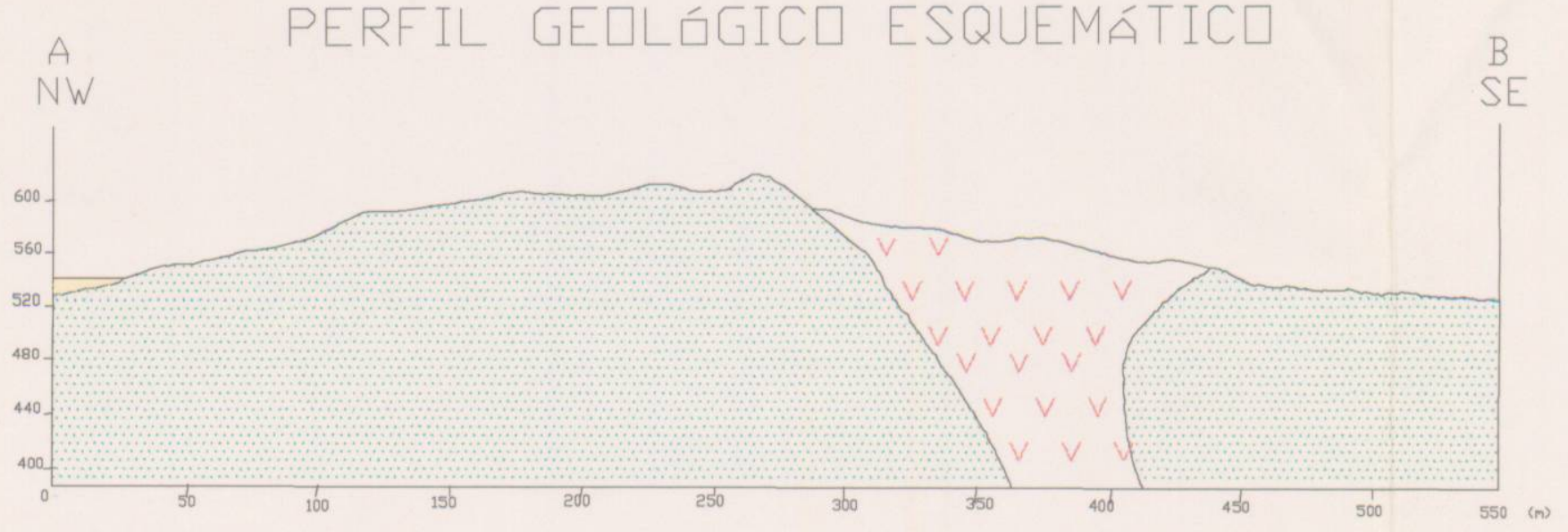

ESC. HURIZDNTAL: $1 / 2.000$ EXAGERD! $2 \times$
ESC. VERTICAL: $1 / 4.000$ 


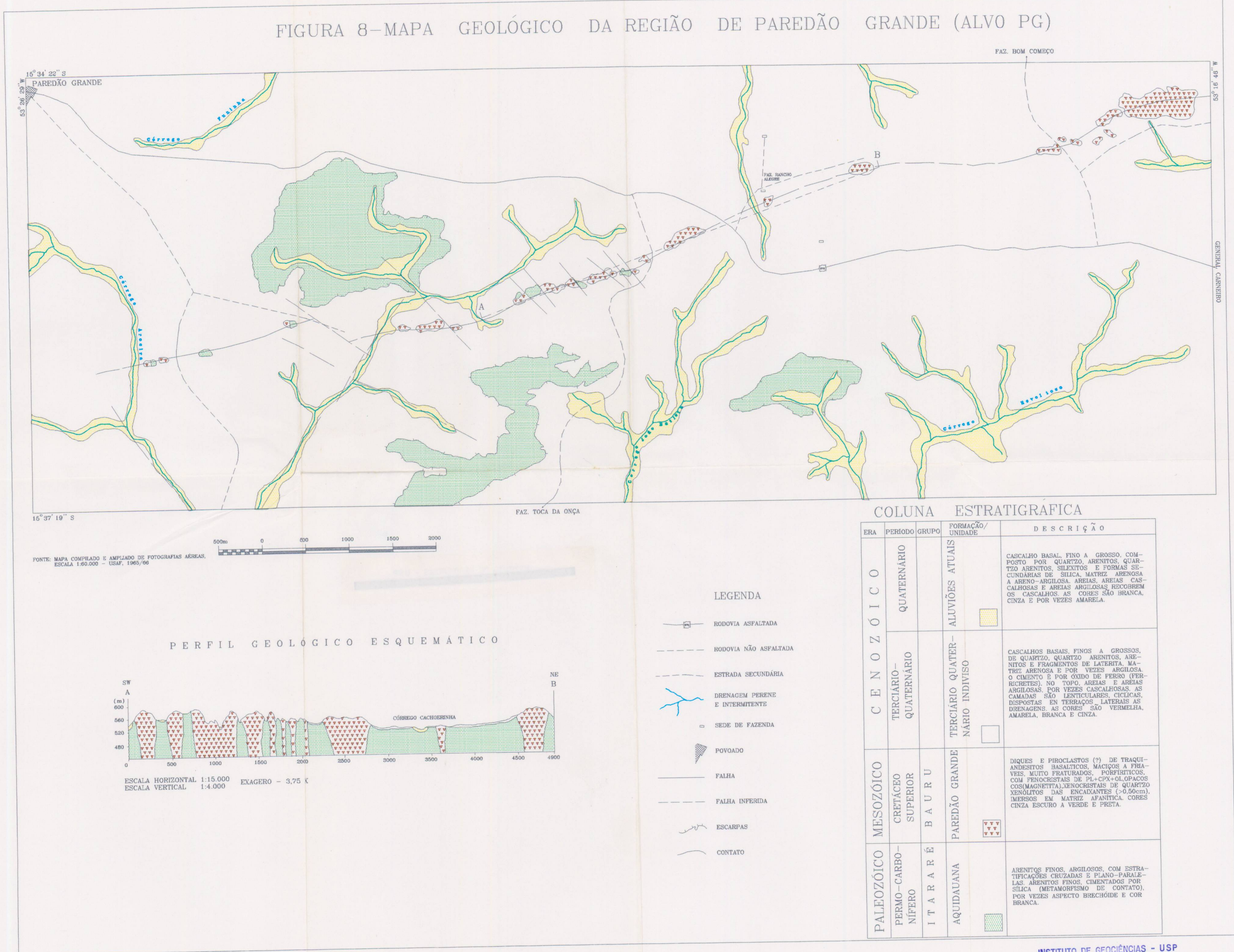




\section{FIGURA 9 - MAPA GEGLúGIC DA REGIã $\square$ D M MERURI, (ALV $\square$ PG).}

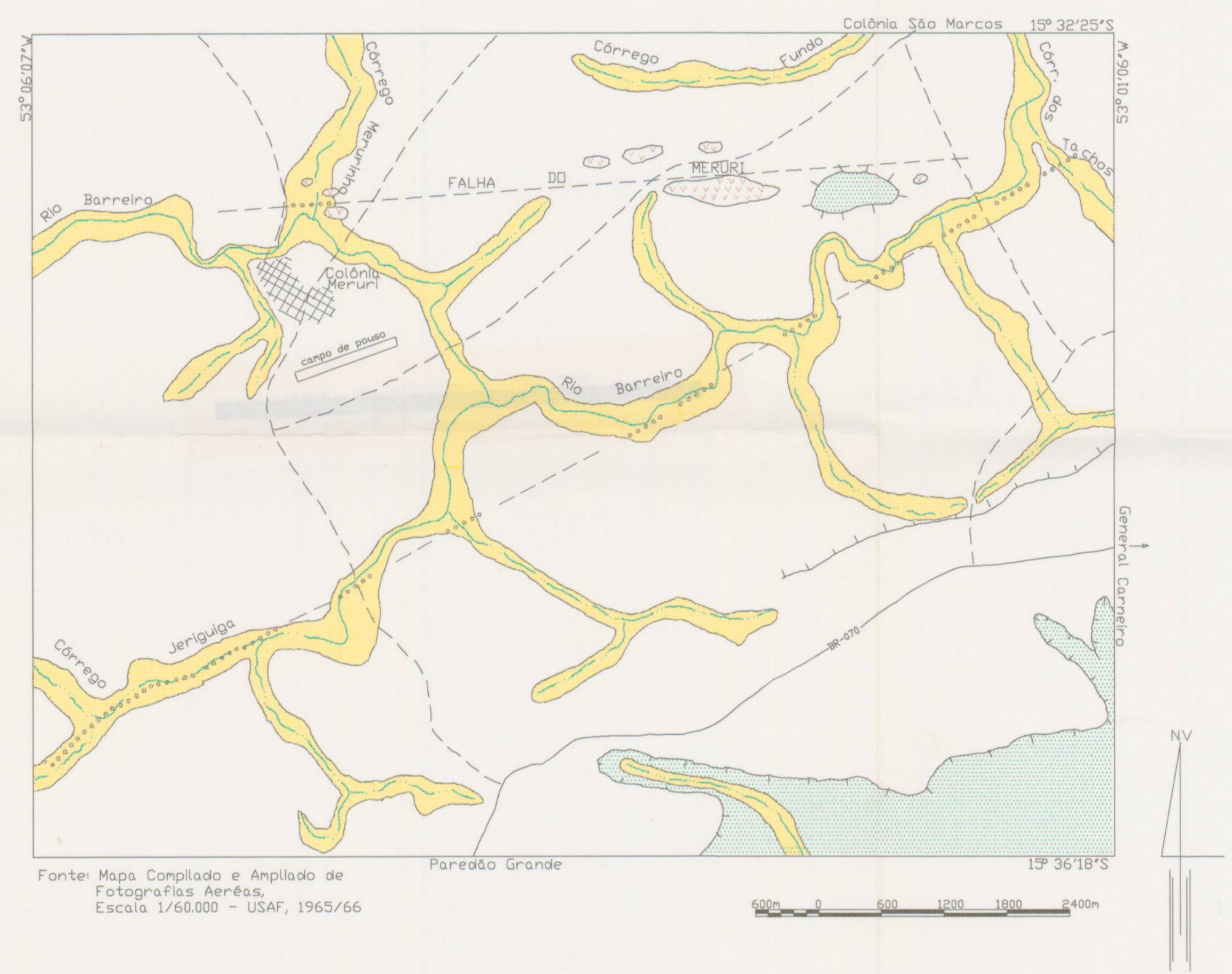

COLUNA ESTRATIGRÁFICA

\begin{tabular}{|c|c|c|c|c|}
\hline & od & & $\begin{array}{l}\text { Formaçaool } \\
\text { Unidade }\end{array}$ & Descrlçä \\
\hline & 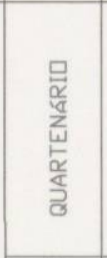 & & $\begin{array}{l}\text { ALUVIGES } \\
\text { ATUAIS }\end{array}$ & 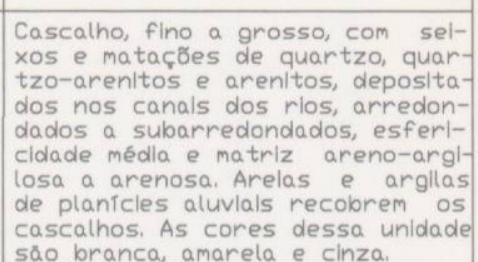 \\
\hline $\begin{array}{l}\text { a } \\
z \\
w \\
0\end{array}$ & 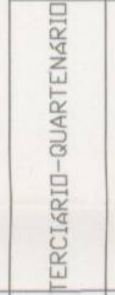 & & $\begin{array}{l}\text { TERCIGRID } \\
\text { QUARTENARRII } \\
\text { INDIVISO }\end{array}$ & 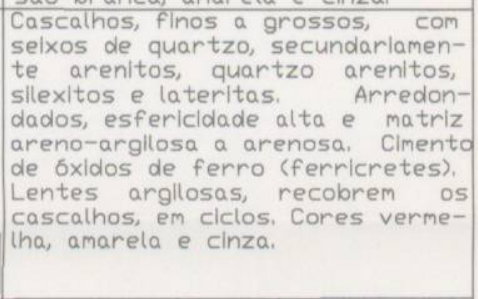 \\
\hline 마 & 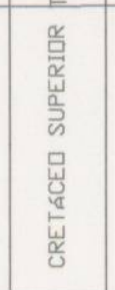 & $\begin{array}{l}\vec{J} \\
\alpha \\
\vec{\alpha} \\
\Phi \\
\infty\end{array}$ & $\begin{array}{l}\text { PAREDAOD } \\
\text { GRANDE }\end{array}$ & 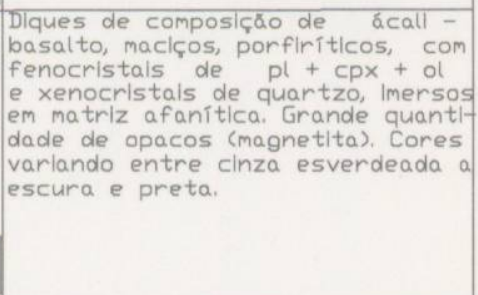 \\
\hline & 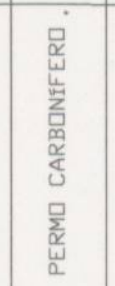 & $\begin{array}{l}w \\
\alpha \\
\alpha \\
\alpha \\
\alpha \\
\leftarrow \\
\\
-\end{array}$ & AQUIDAUANA & 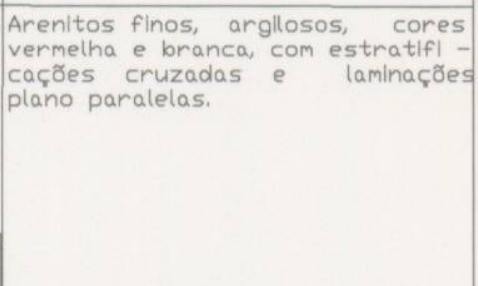 \\
\hline
\end{tabular}

$$
\begin{aligned}
& \text { - BR- RoDDVIA ASFALTADA COLONIA NNIEENA }
\end{aligned}
$$

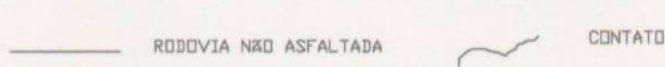

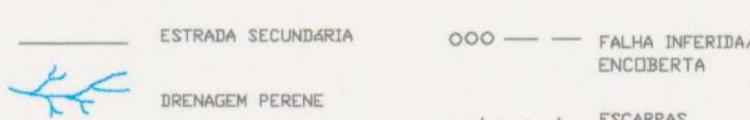

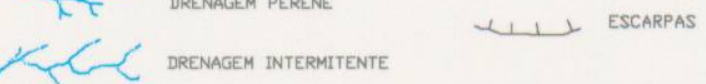

INTITUTO DE GEOCIENNCIAS - USP - BIBLIOTECA - 
